
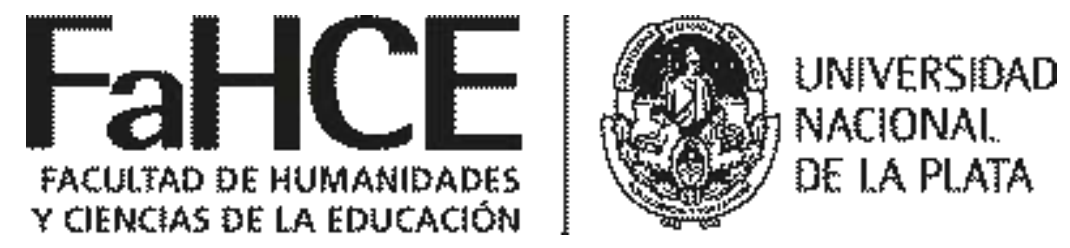

\author{
FACUltad De Humanidades Y CienCias De LA EDUCACIÓN \\ SECRETARÍA DE POSGRADO
}

\title{
TEMPO Y MORALES DE LA CRÍTICA: LAS REVISTAS DEL SURREALISMO E INVENCIONISMO EN ARGENTINA ENTRE 1948 Y 1956
}

Lic. Verónica Stedile

Tesis para optar por el grado de Doctora en Letras Universidad Nacional de La Plata

Director: Dr. Miguel Dalmaroni, Universidad Nacional de La Plata

Codirectora: Dra. Verónica Delgado, Universidad Nacional de La Plata

Ensenada, 19 de julio de 2019 
A Javiera,

por el amor y el asombro ilimitados 


\section{TEMPO Y MORALES DE LA CRÍTICA: LAS REVISTAS DEL SURREALISMO E \\ INVENCIONISMO EN ARGENTINA ENTRE 1948 Y $1956^{1}$}

INTRODUCCIÓN. EI bullicio de la crítica

0.1.El tiempo fuera de la irrupción: problemas iniciales y presentación del corpus. .6

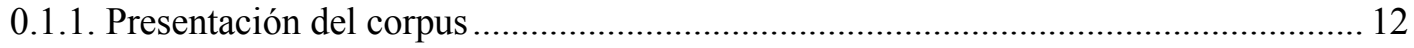

0.1.2. Perspectivas de análisis: las revistas como aparatos estéticos.................................. 18

0.2. Presentación de los capítulos...................................21

0.3. Periodizaciones y desfasajes: los tiempos de las revistas .............26

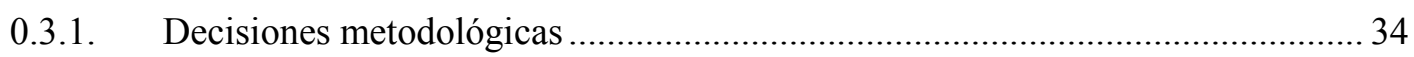

CAPÍTULO I. Modernos, contemporáneos, profetas y embaucadores: la temporalidad como problema crítico en las revistas de vanguardia ..........................36

1.0. Presentación del capítulo.......................................... 36

1.1. Entre la "generación del desierto" y el "país ahogado".............41

1.2. Ciclo. Arte, literatura y pensamiento modernos: el desplazamiento del

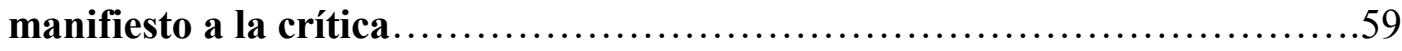

1.2.1. Continuidades y diferencias con Qué (1928-1930) y las revistas de la AACI (1945-

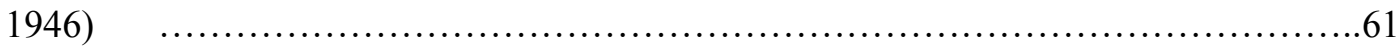

1.2.2. El programa crítico de Ciclo: la exigencia de renovación después del "fracaso de

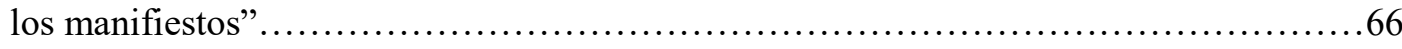

1.3. poesía buenos aires y Contemporánea: el júbilo presente, la profecía

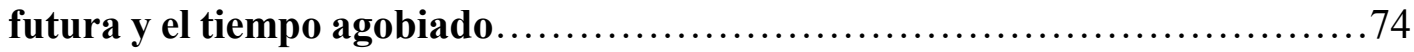

1.3.1. De Contemporánea. Revista de artes (1948-1950) a la "Antología de la nueva

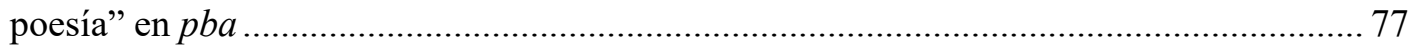

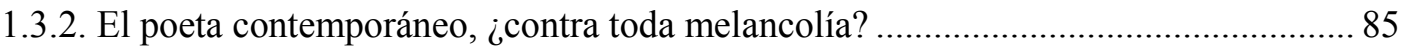

1.4. A partir de cero: imagen y función crítica.........................93

1.4.1 La genealogía surrealista como "relámpago de la conciencia"................................... 97

1.4.2. Una "bomba incendiaria": la imagen que arde como posicionamiento crítico ........ 100

1.5. Letra y Línea: la paradoja de la contemporaneidad.................103

1.5.1. Presentación de la revista ................................................................................... 104

1.5.2. "Vencer al tiempo": la crítica en Letra y Línea .................................................. 112

\footnotetext{
${ }^{1}$ El título original del plan de trabajo presentado a CONICET fue: "Crítica y revistas literarias argentinas en los años '50. Modos de la crítica y presencias de la teoría en A partir de cero (1952), Buenos Aires literaria (1952), Letra y linea (1953), y Capricornio (1953)".
} 
CAPÍTULO II. La vanguardia como ojo del presente. De la imagen total a las series

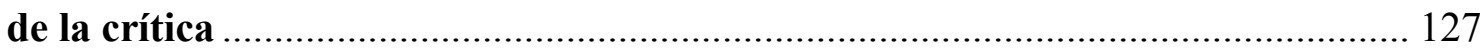

2.0. Presentación del capítulo ...................................... 127

2.1. “Un cadáver": la vanguardia como supervivencia.................134

2.1.1. "Estéticas absurdas" y "escuelas cerebralizadas": lecturas sobre la vanguardia en otras revistas culturales del período ..................................................................................... 137

2.1.2. Cadáver y supervivencia: formas del tiempo no clausurado ................................... 142

2.2. Hacia la imagen total: surrealismo e invencionismo en el límite de la representación.......................................................... 156

2.2.1. Síntesis y depuración: formas de lo total.................................................................. 162

2.3. ¿A quién le importan las obras? Las polémicas de la crítica.............173

2.3.1. Aldo Pellegrini y Julio Payró: la lengua y la biblioteca ........................................... 178

2.3.2. Montaje y genealogía: cómo se delimita la nueva poesía argentina........................ 183

2.3.3. ¿Una polémica arruinada? Bustos Domecq y los surrealistas ................................... 190

2.4. Las series de la crítica. Zonas de contacto...............................199

2.4.1. Vanguardia lumínica y fulminación de la conciencia: la serie crítica de Ciclo....... 201

2.4.2. Políticas de la visualidad: una crítica de lo contemporáneo como contraste y montaje

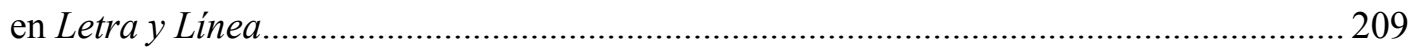

2.4.3. Henri Michaux, Vicente Huidobro y Tristan Tzara: dos miradas de lo mismo....... 215

CAPÍTULO III. Espacio común y morales de la crítica: el instante y la historia...220

3.0. Presentación del capítulo ......................................220

3.1. El archivo de categorías se expande..........................222

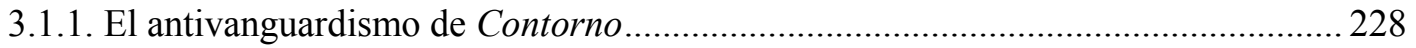

3.1.2. La polémica entre Jean-Paul Sartre y Georges Bataille .......................................... 235

3.2. Insertarse en una comunidad histórica. La polémica entre Aldo Pellegrini y Osiris Troiani: el espacio común de las revistas y las disputas de la

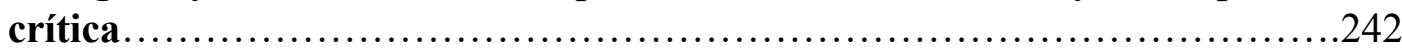

3.3. Hacia una crítica del instante: contra "convencionalismos del lenguaje", "realistas fantasmales" e "hipócritas humanistas" ..............253

3.3.1. Imagen del instante y comunicación en los ensayos de Aldo Pellegrini y Enrique Molina.......................................................................... 256

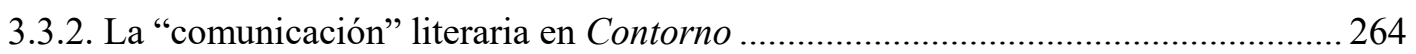

3.3.3. El problema de la comunicación en poesía buenos aires ......................................... 266

3.3.4. La imagen en combustión y los realismos posibles................................................ 269

3.4. La forma de la historia: Edgar Bayley.............................273 


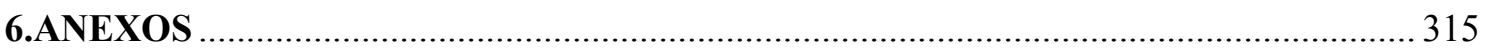

6.1. ANEXO I. FICHAS TÉCNICAS............................................ 315

6.2. ANEXo II. TRANSCRIPCIÓN DE TEXTOS CITADOS PARCIALMENTE …........................... 319

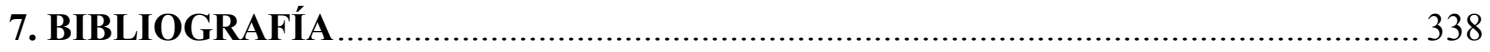




\section{Introducción}

\section{EI bullicio de la crítica}

\subsection{El tiempo fuera de la irrupción: problemas iniciales y presentación del corpus}

Una lectura detallada de las revistas Ciclo (1948-1949), poesía buenos aires (1950-1960), A partir de cero (1952, 1956), y Letra y Línea (1953-1954), ${ }^{2}$ publicadas en Buenos Aires, en las que participaron escritores vinculados a las estéticas surrealista e invencionista, como Aldo Pellegrini, Enrique Molina, Raúl Gustavo Aguirre y Edgar Bayley, permite advertir la configuración de una serie de operaciones críticas que se diferencian de las caracterizaciones dominantes sobre el período, proporcionadas por diversas historias de la literatura argentina e investigaciones sobre la historia de la crítica.

Estas revistas intervinieron en los debates artístico-literarios de mediados de siglo XX, en Argentina, a partir de un conjunto de interrogantes sobre la contemporaneidad, con los cuales pretendían desestabilizar la noción y proponer perspectivas críticas que articularan las lecturas, valores e intereses propios de las vanguardias de principio de siglo (según la recuperación de autores como André Breton, Tristan Tzara, Kazimir Malevich, Piet Mondrian, Vicente Huidobro, César Vallejo), las discusiones estético-políticas de la segunda postguerra (para lo cual tradujeron a otro grupo de autores entre los que se encontraban René Char, Georges Bataille, Maurice Blanchot, Jean Cassou, Henry Miller, Henri Michaux, Aimé Césaire) con las hipótesis y problemas de la cultura argentina en su propio tiempo (si acaso era posible un nuevo realismo, el lugar de Roberto Arlt en la literatura local, la presencia de Borges y la revista Sur, el rechazo a las estéticas de la década anterior). De este modo, las revistas mencionadas cuestionaron aquellas perspectivas que veían en la idea de vanguardia un fenómeno del pasado que debía dejarse

\footnotetext{
${ }^{2}$ Durante el proceso de investigación consultamos los archivos hemerográficos del CEDINCI, la Biblioteca Nacional Mariano Moreno, la Biblioteca Pública Dardo Rocha de la UNLP, la Biblioteca Nacional de Francia François-Miterrand, la Biblioteca Profesor Guillermo Obiols y la Biblioteca del Instituto de Literatura Argentina "Ricardo Rojas". Muchas de las publicaciones citadas se encuentran disponibles en los repositorios digitales Americalee (www.americalee.cedindi.org), Archivo Histórico de Revistas Argentinas (www.ahira.com.ar/), El surrealismo y sus derivas (www.uam.es/proyectosinv/surreal.html) y Gallica (ww.gallica.bnf.fr). De las revistas Contorno, poesía buenos aires, Letra y Línea, Arturo y Arte Madi existen ediciones facsimilares impresas; en todos los casos corresponden a la colección "Reediciones y Antologías" de las ediciones Biblioteca Nacional. En la bibliografía consignamos, para cada una de las revistas citadas, el tipo de disponibilidad, soporte y acceso.
} 
atrás para pensar seriamente en el compromiso del escritor con la historia; la principal vía de ese cuestionamiento se fundamentó en un modo de leer la relación entre obra artística y sociedad como desajuste no reductible de manera lineal a explicaciones históricas, económicas o políticas. Asimismo, Ciclo, poesía buenos aires, A partir de cero, y Letra y Línea discutieron que pudiera hacerse una lectura en términos cronológicos de aquello que se consideraba "nuevo" o "contemporáneo".

Las operaciones según las cuales estas revistas intervinieron son propias de lo que hace la crítica en relación con una tradición: ${ }^{3}$ traducciones, selección de autores para los que se propuso un criterio de conjunto que se diferenciaba del existente, apropiación de términos y figuras críticas, adopción del género polémico, y disputa por el sentido en torno a una zona del vocabulario de la época. Lo que resulta no homologable a las caracterizaciones más frecuentes sobre la crítica del período es que esos modos de intervención estuvieron atravesados por un vínculo inestable y ambiguo en torno a la experiencia de la época, según el cual quienes hacían las revistas Ciclo, poesía buenos aires, A partir de cero y Letra y Linea buscaron adoptar posiciones asociadas a valores propios de las vanguardias (la idea de "júbilo", 4 el rechazo a la idea de retórica y al lamento como forma de expresión, el rechazo a la solemnidad, al progreso), pero no pudieron sustraerse de asignarle al arte y la literatura una misión fundamental en la "causa del hombre" (Podlubne 2014). Por otra parte, sus intervenciones no estuvieron orientadas hacia el estudio de personalidades literarias, ${ }^{5}$ sino al armado de selecciones autorales; este aspecto es correlativo al hecho de que ninguno de los integrantes de las revistas del corpus se constituyera a sí mismo en torno a la figura del crítico.

\footnotetext{
${ }^{3}$ En Marxismo y Literatura, Raymond Williams ha observado que la tradición siempre es "algo más que un inerte segmento historizado", ya que se trata de un medio "poderosamente operativo en el proceso de definición e identificación cultural y social". En ese sentido, se opone a las lecturas que la han considerado "un segmento histórico relativamente inerte de una estructura social" (2009:158). En base a de estas consideraciones propone comprender no "una tradición", sino una tradición selectiva, y afirma: "A partir de un área total posible del pasado y el presente, en una cultura particular, ciertos significados y prácticas son rechazados o excluidos. No obstante, dentro de una hegemonía particular, y como uno de sus procesos decisivos, esta selección es presentada y habitualmente admitida con éxito como "la tradición", como "el pasado significativo". Lo que debe decirse entonces acerca de toda tradición, en este sentido, es que constituye un aspecto de la organización social y cultural contemporánea del interés de la dominación de una clase específica. Es una versión del pasado que se pretende conectar con el presente y ratificarlo" (2009:159). Nos interesa destacar, principalmente, el carácter de "presente" que le da Williams a la noción de tradición, por la cual es posible pensar las operaciones críticas de las revistas de nuestro corpus. Así, el trabajo de selección sobre las vanguardias históricas, se efectuó sobre motivaciones y condiciones que eran parte de la contemporaneidad que sobre la cual buscaban intervenir, y a la que pretendían modelar.

${ }^{4}$ El término es empleado por la revista Arturo (1944) en el marco del poema-manifiesto que abría la revista (ver imagen 1 y 2). Luego es recuperado por poesía buenos aires (1950, n1:1).

${ }^{5}$ A diferencia de Contorno, Sur, Buenos Aires Literaria.
} 
Es tipo de operaciones propuesto por revistas asociadas a "escuelas literarias" 0 "movimientos poéticos"7 no fue del todo advertido por un abordaje que se propuso caracterizar la crítica en términos de "modernización". La idea de que la crítica literaria, en Argentina, atravesó a mediados del siglo XX un proceso que podía ser nombrado de esa manera, y que habría comenzado con la revista Contorno (1953-1959), es una hipótesis historiográfica que podemos rastrear, con distintos énfasis, desde la edición del quinto tomo de la Historia de la literatura argentina de Centro Editor de América Latina (1982), donde se incluyeron los capítulos "La modernización de la crítica: la revista Contorno", por Mangone y Waryley, y "La crítica literaria contemporánea", por Nicolás Rosa, hasta un reciente dossier titulado Historia y usos hispánicos de la teoría (Nacher 2015). ${ }^{8}$ Dentro de esos énfasis observamos tres que son especialmente significativos para pensar la relación entre los modos en que fueron leídos los años 50 a partir de una concepción particular de "lo moderno en la crítica", y el tipo de operaciones que recuperamos del análisis de nuestro corpus. El primero de ellos consiste en identificar la modernización con un efecto de "irrupción" (Cella 1999) o "punto de viraje" (Avaro y Capdevilla 2004) según el cual habría una transformación notable entre un antes y un después. Para Avaro y Capdevilla, la ruptura se materializaba en "nuevos paradigmas", como el materialismo histórico hegeliano y el existencialismo (2004:12), que se oponían a la filología tradicional y la "estilística expresiva e idealista"; en ese sentido, el "sitio inaugural" asignado a Contorno, en la crítica literaria, estaría dado por haber propuesto otro modelo ideológico y metodológico de la reflexión sobre la literatura. La lectura de Cella también se refirió a esos nuevos paradigmas, como forma de caracterizar un momento en el cual la crítica literaria se apropió de sistemas teóricos -especialmente el marxismo, el existencialismo sartreano, el psicoanálisis y el estructuralismo- cuyas discursividades produjeron una "eclosión" en las escrituras locales (1999:52); en ese impacto que denomina "irrupción", Contorno sería el "punto de viraje" (38). De esta perspectiva se desprende el segundo énfasis, que vincula estrechamente la modernización de la crítica con las apropiaciones de la teoría en términos de "discurso" como forma de instalar un tipo de legibilidad reconocible. Tal es la noción propuesta por Nacher para una

\footnotetext{
${ }^{6}$ La denominación “escuelas literarias" es un término propio de las revistas y la época en general, como observamos a lo largo de la tesis.

${ }^{7}$ Se trata de una categorización de las historias de la crítica de 1982 en adelante.

${ }^{8}$ Para un análisis de la revista Contorno en relación a esta perspectiva y sus características, cfr.: Croce (1996, 1999, 2006), Rosa (1982, 1999, 2003), Terán (1986, 1991), Cella (1999), Mangone (1982, 1984), Avaro y Capdevila (2004).
} 
historia de los usos de la teoría en español, que comenzaría en Argentina con la revista Contorno, debido a que sus escrituras habrían renovado la crítica literaria en un "doble registro político y epistemológico" (2015:113), según una apropiación de la teoría literaria francesa. ${ }^{9}$ Estos dos énfasis, que señalan una singularidad extrema en la emergencia de la revista de los jóvenes "parricidas", como los llamaría Rodríguez Monegal en 1956, intervienen sin duda en la consolidación de lo que Jorge Panesi denominó "comienzo mítico" de la crítica literaria argentina (2018: 32 y 120). Por último, el tercer énfasis es el que señala una centralidad de la política como modo de leer la literatura y hacer de la crítica un tipo de intervención pública que alcanzara otros niveles de debate. El "abandono de una postura artepurista" (Cella 1999:34), "abocarse al examen inmediato de la realidad circundante" (Lafleur, Provenzano, Alonso 1962:243), "el compromiso intelectual" (Croce 2006:26, Teran 1999), la lectura de las relaciones de dominación a lo largo de la historia argentina en el desarrollo de la novelística nacional (Rosa 2003), fueron las conceptualizaciones que con mayor frecuencia definieron los alcances de la "política" en Contorno como elementos modernos respecto a las perspectivas anteriores, y por tanto disruptivos.

Por otra parte, las revistas Ciclo, poesía buenos aires, A partir de cero y Letra y Línea fueron leídas por las historias de la literatura argentina en el marco de otro proceso, denominado "segunda época vanguardista" o "vanguardia del 50" (Cristófalo 2007, Espejo 2009, Freidemberg 1984, Giordano 1983, del Gizzo 2017, Maturo 2015, Minguzzi 2013, Poblete Araya 2016). Estas lecturas privilegiaron un enfoque desde los programas estéticos del surrealismo y el invencionismo, centrado especialmente en los textos poéticos y aquellos de carácter claramente programático. La poética surrealista continuaba la idea de los diversos Manifiestos, ${ }^{10}$ la exaltación de la imaginación, la escritura automática, la síntesis de los opuestos, las "yuxtaposiciones insólitas" (Pellegrini 1948, n1:74), ${ }^{11}$ y la lucha contra el imperio de la razón. El invencionismo

\footnotetext{
${ }^{9}$ Uno de los aspectos singulares de la periodización de Nacher es que establece el puente entre Argentina y Francia a través del año 1953, citando la publicación de Le degré zéro de l'écriture de Barthes, y la aparición de Contorno, mientras que es la revista Letra y Línea, también de 1953, el lugar donde Barthes aparece mencionado por primera vez cuando Svanascini informa la salida de Les lettres nouvelles (1953), y consigna su sumario. Si bien la reseña de Barthes, que apenas se menciona como un título más entre otros de los artículos de la revista de Nadeau, es sobre una pieza teatral, y no sobre Le degré, es significativo que parezca más plausible su vinculación con Contorno, aun cuando nada indique una conexión, que con cualquier otra revista donde un detalle contingente e insignificante lo pone de relieve.

${ }^{10}$ Señalamos en cursiva "Manifiestos" aludiendo a los dos Manifiestos del surrealismo, que fueron editados de forma conjunta como libro, después de 1945.

${ }^{11}$ Para la citación de artículos que forman parte de las revistas del corpus o fuentes complementarias, se ha elegido el siguiente criterio: el señalamiento del año en primer lugar, el número de la revista al cual
} 
poético, por su parte, se reconocía en la línea de las vanguardias constructivistas que ponían en primer plano el uso de la razón, en tanto medio para liberar al arte de las representaciones, las alegorías, las significaciones ocultas y simbolismos (Bayley 1945 n1, $1950 \mathrm{n} 1$ ); en ese sentido, proponía imágenes tan inventivas como las surrealistas pero rechazaba el automatismo y el valor diferencial del sueño. A pesar de esas diferencias, fueron programas caracterizados desde la oposición con respecto a la denominada "generación del 40", a cuyos poetas consideraban "neorrománticos", "neorrealistas" y principalmente elegíacos; la literatura asociada al peronismo y el tipo de poesía difundido por la revista Sur. ${ }^{12}$

Lo que estas caracterizaciones historiográficas ponen de manifiesto es que los procesos nombrados como "modernización de la crítica" y "segunda época vanguardista" han sido entendidos como procesos separados, atribuyendo a la idea de "crítica moderna" un modo de intervención estrictamente ligado a la lectura de la dimensión políticoideológica de la literatura y la construcción de discursividades reconocibles por los trazos teóricos que incorporan; y delimitando la idea de "vanguardia" a una caracterización estética que no advertiría el carácter relacional de sus intervenciones, ${ }^{13}$ así como tampoco la posibilidad de construir operaciones críticas de lectura.

El vínculo casi inequívoco entre una idea de "modernización", tal como la caracterizamos anteriormente, y el surgimiento de la revista Contorno como su fundamento ha sido puesto en discusión por algunas investigaciones recientes. La tesis doctoral de Guido Herzovich (2015), titulada La desigualdad como tarea. Crítica literaria y masificación editorial (1950-1960), propone leer la década del 50 a partir de otras publicaciones, entre las que incluye a Letra y Línea, y otros matices como las transformaciones del campo editorial; asimismo, en La conspiración de las formas. Apuntes sobre el jeroglifico literario, Maximiliano Crespi (2011) abordó la revista Letra y Línea como un "artefacto" que se sustrae a los imperativos políticos y morales de la

corresponde, y el número de página; en la referencia bibliográfica se encontrará, además, el nombre de la revista completa. En muchas oportunidades, de un mismo autor se refieren más de un artículo por año; para esos casos, el lector debe guiarse por el número de publicación señalado.

${ }^{12}$ Un tratamiento sobre estos aspectos lo veremos en el capítulo I.

${ }^{13}$ Desde nuestra perspectiva, y en relación con lo que nos interesa leer del corpus, "vanguardia" no es un atributo, sino una relación y una biblioteca. El carácter relacional que le asignamos alude a aquello que las vincula con valores, imágenes, y morales de la literatura asociadas a los movimientos estéticos de vanguardia; la idea de biblioteca designa al conjunto de autores (diversos en épocas y procedencias) que las revistas pusieron a funcionar según sus propios agrupamientos. En la articulación de estos dos aspectos es posible leer el sentido de vanguardia como forma de posicionamiento e intervención en los debates, antes que en términos de un programa a cumplir. 
época y se opondría al proyecto de Contorno. Raúl Antelo (2004, 2013, 2014) leyó el carácter crítico de la revista Ciclo como espacio de resonancia para algunas de las perspectivas posthumanistas de Georges Bataille, que resultaron diferenciales (y según su perspectiva, más modernizadoras) respecto del existencialismo sartreano propuesto por Contorno. Asimismo, vinculó muchas de las intervenciones de Aldo Pellegrini como ensayista y conferencista, con una noción de sujeto en tanto "nadería de la personalidad", en diálogo con la concepción borgeana de la literatura. Por último, Judith Podlubne (2012, 2014) ha retomado los trabajos ya clásicos de Jorge Panesi sobre Contorno y Sur (2004), para desarrollar el modo en que la preponderancia de una perspectiva humanista en los años 50 había sido un limitante para los debates literarios, entre cuyas causas encuentra un episodio manifiesto de "resistencia a la teoría" (De Man 1990a) en el pensamiento contornista sobre el lenguaje. En ese sentido, antes que una "modernización", Podlubne lee un momento reactivo de la reflexión teórica a todo aquello que pusiera en crisis la utilidad y la capacidad comunicativa de la literatura. No obstante estas investigaciones que han sido fundamentales en el desarrollo de las hipótesis propias sobre los modos en que Ciclo, poesía buenos aires, A partir de cero y Letra y Línea intervinieron desde la crítica, no se ha pensado hasta el momento la relación crítica-vanguardia como un problema de conjunto según se manifestó a mediados de siglo en Argentina. En esa relación fue crucial la pregunta por la temporalidad, ya sea que esta se configure en torno a qué es lo contemporáneo, o los vínculos entre arte, literatura e historia, o las implicancias de las genealogías literarias en el presente.

A continuación presentamos las características generales de las revistas del corpus, a partir de las cuales se desprenden las hipótesis crítico-metodológicas que buscamos plantear a lo largo de la tesis, y que pretenden intervenir en los fundamentos sobre los cuales se ha apoyado una idea de modernización. El objetivo principal de la tesis es dar cuenta del modo en que las revistas Ciclo, poesía buenos aires, A partir de cero y Letra y Línea configuraron una serie de intervenciones críticas entre 1948 y 1956, que pueden ser puestas en diálogo con las operaciones que la crítica especializada señaló en la revista Contorno, y al mismo tiempo amplían las consideraciones sobre el período, proponiendo algunos matices menos codificados en torno a los debates sobre arte y literatura en los que participaron. ${ }^{14}$

\footnotetext{
${ }^{14}$ Este tipo de operaciones ha sido pensada por Raúl Antelo (2015a, 2015b) como una sintaxis historiográfica de las conexiones, según la cual se trata de disponer "un objeto cultural en otras redes", que no son las de su procedencia aparente.
} 


\subsubsection{Presentación del corpus}

La caracterización de la "modernización de la crítica" y la "segunda época vanguardista" en tanto procesos poco conectados y que alcanzarían a objetos culturales diferentes (por un lado a Contorno, y por otro a las diversas revistas vinculadas con los movimientos estéticos), ${ }^{15}$ fue advertida como insuficiente, en nuestro punto de partida, cuando nos encontramos con la lectura del nombre "Aldo Pellegrini"" en el número 5/6 de la revista Contorno (1955), en el marco de una polémica con uno de sus colaboradores, Osiris Troiani. Ambos autores debatían allí acerca del lugar del crítico en la historia, y se hacía referencia a diversas publicaciones de la época. El intercambio epistolar entre Troiani y Pellegrini había sido escasamente analizado o mencionado solo de manera aislada en las investigaciones especializadas sobre los años 50. El rastreo de las condiciones y circulación de esa polémica dio lugar a un corpus conformado por las revistas que consignamos al inicio de esta introducción.

Ciclo. Arte, literatura y pensamiento modernos (ver imagen 3 y 4) publicó dos números durante los años 1948 y 1949, con un "comité directivo"17 integrado por Aldo Pellegrini, Elías Piterabarg y Enrique Pichon-Rivière. Los dos primeros habían formado parte de la revista Qué (1928-1930) -publicación surrealista hecha casi enteramente de textos poéticos y manifiestos a través de la escritura automática, firmados con seudónimos-, junto a David Sussman, que ocupaba, en el nuevo proyecto, el lugar de la “administración" (ver imagen 5). Por otra parte, Ciclo involucró a representantes paradigmáticos del arte concreto en Argentina, como Tomás Maldonado, Raúl Lozza y Edgar Bayley, en lugares fundamentales de la revista: diseño, diagramación y reseñas. Asimismo, cada número contiene en la portada un retrato pequeño de dos artistas vinculados a las vanguardias constructivistas, Lázló Moholy-Nagy y Piet Mondrian (ver

\footnotetext{
${ }^{15}$ Nos referimos a "diversas" publicaciones y no a las cuatro que mencionamos desde el comienzo porque, como analizamos en el primer capítulo, hubo otras revistas vinculadas a otros movimientos estéticos a partir de 1944, que se circunscribieron al cumplimiento de su propio programa artístico-literario.

${ }^{16}$ Pellegrini es, en la cultura argentina y latinoamericana, conocido como la figura artística que difundió el surrealismo en el Río de La Plata con traducciones hasta entonces inéditas (El heresiarca de Guillaume Apollinaire, Manifiestos surrealistas de André Breton), creador de la Asociación de Artistas Modernos de la Argentina en 1952, director de colecciones editoriales (en Argonauta y editora Fabril), donde compiló antologías de las vanguardias estéticas, entre ellas la Antología de poetas surrealistas que ha sido formadora de nuestras lecturas más tempranas, y director de revistas.

${ }^{17}$ La denominación es de la revista.
} 
imagen 3 y 4). Las estéticas que caracterizaron a ambos contrastan, respectivamente, con el primer ensayo crítico de cada número, ya que "La moral de Henry Miller" de Georges Bataille, en el primero y "Vida e imagen del Conde Lautréamont" de Enrique PichonRivière, en el segundo, se ocupaban de autores cuyas estéticas están marcadas por la exuberancia, los excesos y desbordes de lo representable. En relación con el contenido de la revista, el noventa y cinco por ciento de las páginas de Ciclo (95 en el primero y 82 en el segundo) fueron dedicadas a textos críticos y documentos teóricos. Las traducciones de autores extranjeros -como André Breton, Max Bill, Piet Mondrian, Lazló MoholyNagy, también René Char, Jean Cassou, Sebastián Salazar Bondy, el italiano radicado en Buenos Aires Ernesto Nathan Rogers y el ya mencionado Bataille- se intercalaban con ensayos críticos de los integrantes de la revista, y algunas colaboraciones externas solicitadas para el espacio de reseñas, titulado "Notas y comentarios".

Estos aspectos (la composición del grupo editorial, la relación entre elementos indiciales como las imágenes de portada y el contenido, y la preponderancia del género ensayo en el sumario) nos permiten afirmar que la propuesta de Ciclo se construyó por fuera de una determinada escuela estética, y privilegió, en cambio, una reflexión crítica sobre el arte moderno a partir de la cual observamos la insistencia en un conjunto de criterios de lectura que pusieron en cuestión que el artista tuviera que ser un cronista de su época (Char, Salazar Bondy), el abandono de las preocupaciones formales en el arte y la literatura (Moholy Nagy, Rogers, Pellegrini), ciertas perspectivas del historicismo marxista (Cassou), una concepción del tiempo como progreso (Bataille), y en términos generales, la perspectiva según la cual la caducidad de determinado grupo o movimiento de vanguardia clausuraba sus efectos en el presente.

poesía buenos aires (ver imagen 6) se publicó a lo largo de diez años, sin interrupciones, entre 1950 y 1960. Fue tal vez la más emblemática de las revistas en relación con las renovaciones poéticas en Buenos Aires a mediados de siglo XX, recordada especialmente por haber publicado a Francisco Urondo, Leónidas Lamborghini, Alejandra Pizarnik, Hugo Gola y Juan L. Ortiz. Raúl Gustavo Aguirre fue el único director que se mantuvo desde el primero hasta el último número (un total de treinta), mientras que Jorge Enrique Mobili, Wolf Roitman, Nicolás Espiro y Edgar Bayley fueron sucediéndose como codirectores. ${ }^{18}$ Se trató de una revista exclusivamente

\footnotetext{
${ }^{18}$ Excepto Bayley -entonces conocido por su participación protagónica en Arturo, Cuadernos de Invención, Arte Concreto Invención y Contemporánea, y autor de un libro que reunía sus poemas escritos entre 1944 y 1949 (En común) - quienes integrarían poesía buenos aires no habían publicado libros de poesía para
} 
dedicada al género poético, en torno al cual observamos una búsqueda insistente por definir la función del poeta y una concepción propia de poesía. En esa búsqueda es posible rastrear una serie de contradicciones según las cuales el poeta era tanto un "profeta", como el hacedor de "una poesía desmantelada".

De las revistas que aquí analizamos, poesía buenos aires fue la que se apropió más explícitamente del término "vanguardia”, tanto para configurar una posición -“¡Nunca dejaremos la vanguardia!” (Espiro 1951, n5:1) - como para definir los alcances generacionales (Móbili 1951, n4:1). Por otra parte, a lo largo de los números, la revista fue dejando atrás el término "invencionista" que había adoptado de una serie de publicaciones con las que se referenciaba, como Contemporánea (1948-1950), los cuadernos Invención de la Asociación Arte Concreto Invención, y el Suplemento poesía de la misma asociación. Como contraparte de ese abandono, las palabras que cobraron relevancia fueron las de "contemporáneo" y "nuevo" como formas problemáticas en las que intentaron definir los alcances de una poesía que consideraban renovadora con respecto a formas pasadas. A partir de la especificidad del género poético y el abandono de una inscripción estética particular, advertimos que las intervenciones de poesía buenos aires están moduladas por la necesidad de establecer criterios de selección que justifiquen no solo a los poetas que eligen publicar, sino también al conjunto poético en que los dan a leer. En ese sentido, la revista reflexiona en distintas oportunidades sobre el carácter de "colección" o "antología" (utiliza los dos términos) que tiene su tarea.

A partir de cero. Revista de poesía y antipoesía (ver imagen 7 a 9) tuvo dos etapas, en 1952 y 1956. Durante la primera publicó dos números bajo la dirección de Enrique Molina; mientras que para la segunda etapa, la revista señalaba una "redacción", integrada por Carlos Latorre, Julio Llinás, Francisco Madariaga, Enrique Molina, Aldo Pellegrini y Juan Antonio Vasco. En 1952, las ilustraciones de Juan Batlle Planas introducían la estética surrealista del montaje y el grabado, a la vez que daban una organicidad visual a lo largo de ocho páginas en formato oblongo, ya que fue el único productor de imágenes a lo largo de las páginas. En el tercero, en cambio, hubo casi tantos autores de imágenes como de textos, y las estéticas fueron más variadas: fotomontaje, grabado, collage, estética pop, malditismo (ver imagen 10 a 16$)^{19}$. A partir de cero es, de las revistas del

1950. Tal vez por ese motivo conformó rápidamente un sello editorial acompañaría la intervención de la revista con un catálogo editorial de dieciocho libros.

${ }^{19}$ Es significativo que la imagen de portada del número 3 estuviera a cargo de Juan Fassio, fundador del Colegio de la Patafísica en Buenos Aires, y colaborador en el último número de Letra y Línea, de 1954, con un estudio sobre Jarry y Les Cahiers du Collége de 'Pataphysique, ya que en la epistemología de lo 
corpus, la única que mantiene una relación de reconocimiento con el surrealismo como movimiento estético, que es definido en el marco de una "línea viva del pensamiento contemporáneo" (Molina n1:1952) que se remitiría hasta el romanticismo alemán. Entre los contenidos, se publicaron textos poéticos de los integrantes de la revista, y otros autores como Benjamin Péret, Giselle Prassinos, André Breton, Paul Eluard, Antonin Artaud, Leonora Carrington, Olga Orozco, Blanca Varela, Antonio Porchia, César Moro, y Georges Schehadém. En la etapa inicial, solo los últimos poetas fueron presentados con semblanzas críticas, y Benjamin Péret fue objeto de un "homenaje especial" con un texto introductorio breve. Se destacaron en cambio los ensayos sobre poesía de Enrique Molina y Aldo Pellegrini, que abrieron y cerraron cada publicación. Son textos confrontativos que formularon una serie de concepciones sobre la lengua e imagen poética, a partir de las cuales la revista asumió una posición polémica con otros espacios de la literatura contemporánea como Sur, la S.A.D.E., los suplementos literarios de la prensa masiva, los escritores vinculados partidariamente con el realismo social y otros autores como Jorge Luis Borges y Raúl González Tuñón.

En relación con estas características, advertimos que $A$ partir de cero intervino en las discusiones sobre la literatura de mediados de siglo, proponiendo articulando genealogías que, pesar de ser "anteriores", resultaban de un carácter prospectivo con respecto a la poesía actual. Por otra parte, Aldo Pellegrini elaboró allí la idea de "imagen en combustión" como figura crítica, que presenta una serie de matices en relación a la temporalidad de la literatura, que se diferenciaron de otros modos de leer la articulación entre época y literatura.

Letra y Línea (ver imagen 17) se publicó en octubre de 1953 con el subtítulo "Revista de cultura contemporánea. Artes plásticas. Literatura. Teatro. Cine. Música. Crítica”, y se extendió hasta julio de 1954, con cuatro números en formato tabloide, de dieciséis páginas cada uno. El director fue Aldo Pellegrini, con un "comité de redacción" conformado por Osvaldo Svanascini, Mario Trejo, Miguel Brascó, Carlos Latorre, Julio Llinás, Enrique Molina, Alberto Vanasco y Ernesto B. Rodríguez, al que se sumó Juan Antonio Vasco en el tercero, y Juan José Ceselli, Juan Esteban Fassio y Francisco Madariaga en el cuarto. Una de las características del comité consistió en la diversidad de trayectorias e intereses estéticos que articuló, ya que sus integrantes se identificaron con

\footnotetext{
"anexacto" de la 'patafísica hay diversas claves para volver a pensar el lugar de las vanguardias a mediados de siglo.
} 
el surrealismo solo parcialmente. Por otra parte, esa diversidad se condensó en la imagen inaugural de la revista, a partir de la elección de un retrato de Roberto Arlt en la portada del primer número (ver imagen 17), donde a su vez la novelística del autor fue objeto del primer ensayo crítico, firmado por Alberto Vanasco. Este aspecto abre una serie de conexiones con la revista Contorno, que meses más tarde publicaría el dossier sobre Arlt en su segundo número. Asimismo, el interés por Arlt no fue un episodio aislado en relación con narradores de la literatura argentina, sino que Letra y Línea se ocupó también de escritores como Eduardo Mallea, Manuel Mujica Láinez, Ernesto Sábato, Valentín Fernando, hacia los cuales adoptó un tono fuertemente polémico; por otra parte, publicó textos literarios de Juan Carlos Onetti, Norah Lange, Arthur Miller y Juan Filloy. Estas selecciones convivieron con ensayos dedicados a poetas representativos de las vanguardias, como Vicente Huidrobro, Aimé Césaire, Henri Michaux, Francis Picabia, Oliverio Girondo, Alfred Jarry y las derivas de su obra en el Colegio de la 'Patafísica, Tristan Tzara.

En la "Justificación" inicial -tal es el nombre del texto que figura como editorialla revista propuso pensar el carácter de ambiguo, no sincrónico, de la contemporaneidad en la literatura. Afirmaba allí que los más contemporáneos no eran quienes compartían un tiempo cronológico común y actual, sino aquellos que experimentaban una vivencia íntima con su época y eran resistidos por la legibilidad de su tiempo, por oposición a aquellos que Letra y Línea se proponía desenmascarar: "Numerosos son los embaucadores que se aprovechan de lo nuevo para medrar. ¡Ojalá fuera siempre posible señalarlos! En ocasiones son tan hábiles y estrategos que sólo el tiempo, al demostrar su nadería, los destruye" (1954, n1:1).

En ese sentido es posible afirmar que la revista se propuso intervenir en la "cultura contemporánea" haciendo de este último término un uso particular, sobre el cual concluyó que era necesario emprender una "tarea discriminativa" desde la crítica literaria. Esta tarea se llevó a cabo, desde nuestra lectura, en un movimiento doble. Por un lado, en los ensayos sobre aquellos autores que la revista estimaba, se expusieron criterios de lectura que caracterizaban a un "contemporáneo", como la desobediencia a los imperativos morales, sociales, ideológicos y políticos de una época, y que lo distinguía de los "actuales" o "embaucadores de lo nuevo". Como un pliegue de ese mismo movimiento, Letra y Línea se ocupó de las novedades del mercado editorial, donde puso a prueba el ejercicio de diferenciación a partir de los valores que atribuía a lo "contemporáneo". Sin embargo, desde nuestra perspectiva, la tarea de diferenciación que se propuso Letra y 
Línea fue presa de lo que aquí llamamos "paradoja de la contemporaneidad"; es decir, quedó inconclusa en tanto el carácter inasible que la misma revista había otorgado al término entraba en conflicto con las exigencias que le imprimió para que fuera una herramienta crítica.

A partir de las características señaladas en la presentación de cada revista, configuramos el objeto de nuestra tesis: las escrituras críticas en las revistas surrealistas e invencionistas entre 1948 y 1956. La idea de moral para referirnos a ellas está asociada al modo en que Roland Barthes pensó morale de la forme en Le degré zéro de l'écriture: como un movimiento antes que un concepto, donde, según la apropiación del término propuesta por Alberto Giordano $(1995,2014)$, actúan “fuerzas” de forma simultánea y muchas veces opuestas. Así, una moral de la crítica comprende tanto la referencia a una posición o un valor -aquello que se quiere que la literatura sea- como el momento de extrañeza que desestabiliza tal posición. ${ }^{20}$ Esto nos permitió pensar el modo en que las intervenciones críticas de las revistas del corpus estuvieron atravesadas por lo que denominamos como "dilema de la vanguardia" en torno a la cultura argentina. Los deseos de renovación artístico-literaria motivados por una biblioteca propia de las vanguardias artísticas y un repertorio de valores e imágenes asociados a ellas, fueron simultáneos a un cuestionamiento de la eficacia de los manifiestos, y una experimentación de la época como "agobio" (Aguirre 1950, n1:1) con matices elegíacos que las revistas se proponían rechazar. Así, este "dilema" se configura en torno a una temporalidad inestable que recupera elementos del pasado para pensar lo nuevo, tensionada por la renovación y el lamento.

Como esa mirada ambigua, la noción "morales de la crítica" alude a la indagación en aquellos momentos que las escrituras de las revistas Ciclo, A partir de cero, poesía buenos aires y Letra y Linea manifiestan una extrañeza en aquello que leen, una experiencia de descalabro o desubjetivación, pero luego comparten un horizonte culturalmente aceptado e incuestionable, como los valores del humanismo que contemplan la convicción de que el espíritu del hombre es una entidad trascendental.

\footnotetext{
${ }^{20}$ Dice Barthes al respecto: Encontramos, en toda escritura, la ambigüedad de un objeto que es a la vez lenguaje y coerción: existe en el fondo de la escritura una 'circunstancia' extraña al lenguaje, como la mirada de una intención que ya no es la del lenguaje [...], y una "justificación" (2011:23-24). A partir de ese análisis, la noción "moral de la forma" aparece en muchos momentos aparece asociada a la ambigüedad que emerge cuando expone un encuentro con lo extraño de la lengua que luego se recuesta en valores ya dados: "toda huella escrita se precipita como un elemento químico, primero transparente, inocente y neutro, en el que la simple duración hace aparecer poco a poco un pasado en suspensión" (2011:22).
} 
0.1.2. Perspectivas de análisis: las revistas como aparatos estéticos

La conformación y el abordaje de tal objeto "escrituras críticas en las revistas surrealistas e invencionistas entre 1948 y 1956" nos permiten volver sobre los fundamentos que caracterizaron la idea de modernidad crítica, a mediados de siglo, según los tres énfasis que señalamos al inicio (la idea de "irrupción", la cristalización de las discursividades teóricas en las escrituras críticas locales, y una correlación particular con la política). Así, la idea de un tiempo de la "irrupción" puede ser repensada en términos de "historia del medio", según denominó Jean Louis Déotte $(2012,2013)$ a una teoría no acontecimentalista de la historia, que permitiera leer la "neblina" de un tiempo no definido. A partir de ese enfoque es posible conjugar la "eclosión discursiva" o el sentido de "ruptura" con el que se caracterizó a la crítica del cincuenta desde la lectura de Contorno con otras las escrituras críticas de nuestro corpus, que no pueden ser analizadas únicamente desde los fundamentos de la "modernización de la crítica". La perspectiva de Déotte se funda, además, en una concepción de "aparatos estéticos"21 -relevante para nuestro objeto de estudio- como aquello que constituye una técnica del aparecer e inventa una relación propia con el tiempo. ${ }^{22}$ Por invención, entiende "no hacer surgir ex nihilo, sino hacer visible lo que estaba allí sin ser visto, del mismo modo que se inventa un tesoro. Hacer aparecer, separar de un caos, de un magma" (2013:50).

Lo que se articula entre invención de un tiempo y técnicas del aparecer es, entonces, una noción de época en tanto “ektasis"-suspensión y acontecimiento a la vez. En contraposición a la lectura acontecimental, aquello que no se ha consolidado del todo en la historia de la crítica literaria argentina -los modos de leer de las revistas de la vanguardia a mediados de siglo XX-produce una "diferencia de tiempos", haciendo "surgir tal o cual temporalidad que se convierte en su propia invención" (50). Se trata, en

\footnotetext{
${ }^{21}$ Si bien Déotte es claro al indicar los cinco aparatos que considera fundamentales de la modernidad cine, fotografía, museo, psicoanálisis y perspectiva - es posible transferir algunas de las condiciones que señala al espacio de la gráfica tal como se exhibe en las revistas. Matías Moscardi en su tesis sobre editoriales de los años 90 ha demostrado la productividad de este concepto para pensar otros soportes de las textualidades y visualidades.

${ }^{22}$ En el sustantivo "appareil" (aparato) confluyen distintas inflexiones: el "appareillage" (emparejamiento / ensamble), el "être en simple appareil" (la desnudez), y el "apparaitre" (aparecer), como las aristas de una sensibilidad, a partir de las cuales Déotte explora la función de "hacer semejante", de "emparejar": comparar lo que hasta ahora no era más que heterogéneo - en nuestro caso, morales de la crítica e imágenes de la vanguardia.
} 
términos de Benjamin, de la emancipación del tiempo, una mónada de tiempo que amenaza siempre con rehacer las imaginaciones, y por tanto los imaginarios.

Déotte repensó esa liberación del tiempo como "historia del medio" o "tiempo del olvido" (43), historia que se encuentra en el espacio aparentemente homogéneo, continuo y por tanto desatendible, anterior a un acontecimiento. La noción de "época" en tanto acontecimiento estaría escandida filosóficamente en dos variables. Una es la irrupción como evidencia - por ejemplo, la bomba de Hiroshima y la posibilidad así afirmada de poder destruir toda vida sobre la Tierra; la otra es la estructura archivística de todo acontecimiento, dice Déotte, ya que por su condición de inaudible no hay contemporaneidad entre el acontecimiento y el testigo. Esta estructura se explicaría por la temporalidad del après-coup freudiano: “cuando eso llegó, el testigo no tenía la capacidad de atestiguar; cuando la tuvo, cuando pudo inscribir el acontecimiento, la cosa había pasado desde hacía largo tiempo" (31). Ahora bien, esta lectura del tiempo no está escindida de los modos de leer la historia, ya que, siguiendo el razonamiento de Déotte, si el tiempo del après-coup no se ha emancipado de la primera noción (la época como evidencia), hace de la historia una especie de pasaje olvidado, porque considera solo un origen de partida y una inscripción como momento de llegada. Así, el tiempo que se encuentra entre los dos momentos del après-coup es un "tiempo no bendecido por los dioses", según Heidegger, "tiempo finalmente sin espesor, de la repetición de lo mismo" (42), o un tiempo de la alienación de la humanidad según Marx, ya que "entre el comunismo primitivo de las tribus germánicas y el comunismo realizado a escala mundial" solo hay "sucesión de formas de lo mismo: la sociedad de clases, según las variantes sucesivas de la esclavitud, el feudalismo, el capitalismo" (42). Por este motivo, el problema de muchas concepciones de la historia ha sido pensar la época como la configuración de un acontecimiento que deja en el espacio de la niebla o del olvido lo que no se inscribe en él:

Se debe regresar a un pensamiento de la época como estasis: detención, detención de juicio, suspensión. Es preciso llegar a decir: hay una multiplicidad de épocas, de mesetas, sin que ninguna pueda ser la última. Es necesario llegar a pensar la desmultiplicación de épocas como sucesión de invenciones de lo que hay de más esencial: las formas de la temporalidad. La época intermediaria, la del olvido y la alienación, debe desaparecer para dejar lugar a una complejización interminable de formas del tiempo y, entonces, de la ficción. (2013:45)

La época intermediaria del olvido y la época intermediaria de la alienación son las de Heidegger y Marx, según las cuales habría un tiempo vacío hasta el momento del 
acontecimiento. Contrariamente a esa forma de leer la historia que caracteriza como teleológica, Déotte propone comenzar por el medio. Toma la estructura del acontecimiento para hendir la Historia y partir de eso que hay entre los dos tiempos del après-coup, "emparejar" esos tiempos desarmando las jerarquías por las cuales la época verdadera se constituiría “después". Así esa fase intermedia deja de ser la historia entendida como "niebla donde las cosas del pasado son indistintas y poco dignas de interés" (43).

Si por el contrario, se parte del "medio", ya no hay dos puntos de tiempo, y eso que era neblina indistinta puede leerse como suspensión; por lo tanto es posible identificar allí "multiplicidad de épocas" sin que ninguna sea la última (el momento consolidado de la inscripción). Así, siempre se podrá interrumpir la Historia, producir un viraje y "reintroducir, siguiendo a Benjamin, a cada instante la posibilidad de dar vuelta la historia como a un guante", para romper la "ley de hierro" o "irreversibilidad" que se construyó en torno a una "segunda época" o "lo que está en el medio" (45). El après-coup pierde su momento de redención, y la historia se abre como "coincidencia de la diferencia de los tiempos". Se ve, entonces, que estamos pensando nuestra historia del medio o tiempo del olvido. Si Contorno fue leída, a partir de su primer editorial "Los martinfierristas: su tiempo y el nuestro", como el otro punto de la irrupción con respecto a lo que significó Martín Fierro (1924-1927), es decir, un après-coup interpretativo de la generación de vanguardia, una perspectiva de la época como ektasis nos permite leer la niebla donde se encuentran estas otras escrituras críticas y polémicas. Eso que Guido Herzovich en su tesis doctoral llama "el iceberg" debajo de la punta que significaron Contorno, Centro y Las ciento y una (2015: vi). Para Déotte, la época entendida como suspensión es permitida por "los aparatos por cuanto ellos van a inaugurar, cada vez, según sus características, una nueva espacio-temporalidad" (2013:46). ${ }^{23} \mathrm{Si}$ los aparatos inventan para la época otra relación con el tiempo y por tanto con lo sensible dado, las revistas se recortan de esa noción como una materialidad propia que establece los modos de diferenciación y desajuste en el proceso de invención.

\footnotetext{
${ }^{23}$ Esta perspectiva cuestionaría una operación historiográfica que asigna productividad a determinados objetos en un tiempo posterior, especialmente si acaso se trató de materiales no considerados en la masividad o el impacto del tiempo de sus propias condiciones de surgimiento. Por ejemplo: "Las revistas más significativas han anticipado líneas críticas y teóricas que, en el momento de su enunciación, acaso no formaron parte del eje de los debates, pero luego se convirtieron en centrales" (Battilana 2015), o "Es posible distinguir entre aquellas revistas que funcionan como una institución, impartidora tradicional de una legitimidad cultural buscada por muchos y renegada por otros, y las que no contienen el peso de esa tradición y por su carácter coyuntural e innovador se permiten un grado de intervención más agudo y definitorio sobre las problemáticas de la cultura" (Schwartz, Patiño 2004).
} 
Desde este abordaje revisamos los alcances y limitaciones de un enfoque como el propuesto por la idea de "eclosión discursiva". Al igual que la idea de "irrupción", permitió caracterizar de manera ajustada aquello que tuvo un impacto lo suficientemente significativo, legible y expansivo como para ser nombrado de esa forma. Sin embargo, la emergencia de aquellos objetos que fueron atravesados por otras experiencias en torno al tiempo y las discursividades que lo modularon, no puede ser leída desde figuras como las de irrupción o eclosión. A partir de esa limitación, elaboramos la imagen del bullicio de la crítica como forma de acercarnos a las revistas de nuestro corpus atendiendo al tipo de intervenciones críticas que las caracterizaron. Con este término aludimos, en primer lugar, a la ausencia de figuras autorales críticas fuertes, por contraposición a las trayectorias autorales más estudiadas desde la idea de la "irrupción” (David Viñas, Adolfo Prieto, Oscar Massota, Héctor Murena). Así, la fuerza de esos “vozarrones” (Lennard 2004, Avaro y Capdevila 2004) entra en contacto con una forma de la enunciación más inestable donde convergen, de forma contradictoria, diversas inquietudes sobre la época, más o menos cristalizadas. En ese sentido, en el bullicio no habría una "asimilación" de la teoría, según el decir de Cella (1999) sino contactos y apropiaciones aleatorios. Por otra parte, lo múltiple, superpuesto y asistemático del bullicio se vuelve descentrado respecto a las configuraciones políticas acontecimentales; por lo tanto, el modo de estas escrituras de entrar en contacto con la dimensión política de su época es refractario con respecto a los esquemas de la serie histórica. A partir de estas perspectivas, decidimos organizar el análisis de nuestro objeto según tres tipos de operaciones críticas que observamos en las revistas Ciclo, poesía buenos aires, A partir de cero y Letra y Línea. Cada una de esas operaciones es el eje de un capítulo.

\subsection{Presentación de los capítulos}

En el Capítulo I abordamos la conformación de una moral crítica del anacronismo según se desprende de los modos en que cada revista interrogó los vínculos entre vanguardia, crítica y temporalidad. Uno de los conflictos que atravesó a las publicaciones fue la relación ambigua que sus integrantes establecieron con la época, según leemos en un conjunto de ensayos. A la vez que buscaron rechazar posturas ligadas a la melancolía, 
la angustia o la elegía, muchas de sus escrituras metaforizaron la experiencia del presente como un "tiempo agobiado" o un "desierto". Esta ambigüedad tiene un correlato en las reflexiones que les suscitó pensar el arte y la literatura desde los valores de la vanguardia, la certeza de que algo de ello había sido clausurado y simultáneamente insistir en los deseos de renovación. La moral crítica del anacronismo da cuenta del modo en que tales conflictos se inscribieron en determinados criterios de lectura -tanto en aquellos propuestos por los integrantes de la revista, como los que leemos en las traducciones incorporadas a las páginas. Se trata de una forma de componer la relación entre obra y época-historia-sociedad que se sustrajera a los imperativos eucrónicos y sincrónicos que la determinara (por ejemplo, la lectura histórica de una obra como representación de las condiciones económicas en que se gestó).

El uso del término "anacronismo" remite al modelo del tiempo que nos propone Jean Louis Déotte, ya que alude a una lectura no eucrónica de los fenómenos históricos. ${ }^{24}$ Nos interesa destacar tres matices de la noción que son relevantes para nuestros análisis, por un lado el carácter discontinuista señalado por Benjamin en las figuras del "salto" [Sprung] e iluminación por medio de las cuales determinados elementos de la tradición se actualizan en un vínculo intenso con el presente $(2014,1973,2016)$, y se produce un montaje de objetos que da lugar a un tiempo diferencial. En la misma línea benjaminiana, Didi-Huberman pensó al anacronismo como un "síntoma" (2015) que pone de manifiesto un elemento inesperado para el conjunto de $\operatorname{creencias}^{25}$ y representaciones de una época; a la vez significa, para el autor, el tipo de emergencias por las cuales determinadas imágenes retornan de manera "superviviente" $(2009,2012) .{ }^{26}$ Por último, tomamos el matiz que le dio Giorgio Agamben para definir al "contemporáneo" como aquel que entra en relación con lo no-vivido de su época, y por lo tanto es el menos actual (2008).

Estos rasgos del término "anacronismo", vinculados con la emergencia inesperada de cierto elemento, el cuestionamiento de las relaciones lineales entre época y representación, nos permitieron pensar las distintas intervenciones de las revistas, según

\footnotetext{
${ }^{24}$ No casualmente dos de los autores que más ha analizado Déotte son Walter Benjamin y Jacques Rancière. ${ }^{25}$ La incorporación de la idea de "creencia" es tomada por Didi-Huberman de Jacques Rancière en "El anacronismo o el pecado del historiador" (1996). Para este último el anacronismo es considerado como un pecado o error metodológico cuando se desconfía de que la forma del tiempo sea idéntica a la forma de la creencia. La eucronía es la consideración según la cual "ser un objeto de la historia es, pues, creer en la creencia "de su tiempo", pertenecer a su tiempo bajo la forma de la creencia, de la adhesión indefectible" $(\mathrm{s} / \mathrm{p})$, por lo tanto, "la creencia no es sino la forma subjetiva del tiempo. Es la semejanza del agente histórico con su tiempo. Ese simulacro de eternidad asegura la posición de verdad del historiador" (1996, s/p).

${ }^{26}$ Didi-Huberman propone una articulación entre método y emergencia de lo que aparece, según la cual la "temporalidad anacrónica" es reconocida cuando el "elemento histórico que la produce" se ve "dialectizado por el elemento anacrónico que la atraviesa” (2015:49).
} 
los modos en que ponen de manifiesto una moral crítica atravesada por los problemas de la temporalidad. En el caso de Ciclo, esta emerge en torno a la discusión con el historicismo y los discursos del fin de la vanguardia que pretendían volver a un régimen representacional del arte como imperativo de la época; en poesía buenos aires, dicha moral se configuró en torno a una experiencia ambigua del presente y la búsqueda por definir a sus "contemporáneos", sin apelar a la inscripción cronológica en el presente ni a la categoría de novedad; en A partir de cero, se cristalizó en la figura crítica de la “imagen en combustión", articulando relaciones entre el pasado y el presente no como herencias o sucesiones sino encuentro entre momentos significativos; y por último, en Letra y Línea, la moral crítica del anacronismo motivó la "tarea discriminativa" de diferenciar entre "contemporáneos" y "embaucadores de lo nuevo", y se configuró como una paradoja de la contemporaneidad ya que lo verdaderamente nuevo o "los auténticos exploradores de lo desconocido" no son alcanzados por las lecturas de la revista.

En el Capítulo II analizamos la articulación entre las nociones de "imagen" surrealista e invencionista, elaboradas por las revistas del corpus de manera afín a la biblioteca de vanguardia con la que se identificaban, y dos tipos de operaciones críticas la intervención polémica y la exposición de series de la crítica- cuyos objetos artísticos examinados no se restringieron a la exposición de procedimientos acordes con una escuela estética en particular. Ambas operaciones tienen en común la capacidad de configurar un problema de lectura en torno a la selección ${ }^{27}$ de autores que son puestos en contacto y las condiciones bajo las cuales se los agrupa. La diferencia crucial entre una y otra es que mientras la polémica es una operación motivada por un miembro de la revista, las series de la crítica intervienen a partir de una configuración de sentidos que se produce por lo que Déotte llama “técnicas del aparecer” $(2012,2013)$. La hipótesis que atraviesa este capítulo consiste en que la noción de imagen surrealista e invencionista propuesta por Ciclo, poesía buenos aires, A partir de cero, y Letra y Línea para pensar la escritura poética adquirió otros alcances en el marco de las dos operaciones señaladas. Esto se debería, desde nuestra perspectiva, a que las operaciones críticas estuvieron atravesadas por el problema de lo heterogéneo que desbordaba la caracterización de "surrealista" o "invencionista", y por lo tanto la noción de imagen resultaba contradictoria e insuficiente.

Asimismo, ambas operaciones se produjeron en el marco de la discusión sobre la caducidad de las vanguardias después de la II Guerra Mundial. Para abordar ese aspecto,

\footnotetext{
${ }^{27}$ Gramuglio (1989) pensó el problema de la selección como planteo de hipótesis, en tanto "problema por excelencia" de las historias de la literatura.
} 
recuperamos a través de distintas lecturas y reseñas de revistas de los años 50 en qué sentido la vanguardia se trató de "un problema" para la cultura contemporánea, qué discusiones se entablaron al respecto y qué imágenes pusieron en funcionamiento cuando hablaban de vanguardia

La noción de series de la crítica es, como se explica en la presentación del capítulo II, una construcción metodológica nuestra para leer los sentidos críticos que emergen de la disposición y agrupamientos de ciertas notas (por ejemplo, la lectura conjunta de un ensayo sobre Arlt, Wilfredo Lam y Juan Carlos Onetti en Letra y Línea). Si bien tiene un vínculo con lo que Sarlo (1992) denominó "sintaxis de revista" -efecto de las decisiones tipográficas, espaciales, gráficas y jerarquizantes que operaban en la puesta en página de sus textos y la serie que armaba entre ellos- ${ }^{28}$ busca diferenciarse de ese abordaje en el matiz teleológico que le asigna Sarlo cuando define a las revistas, a partir de esa operación, como "bancos de prueba", "plataforma de lanzamiento", o "laboratorio[s] ideológico[s]" que contribuye a una "interpretación del futuro" (1992:9-16). ${ }^{29}$ Por este motivo privilegiamos las perspectivas de Porrúa (2011) sobre el montaje y la forma, y de Rogers (2019) sobre las revistas como dispositivos de exposición. A partir del aporte de sus investigaciones y las características materiales de nuestro objeto, llamamos series de la crítica a la secuencia heterogénea de yuxtaposiciones que, en la reunión de materiales discursivos y visuales, producen un efecto de sentido diferente al que tiene cada material de forma aislada. De ese modo, la disposición técnica del aparato revista hace aparecer una imagen no contemplada en la enunciación de los integrantes de las revistas, así como tampoco previamente disponible en la biblioteca de vanguardia.

En el Capítulo III abordamos la dimensión del bullicio de la crítica a partir del reconocimiento de una serie de términos que fueron significativos para diversas revistas de la época, y sobre los cuales buscaron tener el dominio de su definición; estos términos son, principalmente los de "comunicación" y "realismo". Ese bullicio era el espacio

\footnotetext{
28 "La conciencia de su estar en el presente se superpone con su cualidad instrumental: las revistas son medios. A diferencia de los poemas o las ficciones, la sintaxis de la revista (que obviamente los incluye) se diseña para intervenir en la coyuntura, alinearse respecto de posiciones y, en lo posible, alterarlas, mostrar los textos en vez de solamente publicarlos". (Sarlo, 1992:11)

${ }^{29}$ Verónica Delgado también analizó esa "proyección hacia el futuro" de las revistas -"al que en muchos casos aspiran modelar o fundar a través de sus intervenciones"; pero a diferencia de la noción "banco de prueba", ese futuro no sería resultado del "presente de su enunciación", sino como un desdoblamiento por el cual "la selección que conforman es de índole fundamentalmente diversa de la cronología que las involucra o en la que están insertas" (2014:19). En ese sentido es que las revistas no tendrían ya un carácter "antológico", como registradoras de un tiempo que pasa, sino que conforman su propia política del tiempo que modula en parte los procesos culturales de los que participa.
} 
común donde según Caillois (1946, n135:24) se hablaba una única lengua pero había que traducirse constantemente porque las palabras no evocaban las mismas imágenes para nadie. En ese marco es posible leer la relación entre lo términos que las revistas pusisieron de relieve y esa lengua común de valores que era el humanismo (Podlubne 2014). Así, tanto las revistas caracterizadas como "de poesía" o "del segundo momento de la vanguardia", como las revistas asociadas a la conformación de una nueva izquierda cultural y política, compartieron una misma definición de crítica: que esta debía contribuir a discernir valores, y principalmente a sopesar aquello que del pasado sigue vivo en el presente. Sin embargo, esta definición compartida en principio por todos se declinó según morales tan contradictorias entre sí como en sus propios principios. En ese sentido, el uso de las nociones de "instante" e "historia" que hacen Aldo Pellegrini y Enrique Molina en A partir de cero y Letra y Línea, y Edgar Bayley y Raúl Gustavo Aguirre en poesía buenos aires, están en relación con la necesidad de configurar sus propias definiciones de "comunicación" y "realismo".

Para dar cuenta del funcionamiento de ese bullicio, partimos del "archivo de categorías" (Terán 1991) con el cual se pensó la conformación de la crítica en Contorno, y proponemos una expansión posible. Así, la noción de "totalidad” (de procedencia sartreana y hegeliana), con la cual Terán leyó las relaciones culturales en los años cincuenta y sesenta, puede ser puesta en diálogo con la del "instante" batailleano por tres motivos: a) la única traducción del autor que circuló en Argentina hasta fines de los años cincuenta fue publicada en la revista Ciclo $(1948$, n1), y su perspectiva de lectura ese texto, "La moral de Henry Miller", giró en torno a la noción del "instante”; b) la imagen del instante y la iluminación fue particularmente productiva en las revistas $A$ partir de cero y Letra y Línea; y c) hacia 1948 Georges Bataille y Jean Paul Sartre se encontraban discutiendo, en Francia, acerca de los límites del surrealismo, en una polémica que tuvo como conceptos centrales ambas nociones, "instante" y "toalidad". Desde este recorrido histórico-teórico buscamos comprender tanto el modo en que esa polémica marcó posiciones en el ámbito local, como el tipo de apropiaciones que suscitó. En este sentido, las discusiones en torno a los términos comunes estuvieron atravesadas por el modo en que las morales críticas de cada revista se apropiaron y modificaron las concepciones de "instante" y "totalidad". 


\subsection{Periodizaciones y desfasajes: los tiempos de las revistas}

Las investigaciones sobre historia de la crítica e historia literaria que pensaron los años 50 en términos de "modernización de la crítica" y "segunda época vanguardista" dan cuenta asimismo de un problema de periodización; en primer lugar, porque los límites del período se corresponden con fechas significativas para la historia de la política en Argentina, circunscribiendo los fenómenos críticos y estéticos al corte "1945-1955” o "1956-1966", signados por los cambios de gobierno (el peronismo clásico, y los gobiernos dictatoriales denominados "Revolución Libertadora" y "Revolución Argentina"); en segundo lugar el problema de periodización para las revistas Ciclo, poesía buenos aires, A partir de cero y Letra y Línea, cuya lectura acotamos aquí a los años 1948-1956, parece inherente al objeto en tanto las revistas se vincularon con la época desde posiciones discontinuistas y anacrónicas que las vuelve inestables en su propio marco de aparición. A continuación damos cuenta de ese problema en el análisis de las historias de la literatura más recientes que, por otra parte, pensaron este corpus de revistas solo en relación con el proceso de "resurgimiento de las vanguardias" o "vanguardia del 50 ". Finalmente, proponemos nuestra propia periodización.

La Historia de la literatura argentina de Centro Editor de América Latina, en su versión de 1967 y 1983, la Historia social de la literatura argentina de David Viñas (1989; 2006), Historia crítica de la literatura argentina dirigida por Noé Jitrik (20022014), trabajos todos colectivos y de largo aliento, exhiben como síntoma la imposibilidad de acordar, al interior de cada proyecto, una periodización para nuestro corpus de revistas, que asocian a la "vanguardia del '50" o "segundo momento de la vanguardia". Esa imposibilidad se evidencia en el hecho de que las mismas revistas aparecen sujetas no sólo a distintas variables interpretativas, sino a períodos de influencia superpuestos.

Estas tres historias configuran filiaciones y periodizaciones tomando especialmente dos dimensiones: el tiempo de un movimiento estético (invencionismo y surrealismo) o la relevancia de obras determinadas (la de Edgar Bayley, Olga Orozco, Alejandra Pizarnik, Francisco Madariaga),${ }^{30}$ no obstante, cuando abordan a las revistas

\footnotetext{
${ }^{30}$ Ambos criterios eran sopesados con la fuerza gravitante que adquirió la política como espacio de articulación de sentidos para una época que se pensó en esa clave, y la emergencia de una nueva generación de escritores e intelectuales. La clave interpretativa que ofrecía la noción de "generación" fue compartida tanto por actores de la época, según observamos en diversos artículos de la revista Centro dedicados al tema
} 
en el marco de una perspectiva estética, se produce un desajuste entre los materiales y las nociones de época y generación con las que contrastan. En ese sentido, es insoslayable que se trata de un problema en torno al término "vanguardia" y aquello que designa (cuáles son sus posibilidades, qué la delimita en la historia y en el presente, y qué la expande). Por otra parte, la no unidireccionalidad, el retorno de ciertos temas y materiales como recurso de análisis, es decir, volver a narrar, son propios de las historias de la literatura que comparten la característica de ser historias colectivas, por entrega, y diseñadas en medianos y largos plazos. Sin embargo, el problema de periodización en torno a las revistas de nuestro corpus se configura como síntoma, porque resulta inescindible de la política del tiempo que estas efectuaron. Como intentamos mostrar en esta tesis, Ciclo, poesía buenos aires, A partir de cero y Letra y Línea no solo se configuraron en una relación específica con la contemporaneidad, que desacomodó algunas conexiones establecidas, sino que además teorizaron en sus propias colaboraciones sobre la relación entre arte, literatura y temporalidad histórica. Asimismo, proporcionaron modos de lectura según una moral crítica del anacronismo, que advertimos delimitada por problemas diversos en cada revista.

Los prismas periodizadores en las tres historias de la literatura (Capítulo, Historia social e Historia crítica) oscilan entre la postulación de tramos políticos consecutivos que girarían en torno al peronismo clásico (1945-1955) y el surgimiento de una nueva izquierda intelectual (1956-1970), y el entramado recursivo de una vanguardia de larga duración en Argentina. No obstante los límites cronológicos del período parecerían poco variables, las revistas del corpus son, alternadamente, dispuestas en series distintas por las historias de la literatura. Así, Ciclo (1948) permite remontarnos a la experiencia de Qué en los años '20 a partir de una teoría de la imagen, según Raúl Antelo en El oficio se afirma (2004); o se proyecta entre las influencias psicoanalíticas de Literal (García 2011), y la línea no estructuralista de Oscar del Barco en Los Libros ${ }^{31}$. Letra y Línea aparece como "otro polémico" de Contorno, situada en una serie de discusiones que giraban

\footnotetext{
-“Otras reflexiones sobre el concepto de generación”, García 46-51 nro 1951- estrechamente incentivados por el pensamiento expandido de Ortega y Gasset, como por investigadores de la época (Terán, Croce).

${ }^{31}$ Entre 1969 y 1970 Oscar del Barco reseña las traducciones más recientes de Blanchot y Bataille en la revista Los Libros. Como la mayoría de las intervenciones en esa revista, el género reseña es desbordado por puntos programáticos del oficio del crítico; Oscar del Barco no es la excepción y polemiza directamente con las perspectivas sociológicas y estructuralistas de Los libros. Ver "La escritura desencadenada", año 1, $\mathrm{n}^{\circ}$ 5, noviembre de 1969 y "El silencio sobre Bataille" año 1, n⿳9 9, julio 1970. A excepción de Horacio Quiroga: una obra de experiencia y riesgo (1959) no hay rastros contundentes de lecturas sobre Blanchot ni Bataille en la crítica argentina, entre las traducciones de Ciclo y Poesía Buenos Aires y la recepción de Los Libros.
} 
alrededor de las tareas generacionales, o bien como un producto residual del surrealismo. poesía buenos aires es leída como modernización "a la francesa" asociada con el antiperonismo, o como una resonancia de la antipoesía que dio lugar a Leónidas Lamborghini. Dónde se lee el impacto de las revistas es también la pregunta por en qué tiempo se leen. ${ }^{32}$

En la Historia de la literatura argentina de CEAL, el problema de la periodización aparece en la reedición de 1982, como contraste entre los tomos 4 y 5 titulados Los proyectos de vanguardia y Los contemporáneos. ${ }^{33} \mathrm{El}$ cuarto tomo tiene la particularidad de ser transversal temporalmente, considerando tanto el martinfierrismo del '20 como las renovaciones sesentistas. Así, la tensión entre categorías que no designan un orden temporal pero aparentan ser sucesivas, se evidencia en la nueva versión del tomo, donde el fascículo "Las propuestas poéticas de vanguardia" (Baumgart, Crespo de Arnaud y Luzzani Bytrowicz), publicado en Los contemporáneos superpone objetos, miradas, encuadres temporales con "La poesía del "50" (Freidemberg), en Los proyectos de vanguardia. Las revistas Qué, Ciclo, Letra y Línea, Poesía Buenos Aires, emergen en cada fascículo, organizando movimientos, actores, transformaciones y alcances temporales diferentes.

Si las autoras de "Las propuestas poéticas de vanguardia" sentaban la piedra fundamental de la vanguardia en la aparición de Qué (1928) y su consolidación en Ciclo (1948-1949) y A partir de cero $(1952,1956)$ a las que califican como "segundo y tercer momento de la vanguardia" respectivamente, en "La poesía del cincuenta" Freidemberg remite a esta última pero enfatiza en Arturo (1944), "la embestida más radical contra el

\footnotetext{
${ }^{32}$ La revista Arturo - considerada la primera revista de "Arte abstracto" en Argentina, e influencia decisiva para las publicaciones posteriores afines, es quizá paradigmática en este sentido, ya que su año de aparición única, 1944, la vuelve necesariamente desplazable: ¿discute, entonces, más o menos con la estética neorromántica de Ventana Buenos Aires (1952-1956), contemporánea de Poesía Buenos Aires y Letra y Línea? La estética neorromántica y la vanguardia invencionista-surrealista fueron imaginadas como sucesiones opositivas, a modo de combate de programas, pero resultan permanentemente autoimplicadas en las historias: ya sea como continuidades residuales - la revista El 40 publicada en 1951 - o como porvenir - la revista Arturo y un único número en 1944.

${ }^{33}$ En la redición del '82, a menos de veinte años de los primeros fascículos y compilación en tres tomos, se reordena la literatura. La dirección de 1967, a cargo de Roger Pla y un equipo integrado por Luis Gregorich, Adolfo Prieto y Josefina Delgado, había buscado articular tradición con innovación, como respuesta al oganiato "y su pretensión de borrar el pasado y anular una memoria colectiva", según afirma María Teresa Gramuglio (29); el recurso a la "noción generacional", como menciona Luis Gregorich en una entrevista, hizo "que estuvieran presentes todas las generaciones de la literatura argentina representadas por la gente más importante de cada momento" (33), y por lo tanto permitió dar alcance incluso a los escritores inmediatamente próximos de los años '60. Esto produjo los famosos tres tomos Introducción. Los orígenes (fascículos 1 a 23), El desarrollo (24 a 41), y Los contemporáneos (42 a 59). Para la edición de 1983, entre los criterios temporales sucesivos - origen, desarrollo y contemporaneidad - se extrapola otra noción: la vanguardia. La historia se reordena como Desde la colonia hasta el romanticismo, Del romanticismo al naturalismo, Las primeras décadas del siglo, Los proyectos de vanguardia y Los contemporáneos.
} 
romanticismo" (557). Lo que arroja el recorte de materiales es que los años '40 habrían sido salvados del "adormecimiento" gracias a las publicaciones surrealistas, mientras que la década siguiente triunfa como renovación poética en el invencionismo; por ello encontramos a Arturo (1944) y A partir de cero (1951) gravitando años que no son los de su circulación. Así, Arturo permite dar cuenta de la poesía del cincuenta, en el ensayo de Freidemberg, pero es ignorada por el recorrido de que proponen Baumgart, Crespo de Arnaud y Luzzani Bytrowicz en "Las propuestas poéticas de vanguardia". ${ }^{34}$

Las aristas de esta "segunda vanguardia" escapan a las periodizaciones, y por tanto es lógico que sus publicaciones periódicas se recorten sobre entramados diversos, aún extemporáneos a sí mismas, como es el caso de Qué (1928) más cercana a los '50 que al martinfierrismo. Lo que deducimos de ambos capítulos es que mientras "Las propuestas poéticas de vanguardia" se restringe a la década del '40, abordando las publicaciones del surrealismo y el objetivismo, aunque afirma sobre el primero que su mayor auge fue a partir de la década siguiente, de modo disonante con los postulados de Juan Jacobo Bajarlía (1946) para quien lo más importante en términos de vanguardia en la década del 40 fue el invencionismo;," "La poesía del cincuenta", lejos de ser una "sucesión" superpone experiencias con la década anterior. Por esos motivos encontramos desplazamientos considerables, como la centralidad de la revista Qué y A partir de cero (1928 y 1952 respectivamente) en un capítulo que aborda la estética de los años 40 y sus propuestas de vanguardia, y el modo en que Freidemberg se remonta a la primera mitad de los años 40 con Arturo para pensar el invencionismo como una experiencia de los años 50.

El proyecto dirigido por Noé Jitrik ${ }^{36}$ quizá sea el más paradigmático de los tres; las revistas Ciclo, A partir de cero y Poesía Buenos Aires son consideradas en capítulos

\footnotetext{
${ }^{34}$ Las autoras advierten, en relación con el surrealismo francés, que en Argentina, "después de un primer momento de mayor ortodoxia surrealista se verifica un gradual alejamiento de los postulados de Breton (aunque el surrealismo argentino nunca fue mimético, ni siquiera en esta primera irrupción. Por otra parte, hay que discriminar aquellos autores que se nuclean a partir de las premisas surrealistas y que configuraron lo que podría llamarse grupo surrealista argentino, de los que acusan los cambios introducidos por la incidencia de este movimiento en la literatura y en todos los campos del arte, tanto "culto" como "popular", aunque no se definan a sí mismos como surrealistas" (217).

${ }^{35}$ Ver tratamiento sobre el autor en el primer capítulo.

${ }^{36}$ La Historia Crítica de la Literatura Argentina presenta, en el tomo Una patria literaria (2014), un prólogo en clave de lectura: qué se quiere y qué no se quiere para esa historia; qué líneas historiográficas ha tomado cuáles no. Un trabajo de esas características en el siglo XXI requiere, para Noé Jitrik, una justificación y a la vez el empleo del discernimiento: las historias siguen siendo capaces de mostrar, en torno a los procesos, ideas reveladoras. Su historia se definiría por "actuar sobre lo 'todavía no sabido o no pensado o comprendido', arrojando nuevas luces sobre lo historiado" y por aquello que intenta superar: "Dejar de lado designaciones canónicas y estereotipos clasificatorios, que no eran presentados como
} 
específicos sobre esta segunda vanguardia, en los tomos Ruptura $\left(\mathrm{n}^{\circ} 7\right)$, El oficio se afirma $\left(\mathrm{n}^{\mathrm{0}} 8\right)$ y La irrupción de la crítica $\left(\mathrm{n}^{\mathrm{0}} 10\right)$. Mientras estos últimos operan una suerte de continuidad histórica entre sí, caracterizada por distintos ejes de gravitación: la profesionalización del escritor entre 1945 y 1955, y la consolidación de un discurso crítico entre 1955 y 1966, el tomo Rupturas es transversal a la historia literaria. En esos saltos y continuidades, las historias exponen una lectura de las revistas como iterabilidad de lo ambiguo, en otra y la misma serie se superponen los usos y los nombres.

Casi como una réplica de criterios respecto a Capítulo, el tomo Rupturas ${ }^{37}$ de la colección dirigida por Noé Jitrik mantiene la misma separación: experimentación surrealista por un lado en "Los meandros surrealistas" (Espejo, 2009) e invencionista por el otro "Antes y después de Poesía Buenos Aires" (Alonso, 2004). Con respecto al tomo IX, El oficio se afirma, Sylvia Saítta explicita que se ha recortado el período 1945-1955 y focaliza especialmente en el criterio de profesionalización de la literatura. Raúl Antelo, autor de "Poesía hermética y surrealismo", corre los años y arma una teoría de la imagen que va de Qué a Ciclo, de 1928 a 1948, y se extiende hacia Boa (1958). El capítulo se vale de los textos programáticos publicados en Qué y una zona de la poesía de Aldo Pellegrini, así, se desplaza de los límites temporales propuestos por el tomo, pero elige no ignorar la figura quizás más gravitante de esos años: Jorge Luis Borges. ${ }^{38}$

En el tomo X, La irrupción de la crítica, Mariano Calbi analiza el periplo que va de Arturo a los últimos poemas de Alejandra Pizarnik, según una estructura que le permite conjugar invencionismo y surrealismo en un mismo campo de influencia, para explotar su hipótesis: la poesía es una forma de irrupción crítica en tanto crítica del lenguaje. El volumen dirigido por Susana Cella, al igual que el anterior, presenta un recorte delimitado, del derrocamiento de Perón a 1970: la conformación de una nueva izquierda, la hegemonía crítica de Contorno, Walsh, Viñas, Sartre, Cordobazo, literatura y

\footnotetext{
conflictos: "generaciones" "estilos", para pensar "grandes instancias de transición" pero no "movimientos, tendencias o grandes obras", sino el modo por el cual confluyen "rasgos que las caracterizan o definen".

${ }^{37}$ Es quizá el tomo más transversal y por eso mismo inestable de toda la colección, en tanto contrapone en un solo volumen, la idea de "ruptura" a la de tradición que en definitiva sostiene el proyecto integral, como a cualquier historia; "rupturas y tradiciones, términos en apariencia antagónicos pero que se necesitan mutuamente, se anudan así en el corazón del sistema literario para configurar una compleja articulación en la que conviven diversas prácticas y usos aquilatados, siempre en lucha con heterodoxias amenazantes" (7). ${ }^{38}$ Para poner en contacto el surrealismo con los fundamentos de la ficción borgeana. "Yo persisto como inexistencia", dice Pellegrini en "Maneras de hablar del enfermo viejo lleno de pústulas" (Qué, nº1, 1928). Antelo entonces glosa: "Cabría preguntarse, sin embargo, en qué reside la diferencia entre la inexistencia inoperante de los surrealistas y la nadería de la personalidad borgeana, elaborada en simultaneidad con la de aquellos. En oposición a los románticos y nacionalistas, Borges cree que "no hay tal yo de conjunto", que no existe sujeto unificado ni existe la noción misma de conjunto autónomo."
} 
compromiso, son algunos de los ejes que ligan las ideas de "irrupción" y "crítica". Por lo tanto, la recapitulación de una serie de experimentaciones poéticas que, de alguna forma ya habían sido exploradas en otra serie, la de las rupturas, configura más la idea de un retorno que la de una irrupción.

Menos ambigua porque tiene un solo criterio de recorte, la Historia social de la Literatura, diseñada por David Viñas ${ }^{39}$ es menos problemática en relación a este corpus de revistas, debido a que son pensadas bajo la trama cultural del peronismo. Ya sea porque estas lo ausentan absolutamente (al grado del síntoma), o bien porque, como señala Américo Cristófalo, entre la vanguardia y el neorromanticismo no sólo hay una fuerte continuidad, sino que esa tradición poco dispuesta a romperse, sella su pacto en torno a la figura "mesiánica" e "idealista" del poeta y la poesía, que se asemeja al "lado oscuro del discurso cultural del peronismo" (70), el período 1945-1955 tiene la capacidad de anudarlo todo. ${ }^{40}$ El peronismo clásico. 1945-1955 en Historia social de la literatura argentina marca los límites y el objeto de análisis desde el título; la época ordena las lecturas y no viceversa. Américo Cristófalo escribe allí "Metafísica, ilusión y teología poética. Notas sobre poesía argentina: 1940-1955”, capítulo para el cual considera únicamente las revistas Canto y A partir de cero; los poetas analizados son Rodolfo Wilcock, Enrique Molina, Alberto Girri y Olga Orozco. Una selección similar a la de Capítulo le permite contrariar no solo la hipótesis de "Las propuestas poéticas de vanguardia" en 1983, sino también la de Miguel Espejo en Rupturas. Como contraste a la hipótesis de Cristófalo, la idea de una poesía en términos de mero idealismo es socavada en el mismo tomo dirigido al publicarse la polémica entre Aldo Pellegrini y

\footnotetext{
${ }^{39}$ Historia social de la Literatura Argentina, dirigida por David Viñas, tiene también la particularidad de haber sido retomada años después en el proyecto Literatura argentina del siglo XX, donde se reestructura el plan presentado en 1989 a la salida del tomo 7 Yrigoyen, entre Borges y Arlt (Montaldo, dir.). Esta historia recupera un aporte de Capítulo y podría afirmarse que incluso da un paso más en esa misma dirección; si los fascículos monográficos que dirigieron Pla y Zanetti a su tiempo incluían en los márgenes de las páginas fragmentos de lo que podríamos llamar textos primarios, testimonios, prólogos de libros referidos, entrevistas, fragmentos de novelas, poemas, en el proyecto de Viñas la voluntad de incluir textualidades misceláneas adopta el criterio de ser materiales o documentos entre capítulos, menos previsibles. María Teresa Gramuglio ha señalado muy bien la doble fuerza que cruza la "mediación de lo político como instancia articuladora de la relación literatura-sociedad", aún como "pauta explicativa de algo que suele reconocerse como resistente a la explicación: el cambio literario", con la aparición de materiales fragmentarios, heterogéneos, "con destiempos y espacios en blanco, con intersticios" (1989: 27).

${ }^{40}$ Para Cristófalo hay más puntos de contacto que rupturas entre la década del ' 40 y el ' 50 : La potencialidad mágica del canto, su rasgo trascendental (...). Pathos poético de alma bella, que requiere excluir los tonos violentos, dramáticos y disonantes de las representaciones históricas, y se concentra en la figura ideal de la poesía, correlato de religión natural, ingenua, víctima inocente de la barbarie y por extensión, del escandaloso escenario del mundo de los hechos. O la poesía como portadora de verdad esencial: "es un bien precioso y delicado", bajo amenaza "porque difunde demasiado abiertamente la verdad en el mundo" (2007:64).
} 
Osiris Troiani (1953-1954) entre los "materiales primarios" que transcribe la Historia Social. Dicha polémica se dio a lo largo de las revistas Letra y Línea, Contorno y Capricornio. Pero curiosamente esta acompaña el capítulo sobre la publicación de Ferdydurke en Argentina (Gombrowicz 1947) y no al de poesía.

A partir de la lectura de los problemas de periodización mencionados, advertimos que en tanto nuestro objeto se constituye por las intervenciones críticas que las revistas vinculadas al surrealismo e invencionismo llevaron a cabo (y no en las relaciones entre estéticas y revistas), los elementos que determinan nuestro recorte temporal (1948-1956) son de un orden muy distinto a los señalados por las historias de la literatura. Tomamos el año 1948 como inicio del recorte porque ese año marcó un momento particular de las publicaciones periódicas en torno al arte de vanguardia, especialmente el arte concretoinvención, que tuvo consecuencias en los modos de intervención crítica de las revistas de nuestro corpus. A partir de entonces algunos de sus integrantes, como Tomás Maldonado, Edgar Bayley y Alfredo Hlito, quienes habían sido recientemente expulsados del Partido Comunista Argentino por "desfachatez" en sus elecciones estéticas, ${ }^{41}$ pasaron a involucrarse con Aldo Pellegrini en Ciclo (1948-1949). Ciclo abrió otro momento en las revistas de vanguardias donde, como ya anticipamos, el horizonte era la intervención crítica. También para Luciana Del Gizzo (2017) y Daniela Lucena (2015), después de 1948 hubo un momento de relajación en el arte, en el cual se produjo una apertura hacia la "contaminación artística" en el caso de los artistas visuales (Lucena 2015) y la “comunicación literaria” en el caso del movimiento poesía buenos aires (Del Gizzo 2017).

Hay razones también del diálogo con Europa que señalan el carácter gravitante de ese año, por ejemplo el premio a mejor revista de crítica literaria a Georges Bataille como director de Critique, de donde Ciclo tomó uno de sus ensayos para traducción, y las conferencias de Bataille sobre una nueva etapa del surrealismo donde elaboró la noción de "ausencia de comunidad", así como también una perspectiva sobre la crítica literaria como ambigüedad entre ética y moral de la escritura. A su vez este recorte, se caracteriza por ser un momento en el que la crítica literaria se dinamizó principal y casi exclusivamente en las revistas, a diferencia de lo que comienzaría a suceder en 1956, cuando la crítica argentina cobró relevancia en formato libro; Borges y la nueva generación (1953) de Prieto había sido, en ese sentido, un libro precursor, al igual que la edición de poesía buenos aires Realidad interna y función de la poesía (Bayley 1952),

\footnotetext{
${ }^{41}$ Cfr. Lucena y Longoni (2012).
} 
pero poco a poco, esa ligazón casi indestructible de años anteriores entre crítica y revistas, se irá desarmando en la aparición de libros: Sociología del público (Prieto 1956); Horacio Quiroga: una obra de experiencia y riesgo (Jitrik 1959); Leopoldo Lugones: mito nacional (Jitrik 1960); Para contribuir a la confusión general (Pellegrini 1965); Sexo y traición en Roberto Arlt (Masotta 1965), Literatura argentina y realidad política (Viñas 1966).

1956 puede asimismo ser pensado como clausura del período. Para esa fecha Ciclo, A partir de cero, Letra y línea, han desaparecido. No así poesía buenos aires y tampoco Contorno. Sin embargo, el final del año 1956 puede ser tomado como el cierre de una forma de pensar la literatura y la crítica en las publicaciones periódicas, o bien, en el imaginario de David Viñas, como una “traición”. Por un lado, poesía buenos aires no solo había cambiado de formato, sino que incorporaba poéticas totalmente distintas como la publicación de los primeros poemas de Leónidas Lamborghini. Por otro lado, fue en julio de ese año cuando Contorno publicó su famoso número 7-8, una revisión del peronismo como "Examen de conciencia" de la clase media; pasarán tres años hasta que vuelva a aparecer, abril de 1959. En diciembre de 1956, Viñas explicaba que habían sido "la generación traicionada" (Tramas para pensar la cultura argentina, 1960, º7), y proponía esa traición como el fin de una época y del accionar de su generación. Esa traición había sido doble: entre 1956 y 1959 los críticos e intelectuales de izquierda no orgánica al PC sintieron las diferencias con el gobierno de facto de la Revolución Libertadora y luego, la certeza de que "pocos dudan ya -ante los primeros meses de gobierno- de que esa designación (frondizismo) va a tener una fuerte acentuación peyorativa en boca de los pueblos" (Contorno, 9-10, abril 1959).

Para 1956 la crítica y la literatura argentina aceleran sus transformaciones; Rodolfo Wlash está a punto de publicar Operación Masacre, han aparecido las revistas de "la nueva izquierda argentina", como El escarabajo de oro, La rosa blindada, Nueva expresión. Francisco Urondo, en el ensayo "Veinte años de poesía argentina" parece abonar esa hipótesis, ya que si bien su período abarca 1940-1960, nos dice: "En 1957, los intelectuales y artistas de casi todos los sectores -salvo los reaccionarios que siempre los hubo y en abundancia-, como consecuencia de esa latente y creciente politización, apoyan la candidatura de Arturo Frondizi”, y a continuación:

La producción poética se enriquece en tanto al incorporar esas experiencias -ilusiones y fracasos- que ayudan a la embrionaria y paulatina claridad que va despuntando en sus autores sin que por eso decline la jerarquía que sin duda había alcanzado en esos años a través de un severo uso del oficio. 
(...) Consecuencia de esta incorporación es la característica más abierta, menos forzada, de la producción poética posterior a esas crisis políticas. (2009:57)

Sin dudas, Urondo está describiendo esos últimos años del período poético que le preocupa más como un programa literario y político a futuro que como una inspección histórica. Lo que interesa a los efectos del recorte que este corpus de revistas propone es la posibilidad de reconocer, entre el artículo de David Viñas, el análisis de Urondo y las transformaciones de las revistas, el año 1956 como un momento donde se clausura una etapa crítica y estética: poesía buenos aires cambia de política editorial; Contorno ya no publica artículos sobre literatura sino sobre política, a excepción de algunas reseñas extensas; y las preguntas de revistas como Ciclo y Letra y línea permanecerán en suspenso por algunos años.

\subsubsection{Decisiones metodológicas}

La búsqueda por reponer una heterogeneidad y extrañeza en los debates sobre arte, literatura, crítica, vanguardia y compromiso durante los años 40 y 50, supuso una razón para no elegir la figura del crítico-poeta o las relaciones entre crítica y poesía como eje central de la investigación. Si bien se trata de un aspecto o abordaje posible cuya pertinencia está ampliamente justificada por el corpus, o incluso podría ser una exigencia del corpus, se hubiera perdido tal vez la posibilidad de sacar a las escrituras de su propia serie poniéndolas en otras. Al mismo tiempo, a lo largo de la tesis nos centramos con más atención en las figuras de Aldo Pellegrini, Enrique Molina, Raúl Gustavo Aguirre y Edgar Bayley porque son, de alguna manera, articuladores de los colectivos de revistas que integran, o bien porque su presencia es transversal y permanente a distintas formaciones. Pero a su vez, estos autores conviven con otros conocidos, desconocidos y reconocidos que, independientemente de la difusión que alcanzaron en su época o de la que tengan en la nuestra, conforman el universo de lo publicado y lo publicable en el período que nos interesa estudiar.

Por otra parte, y en relación a los límites del objeto, si bien es necesario distinguir entre las escrituras de quienes hacen las revistas, colaboradores, directores, consejos de redacción, y las traducciones de lecturas teóricas, formativas y contaminadas en el mismo proceso de traducción, de autores extranjeros, especialmente europeos, ambas son consideradas parte del corpus porque establecen la serie en la cual la crítica se inventa a 
sí misma un lugar de enunciación, y a su vez porque es posible reconocer préstamos, contactos entre unas y otras. Las nociones de "imagen en combustión" de Aldo Pellegrini, o de "poder de la palabra" están tan atravesadas por restos de la poesía romántica y simbolista, como por las nociones las nociones de ausencia de comunidad o continuidad de Georges Bataille. En este sentido, todos los ensayos y reseñas forman parte de un estado de la crítica porque exponen modos de leer que dialogan con preocupaciones comunes a las discusiones que se están llevando a cabo en las revistas.

La centralidad que damos a las figuras de Georges Bataille y Maurice Blanchot por sobre la de otros franceses contemporáneos, a la vez escritores y filósofos, traducidos en misma proporción por las revistas del corpus, tiene que ver con dos motivos: el primero y principal es que son los dos autores que formaban parte de la discusión que planteaba Sartre en Francia, discusión crucial para pensar la década del cincuenta y sesenta en Argentina. Esta confluencia hace que esos nombres resulten ondas expansivas, en términos de las tramas culturales y conflictivas de la época, más allá de la presencia concreta en un sumario. Y el segundo motivo tiene que ver con que son, además, escritores que estaban en ese momento escribiendo sobre surrealismo sin anteponer una adscripción al movimiento.

Asimismo, se borronearon las fronteras entre crítica de arte y crítica literaria, porque de alguna manera es también borrosa para quienes escriben. Un ejemplo extremo de esto es la respuesta que hace Raúl Gustavo Aguirre en poesía buenos aires exclusivamente dedicada a un género textual - a un ensayo de Tomás Maldonado en Nueva Visión titulado "Problemas actuales de la comunicación" (1953). El texto de Aguirre se titula "Notas para el problema de la comunicación", y mientras uno discute el término en relación al artista visual el otro lo hace en relación al poeta, recorriendo y desacoplando de modo polémico una serie de presupuestos compartidos. 


\title{
Capítulo I
}

\section{Modernos, contemporáneos, profetas y embaucadores: la temporalidad como problema crítico en las revistas de vanguardia}

\begin{abstract}
Los elementos de una concepción diferente del tiempo yacen dispersos en los pliegues y en las sombras de una tradición cultural de Occidente. Giorgio Agamben, 1978
\end{abstract}

\subsection{Presentación del capítulo}

En la conferencia de Giorgio Agamben titulada “¿Qué es lo contemporáneo?”, con la cual dio apertura a una serie de clases, afirmaba que el "tempo" del seminario sería la contemporaneidad, y derivaba de esa frase una exigencia: -“ser contemporáneos de los textos que se examinan" (2008). "Tempo" es la palabra original en italiano, pero los traductores eligieron mantenerla para conservar el sentido no-cronológico que le dará Agamben a lo largo de su exposición. ${ }^{42}$ Aun cuando se hubiera traducido por la acepción frecuente de "tiempo", advertiríamos la imposibilidad de naturalizar el alcance y significación de lo contemporáneo, tal como se deduce de la exigencia propuesta. A partir de este desmontaje entre la contemporaneidad y la coincidencia cronológica de una serie de lecturas, libros o experiencias, la palabra "tempo" es susceptible de convertirse en una noción que nos permite designar las múltiples implicancias que tuvo para las revistas Ciclo, poesía buenos aires, A partir de cero y Letra y Línea, el modo de experimentar su presente, o, desde nuestra perspectiva ya histórica, su "época". Sin duda, uno de los matices de la noción, tal como la emplearemos aquí, alude a la dimensión cronológica, al anclaje en un tiempo delimitado por acontecimientos histórico-políticos precisos: el fin de la II Guerra Mundial, la irrupción del peronismo, el recrudecimiento de las políticas estéticas del Partido Comunista, la consolidación del pensamiento sartreano en los grandes centros de debate cultural e intelectual. Pero es justamente porque las revistas del corpus ponen en cuestión que el presente se limite al horizonte demarcado por ese tipo de acontecimientos, que una noción como tempo tiene lugar: porque instala una dimensión abierta, no clausurada, tanto del pasado inmediato, donde encontramos la genealogía

\footnotetext{
${ }^{42}$ Cfr. la traducción citada aquí de Ariel Pennisi con revisión de Adrián Cangi (2008, online), con la de Cristina Sardoy en Desnudez (2011) por Editorial Anagrama y Adriana Hidalgo.
} 
estética de las vanguardias históricas, como de lo menos audible del presente que se manifiesta en una serie de episodios culturales no dominantes, por ejemplo, los diálogos entre estéticas de vanguardia y peronismo, que se habían cristalizado en tanto oposiciones irreconciliables, o bien la presencia de Georges Bataille y Maurice Blanchot en tanto interlocutores desapercibidos en Argentina de la polémica con Jean Paul Sartre. ${ }^{43}$ Por otra parte, la noción de tempo contempla una descripción de las experiencias en términos contradictorios, paradójicos, en torno a las cuales se superpusieron valoraciones que las revistas procuraron mantener a distancia, como las de "angustia" y "júbilo" (Aguirre en poesía buenos aires) o "protesta” y “exaltación” (Pellegrini en Letra y Línea).

En este primer capítulo se analiza el modo en que las revistas del corpus construyeron su perspectiva crítica en la problematización de la temporalidad, desde una mirada que se distanciaba de otras publicaciones con las cuales discutían. ${ }^{44}$ El primer apartado consiste en un desarrollo del conflicto cultural en el que esa relación entre tiempo y crítica se configuró a partir de las metáforas del "desierto" y el "país ahogado". Tal conflicto estuvo atravesado por la experiencia del peronismo ${ }^{45}$ en su período clásico (1945-1955) ${ }^{46}$, así como también por lo que en la introducción denominamos "dilema de la vanguardia", en tanto las revistas de nuestro corpus asumieron la pregunta por el lugar de lo nuevo después de la segunda postguerra, y se consideraron, al mismo tiempo, integrantes de una genealogía internacional y motores de la renovación en el ámbito local. ${ }^{47}$

Los apartados dos, tres, cuatro y cinco se corresponden con la presentación y análisis de los programas de cada revista a partir de la relación entre crítica, vanguardia y temporalidad. Con respecto al problema central del capítulo, una de las características comunes que atraviesa a las publicaciones es la ausencia de sistematicidad en la selección léxica de aquellos términos que involucran un matiz temporal. Debido a que se trata de

\footnotetext{
${ }^{43}$ Este aspecto será analizado en el capítulo III.

44 Buenos Aires literaria (1952 - 1954); Capricornio. Revista de literatura, arte y actualidades (19531954), Contorno (1953-1959), El 40. Revista de una generación (1951-1953), Sur (en el período 1948 1956), Mairena (1953).

${ }^{45}$ Sobre este aspecto es importante distinguir entre el modo en que las revistas configuran su sensibilidad en relación con una experiencia particular del peronismo, y el impacto de las políticas culturales impulsadas desde el gobierno. Para un análisis más detallado al respecto de esto último recomendamos las investigaciones de Lucena (2015), Korn (2017), Korn y Panela (2010, 2014, 2016), y Fiorucci (2007, 2011). ${ }^{46} \mathrm{Si}$ bien el recorte temporal de la tesis no se corresponde con las delimitaciones de la historia política, nos remitimos a ese marco de tiempo en este aspecto ya que señala un proceso histórico ya ampliamiente analizado, del cual las revistas no se sustrajeron.

${ }^{47}$ En el capítulo II hay un desarrollo específico e historizado de los debates en torno a la vanguardia como problema teórico y crítico.
} 
nociones con las que trabaja el discurso crítico de las revistas del corpus, y no las obras literarias publicadas por ellas, esta cuestión configura un primer nivel de análisis, vinculado al modo en que construyeron el vocabulario de su intervención. El término "vanguardia" alude muchas veces a una dimensión de futuridad, ya que se utiliza menos para designar un conjunto de itsmos y procedimientos que una posición frente al tiempo. El término "contemporáneo" adopta en algunas ocasiones el sentido agambeniano de lo inactual (Agamben, 2008), y en otros momentos es utilizado de forma corriente para referirse a la coincidencia cronológica entre textos o autores. La convivencia de esa ambigüedad no pasa inadvertida en las revistas, ya que cuando se la usa en el primer sentido la palabra es acompañada con atributos o reflexiones. En poesía buenos aires, ${ }^{48}$ Jorge Enrique Móbili definía como contemporáneo al que "no ha negado el simple acto de nacer bajo el signo de un doble desgaste" (1951, n4); en la "Justificación" de Letra y Línea hay un esfuerzo crítico por distinguir contemporáneos de "actuales" (1953, n1). Algo similar ocurre con la idea de lo "moderno", que refiere tanto al "Arte Moderno" como categoría histórica en la cual estarían contemplados los movimientos artísticoliterarios de principios de siglo XX, como a "ser moderno", atributo que funciona de manera oposicional con una serie de valores que se rechazan: la literatura representacional, el regionalismo, el "lirismo social", la literatura de "realismo fotográfico". Esta categoría es mencionada en muchas oportunidades como una advertencia a no dar por superados ciertos intentos de las vanguardias históricas aún no cumplidos en el presente, y en ese sentido se despega del "afán de innovación que resumen la índole de la modernidad" (Páez 2013:44). A partir de esas inestabilidades en los términos, construimos una hipótesis de lectura que aporta un segundo nivel de análisis; ser contemporáneo sería entonces la capacidad de sustraer la innovación de las exigencias de actualidad. Esta hipótesis nos permite leer desde la noción de contemporaneidad algunas intervenciones críticas de las revistas donde problema no fue nominado estrictamente desde esta selección léxica.

En el abordaje de la revista Ciclo. Arte, literatura y pensamiento modernos se privilegian dos ejes de análisis que permiten desplegar las implicancias de la relación entre crítica y temporalidad a partir de los términos señalados: el primero aborda las continuidades y diferencias con la propuesta estético-crítica de la revista Qué (19281929) -integrada por un comité casi idéntico al de Ciclo- y las publicaciones de la

\footnotetext{
${ }^{48}$ A partir de ahora: pba.
} 
Asociación Arte Concreto Invención en Argentina (AACI) ${ }^{49}$ (1945-1946), respecto de las cuales se produjo una superación de cierta dicotomía entre la política visual del arte concreto y el surrealismo. Para leer ese aspecto, analizamos la imagen de portada de la revista, la conformación del staff, la heterogeneidad de los sumarios y las publicacidades editoriales. El segundo eje se desprende de las consideraciones anteriores, y se propone analizar la apuesta crítica de Ciclo, vinculada desde el subtítulo con una idea de "lo moderno". Esa dimensión de la revista se organiza a partir de la prevalecencia de ensayos críticos por sobre obras literarias o artísticas publicadas. El programa de Ciclo consistió en interrogar simultáneamente tanto el lugar de las vanguardias después de 1945, como los fundamentos teórico-históricos que las consideraron caducas. En este sentido, cuestionó ciertos postulados del historicismo marxista según los cuales cual una obra sería producto de su época; como respuesta a eso, propuso un desacople de la relación entre obra y sociedad.

En el caso de poesía buenos aires nos remontamos también a su relación con otra publicación, Contemporánea, ya que se trata de dos proyectos poéticos muy vinculados, tanto por sus colaboradores como por las ideas que los motivaron. No obstante, exhiben contrapuntos necesarios que permiten comprender cómo se produjo un cierto pasaje del ejercicio del manifiesto como programa al ejercicio de la crítica. El análisis se organiza en tres ejes. En principio, se abordan las implicancias de un proyecto como $p b a$, centrado exclusivamente en el género poesía, y cómo esa elección se convirtió en un proyecto crítico, que implicó cambios y desplazamientos característicos con respecto a su antecesora, Contemporánea. Por otro lado, se analiza la ambigüedad que atravesó tanto sus ensayos como los poemas publicados en ella, donde la exaltación del "júbilo" poético o el ataque a "toda melancolía" -valores históricamente vanguardistas- se ven contrariados o superpuestos por la experiencia del tiempo entendido como "agobio" y la necesidad de que el poeta y la poesía ocupen un lugar "profético", diferencial en un mundo que se percibe como decadente. Aunque en $p b a$ se manifiesta de manera más explícita, esta contradicción forma parte de la experiencia del tiempo que atravesó a las

\footnotetext{
${ }^{49}$ El breve período que va de 1944 a 1948 marcó años precipitados para el arte no figurativo en Argentina, así como también en el diálogo con Uruguay y Brasil. Solo meses después de la aparición de Arturo integrada por Camilo Arden Quin, Rhod Rothfuss, Gyula Kosice, Edgar Bayley, Tomás Maldonado y Lidi Pratty-, los hermanos Maldonado-Bayley y Lidy Pratti conformaron la Asociación Arte ConcretoInvención, cuya primera publicación fue firmada por otros catorce artistas en calidad de integrantes del comité de redacción y planteó manifiestamente una distancia con la experiencia anterior. En el apartado 1.2.1. desarollamos un poco más en profundidad algunos aspectos característicos de la AACI y sus publicaciones.
} 
revistas del corpus. Por último, analizamos la política visual de $p b a$ como un modo de leer que actualiza las hipótesis de lectura de los dos ejes anteriores.

La revista $A$ partir de cero es la más breve de las publicaciones estudiadas; son solo tres números con un formato que priorizó el espacio material de la imagen por sobre la cantidad de páginas y de textos. Es analizada según dos ejes de lectura: el primero se centra en la relación entre surrealismo e Historia, o surrealismo y pasado, a partir de la lectura que realiza Enrique Molina -su director- en torno a la frase "el surrealismo hunde sus raíces en el pasado" (Breton 1952, n2:8), y el armado de una genealogía donde se buscaba revelar una impronta surrealista aun anterior al Manifiesto (1924), por ejemplo, remontándose a Charles Baudelaire. En segundo lugar, estudiamos la función de la imagen en la revista como concepto crítico, principalmente lo que tanto Pellegrini como Molina llamaron "imagen en combustión", que configuró un posicionamiento particular en torno a la narrativa realista de la época.

En cuanto a la revista Letra y Línea, analizamos la ampliación de intereses y bienes culturales sobre los cuales interviene, en comparación con una serie de objetos más restringidos que la vanguardia había tratado en publicaciones anteriores, como Arturo, Arte Concreto Invención, Contemporánea, las mismas Ciclo, poesía buenos aires y A partir de cero. Se toman como punto de partida algunos datos que emergen de la primera página de la publicación (imagen de portada, subtítulo, staff de la revista, sumario, nota editorial) en relación con otros elementos materiales (publicidades, separación de algunas secciones como las reseñas y la sección "poesía o no" o "espejo del mundo"). Esta ampliación es leída en el marco de la pregunta que la revista formuló sobre el presente, donde la articulación entre esos distintos elementos constituyó lo que llamaremos "paradoja de la contemporaneidad": un programa crítico donde Letra y Línea se propuso reconocer quiénes eran sus verdaderos contemporáneos, en un movimiento que prescindiera de los criterios de valoración otorgados por paso del tiempo como tamiz natural que distinguiría, a la distancia, lo que en el presente aparece confundido; el límite o incumplimiento de este programa se evidencia en esa misma zona donde la revista quisiera imponerse: las reseñas de novedades editoriales. 


\subsection{Entre la "generación del desierto" y el "país ahogado"}

Desde los inicios de poesía buenos aires en 1950, Raúl Gustavo Aguirre mantuvo una correspondencia frecuente con el poeta René Char. Entre comentarios de libros, solicitudes de poemas para traducir, reflexiones sobre la poesía y referencias a la vida artística e intelectual en París y Buenos Aires, Aguirre anotaba que "en un país ahogado",50 requería de su compañía para atravesar la soledad (2016:33), ${ }^{51}$ y calificaba a los poemas de Char como "alimentos felices" (34), "tan difíciles de conseguir aquí" (37). El intercambio de esas cartas formó parte de la preparación del número 11-12 de poesía buenos aires (1953), dedicado enteramente al poeta francés. Allí además se lamentaba de no haber podido conseguir aún La part du feu de Maurice Blanchot, uno de cuyos ensayos deseaba incluir en el monográfico de la revista. ${ }^{52}$ Meses después, Aguirre envía los ejemplares a Char -que finalmente pudieron contar con la traducción del texto de Blanchot $^{53}$ - y las conversaciones continúan en el tono de exaltación de la poesía y el malestar respecto de un tiempo que se experimenta como agobio. Este sentimiento no es original ni excepcional, y se puede inscribir en lo que Jorge Panesi (2004) llamó un “discurso de la dependencia" según caracterizó las escrituras de las revistas Sur y

\footnotetext{
${ }^{50}$ La referencia acuática para hablar de la Argentina en términos políticos reaparece en el poema que escribe a René Char titulado "Para terminar una carta", uno de cuyos versos/aforismos dice: Le pays des eaux qui haïssent en silence / El país de las aguas que odian en silencio. Al respecto, Magdalena Cámpora advierte que ese aforismo, escrito en una carta de julio de 1953, dos meses después del atentado de los comandos civiles antoperonistas del 15 de abril en Plaza de Mayo, se recupera en Redes y violencias, publicado en 1957, homologando la figura del combatiente de la resistencia a la invasión nazi en Feuillets d'Hypnos 1943-1944 de René Char a la del "poeta del subsuelo" que durante "años de pesadilla" escribió "a oscuras", como afirmará Aguirre en el editorial de poesía buenos aires que se publica inmediatamente después del golpe de estado autodenominado "Revolución Libertadora".

${ }^{51}$ Se trata de la primera carta incluida en el volumen Correspondencia y poemas (Char y Aguirre, 2016), fechada el 6 de octubre de 1952. El 11 de agosto de 1955 escribía: "La Poesía surge hoy de esa lucha que sostiene para defender su derecho, el enigma dentro de nosotros se resiste a la tergiversación, al envilecimiento. Ella, a su vez, inventa esa verdad ante la cual se disuelve el fantasma de un arte tristemente ocupado de sí mismo. Pero es asombroso que a tales alturas de la soledad vivamos todavía juntos. Hay fraternidades incorregibles, como los labios de sus poemas. Y ellas se mantienen sinceramente de pie ante un noche imperativa, pero que seguramente se desangra allí donde la roza nuestra privilegiada pobreza. Mientras, nos unimos en el presente a nuestras nítidas apariciones (esta piedra, este niño, este amor). Y hemos asido de nuevo el qué de la esperanza, la trama de la vida... y nuestra mesa, nuestros papeles, nuestras palabras, ya no destilan esa vergüenza que los arrancó de la realidad" (2016:52).

${ }^{52}$ En La part du feu se publican dos ensayos sobre Renè Char. Finalmente el traducido por Aguirre es el titulado "René Char". Ampliar

${ }^{53}$ El ensayo de Blanchot sobre René Char se publicó antes en la revista Critique dirigida por Georges Bataille, de donde Aldo Pellegrini toma "La moral de Henry Miller" para el primer número de Ciclo, con lo cual es posible que aun no habiendo conseguido el libro pudiera hacerse de alguno de los ensayos de Maurice Blanchot sobre el poeta. Es posible que la circulación de Critique fuera relativamente fluida en un circuito francófilo como el que compartían la mayoría de los poetas entonces, y especialmente Aldo Pellegrini y Raúl Gustavo Aguirre.
} 
Contorno por esos mismos años. ${ }^{54}$ Sin embargo, el modo en que se configuró ese tipo de experiencia en relación al tiempo presente constituye uno de los hilos a partir de los cuales leer la relación entre las revistas vinculadas al surrealismo e invencionismo y su época, en el marco de un proceso que fue nombrado en fases sucesivas como "modernizador" por la crítica que lo estudió. Se trata de un "hilo" y no un camino, porque como intentamos mostrar a lo largo del capítulo, las revistas expusieron contradicciones, matices, experiencias diversas en torno al tiempo, donde se conjugó una lucha "contra toda melancolía" como sugería el manifiesto de la revista Arturo en 1944 -ineludible para todas las experiencias de vanguardia posteriores-, con reflexiones que asignaban a la poesía, el arte y la literatura una responsabilidad trascendente y esencial: "resistir, conducir al nuevo hombre hacia la gran síntesis que le devuelva la unidad perdida" (Enrique Molina en A partir de cero 1952, n1), elevar "la humanidad a la altura de la poesía" (Nicolás Espiro en poesía buenos aires 1951, n5); y atribuían al poeta una suerte de misión como quien "ha venido a sustituir razones, a hundirse en crecimiento por el tiempo agobiado" (poesía buenos aires, 1950,1). Si a la melancolía se le oponía el “júbilo" -ánimo contingente-al "tiempo agobiado" se le opuso el deseo de un futuro que resultaba esencializado por un conjunto de rasgos que el poeta aportaría, como mejorar la condición humana.

En consonancia con el énfasis que las ideas de un "país ahogado" o "tiempo agobiado" hicieron en la experiencia de soledad, la publicación de la revista Contorno (1953-1959) dispuso los elementos necesarios para configurar una ficción del desierto. El famoso editorial titulado "El martinfierrismo, su tiempo y el nuestro" (Sebreli, 1953, n1), se desplazaba casi treinta años hacia el pasado para encontrar un interlocutor válido con quien ajustar cuentas, y por consecuencia construía el presente como un tiempo arrasado. En esa lectura, los años 50 se prefiguraron como los años viejos de "una generación que vive el día después del coito, el triste amanecer cuando la alegría se ha vuelto tedio, la borrachera fatiga y todos sienten náuseas, pesadez de cabeza y un sabor amargo en la boca", "jóvenes envejecidos antes de madurar", generación "desnuda como un desierto" $(1953, \mathrm{n} 1: 2)$.

Las metáforas del desierto, el ahogo y la soledad como formas de conceptualizar una relación con el tiempo dan cuenta de un espacio común compartido por revistas de procedencia e intereses diversos, hasta ahora consideradas en el cauce de procesos en

54 También por Sarlo en Una modernidad periférica (1988), o Gramuglio en Nacionalismo y Cosmopolitismo (2013) o Julio Ramos en Desencuentros de la modernidad en América Latina (1989). 
apariencia separados, como pueden ser Contorno y pba $^{55}$ Asimismo, estas metáforas con las que ambas publicaciones se aproximaron a un tiempo que rechazan, adoptaron dos formulaciones muy generales que a lo largo de las intervenciones y polémicas se transforman: la de idea de que un "presente inédito, no formulado" de la literatura es un excedente -“este más es lo que atañe, aquello de lo que ninguna otra actividad puede relevarla, el territorio de su exploración, de su aventura, de su verdad" (Aguirre, 1974:52) ,$-{ }^{56}$ por un lado; y la exigencia de acción y "reiteración en la crítica y en la denuncia" (Viñas I. en Contorno, 1953, n1:3). ${ }^{57}$ Desbordar el presente o denunciarlo fueron tensores contrapuestos a partir de los cuales estas revistas de la vanguardia artística y literaria configuraron su experiencia con la época. La dimensión de lo epocal se perfiló, en relación con el arte y la literatura, según aspectos específicos como la insuficiencia de explicar una obra a partir de las condiciones históricas en las que emergió, o los criterios para delimitar quiénes son los escritores contemporáneos.

Esa caracterización del tiempo a partir de metáforas como las del agobio o el ahogo, que como mencionamos antes chocan con otros valores de las vanguardias (el júbilo, el juego), permiten desarrollar el modo en que Ciclo, pba, A partir de cero y Letra y Línea tramaron una temporalidad singular signada por un doble desfasaje: su condición de vanguardia estuvo tan tensionada por las políticas culturales del peronismo en Argentina, como por el cuestionamiento a las formas abstractas, concretas, experimentales y no figurativas que después de la II Guerra Mundial marcó el debate artístico en los principales centros culturales, antes referenciados con radicales procesos de transformación estética como Francia, Italia, Rusia y Alemania. En ese sentido es necesario comprender el vínculo que estas revistas establecieron con el pasado y el modo en que elaboraron genealogías estéticas para sus propuestas contemporáneas donde, a diferencia de Contorno, no se incorporó un diálogo con el martinfierrismo. ${ }^{58}$

\footnotetext{
${ }^{55}$ La idea de espacio común como bullicio de la crítica será abordada especialmene en el Capítulo III.

${ }^{56}$ Citado en Aguirre y Char (2016).

57 “Trabajar. Volver a empezar. Cuidarnos de la petulancia. (...) es necesario el afán, la pasión de actuar, de actuar con la vida. Pues nos parece haber sido demostrado que la sola fidelidad al espíritu es traición del espíritu". (Ismael Viñas en "La traición de los hombres honestos", Contorno 1, 1953:3)

${ }^{58} \mathrm{Al}$ respecto, dice Del Gizzo: "Los poetas de las dos generaciones siguientes volvieron al verso medido, las metáforas tradicionales y las referencias mitológicas como un modo de contradecir a la generación anterior; hasta afirmaban ser de vanguardia por esa "ruptura". ¿Cómo era posible entonces que floreciera el lenguaje vanguardista entre los jóvenes de los cincuenta? Nosotros podemos extrañarnos aún más: ¿Cómo ocurrió que el lenguaje poético que legó la vanguardia se volviera casi hegemónico a partir de la década de 1960 cuando antes era un eslabón perdido? Si, como afirma Delfina Muschietti (1989, 2009), Espantapájaros (al alcance de todos) (1932) de Girondo únicamente pudo encontrar su lector modelo en esa época, ¿cómo y cuándo se formó? (...). Mientras el invencionismo procuró desde sus inicios armar una genealogía latinoamericana, solo algunos años después reconoció a Girondo en poesía buenos aires. Y
} 
Es en el marco de ese desfasaje que, lejos de pensarse como vanguardia en los términos que definió Peter Bürger sus modos de hacer tabula rasa con el pasado (2010), prevalece como constante el énfasis que hacen todas ellas en posicionar al arte moderno en general y a las vanguardias históricas particularmente, como avatares de la historia del arte. Menos que la novedad, figuras como las de Aldo Pellegrini, Raúl Gustavo Aguirre y Edgar Bayley organizaron genealogías de lecturas en las que se inscribe una poética que se funda en el pasado. Así, por ejemplo, A partir de cero publicó una entrevista a Breton donde este afirmaba que "El surrealismo tiene sus raíces en el pasado", y que "sus manifestaciones pueden encontrarse en cualquier momento de la historia" (1952, n2); desde otra perspectiva estética, distante el surrealismo, también se insistía en la metáfora vegetal: Ciclo transcribió, en 1948, una conferencia sobre el arte concreto dictada por Ernesto Nathan Rogers en el Salón Nuevas Realidades, donde postulaba que el juicio sobre el arte contemporáneo "será tanto más sólido cuanto mejor acertemos a demostrar que los brotes de este nuevo florecimiento espiritual pertenecen a una planta que tiene firmes y profundas raíces en el terreno de la historia"; en "Realidad interna y función de la poesía", Edgar Bayley se proponía definir el estilo de "nuestro tiempo" como aquello que "reúne las mismas condiciones de existencia de estilos anteriores" (1952, n6: 7).

En relación con el modo en que la dimensión temporal se constituye en problema crítico, las revistas del corpus trabajaron el desencuentro que se produce en el arte entre la significación y la representación social, por sobre los vínculos entre arte y vida o praxis vital. ${ }^{59}$ De este modo, Ciclo, pba, A partir de cero y Letra y Línea apostaron por una crítica que no se fundara en la continuidad entre entre época, sociedad y obra, sino que leyera lo atemporal que hace a la "esencia del arte". Este aspecto, que se vincula con lo que Aguirre denominaba "el presente no formulado" o "ese más" que atañe a la literatura, en encuentra muchas veces articulado sobre el lugar del poeta como figura privilegiada en tanto tiene otra capacidad para elaborar una lectura del tiempo, que cumple la función de la denuncia.

\footnotetext{
aunque los surrealistas fueron más cercanos a este pionero, la consagración y el alejamiento de la experimentación de los otrora vanguardistas les hizo poner una distancia explícita. ¿Entonces era esa actualización subsidiaria de la primera vanguardia? ¿Existieron líneas de continuidad entre ambas oleadas vanguardistas, a pesar de esas referencias? Hal Foster (2001) propone que son las vanguardias de mediados de siglo en adelante las que ponen en obra el proyecto vanguardista por primera vez, porque registran el antecedente de la vanguardia histórica y lo recodifican para instalarlo. En "El inconsciente de la vanguardia. Relaciones entre la primera y la segunda oleada vanguardista en argentina", Káñina, Rev. Artes y Letras, Univ. de Costa Rica XLII (3) 2018 (Octubre-Diciembre): 235-255.

${ }^{59}$ La tesis de Beatriz Sarlo (1988) según la cual la vanguardia martinfierrista procuró separar el arte de la vida con mucha más fuerza que la unión de la praxis vital, es un punto de partida que se desdobla cuando pensamos las relaciones que establecieron las revistas del surrealismo e invencionismo con la época.
} 
Para dar cuenta de cómo esas articulaciones complejas y contradictorias se produjeron en el marco de un conflicto cultural mayor, reponemos a continuación una serie de investigaciones que abordaron distintos aspectos de la trama política en la cual la época se significa, y que aporta alguna de las las heterogeneidades que conformaron a las revistas del corpus.

Como bien ha señalado Daniela Lucena en Contaminación artística. Vanguardia concreta, comunismo y peronismo en los años 40, el fin de la II Guerra Mundial daría lugar, en Buenos Aires, a un "clima de efervescencia política" en el cual los jóvenes artistas sienten "tener el privilegio de participar en la última gran confrontación contra el fascismo y el imperialismo" (Tomás Maldonado, citado en Lucena 2015:58). ${ }^{60}$ A partir de eso, Lucena analiza los posicionamientos de los artistas concretos en relación con el Partido Comunista Argentino, las políticas culturales y las propuestas de planificación urbana del peronismo, y el recrudecimiento de una línea oficial del PC en Rusia que imponía al realismo socialista como única estética posible revolucionaria. Si bien su objeto de estudio es muy diferente al que me propongo abordar en esta tesis, proporciona datos significativos sobre los conflictos culturales del período, que involucraron a gran parte de los grupos artísticos y literarios. Su investigación evidencia el modo en que el entramado político configura aspectos de las publicaciones periódicas no coincidentes con las adscripciones partidarias de sus miembros, ni con las posiciones ideológicas explícitas. A diferencia de nuestro recorte, se remonta a 1941, y en ese sentido ofrece un panorama más amplio del cual extraer elementos que insisten o retornan en años posteriores.

En primer lugar, Lucena señala que la interrupción de contactos directos entre los jóvenes artistas y los maestros europeos, producida por los desastres de la guerra, modificó las relaciones entre "centro y periferia", ya que "el viaje a Europa, ese estadio de instrucción que muy tempranamente se configura en nuestro país como un eslabón obligado para todo aquel que busca convertirse en artista, aparece como un sueño lejano imposible de concretar en ese conflictivo presente" (2015:60). Esa interrupción generó un interés diferente por parte de los artistas europeos en el devenir de América Latina, y

\footnotetext{
${ }^{60}$ Este clima de efervescencia política adquiere una impronta particular en el campo artístico a causa de la llegada a nuestro país de algunos inmigrantes europeos que, ante el desencadenamiento de la Segunda Guerra Mundial, encuentran en Buenos Aires una ciudad próspera, moderna, cosmopolita y relativamente tranquila donde establecerse. Huyendo del nazismo y del fascismo se instalan en esa época en la Argentina, entre otros, el escritor polaco Wiltold Gombrowicz, el pintor y diseñador español Luis Seoane, la fotógrafa alemana Grete Stern y su marido, el argentino Horacio Coppola; todos artistas que comparten las inquietudes de los jóvenes integrantes de Arturo y apoyan sus iniciativas. (2015:58)
} 
en especial de Buenos Aires, según rastrea Lucena en la correspondencia entre el diseñador de la Bauhaus, Max Bill y Tomás Maldonado. ${ }^{61}$

Por otro lado y en relación con la hipótesis principal de su trabajo, Lucena pormenoriza la historia de una relación compleja y contradictoria entre los artistas concretos y la política ya que mientras postulaban un arte materialista, de raíz marxista, concreta, para la transformación social, capaz de emancipar al hombre de las representaciones, poniendo por encima de todo la práctica -aspecto que los lleva a afiliarse al Partido Comunista Argentino en 1945-, ${ }^{62}$ su producción artística resultó marginal dentro del partido ya que las obras reproducidas en el periódico Orientación órgano de difusión del PCA- correspondían a los artistas del Taller de Arte Mural (integrado por Berni, Castagnino, Cándido Portinari, entre otros), quienes promovían un realismo figurativo, y por lo tanto establecían confrontaciones con los jóvenes concretos. Esta controversia se resolvió en 1948 con la expulsión de Maldonado, Bayley y Hlito tras una polémica sobre la libertad del artista en el partido. Poco tiempo después, Julio Notta -miembro importante del PCA- reafirmó, en Orientación: “y, más aún, lo que debe rechazarse con indignación es la desfachatez de aquellos que pretenden invocar la ideología del proletariado, al marxismo-leninismo-estalinismo, para cubrir con esas gloriosas banderas el contrabando de su desesperación, su traición o su cobardía”.

Paradójicamente, a pesar de las duras críticas que los concretos habían pronunciado contra el gobierno peronista -ya que veían en las medidas ${ }^{63}$ para fomentar el pluralismo estético una "intromisión del Estado en la autonomía y las reglas del campo" (Lucena 2015:60)-, a partir de 1948 se establecieron intercambios significativos con la gestión de Ignacio Pirovano como director del Museo Nacional de Arte Decorativo y

\footnotetext{
${ }^{61}$ Parte de ese interés tendrá consecuencias que luego rastrearemos en las implicancias de la noción de "forma" o "gute forme", que Max Bill emplea para pensar el diseño industrial, pero que los poetas y críticos vinculados con el invencionismo mixturan con una vertiente cercana al formalismo ruso.

${ }^{62} \mathrm{La}$ Segunda Guerra y la amenaza del nazismo (actualizada en nuestro país por la neutralidad del gobierno militar, caracterizada por muchos sectores de la oposición como "pro nazi") se configuran para muchos artistas e intelectuales como el punto de partida de un compromiso político ineludible. Efectivamente, son muchos los intelectuales y artistas que, al igual que los miembros de la AACI, se acercan al Partido Comunista para sumar fuerzas al proceso revolucionario que, según se creía, la Segunda Guerra había iniciado. El 19 de septiembre de 1945, en la página literaria y artística de periódico, bajo el título "Artistas adhieren al comunismo" se lee el siguiente texto firmado por Edgar Bayley, Manuel Espinosa, Claudio Girola, Alfredo Hlito, Tomás Maldonado y Aldo Prior: "Los artistas y escritores del Movimiento Arte Concreto se afilian al Partido Comunista: porque el Partido Comunista es una fuerza nacional al servicio del bienestar, la libertad y el desarrollo cultural de nuestro pueblo". (2015:104)

${ }^{63}$ Algunas de esas medidas son: "el privilegio de ciertos temas - generalmente ligados a la representación de las costumbres regionales y el mundo del trabajo-, la aparición de nuevos premios ministeriales, la designación de jurados no representativos, la realización de nuevos salones (regionales o para estudiantes por ejemplo), el cambio en los horarios de visita y en el día de apertura, el aumento del monto de los premios y la decisión de ocultar el nombre de los autores de las obras para evitar favoritismos". (2015:159)
} 
Presidente de la Comisión Nacional de Cultura. Pirovano resultó una suerte de antagonista de la figura de Oscar Ivanissevich, entonces Ministro de Educación, quien en sucesivas ocasiones entre 1948 y 1949 se había referido al "arte abstracto" como morboso, anormal o veneno (Lucena 2015:160, Fioriucci 2007, Plotkin 1999). ${ }^{64}$ No solo Maldonado se desempeñó como director de la Subcomisión Nacional de Diseño Industrial integrada por Hlito, Borthagaray y Bullrich ${ }^{65}$-todos ellos participantes luego en las revistas Ciclo y poesía buenos aires-, sino que también muchas de las obras de los artistas concretos formaron parte de la exposición oficial titulada La pintura y la escultura argentinas de este siglo en el Museo Nacional de Bellas Artes, y del envío "predominantemente abstracto" a la Bienal de San Pablo en 1953 (Lucena 2015:178), organizado desde la gestión de gobierno. Se trataba, en su mayoría, de obras y artistas que circulaban por espacios de formación y consagración impulsados por el crítico Jorge Romero Brest, quien desde 1947 se encontraba expulsado de las cátedras de la Universidad Nacional de La Plata, y se desempeñaba como editor de la revista Ver y Estimar. Romero Brest formaba parte, asimismo, de la Asociación de Artistas Modernos de la Argentina fundada por Aldo Pellegrini en 1952, tras cerrar la editorial Argonauta como consecuencia de las presiones del gobierno peronista. ${ }^{66}$

A estas contradicciones Lucena agrega dos aspectos que resultan fundamentales para sopesar algunos ensayos que aparecen en la revista Ciclo y poesía buenos aires, especialmente. Por un lado, afirma que "pese a las lecturas que homologan las imágenes del gobierno peronista con las de los aparatos propagandísticos nazi o fascista, Gené demuestra que es posible encontrar más semejanzas en las producciones gráficas difundidas por el régimen estalinista o por el gobierno de Estados Unidos durante el período de entreguerras" (2015:158), ya que "en la figura del obrero industrial construida por el peronismo pueden reconocerse herencias iconográficas que datan de varios años antes y provienen, fundamentalmente, de la imágenes difundidas por los partidos de izquierdas" (2015:158). Por otro lado, destaca la creación del Instituto de Arquitectura y Urbanismo (IAU) en la Universidad Nacional de Tucumán, ${ }^{67}$-en 1946, donde se

\footnotetext{
${ }^{64}$ Recientemente, Guillermo Korn (2017) ha cuestionado zonas de esa bibliografía aportando algunos matices y contradicciones a una perspectiva que considera totalizante.

${ }^{65}$ Desde su nuevo cargo oficial Maldonado envía a Borthagaray a Estados Unidos, con el objetivo de entrar en contacto con los miembros del Instituto de Diseño de Chicago fundado por Moholy-Nagy y con el Museo de Arte Moderno de Nueva York. Cfr. también, Del Gizzo 2017:130.

${ }^{66}$ Fuente: entrevista personal con el hijo de Aldo Pellegrini, Mario Pellegrini.

${ }^{67}$ En relación con este aspecto de los vínculos entre peronismo y vanguardias concreto-funcionalistas, recientemente se presentó una exposición sobre la I Feria de América en Mendoza (1953-1954), titulada "Una silla, dos casas, dos ciudades. Itinerarios y encuentros en la modernidad de provincias" en el Museo
} 
desempeñó como docente y arquitecto el italiano Ernesto Nathan Rogers, estimado y publicado por el grupo editorial de Ciclo, integrante del $\mathrm{BBPR}^{68}$ - equipo con el que realizan el "Monumento a caídos en campos de concentración" en el cementerio de Milán.

Rogers es, asimismo, convocado por Emilio Siri, intendente peronista de la ciudad de Buenos Aires para continuar un proyecto esbozado por Le Corbusier a pedido del concejal socialista Américo Ghioldi veinte años antes (163). A partir de estos datos, Daniela Lucena concluye:

La participación de los artistas concretos y los "jóvenes modernos" en iniciativas oficiales debe comprenderse a partir de la confluencia de sus ideales con un sector del gobierno peronista que, al igual que ellos, confía en el desarrollo industrial, la tecnología, el diseño, la planificación y la intervención de la política para lograr el bienestar del pueblo. A diferencia del PCA, que se había negado a aceptar los recursos del arte concreto como guía y regencia en el camino revolucionario privilegiando la figuración como instrumento de comunicación y concientización de las masas, el peronismo,

Provincial de Bellas Artes Emilio Pettoruti. Cuenta su curadora, Carolina Muzzi: "Sucedió al pie de la columna que vertebra América: en los Andes segmento Mendoza, durante casi seis meses en que toda la provincia debe haber pasado por el gran evento del parque San Martín, atracción para todas las edades: una feria en la que, al modo de las Grandes Exposiciones Universales, los países al sur del Río Bravo mostraban su producción y adelantos. Y el país, para el que Perón deseaba junto con Chile y Brasil unos posibles Estados Unidos del Sur de América, mostraba todos sus ministerios en stands increíblemente modernos. Es que la dirección técnica, la curaduría general de la feria fue confiada por el empresario Iván Bacsinszky al arquitecto César Jannello, quien ya llevaba algunos años en la provincia con su pareja Colette Boccara agitando las aguas del pensar y el hacer proyectual junto a las huestes de vanguardia cuyanas que eran muchas (Abdulio Giudici, Leonor Rigau, Santiago R. Barbuy, José Carrieri, Filomena Moyano). Jannello a su vez convocó a un amigo porteño de OAM (Organización Arquitectura Moderna) Gerardo Clusellas, y juntos proyectaron la arquitectura efímera para stands más alucinante que se hubiera visto hasta el momento. Los planos y documentación de aquellas maravillas, están en el libro "Feria de América, vanguardia invisible", que reune el esfuerzo loable de un equipo mendocino traccionado por el incansable Wustavo Quiroga con la diseñadora emblemática Tite Barbuzza para recuperar ese increíble evento sumergido, más bien ahogado por el golpe de 1955. Para el año 1953, cuando se pensó el proyecto de esta suerte de certamen continental Feria de América, las nociones de modernidad y de progreso se pensaron en términos de avance industrial, en materia de economía nacional y de vanguardia proyectual que abarcara el espacio público, la arquitectura y el diseño. Eran también los años en que en la filosofía arraigaban planteos americanistas como los de Rodolfo Kusch, cruces con el legado de Martí, el peruano José Carlos Mariátegui y albores del pensamiento decolonial. Para hacer corta la historia y apuntar a la muestra en el Museo Provincial de Bellas Artes Emilio Petorutti, que toma apenas uno de los nexos entre estas modernidades de provincias (el que es posible de trazar a partir de la silla W de César Jannello entre dos casas y dos ciudades: la Casa del Puente y la Curuchet, en Mar del Plata y Mendoza y su red de autores e intérpretes) cerramos con que aquel gran evento inédito fundió el trabajo de las vanguardias con el de los políticos en una gran cumbre moderna y popular. Es que durante la Feria de América ocurrió la tradicional Fiesta de la Vendimia (primera fiesta popular del país desde 1936) con su carroza y motivos de vides en un marco de tremenda modernidad pensado por Jannello y Clusellas pero también con la imagen gráfica de Tomás Maldonado (que como partió a Ulm implemetó Santiago René Barbuy en catálogos, carnets, afiches y hasta una estampilla postal triangular!) y la partitura sonoro lumínica que Mauricio Kagel diseñó para la Torre de América de Jannello. Así, hace 65 años, en 1953/54 estas huestes actualizaban aquello que hace un siglo, en 1919 había tirado Walter Gropius al fundar la Bauhaus: de una cuchara a una ciudad para calibrar el amplio espectro del diseño. La versión libre americana: de una torre continental a una estampilla nacional. ${ }^{68}$ BBPR fue un equipo de arquitectos fundado en Milán, en 1932. Las siglas son el el acrónimo formado por las iniciales de los apellidos de sus cuatro integrantes: Gian Luigi Banfi (Milán, 1910 - Gusen, 1945); Lodovico Barbiano di Belgiojoso (Milán, 1909 - 2004); Enrico Peressutti (Pinzano al Tagliamento, 1908 Milán 1976); Ernesto Nathan Rogers (Trieste, 1909 - Gardone, 1969). 
con sus ambigüedades y su ausencia de un programa estético, se muestra lo suficientemente ecléctico para incorporar y promover el programa del concretismo, sobre todo en su versión "diseño", aunque también en el estilo pictórico.

Como se ve en esta descripción de la dinámica de artistas concretos -que se toca con el desarrollo de las revistas del corpus porque involucra zonas de tránsito entre los artistas de la AACI que se integraron en Ciclo o comenzaron a publicar en $p b a-$ los vínculos con la política contemporánea no fueron lineales. Marcados por la incomodidad de un proyecto "fuera de lugar", las trayectorias artísticas de muchos de ellos dan cuenta de matices y discordancias que impiden asociar de manera lineal los posicionamientos ideológicos con las obras artísticas, y estas a su vez con la trama político-institucional en la que se insertan. En ese sentido, la conclusión de Lucena contrasta con las expresiones del poeta Raúl Gustavo Aguirre mencionadas al inicio del capítulo, o con la gravedad que los jóvenes contornistas exigen a la crítica cultural.

En el número 21 de poesía buenos aires de 1955, tras el golpe de estado del 16 de septiembre, Raúl Gustavo Aguirre abrió la publicación diciendo "es necesario seguir reteniendo esa libertad sobre el terreno permanente de la vida, ahora que el muro ha sido derribado", y Edgar Bayley, a continuación, insistió "Ahora sabemos que no es posible vivir sin libertad. Es una frase que el orador le cede al poeta. Corríamos el riesgo de creer que sí, que era posible". Podríamos decir que para una fracción de los artistas concretos que habían conformado la AACI, y especialmente para Tomás Maldonado, el tiempo no se experimentó en la encrucijada entre desbordarlo o denunciarlo, sino en la aceleración, la búsqueda de caminos convergentes entre una vanguardia neofuncionalista y la modernización e industrialización de la vida cotidiana, mientras que para los poetas nucleados en poesía, inicialmente vinculados al invencionismo de la AACI, el tiempo se experimentó, como ya se dijo, como júbilo o agobio en relación a una determinada libertad.

La no-correspondencia simétrica entre posicionamientos políticos, ${ }^{69}$ adscripciones partidarias y políticas del arte que pone en evidencia Daniela Lucena al analizar las relaciones conflictivas de los artistas concretos con el PCA y las políticas del

\footnotetext{
${ }^{69} \mathrm{Al}$ respecto, dice Peter Bürger: "Si realmente se piensa que existe una relativa independencia de los subsistemas sociales respecto del desarrollo total de la sociedad, de ningún modo puede darse por sentado que las crisis de la sociedad deben repercutir en una crisis de los subsistemas y viceversa. Para comprender las condiciones de posibilidad de la autocrítica del subsistema social arte es preciso construir la historia de tal subsistema. Esta historia no puede llevarse adelante convirtiendo a la historia de la sociedad burguesa en el fundamento de la historia del arte que queramos concebir". (2010:33)
} 
gobierno de Juan Domingo Perón, fue señalada desde la historia de la poesía por Martín Prieto en "Poesía y peronismo" (2010), a partir del análisis contrastado entre la Antología de poetas peronistas - marcada principalmente por el registro clásico de formas, metros y figuras retóricas como el soneto, la elegía, la oda, con rimas claras, en torno a temas de reivindicación social como la Oda al Aguinaldo- con las propuestas poéticas de César Fernández Moreno en "Argentino hasta la muerte" y Leónidas Lamborghini en $\mathrm{Al}$ público, que darían cuenta, a través de los cambios estéticos y lingüísticos que introducen en su poesía, de una transformación tan novedosa como el tipo de cambio social que se había promovido desde un modelo político. ${ }^{70}$

Por otra parte, En Volver a la vanguardia. El invencionismo y sus derivas en el movimiento poesía buenos aires (1944-1963), Luciana Del Gizzo coincide con el diagnóstico de Prieto en cuanto a las formas poéticas propuestas desde espacios como Mundo Peronista. Agrega, a su vez, que estas resultaban tan atrasadas para los jóvenes invencionistas, como las poéticas de Sur que habrían optado en igual medida por un retorno al metro y la rima. ${ }^{71}$ Estas se oponían a las imágenes sin metáforas de los invencionistas, o la imagen del azar que impulsaban los surrealistas. Ese es el nudo de un conflicto político y cultural que Del Gizzo lee en tanto conflicto lingüístico, caracterizado por la "pérdida de la elocuencia" de la lengua poética.

En relación con ese problema, Volver a la vanguardia propone una hipótesis en torno a la lengua como objeto de debate a partir del cual el invencionismo se configuró. Esto resulta relevante para pensar, en nuestros propios términos, la ambigüedad que atravesó a las revistas de vanguardia a mediados de siglo en Argentina. Del Gizzo postula que "las formaciones antiguas asociaban la poesía con el uso insistente de la elocuencia, entendida como esa zona del lenguaje vinculada al buen decir y al habla apropiada, pero que también acude a ciertos recursos para conmover o persuadir" (41-42); ${ }^{.72}$ sin embargo, el estatuto

\footnotetext{
${ }^{70}$ Afirma Prieto: “cuando hablamos de poesía peronista, no hablamos de la poesía partidaria de Perón que casi no es literatura, según puede verse leyendo la antología poética de la revolución Justicialista (1954) preparada por Antonio Monti y que, cuando lo es, es elegíaca, lírica, epifánica siendo su sujeto, sin embargo, Eva Perón, el caballo del general o, aun, el aguinaldo - sino esa poesía que, más allá de su inscripción ideológica de base da cuenta de la conmoción que el peronismo importa en el mismo cuerpo de la literatura argentina, más allá de las valoraciones y aun más allá de los «posicionamientos» de los escritores en el campo intelectual en su relación con la política. Y en ese orden son tan peronistas el gorila argentino hasta la muerte, de César Fernandez Moreno («no crean en lo general, en el general», «eviten a evita», etc.) como el peronista las patas en las fuentes, de Leónidas Lamborghini)" (2010:180)

${ }^{71}$ La vanguardia invencionista y el movimiento "poesía buenos aires" reaccionaron contra un "lenguaje poético perimido que, tanto por parte de los círculos conservadores como por parte de los peronistas reformadores en lo social, aborda todo el espectro de producción poética" (Del Gizzo 2017).

72 "En este contexto, afirma Del Gizzo, algunos espacios de producción simbólica permanecían como reductos de la cultura liberal y cosmopolita que en general había caracterizado a la élite de poder durante
} 
de la lengua como una materialidad fiable en la designación de la realidad es puesto en duda cuando se reactiva el conflicto entre herencia hispánica y habla popular o autóctona (donde se incluía el lunfardo pero también la pregunta por las lenguas indígenas); ${ }^{73}$ como respuesta a esa inestabilidad o "fin de la elocuencia", se habrían producidos tres reacciones donde la propuesta de los invencionistas, que rechazaba toda representación, no podía encajar: el resguardo cultural de las élites, el lamento neorromántico de la generación del cuarenta, la heroicidad hiperbólica de la épica peronista.

Lo que se produce es una diferencia con respecto al valor de la "pureza del lenguaje" y el modo de afrontar esa "pérdida de la elocuencia" a partir del reconocimiento del fracaso de las figuraciones poéticas vigentes para dar cuenta de las transformaciones históricas. "Pureza del lenguaje" se oponía, para algunos espacios culturales, a "idioma surgido de los sectores sociales bajos y vinculado al delito" (2017:48), que reaccionaban frente a esa pérdida de elocuencia con tonos elegíacos y melancólicos; los sectores asociados al peronismo no reivindicaban una pureza poética pero asumían una capacidad trascendental para la poesía, sustentada en la representación, que pusiera a disposición del pueblo los valores que se buscaba transmitir. Los invencionistas, repara Del Gizzo, también buscaban un pureza del lenguaje, pero "ya no tenía que ver con darle un uso apropiado, sino que pasaba por desarmarlo, por depurarlo de adornos y accesorios hasta reducirlo a una estructura, que era lo único que podía afirmarse como cierto" (2017:72).

Estas discusiones sobre la lengua poética que analiza Del Gizzo, o el desencuentro entre ideología y renovación de las formas en la poesía, según Prieto, así como también los vínculos institucionales conflictivos entre artistas de vanguardia, gobierno peronista y el PCA, que describe Lucena, son relevantes para pensar la significación de las escrituras críticas a partir de las cuales intervinieron Ciclo, pba, A partir de cero y Letra

\footnotetext{
la Década Infame, aunque afloraban en ellos, cada vez con más frecuencia, algunas tensiones producto del cambio social. Las revistas culturales eran voceras de esa cesura: por un lado, reproducían una idea de la literatura como discurso cultural elevado, internacionalista a la vez que restringido a determinados grupos, que estaba en boga desde hacía dos décadas. Por otra parte, comenzaban a reflejar algunas de las disyuntivas que serían cruciales en la década posterior, como la escritura de minorías vs. la escritura para el público amplio, la ruptura y la innovación vs. los clásicos, regionalismo vs. vanguardia, etc.” (2017:39)

73 "A decir verdad, el peronismo mantuvo una política lingüística ambigua: durante la primera etapa de su gobierno defendió la pureza de la herencia hispánica en el lenguaje nacional, para reivindicar después las lenguas indígenas como particularidad autóctona, dejando espacio, también, para el habla popular. Algunos especialistas han interpretado esta actitud del Estado como un intento de mediar entre la herencia hispánica y el sustrato originario en la construcción de una identidad lingüística, pero, dado que no puso en marcha una política de articulación de ambas vertientes, esta apreciación parece incierta. Podría considerarse más bien que esa vacilación es propia de un momento de cambio en la concepción del lenguaje nacional y de la base lingüística oral. En efecto, durante la segunda etapa del gobierno de Perón se consolidó una posición más nacionalista, con el abandono de la hispanofilia y el fomento de la variedad argentina". (Del Gizzo 2017:49)
} 
$y$ Línea ${ }^{74}$ La hipótesis que se desprende de esa primera parte de un estado de la cuestion sobre el conflicto cultural en el que emergen las revistas, es que esa serie de contradicciones que modulan su vínculo con los aspectos político-culturales dominantes de la época en términos generales, pueden encontrarse más específicamente en las intervenciones crítico-ensayísticas que desplegaron. La organización de las lecturas, bibliotecas teóricas y críticas, antologías, encuestas, se dirime, en las revistas de nuestro corpus, en las valoraciones superpuestas que conforman las escrituras críticas. Al inicio del capítulo mencionamos el doble signo de $p b a$, marcada por el sentido del "júbilo" tanto como por el "agobio", o bien cómo A partir de cero postula la fusión entre arte y vida pero resguarda para el poeta un lugar de privilegio en el cumplimiento de esa misión. Estas valoraciones ambiguas pueden ser pensadas en el marco de los programas críticos de cada revista, donde uno de los problemas que se actualiza en cada caso es la relación entre vanguardia y temporalidad. Así, tanto en la búsqueda por definir un presente y quiénes son sus contemporáneos, como en los gestos críticos ${ }^{75}$ que exponen las revistas -la disposición de las series de la crítica (Capítulo II), la elaboración de figuras críticas y las disputas por el sentido en un conjunto de palabras comunes y compartidas por distintos grupos (Capítulo III)- las morales críticas que intervienen en ellos no se explican ni se justifican en una determinada correspondencia ideológico-partidaria.

En relación con la historia de la crítica, ha sido Guido Herzovich quien pensó una zona de este problema en el cruce con la historia de la edición y el proceso de crecimiento del público lector en Argentina. La tesis doctoral titulada La desigualdad como tarea. Crítica literaria y manifestación editorial en Argentina (1950-60) (2015) analiza los años cincuenta a partir de profundas transformaciones en las condiciones materiales -los muchos libros, el ascenso de las clases medias, la creciente formación lectora dada por el acceso ampliado a la educación- que produjeron impactos suficientes en la crítica como para alcanzar a una revista pequeña, Letra y Linea, cuyo grupo estaba “desligado de la

\footnotetext{
${ }^{74}$ Las investigaciones que muestran mayor conflictividad y ambigüedad con respecto a la política (aunque no se detengan siempre en el análisis de aquello que esta modifica o ajusta de una obra) permiten dar un marco más sutil, más matizado, del espacio donde la crítica interviene. Esta aclaración no desconoce que se está superponiendo una exposición del tipo de "campo cultural" como la que hace Lucena, donde la ambigüedad se lee fácticamente en los movimientos de los artistas, con otra perspectiva que es la que se sustrae de explicar esas incongruencias por efectos de la organización del campo (tal como ha pensado Raúl Antelo al proponer la preponderancia del "gesto" por sobre la representación, o Judith Podlubne en su análisis de Sur y los años 60). Sin embargo, la articulación de ambas perspectivas resulta útil para visualizar la conformación de ese espacio donde resuenan las escrituras críticas.

${ }^{75}$ Podemos pensar, con Antelo (2015) en la diferencia entre representación y gesto: el gesto como instancia menos determinada, determinista de otras nociones que se han utilizado para pensar las intervenciones críticas (operación, modos, protocolos).
} 
tradición y los "mitos" liberales que desvelaban todavía a los renovadores emblemáticos de la crítica (Héctor A. Murena, David e Ismael Viñas, el propio Prieto)" (2015:x). Sin detenerse en las adscripciones o rechazos a determinadas políticas partidarias, analiza "las renovadas posibilidades que la relevancia y visibilidad del discurso crítico prometían ofrecer a actores relativamente marginales del espacio literario" (x). Entre esas posibilidades renovadas está la intervención autorizada de un grupo de jóvenes de formaciones diversas, por lo cual Letra y Línea tendría como condición de posibilidad los efectos que produjo la ampliación de las condiciones que establecieron otra relación entre cultura letrada y mercado del libro. La hipótesis principal de Herzovich es que las condenaciones críticas de Letra y Línea enjuician un conjunto de prácticas cuya visibilidad le debe tanto a la reconfiguración de lo artístico derivada de la transformación vanguardista como a la transformación social que venía teniendo lugar en el espacio cultural y que afectó también al estatuto de los materiales literarios (2015:273).

En ese marco de transformaciones Herzovich lee también los veinte años que separan la revista Ciclo (1948-1949) de Qué (1928-1930). ${ }^{76}$ A un momento en el cual la circulación literaria seguía fuertemente determinada por fronteras materiales: las librerías ‘cultas' ofrecían materiales seleccionados para una clientela exclusiva de bibliófilos y lectores de varias lenguas; los kioscos y las librerías de barrio vendían copias baratas y traducciones, se opondría, veinte años después, la incorporación de una heterogeneidad enorme de títulos (prestigiosos, comerciales, coyunturales, populares) por parte de los nuevos sellos editoriales que generó un efecto de indistinción o confusión respecto del cual las revistas cumplieron un rol central, y un grupo de escritores hijos de la clase media inmigrante, como Pellegrini, Piterbarg, Kosice, Brascó, Vanasco, entre otros que circularon por las revistas de vanguardia de los años cuarenta y cincuenta, "consiguió quebrar el predominio hasta entonces casi exclusivo de los interlocutores que pertenecían a la burguesía" (2015:v). A partir de estas consideraciones, Herzovich enmarca a Letra y Línea en un proceso de disputa en torno a los "límites entre zonas de legitimidad e ilegitimidad para la práctica crítica" (271). El análisis conjunto donde pone en relación "vanguardia" y "mercado editorial" ofrece una perspectiva ampliada del proceso denominado "modernización de la crítica", del cual "Centro (1951-59), Las ciento y una

\footnotetext{
76،'Hay en particular un dato sorprendente de su biografía que no ha recibido atención, y que lo vuelve una figura en cierto sentido desfasada: el hiato de 18 años entre las actividades del primer grupo "surrealista fuera de Francia, que Pellegrini fundó en Buenos Aires en 1924-30, y el inicio de su obra poética y crítica recién en 1948" en "Vanguardia y mercado en Argentina: el caso Pellegrini" (Herzovich 2016).
} 
(1953), Contorno (1953-59) son la punta de un iceberg proliferante de actividad crítica y reseñística, a la que conceden espacio crecientemente regular y jerarquizado una gama inédita de publicaciones" (vi).

Desde nuestra perspectiva, el énfasis crítico de Letra y Línea estaría menos en el espacio del mercado, que en la pregunta sobre la contemporaneidad suscitada por esa dimensión comercial que se articula, a su vez, con los valores propios de las vanguardias históricas. En Letra y Línea el tiempo se configuró ya no entre la deriva de la denuncia o el desborde, sino como un problema a derribar. Frente a la rapidez del mercado editorial, como señala Herzovich, Letra y Línea expuso un desafío crítico en relación con el tiempo: elaborar los criterios de diferenciación que se adelantaran al consenso natural que impone el paso de los años (“Justificación”, 1953, n1: 1-2). Este aspecto reconfiguraba la relación histórica entre vanguardia y temporalidad, cuyo objetivo era abolir el tiempo, en el gesto de disparar contra los relojes. ${ }^{77}$ Así, esos límites entre lo legítimo e ilegítimo son, en todo caso, movidos y re-marcados por la inestabilidad que la pregunta por el presente les impone. La revista publicó una carta de Henry Miller a Fraenkel donde es posible leer una de las formas que adopta la preguntó por el presente:

Nosotros estamos acá para discutir lo pasado y lo futuro, como tramoyistas discutiendo las decoraciones que han de subir o bajar. La historia es un telón de fondo sin significado para un espectáculo que no se monta jamás. Nada resulta viviente en nosotros, ni como visión retrospectiva ni como anticipación. El presente es un vacío, un estado coagulado y doloroso, una especie de sala de espera sombría donde yacemos, prontos a estallar al menor cambio barométrico. $(1,8)$

En palabras de Miller, uno de los problemas al que se enfrentaría ese "nosotros" es la inadecuación de lo disponible ("la historia como telón de fondo sin significado") para un presente "vacío" y diferido en relación con esa historia ("espectáculo que no se monta"). Pero además de vacío, ese presente que parece escaparse de la discusión (de la que solo serían objeto "lo pasado" y "lo futuro") se metaforizaba con dos figuras: el estallido y la sala de espera. La espera ha sido pensada por Badiou como una "poética" con la cual los surrealistas, especialmente André Breton, buscaron apropiarse de lo real (2011:40). En el capítulo 3 de L'amour fou, espera y estallido aparecen fusionados: "El surrealismo siempre ha aspirado a ese estado particular del espíritu, desdeñando en última instancia la presa y la sombra por lo que ya no es sombra y aún no es presa: una y otra fundidas en

\footnotetext{
${ }^{77}$ Cfr.: Walter Benjamin (2014).
} 
un relámpago único", y culminaba el párrafo con la idea de que, prescindiendo "de lo que pase o no, lo magnífico es la espera" (citado en Badiou, 2011:40). Podemos pensar, entonces, ese presente vacío de Miller como el desafío crítico de Letra y Línea que pretende establecer sus criterios de valoración anticipándose a los tiempos del consenso, es decir, captar ese instante de relámpago que funde "lo que ya no es sombra y aún no es presa". "Época", “presente”, no se consolidan como sentidos plenos, identitarios, que puedan ser referidos como un conjunto de características o discursividades estabilizadas. Antes bien, parecen nombrar una experiencia que desbordaba formulaciones generales como "nuestro tiempo" o "nuestra época”. Así, el valor de lo "contemporáneo" y quiénes están en condiciones de encarnarlo, sería uno de los tópicos de debates, especialmente en Letra y Línea y poesía buenos aires, como veremos en los próximos apartados. Con tensiones, contradicciones y polémicas, lo cierto es que no se trata de una noción ya dada. En efecto, aun cuando poesía buenos aires se pensó en términos de colección y "viviente antología de la poesía de nuestro tiempo" ( $\mathrm{n}^{\circ}$ 13-14, "Aniversario", s/n), "lo contemporáneo" no es un concepto que la antecede, sino que debe construir y nombrar, por eso afirmaban: "En las páginas que siguen, se presenta -según un orden surgido más allá de la necesidad de aclarar la exposición que de clasificar taxativamente la individualidad creadora de cada uno de ellos- un índice de los poetas que están trabajando en la actualidad, en estas tierras, dentro de un espíritu que podemos llamar contemporáneo" ( $n^{\circ} 13-14$, "Presentación", s/n). Es la selección de poetas la que permite nombrar a lo contemporáneo y no al revés, como una categoría que se encarnaría en ciertas características y que sería representada por determinados nombres. Así, la noción de "presente" es también inestabilizada, ya que si vale preguntarse de quiénes somos contemporáneos, también es posible preguntar cuál es nuestro presente, o lo que cada revista subjetiviza como tal.

Claudia Gilman ha definido la época, refiriéndose al período "años sesenta/setenta", como "campo de posibilidad de existencia de un sistema de creencias, de circulación de discursos y de intervenciones" (2003:19), "un campo de lo que es públicamente decible y aceptable -y goza de la más amplia legitimidad y escucha- en cierto momento de la historia, más que como un lapso temporal fechado por puros acontecimientos, determinado como un mero recurso ad eventa" (36). Sin embargo, estos problemas que fuimos puntualizando nos advierten sobre otra posibilidad: que época no sea principalmente un campo discursivo que goza de legitimidad y escucha, sino también aquello que permanece poco conformado como discursividad atendible, desarticulado, lo 
que en términos de Giorgio Agamben podríamos pensar en tanto experiencia anacrónica de la contemporaneidad: "el presente no es otra cosa que la parte de no-vivido en todo vivido y aquello que impide el acceso al presente es la masa de lo que, por alguna razón (su carácter traumático, su excesiva cercanía) no hemos logrado vivir" (2011:27), ${ }^{78}$ una fuerza intempestiva que no se ajusta a la cultura histórica a partir de la cual determinado período se representó; por ejemplo, los años 50 como una época de censuras en lo cultural, la conformación de una crítica moderna a partir de la recepción del existencialismo sartreano, la centralidad creciente de la literatura de Borges. Así, si bien podemos afirmar, a partir de Gilman, que la ideología del humanismo representa un conjunto de valores hacia donde convergen posiciones diversas en tanto constituye uno de los términos de legitimidad y escucha de la época, ${ }^{79}$ se producen, no obstante, interferencias e intervalos donde emergen otras formas de significar la experiencia que desplazan al sujeto de lo que está en el centro de la discusión. ¿Era legítima una noción como la de “instante” propuesta por Bataille en "La moral de Henry Miller", primer ensayo de Ciclo (1948), que proponía una epistemología de la suspensión de la conciencia y los valores, sin aludir al automatismo surrealista $?^{80} ¿ \mathrm{O}$ la noción de "realidad increada" de Maurice Blanchot en poesía buenos aires?, ¿podía ser decible una crítica literaria y artística que no se articulara con la política como tematización de problemas nacionales, según configuraron Oscar Terán y Nicolás Rosa la razón de la crítica? ${ }^{81}$ ¿Era visible el nombre de Roland Barthes en la reseña que hace Letra y Línea sobre Les lettres nouvelles de Maurice Nadeau, donde se comenta Le degré zero de l'écriture (1953)? La imposibilidad de responder a estas preguntas de manera afirmativa o negativa tiene que ver con ese estar "fuera de foco" entre la clausura de tiempo que había sido marcado por las promesas de las vanguardias y el deseo de renovación que experimentaron quienes hacían estas revistas, entre el gesto vanguardista y la seriedad, entre la denuncia de lo que hay o el desborde exuberante. Estas interferencias respecto de lo audible de una época es lo que Jean Louis Déotte piensa como "dejar lugar a una complejización interminable de formas del tiempo" (2013:45), a

\footnotetext{
${ }^{78}$ La traducción de Pennisi (2008) presenta una redacción confusa en ese pasaje, por eso preferimos citar la de Sardoy (2011) en esta oportunidad.

${ }^{79}$ Cfr.: Podlubne $(2013,2014)$.

${ }^{80}$ Algo de lo inaudible de la presencia de Bataille en los cincuenta puede confirmarse cuando observamos las referencias sobre Ciclo que aparecen en pba: en el número 13-14 se recupera la trayectoria de Aldo Pellegrini, señalando los "notables trabajos sobre el surrealismo y el arte contemporáneo" publicados en Ciclo, respecto de la cual consigna cada uno de sus autores, pero excluye el nombre de Georges Bataille entre los listados.

${ }^{81}$ Un desarrollo de los argumentos a partir de los cuales Rosa y Terán dan cuenta de esa perspectiva, desde disciplinas diversas - la crítica literaria y la historia de las ideas- lo encontramos en el Capítulo II.
} 
partir de lo cual se produce un "aparaillage" o emparejamiento de tiempos heterogéneos. Se trata, entonces, de analizar temporalidades superpuestas que multiplican el estatuto de las discursividades a partir de las cuales conformaríamos una noción de lo legible para una época. Así, mediante una lógica de las singularidades, es posible ampliar la noción de "época" sin reducirla a la medida de los acontecimientos disruptivos que establecen los límites de lo audible o decible.

A los conflictos culturales que fuimos describiendo con el abordaje de otras investigaciones es posible añadir, entonces, el modo en que la temporalidad constituyó un problema crítico en las revistas de nuestro corpus. Este aspecto será analizado según la noción de lo "moderno" en el caso de Ciclo, la iluminación, en el caso de $A$ partir de cero, la vanguardia como expresión del júbilo y combate de un tiempo "ahogado" en poesía buenos aires y Contemporánea y lo contemporáneo en Letra y Línea.

Estas revistas estuvieron atravesadas por lo que llamamos moral crítica del anacronismo, que se fundaba en la idea de una vanguardia capaz de trazar las dimensiones de lo temporal según exigencias no reductibles a la cronología de una época. La dimensión anacrónica se manifestó a través de diferentes figuras y formulaciones. En el caso de Letra y Línea señalamos la inestabilidad de los términos "contemporaneidad" y "presente" con la figura del "vacío" tensionado entre la espera y el estallido. Otras de las figuras que aparecen para significar esta moral son las de "hato de luces", "signo de doble desgaste", "relámpago", "rayo", “combustión", "salto". Así, Jorge Enrique Mobili condensó en $p b a$ lo que otras revistas y otros nombres desplegaron según distintas inflexiones y énfasis:

La generación de vanguardia está compuesta por todos aquellos que no han negado el simple acto de nacer bajo el signo de un doble desgaste; por todos aquellos que han sometido la brutalidad pertinaz de los hechos. Son los que bailan sobre el abismo con un hato de luces elementales sobre las sienes. Los más saludables al fín en la lucha microscópica e irrisoria del siglo. La vanguardia es para muy pocos, los más veraces, los menos contemporáneos. $(1951, \mathrm{n} 4: 1)$

La relación entre vanguardia y temporalidad está dada, en esta cita, por una negación de lo contemporáneo entendido como actual; en ese sentido, el "signo de doble desgaste" puede ser pensado como esa "pequeña parte de su afuera" que la actualidad incluye dentro de sí (Agamben 2011:27), el tiempo del "no todavía" y el "ya no", o en términos de Breton "lo que ya no es sombra y aun no es presa". Asimismo es imposible no advertir el carácter agonístico de esa relación que se trata de la lucha "microscópica e irrisoria del siglo" y 
de someter la brutalidad de los hechos, como una resonancia del tiempo intempestivo, no regido por la significación autoevidente de los acontecimietos históricos o "lo que en el presente no podemos de ningun modo vivir (Agamben, 2011:27). Por otro lado, estos elementos se exponen su precariedad, por oposición a los atributos plenos del escritor comprometido, ${ }^{82}$ ya que no son más que un paquete de luces con el que se baila sobre el abismo. La "generación de vanguardia" se definía, así, en relación al tiempo que la constituye, y este es un tiempo liminar, inestable.

Las figuras del relámpago, el rayo, y la combustión son parte de un imaginario surrealista que alude a los momentos de fusión de materias opuestas, y que se remiten tanto a las Iluminaciones de Rimbaud como a los Cantos de Maldoror de Lautréamont, donde las luminescencias están asociadas o bien con las visiones, en el primero, o bien con sobrevidas. Sin embargo, es posible trazar un arco que va "La moral de Henry Miller" de Bataille, publicada en Ciclo a los ensayos sobre poesía de Enrique Molina en Letra y Linea, donde estas figuras son subsidiarias de una forma de hacer crítica donde prevalece la noción del instante. Una crítica del instante supone una aproximación a las obras donde el tiempo que las atraviesa está, una vez más, sometido a la precariedad del saber.

Otra variable es la del salto; el poema de Bayley en 1944, publicado por la revista Arturo en su primer número puede tomarse como política del arte en torno al tiempo:

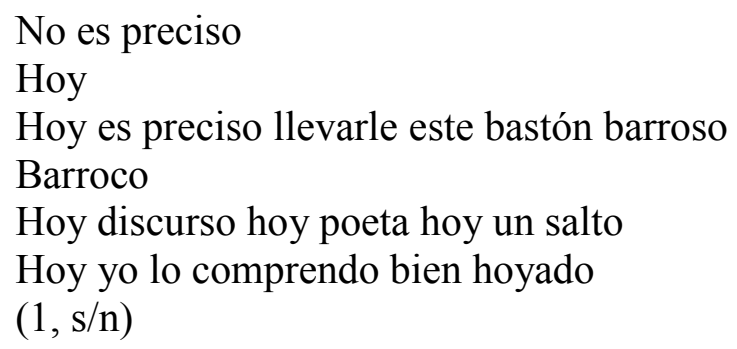

"hoyado" aparece entonces como una variación significante de "hoy", pero no se trata exactamente de un neologismo, arrastra también una pluralidad de sentidos donde podemos leer tanto lo que se cava u horada, como el peso de la desinencia de un participio pasado (hoy-ado), y afirmar que el "hoy" es también pasado. Como en uno de los poemas de Antonio Porchia que traduce Aldo Pellegrini para A partir de cero, el vínculo con la época impone pensar los alcances de un verso que en Voces, nos dice "ya nada es de hoy".

\footnotetext{
${ }^{82}$ Ver Capítulo III.
} 
El verso "hoy yo lo comprendo bien hoyado" condensa todo un programa de lo contemporáneo como sustracción del imperativo de novedad, de estar al día. Por otra parte, un presente hoyado es un presente que no se comprende como unidad ni esencia, al que es preciso aportarle un "bastón barroso". Es imposible a su vez no experimentar en la lectura el efecto del anacronismo de la formulación "barroso-barroco", escrita en la década del cuarenta, que hace saltar al neobarroso perlonghiano desde ese quinto verso que nos pide "hoy un salto". El salto es una figura de la discontinuidad, que puede ser pensada, a su vez, desde la noción de Sprung de Walter Benjamin: lo que hay entre el pasado y el presente son saltos [Sprung], afirma, en contraposición al procedimiento del historicismo consistente en "proporcionar una masa de hechos para llenar el tiempo homogéneo y vacío" (1973:190).

Desde esta perspectiva, podríamos caracterizar a la vanguardia como un órganon de la historia, es decir, "en la época en que surgieron (las obras), representar la época que las reconoce, es decir, la nuestra" (Benjamin citado en Opitz y Wisisla 2014:546). En tanto órganon, las revistas de la vanguardia surrealista - invencionista en Argentina ponen en relación su propio propio presente con una experiencia que había quedado en su momento más alto al otro lado del océano y veinte años atrás. Por eso, en los apartados sucesivos se presentan los programas de cada revista del corpus - su conformación editorial, su política visual, redes culturales - desde un ángulo en particular: el modo en que se vincularon con su tiempo, lo interrogaron y buscaron establecer posiciones críticas.

\subsection{Ciclo. Arte, literatura y pensamiento modernos: el desplazamiento del manifiesto a la crítica}

Los dos números de la revista Ciclo introdujeron nuevos matices tanto en las discusiones sobre arte contemporáneo como en las reflexiones teóricas que se orientaban a construir los criterios de una crítica venidera. Con casi cien páginas cada uno, se trató de un espacio de difusión de ensayos críticos antes que de producciones artístico-literarias o programas estéticos. Los únicos textos literarios publicados por la revista corresponden a la traducción de un fragmento de Trópico de capricornio en el primer número, y dos poemas 
de Mario Trejo en el segundo. ${ }^{83}$ Como comentamos al inicio del capítulo, la intervención de esta revista puede ser pensada desde dos ejes de análisis: el modo en que reconfiguró las propuestas de algunas publicaciones antecedentes, como Qué (1928-1930), Invención (1945), Invención Arte-Concreto (1946), Boletín de la Asociación Arte ConcetoInvención y su suplemento poético (1946), ${ }^{84}$ en el marco de una noción amplia como la de "arte moderno"; y la conformación incipiente de un programa crítico donde el problema de la temporalidad se formuló en torno a dos vertientes, una vinculada al problema histórico del ocaso de las vanguardias, la otra, vinculada con la búsqueda de criterios de análisis que no recayeran sobre lecturas contenidistas del contexto histórico de las obras y que, por el contrario, pudieran leer también la técnica, la forma y una experiencia del tiempo no cronológica. Es en esta última vertiente donde advertimos el funcionamiento de una moral crítica del anacronismo como modo de leer el arte y la literatura.

Ciclo. Arte, literatura y pensamiento modernos fue leída por Raúl Antelo como una intervención disruptiva respecto de los debates de la época, ya que en el ensayo de Georges Bataille sobre Henry Miller delineaba aspectos de un pensamiento posthumanista que constituiría una oposición a la futura Contorno (1953-1959) -"De no haber sido hegemónicos Sartre y Contorno, afirma, otra sería la historia cultural de los sesenta" (Antelo, 2013:179) - y que configuraba otra noción de tiempo -el tiempo del instante “aion" por oposición al tiempo "cronos"- y de sujeto. Desde nuestra perspectiva, esta hipótesis se enmarcaría en un programa crítico mayor, donde el pensamiento del instante como modo de aproximarse a la literatura -en ese caso, particularmente a la de Miller-, es una de las formas en que se manifiesta la moral del anacronismo. ${ }^{85}$

\footnotetext{
${ }^{83} \mathrm{El}$ retiro de tapa del primer número adelanta contenido de "próximos números", con lo cual es posible suponer que Aldo Pellegrini, Elías Piterbarg y Enrique Pichon Rivière imaginaban un tercero que nunca salió.

${ }^{84} \mathrm{El}$ archivo hemerográfico de la $\mathrm{AACI}$ es poco claro, con decisivos blancos que otros investigadores ya han señalado (Cfr. el trabajo de Pérez Barreiro, Gabriel (1994) sobre la falta de fuentes completas sobre las publicaciones y su relación con las muestras entre los años 1945 y 1948), por ese motivo aquí consignamos las tres publicaciones disponibles -Invención (1945), de Invención Arte Concreto (agosto, 1946), Boletín de la Asociación Arte Concreto-Invención y su suplemento de poesía (diciembre, 1946)- de las cuales, la de agosto aparece como "primera" porque se trata de una producción colectiva, a diferencia de los cuadernos Invención orientados a la difusión gráfica de la teoría o manifiesto de un artista en particular (los dos disponibles corresponden a Edgar Bayley y Gyula Kosice).

${ }^{85}$ La noción de un pensamiento del instante que se desprende de este ensayo, y es posible rastrear a lo largo de distintas intervenciones de las revistas del corpus, es analizada en el Capítulo II como parte de las "series de la crítica" y en el III, en relación con el pensamiento sartreano y el antivanguardismo de Contorno.
} 
1.2.1. Continuidades y diferencias con Qué (1928-1930) y las revistas de la AACI (1945-1946)

El aporte de nuevos matices se debió, en relación con nuestro primer eje de análisis, a que la revista intervino en una serie de debates más amplios con respecto a los que habían llevado adelante otras publicaciones de vanguardia inmediatamente anteriores a 1948. Después del número único de Arturo. Revista de artes abstractas en 1944, el proyecto del arte no figurativo había derivado en tres espacios de investigación visual: la Asociación Arte Concreto-Invención, Arte Madí, y Perceptismo ${ }^{86}$. Las publicaciones provenientes de esos movimientos habían discutido conceptos específicos y particulares del arte no figurativo, como la disposición coplanaria o el problema del cuadro recortado en relación con la teoría marxista. Por otra parte, los matices teóricos y artísticos que diferenciaban a un movimiento de otro fueron percibidos como radicales oposiciones, especialmente aquellos que pudieran asociarse con la estética surrealista, a la que consideraban una variable maravillosa e inconsciente de la representación. ${ }^{87}$ En sucesivas oportunidades, los números de la revista Arte Concreto-Invención y el Boletín de la Asociación Arte Concreto-Invención se ocuparon de esclarecer confusiones en las "vastas aguas de la nofiguración”; así, este último publicó una nota aclaratoria donde refutaba la noticia aparecida en el número 6 de la revista Cabalgata que declaraba a Arden Quin y Gyula Kosice como fundadores de Arte Concreto-Invención. Para enfatizar en el error y distanciarse, señalaron que Quin “era un poeta superrealista”. En conclusión, la nota afirmaba, "aprovechamos esta oportunidad para dejar, también, debidamente aclarado que nuestro movimiento no guarda relación alguna con el grupo llamado Madí”. La AACI se proponía un programa de delimitación y sistematización caracterizado por un doble movimiento, donde observamos el objetivo de depurar la imagen de todo resto

\footnotetext{
${ }^{86}$ Para una mayor precisión sobre las derivas de la vanguardia de los años '40 en Argentina, así como sus encuentros y desencuentros en relación al grupo nucleado en el número único de Arturo, cfr.: Alcide, Carmen (1997); Lucena, Daniela (2011, 2015); de Rueda, María de los Ángeles (2000); Pérez Barreiro, Gabriel (1994). Para Alejandro Crispiani (2011) no se trata de tres "ramas" o "grupos", sino de cuatro: movimiento Madi, movimiento Madimensor, la Asociación Arte Concreto Invención y el Perceptismo (33). 87 "Es evidente que cuando se renuncia a la voluntad de estructura se abandona irremisiblemente el campo de la invención y se pasa a una incontrolada 'tierra de nadie', que, en última instancia, resulta ser la tierra del sueño, del subconsciente, de la intuición pura, de la agorafobia, de las expresiones delirantes, de todos los matices posibles de la ilusión y de la representación”, Maldonado (citado en Cipollini, 2012).
} 
representativo ${ }^{88}$ y constituirse como vanguardia superadora en la línea progresiva de los movimientos no-figurativos. ${ }^{89}$

Ciclo retomó algunos de los aspectos que habían ocupado a la AACI -en "Ubicación del arte concreto" de Ernesto N. Rogers (1948, n1: 39-52), "La expresión estética de la construcción” de Max Bill (1949, n2:29-34)- pero publicó además ensayos, conferencias y documentos que tuvieron por objeto tanto el devenir del surrealismo y su relación con el existencialismo, como a Wolfgang Paalen, artista latinoamericano que promovía la superación de las escuelas estéticas, o a un narrador como Henry Miller. En ese sentido, se constituyó como revista dedicada al arte moderno, conformada por un corpus textual donde se encontraban presentes distintas perspectivas que podríamos denominar como vanguardistas por sus búsquedas no representacionales, pero no ceñidas a un manifiesto o propuesta estética en particular. Esa heterogeneidad de perspectivas inhibe la definición de un "ser" del arte de vanguardia y produce una reformulación de las relaciones entre arte y manifiesto, donde lo que emerge no es ya una poética artística única, sino criterios o nociones propuestos como herramientas para la lectura del arte y la literatura.

Asimismo, podemos advertir su radical discontinuidad con el proyecto de Qué (1928-1929). Este se articuló en torno a la búsqueda de una escritura automática, ocultista y experimental de inspiración surrealista, y estuvo integrada por el mismo grupo que a mediados de siglo fundaría Ciclo. Arte, literatura y pensamiento modernos: Aldo Pellegrini, Elías Piterbarg y David Sussmann, con la diferencia de que a esta última se sumaría Enrique Pichon Rivière. ${ }^{90}$ Si bien el nombre mismo de la revista inscribe el gesto de un retorno, las propuestas guardan poca relación entre sí, ya que aunque el filón surrealista de los directores continuaba siendo una búsqueda, en Ciclo se configuró como una de las variables del arte moderno sobre las que se reflexionó, mientras en Qué había

\footnotetext{
${ }^{88}$ La depuración de la imagen no se limitó a señalar vestigios de figuras representadas - "mientras haya una figura sobre un fondo ilusoriamente exhibida, habrá representación" (1946a, 5)- sino que se avocó a la tarea de "destruir el espacio representado", retomando la teoría de Piet Mondrian. Por este motivo Torres García es considerado un detractor y un ecléctico, porque no solo insistió en pintar "pecesitos", sino que mantuvo la "modalidad planista", dejando sin resolver "el problema que determina una figura sobre un fondo" (1946b, 1).

${ }^{89}$ Luego de las investigaciones llevadas a cabo por la AACI, se afirma, "hoy, el arte no-representativo se encuentra, por primera vez, en la posibilidad de encarar el espacio y el movimiento desde un punto de vista absolutamente concreto" (1946a:6). A partir de esa idea se postuló la noción de "anti-teoría del contenido": "Construir un arte en consonancia con la emancipación materialista del conocimiento. Al no separar el objeto de sus cualidades, determina que la propiedad estética resida en la concreta materialidad de la obra de arte" (Alfredo Hlito, "Notas para una estética materialista", 1946a).

${ }^{90}$ Para un análisis pormenorizado de la revista Qué, cfr.: Minguzzi (2013, 2014); Antelo (2014, 2004).
} 
constituido una experiencia vital a replicar en el ejercicio de la escritura, donde todos los textos eran poético-programáticos y firmados con seudónimos. En el artículo de Aldo Pellegrini sobre Wolfgang Paalen, publicado en el primer número de Ciclo, advertimos el desplazamiento hacia un interés teórico, donde imaginación y razón ya no resultan facultades contrapuestas como en las discusiones entre surrealismo y arte concreto, sino una síntesis que afronta la "crisis del tema" en el arte:

En una brillante serie de ensayos, [Paalen] intenta una fundamentación de su pintura. Parte de las concepciones del filósofo americano John Dewey, quien preconizó la síntesis de imaginación y razón. La pintura para Paalen debe resultar de la fusión de la ciencia (ecuación lógica del universo) y del arte (ecuación rítmica del universo); por este camino se logrará superar-dice- al surrealismo que postuló la omnipotencia de lo irracional y al materialismo dialéctico que afirmó la omnipotencia de la razón. La belleza, según Paalen, aparece cuando, lo que piensa el yo y lo que siente el yo, se integra en un modelo coherente, o sea, cuando las ecuaciones intelectuales y emocionales se fusionan. (1948:81)

A partir de esta cita advertimos que el objeto de análisis de Pellegrini no son las obras de Paalen sino la fundamentación de sus ensayos, en donde se propone una pintura de la integración que resulta, por otra parte, la condición de surgimiento de "la belleza". En ese sentido, no es una solución que podríamos considerar histórica - superar las oposiciones binarias de las escuelas artísticas - sino una poética que constituye su singularidad en ese límite, ya que para Paalen todos los tratamientos que había recibido el problema del tema en el arte moderno habían sido "no satisfactorias" (Pellegrini, 1948:81). ${ }^{91}$

Las relaciones entre Ciclo y las publicaciones consignadas que la antecedieron se manifiestan también en la conformación del grupo editorial. En primer lugar, y contrario a los límites precisos de las oposiciones que marcaban las revistas del arte concreto o surrealismo, en los nombres de quienes hacían Ciclo reconocemos un circuito del arte mucho más amplio y dinámico, así como también advertimos una serie de puntos compartidos en las trayectorias de sus integrantes. Mencionamos a Pellegrini, Piterbarg, Pichón Rivière y Sussmann como los nombres que habían participado de Qué y ahora conformaban el comité directivo; pero a ellos se sumaban Edgar Bayley, Tomás Maldonado y Alfredo Hlito -responsables del diseño-, quienes habían participado de

\footnotetext{
91 "Los cubistas se dedicaron al análisis plástico del tema; los surrealistas procedieron a la destrucción poética del tema utilizando las yuxtaposiciones insólitas, e introduciendo finalmente a la literatura en la plástica; el arte abstracto brega por el abandono del tema", afirma Pellegrini a modo de reseña de los argumentos de Paalen (1948, n1: 81). Frente a esto, la propuesta del pintor austro-mexicano es "la creación de una cosmogonía plástica con la que se intentaría dar una imagen de las fuerzas ocultas en la naturaleza" (81).
} 
manera activa en las experiencias revisteriles de la AACI y diversas muestras, entre ellas, las que se llevaron a cabo en los domicilios particulares de Grete Stern y Enrique Pichón Rivière en 1945. El vínculo entre Pichón-Rivière y los jóvenes de la AACI resulta singular ya que el psicoanalista había llegado a interesarse en el surrealismo y dadaísmo por el valor que estos daban al inconsciente, mientras que los artistas concretos desconfiaban de todo aquello que no tuviera por objeto la conciencia y un proceso de razón o racionalización del arte, razón por la cual habían calificado al surrealismo de producir "agorafobia", "ensimismamiento" (Maldonado 1946, n1:5). Por otra parte, en relación con las trayectorias comunes, resulta significativo que ninguno de los tres miembros del comité directivo contara para entonces con un libro publicado, y que tampoco lo hicieran en el marco de edición de la revista. ${ }^{92}$ Un comité editorial conformado por escritores sin obra publicada, y artistas sin muestras en salones o galerías profesionales, dan la pauta de que no se trató de una revista entre cuyos objetivos estuviera la difusión de sus producciones.

Otro de los espacios donde se expresan las relaciones de continuidad y distanciamiento respecto de las propuestas estéticas del surrealismo y concretismo es en las portadas de cada número y la heterogeneidad de los sumarios. Hay permanencia de algunos de los objetos de interés de ambas estéticas, pero donde se evidencia, asimismo, una ruptura con el género que sostenía a tales objetos, ya no se leen más en el marco de manifiestos programáticos sino en el horizonte ampliado por el término "arte moderno" que delimita la inscripción de la revista desde su subtítulo -"revista bimestral. Arte, literatura, pensamiento modernos". La ausencia de un editorial o programa explícito firmado por los miembros de Ciclo. Arte, literatura y pensamiento modernos nos permite suponer que son los textos e imágenes los que funcionan como elementos materiales que intervienen produciendo significaciones menos mediadas. ${ }^{93}$ Desde la portada del primer número se anunciaba una estética blanca, despojada de exuberancias, donde el retrato en pequeño formato de Lazló Moholy-Nagy -fotógrafo húngaro, pintor y artista perteneciente a la escuela de la Bauhaus y promotor de experimentos lumínicosanunciaba algo muy diferente a la introspección o las imágenes de resonancia ocultista que caracterizaron a Qué. Con respecto a los sumarios, advertimos que el criterio articulador fue el carácter crítico-ensayístico de las escrituras publicadas, donde el

\footnotetext{
92 Pichon-Rivière, para entonces referente del psicoanálisis en Argentina, no publicaría un libro propio hasta los años setenta.

${ }^{93}$ A esto llamamos "series de la crítica" en el capítulo II.
} 
surrealismo y el arte concreto se presentan como una de las derivas posibles. A lo largo de las noventa y cinco páginas del primer número y las noventa y dos del segundo, en un formato casi libro, Ciclo dispuso una serie muy específica de escrituras que provenían de traducciones propias (por ejemplo el ensayo de Georges Bataille sobre Henry Miller, traducido de la revista Critique, 1946; el ensayo de André Breton sobre Jacques Hérold), de la transcripción de conferencias, como la de Rogers, artículos que funcionaban como adelantos de libros por salir (el extenso ensayo sobre lo maravilloso de Aldo Pellegrini, o la conferencia de Enrique Pichon Rivière sobre Conde de Lautréamont), correspondencia, como la de Lázlo Moholy-Nagy a Kalidova; crónicas y entrevistas como la de Elías Piterbarg a André Breton, Tristan Tzara y Ristch; curadurías de documentos teóricos, como la traducción de Bernardo Kordon sobre Piet Mondrian. Así, la publicación hace de la idea de "lo moderno" una suerte de matriz que impregna la política de aparición de los ensayos y las publicidades.

La idea de que el arte moderno es un punto de partida amplio parece reforzarse de un número a otro, según observamos en la publicidad de la editorial Argonauta, dirigida por Aldo Pellegrini. ${ }^{94}$ En el primer número se trata de la última publicidad de la revista, casi a retiro de tapa a página completa, donde los libros están agrupados según tres secciones: títulos “en francés", donde podemos encontrar Tropique de Cancer, Printemps noir de Henry Miller, Histoire du Surrealisme I y II, cuatro libros de Sartre (Baudelaire, Situations, Les Chemins de la liberté, I y II, L'imagination); L'Éxistentialisme de Simone de Beauvoir, La peste y L'Étranger de Camus, entre otros; títulos “en castellano”, y ahí contamos con una lista más breve de publicaciones, entre los cuales están Heresiarca y Cia. de Apollinaire, El libro de Monelle de Marcel Schewon, El dominico blanco de Gustav Meyrink, Las cuevas del Vaticano de André Gide, y tres libros centrales de Herman Hesse, Demian, Sidartha y La ruta interior; por último, aparece el subtítulo "Dos obras de gran interés para el artista moderno", presentando Psicología de la forma, de Wolfgang Kölhler y Arquitectura del hombre de Pierre Mobile (ver imagen 18). A diferencia de las dos secciones anteriores, donde el criterio editorial es idiomático, esta última responde al slogan como forma de publicidad, donde la idea de lo moderno delimita el público interesado. Ahora bien, en el segundo número de la revista, "obras de

\footnotetext{
${ }^{94}$ Para una historia de la editorial Argonauta, cfr.: http://www.editorialargonauta.com.ar/editorial.html. Queda pendiente establecer filiaciones entre el período de la editorial en los años cuarenta, con algunas algunas publicaciones anarquistas de los años veinte - que no se consignan en la página citada - y que habrían sido los primeros libros editados por Aldo Pellegrini.
} 
interés para el artista moderno" se transforma en la bajada que acompaña al nombre la editorial (ver imagen 19), y son muchos menos los libros que se anuncian, todos en castellano, donde además ya no encontramos los dos anunciados en el subtítulo anteriormente dedicado. La noción de "arte moderno" y "artista moderno" organiza, para el editor-director de la revista, una forma de exposición de aquello que se quiere vender, un modo de contarse antes que una clasificación del catálogo. En ese sentido se trata de la marca de una sensibilidad en transformación, que se materializa en la puesta en página. Esa ampliación de lo moderno que alcanzaba solo a dos títulos de la editorial Argonauta, ahora convertido en slogan del proyecto conjunto, es el eje que permite la articulación entre reflexiones que se ocupan especialmente de artistas surrealistas, problemas o novedades de la escuela de la Bauhaus, e interrogantes acerca del devenir de las vanguardias en Europa y América después del "fracaso de los manifiestos", para decirlo en las palabras de Lázló-Moholy Nagy según la traducción de la revista (1948, n1: 57 $64)$.

1.2.2. El programa crítico de Ciclo: la exigencia de renovación después del "fracaso de los manifiestos"

Según Mario Pellegrini, hijo de Aldo, la idea de hacer una revista como Ciclo habría nacido del encuentro de su padre con Marcel Duchamp en Estado Unidos a fines de la década del cuarenta, ${ }^{95}$ como respuesta a la insistencia del artista en la necesidad de difundir las diversas producciones de la vanguardia de postguerra desde la crítica y la teoría, es decir de intervenir de modo más explícito en la conformación de lectores y espectadores del nuevo arte. ${ }^{96} \mathrm{Si}$ el arte moderno es, como dijimos, un punto de partida amplio, este requiere formar opiniones, producir documentos, traducir a "los pensadores del arte moderno", escribir reseñas, generar registro de las discusiones de cada muestra. Fuera más o menos preciso el relato de Mario Pellegrini, lo que se evidenciaba en su recuerdo es que Ciclo había sido fundada para contribuir a la circulación de teorías del arte moderno, aspecto que verificamos en relación con los índices. Pero a su vez, esa

\footnotetext{
${ }^{95}$ Gonzalo Aguilar (2002) señala que "una vez clausurado el ciclo de las vanguardias históricas", hacia los años sesenta, una de las figuras más reivindicadas fue la de Marcel Duchamp, así como también las vanguardias nihilistas (dadaísmo, futurismo, surrealismo), como respuesta a las lecturas de la década anterior (234-235).

${ }^{96}$ Fuente: entrevista personal.
} 
circulación no podía encarnar en la forma de los programas o manifiestos como en la Asociación Arte Concreto Invención porque de ser así el programa amplio del arte moderno estaría nuevamente parcelado en los principios de múltiples y pequeños movimientos estéticos.

Ciclo manifiesta este dilema (entre escritura, nuevas teorías del arte y el género manifiesto) como un conflicto de temporalidades: a un tiempo que se experimenta como el ocaso de las vanguardias ${ }^{97}$ es necesario responder con el aporte de otras renovaciones posibles, vinculadas a los modos de ver y leer que no fueran subsidiarios del imperativo de la época, entendida como "contexto histórico". Es decir que a un problema preponderamentemente eucrónico -en términos de Didi-Huberman (2015)- como las condiciones del arte en la segunda postguerra, se le responde con una moral crítica del anacronismo, que procura desujetarse de las necesidades que la época procura leer. Para dar cuenta de cómo este conflicto constituyó el programa crítico de Ciclo se abordan los siguientes textos: "Carta a Kalidova”, de Moholy-Nagy, László (Ciclo, n1); "Surrealismo y surrealistas en 1948”, de Elías Piterbarg (n1); "El poeta", de René Char (n1); "La libertad del artista anuncia la libertad del hombre", de Jean Cassou (n2); "Noticia de Szyszlo" de Sebastián Salazar Bondy (n2); “La expresión artística de la construcción”, de Max Bill (n2); y la reseña de David Sussman sobre Sens-plastique de Malcom de Chazal (n2). ${ }^{98}$

Con respecto al primer término del dilema (la relación entre vanguardias y el género manifiesto), Ciclo es explícita según nos permiten pensar la traducción de Moholy Nahy que mencionamos anteriormente y la crónica de Elías Piterbarg. En "Carta a Kalidova", el primero postulaba a las vanguardias como proyecto deseado y como ruina. Allí afirmaba: "Hemos publicado muchos programas, hemos lanzado al mundo muchos manifiestos. La juventud tiene derecho a saber por qué han fracasado nuestras aspiraciones, por qué no se han cumplido nuestras promesas" (1948: 60). Sin embargo, a ese fracaso no le correspondía un final, sino la exigencia de renovación: "la juventud tiene el deber de no cejar en la búsqueda y difusión de las nuevas formas” (60). En ese sentido,

\footnotetext{
${ }^{97}$ Ver en el Capítulo II las referencias de ortas revistas contemporáneas a las de nuestro corpus donde insisten en la necesidad de superar ese momento de "juego" o "gasto inútil".

${ }^{98}$ En este abordaje dejamos de lado los dos textos críticos más importantes y extensos publicados en Ciclo - "La moral de Henry Miller", de Georges Bataille y "Vida e imagen del Conde de Lautréamont" de Enrique Pichón-Rivière - ya que si bien forman parte del programa crítico de la revista no están atrevesados por el problema de temporalidad que analizamos en este apartado, sino por otra pregunta sobre el tiempo: el pensamiento del instante, que se despliega como una forma de intervención específica; y los modos de conformación de una genealogía de vanguardia. Ambos aspectos son tratados en el Capítulo II como parte de las "series de la crítica".
} 
aparece una dimensión "relacional” (Aguilar, 2002:232) 99 de la idea de vanguardia en tanto posición en disponibilidad para los artistas del siglo XX, que postula la necesidad de nuevas formas, no obstante perciba el agotamiento o incumplimiento de "nuestras aspiraciones".

La traducción de la carta a Kalidova se complementaba con una perspectiva propia en la crónica de Elías Piterbarg, uno de los miembros del comité directivo. Resultado de un recorrido por París y sus cafés más destacados donde el autor había conversado con André Breton, Benjamin Péret, TristanTzara y Marco Ristich, "Surrealismo y surrealistas en 1948" daba cuenta de una decepción: "[sus manifestaciones] no conmueven hasta la raíz ni a las masas ni a la flor de la juventud en París" (1948:72). Si bien Piterbarg considera al surrealismo entre los movimientos más interesantes de su época, no puede dejar de advertir que no se han cumplido las promesas:

En París me ha conquistado la impresión de que, confesos o no, los surrealistas de distinta denominación se ven ceñidos a expresar su surrealismo en la única forma posible hoy para ellos: la expresión artística o literaria. Es innegable, como dijo Tzara, que el surrealismo ya no es combativo. Ya no escandaliza. No provoca remolinos ni en las calles ni en los espíritus. (...) No son mucho los jóvenes que hoy en París se apasionan por el surrealismo. Son muchos más los que colman las salas de conferencias y polémica de existencialistas y comunistas. (72)

Sin escándalo, sin remolinos, sin la confrontación del combate, sin conmoción, el surrealismo es presa del tiempo en el sentido cronológico del término, ya que otra actualidad se impone -el existencialismo- y lo desplaza. Sin embargo, tanto Piterbarg como Moholy Nagy se resisten a tomar una posición reactiva, ya sea aquella que buscaría renunciar a la disponibilidad de la vanguardia, como la creencia de que se encontraba “todo en pudrición” y "el único islote sano lo constitu[ían] los surrealistas" (73). Por el contrario, propone comprender "estas formas jóvenes de la necesidad (...) que traen consigo la promesa de lo original"100 y empujarlas hacia la "realización 'plena' del deseo" (73). ${ }^{101}$

\footnotetext{
99 "Los movimientos de vanguardia [históricos] instalaron un modo de intervención que ha sido reanudado en períodos posteriores por otros grupos de artistas que asumieron tareas de renovación y ruptura" (Aguilar, 2002:234). Esta perspectiva es relevante porque da cuenta de que el término sirvió para "articular y designar posiciones" en interacción con un contexto determinado.

${ }^{100}$ Con "formas jóvenes de la necesidad" Piterberg se refería al existencialismo, por oposición a la libertad irrestricta del surrealismo.

${ }^{101}$ Esta crónica puede ser leída junto con un documento encontrado por Andrea Giunta en el archivo Julio Llinás: se trata de una carta nunca enviada por el poeta a Aldo Pellegrini, durante su primera estadía en París en 1952. Lo significativo es que un año más tarde, a su retorno, integraría el comité de redacción de Letra y Línea, dirigida por Pellegrini, siendo junto con Carlos Latorre los únicos que se reconocieron plenamente surrealistas dentro del grupo editor de la revista. Se trata de una cita extensa, pero vale la pena
} 
¿Cómo podía pensarse una renovación en ese marco?, ¿cómo responder a esa exigencia de Moholy-Nagy de "no cejar en la búsqueda y difusión de las nuevas formas", o dar curso al deseo frente al imperativo de la necesidad? Una de las respuestas que dio Ciclo a esa pregunta fue una forma distinta de posicionarse frente al tiempo que se evidencia en los modos de aproximarse a las obras artísticas y literarias. Si el manifiesto se caracterizó, para las vanguardias del siglo XX, por afirmar "una retórica que sirve de refugio a algo distinto de lo que nombra y anuncia" (Badiou, 2011:175), ya que reconstruye un "futuro indeterminado" de aquello que no se deja nombrar en presente, delineando las condiciones para que emerja un futuro en el arte cuya posibilidad de ser aún no existe (2011:174), ${ }^{102}$ el ejercicio de la crítica no se distingue de este por un carácter menos programático, sino por la selección de un objeto en presente sobre el cual se ciñe y a partir del cual se define. También poesía buenos aires experimentaría esa desconfianza cuando enunciara que no le interesaban los manifiestos sino dar cuenta de una "cierta actitud y cierta conciencia poética" (“Hoja de ruta”, n15).

transcribirse completa porque en el desarrollo de ciertas imágenes se lee el movimiento de estas vanguardias a destiempo, que entre el fracaso y el deseo de renovación, insisten: "He penetrado en la casa de Tristán Tzara como en el templo de Chefren, para encontrar el idolillo que había hecho la epopeya del hombre elemental, hombre un poco animal un poco flor un poco metal un poco hombre, para encontrarlo, decía, jugando solo al ajedrez con obsesión casi mística, él que había querido reemplazar la noción arcaica de inspiración por su propio manejo del delirio.

En aquel piso inmenso del bulevar Saint-Germain, solo habitado por sus libros, que eran miles, sus esculturas de África y Oceanía, que eran cientos, y por su fanasma, que era la humanidad entera para el peregrino devoto, que es quien confiere a los templos del hechizo, sin saber qué decirnos, nos miramos.

Y caminó conmigo por los grandes cuartos, como un modesto guía del museo de sí mismo, del museo del hombre que había sido o, tal vez, del hombre que hubiera querido ser, vaya a saberse.

Yo no veía los objetos que él me describía, ni escuchaba las cosas que decía. Lo veía, en cambio, treinta y cinco años atrás aullando: 'El pensamiento se produce en la boca', o batiendo ferozmente el parche de un tambor, en plena escena de un acto Dadá, mientras Serner depositaba un ramo de flores a los pies de un maniquí de costurera y una voz, surgiendo bajo un enorme sombrero con forma de pan de azúcar, declamaba poemas de Hans Arp. Lo veía describiendo: ‘Cómo ordenar el caos que constituye esa infinita e informe variación: el hombre?'

Pero la ceniza que estragaba las facciones de aquel pequeño duende casi sagrado provenía, tal vez, de otras fuentes menos prístinas: las de la política, que lo había llevado, siguiendo el criterio marxista de interpretar la historia, a retractarse de sus grandes voces. Yo no quería ver lo que veía ni oír lo que oía. Quería estar junto al mismo pequeño gigante que había encontrado, en casi todos los principios relacionados, fallas esenciales que los conducen a ser la prisión del ser humano, en vez de la manifestación de su poder y de su capacidad de dicha terrestre.

De igual manera, aquel Breton del Café de la Place Blanche tampoco era el que había amado frenéticamente, el de Les pas perdus: 'Dejad vuestras esperanzas y temores. Sembrad vuestros hijos en un rincón de un bosque. Dejad la presa por la sombra. Abandonada a la necesidad lo que era una vida cómoda, lo que os permitía esperar un porvenir. Partid por los caminos'. Definitivamente, yo había llegado tarde.” (1952, citada en Giunta, 103-104)

102 "Lo programático no es, al parecer, del orden de la urgencia presente de lo real. Se trata de una finalidad, de las condiciones de lo que algún día sucederá, de una promesa" (Badiou, 2011:174). Esta concepción del manifiesto como forma de intervenir en el futuro que propone Badiou, se articula con lo que Carlos Mangone y Jorge Warley identifican -de manera algo más esquemática- como "discurso épico" del manifiesto, ya que este propondría "la absolutización del mundo, la coherencia ideológica, la división antinómica, la conciencia de participar de una gesta histórica" (1993, p. 26) 
A partir de estas afirmaciones generales es posible dar cuenta del modo en que Ciclo recupera problemas y teorías de la vanguardia surrealista y concretista/ invencionista, pero no en la apelación a un futuro del arte o con fines de depuración estética, sino para ocuparse de un tiempo histórico que se experimenta entre el ocaso de las vanguardias en Europa y la necesidad de renovación estética en el Río de La Plata, con respecto a las producciones estéticas dominantes de los años 40 y 50 como el neorrealismo y neorromanticismo (Del Gizzo, 2017; Freidemberg, 1984; Giordano, 1983, 1992; Porrúa, 2011; Prieto, 2006, 2010). Los términos “época", "tiempo" e "historia" son nociones problematizadas desde la pregunta por el arte, que tensionan las configuraciones que harían del arte y la literatura una caja de resonancia directa de aquello que se cristalizaría como "la realidad" o "la época". Así, por ejemplo, René Char afirma en un fragmento de "El poeta", publicado en el primer número de Ciclo, que este "agrega nobleza a su caso cuando duda de su diagnóstico y del tratamiento de los males del hombre de su época, cuando formula reservas sobre el mejor modo de aplicar el conocimiento y la justicia en el laberinto de lo político y lo social" (1948, n1: 38). La época es pensada, desde la perspectiva de Char, en relación con la responsabilidad del poeta, pero esta se articula antes sobre la duda que en torno a la acción o la denuncia. El tipo de relación que se establece entre el laberinto de lo político-social y "la insolvencia del poema" (38, la negrita es del original) es la de la incongruencia: no es posible superponer sin más una realidad a la otra, ya que el poeta, "parte refractaria a las combinaciones", "debe saber que el mal viene de siempre de más lejos de lo que se cree, y que él no muere forzosamente en la barricada que se le ha elegido" (38), por lo tanto, la nobleza del poeta es trabajar sobre ese desencuentro. Como anticipamos, una moral crítica del anacronismo busca poner en evidencia que la relación entre obra y sociedad no está regida necesariamente por condiciones de causalidad o representación, según las cuales una obra respondería a las condiciones de su época, sino que el poeta, artista, crítico o escritor, trabajan en el intervalo que separa a una y otra.

Como anticipamos, el ensayo de Jean Cassou, "La libertad del artista anuncia la libertad del hombre" (1949, n2), es una intervención crítica sobre el problema de la temporalidad, que en este caso se configura en tanto "época" o "historia" como dadoras de significado a la obra de arte. En relación con el ocaso de las vanguardias, constituye una manera de responder a las perspectivas que exigían una mayor correspondencia entre las obras y su tiempo, como el realismo social o la literatura comprometida. Cassou no abandona la interpretación marxista de los vínculos entre arte y sociedad -ya que cita 
indirectamente a Marx cuando afirma "El arte sirve para defender a los vivos de los muertos deteniendo en determinados objetos la fuerza maléfica de los muertos" (1949, n2:35)-, pero cuestiona el abordaje historicista que caracterizó esos vínculos: "El análisis histórico se ha complacido, y se complace todavía muy a menudo, en identificar estrictamente la actividad artística con las actividades sociales, en la misma forma en que lo hacen y desean las sociedades" (36).

Cassou se propone demostrar que la obra de arte es irreductible a la "identificación aparente con una actividad social definida, orientada por las exigencias de la religión y de la política" (35). El poder del arte consistiría en una variación respecto de un modelo standard (36), por lo tanto, el objeto puede ser despojado de sus "significaciones e intenciones" (35) que se nos seguiría apareciendo como un objeto de arte: "El arte se manifiesta en esa variante. Ella producirá en el espectador una emoción extraña y nueva, distinta de la emoción convencional en la cual la sociedad quiere confundir las conciencias individuales de sus miembros" (36). Este carácter diferencial del "objeto" que se manifiesta en el extrañamiento es lo que el historiador no ve porque "se contentan con reconocer en el arte de una sociedad, los ritos de esta, es decir, una forma de su expresión religiosa o política" (36), o bien porque comprenden "al artista estrechamente sometido a las condiciones económicas y a las subestructuras intelectuales de su tiempo".

La hipótesis de Cassou resulta libertaria porque emancipa al tiempo de la obra de reproducir las condiciones de enajenación, aunque no está excenta de valoraciones trascendentales marcadas por el fuerte humanismo del ensayo. A la referencia sobre el 18 Brumario en la expresión sobre el arte, los vivos y los muertos, se suma la lectura de Henri Lefebvre a través de quien se propone pensar al "creador estético" como el sujeto que recupera la riqueza humana dilapidada por la enajenación. Este creador es el que busca "expresar la totalidad de las manifestaciones de la vida, incorporándolas a un objeto" (37), aun cuando siempre esté a punto de fracasar. Por otro lado, es la autonomía del arte la que garantiza que una obra no se agote en su época: "cuando finalizan las condiciones en las cuales se ha realizado una obra de arte, dicha obra seguirá siendo para nosotros un testimonio válido que ha de continuar conmoviéndonos y elevándonos por encima de nosotros mismos. Al conquistar de manera constante su propia autonomía, el arte nos ayuda a lograr nuestra propia humanidad" (38). Desde esta última afirmación podemos pensar que el desacople entre arte y sociedad se constituye en un valor destinado a salvar las obras -que expresan la riqueza de lo humano- de la lectura contextual y por lo tanto salvarlas literalmente, lo que no parece un detalle menor si consideramos en la 
Europa del nazismo y stalinismo desde donde escribe Cassou. ${ }^{103}$ A modo de conclusión, el autor articula el poder de la variante que produce extrañamiento con la idea de liberación de la riqueza humana, ya que "encontrar un lenguaje distinto del que se usa convencionalmente" es lo que establecerá "comunicaciones más intensas e intercambios más nuevos y fructíferos". La idea de que el desafío a los lenguajes convencionales era una de las condiciones indispensables para la verdadera comunicación, opuesta a la concepción informativa, fue uno de los tópicos más relevantes para las revistas de la vanguardia surrealista e invencionista; ${ }^{104}$ en ese sentido, encontrarla en un ensayo que cuestiona una lectura determinista de las obras en relación con el tiempo en que emergieron, es relevante para dar cuenta de cómo las morales críticas (cristalizada aquí en el valor del extrañamiento) se configuraron como posiciones respecto a la temporalidad.

Un aspecto de las consideraciones de Cassou resuena en la crítica que hace Sebastián Salazar Bondy sobre la obra de Szyszlo, ya que plantea como desafío no reducir el vínculo entre sociedad y obra a una expresión de los motivos de su época y territorio. En el segundo número de Ciclo, el artista y crítico peruano afirma que la particularidad del artista americano consiste en que "al descubrimiento de sí mismo, ha de sumar el descubrimiento de lo que realmente constituye el sentido de su obra en la sociedad en que vive y trabaja" (1949, n2: 39, la cursiva es nuestra); no obstante, uno de los riesgos en relación con esa búsqueda es confundir la "aparente grandeza social del tema con la finalidad de la obra de arte", como hicieron los muralistas mexicanos, quienes "cayeron en una suerte de alegato gráfico o crónica pintada" (39). Es decir que la exigencia de una relación particular entre obra y sociedad no puede ser respondida en la representación de un tema que la describa, o no al menos en un tipo de apropiación lineal como la que sugiere la idea de "alegato gráfico". Eso sería repetir tanto los "fracasos de todo intento regionalista que adoba de mentido folklorismo, fácil y retórico" como "la frustración de tantos imitadores de las corrientes occidentales pasadas y presente".

Si bien la crítica de Salazar Bondy hacia el muralismo mexicano no es necesariamente un cuestionamiento anti-historicista, ya que no involucra el vínculo con el tiempo o la época sino un posicionamiento frente al tipo de representación, la respuesta

\footnotetext{
${ }^{103}$ Por otro lado, el ensayo de Cassou es editado por la revista poesía buenos aires en 1956, con el mismo título. El contraste de ambos contextos de edición y publicación nos permitió establecer una hipótesis sobre la implicancia de la noción de "libertad" en cada caso.

${ }^{104}$ Esta hipótesis se desarrolla en el capítulo III.
} 
que encuentra en la obra de Szyszlo es la que un tipo de moral crítica del anacronismo le permite formular. El mérito de Szyszlo "consiste en el hallazgo de sutiles elementos en la personalidad que indudablemente nos distingue de los demás pueblos y bajo la cual les [es] imposible medrar a los corifeos del aislamiento" (39) - por corifeos del aislamiento entiéndase, "nacionalistas". Sustraer del dominio de los discursos nacionalistas los elementos de la "condición americana" supone un proceso de insubordinación donde esos elementos se resisten a ser codificados en la clave de un sentido reconocible. Por esta razón, las obras de Szyszlo son "germen de una revelación futura":

Los óleos de Szyszlo adquieren así una precisa característica individual. Son ámbitos de misteriosos caprichos animados de magia y sueño. Allí, despojados de todo afán real, detenidos y vivos, intemporales en fin, los objetos y las figuras pertenecen al patrimonio de la verdad puramente artística, sin entes de ficción. (41) ${ }^{105}$

Una de las derivas de este modo de leer -atento al elemento irreductible a la significación social dominante- es la insitencia en la "técnica" como dimensión artística que evita caer en el mero contenidismo. Esto es relevante para pensar el programa de Ciclo porque alude a un aspecto que es específico de los intereses de la crítica. En el primer número, la reseña de Les jours de notre mort de David Rousset, firmada por W. Baranger, se ataca la anécdota o el comentario como aquello que desplaza el trabajo con la técnica. Así, se opone "la simple enumeración de recuerdos" a la "técnica literaria", y por ese motivo cuestiona al autor que el problema de su obra no consiste en carecer de propósito novelesco, sino en no advertir que

la brutalidad de la notación pura, hiere más que cualquier comentario, aún el uso del vocabulario específico de los campos, de las palabras alemanas, rusas, etc., contribuye a crear la impresión de extrañeza y desamparo del hombre separado de su vida y de su pasado, cuya precaria existencia dejó de tener valor para todos. $(1948, \mathrm{n} 1: 86)$

Pero donde la cuestión de la técnica y la forma se evidencian es en la única tensión o discrepancia explícita al interior de la revista, ya que mientras en el primer número se publica un ensayo de André Breton sobre Malcolm de Chazal y Jacques Hérold, suscitado por la salida de Sens Plastique, libro del primero que califica como "el acontecimiento más destacado del año" (1948, n1:54), David Sussman, integrante de la revista cuestiona "el incesante hurgar de los sentidos" (1949, n2:79), ya que, como un "método de percepción, dudamos de su eficacia" (79). La relación entre procedimiento y

${ }^{105}$ El autor indica a ver sus "Naturaleza Muerta" (1947) y "Figura" (1947) y su "Mujer peinándose" (1948). 
representación de la época aparece como un punto de debate central sobre el que se esgrimen posiciones y argumentos diversos. En ese sentido, la moral crítica del anacronismo se constituyó, para la revista Ciclo, en contraposición al problema de la historia como conjunto de temas, condiciones económicas, creencias, eran representados por el arte y la literatura en su mismo tiempo; y postuló tanto el desacople entre obra y sociedad en términos de correspondencia, como la relevancia de los procedimientos artísticos para evitar la mera anécdota.

\section{3. poesía buenos aires y Contemporánea: el júbilo presente, la profecía futura y el tiempo agobiado}

poesía buenos aires surgió en 1950 como el deseo de hacer una publicación exclusivamente dedicada al género poético. Muchos de los jóvenes poetas de los años cincuenta fueron publicados por primera vez en las páginas de $p b a$, ya que encontraban allí un espacio que no era frecuente en otras revistas. ${ }^{106}$ Asimismo, hizo de la poesía un objeto de reflexión crítica y teórica que en los primeros números estuvo centrada, según los artículos firmados por sus directores -Raúl Gustavo Aguirre, Jorge Enrique Móbili, Wolf Roitman- ${ }^{107}$ en la búsqueda por definir una concepción de la escritura poética, ${ }^{108}$ alrededor de tres objetivos que podemos identificar: su "desmantelamiento" (Aguirre 1951, n3:1) ${ }^{109}$ con respecto a los tópicos y retóricas de la poesía neorromántica y neorrealista; su ampliación en relación con una escuela poética en particular; y la elaboración de una teoría en los mismos términos en que se pensaba el lenguaje poético. Estos objetivos se explicitaron en el carácter de "colección" (n5, n15) que pba buscó darle a sus números -ese término a veces es sinónimo de "antología” y otras, la condición para

\footnotetext{
${ }^{106}$ Cfr.: Urondo (2009), Saer (2005), Piglia (1990).

107 Jorge Enrique Móbili fue director junto con Raúl Gustavo Aguirre hasta el número 4, y Wolf Roitman del 5 al 7.

${ }^{108}$ El primer número traía una portada textual, con un ensayo titulado "El poeta"; en el segundo, Raúl Gustavo Aguirre era el autor de "La poesía", y la misma entrega cerraba con "Proposiciones. En la poesía reside la facultad de migración de la especie"; "Poesía para respirar", también por Aguirre, era el texto inicial del tercer número; "Noción de poesía", del cuarto, con fragmentos firmados por Aguirre, Roitman y Móbili, y con el mismo título Nicolás Espiro escribía el texto de portada del quinto.

${ }^{109}$ Si bien las páginas de $p b a$ no son numeradas, incorporamos una referencia numérica, partiendo de la portada como n1, para facilitar el cotejo de la cita en caso de ser necesario. Cuando los textos citados no tienen firma autorial se referenican como " $p b a$ " o "La dirección" si es que la revista indica la autoría bajo esa inscripción.
} 
que esta última se conforme- y por otro lado, en la repetida decisión por parte de sus integrantes de "no devenir institución".

Rodolfo Alonso, de quien suele decirse que fue "el más joven de poesía buenos aires", rememora la posición de pba en términos de estar

por fuera de los diferentes espacios de poder, tanto de la cultura oficial del peronismo gobernante, decorativamente populista y en ciertos matices reaccionaria, como de la otra cultura oficial con la que rompimos o no queríamos tomar contacto: los suplementos literarios de los grandes diarios, la revista Sur, los premios literarios, la misma Facultad de Letras o una Academia Nacional que aun mantenía influencia, y también con las empresas editoriales que por aquella época solo publicaban literatura, incluso de la buena. Y tampoco podíamos comulgar con el mal llamado "realismo socialista", autoritariamente regimentado por el Partido Comunista. (Alonso, 2014:13)

Estos cincos espacios a los que Alonso califica como "de poder" (la cultura del peronismo, otra forma de "oficialismo" como la representada por sectores más liberales, la Universidad, el PCA y el mercado editorial) configuran la posición de la revista como vanguardia, que encontraría su radicalidad - ese "afuera" - en dedicarse exclusivamente a la poesía, en tanto escritura que rechazaba los valores que esos espacios de poder encarnaban - lo decorativamente populista, la "literatura", el realismo socialista. Con “poesía desmantelada" (Aguirre, 1950, n2:1), pba aludía a alcanzar una forma poética liberada de esos efectos de poder. Asimismo, esta posición solitaria que parece ocupar la revista es compensada por un programa de ampliación, que consiste en publicar a todos aquellos que manifiesten una "actitud o un espíritu nuevos" -por oposición a quienes "se encuentran vinculados a núcleos pretéticos"- (pba 1953, n13-14:1). Y para tal propósito, pba requería un dispositivo de lectura como el de la colección o antología, regida por criterios que va formulando a lo largo de los números.

Por otra parte, la decisión de ser una revista exclusivamente "de poesía", puede pensarse en diálogo con el lugar central que ocupó Sur en la cultura argentina durante el ascenso del fascismo internacional, II Guerra Mundial y la postguerra. ${ }^{110}$ La perspectiva humanista atravesó tanto a Sur como a pba, que moduló sus intervenciones sobre la noción de poesía en función de "el hombre" y "la humanidad"; asimismo, compartían la valoración de la literatura europea, el interés por la internacionalización de la cultura local y la política de traducciones. No obstante, pretendían diferenciarse de ese carácter que

\footnotetext{
${ }^{110}$ Cfr.: King (1989), Gramuglio 1983, 2013; Podlubne 2003, 2014.
} 
provocativamente Alonso califica como "cultura oficial” y que se evidenciaba, para los integrantes de $p b a$ en tres aspectos: que la no poesía no ocupara en aquella más que las páginas misceláneas, la evaluación de esa poesía como el resultado de "maneras tenidas por prestigiosas" (1953, n13-14:1), y que el lugar central de Sur hubiera sido conquistado en una trama institucional a la que solo le interesaba la poesía como objeto de belleza o del buen decir y no como experiencia de vida - el suplemento literario de La nación, la editorial Sudamericana. No devenir institución era, en parte, no devenir una revista como Sur.

Según otra perspectiva, Luciana Del Gizzo lee la exclusividad de la poesía en $p b a$ a partir de la historia inmediata de las publicaciones del invencionismo y el arte concreto. La publicación de la revista nueva visión (1951) y las inclinaciones de los artistas concretos hacia el diseño industrial habría producido el "repliegue del lenguaje plástico en sus propias premisas" (2017:141). Como respuesta, la poesía invencionista que había surgido en el marco del programa concreto argentino se orientó hacia una búsqueda de pureza distinta: liberada del "lenguaje edulcorado, recargado de regionalismos artificiales y tan sometido a su coyuntura que quedaba encerrado en su inmediatez y no lograba traspasar esos límites que descubren en la poesía la resistencia discursiva que determina su función principal" (Del Gizzo 141). En ese sentido, una publicación dedicada exclusivamente a indagar en las posibilidades del género (su desmantelamiento, expansión, teorización) resultaba prometedora y desafiante para un grupo de jóvenes de diversas procedencias, sin trayectorias de universitarias o trabajos en espacios relacionados con la literatura -suele insistirse al respecto con el empleo de Aguirre, trabajador bancario a lo largo de casi toda su vida- ${ }^{111}$ interesados, tal vez por eso en ocupar "la tierra de nadie" (Alonso 2014:13) y "no devenir institución".

Esta auto-configuración de la revista como estar por fuera de los espacios de poder fue decisiva en el rechazo de publicidades privadas o subvenciones estatales, con lo cual la revista se financió casi exclusivamente de las ventas por suscripciones, bonos contribución y fiestas organizadas por sus integrantes. Ahora bien, esta ausencia de la

\footnotetext{
111 Dice Rodolfo Alonso: "Casi ninguno de ellos parecía impulsado con exclusividad por un proyecto literario; Nicolás Espiro, entonces estudiante de medicina y luego psicoanalista en Madrid, después de haber codirigido durante muchos años la revista, nunca se decidió a publicar un libro propio. Y muchos tampoco fueron poetas, o solamente poetas. Wolf Roitman, otro temprano director, muy pronto se radicó en París donde desarrolló una obra de artista visual; el músico Daniel Saidón o Jorge Souza, un escultor concreto, también amigo y huésped entrañable, al mismo tiempo que responsable directo del diseño gráfico." (Alonso, 2014:10). El diseño gráfico, en rigor, estuvo más a cargo, en "diagramación y tipografia", de una mujer, Nélida Fedullo, que de Souza.
} 
estructura económica que se inscribe en la materialidad de la imagen publicitaria puede ser repensada en relación con la experiencia visual que $p b a$ había asimilado de poetas y artistas referentes. Así como no había publicidades, tampoco se numeraron las páginas de la revista. En ese sentido podríamos preguntarnos si la colección como antología de textos que señalamos antes, no es también una colección visual. Una página sin publicidades y sin números, no solo puede ser reordenada y leída como prefiera quien la tome en sus manos, sino que puede ser enmarcada y expuesta, haciendo de la letra una imagen. Separar una imagen de su contexto de producción para enmarcarla y exponerla es también lo propio de la institución arte -que la vanguardia histórica se había propuesto destruir-, pero entonces esas páginas de pba con destacados tipográficos que borran los límites entre "título" y "textos" (ver imagen 20), poemas enmarcados (ver imagen 21) y diagramaciones encargadas a la artista Nélida Fedullo, invitan a hacer de una práctica propia de las galerías y museos, una práctica sin mediación, conforme con la idea del "estar afuera". Nos encontramos, como planteamos en la introducción, en ese movimiento constante entre el "tableau" como cuadro y el "tableau" como mesa (Antelo 2015), de la dimensión vertical a la horizontal donde las técnicas del aparecer modifican los efectos de lectura.

A partir de las indagaciones en torno al desmantelamiento, ampliación y teorización de la poesía, y las operaciones en que estas cristalizaron (el carácter antológico con el que se pensó la revista y su rechazo a lo institucional) abordaremos los dos ejes que comentamos al inicio del capítulo: 1) las características de su intervención crítica según se modularon en las continuidades y diferencias con Contemporánea; 2) las contradicciones que muchos de los ensayos de $p b a$ exponen en sus concepciones sobre la poesía y el poeta, atravesadas por el problema de la temporalidad como valor; por último, la dimensión visual será abordada de forma transversal cuando sea pertinente.

1.3.1. De Contemporánea. Revista de artes (1948-1950) a la "Antología de la nueva poesía" en $p b a$

La revista Contemporánea (ver imagen 22), dirigida por Juan Jacobo Bajarlía, fue el espacio donde se conocieron muchos de quienes harían $p b a$, y puede pensarse como un puente entre las publicaciones de la Asociación Arte Concreto Invención y el proyecto de Aguirre. Si bien este último y Móbili habían tomado la influencia de las publicaciones 
concretas (en el diseño, la idea de invención, el rechazo a la representación) no habían participado en ellas. Fue a lo largo de las cuatro entregas que tuvo Contemporánea donde se encontraron con Juan Carlos Aráoz de La Madrid, Edgar Bayley, Juan Melé, Jorge Souza, así como también con Osvaldo Svanascini y Julio Llinás -estos dos últimos vinculados al surrealismo. Para Luciana Del Gizzo, Contemporánea habría operado, a su vez, como un pasaje de legitimación para los jóvenes de $p b a$, ya que en la publicación de Bajarlía encontraron la legitimidad que les daba la interdisciplinariedad -abandonada por los artistas concretos- que luego mutó hacia la autorización que les ofrecía la práctica colectiva (149).

El surgimiento de Contemporánea no puede desvincularse del relato que hace Bajarlía acerca de cómo conoció el invencionismo poético, ya que muestra el interés por formas del arte que avanzan más allá de las “escuelas poéticas” conocidas; asimismo, ese relato nos revela zonas de conexión con $p b a$ en tanto la noción de vanguardia se desplaza de sus límites históricos para ser pensada, por la figura del crítico, a partir de ampliaciones y selecciones temporales que la vuelven relevante para el ámbito local. Bajarlía, conocido luego como el "primo profesor" de Alejandra Pizarnik, ${ }^{112}$ no formaba parte de ninguno de los grupos de pequeñas revistas de vanguardias antifigurativas que habían caracterizado la escena de los años 1944-1948, sino que dictaba cursos sobre la "literatura de vanguardia”. En 1946 se publicó el libro que recopilaba sus clases, titulado Literatura de vanguardia. Del Ulises de Joyce y las escuelas poéticas. Allí cuenta que "un año después de[1] cursillo sobre poesía, cuando las cuartillas se hallaban en sazón a la espera de la imprenta", sintió "un extraño aguijamiento producido por una conversación acerca de cierto movimiento estético que ignoraba" (1946:159). Ese movimiento estaba conformado por jóvenes que "rompían con los cánones del arte representativo - ya fuese objetivo o subjetivo -y se adentraban en un mundo de realidades, donde los objetos y las imágenes eran creados en función de una actitud invencionista" (159). Lo que le llama la atención al autor es que estos jóvenes "empeñados en novísimas formas del arte”, no se reconocieran ni simbolistas, ni cubistas, expresionistas o surrealistas. Ese "aguijamiento" que le provoca a Bajarlía la conversación lo lleva a conocer a "este grupo de estetas" y a “redactar una exposición más para ser agregada, después de un año, al cursillo sobre poesía", donde el invencionismo es un capítulo que se añade a la secuencia de "literatura de vanguardia". Para hacer esa inclusión Bajarlía debió detener el curso del libro en

${ }^{112}$ Cfr.: Aira (2001) 
imprenta y asumir que algunas de las conclusiones de los capítulos anteriores son susceptibles de una "nueva formulación estética. Que más de una premisa puede ser discutida" (160), pero decide no modificarlos para ser fiel, podríamos decir, al efecto de ese "aguijamiento" y poder publicar el libro con el capítulo sobre el invencionismo con la mayor celeridad posible. De modo que el autor privilegia responder a la urgencia de la novedad, con las consecuencias de un salto argumentativo y las incongruencias que puedan aparecer respecto a su trabajo a lo largo de un año, por sobre la integralidad de la historia que se proponía realizar. Y entonces concluye: "Ya vendrán otros críticos (es imprescindible que vengan en este país donde no hay una tradición de tal categoría) que pondrán en su punto mis asertos. Y si esto sucede, habremos dado un gran paso en la marcha de nuestra afirmación estética" (1946:160). La figura del crítico se impone por sobre la del historiador; Bajarlía asume el corte que ese "movimiento ignorado" hace respecto de lo conocido y se propone explicar por qué el invencionismo no es una deriva del creacionismo, del surrealismo o del cubismo, sino una manifestación auténtica con sus propias reglas de creación. ${ }^{113}$

A partir de ese relato que hace Juan Jacobo Bajarlía sobre su vínculo con el invencionismo poético, y los contenidos publicados en la revista Contemporánea, podemos advertir que esta última estuvo atravesada tanto por los efectos de la irrupción de un movimiento cuyo director desconocía hasta entonces, como por la tarea crítica de

\footnotetext{
${ }^{113}$ En el útlimo capítulo del libro, titulado "La batalla por el invencionismo estético" - parafraseando el manifiesto de Bayley de 1945 La batalla por la invención publicado como uno de los cuadernos de la AACI - explica esta diferencia: "el poeta [invencionista] abandonó los materiales inconscientes y anecdóticos, para construir un concepto de nuevo tipo, en el que la combinación inventada de los vocablos produjera un deleite o una aproximación más directa con la realidad concreta" (1946:161). Por esta vía la imagen se independiza: "tampoco debía venir del inconsciente o del infra-yo, como lo haría un surrealista. Ni de la proyección ortogonal de las figuras sobre los planos. Ni de la combinación de estos, como podría resultar del cubismo" (161). Las páginas finales del libro, "Anticorolario" son dedicadas a analizar en la construcción de imágenes las diferencias mínimas pero contundentes según Bajarlía, entre "creacionismo" e "invencionismo". Los vínculos con Huidobro eran evidentes no sólo por su colaboración en Arturo, sino también por la insistencia del poeta chileno en definir qué se entiende por "inventar", como una forma de sustraer el poder creador a la naturaleza para desafiarla - "inventar es hacer que dos cosas paralelas en el espacio puedan hallarse en el tiempo", o en "Non serviam": "No he de ser tu esclavo, madre Natura; seré tu amo. [...] Y ya no podrás decirme: 'Ese árbol está mal, no me gusta ese cielo..., los míos son mejores"”. Por eso Bajarlía insiste: "los invencionistas huyen del sortilegio demoníaco porque creen que la imagen debe surgir sin la sugerencia de huellas expresionistas. Huidobro, en cambio, toma las palabras, las pone a hervir con los secretos de la alquimia, y nos obsequia una imagen mágica" (185). Compara los versos de Huidobro "mis miradas con un alambre en el horizonte para el descanso de las golondrinas" o "el viento mece los horizontes" -cuyo procedimiento sería la trasposición de los atributos de las cosas, arrastrando elementos figurativos - con una estrofa del invencionista Simón Contreras: "ya no es apenas el glaciar de bolsillo / cuando la aguja ordena su pelambre / y el martillo reembolsa danzómetros dentados / ya sin mango ni adiós, como tanto poema" (187), que se caracteriza, como los poemas del Edgar Bayley por el peso de la unidad gramatical donde las imágenes están engarzadas y por tanto sería imposible extraer alguno de los elementos del poema. Es un análisis intempestivo, interrumpido también, de corte abrupto en el final del libro.
} 
dar un "gran paso en la marcha de nuestra afirmación estética". Como las revistas de la Asociación Arte Concreto Invención, Arte Madí o las del perceptismo, Contemporánea se presentó a sí misma con un texto titulado "manifiesto" que recuperaba el espíritu de Arturo en su rechazo a toda melancolía (ver imagen 2). Apuntaba al respecto que "todo lo que se oponga a la revolución en el arte [...] pretende detener el patrimonio de épocas o doctrinas en las que el individuo y su arte debatían en el dolor y la muerte, rimando sus lágrimas con la melancolía, la tisis, la traición y otras purulencias que aherrojaban su capacidad creadora" (1948, n1:1). A continuación enumeraba una serie de puntos que caracterizaban esa actitud de reacción negativa: "Predicar contra un arte deshumanizado, para justificar la cursilería de temas y situaciones manidas"; "Afirmar que una nueva tendencia es algo sobrepasado o superado, sin conocer la historia y el contenido progresista de los movimientos de vanguardia"; "incurrir en el magister dixit y apoyar el principio de autoridad para defender luego el existencialismo" (1948, n1:1). ${ }^{114}$ Estos enunciados a los cuales Contemporánea se oponía son relevantes porque por un lado dan cuenta del programa de la revista a partir de una evaluación de lo que otros dicen sobre el arte de vanguardia, y en ese sentido la revista se afirmaba, como en toda intervención crítica, a partir del análisis de un enunciado ajeno; por otra parte, condensa una serie de posiciones polémicas que $p b a$ toma en su propio desarrollo. Una de ellas se refiere a la dicotomía entre "arte humanista" y "arte deshumanizado" según la cual este último se correspondería con las estéticas de vanguardia, y que ciertas lecturas de Ortega y Gasset (1925) habían instalado para cuestionar el lugar de las vanguardias. La impronta fuertemente humanista que atraviesa a las revistas del corpus, así como también a estas publicaciones con las cuales establecieron conexiones, rechaza esta oposición y afirma que en ella se ocultan otros valores, como los de la "cursilería" o la permanencia en formas perimidas del arte. Para desarmar tal dicotomía, Contemporánea hace una intervención propia de la dinámica que tuvieron este tipo de discusiones: apropiarse del término "humanismo" - fuera de debate - para establecer que solo el arte de invención es "la emergencia de un arte neo-humanista para las transformaciones neodemocráticas sociales". ${ }^{115}$ En segundo lugar, la desconfianza hacia los discursos que dan por superado el arte de vanguardia es otra de las marcas que atraviesa a $p b a$ y que se convierte en un

\footnotetext{
${ }^{114}$ El texto aparece firmado por "la dirección"; dado que Bajarlía fue el único director de Contemporánea, en la bibliografía se consigna con su nombre, para una mejor organización de las referencias.

${ }^{115}$ Este tipo de operaciones donde a un mismo término se le imprimen y disputan dos o más significados se analiza en el capítulo III de la tesis, como un fenómeno que atravisa a todas las revistas del corpus.
} 
punto de partida para publicar a los jóvenes de la "poesía nueva". Este aspecto se vincula con el tipo de relación que las revistas del corpus establecieron con el existencialismo, al que no podían negar por su impronta humanista, pero consideraban que ofrecía una versión muy reducida de las capacidades de "lo humano". ${ }^{116}$

pba mantiene, a través de Contemporánea, los vasos comunicantes con una idea de invención en tanto trabajo con las palabras por su vínculo inventivo y no representacional, como había sido esbozada en las publicaciones de la AACI; asimismo toma esos tres puntos que Contemporánea señala como oposiciones entre la vanguardia y las estéticas o pensamientos que considera conservadores; no obstante, se desplaza hacia otro lugar con respecto a la idea de "escuelas poéticas", ya que los directores de $p b a$ consideran que el "espíritu nuevo" no puede reducirse a límites que cada una impone. El proceso de desmantelamiento -que Del Gizzo califica como “depuración” y "liberación” luego de la sepración entre arte concreto y poesía invencionista- se produjo en simultáneo con la búsqueda de expansión del género respecto a programas poéticos de las revistas que antecedían a pba. Así como Ciclo se distanció de algunas revistas antecesoras por la ausencia del género manifiesto en sus páginas, $p b a$ se distanciaba de Contemporánea en la búsqueda de definición de un movimiento particular, pero tomaba el impulso crítico propuesto por Bajarlía. En ese sentido, se produjo una ampliación que iría dejando atrás el programa del invencionismo para alcanzar una función más integral. Este aspecto se manifestó según dos operaciones diversas: por un lado, la diagramación del único texto nominado "invencionismo" en una sección dedicada a Edgar Bayley, motivo por el cual podemos pensar que el nombre de un movimiento no es extensivo a toda la revista sino que se mantiene bajo la órbita de una firma autoral; y por el otro, de modo más explícito, en la conformación de la Antología de la nueva poesía", donde se exponen una serie de criterios propios de la crítica literaria como argumento para justificar la decisión de incluir a poetas vinculados con diversas influencias estéticas.

Como ya señalamos, $p b a$ no publicó imágenes, ni originales ni reproducciones, pero le dio relevancia autorial a sus responsables de la diagramación y tipografía, aspecto que nos permite pensar que la organización de los textos en las páginas era una de las dimensiones significantes en la revista. Luego de las dos primeras páginas donde se exponía un programa en forma de texto poético (ver imagen 6), se dedicaba una página a un autor en particular con poemas propios y un pequeño "artículo crítico" (en palabras de

\footnotetext{
${ }^{116}$ También para un desarrollo particular de este aspecto, ver capítulo III.
} 
la misma revista) que presentaba la poética del personaje seleccionado. En el primer número fueron todos autores cercanos al comité, Bayley, Lamadrid, Trejo, Trejo, Aguirre y Mobili. Esos cuerpos de textos eran, a su vez, contenidos dentro de líneas rectas que funcionaban como marcos estableciendo límites y encuadres entre los poetas. Es esa serie expositiva la que incluyó el texto de Bayley titulado "invencionismo", donde configuraba una noción de "tono" como el momento en que "una experiencia individualísima de la palabra" devenía común, des-individualizada, sin por ese motivo aplanarse en el significado convencional. Así, en tanto el lenguaje poético articularía esas dos fuerzas lo subjetivo y lo común- la poesía nueva "no rompe con la tradición porque su lenguaje es el de la poesía de todos los tiempos”. Esta perspectiva lo lleva a afirmar que el “invencionismo" es un "título provisorio" para una operación que lo desborda. Dichos aspectos han proporcionado una lectura de este texto como el dato manifiesto de esa ampliación que señalamos antes (Alonso 2014, Del Gizzo 2017). Sin embargo, esa ampliación se produce antes, en la decisión de dar a leer un texto que lleva por título el nombre de un movimiento en el encuadre de una poética autoral, separado del espacio programático de la revista.

En el número 13/14 se publicó la "Poetas de hoy: Buenos Aires, 1953”. El problema en torno a las "escuelas poéticas" aparece allí de modo más explícito, y no es casual que esté acompañado por la formulación de criterios de selección. Es justamente en virtud de esa ampliación de los límites programáticos que definen lo que el arte es o debe ser para un grupo determinado, que la revista se abre a otros criterios. En este movimiento crítico se formula el problema sobre cómo delimitar el alcance de un atributo como "contemporáneo". Tal es el punto de partida de la revista en "Poetas de hoy: Buenos Aires, 1953":

En las páginas que siguen, se presenta -según un orden surgido más de la necesidad de aclarar la exposición que de clasificar taxativamente la individualidad creadora de cada uno de ellos- un índice de los poetas que están trabajando en la actualidad, en estas tierras, dentro de un espíritu que podemos llamar contemporáneo. (pba 1953, n13-14:1)

La dirección de la revista anunciaba así un valor -lo contemporáneo- y una operación mostrar ese "índice de poetas" según un "orden” que no sería determinado por las particularidades poéticas indivisuales. Lo que advertimos es que llamar contemporáneo a un poeta no era una evidencia cronológica, sino que requería en principio una organización, y luego un crierio que justificara lo que la mera simultaneidad temporal no 
podía hacer. En ese aspecto es donde la pertenencia a una escuela poética-como marca de vanguardia- resultaría insuficiente y restrictiva:

[...] es necesario destacar que la actitud señalada no se limita a una particular tendencia, a un ismo determinado. Ha tenido, lógicamente, sus iniciadores y sus precursores. Hay, sin duda, direcciones más o menos definidas a las que tal vez pudiera llamarse movimientos. Pero es la diversidad de estas direcciones y en particular la presencia espontánea de poetas no vinculados a ninguna de ellas y que revelan, desde un comienzo, haber forjado en la soledad semejantes experiencias, la que induce a meditar sobre razones más profundas que la mera presencia de un determinado grupo, agitador $\mathrm{y}$ proselitista. (1)

Si la diversidad de poetas "de una actitud o de un espíritu nuevos" (en este caso usado como sinónimo de contemporáneos) se debería ordenar por "razones más profundas" que la presencia de un grupo, $p b a$ tiene que formular y exponer cuáles fueron esas razones para incluir a más cincuenta poetas según los siguientes apartados: "poetas del espíritu nuevo", "poetas madí", "poetas surrealistas" y "poetas del espíritu nuevo II". En ese marco, la dirección de pba hizo una valoración negativa de los alcances de ciertos movimientos, en la presentación de los "poetas madí, ya que mientras el invencionismo primigenio de Arturo habría evolucionado hacia una "integración con la realidad vital, emotiva y coherente del individuo", Kosice y los miembros de la revista arte madí "permanecieron, escolásticamente y sin preocupación por la esencia de los hechos de la poesía, en la posición original, es decir, en lo que podría ser un equivalente del letrismo y llamarse, por comparación y en consecuencia, palabrismo” (1953, n13-14:9). ¿Cuáles son entonces los criterios que $p b a$ exponía en esa división entre poetas de lo nuevo y aquellos que podían inscribirse en un grupo determinado?, ¿habría dos tipos de espíritus nuevos?, ¿en relación con qué?

Esa clasificación da cuenta de que $p b a$ no podía desprenderse de las formas de organización que una historia de las escuelas poéticas le ofrecía, y al mismo tiempo introducía una valoración propia de las vanguardias, la idea de "lo nuevo", que se le sustrae a esa forma de organización. Para determinar esa idea es que postulan un criterio cronológico y estético que debe complementarse: "unos pocos sobrepasan los treinta años - es decir, se encuentran situados, en lo que se refiere a su obra, más acá de la mitad del siglo" (1953, n13-14:1), pero a su vez es su expresión poética la que tiene "un sentido claramente distinto de aquel que podemos encontrar en sus predecesores inmediatos". Estos criterios se ponen a prueba en "la abierta rebelión contra los supuestos formales de la poesía, contra las maneras tenidas por prestigiosas, contras las convenciones literarias" 
(1). A continuación se explicita lo que "no se reconocerá en los dominios de la poesía moderna": uso de formas retóricas clásicas, la angustia sin salida, la miseria espiritual, el refinamiento burgués, y la poesía adjetiva, ${ }^{117}$ donde encontramos los puntos que Contemporánea había señalado com rechazos en el manifiesto del primer número. Advertimos un cambio de valoración entre "nuevo" y "moderno", en tanto este último atributo alcanzaba a todos, incluso a aquellos que insisten en una posición original como la de reconocerse según los límites del grupo. "Contemporáneo", "nuevo", "moderno" son términos que se superponen para dar cuenta de un estado de la poesía cuyos límites se organizan por valores que preexisten a $p b a$ y que no obstante la revista actualiza para pensar su propio presente. pba establece la operación crítica de seleccionar valores del pasado para organizar como novedad un tiempo que se experimenta como reactivo respecto de las posibilidades modernizadoras de ese pasado. Y dentro de esa selección hace su propia invención de clasificaciones al separar lo ya codificado - "surrealistas", "madí" - de aquello que lleva el nombre provisorio de "lo nuevo", conformado por experiencias "forjadas en soledad".

En el número siguiente poesía buenos aires es más explícita en su decisión e incorpora la palabra crítica para pensar ese movimiento de ampliación:

A través de los poemas, artículos críticos y notas editoriales que se publicaron, una cierta actitud y una cierta conciencia poéticas fueron transparentándose. Es posible que alguien hubiera preferido a todo ello una serie de manifiestos de la dirección, donde, en forma taxativa, se indicaran los principios que deben regir hoy la creación poética y la conducta humana. Sin desconocer la importancia que han alcanzado o pueden alcanzar manifiestos de esta clase, hemos creído que casi nunca los manifiestos consiguen generar actitudes de vida, de sentido renovador y alcance poético. Antes bien, descontando el valor teórico y de orientación de algunos de ellos, los manifiestos constituyen con frecuencia intentos frustrados de escuelas o tendencias. (...)

\footnotetext{
${ }^{117}$ Este último aspecto (lo que excluye antes que lo que reúne) será razón de polémica en Letra y Línea (Cfr. Capítulo III): "Por otra parte, queremos insistir en no reconocer dentro de los dominios de la poesía a los siguientes supuestos: a) EL de las formas retóricas clásicas concebidas apriorísticamente, es decir, como ejercitación verbal de la que pueden llegar a obtenerse resultados felices dentro de un juego de convenciones generalmente admitido. Actitud superficial que implica una parcialización del trabajo creador y un artificioso retorno a épocas donde estas formas eran expresión natural y legítima. B) el de la invalidez, la angustia sin salida, la miseria espiritual del hombre, tema que se origina sea en un superficial contacto con el existencialismo, sea en la influencia de poetas del tedio y el refinamiento burgués (Baudelaire, Rilke, Eliot, etc.). Esta escritura de desaliento, de suciedad, de postración, de caos, de patología, nada tiene en común con el sólido y viril - y a veces irónico - estoicismo que sería, cuando menos, la traducción poética de un mal semejante, si es que realmente fuera experimentado por el poeta. C) el de la poesía adjetivada (social, popular, mística, etc.), en cuanto ella significa una postura literaria y no, como debiera ser, un compromiso vital asumido hasta sus últimas consecuencias (Maiakovski, García Lorca, Vallejo) o una intimidad real, de cultura, de lengua y de espíritu, con el pueblo (Píndaro, Juan Ruiz, Villon, Carlos de la Púa).” (1953, n1:1)
} 
poesía buenos aires no se constituyó en representante de ningún grupo en particular, aunque tuviera - desde el primer momento- una orientación estética perfectamente determinable, no obstante su evidente amplitud.

$(1954$, n15:8)

Es decir que Contemporánea es un puente entre el invencionismo y poesía buenos aires no solo por el espacio que promueve para la poesía, y el tipo de comunidad que establece, también lo es porque produce un desplazamiento hacia la crítica en ese clivaje de la "ampliación estética" o "relajación de la vanguardia" como lo ha leído Luciana Del Gizzo. Donde Bajarlía pedía un crítico, pba colocó la figura del editor-antologadorseleccionador que ya no puede regirse por un manifiesto, pero debe dar cuenta de los límites entre "nueva poesía" y "reacción poética" sin constituirse a su vez en un nuevo manifiesto.

\subsubsection{El poeta contemporáneo, ¿contra toda melancolía?}

A partir de los puntos de contacto entre Contemporánea y pba, que se manifiestan en la operación crítica de construir una antología de "lo nuevo" donde postuló los criterios acerca de qué se entiende por poetas contemporáneos -en tanto se abandona como principio organizador único la pertenencia a un movimientos o grupo poético-, es posible detenernos en otro aspecto vinculado con la temporalidad como problema crítico. La experiencia en torno al tiempo presente se configuró, en nociones como "el poeta" y "la poesía", según contradicciones recurrentes: una exaltación de ciertos valores históricamente ligados a las vanguardia -como el "júbilo", el rechazo a la melancolía, (Aguirre 1950, n1:1, 4), la idea de una poesía desmantelada (Aguirre 1950, n3:1), la rebelión contra el símbolo (Móbili 1950, n1:4)- se superpuso con otros que estaban en continuidad con aquello que pba decía rechazar -la angustia, lo trascendental-o bien se articuló con una experiencia mucho más grave y seria de lo que se esperaría de una vanguardia, como la que podemos advertir en una caracterización del tiempo desde el atributo de "agobio", que señalamos al inicio del capítulo. Se trató de una moral crítica en el sentido expuesto en la introducción: así como se produce un movimiento hacia la extrañeza, hacia ese presente "hoyado", donde no hay lamentos por lo que la cultura no es, se produce otro movimiento u otra fuerza, donde ese mismo golpe de lo inquieto busca estabilizarse con un valor: el agobio, el retraso, la pesadez. 
En el dossier sobre poesía buenos aires que publicó Punto de Vista (1981, año IV, n12), Daniel Saimolovich afirmaba que "el vanguardismo pasa”, en la revista de Aguirre, "por la decidida afirmación del personaje del poeta, adelantado del futuro, cuyo ahora se continúa 'hasta que la humanidad la iguale' (Aguirre, n3: s/n)” (1981:29). Este personaje estaría caracterizado por dos "elementos fundamentales", "extremos de una contradicción": "su asimilación al poeta negro, "portador de la ostra maldita', que encarnaría Rimbaud, a la vez que al poeta como ser dotado de 'una inmensa voluntad empeñada por la confianza' y destinado a 'concebir los planos del mundo"” (29). Esa contradicción que señaló Saimolovich puede ser repensada, desde nuestra perspectiva, en torno a cómo atraviesa la configuración de la temporalidad en pba. Estas dos fuerzas júbilo y agobio- las podemos rastrar como tensiones tanto en una serie de textos de los integrantes de $p b a$ como en la relación entre estos y aquellos que la revista decide traducir, que resultan muchas veces radicales o denegatorios respecto de los anteriores. Para eso seleccionamos el siguiente corpus textual: "El poeta", "Nos proponemos dar a la poesía" (Móbili), "Noción de poesía" (Aguirre), "La poesía" (Aguirre), "Poesía para respirar" (Aguirre), "Noción de poesía” (Espiro), “Conversación con René Char” (Berger y Char), "René Char" (Blanchot), "Poetas de hoy: Buenos Aires, 1953", "Búsqueda de poesía" (Drummond de Andrade).

Esta ambigüedad de la experiencia se manifiesta desde el relato de una de las escenas fundacionales que los integrantes de $p b a$ suelen contar sobre los comienzos de la revista, marcada tanto por la imagen del desparpajo y la picardía como de la carencia. En la preparación de lo que luego sería el primer número de la revista hay un robo, posibles piñas y una noche de bar. Cuando a fines de los años cuarenta Aguirre y Jorge Enrique Móbili se propusieron hacer una publicación dedicada exclusivamente a la poesía, estimaron que era imprescindible contar con la colaboración de Edgar Bayley y Juan Carlos Lamadrid, a quienes admiraban como verdaderos vanguardistas, pero se sentían intimidados por sus figuras e incapaces de convencerlos. Entonces evaluaron que lo mejor era afrontar la situación en el bar a donde solía ir Lamadrid:

le dimos vino y lo dejamos hablar del boxeador Justo Suárez, «Torito». «Dale más vino», le decía yo a Aguirre. Aguirre era un tipo pulcro, medido, coherente y yo, serio, le decía: «Dale más vino». En un momento, notando los originales debajo del sobretodo de pelo de camello que tenía Lamadrid, Aguirre me dijo por lo bajo: «Los poemas». Pasaba el tiempo y Aguirre se ponía cada vez más nervioso y Lamadrid hablaba y hablaba. Entonces le dije a Aguirre: «Afanáselos». Aguirre se puso blanco como un papel. Y nos afanamos los poemas. Al otro día se armó un lío bárbaro del que se enteró 
todo Buenos Aires. Lamadrid decía: "Me mamaron en una cantina y me afanaron el libro". ("Reportaje a Jorge Enrique Móbili", en Fondebrider, Freidemberg y Samoilovich: 14, citado en Del Gizzo 156)

Ese robo constituye una doble identidad, que Luciana Del Gizzo nombra como “autorización fraudulenta" (156): la aventura nocturna, la fantasía de ilegalidad, la poesía como contrabando, por un lado; y la seriedad de cumplir el propósito deseado, por otro. Tiempo después, ya en 1954, Aguirre organizó un evento titulado "Presentación de la Nueva Poesía Argentina: la generación última”, en el teatro Florencio Sánchez, en torno al especial de poesía buenos aires sobre "poetas de hoy" y a la edición de Antología de una poesía nueva. Según Francisco "Paco" Urondo, a la salida, Oliverio Girondo dijo, tal vez no sin malicia, "Este Aguirre es milagroso, ¿cómo habrá hecho para encontrar 40 poetas en Buenos Aires?”. También hace mención a ese exceso Aldo Pellegrini en el número 3 de Letra y Línea, en la polémica que inicia con pba (Cfr. Capítulo II). El robo y la exuberancia de reunir a cuarenta poetas cuando parecería impensable proponen una forma especial de pensar la relación entre la vanguardia entendida como modernización cultural, y el ámbito local experimentado como carencia. "Vanguardistas apócrifos o por apropiación", los llama Del Gizzo; así los jóvenes de poesía buenos aires habrían inventado las condiciones para su emergencia. O más bien, espectacularizaron la invención de esas condiciones en el gesto performático que contiene toda vanguardia. La carencia y exceso, el agobio o el desparpajo, son figuras que están en la base del problema ambiguo de la época tal como se plantea en la revista.

El primer nudo que observamos en relación con este problema es que la caracterización del tiempo presente o del vínculo entre el poeta y la época se carga de una serie de atributos y exigencias que una política de la creación radicalmente negadora del símbolo y la melancolía no asumiría. En el número inicial de la revista leemos casi un monumentalismo de la figura del poeta, que se construye con imágenes que aluden a esas dos fuerzas, donde prevalece cierta moral de la responsabilidad: es quien "ha venido a sustituir razones, a hundirse en el crecimiento del tiempo agobiado", a "[resistir] la dictadura y la anarquía, la melancolía y la carcajada sin brazos, la muerte y la vida", sufrirá porque "supera a su naturaleza y a su ciencia", afirma $p b a$. En el párrafo siguiente aparece la palabra "júbilo" rodeada de una serie de condiciones: "[al poeta] habrán de acercársele, porque en tanto conserva sus razones, su juventud y la inviolable pujanza de su origen, transmitirá un júbilo insospechado para aquel que resista la intensidad de su desnudez y la justificación de su dramática paradoja” (“El poeta”, 1950, n1:1). En un 
mismo texto las figuras del júbilo y el rechazo a la melancolía son moduladas por la exaltación de todo aquello que deberá atravesar este poeta más atormentado que jubiloso: el sufrimiento, la dictadura, la dramática paradoja, el hundimiento en un tiempo sin aire.

A vuelta de página encontramos un texto firmado por Jorge Enrique Móbili, "Nos proponemos dar a la poesía", ${ }^{118}$ que coloca al poeta fuera del sufrimiento que marcaba al pasaje anterior y se inscribe mediante un "nosotros" en ese lugar: "No lloramos el presente y cultivamos la vida donde nuestra es la referencia y la medida del espacio, la calle". Esa negación de la melancolía frente a un presente contiene el arte poética de lo que pba propuso a en distintos textos programáticos, ya que alude a la ausencia de descripciones, anécdotas o imitaciones pictóricas en la poesía, que responderían a una actitud regresiva del vínculo con el presente: "Ya no describimos la visión en su cocina ni en su trastienda secular de vigilia o de impotencia, ya no pintamos la anécdota, la fraguamos; le inventamos privilegios a la acción humana recapacitando los vínculos frente a la angustia sideral" (Móbili 1950, n1:2). No se trata de una alegría del derroche, del exceso, sino de la finalidad por salvar algo que se considera sagrado y trascendente de la condición humana. También Aguirre lo pone en esos términos en el homenaje a Guillaume Apollinaire, a partir del cual advertimos que la insistencia en el "júbilo" es dependiente de otros diagnósticos a los que el poeta responde con seriedad y compromiso, estando nada menos que "en el frente" de batalla: ${ }^{119}$ "Hay un poeta preparado para cada injuria, para cada día que se pretende despojar de su júbilo. Y como tú, Guillermo, está en el frente y te saluda" (1950, n1:8).

Otra variable en relación con la temporalidad y el modo en que el poeta está atravesado por esa experiencia se manifiesta en el contraste entre algunos textos de sus integrantes. Mientras Edgar Bayley configura ese vínculo como una fugacidad que se retira del compromiso - "esa tensión fugitiva, pero renaciente tras cada desfallecimiento, no quisiera cumplirse en el destierro del tumulto o el compromiso" y que "no puede encenderse bajo condiciones previsibles y necesarias" (1950, n1:4) $)^{120}$ - Aguirre lo pone en términos de profecía, clarividencia o premonición: "el poeta posee las raíces de la clarividencia y de la historia" (1950, n2:2); o el que trae la "reminiscencia premonitoria

\footnotetext{
${ }^{118}$ Este texto no se encuentra ni en la edición facsimilar impresa de poesía buenos aires editada por la Biblioteca Nacional, ni el pdf online de la misma edición, ya que señala como "fe de erratas" la omisión de dos pliegos.

${ }^{119}$ Se opone a una posición nihilista como la que podríamos esperar en relación con la idea de "risa" que Bataille construye a partir de su lectura de Nietszche.

${ }^{120}$ Texto sin título. En la bibliografía se consigna como "esa tensión fugitiva".
} 
de los nuevos días" (1950, n1:5); y Wolf Roitman califica al poeta de "profeta sin párpados que nos persigue" (1951, n3:7). La experiencia de la visión que marca el vínculo con el tiempo aparece desdoblada entre el instante del no-saber, de lo que se fuga, la posesión de un origen, el anacronismo del recuerdo futuro, y el tormento de quien está obligado a ver, en las cuales hay una inestabilidad entre figuras que aludirían a un orden de la contingencia y aquellas que ponen al poeta en un lugar privilegiado de conocimiento.

Algunos de estos aspectos que asignan al poeta una misión y un saber especial en el vínculo con su época como catalizador de la vida, profeta que "mantiene al universo en estado de conciencia" (Aguirre 1951, n4:1), se asemejan a la gravedad que caracterizó a las revistas de las cuales pba buscaba distanciarse. En El 40. Revista de una generación, León Benarón afirmaba: "Nosotros somos graves, porque nacimos a la literatura bajo el signo de un mundo en que nadie podía reír" $\left(1952\right.$, n1:3), ${ }^{121}$ en la misma línea que Verde memoria había iniciado su publicación diez años antes: "todo es triste en un mundo lleno de confusión y de violencia. Ahora no basta el recuerdo de los poetas amados leídos sobre la suave hierba" (1942, n1). No obstante, mientras estas publicaciones no dudan en definir bajo una serie de puntos precisos los límites de una "generación", ${ }^{122}$ en pba esos límites son difusos cuando busca pensar el problema de lo contemporáneo.

Jorge Enrique Móbili, quien como vimos en el primer apartado de este capítulo, había definido a la generación de vanguardia por su condición de "signo de doble desgaste" del tiempo, y por tanto los llamaba "los menos contemporáneos" (1951, n4:1), lo plantea en otros términos cuando define a los poetas César Vallejo, Vicente Huidobro y Plablo Neruda, al explicar por qué la revista decidió agruparlo. Se trata del mismo número de $p b a$ donde aparecía la cita anterior, pero en "Una concienica americana" la idea de lo contemporáneo no aparece ligada al doble tiempo, al abismo y el "hato de luces", sino a lo desconocido y lo nuevo:

Hay un frente de gracia para reunir el tiempo. Los grandes poetas dejan siempre más espacio, además del que supieron ocupar. La gran poesía se hace siempre en el espacio desconocido y con un nuevo lenguaje. (...) Solo a ellos aceptamos como contemporáneos. (El énfasis de la cursiva es mío 1951, n4:3)

\footnotetext{
${ }^{121}$ Luis Soler Cañas, por su parte, escribía en 1952 que "los jóvenes del 40 no están para bromas: actúan en serio, muy en serio, y por eso, en cambio, el brulote se maneja desaprensivamente [...]. Tienen una disculpa: la poca edad, la vehemencia y, sobre todo, que no lo hacen por jugar, por pasar un buen rato a costa del prójimo o del colega. Actúan con una terrible seriedad: son los infantes serios y terribles". ("Los jóvenes son serios", en Democracia, citado en Soler Cañas 1981:99)

${ }^{122}$ Cfr.: "Tesminonio" en El 40. Revista de una generación (1951, n1:3-5) y "Otras reflexiones sobre el concepto de generación" en Centro (García 1953, n7:46-51).
} 
Tiempo y poesía, o contemporaneidad y poesía auténtica no se autoimplican, más bien instalan en la relación que necesita ser justificada y que deviene moral de lectura, "solo a ellos aceptamos como contemporáneos". A la idea de lo "nuevo" se la contrapone con "no desconocemos los cánones, la fuerza vertebrada de la historia, las relaciones del mundo continuo en el amor y en la lucha; no desconocemos el tiempo" (Móbili 1950, n1:2); la vanguardia son los menos contemporáneos, "lo nuevo es el origen" (1950, n1:2), como si el tiempo fuera lo urgente a definir a la vez que una dimensión a demoler para que emerja solo de la experiencia que instala la poesía. Como afirmaba Blanchot sobre el "eterno retorno", "el hecho de pertenecer a este momento en que se cumple un cambio de época -(si lo hay)-, también se apodera del saber certero que quisiera determinarlo, haciendo inapropiada tanto la certidumbre como la incertidumbre. Nunca menos que en ese momento podemos recorrer nuestro contorno: es decir, ante todo, la fuerza discreta del viraje" (2008:339).

"La personalidad del arte" de Nicolás Espiro (1952, n8:5-6) presenta un punto de anclaje crítico que pone en diálogo la inestabilidad de una definición epocal de los artistas con los modos de leer una obra. El texto presenta una discusión situada con otro libro de publicación reciente, en torno al cual se propone resignificar el sentido de lo "personal" e "impersonal" en la historia. ${ }^{123}$ Sin adentrarnos en ese debate, se trata de un análisis relevante para pensar el problema de la temporalidad en relación con la crítica, y más específicamente el modo en que los integrantes de $p b a$ definen con indeterminación la idea de lo contemporáneo. A partir de una cita de Chateaubriand, Espiro establecía una diferencia entre "el hombre de la época y el hombre de todas las épocas" e identificaba a este último con el artista, para cuestionar las lecturas que, desde su punto de vista, "subordinaban" a la obra a ser el reflejo de un tiempo histórico:

Que una obra de arte refleja, después de un cierto número de siglos, un estado social que es necesario conocer (y asimilar) para llegar a su plena comprensión, me parece la menos importante y la más exterior, con respecto al arte, de las afirmaciones. Que el valor de una obra de arte no está en ese

\footnotetext{
${ }^{123}$ El título del texto proviene de una discusión con un libro reciente -Spirito Hugo, Impersonalidad del arte, Buenos Aires, Facultad de Filosofía y Letras, Instituto de Filosofía 1952, Cuadernos de Filosofía Vcon el cual se propone discutir e interrogar a partir de las siguientes preguntas: "¿Tiene la obra de arte origen en esa vida impersonal que constituye el sustrato histórico?”, "¿Es lo mismo, al referirnos al fundamento de la historia, hablar de fuerza o vida personal o suprapersonal?". Para Espiro, a lo "impersonal de la historia" se le opondía lo "suprapersonal como antítesis de lo histórico", y en este sentido se propone distinguir entre dos varaibles de la "despersonalización": el hombre puede "despersonalizarse impersonalzándose", es decir, "reducirse [en relación con la obra] a una modalidad simple de justicia, a un determinismo social de sus acciones, y se funde en el curso histórico"; o bien puede, "despersonalizarse suprapersonalizándose", dando cuenta de una "manifestación de vida superior y única, sobrenatural y asombrosa por ser la masa quien la expresa".
} 
reflejo para los "ojos actuales que en cierto modo vuelven a crearla" me parece evidente. (5)

Desde una perspectiva como esta se comprende por qué el criterio para definir a los “contemporáneos" de $p b a$, o a los poetas del "espíritu nuevo" no puede ser el cronológico, ya que sería de todos modos no sería extensible a las obras que produjeron. Para Espiro, habría "algo en la forma, algo en el equilibrio o desequilibrio específicamente bizantino [de la obra], que trasciende la problemática o la situación propia de un período histórico" (1952, n8:5), y por eso el crítico no puede perder de vista lo que se resiste a ser explicado desde las nociones de "medio cultural" o "estado social" que es nada menos que lo "bizantino", ínfimo, fútil de una obra. En ese sentido, como Jean Cassou en el texto publicado por Ciclo, se proponía dar cuenta de una relación compleja y disimétrica entre la significación de una obra y la época en que esta surguó. Como en Contemporánea, para pba el problema de la época en relación al arte no se dirime en la cuestión de lo nuevo, sino en la elaboración de criterios y argumentos que deslinden las relaciones o injerencias de la historia (como conjunto de representaciones) y lo social (como componente determinante en lo que se cuenta) en el sopesamiento de las lecturas posibles del arte.

Por otra parte, la pba publicó textos de otros autores donde la relación del poeta con el tiempo es más discontinuista e indeterminada de lo que proponían los integrantes de la revista. Y en ese sentido advertimos que los criterios de selección de la revista se apoyan en valores ligados con las vanguardias históricas, como la afirmación de un espacio desconocido y nueva lenguaje, de un modo más articulado respecto del que aparece en las autofiguraciones de sus integrantes. Así, en la entrevista con la cual $p b a$ elige iniciar el número especial dedicado a René Char - una entrevista que gira sobre las relaciones entre época, política y poesía- aparece una figura de poeta que incluso cuestionaría algunos de los atributos con los que Aguirre, Móbili, Roitman y Bayley definían al poeta:

Yo le hablo en tanto ser que vive sobre una tierra presente, inmediata, y no en tanto ser que tiene mil años de camino delante suyo. Hablo para los hombres de mi tiempo, que han hecho morir como nunca, y no hipotéticamente para los hombres de la distancia. Se acostumbra, para tentarnos, a desplegar ante nosotros la sombra clara de un gran ideal. Sin embargo, la edad de oro prometida no podría serlo sino en el presente. ¡La perspectiva de un paraíso ha inflado al hombre!

Tenemos una tarea, eso sí... Bien sé que los poetas tienen a menudo curiosas pretensiones. Sin cesar, ellos se creen obligados a tocar el clarín, de donde su rápida pérdida de influencia... (Berger y Char 1953, n11-12:3) 
El poeta de Char no anuncia ningún futuro, su palabra no cae en otro tiempo, sino en la cercanía inmediata. Si ponemos en diálogo este pasaje con el texto que Ciclo había publicado de René Char, "El poeta", advertimos que el problema del tempo no se manifiesta por un desafasje entre presente y futuro - que el poeta vendría a ligar - sino en la incomprensión inmediata del mismo presente donde desconfiar de los diagnósticos del mal de la época supone advertir lo no-vivido de lo vivido de esos "hombres de mi tiempo" a quienes se habla.

Asimismo, en el número 15 la portada es un extenso poema-programa de Oswald de Andradre, que se apoya en la idea del poema como imagen que solo responda a sí misma, despojada de cualquier cercanía con el aura profética de pba. ${ }^{124}$ El punto de partida del texto es el borramiento de lo personal, "Las afinidades, los aniversarios, los incidentes personales no cuentan" (1), pero da un paso más respecto de lo personal como "subjetividad" -que Bayley había planteado a su manera desde el primer número de la revista- porque afirma: "la poesía suprime sujeto". Por otra parte, la palabra de esta poesía tiene "cara neutra", por eso "Tu gota de bilis, tu careta de gozo o de dolor en la oscuridad son indiferentes", al contrario de la palabra clarividente y agobiada del poeta de pba. Asimismo, y en relación con las ambigüedades entre los valores de la vanguardia en la experiencia del tiempo y la configuración de este como gravedad que exige una misión, no es casual que $p b a$ haya elegido este texto ya que ataca dos palabras claves que dan título a las revistas "elegíacas" -Verde memoria (1942) y Canto (1940)-: "no osciles entre el espejo y la memoria en disipación. Si se disipó no era no era poesía. Si se partió,

\footnotetext{
124 Texto completo: "No hagas versos sobre acontecimientos. No hay creación ni muerte ante la poesía. Frente a ella, la vida es un sol estático, no da calor ni ilumina. Las afinidades, los aniversarios, los incidentes personales no cuentan. No hagas poesía con el cuerpo, ese excelente, completo y confortable cuerpo, tan indefenso a la efusión lírica. Tu gota de bilis de bilis, tu careta de gozo o de dolor en la oscuridad son indiferentes. No me reveles tus sentimientos, que se aprovechan del equívoco o intentan un largo viaje. Lo que piensas y lo que sientes, esto no es aún poesía. No cantes tu ciudad, déjala en paz. El canto no es el movimiento de las máquinas ni el secreto de las cosas. No es la música escuchada de paso, el rumor del mar en las calles junto a la línea de espuma. El canto no es la naturaleza de los hombres en sociedad. Para él lluvia y noche, fatiga y esperanza, nada significan. La poesía (no extraigas poesía de las cosas) suprime sujeto, yate de marfil, tu zapato de diamante, vuestras mazurcas y supersticiones, vuestros esqueletos de familia desaparecen en la curva del tiempo: son algo inservible. No recompongas tu sepultada y melancólica infancia. No osciles entre el espejo y la memoria en disipación. Si se disipó, no era poesía. Si se partió, cristal no era. Penetra silenciosamente en el reino de las palabras. Allí están los poemas que esperan ser escritos. Están paralizados, pero no hay desesperación: hay calma y frescura en la superficie intacta. Allí están solos y mudos, en estado de diccionario. Convive con tus poemas, antes de escribirlos. Si son oscuros, ten paciencia. No fuerces al poema a desprenderse del limbo. No recojas del suelo el poema que se perdió. No adules al poema. Acéptalo como él aceptará su forma definitiva y concentrada en el espacio. Acércate más y contempla las palabras. Cada una tiene mil caras secretas bajo una cara neutra y te pregunta, sin interés por la respuesta pobre o terrible que le dieres: ¿Trajiste la llave? Repara: hermanas de melodía y concepto, las palabras se refugian en la noche. Todavía tímidas e impregnadas de sueño, ruedan por un río difícil y se transforman en desprecio". (de Andrade 1954, n15:1)
} 
cristal no era"; "El canto no es el movimiento de las máquinas ni el secreto de las cosas. (...) Para él lluvia y noche, fatiga y esperanza, nada significan”.

Esta articulación ambigua o inestable entre la búsqueda de una poesía sin sensiblería, anécdotas, regionalismos, que fuera pura invención de la imagen en el taller de la lengua, y la afectación de esa misma búsqueda por un sentimiento de desolación donde el poeta cumple un rol espacial, puede leerse como una apropiación particular de las lecturas internacionales (René Char, Oswald de Andrade, como veíamos en el ejemplo). Así, las imágenes del desierto o el ahogo, que señalábamos al inicio del capítulo, y la búsqueda del júbilo, de la renovación, están marcadas por un vínculo conflictivo con el pasado y un presente en la escena local que parece exigir seriedad como demanda Contorno-y responsabilidad -como insiste la generación del cuarenta. ${ }^{125}$ Esas exigencias no resultan indiferentes a los deseos de renovación de las vanguardias, y en ese sentido sus poéticas están tensionadas entre la trascendencia (el poeta fuera del tiempo para salvar al tiempo) y el desmantelamiento de las palabras prestigiosas, los recursos retóricos ampulosos, los grandes temas en la poesía. Francisco Madariaga condensa esa ambigüedad cuando escribe "con un don infernal de encanto y sonido / lloras entre los hombres tu desacuerdo con el lenguaje" (1953, n13-14:4). Llorar el desacuerdo con el lenguaje contiene los dos movimientos de la contemporaneidad que pba atraviesa: el agobio y la novedad.

\subsection{A partir de cero: imagen y función crítica}

Bajo la dirección de Enrique Molina y la presencia significativa de Aldo Pellegrini, en 1952 se publicaron dos números de A partir de cero. En el tercero, de 1956, la figura del director fue desplazada por una "Redacción" que integraron Carlos Latorre, Julio Llinás, Francisco J. Madariaga, Enrique Molina, Aldo Pellegrini y J. A. Vasco, consignada en este mismo orden alfabético. Si bien se mantuvo la impronta visual y tipográfica de la portada en el encabezado que da a leer el nombre de la revista, la salida del artista Juan Battle Planas como ilustrador obligó a producir cambios en las líneas del título (ver imagen 7 y 9); asimismo la revista adquirió entonces una impronta grupal más

\footnotetext{
${ }^{125}$ Cfr. en esta tesis: apartado 2.1 del segundo capítulo, y apartados 3.1 y 3.2 del tercero.
} 
fuerte ya que los integrantes de la redacción además de publicar textos poéticos, narrativos y ensayos, aportan collages e ilustraciones.

A diferencia de la trayectoria de Aldo Pellegrini al momento en que inició la publicación de Ciclo en 1948, o de Raúl Gustavo Aguirre y Jorge Enrique Móbili en los comienzos de poesía buenos aires -todos poetas sin obra que encaraban una revista cultural- Enrique Molina había publicado Las cosas y el delirio (1941, Editorial Sudamericana), Pasiones terrestres (1946, Emecé) y Costumbres errantes o la redondez de la Tierra (1951, Botella al Mar), en tres editoriales cuyos catálogos circulaban entre lectores de poesía. ${ }^{126}$ A su vez, había colaborado en las revistas Canto (1940) y en el número cuatro de Los Anales de Buenos Aires (1946), dirigida por Jorge Luis Borges, dato relevante ya que se trató del primer escritor argentino con el cual A partir de cero se propuso polemizar, y con quien sustuvo la confrontación hasta el tercer y último número. La vinculación de Molina tanto con las revistas de la generación del cuarenta, como con los jóvenes surrealistas que comienzan a publicar una década después, es representativa de la propuesta temporal de la revista, ya que el programa de $A$ partir de cero buscó construir una genealogía ${ }^{127}$ surrealista, que se remontaba hasta el romanticismo, para leer el presente.

A pesar de la continuidad que supondría el nombre de Aldo Pellegrini, las traducciones y una nueva entrevista a André Breton, referencias a Roger Caillois y Lautréamont, A partir de cero se diferenció de Ciclo porque hizo de la poesía el objeto principal de reflexión, y le dio a la revista una impronta visual distintiva. Entre los materiales que publicó, encontramos poemas hasta entonces inéditos y ensayos de los colaboradores argentinos, así como también traducciones de poesía. La reseña crítica se utilizó principalmente para presentar de manera breve a aquellos poetas de quienes se publicaban por primera vez sus textos: Antonio Porchia, ${ }^{128}$ César Moro, y Georges Schehadém. Si bien la revista no tuvo secciones definidas, en los dos números de la primera época las páginas del pliego central se dedicaron, desplegadas, al tratamiento de uno o dos autores del surrealismo francés, cuyos textos se diferenciaban del resto por estar diagramados en posición horizontal, obligando al lector a girar el objeto para poder

\footnotetext{
${ }^{126}$ Para una ampliación sobre ese aspecto, cfr.: José Luis de Diego (2014).

${ }^{127}$ La palabra "geneaología" es preferible a la de "linaje" o "corriente" porque estas últimas se vinculan con la idea de herencia en el primer caso o de lo continuo, en el segundo. Cfr.: Revel, Judith (2009) Diccionario Foucualt. Buenos Aires: Ediciones Nueva Visión, pp.: 71-72

${ }^{128}$ Quien había adquirido popularidad entre André Breton, Henry Miller y Georges Bataille, después de la publicación de Voces a cargo de Caillois en París (Voix, 1949), para la serie G.L.M.
} 
leerlos. El formato oblongo, las escrituras invertidas a la disposición vertical de la página, collages grabados, textos manuscritos, las imágenes de Battle Planas en los dos primeros números, y la diversidad de artistas convocados a participar del tercero, caracterizaron la impronta visual de una revista surrealista. La combinación de imágenes extraídas de libros antiguos que aludían a situaciones de exploración o experimentos científicos, los collages con partes del cuerpo diseccionadas, o simplemente cuerpos cuya organicidad ha sido alternada, así como también el uso de máquinas o dispositivos mecánicos, son propias del imaginario que encontramos en La révolution surréaliste y Le surréalisme au service de la révolution.

El subtítulo de la revista "poesía y anti-poesía" aludía a una intensificación del axioma surrealista de unir el arte y la vida, antes que a una poética cuyos materiales de trabajo fueran parte del lenguaje popular, como en los antipoemas de Nicanor Parra. ${ }^{129}$ No era la primera vez que el término aparecía entre las revistas del corpus; la portada tipográfica del número 7 de $p b a$, cerraba con el siguiente enunciado: "La poesía deviene, violentamente, antipoesía. Ella se instala ahora en vuestros cuerpos, habita vuestras casas y combate por vuestra dignidad en todos los frentes" (Aguirre 1952, n7:1). Desde esta negatividad, la revista de Molina impugnó el "manipuleo litúrgico de restos fósiles retóricos, la composición de elegantes sonetos o de cualquiera otra de esas banalidades decorativas elaboradas por el ocio y la cobardía” (Molina 1952, n1:1). Y en el tercer número, la concepción de la poesía como antinomia de las formas retóricas aceptadas, es una vía para reafirmar que ella se encuentra en "cualquier tipo de actividad' dirigida a destruir los sentimientos convencionales y cuanto frustra, en nombre de un orden que sentimos como una opresión, el impulso de una auténtica aventura espiritual" (Molina 1956, n3:2). El antipoema aludía, en este sentido, a una condición vital opuesta a una idea de poesía como "bellas artes" que se cristalizaba, institucionalmente, en la S.A.D.E., los premios y menciones de reconocimiento. ${ }^{130}$

Estas consideraciones generales y descriptivas sobre la impronta visual y la definición de poesía que se propuso desplegar $A$ partir de cero, son el marco donde

\footnotetext{
129 Poemas y Antipoemas de Nicanor Parra (1954), Heriberto Yépez agrega el nombre de Enrique Bustamente y Ballivián, cuyo libro de 1927 se titulaba Antipoemas.

${ }^{130}$ En el número 3 de la segunda época, Molina hacía mención a "cierto tipo de actividades donde se confunde la osteología y la "haute couture" que "osan denominarse con un nombre fulguranete: S.A.D.E. Para nosotros ese nombre solo puede evocar uno de los momentos de mayor dignidad en la historia del espíritu y su sola mención aparece como un escarnio de un tipo muy particular y sangriento sobre las cabezas de quienes se atreven a utilizar esas letras sagradas para presidir actos de festejos patrios, de festejos gastronómicos, de festejos declamatorios y demás festejos de distribución de premios y cursos de puericultura" (1956, n3:2)
} 
leemos el programa crítico de la revista atravesado por el problema de la temporalidad. Así como Ciclo propuso una biblioteca teórico-crítica para el arte moderno, que cuestionaba los criterios del manifiesto como unidad de lectura y en cambio proponía un desacople entre la obra de arte y el medio histórico-social de emergencia, en A partir de cero es la noción de imagen la que nos resulta relevante para pensar las relaciones entre el tiempo y la crítica. Las diversas articulaciones que tuvieron, a lo largo de la revista, la imagen como noción crítico-poética y como materialidad, y la concepción de poesía, permite establecer dos niveles de análisis. El primero tiene que ver con la imagen en tanto disposición de los materiales que la revista da a ver y leer, donde se observa la organización de una una genealogía del surrealismo, a partir de cuyos valores $A$ partir de cero confrontó con Borges, Raúl González Tuñón, y los escritores de la S.A.D.E. que representaban la lírica fosilizada. En un segundo nivel, la imagen es una noción crítica que encarna en la figura de la "combustión” (Pellegrini 1952, n2:3), a partir de la cual se establecieron posisionamientos polémicos con los escritores realistas.

La imagen-combustión o "bomba incendiaria" se asemeja a la iluminación benjaminiana de "El surrealismo: la última instantánea de los intelectuales europeos" (2014) [1929]. Esta imagen ha sido pensada tanto por Benjamin como por Didi Huberman en diálogo con las temporalidades complejas, como un momento donde dos o más tiempos se cruzan. ${ }^{131}$ En A partir de cero se constituye como fogonazo que ilumina a la vez el pasado y el presente, y establece una relación diferencial con la temporalidad respecto a otros modos de leer, articulados sobre una idea de representación o, en términos de la propia revista, "percepción” (Pellegrini 1952, n2:3); por tanto deviene operador crítico que pone en cuestión la "lírica fosilizada", el existencialismo, el realismo social.

Antes de avanzar sobre cada uno de los dos niveles de análisis, es necesario aclarar que $A$ partir de cero no se referenció a sí misma con el término "vanguardia", como habían hecho algunos integrantes de $p b a$ - "nunca dejaremos la vanguardia" exclamaba Móbili- ni hizo alusiones al género manifiesto como la revista Ciclo; y en cambio estableció como punto de partida la identificación con el surrealismo -por oposición al

\footnotetext{
${ }^{131}$ Como la iluminación profana de Walter Benjamin (2014), es la advertencia de lo desconocido, de la descomposición temporal, de la extrañeza subjetiva, en lo cotidiano y común de lo sensible. Se trata de una imagen que vuelve de donde nunca ha estado. La iluminación profana es el relámpago por el cual una imagen se sale del curso de la Historia y toma parte de la política, enloquecida, emancipada. Didi-Huberman lee esa imagen como "operador político de protesta de crisis, de crítica, o de emancipación” que se revela "capaz de franquear el horizonte de las construcciones totalitarias" (2009:91).
} 
progresivo abandono del término "invencionista" que $p b a$ había decidido hacer número a número, hasta omitirlo en tanto criterio clasificatorio en la exposición de la "nueva poesía" (1953, n13-14). El surrealismo es una apropiación relacional del pasado de vanguardia para intervenir en los debates literarios que implicaron a las revistas de nuestro corpus con otras publicaciones.

\subsubsection{La genealogía surrealista como "relámpago de la conciencia"}

La visualidad de $A$ partir de cero se constituye como un movimiento doble: por un lado observamos que algunas de sus páginas funcionan como láminas, exposiciones o una versión plana de la boîte en valise, que refuerza una política del dar a ver. En los dos números iniciales de la revista, leemos, en la exacta mitad, y a pliego entero, una lámina poética como homenaje y exposición: en el primero encontramos fragmentos de los manifiestos del surrealismo, bajo el título "Línea de fuego", y poemas de Benjamin Péret; el segundo es un homenaje dedicado enteramente a Paul Éluard. La idea de "exposición" que atribuimos a esos pliegos no resulta extraña si tenemos en cuenta los vínculos entre arte y poesía que fueron constitutivos de las experiencias creativas por entonces, no solo desde el punto de vista de las influencias y los préstamos de lenguajes, sino desde las sociabilidades, los encuentros e intercambios entre artistas. Pero además, es con el nombre "exposición” que poesía buenos aires presentaría su selección de poesía en "Poetas de hoy: buenos aires 1953" (n13-14). Que no usaran la palabra antología, con la cual sí titulan el libro Antología de la nueva poesía (1952), donde se incluyen muchos de los poetas luego incorporados en la revista, da la pauta de que por entonces, al menos en estos grupos, la revista constituía, como soporte, una dimensión visual abierta, diferenciada del libro, donde lo expuesto cobraba un significado particular no homologable a los términos utilizados en las colecciones editoriales.

Asimismo, esas láminas pueden pensarse en diálogo con los textos principales de la revista -"Vía libre" en el primero, y "Un golpe de sentido sobre el tambor" y "La poesía debe ser hecha por todos" en el segundo-, firmados por su director Enrique Molina, que abrían y cerraban cada número, como extremos textuales del contenido. Así, el armado de una "línea particularmente viva del pensamiento contemporáneo" (1952, n1:1), como define Molina a lo que desde nuestra perspectiva denominamos como "genealogía surrealista", se afirma en citas de Breton y de Baudelaire incluidas en las láminas. 
Para Enrique Molina, en "Vía Libre”, se trataba de "capitalizar" y "continuar hasta sus últimas consecuencias" con las "conquistas" a las que había apuntado una línea "viva y permanente de la más honda poesía", que él trazaba “desde el gran romanticismo alemán hasta las deslumbrantes experiencias del surrealismo" (1952, n1:1). En esa línea se encontrarían Kleist, Arthur Rimbaud, Nerval, Van Gogh, Mayakosky, Crevel, Artaud, hilvanados sobre la idea de que la "aventura poética" es una experiencia de "conocimiento" -no de belleza ${ }^{132}$ o elocuencia, tampoco de la búsqueda de la precisión de la palabra- y que por lo tanto son quienes llevan tal experiencia al límite de lo posible los que hacen de la poesía una "conducta fundamental".

A esos nombres se pliegan los incluidos en las citas de la sección "Línea de fuego" donde se proponía ofrecer una serie de "conceptos" que dieran cuenta de la trayectoria del surrealismo desde el primer Manifiesto (1924) hasta Haute Fréquence (Breton 1951). Uno de los motivos por los cuales establecemos un diálogo significativo entre el ensayo de Molina y la sección "Línea de fuego", se debe a la irrupción del nombre de Charles Baudelaire entre un conjunto de autores referenciados estrictamente con el surrealismo, ya que los conceptos que se recuperan pertenecen a Marcel Raymond, Michel Carrouges, André Breton y Maurice Blanchard. En ese conjunto advertimos la siguiente cita de Baudelaire: “...esos razonadores tan comunes, incapaces de elevarse a la lógica de lo Absurdo" (1952, n1:6). ¿A qué se debe esa intromisión y qué podía tener que ver con esa línea viva y contemporánea de la poesía? La respuesta nos la da el primer párrafo de la presentación de la sección, donde la línea temporal para pensar el surrealismo resulta más amplia que la delimitada entre dos publicaciones de 1924 y 1951: "El surrealismo atraviesa como un relámpago magnífico el campo de la conciencia contemporánea".

Para Armando Minguzzi (2013), la traducción de fragmentos del reciente Haute Frequénce consiste en una reivindicación del carácter revolucionario del surrealismo; sin embargo, las referencias parecen indicar que antes que una revolución postula una historicidad por la cual en todo caso la revolución se constituye también como apertura de un pasado utópico no clausurado, donde las formas temporarias de ese pasado no hablan de su caducidad sino de la resignificación. ${ }^{133}$ Asimismo, en la presentación de una

\footnotetext{
132 "Escribir poemas es un bello ejercicio (en fin ¿qué son poemas?). Incluso se lo puede practicar sin mayor riesgo al resplandor de todos los focos de la vanidad y el esteticismo. Vivir la poesía es cosa distinta" (Molina 1952, n1:1)

133 'Muchos se reconfortan hoy día creyendo constatar el desgaste de ciertas formas de 'escándalo' puestas en vigor por el surrealismo, sin apercibirse que ellas no podían ser más que formas temporarias de resistencia y de lucha contra el escándalo que constituye el espectáculo del mundo tal como resulta de sus instituciones" (Breton 1952, n1:4)
} 
una entrevista a André Breton, a propósito de su nuevo libro, A partir de cero iniciaba el diálogo de la siguiente manera: "El pensamiento surrealista no es una explosión súbita y asilada, sino una corriente de ideas con hondas raíces en el pasado, una actitud del espíritu cuyas manifestaciones pueden encontrarse en cualquier período de la historia” (Editorial $1952 \mathrm{n} 2: 8)$.

En este sentido, es $A$ partir de cero la que interviene sobre la textualidad y el imaginario surrealista para expandirlo hacia el pasado en tanto sustrato irreductible de una experiencia que lucha contra la "tiranía de la razón”. La idea del relámpago, la iluminación, actúa como un "vaso comunicante" a lo largo de la revista, que redefine los límites de lo contemporáneo. Así, en el segundo número de $A$ partir de cero, el texto de Molina titulado "Un golpe de su dedo sobre el tambor" llama "poesía prospectiva" a la que habrían abierto Novalis y Rimbaud, mientras que sería el presente de la poesía el que "mira siempre atrás" (no al pasado, sino a la "lírica tradicional"):

Hay, es sabido, una poesía de residuos, que actúa sobre especies secas de recuerdos, emociones, etc. Es la actitud lírica tradicional. Mira siempre atrás. Y hay la poesía aventurera del conocimiento, la poesía prospectiva, intuida desde Novalis a Rimbaud: "un golpe de su dedo sobre el tambor descarga todos los sonidos y comienza la nueva armonía". La fuente de tal poesía está en lo profundo del inconsciente y es necesario abandonarse a su ola sin terror.

Dos eran los tipos de enemigos a los que esta poesía prospectiva atravesaría como un relámpago de la conciencia, desenmascarando sus principios más conservadores. Por un lado, el "nuevo realismo" (entrecomillado por Molina a modo de distanciamiento) que "resulta una concepción completamente reaccionaria y renuncia de antemano a toda exploración profunda de la realidad", y por lo tanto "pretende reducir el concepto de liberación del hombre solo al plano económico, mientras se lo rechaza en el plano del espíritu” (1952, n1:1). Dentro de esta emergencia, Molina polemizó con Raúl González Tuñón, a quien acusa de hacer "poesía-miseria" (1952, n2:8) y con el existencialismo, que explotaría la angusita del hombre en "calidad de empresario" en lugar de combatir las condiciones de opresión que la producen, como la falta de libertad espiritural y la reducción del hombre a un fin útil $(1952, \mathrm{n1}: 1,7)$. La confrontación con González Tuñón se debió a un libro recientemente publicado - Alguien que está esperando (1952)-, cuyo epígrafe atribuía a Lautréamont la siguiente frase: "La poesía debe ser hecha para todos". Fuera una reescritura o un error -Molina no se detiene en ello-, para el director de $A$ partir de cero coincidía "perfectamente con el criterio que prevalece a lo largo del libro", y que calificaba como "aceptación de la miseria espiritual del hombre considerándola 
como definitiva e irreparable y arrojándole entonces los mendrugos de la más baja cocina intelectual" (1952, n2:8). Para Molina, el "para" que había incluido González Tuñón en el epígrafe hacía de la concepción "progresista y revolucionaria" que caracterizaba a Lautréamont, una concepción pasiva del hombre, como "simple receptáculo con cabida solo para lo mínimo" (1952, n2:8).

El otro enemigo de la poesía prospectiva era el "ejercicio retórico" representado principalmente por la poesía que publicaba entonces Sur, "avalada por Borges" (1952, n1:8). Para Molina hay "falta de rigor" en la poesía argentina para asumir un "espíritu de ruptura" que tiene sus mayores consecuencias en la imposibilidad de "conocimiento del hombre", ya que la poesía retórica mantiene a los sentidos dentro de los límites de un "lirismo adocenado" que no se atreve a explorar más allá de lo convenido. Como prueba de esto analizó una selección de poemas incluidos por Borges en "su Antología de la poesía argentina" y un poema de Arsinoe Moratorio incluido en Sur. ${ }^{134}$

La genealogía propuesta por Molina en A partir de cero, y que le permitió oponer un tipo de poesía que llama "prospectiva" aunque fuera pasada, a una poesía "adocenada", "miserable", "fotográfica" como la de su presente, expuso, a su vez cierta centralidad de la idea de "conocimiento" en relación con el lenguaje poético. Es como figura crítica de esa relación que la revista empleó el término "imagen en combustión” o “imagen que arde" en los ensayos de Aldo Pellegrini.

\subsubsection{Una "bomba incendiaria": la imagen que arde como posicionamiento crítico}

Así como el armado de una genealogía amplia del surrealismo fue un modo de discutir el presente de la poesía argentina, la idea de "imagen en combustión” tiene una relevancia especial para pensar los problemas de la temporalidad en la crítica, ya que postuló una idea sobre el lenguaje refractaria a las estabilizaciones representacionales e históricas.

En "El poder de la palabra", Aldo Pellegrini desarrolló una teoría de la comunicación $^{135}$ donde opuso "comunicación convencional” como restricción (las

\footnotetext{
${ }^{134}$ Un análisis ampliado de este aspecto se tratará en el capítulo II, sobre las polémicas de la crítica.

${ }^{135}$ La definición de un sentido comunicativo de la lengua que se desmarcara de los sentidos informacionales fue una de las búsquedas críticas más insistentes que atravesó a las revistas. Dada esa relevancia, tanto este ensayo como "El huevo filosófico" serán retomados en el capítulo III para analizar, desde otros aspectos, el vínculo entre una teoría de la comunicación y la "crítica del instante". Al mismo tiempo, observamos cómo ambos textos parecen acercarse a una propuesta del lenguaje poético como forma de "(i)relación" con lo real, que dialogaría con las lecturas de Maurice Blamchot y Geoges Bataille puestas a circular por
} 
palabras serían, en ese sistema, "solapados verdugos que se presentan para dar un sentido a la vida y en cambio la destruyen" (1952 n1:3)) a "lo realmente vital del lenguaje" o "verdadera comunicación humana" (3). Esta última solo se produciría en el lenguaje popular, el amor y la poesía, pero es la poesía la que "desarrolla en [los fragmentos muertos del lenguaje] una incandescencia sorprendente" (3), dado que "estalla como una bomba incendiaria cuando se pone en contacto con el lenguaje convencional" (3). Como vemos, en estas reflexiones no aparece aún la "imagen combustión", sino la imagen del incendio en tanto estallido y bomba, es decir un efecto fugaz (o fulgurante como afirmaría Molina de la poética de Césaire en el primer número de Letra y Línea). Para Pellegrini, si la comunicación dada por el lenguaje convencional se anuda a la utilidad de "estabilizar y propagar el conocimiento, organizar la sociedad y la familia en sólidas estructuras" (3), el poder de la poesía radicaría en la intensidad e intermitencia de un "contacto"; con respecto a este punto es importante observar que Pellegrini no se refirió a una diferencia cualitativa en la capacidad de comprensión o representación del lenguaje poético, sino a una relación de encuentro por contacto incandescente.

En "El huevo filosófico", publicado en $A$ partir de cero n2, esta imagen incendiaria tiene otro alcance, ya que no se presenta en relación con el lenguaje convencional sino como forma de acercamiento a lo real. Pellegrini se proponía explicar por qué si bien "lucha permanente contra los límites que significan las apariencias de las cosas" había sido una constante en la "historia de la ciencia, con objeto de apresar lo que en última instancia constituye lo real" (1952 n2:3), esta fracasaba, en tanto lo real "parece estar al alcance de la mano", pero "huye cuando se intenta asirlo" (3). En tanto postulaba que el terreno de "investigación" del surrealismo era "lo desconocido ilimitado" (3), planteó una continuidad entre el poeta y el científico, para luego establecer una diferencia decisiva:

Hay un momento en que el hombre de ciencia se convierte en poeta: en el momento de la creación de la hipótesis, hay un momento en que el poeta invade la esfera del sabio: cuando crea una imagen en la que condensa la suma de los conocimientos posibles, la imagen que entra en combustión, la imagen iluminadora. (3) ${ }^{136}$

\footnotetext{
las mismas revistas del corpus, pero reconducen muchas de las ideas hacia una zona más predecible para la época como la de la trascendencia ("La poesía por su íntima vinculación con lo estrictamente humano se encuentra en el extremo opuesto (...) de todo juego verbal intrascendente y decorativo" (Pellegrini 1952, n1:3)), y relevancia moral ("En ese sentido la poesía se convierte en la gran moralizadora, posee una violenta actividad agresiva frente a lo falso y trivial por más disimuladamente que se presente" (3)).

136 Si bien no será abordada en esta tesis, no desconocemos la importancia de la relación entre ciencia y surrealismo, que tiene a su vez un punto de anclaje en el hecho de que tanto Aldo Pellegrini como André
} 
Si la continuidad está dada por la creación, la diferencia es el estatuto de lo que se crea: una "hipótesis" o una "imagen que entra en combustión". Este aspecto es fundamental porque para Pellegrini, lo real tendría la forma del lenguaje poético "que también fluye inasible”, mientras que el lenguaje científico, “en cambio, es rígido, inmóvil, siempre queda detrás de la realidad". Así, concluye:

Ese infinito fluir en que consiste el conocimiento solo puede ser dado íntegramente por la poesía. Y la poesía lo da mediante la imagen que se produce y destruye a sí misma, dejándonos la luz del conocimiento. Solo cuando la imagen es combustión puede iluminar la realidad (3).

Es importante señalar en este punto que el poder de la imagen propuesta por Pellegrini tiene cierto poder de impugnación respecto a la idea de "luz del conocimiento" que atraviesa el párrafo, ya que esa iluminación se daría en el acto de la combustión y destrucción cuya durabilidad es discontinua. En ese sentido, el vínculo entre "imagen” y "conocimiento" se establecería por una condición de fugacidad, interrumpiendo la linealidad temporal. Esta idea le permite a Pellegrini desplazar la imagen del "sabio" o "científico" a la del escritor realista, oponiendo ya no dos formas de creación según sistemas disímiles, sino dos formas de lenguaje. Este escritor "solo puede aprehender el mundo por lo datos de la percepción sin elaboración" (3), pasando por alto que "los sentidos solo nos permiten captar un velo que no presenta sino que oculta lo real" (3). El problema consistiría en que los escritores realistas intentan hacer pasar esta "realidad empírica", construida a base de percepciones y sentidos insuficientes, en "realidad en sí"; por este motivo solo ofrecen una realidad de aspecto fotográfico que tiene el efecto de un "fenómeno espectral".

Así, el estatuto de la imagen iluminadora -incandescente, efímera, que actúa por contacto- tendría un vínculo con lo real tan intenso como breve, que la opone a la representación fantasmal de la realidad empírica. En este sentido es que una imagen que alude a una temporalidad inestable interviene críticamente en la discusión en torno a los realismos contemporáneos articulando tanto la idea de un tiempo desbordado como una lectura de lo intermitente o refractario a las referencialidades políticas e históricas.

Breton provenían del campo de la medicina, e hicieron intervenir muchas veces sus conocimientos sobre el tema en las discusiones en torno a lo "real" en la literatura. 


\subsection{Letra y Línea: la paradoja de la contemporaneidad}

La línea es un punto en movimiento; tiene que revelar su origen y preanunciar su fin.

Leonardo Da Vinci citado en Letra y Línea

No para explicar, no para exponer, no en terrazas, no monumentalmente Más bien como por el Mundo hay anfractuosidades, sinuosidades, como hay perros errantes En fragmentos, en comienzos, tomada por sorpresa una línea, una línea... ... una legión de líneas

Escapadas de las prisiones recibidas por herencia, venidas no para definir, sino para indefinir, para pasar el rastrillo por encima, para volver a hacerse la rabona, líneas, por aquí y por allá, líneas

“Líneas”, Henry Michaux

Letra y Línea. Revista de cultura contemporánea. Artes plásticas. Literatura. Teatro. Cine. Música. Crítica publicó sólo cuatro números entre octubre de 1953 y julio de 1954, que fueron suficientes para entablar polémicas con otras publicaciones como Sur, Contorno, poesía buenos aires; discutir con críticos como Julio Payró -junto con Romero Brest el crítico de arte más reconocido en el momento; y con escritores como Jorge Luis Borges y Adolfo Bioy Casares. Su primer número instaló el gesto de lo no previsible. Como indicamos en la Introducción, resultaba singular que una publicación dirigida por el entonces ya muy conocido "difusor del surrealismo en Argentina", ${ }^{137}$ Aldo Pellegrini, seleccionara un retrato fotográfico de Roberto Arlt como primera imagen de la revista (imagen 10). Si hasta entonces los retratos que habían acompañado a las publicaciones donde participaba Pellegrini eran los de Lászlo Moholy-Nagy y Piet Mondrian en Ciclo, o fotomontajes surrealistas en A partir de cero, la figura de un escritor como Arlt, hasta el momento sin mayor interés para las vanguardias estéticas, abría un recorrido de lectura singular. El primer número de Letra y Línea se desplegaba entre dos narradores: Roberto Arlt -a quien no solo se le dedica la portada, sino también el primer ensayo literario- y la carta del norteamericano Henry Miller a Michel Fraenkel, que citamos antes, produciendo un desplazamiento geográfico de Europa a América, que puede ser pensado como un gesto de comienzo (Said, 1985). Por otra parte, la revista se proponía como "de cultura contemporánea" y decidía referenciarse visualmente con un escritor que había muerto

${ }^{137}$ En esos términos lo definen Cella (2013), Minguzzi (2013) y Herzovich (2015). 
diez años atrás. Estos aspectos dan cuenta de que en la primera página se esbozaban las líneas de un programa para la publicación; en ese sentido proponemos analizar una serie de elementos indiciales que Letra y Línea dispuso (el subtítulo, la composición del grupo editor, las secciones, los sumarios y publicidades) en tanto nos permiten pensar la relación entre vanguardias, crítica y temporalidad. En un segundo momento de este apartado se aborda el programa crítico de la revista, cuya moral del anacronismo está atravesada por lo que aquí llamamos paradoja de la contemporaneidad. Nuestra hipótesis al respecto se desprende de las intervenciones más recientes del estado de la cuestión sobre Letra y Linea.

\subsubsection{Presentación de la revista}

Entre el nombre inscripto en un diseño de estética mondriana y el retrato de Arlt, leemos el subtítulo que la presenta: "Revista de cultura contemporánea. Artes plásticas. Literatura. Teatro. Cine. Música. Crítica”. Esta información es relevante porque anticipa otro desplazamiento. Si Ciclo se había presentado como "Revista de artes y pensamiento modernos" o A partir de cero era "Revista de poesía y antipoesía", Letra y Línea ubicó en el centro de su discusión la multiplicidad disciplinar, y tres nociones que estarán permanentemente en disputa: cultura, contemporaneidad y crítica. Podríamos decir que hay, en principio, una redefinición en torno al problema de la temporalidad y la forma de intervención: desplazarse desde lo moderno hacia lo contemporáneo, y del pensamiento hacia la crítica. Es decir, si a Ciclo le interesaba, como antes a la revista Arturo, intervenir sobre la concepción de arte de vanguardia como moderno, Letra y Línea postula también un término de definición y valor temporal, pero ya no como localizable en la historia del arte, sino en el problema mismo de la indefinición que presenta el término “contemporaneidad". A su vez, si la forma de aproximación a lo moderno estaba dada, en Ciclo, desde la figura del pensamiento, Letra y Línea explicita un tipo de intervención que se inscribe bajo el nombre "crítica". El pensamiento en torno a lo moderno buscaba criterios de lectura propicios donde se articulara de un modo complejo la relación entre obra e historia, mientras que la crítica de la contemporaneidad es la disputa por hacerse lugar en el presente, un presente que no parece sencillo localizar y que encontramos disputado entre una moral anacrónica de la vanguardia y el deseo de explicar el funcionamiento del mercado editorial donde la novedad es el valor de cambio. 
La nómina de los integrantes del grupo editor también da cuenta de una ampliación de intereses respecto a las publicaciones tanto surrealistas como invencionistas que precedieron a Letra y Línea. A diferencia de Ciclo, Pellegrini es el único director, pero como señalamos en la introducción, los integrantes responsables son numerosos. Osvaldo Svanascini y Mario Trejo, secretarios de redacción, tenían trayectorias disímiles; Trejo (1926-2012) era entonces un joven poeta -el único argentino publicado por Ciclo-, que había participado en experiencias disruptivas como el H.I.G.O. Club, donde promovía, junto a Alberto Vanasco, intervenciones similares a lo que luego serían los happenings: exhibiciones de pintura y escultura que duraban pocos minutos, acompañadas por lecturas de poemas, así como también se ocupaban de pequeñas ediciones de sus libros. Años después se dedicaría a la publicidad y al periodismo. Osvaldo Svanascini (1928-2015), en cambio, era conocido y destacado como crítico de arte oriental, y había publicado en diversas revistas de la época (Sur, Anales de Buenos Aires, Saber vivir, poesía buenos aires); a pesar de ser apenas más joven que Mario Trejo, su nombre tenía mayor resonancia entre lectores de las revistas artístico-literarias de mediados de siglo. Como se ve, ninguno de los dos tenía una filiación anterior estrecha con el surrealismo. Alberto Vanasco había publicado por H.I.G.O. una novela experimental en cuanto al uso de los tiempos verbales, y la transformación de las secuencias lógicas, titulada Sin embargo Juan vivía (1946); ${ }^{138}$ asimismo, era publicado ocasionalmente en $p b a$ como poeta. Miguel Brascó tenía un perfil periodístico, como especialista en novedades musicales, y fue a su vez, uno de los traductores de Bercht en los años cincuenta. Carlos Latorre y Julio Llinás de Santa Cruz fueron los dos integrantes que se identificaron con el surrealismo de mediados de siglo. Latorre había comenzado a publicar en Botella al Mar $^{139}$ y luego lo haría en la colección editorial de Letra y Línea y A partir de cero, ${ }^{140}$ al igual que Juan José Ceselli, Francisco Madariaga y Juan Esteban Fassio (responsable de la escuela de la 'Patafísica en Buenos Aires) quienes se sumaron al "comité de redacción" en el cuarto número. Julio Llinás, como referimos en el apartado sobre Ciclo, había decidido viajar a Francia a principios de la década del 50, para conocer a los escritores más importantes del surrealismo entonces, pero lo decepcionió reconocer que "había llegado tarde” (Llinás

\footnotetext{
${ }^{138}$ Para una ampliación sobre el tema, cfr. los textos de Rafael Arce sobre la novela conjetural de Vanasco (2013, 2014)

${ }^{139}$ Puerta de arena (1950) y La ley de gravedad (1952).

${ }^{140}$ El lugar común (Letra y línea, 1954). Los alcances de la realidad (Letra y línea, 1955). La línea de flotación (A partir de cero, 1959).
} 
citado en Giunta 2001:104). ${ }^{141}$ Excepto Enrique Molina, de quien ya hemos referido aspectos de su trayectoria, y Osvaldo Svanascini eran jóvenes escritores o críticos que no habían transitado por los espacios más tradicionales de la cultura letrada liberal en Argentina.

Por otra parte, la apariencia material de Letra y Línea, con páginas tabloides (de cuarenta centímetros por veintiocho), abigarradas de notas y publicidades, se asemejaba a la de un periódico. La posibilidad de explorar los formatos y modelos gráficos propuestos por el periodismo se evidenció en la separación en secciones, dentro de las cuales no se incluyen sólo las reseñas sino otras "brevedades" más fugaces como pequeñas polémicas y noticias de la sociabilidad literaria. A su vez, la notable cantidad de anuncios publicitarios que abundan en cada uno de los cuatro números, pone en cuestión el mito fundacional según el cual Letra y Línea se habría financiado con la fortuna de Oliverio Girondo, y la liga con lógicas de sustentabilidad afines al periodismo. Así, el proyecto crítico de Letra y línea es susceptible de ser pensado en la relación conflictiva y contradictoria, que ligó a las vanguardias literarias con la prensa desde fines del siglo XIX. ${ }^{142}$ En este vínculo comercial con la dimensión publicitaria puede leerse un efecto cómico y crítico de los anuncios a partir del lugar donde se los dispone. Entre las notas centrales $-\mathrm{o}$ aquellas donde se aborda a un escritor o artista al que se estima- no hay casi publicidades y las que aparecen corresponden a casas editoriales o galerías de arte, es decir, anuncios afines. En el número 2, en cambio, se publica una reseña del Suplemento de Cultura de La Nación, al que se caracteriza como "Literatura para los días domingos". ${ }^{143}$ Esta columna va acompañada por el anuncio de un loteo "en los ex links del Golf Club Olivos Central" (ver imagen 23). Algo similar sucede con la placa "Neira y Ezcurra. Ingenieros agrónomos. Parques y jardines", que se imprime en el número tres $\mathrm{y}$ el número cuatro. En el primer caso acompaña un texto breve de Osvaldo Svanascini titulado "Paradojas de la poesía", contacto visual que puede funcionar como continuidad de esa paradoja anunciada (que una reflexión que se denomina tal sea financiada por especialistas en jardines) o bien, ya adentrados en la lectura, como un juego de efectos,

\footnotetext{
${ }^{141}$ Luego de su participación en Letra y Línea, insistiría en los caminos de la vanguardia, fundando Boa. Cuadernos internacionales de documentación sobre la poesía y el arte de vanguardia (1958).

${ }^{142}$ Cfr.: Sutter Suter, Patrick (2010). Le journal et les Lettres: La presse dans l'œuvre: vers une écologie littéraire (Butor, Simon, Rolin). Voltiges: Vol. 2. Genève: MētisPresses

${ }^{143}$ La nota continúa: "El periodismo argentino es tolerante con la literatura; suele dedicar alguna de sus ediciones semanales a la divulgación de noticias sobre escritores (ocasionalmente argentinos), artículos sobre arte y letras, imprevisibles comentarios sobre las novedades bibliográficas, y añadiduras mediata o inmediatamente vinculadas con el tema de la cultura" (Brascó 1953 n2:15).
} 
en la medida en que el párrafo que "choca" contra esa publicidad -y que esta obliga a cortar y seguir más arriba- dice: "Ya no es posible valorizar la opinión de esos aletargados en relación a su tiempo, que persisten en una ignorancia con respecto a la comunicación actual" (Letra y Línea 3, 5) (ver imagen 24). En el segundo caso, la misma publicidad cierra un ensayo de Juan Antonio Vasco titulado "Sobre la poesía órfica. (A propósito de Los nombres, de Silvina Ocampo)", donde sin ocultar la misoginia y el gesto paternal de enseñarle a la joven poeta cómo debe escribir, caracteriza su libro como "poesía del aburrimiento" y afirma: "Silvina Ocampo cree de veras en ese mandato del destino que la impele a mascullar eviternamente lo que viene siendo mascullado desde hace algunas centurias" (Letra y Línea 4, 10), o, para finalizar: "Este conmovedor pasaje demuestra que para Silvina Ocampo la vida, sin anáforas, carece de sentido. Está dispuesta a recibir la muerte en el mismo instante en que se le ocurra un pensamiento inédito, una imagen sin precedentes" (10). En ese marco, la publicidad de "parques y jardines" no es ni una paradoja ni un juego de lectura que opera desde el par continuidad/interrupción como en el caso anterior, sino que tiene consigo el gesto performativo de "ubicar" al interlocutor. Si al suplemento de cultura de La Nación, y por tanto a Eduardo Mallea (su director), se lo ubica en un loteo de Golf, al universo de Silvina Ocampo le correspondería el universo de los jardines (ver imagen 25).

A su vez, es la única de las cuatro revistas del corpus que se ocupa de reseñar y discutir aspectos de la narrativa argentina reciente, e incorpora ficciones de autores como Juan Carlos Onetti, Norah Lange, Juan Filloy, Miguel Brascó. Un porcentaje significativo de reseñas de novelas (alrededor de un treinta por ciento) da la pauta del desplazamiento de la poesía -como el género más abordado por las revistas de nuestro corpus- hacia la narrativa, que sin embargo no significa una jerarquización, ya que el espacio de ensayos críticos o artículos principales lo mantienen aquellos temas u objetos que parecen más acordes a la línea estética de una publicación de vanguardia. Los artículos centrales están dedicados al poeta antillano Aimé Césaire (director de la revista surrealista Tropiques, 1941-1945), a la carta de Henry Miller, Vicente Huidobro, Wilfredo Lam, Jean Dubuffet y la música dodecafónica en el primer número; a Henri Michaux, Enrico Grass, Oliverio Girondo, Wozzeck, el movimiento de Stijl en el segundo; a Francis Picabia, Edgar Varesse y la música experimental, Dylan Thomas y Arthur Miller en el tercero; y a Alfred Jarry, el Colegio de la Patafísica, Bertold Bretch y Tristan Tzara sobre dadá, en el último y cuarto número. 
Letra y Linea ha sido analizada recientemente por tres investigadores desde distintos énfasis (la relación entre crítico y mercado editorial, en el caso de Herzovich; el desborde de la tipificación política, por Crespi; y el carácter de vanguardia artística, por Cella). Como se adelantó en la primera parte de este capítulo, la lectura de Herzovich (2015) circunscribe la aparición de Letra y Línea a la interdependencia de dos fenómenos: la "irrupción de la crítica" fechada en 1953 por la aparición de Contorno y el cierre de la “época de oro del libro argentino”. En el marco de la cual

la voluntad que anima [a los jóvenes colaboradores de Letra y Línea] es menos la de construir un corpus de objetos de calidad - una 'tradición' bajo un criterio u otro- que marcar los límites entre zonas de legitimidad e ilegitimidad para la práctica artística. El leit motive crítico tradicional era la carencia: de autores, de editores, de tradición, de lengua nacional, de público. Para Letra y Línea es en cambio la confusión: de ahí la necesidad de 'ajustar cuentas' con los prestigios establecidos. (2015: 286-287)

Esa hipótesis contribuye a "releer la historia editorial argentina a partir de una tensión entre políticas opuestas de singularización y serialización", donde el interés pasa por señalar que lo que se denominó "irrupción de la crítica" fue "concomitante con el declive de la legitimidad de la bibliofilia como práctica de apropiación" (2015). ${ }^{144}$ En ese sentido, Herzovich incorpora las relaciones con el mercado editorial a una historia de la crítica que se había basado en los vínculos entre corrientes teórico-disciplinares (la filología clásica, la retórica, estilística, el marxismo, el existencialismo) y su apropiación local en la crítica. Por ese motivo, el autor de La desigualdad como tarea, lee especialmente lo que él llama "guía cultural" (espacio de reseñas de cine, teatro, narrativa, poesía, exposiciones artísticas), haciendo particular énfasis en el lugar del cine como algo que no entra en la agenda estética de la revista pero está puesto ahí porque tiene relevancia "actual”; o bien lee el espacio titulado "espejo del mundo" en relación con las polémicas, como zona de legitimación. No obstante lo acertado de tales hipótesis, si volvemos sobre las características que emergen de la portada de Letra y Línea, donde además leemos la primera parte del editorial titulado "Justificación", es posible advertir lo que a continuación desarrollaremos como paradoja de la contemporaneidad, en tanto efecto de

\footnotetext{
${ }^{144}$ Como parte de una "infraestructura crítica", el discurso de Letra y Línea es la "contracara del proceso de indiferenciación material" que se había producido en el crecimiento de la industria editorial y la correlativa disputa por el valor social del libro. Se trató, además, de "la edad de las pequeñas revistas", caracterizada por "desarrollar estrategias complejas para impugnar a la vez el modelo excluyente de la élite literaria y la multiplicidad de los usos "recreativos" de la lectura que hacía visible un público lector en rápido aumento, el cual se les aparecía alternativamente como una oportunidad histórica inédita para la literatura (y por lo tanto para el país) o como un engranaje más, igualmente indiferenciado, del aparato industrial y publicitario de las nuevas editoriales" (Herzovich 2015:viii).
} 
las operaciones que proponen un conjunto de ensayos atravesados por la moral crítica del anacronismo, y su articulación con los juicios de lectura que advertimos en las reseñas. En ese sentido, se trata de una hipótesis de lectura que no excluye la dimensión del mercado editorial, pero la articula con la pregunta acerca de cómo hablar del tiempo presente y de qué manera las genealogías de vanguardia que establece Letra y Línea inciden en esa operación donde la cuestión de las legitimaciones frente a la dinámica de mercado son desbordadas por otras indeterminaciones.

En el capítulo "Letra y línea: la insolencia del corte" de La conspiración de las formas. Apuntes sobre el jeroglifico literario (2011), Maximiliano Crespi lee esta revista en el marco de un conjunto de publicaciones que, según entiende, desafiaron los vínculos establecidos entre literatura y política (además de Letra y Línea, selecciona Literal y Sitio), y la piensa desde una figura particular: la de insumisa acefalía (2011:44) en una referencia implícita a Bataille que no se enuncia ni se analiza. Para hacer esa operación, Crespi - al contrario que Herzovich - toma solo los ensayos principales, donde la experiencia estética se intensifica por la política anti-totalizante del corte (lógica de presentación y de lectura de las notas, según la cual cada nota es interrumpida por otra, y esta por otra nuevamente, hasta entrar una especie de laberinto y saltos de lecturas), aspecto que convertiría a la revista en un artefacto, "condición intratable en la tipificación política" (23). ${ }^{145} \mathrm{El}$ artefacto, según expone Crespi, se corre de la noción de revista como formato o soporte, para poner en cuestión principalmente la idea de escritura como discurso. Lo que deja de lado es aquello que Herzovich pone de relieve: la guía cultural y las polémicas, por considerarlas "cegueras de Letra y línea": "La conspiración vanguardista procura materializarse en esa desautomatización de la percepción, pero esa

\footnotetext{
${ }^{145}$ Herzovich ha refutado la hipótesis de que "el corte" sea una insolencia o efecto anti-totalizante de la vanguardia: "En un análisis extenso y reciente de Letra y Línea, Maximiliano Crespi cometió dos anacronismos imperdonables y significativos: consideró la guía cultural que cierra cada número como su parte 'más convencional' (cuando es históricamente la más novedosa) y opinó que la modalidad de cortar los artículos cuando se acaba la página y continuarlos donde Dios permita - comenzando otro nuevo en la siguiente - era un procedimiento vanguardista, destinado a perturbar la lectura lineal, cuando es de hecho tan populista que publicaciones mucho más conservadores lo han llevado a cabo con mayor radicalidad.(...) La ortodoxia teórica le indica a Crespi que hay en Letra y Línea una ambivalencia incriminable. Intenta aplicarle su delicado reactivo y obtiene un resto negruzco que le repugna. Esa ambivalencia es sin embargo programática, según advierte él mismo en la 'Justificación' que trae en tapa el primer número de la revista" (2015:256). Sin embargo, desde nuestra perspectiva, tal vez se trate de correr del centro de la afirmación una idea de voluntad o intencionalidad que atribuiría una característica especial (vanguardista, como afirma Crespi o relativa a la prensa, como dice Herzovich). Esos cortes, inusuales en cantidad respecto a otras revistas de vanguardia u otras de su época, eran asimismo frecuentes en la prensa periódica comercial. Si los pensamos en tanto técnica del aparecer, del dar a ver y hacer legible un texto, podríamos afirmar que tienen algún tipo de efecto de lectura al establecer distintas zonas de contacto entre una misma nota y diversas páginas. (Cfr. Capítulo II)
} 
desautomatización sólo es pensada de manera transitiva (...), cuando ella misma es en efecto ese no-lugar, ese centelleo violento y luminoso en que lo real acontece.” (73).

En "Letra y Línea, entre la parábola y la elipse” (2013), Susana Cella postuló tres hipótesis de lectura con las cuales nos interesa dialogar. En primer lugar, reparó conjuntamente en el carácter heterodoxo de la publicación y la centralidad que adquiere en ella la discusión sobre lo contemporáneo, ya que esos dos aspectos responderían, simultáneamente a "estar en sintonía con lo que para la vanguardia en general cobraba un valor sustantivo" (2013:202). Desde esta perspectiva, Letra y Línea buscaría responder a las preguntas

qué hay, qué pasa, qué surge, qué puede ser interesante y materia de discusión en un campo artístico no acotado por géneros, artes o específicos lugares, sino, muy señaladamente, a lo que, como propuesta artística vindicadora de nuevas expresiones, búsquedas, rumbos, se encuentra en un horizonte elástico, es decir, despojado de lindes en varios órdenes. (202)

A esta exigencia de estar en sintonía con lo que sucede, Cella agrega la voluntad de "alimentar una tradición", en el marco de lo cual inscribe la declaración de la revista de no hablar de jóvenes en términos de criterios etarios (203). Lo que se produce así es una doble temporalidad: la exigencia del presente y la contribución al pasado. Sin embargo, esta hipótesis omite el carácter inestable inherente a la noción de "contemporaneidad" tal como aparece en los textos programáticos de la revista. En ese sentido, hablar de “jóvenes" sin apelar al criterio etario-cronológico es menos una forma de expandirse hacia el pasado, que de ampliar las temporalidades del presente donde un pasado intenso tiene lugar. ${ }^{146}$

Por otro lado, Susana Cella destaca el carácter preponderante de la crítica como género en la revista, y lo asocia al ejercicio del artista-crítico, apelando a la teoría de Oscar Wilde:

el hacer un objeto (póiesis), el objeto artístico en su concreta materialización capaz de comunicar (según Pellegrini), dar a conocer, mostrar la resultante de ese ímpetu creador como una causa eficiente, o sea, lo que ha impulsado y pudo ser fijado en un cuadro, una escultura, un poema, un relato, un film y aun en una evaluación que no hace sino sustentar la idea wilderiana del artista como crítico (Wilde 1994:127-208). (202)

Desde nuestra perspectiva, la idea que prevalece en Letra y Línea no es la del "artista como crítico" -que aludiría, además, al acto de desplegar un pequeño programa en cada

\footnotetext{
${ }^{146}$ En el capítulo II analizaremos esta dimensión desde la idea de "supervivencia" (Didi-Huberman 2009, 2012), articulada con la de "tradición".
} 
obra-, sino la figura del crítico como actor diferencial que, en la revista, se organiza alrededor de la capacidad de discernir valores, procedimientos, con el objetivo de discriminar lo que pueda parecer confuso para un público amplio. Y que por otro lado experimenta una tensión, en la escritura, entre las nociones poéticas que postula y el modo en que polemiza al respecto, ya que el espacio polémico le demanda regirse por las operaciones de la crítica más corrientes, como la selección, organización de conjuntos de lectura y el discernimiento de valores. ${ }^{147}$

Por último, y en relación a la disposición gráfico-visual de los artículos en Letra y Línea, Cella la califica como "caleidoscópica mostración" (206), ya que se trata de una: Invitación a efectuar otros trayectos no asimilables a la lectura sintagmática y propuesta de enlace entre lo que aparece conjunto en el espacio común de una hoja y que bien puede verse como no homogéneo, lo que desafía al lector a interpretar tales modalidades de presentación. Y si bien se puede considerar que estos diseños atañen a los propios de las revistas, sin embargo, algo incide y suscita marchas, contramarchas, ondulaciones, desplazamientos. (206)

Esta consideración resulta productiva para señalar que, independientemente de las intenciones manifiestas, las técnicas del aparecer de los diferentes aparatos estéticos configuran efectos de sentidos, tramas y articulaciones entre los textos y autores.

Las hipótesis sobre Letra y Línea planteadas hasta acá han reparado acertadamente en la compleja relación entre mercado, ${ }^{148}$ vanguardia, contemporaneidad y política que atravesó a la revista y que la volvió una de las más singulares de su época (Crespi 2011). En diálogo con esas lecturas, nos interesa plantear otra variable como hipótesis de lectura, según la cual Letra y Línea habría configurado un programa crítico donde lo contemporáneo se efectuó como una paradoja. En la "Justificación" de Letra y Línea texto de carácter editorial que se publica solo en el primer número- los integrantes se interrogaron sobre la contemporaneidad y dejaron entrever lo inestable del problema; sin embargo, buscaron codificar esa inestabilidad en una serie de "fundamentos" que les permitieran distinguir entre "contemporáneos” y “embaucadores de lo nuevo". Así, entre la indeterminación y el deseo de conformar un programa crítico que cumpliera con la "tarea discriminativa", la revista se propuso "vencer al tiempo" identificando entre la confusión a los verdaderos contemporáneos, pero los fundamentos de la

\footnotetext{
${ }^{147}$ Estos aspectos son abordados en el capítulo II.

${ }^{148}$ El mercado no representa, como podría suponerse, el lugar de lo masivo o ausencia de prestigio cultural, sino, que por el contrario, para Letra y Línea constituye el espacio donde circulan principalmente, y con mayores privilegios, los textos consagrados por lo que consideraban las élites culturales del momento: principalmente Sur, La nación y las editoriales vinculadas con esas firmas, como Sudamericana, EMECÉ, la misma Sur, Santiago Rueda, entre otras, que dan en llamar, despectivamente, "editoriales de literatura".
} 
contemporaneidad parecen ajustarse solo a los escritores del pasado. Este último aspecto es propio de una moral crítica del anacronismo como consignamos hasta ahora, no obstante, resulta insuficiente para la tarea que Letra y Linea se propuso hacer: encontrar a los contemporáneos -y distinguirlos de los ebaucadores- también en las novedades editoriales, y no solo a partir de una selección de autores y artistas que conformarían una genealogía de vanguardia.

A partir de los elementos indiciales que señalamos (portada, retrato, subtítulo, sumario, publicidades, grupo editorial) y lo propuesto por nuestra hipótesis, en el siguiente apartado analizamos la paradoja de la contemporaneidad poniendo en diálogo el programa de la "Justificación" con una serie de artículos ensayísticos ("Roberto Arlt", de Alberto Vanasco; "Sobre el destino del hombre moderno", de Henry Miller; "Aimé Césaire”, por Enrique Molina; “A cinco años de un sosiego", por Osvasldo Svanascini en el primer número; "Henri Michaux", por O. Svanascini; "Nuevos poemas de Oliverio Girondo" de A. Pellegrini en el segundo número y "Eduardo Mallea o así anda la literatura", por Vanasco, del cuarto número); la sección de Carlos Latorre titulada "poesía o no"; y pequeño corpus de reseñas ("Retablos de Navidad y de la Pasión, Eduardo González Lanuza”, por Miguel Brascó; “Los ídolos, Manuel Mujica Láinez”, por J.O. Pérez; “Desde esta carne, Valentín Fernando", por Cabrera; "Buenos Aires y Guibert. (A propósito del libro Poeta al pie de Buenos Aires)" por Enrique Molina y "Poeta al pie de Buenos Aires" por Miguel Brascó). En este corpus de ensayos y reseñas advertimos que si bien están orientados por el modo de leer que se propsuo la "Justificación", no constituyen un cumplimiento del programa crítico que ella esbozaba.

\subsection{2. "Vencer al tiempo": la crítica en Letra y Línea}

Como señalamos, la "Justificación” es el primer y único editorial de la revista donde se plantea un vínculo particular entre crítica, vanguardia y temporalidad. Letra y Línea se inscribía, como suele ser frecuente en muchas publicaciones periódicas, en un vacío que era necesario ocupar. La nota reclamaba una deuda de los espacios literarios respecto a "los nuevos", ya que, "desgraciadamente, para estos artistas realmente nuevos, están habitualmente cerradas las revistas comunes. Tales publicaciones solo los admiten cuando el consenso los ha impuesto" (1953, n1:1). En esta breve cita advertimos un primer nudo del problema: que el énfasis puesto en "realmente nuevos" señala de modo 
implícito a quienes tomarían ese atributo pero de modos "falsos" o "no reales", y que el ingreso a la circulación impresa de esos artistas a los que Letra y Línea quiere dar lugar es un problema de tiempo: se los admite en un después, después del consenso o después de la consagración. El lugar desde el cual Letra y Línea piensa "lo nuevo" es inescindible de la temporalidad crítica; así se deduce del siguiente desarrollo:

Los auténticos exploradores de lo desconocido no suelen llevar una multitud de boquiabiertos detrás de sí. Pero estos aislados creadores de hoy son frecuentemente los que construyen el futuro cultural y significa vencer al tiempo señalarlos hoy mismo.

Sin embargo, el aislamiento de algunos renovadores no significa que su obra esté fuera del tiempo. Por el contrario, una esencial contemporaneidad es el sello indeleble de toda obra auténtica. Pero tampoco contemporaneidad debe entenderse en un sentido estrictamente cronológico: no basta con que un artista viva en nuestra época para que lo consideremos contemporáneo, ni basta con que anecdóticamente la describa. Los problemas esenciales del hombre que la vive, su íntima y peculiar vivencia son los que fundamentan la contemporaneidad y dan características reconocibles a la obra de una época. Esta tarea de información debe completarse con una intención discriminativa. Numerosos son los embaucadores que aprovechan de lo nuevo para medrar. ¡Ojalá fuera siempre posible señalarlos! En ocasiones son tan hábiles y estrategos que solo el tiempo, al demostrar su nadería, ${ }^{149}$ los destruye. (“Justificación”, 1953, n1: 1-2)

Dos aspectos fundamentales se desprenden de este fragmento del que partimos para pensar la hipótesis. En un primer nivel encontramos que es el mismo concepto de lo nuevo lo que habilita la confusión: son numerosos los embaucadores e invisibles para las multitudes los auténticos exploradores de lo desconocido, por eso la revista quiere dar cuenta de los fundamentos de la contemporaneidad (la íntima y peculiar vivencia de la época por oposición a la descripción anecdótica). De ese problema-distinguir entre embaucadores y contemporáneos- se desprende el siguiente: el conflicto entre tiempo y criterios de evaluación -“significa vencer al tiempo señalarlos hoy mismo", agrega Letra y Línea; si el tiempo es un natural distribuidor de consagraciones justas, la tarea crítica es la de captar la contemporaneidad como aquello aún no codificado, ya que esa idea de un tiempo que deviene clarificador se parece demasiado a lo que se nombra como "consenso", es decir, a la estabilización de lo desconocido que leen las "revistas demasiado cómodas, demasiado burguesas", definidas como conformistas. El consenso es, entonces, la falta de riesgo en el tiempo, que implica tanto celebrar a "embaucadores"

\footnotetext{
${ }^{149}$ Para un análisis sobre el uso de esta palabra en Borges y Pellegrini ver Antelo (2004), "Poesía Hermética y surrealismo".
} 
con criterios ya valorados por la época - no percibir la diferencia que es causa y motivo de una "intención discriminativa"-, como rescatar a los contemporáneos años después, cuando ya han construido "el futuro cultural”. Así, Letra y Línea asume la tarea crítica de inventar criterios por fuera de lo disponible en el proceso de codificación que otorga el tiempo. No obstante establece "fundamentos" que, como veremos en los ensayos principales, se condensan en torno a valores ya existentes (la desarticulación del lenguaje, la violencia vital, la reacción a elementos formales, el riesgo, el fracaso) aunque no sean los dominantes en otras publicaciones de crítica literaria.

La idea de que la vanguardia funda, en el arte, un tiempo ajeno a la cronología de la cultura formaba parte de los valores estético-críticos de las publicaciones anteriores; lo singular de Letra y Línea es que tal noción no consiste en un acto auto-afirmativo, sino en esa tarea crítica de la "discriminación" donde el campo de batalla es el mercado. La revista intentará definir una poética crítica de lo contemporáneo capaz de afirmar "con solidez" que el artista contemporáneo es aquel "que se arriesga por caminos desconocidos o poco conocidos, aquel a quien no arredra el temor a equivocarse" (I,1). La actualidad es entonces, para Letra y Línea, algo así como una fatalidad cronológica: mucho de lo que se publica en su propio ahora es actual. Por este motivo, en el proceso de “discriminación", donde se busca distinguir entre los "verdaderos contemporáneos" (exploradores de lo desconocido, quienes vivencian de manera "íntima y peculiar" su propio tiempo, quienes toman riesgos) y los "embaucadores de nuevo" (escribientes de anécdotas y descripciones, estrategas, quienes "han nacido con gerontismo" siendo actuales), la revista encuentra la encrucijada de identificar aquellos elementos estéticos del presente ganándole al tiempo la sedimentación de los sentidos que operan cuando la consagración ya no implica el riesgo de la crítica, aquello que Raymond Williams nombra como "la extracción a partir de la experiencia social que resulta concebible solo cuando la propia experiencia social ha sido categóricamente (y de raíz, históricamente) reducida" (2009:182).

En esta búsqueda por encontrar los criterios de lectura que puedan dar cuenta de esos elementos del presente no reducidos por la historia, la biblioteca del arte moderno que había comenzado a construirse en Ciclo es puesta a prueba, y lo que estaba fuera del alcance del juicio en A partir de cero se pone a disposición. Si, César Moro era el autor de una obra "lo suficientemente auténtica y original como para que su nombre escape a la adulación del coro de adeptos a los recitales y a las referencias descriptivas sobre las variantes del folklorismo" (A partir de cero), por ejemplo, o si los "auténticos 
contemporáneos" son siempre víctimas de "la impotencia aguda de la crítica, la cobardía permanente provocando el confusionismo más bajo" (Molina en A partir de cero, 1), en Letra y Línea se incorporan las novedades del mercado, la tradición novelesca de la literatura argentina y los referentes poéticos de la vanguardia para someter todo a ese proceso de diferenciación. Por eso la preocupación por evitar que la narrativa experimental se confunda con la novela psicológica o el realismo interior "como lo pedía Rilke" (Cabrera, I, 14); evitar que el epigonismo arltiano (Brascó, I,16) o que la profundización de una gramática signada por la RAE (Pérez, I, 14) aparente ser la renovación de los lenguajes literarios, así como Enrique Molina planteaba el mismo problema en torno a la poesía de Aimé Césaire, descripta como "intransigencia total hacia un orden social tras cuyo hipócrita humanismo se mantienen vigentes las más feroces discriminaciones raciales", y que no debía confundirse con "la llamada 'poesía social', fruto de un espíritu reaccionario" (Molina 1953, n1:4 y 16)

Ahora bien, si el programa crítico de la revista era, por un lado, emprender una "tarea discriminativa" capaz de dar cuenta de un tipo de "vivencia íntima" entre un autor y su época, no signada por la variable cronológica, y prescindir de los parámetros ya establecidos por la crítica; por el otro, cuando la revista lee en sus reseñas la literatura de la época, solo encuentra actualidad en lo que respecta a la narrativa, descripción anecdótica. Simultáneamente, la revista publica las ficciones "Resurrección de Diaz Grey”, de Onetti; "El diálogo", de Vanasco; "El juego de ajedrez”, de Miguel Brascó, "Silencio responsable", de Filloy y "La mesa", de Lange, pero no produce discurso crítico sobre ellas. La paradoja de la contemporaneidad consiste entonces en la imposibilidad de cumplimiento del programa, ya que este se encuentra con el límite de lectura impuesto por la fatalidad temporal y por sus propios fundamentos sobre lo contemporáneo, que toma del pasado: la crítica de Letra y Línea no puede, finalmente, adelantarse al discurrir del tiempo en el señalamiento de los verdaderos contemporáneos, porque no los encuentra, ya sea porque se impone lo inestable del término, o porque sus fundamentos son impotentes frente a lo nuevo.

En los ensayos o artículos centrales dedicados a artistas y escritores que la revista estima se articulan una serie de valores que desmarcan su contemporaneidad de la coincidencia cronológica o del hecho de ser "actuales". Si bien no se lo explicita en esos términos se formula, en cada caso, un argumento que da cuenta de cierta condición suplementaria con respecto al tiempo en que produjeron sus obras. Como anticipamos, el primer ensayo dedicado a un autor en particular, ya fuera de la "Justificación", es el texto 
de Vanasco sobre Roberto Arlt. Letra y Línea proponía a un autor argentino, popular principalmente en y por el periodismo, "al parecer sin cultura, con desordenados y superficiales conocimientos literarios y filosóficos" (Vanasco 1953, n1:2), que contrastaba en principio con el propósito de la revista: "ser campo experimental donde se ensayen las fuerzas creadoras de los nuevos escritores" (“Justificación”, n1:1). Roberto Arlt es rescatado a pesar de sus "problemas de cultura" porque encarna la experiencia vital que la revista propone en la justificación: se trata, en suma, de un autor que "se adelanta por encima de dichos obstáculos de una manera incontestable y avasalladora, con la violencia vital de todo lo que tiene que decir" (Vanasco 1953, n1:6; la cursiva es nuestra).

Si tomamos los ensayos sobre dos poetas -Aimé Césaire, escrito por Enrique Molina y Vicente Huidobro, por Osvaldo Svanascini-, observamos que lo contemporáneo se produce por una dimensión doble: cierta condición de futuridad en sus poéticas y el desafío a determinados órdenes sociales. Así, en el caso de Huidobro, el autor destaca que haya preferido "participar del triunfo de la derrota" (1953, n1:3) cuando "el propio combate librado contra su medio hizo que este se volviera contra él" (3). Por otro lado, en un tipo de valoración propia de aquello que los señalamientos de una revista como Arturo había abierto en 1944, se destaca que "Huidobro superó la melosa pretensión de una melancolía aplastante y además se alzó contra un sistema menstrual de sonidos perpetuadores del pasatismo poético americano". Por último, "la insólita alquimia de su invención desde el punto de vista de la imagen" (3) que efectuó el poeta chileno es determinante en la poesía que vendrá:

La creación, tomada en el sentido que él le insuflara, permitió valorizar el futuro de una poesía que primero se concebía como reacción de sus elementos formales. Así tuvo lugar el encuentro con la imagen contrapuesta, el sistema de los atributos alterados, la yuxtaposición de sílabas y hasta el empleo de la onomatopeya y un constante empeño en fortalecer ese equivalente sensorial de la poesía. (13)

En relación con Aimé Césaire, Enrique Molina rescata una cita de Picon, a partir de la cual afirma que la lengua del poeta antillano es "uno de los laboratorios donde la poesía del porvenir puede salir enriquecida y transformada". Es decir que en ambos poetas el valor que aparece es el de un diálogo con un tiempo que escapa al propio, como supervivencia, o perduración en ese gesto de triunfo de la derrota, antes que el éxito de una consagración por las vías de lo que se impone. La poesía de Césaire sería irreductible, según Molina, a aquello que los “espíritus reaccionarios” denominan como "poesía 
social", ya que en sus libros "el idioma es deshecho, destruido, desarticulado en sus resortes lógicos para volver a inventarlo con la libertad sin límites de la inocencia". Finalmente, y en sintonía con los criterios que elaboraba Letra y Línea en el editorial, se enfatiza en la "íntima comunicación con el mundo":

El enigma oculto bajo las apariencias de la 'realidad rugosa' es penetrado por medio de oscuras oscilaciones hasta crear el sentimiento de una íntima comunicación con el mundo. (...) Hay en [en los poemas] esa toma de contacto esencial, esa conmoción súbita de todo el ser, intraducible a otra lengua que la poética. (1953, n1:4)

Este modo de pensar la lengua poética como "íntima comunicación con el punto" o "comunicación directa" se opone a la idea de literatura como mediadora de representaciones sociales. Es decir, la comunicabilidad que procuran leer los jóvenes contornistas en el lenguaje ("nos acercamos a la literatura como testimonio", Contorno 1955, n5-6:2), es desarticulada por Letra y Línea afirmando que la comunicación, en la literatura, es incompatible con lo disponible del lenguaje e intraducible a otras formas de codificación de la experiencia. En ese sentido, Aimé Césaire sería un contemporáneo porque produce un desfasaje respecto de la lengua organizada en los "resortes lógicos", y establecería con "su tiempo" una vivencia íntima no circunscripta a lo anecdótico.

Estos aspectos son también señalados en la presentación que hace Svanascini de Henri Michaux, para la portada del segundo número:

El caso de Michaux es virtualmente el del rebelde consigo mismo. El de quien se levanta contra el hábito, formula las preguntas y responde a ellas con sus armas dispares, sin necesidad de especular con su vida privada, homenajes, propaganda y otras maneras de elevar el artificio.

(...) para los que alardean en contra de una estética pura, "falta de humanidad" y de "búsqueda", hemos elegido el "caso Michaux", como antecedente del esteta en función del hombre, de quien además de poeta, realiza una obra que se niega como tal, de quien no vacila en sumergirse en la desesperación contradiciendo los conceptos especulativos para resolverse mediante la agudeza y el enfrentamiento. (1953, n2:1)

Esa forma de ser un esteta en función del hombre, sin circunscribirse a lo que Molina llamaba el "epidérmico social" es lo que lo convierte en contemporáneo:

Pero sobre todo tiene la facultad de equivocarse, de ser quizás el primero en reconocer la importancia de una falla que promueva una experiencia. Por eso su obra, ajena a la perfección inquebrantable, es profundamente actual ya que, esencialmente, no deja en ningún momento de ser un riesgo. (1953, n2:1) 
A la vez que el tipo de compromiso o humanismo de Michaux estaría dado porque "en él caben las antinomias, los contrastes y los absurdos. De allí que no puede situársele correspondiendo a una clasificación formalista" $(1953, \mathrm{n} 2: 1)$ y "el anexamiento de la poesía a lo real” (1), en su caso, “está sostenido como una reacción de lo insólito" (1).

También Aldo Pellegrini separa la "juventud" de las marcas temporales cronológicas, cuando lee En la másmedula de Oliverio Girondo:

Ese ardiente contenido que funde en su fuego las palabras no es más que desmesurado amor a la vida y por ello la poesía de Girondo resulta siempre nueva y rezuma juventud. Porque lo que llamamos juventud es pura y simplemente ese exaltado amor a la vida que el hombre común se resigna a perder en el curso de los años y que el poeta conserva indefinidamente, aunque no escriba. (1953, n2:2)

Esa juventud como exaltación que no se deja apresar por el paso de los años, y que distingue al poeta del hombre común, es la que se opone a esos "jóvenes que han nacido con gerontismo". Así, a la selección de sus contemporáneos, Letra y Línea contrapuso los gerontes de la década del cincuenta, que resultan ser aquellos que la revista entiende como “consagrados". Ya vimos, en el inicio de este apartado, al referirnos al uso cómico-crítico de las publicidades, el lugar que se le dio a una poeta como Silvina Ocampo. En ese mismo número 4, Eduardo Mallea fue otro de los autores atacados. Así, Letra y Línea se abría con Roberto Arlt, el autor de las "auténticas vivencias" y "violencia vital” y se cerraba en el cuarto y último número, con el ensayo de Alberto Vanasco sobre Mallea, uno de los escritores, se nos dice, a quien "debemos atribuir, en parte, el estado informe y gelatinoso" de "nuestras letras": "Técnicamente, puede decirse que sus obras carecen de tempo, de ese elemento ineludible que da al mundo de la ficción su suficiente apariencia de vívido, su marco de humanidad, su atmósfera propia y necesaria" (IV, 7; la cursiva pertenece al original). Alberto Vanasco recorre la obra de Mallea desde La sala de espera y Chaves, ambos publicados en 1954, hasta Cuentos para una inglesa desesperada, de 1926. Ese es también el año de El juguete rabioso, aspecto que Vanasco no desconoce en su ensayo inaugural (1953, n1: 2 y 6). Sus observaciones sobre Mallea son, por lo tanto, también las observaciones sobre un período literario en el cual se impuso una forma del realismo por sobre otra, la que proponía Roberto Arlt. El arco de lecturas, que parte de 1926 y llega a 1954, resulta productivo para pensar la relación de la vanguardia con los comienzos como forma de radicalidad. En este sentido se comprende que Letra y Línea partiera de Roberto Arlt y no de Eduardo Mallea, quien además 
representaba en buena medida la literatura de Sur, La Nación y lo que publicaba Sudamericana. La tarea discriminativa parece necesaria no solo respecto de la actualización bibliográfica, sino también de la tradición literaria, ya que un sentido de lo contemporáneo se componía en la intersección de ambas, por lo cual el único que cumpliría ese criterio era Arlt a pesar haber muerto diez años atrás, y no Mallea, quien ostenta una prolífica producción actual. Si algo unía todavía a estas revistas con las ansias vanguardistas como escándalo, Letra y Línea fue la que más se aproximó, pero no fue por vía de la poesía o la pintura, sino por la crítica de un género del mercado como la novela.

En relación con la poesía, es Latorre quien se propone despejar la confusión en la sección "poesía o no". Se trata de una sección que alcanza solamente a los números 1 y 2 de la revista y pretende ocuparse de los poetas del "consenso", los que transitan las publicaciones "demasiado cómodas, demasiado burguesas para correr riesgos", que "prefieren a los jóvenes conformistas que no provocan resistencias y que desaparecen sin dejar rastros" (“Justificación” 1953, n1:1). Así, en la primera entrega Latorre analiza la poética de Francisco Bernárdez y luego, en la segunda, de Ricardo Molinari, ambos poetas publicados con cierta frecuencia por Sur, Buenos Aires Literaria y Anales de Buenos Aires. No nos detendremos ahora en el análisis pormenorizado que se hace de cada uno, sino en los fundamentos de la sección. Dice Latorre al respecto:

Estos prestigios no resultan peligrosos siempre que su influencia no exceda los límites de la generación a la cual pertenecen. (...) cuando esos nombres amenazan con rebasar sus límites aumentando la confusión reinante ya sea por su habilidad para perdurar mediante un eficaz despliegue sofístico de aptitudes político-literarias, o mediante un sabio sabotaje de los auténticos valores llamados a reemplazarlos, o aun cuando persisten sostenidos por un fenómeno de inopia casi general, el hecho adquiere entonces gravedad. (...) Buscando entre esos nombres que tratan de permanecer, o que aún permanecen por las razones expuestas (...) se me ocurren por ahora, y entre otros, los nombres de Francisco Luis Bernárdez y Ricardo Molinari. Quizás resulten tan responsables como ellos mismos de la confusión, o más aún, los "jóvenes poetas" ansiosos de competir en esa vergonzosa estupidez en la que parecen más dispuestos a adular que a trabajar, más inclinados a imitar que a crear, a consagrar que a reclamar su propio lugar en el espacio. (1953, n1:3)

Dentro de las intervenciones que se proponen cumplir lo que anuncia la "Justificación", la presentación de este ensayo es una de las más explícitas en la mención a la "tarea discriminativa"; se alude a una "confusión reinante" y se enfatiza en un tipo de vínculo particular con el tiempo histórico. No obstante, donde antes leíamos que "la íntima y peculiar vivencia son las que fundamentan la contemporaneidad" (1953, n1:1), ahora se 
trata de "convertirse en cronistas del tiempo histórico". Esta afirmación puede emparentarse con la concepción testimonial de la literatura que propone Contorno en su edición 5-6 de la revista, dedicada a la novela argentina, sin embargo, existe una diferencia fundamental y esta radica en la función que adquiere lo contemporáneo para la crítica. Mientras para Contorno "la contemporaneidad nivela a todos por igual", ya que "hoy el tiempo no está para chistes" (1953, n1) - es decir, se vuelve una suerte de exigencia indeclinable bajo la cual serán juzgados todos aquellos que escriben en un mismo tiempo -, para Letra y Línea la contemporaneidad se dirime, por el contrario, en la capacidad de des-nivelar, separar lo que parece semejante. Por ese motivo Latorre cuestiona tanto a los "jóvenes poetas" puestos entrecomillas, que por "ansiedad" se apoyan en las mismas operaciones que quienes "rebasan sus límites generacionales", como a los consagrados Bernárdez y Molinari que sabotearían los "auténticos valores"; y así, “jóvenes poetas” se diferencia y se distancia, mediante las comillas, de la juventud girondiana. ${ }^{150}$

Otro ejemplo de esa voluntad por "diferenciar" lo constituye Miguel Brascó en una reseña irónica sobre Retablos de Navidad y de la Pasión (Eduardo González Lanuza, editorial Raigal) donde todos los párrafos excepto el último están dedicados a exaltar la "manufactura del libro" -"la perfección de la técnica beneficia al lava-ropas (al cepillo de dientes, al limpiauñas, al limpiaoídos, al limpiaparabrisas). Raramente al libro, que

\footnotetext{
${ }^{150}$ Otra de las perspectivas posibles para pensar esta sección se vincula con la puesta en página de los textos y los diálogos que se arman entre ellos. En la página 7 del primer número de Letra y Línea la sección "poesía o no" está editada en forma de columnas que rodean o encierran dos poemas de Eduardo Jonquieres. Latorre se burla, en esas columnas, de las combinaciones entre "sustantivos y adjetivos" -que enfatiza seleccionando aquellas que hacen rima asonante con la formulación que las introduce, "viento fugitivo", "árbol sensitivo", "pájaro cautivo" - y cuestiona la mesura en su poesía (1953, n1:7), este señalamiento se ajuste a las críticas más frecuentes que las revistas del invencionismo y surrealismo hicieron a la generación del cuarenta, neorromántica y neorrealista. Pero Latorre insiste en que no quiere anular la continuidad generacional, sino despejar confusiones. Los dos poemas de Jonquieres, "Paso del verano" y "Absolución" pueden leerse como contraposición y como marca de un problema estético que tiene uno de sus conflictos en la caducidad de una estética que se vive como "anterior". Así, si bien "Paso del verano" está construido inicialmente sobre rimas asonantes de participios pasados - "El gran juego vedado / Negado para la negra eternidad del sol. / Los pasos contados de la sangre, / Las sienes durmiendo en otra playa, / Pero a veces el aire, / La flor a veces sostenida, / El verano que se instala de repente /Con su pico agudo y sus alas levantadas / Le vencen justo la carne justa"-, la acción que está en el centro visual del poema es "nombrar las cosas", como una disposición "y se pone a nombrar" (por su nombre agua / el cuerpo como rama / la cara como sonrisa / las manos como hoja / el momento de la luz que espera / con la zarza del calor en medio). Y el siguiente, "Absolución", invita a dejar atrás las metáforas, los nombres, a absolverse de la repetición "no nos dejaron ni una migaja / ni una brizna siquiera de la noche. / Todos la recorrimos toda /Sin encontrarle una sola estrella de reposo. / (...) Atrás/ Quedó el tiempo de la noche. / Las horas que se esconden, /El espejo que se quiebra de un golpe. / Hubo que asumirlo todo. / Hubo que dejar que nos dejaran. / En nosotros, de pronto, / La luz descubrió, intacto, /Un cielo de fuego y veredicto.”
} 
suele cumplir también una tarea higiénica, y no de las menos importantes" (1953-1954, n3:15) - para finalmente definir al libro con la extracción de dos versos: “¿Contabais con lo absurdo? No contabais / ¿Verdad que no? ¡Varones prudentísimos!’. No hablar del libro y en cambio citar solo paródicamente dos versos es una forma de ponerlo aparte, correrlo del estatuto de lo que merece ser hablado. Diferenciar, es, para Letra y Línea, apartar todo aquello que pueda camuflarse como nuevo, moderno, pero que en realidad representa "una cierta 'literatura' que mejor pasara ya a los libros de texto escolares y nada más" (J. O. Pérez sobre Los ídolos 1953, n1:14).

Como vimos hasta ahora, el problema no es solo qué tipo de literatura se produce, sino qué categorías se utilizan para pensarla, por eso se trata de un problema crítico donde ciertos valores de la vanguardia (la rarefacción de los sentidos, la experiencia vital, la desarticulación del lenguaje) no son desplegados como procedimientos a leer sino como prismas con los cuales evaluar. Asimismo, el presente no puede ser nombrado con ninguna de las categorías ampliamente utilizadas por una doxa crítica, como novela psicológica, realismo social, literatura interior, color local. El desafío de la revista es, entonces, llevar adelante una tarea precisa y específica: el discernimiento de lo contemporáneo pero sin recurrir a lo dado, establecido; partir de lo actual, de leer todo aquello dispuesto por el mercado para su circulación, pero sin las categorías de lo consagratorio, que en el imaginario de Letra y Línea son las claves de lectura ofrecidas por Sur y el suplemento literario de La Nación. Para que se cumpla su objetivo, "convertirse en órgano cultural viviente", Letra y Línea debe ser radical, no dejarse engañar ni por "embaucadores de lo nuevo", ni por viejos criterios, y "vencer al tiempo" encontrando a los "auténticos exploradores de lo desconocido".

Sin embargo, cuando ingresamos en la "guía cultural" o sección de reseñas, las valoraciones que permitirían reivindicar un conjunto de escritores como contemporáneos, no pueden poner en marcha el programa de la “Justificación". Las lecturas sobre narrativa recientemente publicada sólo arrojan la impugnación a toda aquella literatura que no es contemporánea, como si la novela y el cuento argentino que las editoriales ponen en circulación fueran la reproducción de un viejo orden. Letra y Línea amplía sus intereses a otras zonas como la narrativa y más específicamente la narrativa realista, pero allí solo encuentra actualidad.

En el primer número de la revista, de seis reseñas literarias, sólo una es de un libro de poesía, mientras que el resto corresponde a narrativa y ensayo: De esta carne (Valentín Fernando), Los ídolos (Manuel Mujica Láinez), Lunes de carnaval (Juan Goyanarte), 
Heterodoxia (Ernesto Sábato), La música en los Estados Unidos (Juan Carlos Paz) y Vigilia torturada (Osvaldo Svanascini). Me detendré en los tres primeros títulos, ya que se trata de tres novelas. El predominio de la novela y el ensayo están ligados con una apuesta por la actualidad editorial que se diluye hacia el último número de Letra y Línea.

En la reseña de Cabrera sobre De esta carne, se nos advierte: "no es una novela social. No se lo propuso. Debería haber sido una novela psicológica”. Este imperativo no lo exime de la burla, más bien lo contrario: "Hay en Fernando un buceador psicológico. Quisiéramos saber si la necesidad de esta novela fue interior, como lo pedía Rilke. Nos alegraríamos por Fernando si así fuera" (Cabrera 1953, n1:14; la cursiva es del original). La ironía del reseñista rechaza la tradición abierta en la generación del '40, el neorromanticismo, uno de cuyos referentes era Rilke, al mismo tiempo que le niega la posibilidad de ser leída como renovación del realismo social. En la misma orientación, Miguel Brascó critica Lunes de carnaval, de Goyanarte, publicado por Editorial Sur ese año. Según Brascó, este libro no salva a la ficción de la retórica, y “aquello que era una constante en Arlt constituye una consigna" artificiosa. De este modo, queda desactivada toda potencialidad de la novela para formar parte de las intimas e intensas vivencias de los contemporáneos, como exigía el editorial.

Las referencias a la novela psicológica reaparecen en la siguiente reseña, sobre Los ídolos, de Manuel Mujica Láinez. Ya no funcionan en la desacreditación de referentes pasados, sino que se asemeja al tono irónico que Borges utiliza para el famoso prólogo a La invención de Morel (1940) al referirse a "amantes que se suicidan por felicidad". Así, el reseñista J. O. Pérez ironiza sobre "una densa película de metáforas trasnochadas", "palabras que son frecuentes solamente en el diccionario legislante de la academia real" y llevan al personaje Monsieur Chénir a un absurdo suicidio. En lugar de imaginación abrumadora hay metáforas trasnochadas. Pero lo que interesa al reseñista es lo que la confusión oculta:

Pero usted y yo sabemos que mientras esto se edita, mientras esto se pone en grandes titulares de propaganda son muy pocos los que divulgan a Arlt, por ejemplo que pese a novelas tipo Los ídolos, han sabido triunfar sobre el tiempo, el desconsuelo, la miseria, la soledad y el rastacuerismo. Pero es que todo esto tiene que tener un vuelco definitivo y hay que proponerse darlo. Cuando usted hojea este libro medita acerca de los destinatarios del mismo, e idéntica cosa me pasa a mí. Pensamos entonces que hay mucha gente desorientada, que en este Buenos Aires peor que en otras partes, habrá un estudiante anhelante, una secretaria de vuelta de la oficina, un metalúrgico que camina entre las vidrieras, y ellos quizás vean el libro este, u otros semejantes, y los compren, empiecen a leerlo y tengan una visión muy pobre 
de nuestra escritura nacional. Allí créanme es cuando nos agostamos y preguntas como “¿qué pasa con la novela argentina?” pueden tener muchas respuestas. Este es el peligro, la divulgación y el prestigio que tienen cosas como estas, en tanto que lo que verdaderamente vale, lo que debe ser una novela duerme en el cajón de un oscuro empleado de Ministerio que los sábados por la tarde y algunos domingos escribe algunas cosas que siente profundamente. Y allí está la diferencia con estos ídolos de barro: en lo que se siente, como la carne y la sangre; y lo que se fuerza más o menos ingeniosamente para que suene bien o aparezca "ingenioso", no se siente ni en el estómago ni en la cabeza. (Pérez 1953, n1:14)

Esas conclusiones de la reseña permiten señalar dos o tres puntos claves en torno a los valores que Letra y Línea delimita en su aparición, y se expanden en artículos como el de Vanasco sobre Arlt. Porque la diferencia entre lo que se "fuerza más o menos ingeniosamente" para que suene "ingenioso" y lo que se siente "como la carne y la sangre", es la diferencia entre la metáfora trasnochada y la violencia vital, entre la imaginación sin límites y el verosímil. Por un lado se insiste en que no alcanza con la "resistencia" de una obra en medios donde debe sobreponerse al "rastacuerismo" y la propaganda entre amigos, sino que es urgente "dar un vuelco", ganarle al tiempo; por otro lado, el problema de la desorientación tiene que ver con el presente, qué pasa con la novela argentina. Letra y Línea no se pregunta por el diálogo entre la actualidad literaria y editorial y la tradición; el desvelo de Brascó es la desorientación el lector lego, que quedará con una "visión muy pobre" de la escritura nacional.

Como se dijo anteriormente, la escritura crítica de las reseñas se presenta como impugnación de lo actual, sin que se deje entrever el lugar que la revista se proponía dar a los contemporáneos. Es decir, si la revista contuviera sólo reseñas sobre publicaciones de novelas o cuentos, restringidas al mercado editorial de los inmediatos años '50, deberíamos decir que no hay rastros o huellas posibles de que emerja lo contemporáneo de la escritura "actual". Toda la novela argentina que releva es psicologicista, epigonal, meramente retórica, puritana de la lengua. La crítica en Letra y Línea se construye por oposición; si amplía sus intereses, de modo que ya no es una revista de vanguardia poética, al ocuparse de las "novedades bibliográficas" en narrativa, el proyecto crítico enfrenta una limitación, y es que no encuentra una retórica para el presente.

Así, en la ampliación del objeto que presenta Letra y Línea, que supone al mismo tiempo seguir apostando a distinguir lo contemporáneo de lo actual, la revista no encuentra la suspensión de "los consensos" en lo publicado, y queda a los lectores vérselas con la letra sin glosa: "la línea no venida para definir, sino para indefinir", como el poema 
de Michaux que dialoga con el nombre. Será necesario desplazarse a los textos literarios publicados en sus páginas, "Resurrección de Diaz Grey" (Onetti); "El diálogo" (Vanasco); "El juego de ajedrez" (Miguel Brascó); "Silencio responsable” (Filloy); "La mesa" (Lange), donde la dimensión de la letra y la línea lanzada al texto sin comentarios, significaciones, consensos ni tiempos de la consagración, pareciera ser la única capaz de exponer un carácter de contemporaneidad. La pregunta es entonces si acaso esa "solidez" que quedaría después de la conmoción se resuelve en una poética crítica o en la literatura. La experimentación de lo desconocido y la contemporaneidad de la narrativa argentina, emergen, entonces de la letra y la línea, y no de la "solidez" que quedaría como saldo positivo luego de la discriminación crítica.

Con respecto a las reseñas de poesía, hay un episodio clave en la revista que es cierta polémica interna, entre Miguel Brascó y Enrique Molina en torno a la contemporaneidad de un reciente libro de poesía titulado Poeta al pie de Buenos Aires de Fernando Guibert. Libro que, al igual que Desde esta carne de Fernando y Los ídolos de Mujica Láinez, había sido ampliamente reseñado en otras publicaciones de la época. En “Buenos Aires y Guibert. (A propósito del libro Poeta al pie de Buenos Aires)”, Enrique Molina destacaba al poemario de casi doscientas páginas como "una obra que tarde o temprano acabará por imponerse como lo que es: una obra viviente y original dentro de la moderna poesía argentina", e iniciaba su intervención poniendo en el centro el rol de la crítica -“para las perezosas ratas de la crítica resultará muy superior a su roer de costumbre la envergadura, la extraordinaria fluencia lírica (...) de un poema dedicado a Buenos Aires" (1953-1954, n3:12). En la búsqueda "discriminativa" de Letra y Línea, Molina explica por qué este libro de Guibert no tiene nada que ver con el "largo discurso retórico en el que los nombres propios crean el decorado, a la manera del Canto a Buenos Aires, de Mujica Láinez (especie de vago muestrario de postales)" (12), y construye, en cambio, "un diálogo inmenso con cada uno de los elementos de esa realidad multiforme de la ciudad. No un retrato, una visión estática e inmóvil, sino un diálogo agotador, vibrante, con todas sus materias y sus seres" (12). Como valoraba Svanascini de Vicente Huidobro, el mérito de Guibert era, para Molina, su capacidad de someter "el idioma a un verdadero proceso de alquimia" (12). Esto cobraba doble relevancia si se piensa que había elegido un "tema épico" como la ciudad de Buenos Aires; por este motivo Molina quiere desplegar el método, el procedimiento que lo diferencia de otros poetas meramente temáticos y localistas: 
[se trata de] romper los moldes estratificados del lenguaje, las formas expresivas a las que el uso acaba de quitar su poder de comunicación. Guibert crea así un verbo poético extraordinariamente dinámico, de gran capacidad explosiva, por completo original, virgen, en cuyo haz se concentran a lo largo de cualquier frase múltiples asociaciones de índole sensorial, reflejos sentimentales, estímulos. Se irisa, reverbera, accede a los planos más hondos de la emoción, articulándose de manera fulgurante con todo el contenido del inconsciente. (12)

Molina inscribe a Guibert en una tradición de poetas que problematizaron la identidad local interviniendo en una política de la lengua que no se restringiera a la descripción localista. Esta intervención tendría entonces dos énfasis; una alquimia del lenguaje consistente en producir nuevos sentidos dentro del lunfardo porteño, que niegan "el viejo ya gastado por el uso", y así lo "afirma[n] y se le recrea[n]" - operación que Guibert emparienta con "uno de los puntos capitales de la obra de Queneau" (12); y el segundo estaría dado por la modernidad lírica con que Guibert pulveriza la esencia de Buenos Aires: "La gran masa sinfónica que Guibert desencadena disuelve en su impulso todas las esencias de la ciudad. (...) Su canto deshace la ciudad, la pulveriza, crea la ciudad, la proyecta al mito, al fuego" (12).

Al final del mismo número aparece, como última reseña de la sección, una nota de Miguel Brascó que lleva por título el nombre del libro en cuestión. Allí Brascó cuestiona una cita cuyo autor no explicita (¿se trata de la contratapa del libro?, ¿de una perífrasis de Molina?) donde se habla de Guibert como el "germen épico de la nueva altamente inspirada poesía argentina”. Lo que parece fastidiar más hondamente al reseñista es que se lo considere un libro de vanguardia - se trata, en suma, dice, de "un poema demasiado extenso, interesante a veces, pero que poco tiene que ver con la poesía y nada absolutamente con la poesía argentina de vanguardia” (15). Donde Molina veía "alquimia de la lengua", Brascó reconoce la ausencia de unión entre los detalles, aspecto que lo vuelve una mera enumeración "sin selección y sin método, más abigarrado aún que el mismo abigarrado vivir" (15), un Mujica Láinez podríamos decir, recuperando la oposición inicial de Molina. Es la política de la lengua lo que molesta a Brascó, más que el "concepto traspapelado y romántico del poeta abrumado ante la polifacética ciudadana - que se soporta hasta el Lorca neoyorkino inclusive - expuesto con la ya caduca técnica del simultaneísmo" (15), porque lo que agrava ese lugar común es el "abuso de recursos meramente fonéticos y formales, como el constante del adjetivo-sustantivo del tipo de sonoro-sonando, de granado-granadero, la máquina-mecánica, la gente-gentecilla y las figuritas-figurines que fastidian la lectura desde el principio" (15). Lo interesante de 
ambas perspectivas es que a pesar de las evaluaciones contrarias, el criterio parece ser el mismo: una articulación entre lengua y paisaje que rechaza la crónica de lo visto, el retrato o el ejercicio de acumulación de nombres y detalles como prueba de la experiencia urbana y local. Lo curioso es que sea un escritor vinculado a la prosa y al periodismo como Brascó quien se preocupe por desmarcar a Guibert de toda posibilidad de vanguardia, y Molina - exdirector de A partir de cero, personaje central del surrealismo en Argentina a mediados de siglo - el que empariente este libro sobre Buenos Aires con las técnicas del oulipista Raymond Queneau. 


\title{
CAPÍTULO II
}

\section{La vanguardia como ojo del presente. De la imagen total a las series de la crítica}

\begin{abstract}
La prestigiosa palabra cuadro, en francés cuando menos, deriva directamente de un vocablo latino en extremo trivial, tabula, que significa tabla, simplemente. Una tabla para todo: para escribir, para contar, para jugar, para comer, para ordenar; para desordenar. En la práctica del Atlas de Gherard Ritcher, como antaño en las series de láminas grabadas en varios "estados" por Rembrandt, se trata sin duda de mesas más que de cuadros. Lo cual significa, ante todo, renunciar a cualquier unidad visual y a cualquier inmovilización temporal: espacios y tiempos heterogéneos no cesan de encontrarse, confrontarse, cruzarse o amalgamarse. El cuadro es una obra, un resultado donde todo está consumado; la mesa, un dispositivo donde todo podrá volver a empezar siempre. Georges Didi-Huberman ${ }^{151}, 2011$
\end{abstract}

Hay que recordar una vez más que, estructuralmente, el sentido no nace por repetición sino por diferencia, de modo que un término raro, desde que está captado en un sistema de exclusiones y de relaciones, significa tanto como un término frecuente. (...) Sin duda, por ella sola, una imagen no hace lo imaginario, pero lo imaginario no puede describirse sin esa imagen, por frágil o solitaria que sea, sin el eso, indestructible, de tal imagen.

Roland Barthes

\subsection{Presentación del capítulo}

Una de las diferencias más notorias entre las revistas del corpus y otras publicaciones que las antecedieron, también vinculadas con la vanguardia, es la ausencia del género manifiesto en tanto escritura reconocible que señala lo que una obra o la crítica deberían ser. ${ }^{152}$ Como analizamos en el capítulo anterior, el abandono del manifiesto marcó, en los programas críticos de Ciclo, pba, A partir de cero y Letra y Línea, la búsqueda de criterios de lectura y selección que involucraron para ello la pregunta por la temporalidad como elemento central. Un programa, a diferencia del manifiesto, no se restringe a la postulación explícita de los objetivos y definiciones de una obra o escuela, sino que puede emerger de distintas decisiones que las revistas adoptan y cristalizan con grados variables de aparente desconexión entre sí (como la ausencia de numeración de página en poesía

${ }^{151}$ Citado en Antelo Archifilologías (2015).

152 Badiou (2011) y Mangone y Warley (1993) citados en el capítulo I. 
buenos aires, la ubicación de las publicidades en Letra y Línea, la secuenciación de los artículos, las notas editoriales, la poética crítica con la que se elige hablar de un autor, etc.). Los programas de cada una de las revistas del corpus configuraron el problema de la relación entre vanguardia, crítica y temporalidad según tres operaciones distintas: la conformación de una moral crítica del anacronismo, como vimos en el primer capítulo; la intervención polémica y el armado de series críticas; y la disputa por el sentido de aquellos términos o "palabras clave" (Williams 2003) que consideraban más relevantes en la formación de sus programas. ${ }^{153}$

Tal como anticipamos en la introducción, el modo de intervención crítica de estas revistas ha pasado inadvertido por las historias de la literatura argentina, y en particular por los estudios sobre la historia de la crítica, especializados en el período que aquí nos ocupa. Esto se debe, en parte, a que las figuras más predominantes de nuestro corpus Aldo Pellegrini, Enrique Molina, Raúl Gustavo Aguirre, Edgar Bayley- no fueron asociadas al oficio crítico, ya que se trató, en efecto, de escritores casi sin producción en el género, publicada en formato libro. Por otra parte, tales investigaciones produjeron sus lecturas del período a partir de nociones que hicieron énfasis en un modo particular del ejercicio crítico. Susana Cella lo pensó en torno a la idea de "irrupción" (1999) como un momento en el cual diversas corrientes, el existencialismo, el marxismo, el psicoanálisis, y el estructuralismo suscitaron una "eclosión discursiva" en la crítica literaria que las “asimiló, transformó e intersectó" (1999:52). El impacto de esa irrupción se asoció, en primer lugar, al gesto de la denuncia que caracterizó a Contorno (Avaro y Capdevilla 2014), e hizo pensar en los años cincuenta como "década de los vozarrones". Por otra parte, tanto Nicolás Rosa (1999) como Oscar Terán (1991, 1986), propusieron desde disciplinas diferentes - la crítica literaria y la historia de las ideas - una articulación particular entre crítica y política. Para Terán, la representatividad de los "rasgos de la cultura argentina en la década del cincuenta" se localizaba en aquellos actores culturales cuyo modelo de intelectual había articulado la coyuntura histórica, la colocación institucional y la discursividad (1986). Asimismo, Nicolás Rosa afirmaba en 1999 que la pregunta por la historia de la literatura en relación con la historia de la crítica sólo podía

\footnotetext{
${ }^{153}$ Esta última operación la analizamos en el siguiente capítulo.
} 
tener sentido "si apelamos a lo político"154 y desagregaba esto último según distintas instancias de formación. ${ }^{155}$

Estos enfoques sesgaron la posibilidad de leer otros modos de la crítica con los cuales la politicidad de revistas como Contorno dialogaba. Sin embargo, desde nuestra perspectiva, los criterios de selección y evaluación que las revistas del corpus procuraron establecer en la cultura contemporánea son propios de las operaciones críticas que trabajan sobre una tradición, donde la forma de organización de las temporalidades es un problema central. En este capítulo abordamos el modo en el cual esos criterios operaron sobre una biblioteca de la vanguardia ${ }^{156}$ y cómo se manifestaron particularmente en lo que aquí llamamos "series de la crítica”, así como también en un conjunto de polémicas. Estos aspectos dan cuenta de que para pensar las intervenciones críticas de estas revistas, las categorías ofrecidas por distintas lecturas historiográficas sobre el período (“eclosión discursiva”, “irrupción”, “vozarrón”, “apelación a lo político”) resultan insuficientes. En simultaneidad a esas configuraciones históricas, proponemos leer las escrituras críticas

\footnotetext{
154 “En su ensayo sobre Racine (Barthes, 1963), en el capítulo final, aparece claramente la problemática que nos ocupa en el sentido en que todavía hoy puede postularse, es decir, interrogativamente: ¿historia o literatura? La pregunta desplazaba nuestra propuesta inicial, pues al marcarla como una disyunción ya oponía la improbable resolución. El intento era el de establecer una relación entre la literatura y el medio social a partir de la ideología inscripta en la obra. El presupuesto fue importante, más allá de su difícil solución, que había desvelado también a Mijaíl Bajtin. En la contemporaneidad y en nuestro país, formular esa pregunta solo puede tener sentido si apelamos a lo político. Entendemos que la política no desaloja lo ideológico sino todo lo contrario, es su sostén en el orden de la praxis si aceptamos que la resolución política del entramado cultural, y en la llamada "obra literaria", en la secuencia escritor - obra - medio, tiene su correlato de mediaciones y emplazamientos diversos de la sociedad latinoamericana y, en particular, en la sociedad argentina". (Rosa, 1999:10-11)

${ }^{155}$ Con ellas se refería a "la política general que gobierna una sociedad determinada, en sus estructuras de clase y sectores", "la política de la institución literaria (universidades, academias, ateneos, clasificaciones, premios, distinciones)", "las políticas de la lengua como un sistema de mediaciones de las políticas de escritura", "las políticas de escritura soportadas por las relaciones entre cánones y géneros, géneros y estilos y estilos y estilemas. La historia de la literatura se establece sobre estos soportes". Y en relación a la crítica establecía entonces las preguntas fundacionales: En el mismo momento en el que se originan las escrituras comienza la evaluación de estas y de su sistema de producción, y sobre todo el intento de explicación del fenómeno mismo: cómo se produce, cuáles son sus causas, cuál es la valencia social, cuáles son las relaciones que mantiene con el entorno y qué sentido tiene con la constitución, en diversas manifestaciones, de lo argentino, de lo nacional, de la "conciencia nacional", de la comunidad argentina, de las formulaciones sociales en las variantes más nítidas, nacionales, liberales e izquierdistas. (1999:12)

${ }^{156}$ Una "biblioteca de la vanguardia" puede ser pensada desde la articulación entre "dispositivo" y "tradición", tal como propone Marina Yuszczuk en su tesis doctoral titulada Lecturas de la tradición en la poesía argentina de los noventa (2011). La noción de "dispositivo" no alude al tratamiento que le dio Foucault al término- aspecto teórico con el cual discute la política de los aparatos de Déotte $(2012,2013)$ , sino que es retomada de Deleuze para vincularla con la "tradición selectiva" de Williams: "“una especie de ovillo o madeja, un conjunto multilineal' que en este caso nos permite recorrer tanto los artículos críticos como las enunciaciones de poéticas y los poemas mismos. Según Deleuze, un dispositivo 'está compuesto de líneas de diferente naturaleza y esas líneas del dispositivo no abarcan ni rodean sistemas cada uno de los cuales sería homogéneo por su cuenta (el objeto, el sujeto, el lenguaje), sino que siguen direcciones diferentes', forman procesos siempre en desequilibrio y esas líneas tanto se acercan como se alejan unas de otras'. Es en este sentido que haremos uso del término, en tanto aparato de lectura, crítica y escritura con distintos puntos de contradicción y confluencia, que atraviesa objetos heterogéneos." (2011:54)
} 
de Ciclo, pba, A partir de cero y Letra y Línea como parte de un "bullicio de la crítica". Este término alude al desplazamiento de las trayectorias autorales señaladas (en las figuras de David Viñas, Adolfo Prieto, Oscar Massota, Héctor Murena) hacia una dimensión más inestable, como las polémicas y las series de la crítica; asimismo, en el bullicio no habría una "asimilación”, según el decir de Cella (1999) de las discursividades teóricas sino contactos y apropiaciones aleatorios.

Nuestro punto de partida en este capítulo es la pregunta acerca de cómo se articularon las nociones de "imagen surrealista" e "imagen invencionista" sugeridas por algunos integrantes de las revistas, con las intervenciones críticas que apelaron a distintas referencias de las vanguardias. Para responder a ese interrogante, analizamos en primer lugar el carácter problemático del término "vanguardia" a mediados del siglo XX en Argentina, y el modo en que el surrealismo se conformó, en torno a la figura del “cadáver”, como una estética de la supervivencia (Didi-Huberman 2009, 2011), según la cual las revistas del corpus cuestionaron los discursos superacionistas que buscaban descartar las experiencias de las vanguardias relegándolas a un tiempo clausurado. En el segundo apartado, damos cuenta de la relación entre imagen y representación, atendiendo a la aspiración compartida tanto por el surrealismo internacional como por el invencionismo vernáculo de alcanzar una imagen "total", ya sea por la depuración de cualquier rastro representacional o semblante, como en el caso de la imagen invencionista y concreta, o por el sueño de localizar a la imagen en una anterioridad con respecto al lenguaje, como pretendía el surrealismo. Estas nociones de imagen, que recuperamos de distintos fragmentos en las revistas, parecen ser un limitante en las intervenciones críticas que solo las incorporan, transformadas, tomando algunos de sus matices entre los que ya no se cuenta la aspiración de totalidad en el rechazo a la representación. Así, advertimos que las intervenciones críticas se caracterizaron por un desplazamiento: desde la búsqueda de una imagen total hacia la pregunta por lo heterogéneo y compuesto, es decir, qué autores son susceptibles de ser pensados junto a otros, y qué imágenes pueden articularse con otras. En el análisis de las polémicas de la crítica, que abordamos en el tercer apartado, damos cuenta de que los desacuerdos entre posiciones críticas se produjeron como cuestionamiento de los criterios que propiciaban unas relaciones entre autores diversos por sobre otras. En el cuarto apartado, vemos cómo esa condición heterogénea y compuesta de la vanguardia que atraviesa a las revistas en tanto preocupación crítica se establece por zonas de contacto, en lo que llamamos series de la crítica. 
Series de la crítica $^{157}$ es entonces la forma en que cristalizó el pasaje del manifiesto y la imagen total hacia una intervención crítica que requirió, como operación, advertir un conjunto de factores heterogéneos que modulaban efectos críticos al inventar zonas de contacto entre autores y artistas. Asimismo, Raúl Antelo ha pensado los procesos de las vanguardias y la modernidad en términos de "configuraciones y encabalgamientos regidos por el con (...) más que por una esencia pretendidamente común o compartida" (2016:263). Se trata del modo en que distintos nombres (el de Roberto Arlt, Juan Carlos Onetti, Wilfredo Lam, Georges Bataille, Lázló Moholy Nagy, César Vallejo, René Char, Henry Michaux) fueron puestos en contacto produciendo un efecto suplementario no restringido a lo que cada indagación autoral aportaba, sino que emergía del espacio común. Una serie de la crítica es, por lo tanto, una secuencia heterogénea de yuxtaposiciones donde un conjunto de materiales discursivos y visuales producen cierto efecto de sentido a partir del cual es posible identificar una intervención crítica ya que expone valores y criterios de selección acerca de qué puede ser juntado con qué, donde interviene un principio del anacronismo. ${ }^{158}$ Esta noción de serie crítica exhibe su semejanza con la del montaje de la obra de vanguardia (acercar y ensamblar elementos heterogéneos), sin embargo se separa de ella porque no remite a la composición de un

157 Si bien notamos que la palabra "serie" arrastra el sema de lo continuo, contrario a la idea de heterogeneidad y alternancia que aquí proponemos, sigue pareciendo la más adecuada por sobre otras que indican relaciones de conjunto, ya que no está determinada por un sentido de causalidad o direccionamiento como las palabras "secuencia", "líneas", "sucesiones", "encadenamiento" que pueden pensarse como sinónimos. En efecto, las definiciones de "serie" aluden a los rasgos comunes de los elementos, y señalan que tales rasgos son independientes de su ordenamiento. Por otro lado, y según el uso de Daniel Link, la "serie" proporciona una "máquina interpretativa", ya que "no tiene un principio clasificatorio, por eso puede agrupar elementos heterogéneos y, sobre todo, está regida por el azar y la coacción" (2003:27).

158 Anacronismo de las imágenes históricas y montaje de objetos son las dos operaciones historiográficas del principio constructivo propuesto por Walter Benjamin, que resultan pertinentes para pensar las escrituras críticas en las revistas de vanguardia. "Las ideas se relacionan con las cosas como las constelaciones con las estrellas" [I/1, 214] (2012:68) afirma Benjamin; así, la historiografía no cuenta las estrellas, sino que interpreta las constelaciones. Procuraba entonces el "despertar de un saber, aún no consciente, acerca de lo que ha sido" (2013:35). Ese modelo anacrónico por el cual se mira al pasado como un fragmento que leemos a partir de intereses actuales y no como una "cadena de recuerdos continuos", tiene como objetivo "arrancar a la tradición al conformismo que está a punto de subyugarla" (1973: 180). Asimismo, otro de los puntos de contacto entre el estado de la vanguardia en Argentina a fines de la década del 40 y mediados del 50, y el surrealismo en 1929 según Walter Benjamin, es su presunción de ocaso. La idea de que la vanguardia se encontraba en decadencia ya estaba expandida y a su vez crecía una noción de compromiso que pretendía rechazar las formas y sonidos de una vanguardia que leían en clave liberal. Desde la perspectiva de Didi-Huberman, el anacronismo se trata de dos duraciones heterogéneas -"la apertura repentina y la aparición (aceleración) de una latencia o de una supervivencia (islote de inmovilismo)" (2015:66)-, de la diferencia en la repetición; de eso está hablando esta vanguardia hecha de genealogías, tradiciones y sueños de modernidad que pone de manifiesto a la vez la gramática olvidada de "Un cadavre" en los años veinte con la 'Patafísica, los ensayos recientes de Bataille sobre el surrealismo como ausencia de comunidad, traduce ideas claves de la obra de Blanchot como la crítica a la categoría de "inspiración”, y enormiza la figura del poeta como profeta. 
espacio en particular, debido a que en la serie, tal como es pensada aquí, el espacio es discontinuo y va más allá de una página de revista como límite; en todo caso, si mantiene el efecto del montaje es porque establece vínculos por disimilitud. Por otra parte, lo que aquí nombramos como "noción" sin duda remite a una categoría elaborada en el marco de las teorías que propusieron los formalistas rusos para pensar las relaciones entre lo artístico y lo político o extraliterario. Así, "serie literaria" y "serie extraliteraria" son funciones en un sistema teórico que se proponía explicar los principios constructivos por los cuales se configuraba una forma determinada, donde era posible identificar el hecho literario como una especificidad no reductible a ser explicada por otras variantes, como la serie económica, política, social, etc. En nuestro caso, no se trata de una categoría que aporta ese tipo de función. Lo que interesa es anclar un punto de contacto entre la serie como forma de exposición de materiales y la construcción de recorridos orientados donde las decisiones de organización en torno a lo visible y lo legible constituyen una dimensión performativa de la escritura, que "puede o no coincidir con las declaraciones explícitas" (Rogers 2019: en prensa). Tal punto de contacto puede vincularse con la relectura que hace Ana Porrúa del formalismo ruso, menos atenta a las exigencias de una ciencia literaria que a los efectos críticos de aquellos momentos donde en determinados ensayos de Sklovsky y Tinianov, se produce una singularidad que escapa a la ley y permite leer lo nuevo en lo viejo, la forma en la historia, la diferencia y lo continuo:

Tinianov, por su parte, en 1924, decía que la forma puede leerse en el momento de conflicto entre principios constructivos, o de hecho entre estos y los materiales que tratan de deformar. Leer en la diferencia y en el movimiento. Es un gesto de vanguardia, claramente, y no hay que olvidarlo. Pero leer el contraste y el movimiento supone, en este caso, leer lo viejo y lo nuevo, o tal vez lo nuevo en lo viejo. Por eso, trabajaron la poesía de Maiakowsky, pero sobre todo, la tradición de la poesía rusa. (...) En el Tinianov crítico no se impone la dureza de la ley que debe cumplirse siempre del mismo modo, sino la heterogeneidad de los materiales y la multiplicidad de las relaciones. En el pasaje de un material de una serie a otra, o en su renovación dentro de la poesía, está, de hecho, la historia. Otra vez, el "entre". (Porrúa 2011:47)

Las series de la crítica en las revistas de vanguardia conforman técnicas y procedimientos del aparecer propios de un aparato estético donde el modo en que se manifiestan los materiales construye sentidos que modulan aquello que los programas o manifiestos explícitos no acaban de decir. Se trata de una superposición de signos, un modo de "mezclarlos o fundirlos, armar una geometría diferencial o una relación aleatoria" (Porrúa 2011:57). De esta manera, la serie puede funcionar como un espacio donde la vanguardia 
se convierte en el "ojo de la crítica" de las revistas, una mirilla a través de la cual lo que se mira entra en otra temporalidad.

Desde la perspectiva metodológica de Rogers, puede afirmarse que proponer una política de exposición de materiales y construcción de recorridos orientados es lo propio del hacer de las revistas desde su surgimiento, emparentado con las transformaciones de la arquitectura comercial, los anuncios publicitarios y el diseño de la vida pública a partir de los grandes almacenes, las ferias de curiosidades y las exposiciones anuales (Benjamin 2016). En la lectura del corpus de revistas que proponemos aquí, esa condición general del hacer de las publicaciones se vuelve productiva para analizar cómo organizaron modos de lectura yuxtaponiendo valores estéticos -luego devenidos críticos- que no estaban de antemano conformados como un conjunto, y en ese sentido habilita hipótesis particulares. La disimilitud articulada permite advertir la lectura temprana de Roberto Arlt en el vértice de las discusiones entre vanguardia y realismo en Letra y Línea, o el tipo de política de la historia que se configuró entre Georges Bataille y Lázló Moholy Nagy en Ciclo. ${ }^{159}$ La noción de serie es una construcción crítico-metodológica que proponemos en esta tesis, motivada por la observación de textos e imágenes, y sus efectos de sentido en relación con lo que en el capítulo I caracterizamos como los programas de cada revista. Cobra relevancia especial para el objetivo de este capítulo porque nos permite pensar las operaciones críticas en una variable desplazada tanto del valor de la firma del crítico, como del peso demarcatorio que tuvieron las nociones de imagen en las revistas. Asimismo, y en relación con las polémicas, presenta como continuidad el problema de las relaciones de conjunto (si es posible poner bajo un mismo enunciado a Baudelaire con T.S. Eliot, o qué líneas conectan a Vicente Huidobro con Henri Michaux).

En este sentido, el montaje donde se yuxtaponen materiales heterogéneos y también heterocrónicos (Arlt y Lam), posibilita leer las diversas intervenciones críticas implicadas sin el corset ${ }^{160}$ de la repetición, el epigonismo, el anacronismo como "pecado del historiador" (Rancière 1996), para dar lugar a una "la historia del medio" (Déotte 2013), poniendo en suspenso o ampliando la noción de época como conjunto de enunciados decibles y legibles - condensados, para los estudios de los 50 sobre crítica y literatura en los valores que mencionamos antes. El desafío es, según Déotte, “dejar lugar a una complejización interminable de formas del tiempo" (2013:45), mediante el "aparaillage" o emparejamiento de tiempos heterogéneos que constituyan una lógica de

\footnotetext{
${ }^{159} \mathrm{El}$ vínculo entre ambos autores es tratado en este capítulo, Cfr. 2.4.1.

${ }^{160}$ Cfr. Longoni (2006)
} 
las diferencias superpuestas, de las singularidades, y no una normalización de la época a la medida de los acontecimientos disruptivos. Leer la especificidad del carácter crítico que estas revistas pusieron de relieve en discusiones de horizonte común y ampliado, como las que mencionamos al inicio de la introducción, supone leer de forma conjunta el espacio que permite esa comparación de los heterogéneos y la singularidad de una historia del medio que permanece en el suspenso de esa neblina entre acontecimientos.

\section{1. "Un cadáver": la vanguardia como supervivencia}

En el año 2017 la Fundación OSDE montó una muestra dedicada al arte surrealista en Argentina. Santiago Villanueva y Claudio Iglesias, quienes intervinieron como críticos y curadores, se refirieron al movimiento como un "espíritu barrial y kitsch" (2017:7-12). Negando cualquier postura de sofisticada transgresión o hermetismo, ${ }^{161}$ lo describían como un movimiento ingenuo, que prefiere callar cuando los mayores hablan de cosas importantes, que a su vez ostenta una accesibilidad infinita al hacer artístico: sea artista por un día, sea surrealista, podríamos decir continuando la retórica kitsch propuesta por Villanueva e Iglesias. ${ }^{162}$ Esa observación puede remontarnos a algunas de las reflexiones que ocuparon a Maurice Blanchot en los años inmediatamente posteriores a la II Guerra Mundial, cuando advirtió que la escritura automática -trasladada en cadáveres exquisitos al espacio de la pintura- aportaba como descubrimiento "un método de facilidad, un instrumento siempre disponible y siempre eficaz, la poesía cercana a todos y convertida en la presencia feliz de lo inmediato" (2002:160). Aunque luego, y en contraposición a lo anterior, señalaba que

detrás de esa certeza, ese don ofrecido a todos y revelado en todos, sin apelar al talento ni recurrir a la cultura, se disimulaba la inseguridad de lo inaccesible, la experiencia infinita de lo que ni siquiera puede ser buscado, la puesta a prueba de lo que no se prueba, de una búsqueda que no es una búsqueda, y de una presencia que nunca está dada. Nada parece más cercano

\footnotetext{
161 Las teorías más aceptadas sobre las vanguardias históricas (Bürger 2010, Adorno 2013) y las neovanguardias (Foster 2001) enfatizan el carácter negativo de las obras de arte vanguardista o conceptual y hermético en las más recientes. Aunque este último cuestiona a Bürger que esa característica sea considerada como un fracaso.

${ }^{162}$ Tal vez tenemos que tomar ese mismo impulso y, contrariamente a Pellegrini, entender al surrealismo desde Orión a nuestros días como un surrealismo rosa, que en su relación con un mercado invisible constituyó su propia genealogía: una vanguardia que contempla a todos aquellos que quieren participar, que renueva diariamente su programa y sus objetivos, que no entiende la teoría como espacio de coincidencia, sino que recurre al entusiasmo grupal.
} 
que la poesía de la escritura automática, ya que nos orienta hacia lo inmediato. Pero lo inmediato no es cercano, no es cercano de lo que nos es cercano, nos conmueve, es, como dijo Hölderlin, la fuerza terrible de la conmoción. $(2002: 160)$

Esta lectura repone una suerte de constante histórica: así como el surrealismo es una referencia presente en los relatos iniciáticos de escritores y artistas, ${ }^{163}$ el hecho de que trajera consigo la inagotable disponibilidad a ser parte de él quedó solapado bajo la insistencia en su carácter provocativo y transgresor. ${ }^{164}$ Dos textos de la revista $A$ partir de cero dan cuenta de esa constante histórica donde accesibilidad infinita y transgresión -esta última reservada solo para algunos pocos- se superponen. En el primer número de su revista, Enrique Molina hacía una selección particular de la unión entre arte y praxis vital, propia del surrealismo, construyendo una genealogía del desastre:

El disparo que arroja Kleist al fondo de su alma, el silencio de Rimbaud, la soga de la que pende el cadáver de Nerval - precio de su tentativa de "dirigir el sueño"- la pureza sobrehumana que desgarra en Van Gogh todas las apariencias de la realidad, la bala que sella la absoluta sed de libertad de Mayakovsky, el gas que ilumina la noche eterna de Crevel, los nueve años que pasa Artaud en el hospicio de Rodez, son pruebas demasiado dramáticas de que la aventura poética es una auténtica aventura del conocimiento, y del precio que la sociedad exige a quienes se atreven a poner su acento solo en las cosas esenciales. $(1952, \mathrm{n} 1: 1)$

Al mismo tiempo, en la reseña sobre Hay alguien que está esperando, de Raúl González Tuñón (1952), se enfatiza, como señalamos en el capítulo anterior, acerca de la diferencia entre afirmar que la poesía "debe ser hecha para todos" o "por todos". Solo esta última constituiría "una concepción progresista y revolucionaria" que "se extiende a toda manifestación vital, ennobleciéndola", en la cual "deben participar todos los hombres" (1952, n2:8). Así, en el valor ético del "hecha por todos", la revista recuperaba esa accesibilidad infinita a la poesía, pero encontraba a su vez un límite en las palabras anteriores de Enrique Molina sobre las "pruebas demasiado dramáticas de la aventura poética" $(1952, \mathrm{n} 1: 1)$ ya que la transgresión radical -que comprometía la propia vida-era solo protagonizada por algunas pocas firmas. Esta ambigüedad de alcances y limitaciones que expone el surrealismo involucra especialmente su relación con la historia, así como

\footnotetext{
163 “Il n'y a plus d'école, mais un état d'esprit subsiste. Personne n'appartient plus à ce mouvement, et tout le monde sert qu'il aurait pu en faire partie", afirmaba también Blanchot en La part du feu. (1949:90)

164 Este carácter provocativo y transgresor sería una apropiación cultural de la "fuerza terrible de la conmoción" que Blanchot recupera para pensar lo inaccesible de lo accesible.
} 
también la temporalidad que abre cada una de sus manifestaciones. A diferencia de otras vanguardias históricas, como el dadaísmo, futurismo o suprematismo, el surrealismo no parece haber experimentado el proceso de autocrítica feroz sobre la institución arte, cuya consecuencia fue en la mayoría de los casos la caducidad y evanescencia de los movimientos, según analizó Peter Bürger desde una perspectiva de la ciencia crítica, y Alain Badiou desde la filosofía, al señalar que "una vigorosa corriente de pensamiento [en torno a las vanguardias] afirmó que era mejor sacrificar el arte que ceder en cuanto a lo real" (2011:167). El surrealismo manifestó desde un inicio "hundir sus raíces en la historia" (A partir de cero, "Diálogos con Breton" 1952, n2: 7-8), reapropiarse de diversos mitos, y asumió que su tarea no estaría cumplida hasta que el espíritu del hombre no se liberara de las ataduras impuestas por las oposiciones binarias entre sueño/vigilia, realidad/irrealidad, consciente/inconsciente. ${ }^{165}$ Así, fue la única corriente de las vanguardias históricas que perduró con el nombre original hasta inicios del siglo XXI, reactivándose en publicaciones periódicas y pequeños grupos libertarios en países que no habían sido anteriormente interpelados por el tipo de ruptura que produjeron las obras del período de entreguerras. ${ }^{166}$ Por otra parte, se trata de la historia de un movimiento que surge como si siempre hubiera sido de todos, pero que produce sucesivamente manifiestos donde se enuncia su delimitación y re-orientación en cada caso.

El modo en que las revistas procesaron el espesor y significación de términos como "surrealismo", "invencionismo", "vanguardia", influyó en las operaciones críticas que realizaron, las disposiciones o elecciones que procuraron y las morales con las que juzgaron la contemporaneidad del arte. A partir de estas inestabilidades, interesa explorar dos dimensiones que tienen que ver con el modo en que intervinieron las revistas Ciclo, A partir de cero, poesía buenos aires y Letra y Línea en las discusiones culturales de su tiempo: la cristalización que una serie de publicaciones del período analizado (19481956) hizo sobre las experiencias de vanguardia como algo que debía ser dejado atrás y en segundo lugar, la configuración que las revistas del corpus hicieron de la vanguardia como dimensión abierta de "lo pasado", a partir de la figura del "cadáver", especialmente relevante en el surrealismo.

\footnotetext{
${ }^{165}$ Discusión que no alcanzó, evidentemente, a cuestionar los binarismos de género y sexo, salvo contadas excepciones hacia la década del cincuenta.

${ }^{166}$ Cfr.: Castro (2013). "El surrealismo en su presente" en El surrealismo y sus derivas. Visiones, declives y retornos. Madrid, Abada editores.
} 
2.1.1. "Estéticas absurdas" y "escuelas cerebralizadas": lecturas sobre la vanguardia en otras revistas culturales del período

Con respecto a la primera de esas dos dimensiones, advertimos que existe una relación entre la dificultad teórico-histórica que la idea de vanguardia suscitó en las principales investigaciones sobre el tema en América Latina, y las discusiones que generó el uso de ese término en las revistas de los años 50. Distintas teorías y análisis críticos sobre arte y literatura (Schwartz 1991, 2016; Giunta 2001; Del Gizzo 2017; Pizarro 1981; Aguilar 2002, 2003; Sarlo 1988; Bugnone 2014, 2017) advierten que "vanguardia" es una categoría que nunca termina de agotarse pero que a su vez aparece siempre desfasada temporalmente respecto de aquello que se significó como "vanguardia histórica". Esta incomodidad teórica es coincidente con las condiciones de legibilidad que el "contexto de lectura" y "de circulación" (Louis 2014) ${ }^{167}$ le plantearon a las revistas de nuestro corpus, poniendo en cuestión no solo su pertinencia como novedad, sino también que fueran capaces de cumplir con las necesidades de su época. Eso que "nuestro tiempo" necesita fue expresado según distintos énfasis por las revistas del entorno; así para Ventana de Buenos Aires (1952- 1956), dirigida por Hurtado de Mendoza y De Lellis, se trata de "un esfuerzo por 'vivificar' nuestro idioma" (1952, n2:1) y reinscribir el nacionalismo literario desechando "lo chabacano por apoético y el gauchismo por inactual"; para Contorno (1953-1959) la exigencia era la "objetivación histórica” y la denuncia; para Sur (1931-1989) la consagración de un humanismo moderno que privilegiara la libertad como valor supremo y una lengua capaz de acompañar el elevado espíritu que tal empresa requería. En ese marco, las "escuelas literarias" son puestas bajo sospecha, en la presentación de la revista El 40 (1951-1953), León Benarós afirmaba:

Los años transcurridos entre 1940 y 1951 nos han enseñado, entre otras cosas, a no sobreestimar el gesto, la exterioridad. El gesto, la exterioridad implican, por su propia naturaleza mundana -a menudo adventicia-, una subestimación tácita de las categorías esenciales y menos ostensibles de la persona. De ahí que a esta altura del siglo nos parezcan extraños y anacrónicos aquellos

\footnotetext{
167 "La noción de contexto de lectura designa las condiciones de lectura de los textos, tal como se inscriben en los aspectos materiales de las publicaciones. Es necesario diferenciar el concepto del de contexto de recepción, que concierne la forma en que son efectivamente recibidos los textos, e implica una investigación de otro tipo, aunque igualmente necesaria para comprender el impacto de un medio en una cultura. Aquello de lo que se ocupa el contexto de lectura es de la lectura propuesta por las formas, y no de la recepción efectiva. Uno de los métodos para estudiar el contexto de lectura consiste en considerar la circulación de los textos entre revistas y libros." (Louis 2014), y habría que agregar, en esa forma de circulación, las discusiones más generales que rodean la intervención de una revista en particular.
} 
desplantes característicos de ciertos grupos literarios que encabezaban sus publicaciones con un ruidoso manifiesto o con la inevitable declaración de principios.

Ni manifiesto ni declaraciones apriorísticas nos urgen ahora. La verdad es que no nos seducen ni nos deslumbran ya esas posturas. Si fueron oportunas y, en buena medida, eficaces o adecuadas a los propósitos de quienes las ensayaron hasta lo hiperbólico, no lo son ya para nosotros. Testigos de tiempos universales más dramáticos -más problemáticos-, nuestro testimonio no podría cohonestarse ya con arrestos verbales, ni con la incursión desaforada en esta o en aquella teoría estética, no siempre redentora y, cuántas veces, deleznable y absurda. (1951, n1:3)

El género manifiesto es puesto nuevamente bajo sospecha, pero el problema es de un orden muy distinto al que advertíamos en las revistas del corpus. Para Benarós, los manifiestos encarnaban "teorías estéticas absurdas y deleznables" a diferencia de lo que señalamos sobre poesía buenos aires, donde el problema era la relación entre los modos de leer habilitados por tal género y la comprensión u ordenamiento de la literatura contemporánea. Por otro lado, Benarós destaca la "ineficacia" de los manifiestos, y los circunscribe al anacronismo como forma de señalar su temporalidad errónea, o el "pecado" de su presente, en términos de Didi-Huberman (2015) y Rancière (1996). Finalmente, esa presentación de la revista da cuenta de una serie de oposiciones como la idea de "gesto" o "exterioridad" a la de "categorías esenciales" o "tiempos dramáticos". Es decir que habría algo del orden de lo superficial que un tiempo grave y profundo necesitaba empujar hacia el pasado para siempre.

Esa "exterioridad" es también la que parece juzgar Cosmorama al referirse a la revista Arturo de la siguiente manera: "salvados ciertos anacronismos de principios ('el arte como puro juego', la creación artística como INVENCION, la revisión de los valores estéticos desde el punto de vista CONSTRUCTIVO ...) [Arturo. Revista de Arte Abstracto] cumple una útil polarización (...) de todo ese movimiento que FUE de vanguardia" (Cosmorama 1944, n4:12, las mayúsculas son del original). El énfasis de Cosmorama, que destacaba tipográficamente las palabras del arte concreto-invención y un verbo en pasado, y las oposiciones de Benarós en El 40, dialogan con el editorial del primer número de Ventana de Buenos Aires (1952) donde la poesía llamada por la "verdad" se opone a la "intromisión de escuelas cerebralizadas":

Alcanzamos un "arte culto" a las manos de quienes sienten de verdad y a quienes se las ha prohibido la absorción de lo poético por intromisión de escuelas cerebralizadas. (...) Desechamos el sofisticamiento, lo snob, la imitación de lo foráneo. Lo desechamos por antinatural, porque eso no contribuye a forjar nuestra personalidad artística. (1952, n1:1) 
Esta idea de "verdad" aparecía también en el número 3 de la revista Contrapunto donde se había lanzado una encuesta titulada “¿Hacia dónde va la pintura?” (abril, 1945). Mientras Maldonado afirmaba que la pintura "evoluciona hacia lo concreto, superación dialéctica de lo abstracto" (citado en Lucena, 50), Antonio Berni respondía:

Toda la especulación abstracta poscubista, todas las preocupaciones por problemas ya resueltos hace tiempo, pasarán a un plano inferior comparados con la nueva verdad que va más allá de la artesanía menor de copiar objetos o de crear imágenes abstractas - por más "concretas" que se llamen-y otras cositas para boudoir de damas aburridas o neurasténicas. (citado en Lucena, 51) 168

Asimismo, en la revista Sur, Carlos Mastronardi rescataba la obra de Guillaume Apollinaire a partir de una relectura del lugar que las vanguardias montaron para el "arte nuevo" y los caligramas: "Acaso pueda afirmarse que algunos momentos de su poesía comportan una negación involuntaria del arte abstracto, de las juiciosas construcciones cubistas" ( 1947, n150:91); así, Mastronardi retiraba a Apollinaire como el precursor de las vanguardias y lo inscribía como poeta de los males del hombre en el tiempo de la Gran Guerra. En una reseña sobre Ver y Estimar también en Sur, se delineaba una diferencia entre vanguardias y las "potencias del hombre":

Romero Brest no da la razón al público, 'que subestima el magnífico esfuerzo de los artistas de vanguardia', ni a los artistas de vanguardia que 'ignoran sistemáticamente las potencias de la tierra y del hombre'. Sin embargo, ¿merece llamarse 'magnífico' el esfuerzo de quienes ignoran las potencias de la tierra y del hombre, es decir, todo? Por otra parte, merece llamarse 'torpe' a un público que 'subestima' a quienes ignoran todo? (E.L.R. 1948, n162:120-121)

Tanto las revistas de corte nacionalista como las publicaciones de la izquierda organizada en estructuras partidarias y aquellas que promovían la riqueza del espíritu universal miraban con recelo la pretensión de manifestaciones más experimentales o que mostraran una afinidad con los procedimientos y valores de las vanguardias. Es evidente que cuando los artistas concretos, los poetas de poesía buenos aires y los integrantes de revistas como A partir de cero cuestionaban la idea según la cual la vanguardia sólo se ocuparía de "viejos problemas", respondían a estas afirmaciones y los presupuestos que las sustentaron. La idea de "superación" que proponía Pellegrini sobre Paalen, analizada

\footnotetext{
${ }^{168}$ Los artistas del Taller de Arte Mural - integrado por Berni, Spilimbergo, Demetrio Urruchúa, Juan Castagnino, y Manuel Colmeiro - se configuraron como los principales rivales de los artistas concretos.
} 
en el apartado sobre Ciclo, ${ }^{169}$ puede entenderse como una intervención al respecto, ya que se le otorgaba un sentido distinto, donde aludía a la construcción de un espacio de cruces, ensambles y mixturas entre escuelas estéticas antes delimitadas, y no al rechazo de las experiencias de la vanguardia. "Superar" adquiría así un sentido de síntesis, que a su manera refutaba la pertinencia de dejar atrás "todas las preocupaciones por problemas ya resueltos hace tiempo" (Berni citado en Lucena 2015:51).

La pregunta de Andrea Giunta sobre la posibilidad de nombrar un conjunto de obras de los años sesenta como obras de vanguardia, ${ }^{170} \mathrm{o}$ bien el señalamiento de Foster respecto de aquellas vanguardias que constituyeron una "extraña temporalidad, perdida en las historias del arte del siglo XX" (2001:7), fueron inquietudes problematizadas por las revistas de los años cuarenta y cincuenta en Argentina. Si bien no es el objetivo de esta tesis determinar el carácter vanguardista de Ciclo, Letra y Línea, A partir de cero y poesía buenos aires analizando sus programas estético-críticos en relación con las obras artísticas y literarias que publicaron en sus páginas, sí resulta importante no perder de vista la inestabilidad de los límites y alcances de lo que era considerado vanguardia o “escuelas poéticas" dentro de un espacio más amplio de discusiones, ya que esa misma inestabilidad permite modulaciones especiales en las intervenciones críticas de las revistas del corpus.

Contra el tipo de sospecha y desdén que generaban las propuestas cercanas a una búsqueda experimental en una cantidad considerable de revistas contemporáneas, $p b a,{ }^{171}$ en el número 13/14, cita un pasaje de la Guía ilustrada de la literatura francesa moderna, de Marcel Girard-“Cuando en 1945, entre otros balances, los franceses hicieron el de su poesía, se encontraron con que nueve de sus diez mejores poetas contemporáneos habían sido formados por el surrealismo"- y reclama:

Resulta curioso comprobar cómo un movimiento estético que ha tenido tanta importancia en la literatura europea de los últimos treinta años, ha sido casi completamente desconocido por nuestras anteriores generaciones literarias.

\footnotetext{
${ }^{169} \mathrm{Cfr}$. Apartado 1.1.1. en esta tesis. Recuperamos la cita para facilitar la referencia: "La pintura para Paalen debe resultar de la fusión de la ciencia (ecuación lógica del universo) y del arte (ecuación rítmica del universo); por este camino se logrará superar -dice- al surrealismo que postuló la omnipotencia de lo irracional y al materialismo dialéctico que afirmó la omnipotencia de la razón" (1948, 81, la cursiva es mía).

${ }^{170}$ Dice Giunta al respecto: - ¿¿No es este un término legítimo para referirse al arte de preguerra, pero inadecuado para producciones que no eran más que reciclajes del período heroico de las vanguardias históricas? ¿Cuáles eran los marcos de referencia que se utilizaban para pensar el propio proceso artístico?” (2001:164)

${ }^{171} \mathrm{Si}$ bien podemos suponer que es Aguirre el responsable de esta parte de la presentación sobre los "poetas surrealistas", no hay firmas críticas en todos el número, y tanto la selección de poetas como los textos críticos que acompañaba cada agrupamiento son asumidos por la dirección editorial.
} 
La de Martín Fierro solo tuvo de él una idea muy confusa, como demuestran algunos de sus integrantes, jamás tocados en su vanguardismo sino por un ingenio fácil (que nada tenía en común con la seria actitud espiritual que entraña el surrealismo) y que tendía a los aspectos superficiales de la poesía contemporánea, reducidos a problema retórico. Se explica así, después de años y años de desconocimiento y tergiversación, que hoy se hable de este movimiento, en algunos círculos, como de algo periclitado (cuando los hombres que han hecho la experiencia del surrealismo constituyen hoy un sector numeroso y activo que ha contribuido a elevar el nivel de la poesía en varios países europeos y americanos), que se confunda a Apollinaire (muerto en 1918) con los surrealistas, que se hagan con respecto a este movimiento las afirmaciones más ridículas, producto indudable de una irresponsabilidad que implica emitir opinión sobre temas que no ha tenido el cuidado de conocer previamente. (1953, n13-14:10)

poesía buenos aires produce a continuación un desplazamiento: lee las consecuencias de esos desconocimientos, cuya manifestación discursiva más concreta sería la de dar por "periclitado" algo que se ignora o solo se lo comprendió en términos retóricos, en la literatura de una generación posterior:

Habiendo tomado lo superficial y aparente de la poesía europea de vanguardia, los martinfierristas dieron lugar a un cabriolismo que, desgraciadamente, contribuyó -en parte por lo menos- a la formación de un general prejuicio sobre los caracteres de la poesía contemporánea. Esta situación, acentuada por el paso de una generación reaccionaria en literatura, como lo fue la llamada del 40, que nada se ocupó de la realidad literaria del siglo, debieron enfrentar los primeros poetas que en nuestro país se dedicaron a una exploración seria y directa de la poesía surrealista, a través de los manifiestos y los trabajos de Breton, de Éluard, de Péret, de Artaud, d Tzara, de los antecedentes literarios del movimiento (Blake, Novalis, Rimbaud, Lautréamont, etc.) de las obras de exégesis y de las expresiones surrealistas paralelas en las artes plásticas, en el teatro y en el cine. (10)

Esos "primeros poetas" serían, según se consignaba en la nómina de la selección de "poetas surrealistas", Aldo Pellegrini, Enrique Molina, Julio Llinás, Carlos Latorre y Juan Antonio Vasco. Para Aguirre, si había un desfasaje temporal en la "exploración seria y directa" de los diversos manifiestos del surrealismo, este se debía a los efectos de las lecturas promovidas por generaciones anteriores. En ese sentido, los primeros poetas que se enfrentaron al prejuicio y la reacción heredados serían una suerte de arqueólogos de lo moderno. ${ }^{172}$

Por otra parte, resulta singular una particularización que hizo $p b a$ en otro pasaje del mismo texto, donde se refería al surrealismo como una "fuente de creatividad"

\footnotetext{
${ }^{172}$ Cfr.: Agamben (2009)
} 
extendida en la historia, teniendo en cuenta que en ese número de la revista, el 13-14, el criterio de lectura anticipado era la prescindencia de seguir "escuelas literarias" para una exposición de lo nuevo. Encontramos tres elementos (la crítica a los escritores martinfierristas y los “conservadores del 40", el abandono de las escuelas estéticas como medida de la crítica, y el cuestionamiento a una concepción de la historia literaria como escalones de superación) que se asemejan al tipo de operación que propuso Ciclo con la lectura de Lazló Moholy-Nagy: nuestros manifiestos han fracasado, pero es preciso insistir en la renovación del arte. $p b a$ reclamaba además una temporalidad propia para la vanguardia en la literatura argentina, dando a entender que la discusión acerca del fracaso de las vanguardias en Europa no remite al diagnóstico local, donde estas fueron desconocidas o mal comprendidas. Por este motivo, cuando en distintas revistas y pequeños grupos de intelectuales, artistas, escritores, emerge una tensión en torno a si dar por cerrada o no una etapa de experimentaciones, lo que leemos es también el reclamo por el derecho a experimentar lo no clausurado del pasado, a experimentar lo que fue dejado de lado, o no vivido de manera suficiente.

\subsubsection{Cadáver y supervivencia: formas del tiempo no clausurado}

La segunda dimensión que se pone de relieve a partir del modo en que las revistas significaron el alcance de términos como "surrealismo", "invencionismo", "vanguardia", tiene que ver con la forma del tiempo en la cual esos términos se inscribieron. Si bien es cierto que las distintas historias de la literatura los han pensado como parte de una "segunda oleada vanguardista en Argentina" o "segunda vanguardia" (Freidemberg 1984, Baumgart 1982, Espejo 2009, Calbi 1999, Cristófalo 2007), lo que podemos nombrar bajo esa denominación no tuvo como programa fundamental la pasión por lo nuevo que definió a los años 20 (Sarlo 1988, Prieto 2006); ${ }^{173}$ tampoco fue la identidad cultural el problema que desveló sus preocupaciones -interrogante que los investigadores de la vanguardia a escala continental advierten como constante a pesar de que se haya producido con

\footnotetext{
${ }^{173}$ En Estudios de literatura argentina, Adolfo Prieto describía, en torno a los años 20, cómo una serie de acontecimientos locales e internacionales (la apertura democrática y el triunfo del radicalismo, la Reforma Universitaria de 1918, el Fin de la Guerra, la Revolución Rusa de 1917) contribuyó a crear la sensación de que se estaba viviendo una nueva era, en la que se "confirma la presunción ampliamente sustentada en otros lugares, y por otros motivos, de que la juventud liquidará el mundo de los viejos" (1969: 32).
} 
diferencia de años en la primera mitad de siglo XX. ${ }^{174}$ El deseo de vanguardia aparece sobre todo como deseo de intervenir sobre lo no clausurado y desconocido del pasado para conectarlo con las manifestaciones artísticas experimentales de mediados de siglo. La posición de las revistas del corpus para con la historia fue, con respecto a los modos de leer de otras publicaciones, igualmente seria ya que nunca abandonaron el tono grave de la época. Sin embargo, el énfasis de esa seriedad estuvo puesto en otros lugares. En un tiempo que se experimentaba agobiado, decadente, la remisión a las vanguardias históricas y sus conexiones con poetas de la segunda postguerra como Césaire, Michaux, Char, era una forma de intervenir de manera diferencial en la responsabilidad de los “dramáticos tiempos universales", proponiendo el valor de la exuberancia, el riesgo o el no-saber.

Como señalamos en el primer capítulo, el término "vanguardia" fue apropiado de modo diferencial por cada revista. Mientras A partir de cero no lo utilizó, pero se inscribió explícitamente en un programa surrealista, pba buscó ampliar la idea del invencionismo hasta diluir sus límites, pero insistió en que nunca dejarían la vanguardia (Espiro 1951, n5:1). A su vez, mientras lo que podemos considerar surrealismo en Argentina es un reapropiación del surrealismo francés (en el caso de Aldo Pellegrini es una continuidad que representa el deseo de trasladar una forma de vida a la mayor cantidad de puntos geográficos posibles), el invencionismo de los cuadernillos poéticos de la ACCI, la revista Contemporánea y los primeros números de $p b a$, pretende ser una vanguardia vernácula que se distancia tanto del creacionismo de Vicente Huidobro, como del surrealismo y luego, retrospectivamente del concretismo brasileño, ${ }^{175}$ y que reclama para sí una diferencia con respecto al arte concreto-invención, movimiento del cual se desprende. En ese sentido, el término neo-vanguardias, ${ }^{176}$ a partir del cual Peter Bürger caracterizó los proyectos artísticos de la segunda Postguerra, tampoco sería apropiado para pensar el vínculo particular que las revistas del corpus establecen con el surrealismo e invencionismo, ya que en el primer caso aparece un deseo de continuidad y en el segundo la intención de absorber distintas características de movimientos diversos. En ninguna de

\footnotetext{
${ }^{174}$ Cfr.: Schwartz (1991), Bossi (1991), Sarlo (1988).

175 Cfr. Gonzalo Aguilar (2003) en Poesía concreta brasileña: las vanguardias en la encrucijada modernista, especialmente la introducción y el primer capítulo, "Formas de las vanguardias".

176 Del Gizzo entiende la vanguardia "no como una categoría estética de ruptura y novedad" -como una "estética del umbral" que, como el manifiesto, "explicita la intención de intervenir sobre lo que ya no es, al tiempo que ofrece en potencia aquello que todavía no ha tomado forma" (2017:159)
} 
las revistas estudiadas aparece la voluntad de sacudir la institución arte-literatura ${ }^{177}$ deseo que Bürger identifica como fallido en los movimientos de los años cincuenta y sesenta- como principio organizador del programa. Dice Bürger al respecto:

El concepto de movimientos históricos de vanguardia se distingue de todos los intentos neovanguardistas europeos de los años '50 y '60. Pese a que los objetivos que se plantearon las neovanguardias fueron, en parte, los mismos que los movimientos históricos de vanguardia, la pretensión de que luego el arte regrese a la praxis cotidiana no tiene asidero en la sociedad actual, luego de que fracasaran los movimientos de vanguardia. Cuando hoy un artista coloca una estufa en un museo, no tiene la misma intensidad de protesta que los ready made de Duchamp. Por el contrario, mientras el urinor de Duchamp sacude la institución arte (con sus formas específicas de organización, como el museo y las exposiciones), el artista que exhibe una estufa reclama para sí el carácter de "obra" que desea entrar al museo. En este caso, la protesta vanguardista se volvió su contrario. (24)

La lectura de Bürger se apoya en dos concepciones de la relación entre arte e historia que son puestas en crisis por las mismas discusiones de la segunda Postguerra en torno a lo que una vanguardia puede: la idea de que el fracaso es una clausura y la idea de que sería imposible una supervivencia del espíritu de revuelta en tanto la relación entre arte y praxis cotidiana "no tiene asidero en la sociedad actual" como consecuencia de una derrota anterior. Georges Bataille discutió lo primero en el ciclo de conferencias sobre surrealismo y existencialismo que dictó en el año 1949, donde afirmaba:

Lo surreal no puede conducir a verdaderas realidades porque los hombres no las creen, porque el conjunto de los hombres no las creen y no pueden creerlas. (...) Con esto no tengo la intención de definir el fracaso del surrealismo, no hay resultados en la vida, en la historia, que no conlleven un poco de fracaso y el fracaso está muy lejos de merecer ser tomado como hacen aquellos que no quieren ir más allá, es decir como una suerte de prueba de vanidad; por el contrario el fracaso no puede ser tomado sino como aquello que debe buscar muy atentamente aquel cuya impaciencia convoca a un resurgimiento. Aqui excederé lo que es la adquisición del surrealismo para representar lo que, a mi entender, sigue siendo posible. (2008:51, la cursiva es mía)

¿Qué era lo seguía siendo posible del surrealismo?, y ¿cuál era ese "más allá" al que podrían ir las publicaciones argentinas dejando de lado el fracaso? Para Aguirre, según la

\footnotetext{
177 Si bien es posible rastrear algunas intervenciones de Pellegrini y Molina donde hablan "contra el Arte" y contra la "gran poesía", y cuestionan los premios literarios, las instituciones, se trata de una forma de organizar un posicionamiento diferente, pero que no alcanza a proponerse el cuestionamiento de la institución-arte como tal, ya que los valores atribuidos a la las manifestaciones artísticas que rescatan son propios de las obras acogidas también por la institución arte.
} 
cita que analizamos de poesía buenos aires n13-14, el surrealismo era posible en la indagación de un pasado aún desconocido. Algo del orden del resurgimiento es lo que este reclamaba al rechazar que la vanguardia fuera algo "periclitado". También resurgía la búsqueda de un asombro renovado en un texto aparentemente de regresión con respecto a las experimentaciones poéticas como Campo nuestro (1946) de Oliverio Girondo, quien recién en el ámbito de revistas surrealistas e invencionistas volverá a publicar un libro como En la masmédula (1954) que reconecta con el espíritu de Veinte poemas y Espantapájaros e incluso lo radicaliza. En Las vanguardias latinoamericanas. Textos programáticos y críticos (2006), Alfredo Bossi rescata los siguientes versos de Girondo, de 1946: "Nunca permitas, campo, que se agote / nuestra sed de horizonte y de galope" (2006:22). Lo que Bossi lee en clave de indeterminación de los límites regionales (el suelo propio como horizonte y no como encierro), puede ponerse en relación con las tensiones entre fracaso y deseo de renovación, aspectos decisivos del programa de Ciclo, ya analizado en el capítulo anterior.

Así, ese "más allá" del fracaso implica, para las revistas del corpus, la articulación de dos temporalidades: el pasado inconcluso y el presente de aquellos elementos que lo interpelan. En ese sentido resulta pertinente pensar la relación entre surrealismo, invencionismo y vanguardia a mediados de siglo en Buenos Aires, a partir de una figura dominante en los documentos, manifiestos, panfletos y publicaciones del surrealismo: el “cadáver” como materia orgánica/inorgánica que habita a la vez el espacio inestable de lo vivo y lo muerto, lo presente y lo ausente, el presente y el pasado, entre lo común y lo identitario, entre el efecto o consecuencia extrema de la transgresión (el disparo al azar a la multitud como proclamaba Breton, el suicidio en la búsqueda del límite entre consciencia e inconsciencia) y la apelación común-compartida del más allá como búsqueda de otro tipo de conocimiento. El cadáver es una de las figuras de la supervivencia (Nachleben) ${ }^{178}$ que resulta del desborde de los diagnósticos de caducidad, como ese otro tiempo que "en una cultura aparece como desecho, como una cosa fuera de época o fuera de uso" (Didi-Huberman 2009:52), también como una obsesión, “algo, alguien, que no se puede olvidar pero que, sin embargo, es imposible reconocer con claridad" (26).

\footnotetext{
${ }^{178}$ En La imagen superviviente. Historia del arte y tiempo de los fantasmas según Aby Warburg, Georges Didi-Huberman desarrolla una breve genealogía del término "superviviencia" o "nachleben" que Warburg habría tomado de la antropología anglosajona, especialmente del término "survival" empleado por el etnólogo Edward B. Tylor. La noción de supervivencia también cobraría relevancia en el famoso ensayo de Mau sobre el potlach en las sociedades primitivas. Cfr. Didi-Huberman, 2009: 45-62.
} 
La referencia al cadáver y al funeral abre un espacio significativo en relación con las prácticas que vinculan arte y vida o arte y política, pero sobre todo en relación con el tiempo propio de la supervivencia. Gabriel Giorgi ha definido ese espacio como "tensión entre el cuerpo vivo y el resto, eso que ya es materia inorgánica, fósil, que viene con otros tiempos y otras escalas, y que aquí no está dado — no tiene ritual, ceremonia, exequiassino que, por el contrario, hay que producir, hay que crear, hay que instituir" (2017:250). Es posible encontrar una genealogía de los cadáveres del surrealismo en la iniciación argentina de Aldo Pellegrini:

Fue exactamente en el año de su fundación. Con motivo de la muerte de Anatole France, el diario Crítica de esta capital publicó un número completo de homenaje al escritor, que por entonces parecía tener una importancia similar a la de Hugo. A mí la falta de pasión y el escepticismo barato me parecían la caricatura del verdadero disconformismo. Por esa época me interesaba especialmente Apollinaire. En ese número de Crítica aparecía un telegrama de París con el anuncio de la aparición de un panfleto contra France denominado "Un cadavre", con la lista de los firmantes. Envié esa lista a Gallimard, que por entonces me proveía de libros franceses, pidiendo que se me mandara lo que tenían publicado. Así me llegó el primer número de $L a$ révolution surréaliste y el Primer manifiesto de Breton. Por entonces yo estudiaba medicina y hablé con entusiasmo a mis compañeros David Sussman y Mariano Cassano, y después a Elías Piterbarg, quien trajo a su hermano Ismael y a Adolfo Solari. Todos formamos una especie de fraternidad surrealista, la que realizaba experiencias de escritura automática. La actividad del grupo, totalmente desvinculado de las corrientes literarias de entonces (sólo estimábamos a Oliverio Girondo y a Macedonio Fernández), culminó con la publicación de los dos números de la revista Qué. (Citado en Solas 1967:111)

Pellegrini no remite allí al contenido del panfleto Un cadavre sino a la lista de firmantes, a partir de los cuales toma conocimiento del surrealismo francés. Allí se encontraban: Auteurs Philippe Soupault, Paul Éluard, Pierre Drieu La Rochelle, Joseph Delteil, André Breton y Louis Aragon. Sin embargo, la serie de expresiones que utiliza remite al tono de los artículos publicados en ese panfleto de dos pliegos (ver imagen 26): "falta de pasión", "escepticismo barato" y "disconformismo" se leen en Breton y Éluard:

Avec France, c'est un peu de la servilité humaine qui s'en va. Que ce soit fête le jour ou l'on enterre la ruse, le traditionalisme, le patriotisme, l'opportunisme, le scepticisme, le réalisme et le manque de cœur! Songeons que les plus vils comédiens de ce temps ont eu Anatole France pour compère et ne lui pardonnons jamais d'avoir paré des couleurs de la Révolution son inertie souriante. (Breton)

La beauté, cadavre, nous la connaissons bien et si nous nous y prêtons, c'est qu'elle ne nous donne pas précisément à sourire. Nous n'aimons le feu et l'eau 
que depuis que nous avons envie de nous y jeter. L'harmonie, ah! l'harmonie, le nœud de la cravate, mon cher cadavre, et la cervelle à l'écart, bien rangée dans le cercueil et les larmes qui sont si douces, n'est ce pas. ${ }^{179}$ (Paul Éluard)

Si efectivamente Aldo Pellegrini leyó en 1925 el panfleto completo o solo las firmas, y si acaso el conjunto de valores asociados al disconformismo surrealista son una construcción de la memoria que se trama en el relato de iniciación, interesa menos que la persistencia de esos valores en relación con la figura de un muerto ${ }^{180}$ que marca el comienzo del surrealismo francés como forma de provocación pública y el pequeño grupo que conformaría Qué, en Buenos Aires en 1928. “Anatole France n'est pas mort : il ne moura jamais", decía la primera línea del panfleto.

André Breton, Paul Eluard y Louis Aragon partían de la división entre cuerpo y memoria para borronearla e instalar el poder de los insultos en esa cesura cultural entre lo que pervive (la memoria) y lo que parte (el cuerpo). "Avez-vous déjà giflé un mort?" preguntaba Aragon a una suerte de interlocutor presente en el funeral; abofetear a un muerto era traspasar el límite entre materia y espíritu porque implicaba ir más allá de insultar eso que puede ser retenido por las personas queridas (el espíritu, el recuerdo), afrentando también lo que se perderá en el entierro. Suponía, por eso, iniciar la "revuelta" no solo con un escándalo que corría los límites de lo culturalmente aceptable, sino

\footnotetext{
179 Amamos el fuego y el agua solo porque queremos arrojarnos a él. Armonía, ¡ah! La armonía, el nudo de la corbata, mi querido cadáver y el cerebro fuera del camino, ordenados en el ataúd y las lágrimas que son tan dulces, ¿no es así?

${ }^{180} \mathrm{Il}$ n'a jamais songé qu'à son petit intérêt, à sa petite santé. Il attendait la mort, paraît-il. C'est une jolie solution. Mais à part cela, sérieusement qu'a-t-il fait, à quoi a-t-il pensé ? Puisqu'il ne s'agit aujourd'hui que de déposer une palme sur un cercueil, qu'elle soit aussi lourde que possible et qu'on étouffe ce souvenir. Un peu de dignité, Messieurs de la famille ! Pleurez toutes les larmes de votre corps, Anatole a rendu ce qu'on appelait son âme. Vous n'avez rien à attendre de cette mémoire molle et sèche. C'est fini !

On rapporte régulièrement le mot de Barrés : "C'était un mainteneur ». Quelle cruauté ! Le mainteneur de la langue française : cela fait penser à un adjudant ou à un maitre d'école très pédant. Je pensé que c'est une singulière idée que de perdre quelques minutes à adresser des adieux à un cadavre dont on a retiré le cerveau ! Puisqu'enfin tout est fini, n'en parlons plus.

Pour y enterrer son cadavre, qu'on vide si l'on vêut une boîte des quais de ces vieux livres « qu'il aimait tant » et qu'on jette le tout à la Seine. Il ne faut plus que mort cet homme fasse de la poussière.

André Breton

Les conseils municipaux de localités à mes yeux indistinctes s'émeuvent aujourd'hui d'une mort, posent au fronton de leurs écoles des plaques où se lit un nom. Cela devrait suffire à dépeindre celui qui vient de disparaître, car l'on n'imagine pas Baudelaire, par exemple, ou tout autre qui se soit tenu à cet extrême de l'esprit qui seul défie la mort, Baudelaire célébré par la presse et ses contemporaines comme un vulgaire Anatole France. Qu'avait-il, ce dernier, qui réussisse à émouvoir tous ceux qui son la négation même de l'émotion et de la grandeur?

Tout le médiocre de l'homme, le limité, le peureux, le conciliateur à tout prix, la spéculation à la manque, la complaisance dans la défaite, le genre satisfait, prudhomme, niai, roseau pensant, se retrouvent, les mains frottés, dans ce Bergeret dont on me fera vainement valoir la douceur. Merci, je n'irai pas finir sous ce climat facile une vie qui ne se soucie pas des excuses et du qu'en dira-t-on.

L'haleine de mon interlocuteur est empoisonnée par l'ignorance. Louis Aragon
} 
también de un tiempo intermedio: lo que ya no es pero sobrevive, y lo que aún no habrá sido. Abofetear a un muerto era poner a dialogar el surrealismo con un tiempo no existente, el de la sobrevida de un cuerpo "dont on a retiré le cerveau" pero cuya materia orgánica pervivía, ${ }^{181}$ como si también asumiera en ello ser la vanguardia histórica que irrumpe cuando la virulencia del dadaísmo, los sueños técnicos del futurismo, la depuración de las formas en el suprematismo, comenzaban a reconfigurarse hacia otros horizontes. En esta clave es necesario leer el vínculo del surrealismo con el pasado y el modo de organizar una genealogía porvenir, o "la determinación en el pasado de una genealogía de las intensidades del presente" (Badiou, 2011:172). ${ }^{182}$

Ahora bien, el cadáver es también la imagen con la cual se quiebra el colectivo que había abofeteado a France. Entre fines de 1929 e inicios de 1930 se sucedieron un conjunto vertiginoso de episodios que culminaron con la publicación del panfleto titulado igualmente Un cadavre. Esta vez contenía, como cuerpo profanado, un retrato de Breton sangrando por la corona de espinas que decoraba su cabeza (ver imagen 27) y era firmado por Baron, Boiffard, Desnos, Leiris, Limbour, Morise, Prévert, Queneau, Vitrac, Carpentier, Ribemont-Dessaignes y Bataille. En 1929, Breton había tenido que elegir entre el surrealismo como revuelta y una conciencia revolucionaria que redujera las sospechas del Partido Comunista Francés; tras las presiones, había intentado orientar la decisión del colectivo hacia la afiliación en el partido, pero las discusiones y las persecuciones internas rápidamente enturbiaron la relación y muchos de los integrantes decidieron separarse del grupo. En La révolution surrealiste, publicación integrada por algunos de los poetas que firmarían el nuevo panfleto, Breton decidió publicar Le second manifest du surrealisme $(15 / 12 / 1929, \mathrm{n} 12)$, atacando a sus compañeros por pretender separar el surrealismo de la lucha de clases (años más tarde, en la redición de los manifiestos diría “el tiempo se ha encargado de suavizar por mí sus aristas más polémicas. Deseo que haya corregido, aunque sea hasta cierto punto a mis expensas, los juicios a veces apresurados que emití sobre diversos comportamientos individuales tal como creí verlos delinearse entonces") y con especial virulencia, la figura de Georges Bataille, entonces director de Documents. ${ }^{183}$ Esto motivó la aparición de Un cadavre, que tendría a su vez respuesta en una nueva revista, dirigida por Breton, y titulada Le surréalisme au

\footnotetext{
${ }^{181}$ Je pensé que c'est une singulière idée que de perdre quelques minutes à adresser des adieux à un cadavre dont on a retiré le cerveau ! Puisqu'enfin tout est fini, n'en parlons plus.

182 Badiou señala a "Sade, algunos románticos alemanes, Lautréamont”. (2011:172)

${ }^{183}$ Para una historización de la relación entre Georges Bataille y André Breton, ver: Michel Suyra (2013).
} 
service de la révolution. ${ }^{184}$ Según Frédéric Aribit el panfleto es una autopsia del cadáver de Breton como corte y montaje de fragmentos que este había publicado en Un cadavre (sobre France). ${ }^{185}$ Uno de los focos de énfasis es la imagen del polvo a la que había aludido Breton en 1924. Así, afirma Aribit :

À la volonté de d'expliquer, de se défendre par la parole, de piéger l'autre dans les tours de son propre langage repris et commenté, soit réintroduit dans une nouvelle dynamique argumentative, comme on pouvait encore la lire chez Breton (voir le Second manifest), succède ici le refus d'entrer dans le débat, et la volonté d'en terminer avec l'autre, avec tout discussion possible, en découpant le corps de son texte comme un corps démembré. Ainsi, plus encore qu'un pastiche, le Cadavre est un palimpseste écrit sur le corps mort (l'œuvre achevée, elle-même morcelée, décomposée) de Breton.

El cadáver como memoria o como materia en la que se imprime una huella, proponía al cuerpo como palimpsesto y postulaba otra de las formas por las cuales el surrealismo se inscribía en los límites entre lo vivo y lo muerto. ${ }^{186}$ Pocos meses después, César Vallejo publicaría el famoso ensayo "Autopsia del superrealismo", donde parte de la fragmentación del pensamiento social según un contraste de este con la emergencia exacerbada de "escuelas literarias":

Anarquía y desagregación semejantes no se vio sino entre los filósofos y poetas de la decadencia, en el ocaso de la civilización greco-latina. Las de hoy, a su turno, anuncian una nueva decadencia del espíritu: el ocaso de la civilización capitalista.

La última escuela de mayor cartel, el superrealismo, acaba de morir oficialmente.

En verdad, el superrealismo, como escuela literaria, no representaba ningún aporte constructivo. Era una receta más de hacer poemas sobre medida, como lo son y serán las escuelas literarias de todos los tiempos. Más todavía. No era ni siquiera una receta original.

En esa autopsia realizada ahora por el poeta peruano, se historiza el vínculo de los surrealistas con el "afuera político" (la calle, el marxismo) y su fracaso o "muerte".

\footnotetext{
184 Para un análisis pormenorizada del avatar de rupturas, polémicas y decisiones vinculadas a los alineamientos políticos dentro del surrealismo, véanse: Mora (2017), Rojo (2013), Rincón (2009), Aribit (2007).

185 "Il ne faut pas que mort cet homme fase de la poussière", y del Manifest $d u$ surréalisme: "Ce monde dans lequel je subis (n'y allez pas voir), ce monde modern, enfin, diable ! que voulez-vous que j'y fasse ? La voix surréaliste se taira peut-être, je n'en suis plus à compter mes disparitions. Je n'entrerai plus, si peu que ce soit, dans le décompte merveilleux de mes années et de mes jours. Je serai comme Nikinski, qu'on conduisit l'an dernier aux Ballet russes et qui ne comprit pas à quel spectacle il assistait." Estos son los dos fragmentos del primer Cadavre (1924) que se tomaron luego en el II (1929).

186 Asimismo, la imagen de Breton convertido en cadáver sobre el cual se escribe dialogaba con la perspectiva anti-idealista de Bataille desarrollada en Documents alrededor de 1930.
} 
Recupera entonces distintos fragmentos de Cadavre de 1930, ${ }^{187}$ donde concluye: Breton vivió siempre de cadáveres. Esta acumulación de sobrevidas, desapariciones intermedias y que retornan, parece constitutiva al devenir que tuvo el surrealismo como movimiento, grupo, vanguardia o conjunto de procedimientos estéticos. Es de las vanguardias históricas -si se cree posible contarlo entre ellas- la que desarrolló una extraña capacidad de ser experimentada entre destiempos, reemergencias, rupturas, nuevas alianzas, desplazamientos y apropiaciones. Como si su propia composición estuviera hecha de elementos vivos y muertos a la vez, extemporales como los de un sobreviviente.

Este recorrido nos permite repensar la reemergencia del surrealismo en Argentina a mediados del siglo XX como una deriva más de la obsesión por aquello que vive y aquello que muere en tanto espacio inestable de las vanguardias, y no como como un episodio meramente epigonal o reproductor de las discusiones culturales europeas. ${ }^{188}$ En primer lugar, las revistas argentinas no replicaron las divisiones que se habían suscitado en Europa. A pesar de que en Buenos Aires, Aldo Pellegrini fuera nombrado con sorna como el "jefe del surrealismo" -en alusión a Breton, quien había sido burlado como el "papa del surrealismo"-, lo cierto es que, incluso una publicación como A partir de cero, auto-referenciada con el surrealismo como modo de promocionar un vínculo entre arte y experiencia vital, difundió tanto la obra de Benjamin Péret (el "siempre fiel a Breton") como de Antonin Artaud (el rebelde de 1929). Y por otra parte, problematizaron la figura del cadáver de modo tal que permite, desde nuestra perspectiva, advertir allí un espacio donde se configuraron los conflictos temporales que interesan para pensar las intervenciones críticas.

\footnotetext{
187 "Un instante — dice Ribemont-Dessaignes— nos gustó el superrealismo: amores de juventud, amores, si se quiere, de domésticos. Los jovencitos están autorizados a amar hasta a la mujer de un gendarme (esta mujer está encarnada en la estética de Breton). Falso compañero, falso comunista, falso revolucionario, pero verdadero y auténtico farsante, Breton debe cuidarse de la guillotina iqué estoy diciendo! No se guillotina a los cadáveres". "Breton garabateaba, - dice Roger Vitrac. Garabateaba un estilo de reaccionario y de santurrón, sobre ideas subversivas, obteniendo un curioso resultado, que no dejó de asombrar a los pequeños burgueses, a los pequeños comerciantes e industriales, a los acólitos de seminario y a los cardíaces de las escuelas primarias". "Breton — dice Jacques Prevert- fue un tartamudo y lo confundió todo: la desesperación y el dolor al hígado, la Biblia y los Cantos de Maldoror, Dios y Dios, la tinta y la mesa, las barricadas y el diván de madame Sabatier, el marqués de Sade y Jean Lorrain, la Revolución Rusa y la Revolución superrealista... Mayordomo lírico, distribuyó diplomas a los enamorados que versificaban y, en los días de indulgencia, a los principiantes en desesperación". "El cadáver de Breton - dice Michel Leiris - me da asco, entre otras causas, porque es el de un hombre que vivió siempre de cadáveres". "Naturalmente - dice Jacques Rigaud— Breton hablaba muy bien del amor, pero en la vida era un personaje de Courteline".

${ }^{188}$ Esta perspectiva es la que ha primado en muchas de las investigaciones sobre el tema; cfr.: Prieto 2006, Cristófalo 2007.
} 
Una de las apariciones de ese espacio la encontramos en el número 4 de $p b a$, dedicado a "El frente de la poesía: América", y especialmente a Pablo Neruda, César Vallejo y Vicente Huidobro, donde se publica también un análisis sobre el surrealismo. Después del número 3, donde se proclamaba una "poesía desmantelada", la mudez de lo nuevo, la "desaparición de las oquedades veneradas" y la "poesía cotidiana", en la búsqueda por definir una vanguardia poética que renunciara a las significaciones del símbolo y las explicaciones de sentidos ocultos, reclamando a su vez una jerarquización de la poesía por sobre otras prácticas lingüísticas, $p b a$ se desplazaba de las citas de René Char, Paul Éluard, Tristan Tzara y Henry Michaux -jueces y partes del surrealismo y de las esquirlas de los estallidos sucesivos entre 1930 y 1936 con el paso de Breton por México y su exilio en Estados Unidos- hacia los poetas de América. En "César Vallejo - Pablo Neruda - Vicente Huidobro en una conciencia americana", Jorge Enrique Mobili; ${ }^{189}$ insistía con definir lo contemporáneo ${ }^{190}$ a partir de valores vinculados con lo vital y el curso intemporal de los progresos. Este énfasis se observa en las palabras usadas para nombrar a los tres poetas del "frente" - palabra de clara alusión vanguardista. Así, Vallejo es el que no habla por los manifiestos sino por la vida ("Más cierto es que César no se murió bisbiseando, sino de agua y de piel, como dijimos, por estas páginas, que se muere un poeta. Como dijimos por estas páginas que no se hacían manifiestos sino que se hablaba de la vida por el curso estelar de la aventura y que la aventura elegía a sus sobrevivientes"), Neruda es el que "se gasta hasta el origen" y Huidobro el que sabía de la "poesía como síntesis" y “magia de un tiempo primogénito" (1951 n4:3).

La conexión entre la genealogía vanguardista francesa del número 3 y los poetas de las vanguardias latinoamericanas, la encontramos a continuación en este mismo número 4, en una página que se abre sin título con un ensayo firmado por Wolf Roitman y un poema de André Breton traducido por Raúl Gustavo Aguirre, titulado "El aspecto del agua". Con letras mayúsculas a mitad de página leemos: "Presencia y epitafio del surrealismo en André Breton” (ver imagen 13), la ambigüedad de la conjunción

\footnotetext{
${ }^{189}$ Móbili asumía cierto matiz de dispersión en la decisión de publicar a estos poetas en las páginas de una revista, y no antologados en un libro, por ejemplo: "La poesía en la que creemos la publicamos (...) Podríamos vindicarlos [a Vallejo, Neruda, Huidobro] con ánimo menos disperso, menos delicuescente, menos acuático, con más rigor, con más elementos establecidos contra el olvido, con otro ejército, con la selección establecida en la confianza de los días. Pero la poesía jamás se hace para sobrevivir sino para permanecer. Sus sentidos son el curso de la cosmogonía, la clepsidra sobre el último maremoto" (1951 $\mathrm{n} 4: 3$ ). Encontramos en este pasaje un elemento para pensar las relaciones ente la revista $p b a$ y la editorial del grupo poesía buenos aires. Si bien no son analizadas en la tesis, pueden tomarse como un punto de partida de futuras investigaciones.

${ }^{190}$ Afirma Móbili: "solo a ellos aceptamos como contemporáneos" (1951 n4:3). Este aspecto se ve también en otras citas analizadas en el Capítulo I.
} 
(presencia y epitafio) se expande a los textos de la página, puesto que no sabemos si se refiere al poema traducido o si se trata del título del ensayo de Roitman, o bien, compone una lápida con la breve cita que poesía buenos aires transcribe de Breton:

Es a la inocencia, a la cólera de algunos hombres del porvenir, a la que corresponderá poner aparte del surrealismo lo que no puede dejar de subsistir vivo, para restituirlo, mediante una buena expurgación, a su propio sentido. (1951 n4:7, la cursiva es nuestra)

¿Qué es lo que no puede dejar de subsistir vivo del surrealismo? ¿Por qué poesía buenos aires se dispone, en un número especial dedicado a César Vallejo, Vicente Huidobro y Pablo Neruda, a convertir en zombie -antes que muerto- una sinécdoque del surrealismo (Breton por el movimiento)? Dice Roitman:

Las noticias necrológicas olvidaron citar, como una de las primeras víctimas de la segunda guerra mundial, al surrealismo. (...) Un organismo está muerto en el preciso momento en que su respiración no puede alcanzar la vertical impuesta por su propio rigor. En el preciso momento en que se comienza a tratar vanamente de mantener el equilibrio a toda costa del recuerdo. (1951, $\mathrm{n} 4: 7)$

Y a continuación, en coincidencia con los reproches formulados por Osiris Troiani desde la revista Contorno en 1954 a Aldo Pellegrini sobre la falta de madurez y objetivación histórica del movimiento en Argentina, ${ }^{191}$ Roitman concluye:

Lo importante es ocupar plenamente una edad en la parábola - y el surrealismo supo ocuparla, el pecho siempre descubierto, en todo fuego graneado que promovía la conquista de lo desconocido. (...) A él le tocó cerrar todo un período en la historia de la civilización: en sus veinte años de vida, dentro de la confusión de un sistema que se derrumbaba (sin salvarse de ella), el lenguaje alcanzó todas sus fracciones. (1951, n4:7)

En 1951, en Buenos Aires, la lápida, el epitafio, el cadáver, emergen nuevamente como posibilidad de configurar una manifestación que se encuentra fuera de su tiempo. En la página anterior a "Presencia y epitafio del surrealismo en André Breton", poesía buenos aires publica la traducción de un poema de Tristan Tzara, "El hombre aproximativo", poema repleto de ojos y un mañana que no termina de llegar - "es preciso saber mirar con un ojo más grande que una ciudad", se dice -, el hombre aproximativo es "diverso incomprendido según la voluptuosidad de las corrientes interrogadoras / hombre aproximativo moviéndote en los por poco del destino", a quien "la noche descartada da a luz un navío”, ¿cuándo?, “mañana mañana / mañana sellada de cristal y de larvas / mañana

\footnotetext{
${ }^{191}$ Esto es analizado en el capítulo siguiente.
} 
de pan cocido / mañana de puertas enloquecidas / mañana de guardiana de la caballeriza / mañana de ardillas y civilizadores de vidrios frescos en el río / mañana de buen olor / aliento unido a las estrías del iris" (Tzara $1951 \mathrm{n} 4: 6$ ). Se trata de un poema enmarcado que separa las páginas sin numeración de poesía buenos aires, conecta y distancia al frente de la poesía americana con las subsistencias de Breton, pero también con el ensayo de Tzara que $p b a$ había publicado en el número anterior: "Le surréalisme et l'àpresguerre":

Aparte de la tradición ideológica revolucionaria, existe en los poetas contemporáneos una tradición revolucionaria específicamente poética. yo deseo hablar de la que tiene su origen en los innovadores, en los poetas "malditos", en su espíritu casi heroico frente a los conformismos de la burguesía y que, a través de Nerval, Baudelaire, Lautréamont, Rimbaud, Mallarmè, Jarry, Saint-Pol-Roux y Apollinaire, reunió las diferentes tendencias que van de lo maravilloso al humor, en una visión del mundo a la que, hoy todavía, la poesía no sabría renunciar. (1951, n3:5)

La necesidad de localizar, re-genealogizar el surrealismo, ubicarlo y al mismo tiempo desplazarlo de los lugares asociados a lo vital retorna permanente en las revistas argentinas a mediado de siglo, pero no solo en relación con el surrealismo, sino también con la idea de "escuelas estéticas". Podría pensarse que "el epitafio y presencia" de Breton efectuaba un doble movimiento: por un lado, daba paso a otras formas de la poética vanguardista, según la tríada Vallejo - Huidobro - Neruda; por el otro, resultaría impugnatoria de la pronta aparición de la revista $A$ partir de cero, unos meses después a principios de 1952, dirigida por Enrique Molina y con la fuerte presencia de Aldo Pellegrini, ya que esta última se referenciaba con la "línea particularmente viva del pensamiento contemporáneo" que iba desde el romanticismo alemán al surrealismo (Molina $1952 \mathrm{n} 1: 1$ ).

Por otra parte, A partir de cero dialogaría con la idea extendida de que el surrealismo era algo "muerto". ${ }^{192}$ En esta revista se tradujo por primera vez no solo una selección de fragmentos del Manifiesto surrealista, sino también del entonces reciente Haute Fréquence, como cuestionamiento a la convicción de que el surrealismo - y con él los espíritus de revuelta en el arte - eran un episodio del pasado:

Ni escuela ni capilla, mucho más que una actitud, el surrealismo es, en el sentido más agresivo y más total del término, una aventura. Aventura del hombre y de lo real, lanzados el uno por el otro en el mismo movimiento. Aunque pese a los espiritistas de la crítica sentados alrededor de la mesa, con

\footnotetext{
${ }^{192}$ Esta referencia reaparece en la polémica entre Osiris Troiani y Aldo Pellegrini en 1954 que analizamos en el capítulo III.
} 
todas las luces apagadas para evocar su sombra, el surrealismo continúa defendiéndose en relación con la vida, cuyas fuerzas no ha dejado de exaltar. No hay que tomar al pie de la letra lo que fue antaño, mucho menos la caricatura que de él proponen sus adversarios. Traficantes de una versión de su pasado histórico ritualmente expurgada por sus cuidados, es en vano que intenten presentar como límites del surrealismo los límites, sumamente estrechos, de su entendimiento. (1952, 1:4-5)

En esta cita advertimos una continuidad con la idea del hombre y lo humano como aspecto central que atravesó a las revistas del corpus, pero también a aquellas con las que discutieron. Asimismo, observamos una insistencia en la mención a "lo real" (y no "el realismo") que fue relevante en la construcción de las nociones de imagen a partir de las cuales, las revistas del corpus establecieron operaciones críticas divergentes con respecto a las caracterizadas como "modernizadoras" por las historias de la crítica que leyeron principalmente en Contorno un punto de inflexión.

Dado que fueron las mismas revistas las que discutieron el alcance y la validez de la significación e implicancia de términos como "vanguardia", "surrealismo", "invencionismo", habilitaron también de ese modo operaciones de traducción y selección a través de las cuales establecieron conexiones heterogéneas, por ejemplo vinculando a Roberto Arlt con artistas del surrealismo, o a Bataille con Moholy Nagy. El tiempo de la supervivencia, como tiempo que no termina de morir ni de irrumpir, configura una clave de interpretación del presente antes que la conformación de un programa o manifiesto. Se trata de un tiempo abierto entre un pasado utópico (aún en el sentido distópico de la palabra, si pensamos que aún con la experiencia de Qué en 1928 no hubo un surrealismo en Argentina) pero del cual hay que "poner aparte" "lo que no puede dejar de subsistir vivo". Como afirma Didi-Huberman, las supervivencias "no son, en absoluto, las premisas de una teleología en curso, de un 'sentido evolutivo' cualquiera”, sino “síntomas portadores de desorientación temporal" que portan, "el testimonio de un estadio más originario - y remoto - pero no dicen nada de la evolución como tal” (2009:58). Con lo cual habría que preguntarse, en todo caso, por qué la insistencia en las vanguardias fue una manifestación de la cultura a mediados de siglo XX cuando parecía que eran un conjunto de manifestaciones ya superadas y que ocupaban su lugar en las historias del arte y la literatura.

En este sentido es que las revistas del corpus, leídas desde las historias de la literatura más recientes como "revistas de poesía", pueden ser re-pensadas en una trama propia de la historia de la crítica, en tanto establecieron operaciones que consistían en arrancar del pasado el hecho inconcluso para emparentarlo con el presente. La vanguardia 
no es para Pellegrini, ni Bayley ni Molina una novedad sino una forma de biblioteca que se vuelve dispositivo a partir del cual interpretar el presente.

En esa clave es importante pensar la lectura de la historia de las revistas de vanguardia con la lectura de la historia que hicieron Contorno y Centro, y la configuración de la crítica. Ya que los modos de leer operan desde esa recuperación de utopías pasadas. Ese pasado inconcluso o supervivencia constituye la "historia del medio" de un entre-tiempo que pide ser pensado en la clave de "esa extraña temporalidad perdida" sin los parámetros de la novedad o las teleologías de los precursores. Entre lo nuevo y lo viejo, entre la biblioteca y la polémica, la vanguardia se convierte en un “ojo crítico", una forma de mirar e interpretar los textos del mundo contemporáneo.

La configuración de la vanguardia como dispositivo de lectura temporalmente abierto es leída a continuación como un espacio conflictivo donde nos encontramos con tres tipos de elementos que se tensionan entre sí. En primer lugar, encontramos que las revistas del corpus postularon diversas nociones de "imagen" que recogen distintos aspectos de las imágenes propuestas por el surrealismo desde el primer Manifiesto (1924) y las vanguardias constructivas. Estas nociones tienen una aspiración de totalidad o absoluto con respecto a la búsqueda de "lo real" en el arte, que se vuelve problemática y contradictoria cuando la vanguardia es el dispositivo de lectura. En el siguiente apartado nos ocupamos de caracterizar la imagen "surrealista" e "invencionista" en relación con los presupuestos de las vanguardias históricas; a partir de ese aspecto analizamos el desplazamiento que las intervenciones críticas de las revistas del corpus hacen con respecto a esas nociones. Las intervenciones que analizamos en este segundo capítulo tienen que ver con la pregunta por las conexiones posibles de establecer entre escritores y artistas. Así, en el apartado sobre las polémicas de la crítica vemos cómo el modo de escribir sobre esas conexiones resulta denegatorio de las imágenes poéticas que se postulan: en el marco de la confusión del presente, Aldo Pellegrini-el principal polemista de las publicaciones- se ve obligado a abandonar el habla de la imagen y exige argumentos, razones, fuentes eruditas. Por otra parte, en el apartado sobre las "series de la crítica”, cuyo problema es también el de las conexiones, analizamos cómo las selecciones que allí se exhiben dan cuenta de una heterogeneidad que las aspiraciones de totalidad o absoluto propias de la imagen no resisten. 


\subsection{Hacia la imagen total: surrealismo e invencionismo en el límite de la representación}

Antes de explicitar las diferencias entre la imagen surrealista y la imagen invencionista según se configuraron en las revistas del corpus, me interesa detenerme en la figura de "iluminación profana" que Walter Benjamin elaboró como formulación crítica cuando leyó los (recientes) avatares del surrealismo en Europa a fines de la década del veinte, ya que esta figura nos permite advertir límites y alcances de las discusiones sobre lo real que propusieron Ciclo, pba, A partir de cero y Letra y Línea.

En "El surrealismo: la última instantánea de los intelectuales europeos", Walter Benjamin postuló un desacople entre "imagen" y "comparación" -"nunca se encuentran ambas tan drástica, tan irreconciliablemente separadas como en la política", afirmaba (2014:52) -, sustrayendo a la primera del conjunto de formas retóricas posibles. La diferencia radicaría en que mientras la imagen o "iluminación profana" interviene sobre lo sensible, la comparación solo deviene "iluminación simbólica" ya que se produce sobre la base de la representación. Como señaló Ana Porrúa, esta distinción es propia de las vanguardias, ya que "deja de hablarse de metáfora y se habla de imagen, otra configuración del lenguaje", cuando "Breton, Soupault o Aragon conocen Les chants de Maldoror de Lautréamont, alrededor de 1917/1918" (2019:153). Metáfora y comparación adquieren, en el ensayo de Walter Benjamin, un peso que si no es sinonímico, sí gravita sobre lo mismo que busca rechazarse, ya que el "mal canto a la primavera colmado de metáforas" (2013:51) de los poetas social-demócratas se opone a la revuelta, al "camino del surrealismo, transitado por tejados, pararrayos, goteras, barandas, veletas, artesonados" (35).

El rechazo a la comparación y a la metáfora puede rastrearse en el Primer Manifiesto Surrealista (Breton, 1924):

[...] del acercamiento fortuito de dos términos ha brotado un fulgor particular, el fulgor de la imagen, a cuyo brillo somos infinitamente sensibles. El valor de la imagen depende de la belleza de la chispa obtenida, y por lo tanto es función de la diferencia de potencial entre los dos conductores. Cuando esta diferencia es mínima, como pasa en la comparación, la chispa no se produce. (2012:57)

Y alcanza a nociones como la de "elección objetiva" de René Char, apropiada por Edgar Bayley en poesía buenos aires para afirmar que el poeta no traduce imágenes en palabras 
(no compara ni hace metáforas), las "inventa" (1952, n6); y expandida por Maurice Blanchot en el número de pba dedicado al poeta de Hojas de Hipnos;

Las imágenes, en el poema, no son de ninguna manera una designación o una ilustración de las cosas y de los seres. No son tampoco la expresión de un recuerdo personal, de una asociación objetiva de elementos colocados juntos. Por ejemplo, viendo sobre unas tejas redondeles de luz semejantes a las aceleraciones de un plumaje, digo: "el sol, pavo real sobre el techo"; pero no se trata aquí sino de una metáfora, de un índice exterior, sumamente ajeno a los valores poéticos. (...)

La imagen, en el poema, no es la designación de una cosa, sino la manera en que se cumple la posesión de esa cosa o su destrucción [...]. La imagen es ante todo una imagen, puesto que es la ausencia de todo lo que ella nos da y nos hace alcanzar como la presencia de una ausencia. [...] En esta presencia nueva, la cosa pierde su individualidad de objeto cerrado por el uso, tiende a metamorfosearse en un cosa distinta y en todas las cosas, de manera que la imagen inicial está, ella también, llevada a cambiar y, arrastrada en el ciclo de las metamorfosis, deviene sin cesar un poder, más complejo y más fuerte, de transformar el mundo en un todo mediante la apropiación del deseo. (1953, n11/12:33-34)

El cuestionamiento que Benjamin hace a la "comparación" tiene una densidad política que se conecta lateralmente con la lectura de Blanchot sobre René Char. Para el autor de La part du feu, el "poeta de la resistencia" ofrecía una idea intransitiva de la imagen ("la imagen es ante todo una imagen") donde las cosas se metamorfoseaban perdiendo la individualidad y la significación gastada por el uso. Si bien se trata de una traducción casi literal del original francés ${ }^{193}$-aspecto que descartaría una apropiación particular- no podemos dejar de observar que ambas nociones (lo individual y el uso) eran relevantes para quienes integraban $p b a$, donde este ensayo se publicó por primera vez en español. Para Bayley el poder de la nueva poesía radicaba tanto en la condición vanguardista de desautomatizar a las palabras de su desgaste y naturalización habitual, como en la posibilidad de volver común lo subjetivo. ${ }^{194}$ En ese sentido, la poesía era "conquista social" que "tiend[e] a aumentar el número de los que pueden ver a expensas del número de los que no pueden ver” (“La dirección” en pba 1952, n6:1). Asimismo, la diferencia entre metáfora y metamorfosis que establece Blanchot en torno a la poética de

\footnotetext{
193 'Dans cette présence nouvelle, la chose perd son individualité d'objet fermé par l'usage, elle tend à se métamorphoser en tout autre chose et en toutes choses, de sorte que l'image première est, elle aussi, conduite à changer et, entraînée dans le cycle des métamorphoses, devient sans cesse un pouvoir plus complexe". ${ }^{194}$ Ver nota en Capítulo I.
} 
Char nos remite, políticamente, al ensayo publicado por Ciclo, "El poeta", donde este último postulaba la condición "insolvente" y "refractaria" del poema respecto a "los males de la época".

Walter Benjamin lee a partir de los cruces entre la comparación y la "iluminación profana" del surrealismo una conquista de las vanguardias para pensar la política, y en ese sentido, esta última no se constituye como el parámetro de aquello que las poéticas deben acatar, sino como una forma de intervención cuyo vínculo con lo real tendría tanto para cuestionarse sobre el lenguaje y las imágenes como la literatura. Según Benjamin, el "tesoro imaginero" de los poetas de "la inteligencia burguesa bienpensante de izquierda" -cuya "función propositiva se asienta por entero en un sentido del deber no para con la revolución sino con la cultura tradicional"- (45) son la comparación, el "como si” y el optimismo; es necesario entonces recurrir a la política materialista que se manifiesta en el tipo de imagen que inventaron los surrealistas, para eliminar la "metáfora moral", “organizar el pesimismo". ${ }^{195}$ Sigrid Weigel ha leído este ensayo sobre el surrealismo poniéndolo en relación con otras zonas de su obra donde aborda la distinción entre metáfora e imagen, ${ }^{196}$ y afirma que el centro de la discusión pasa por la idea de que la memoria y la acción se articulan en imágenes y no por su codificación, como sugería

\footnotetext{
${ }^{195}$ Susan Buck Moors (1989), Michael Löwy $(2006,2013)$ y Ricardo Ibarlucía (1998) han leído en este ensayo claves distintas, pero coinciden en afirmar que Benjamin produce un descentramiento del programa artístico para pensar el "ámbito de imágenes" como explosión del tiempo. "De lo que se está hablando es de la revolución, afirma Löwy, desde el principio hasta el final de este ensayo, y todas las iluminaciones profanas solo adquieren su sentido en relación con este último y decisivo punto de fuga". Ibarlucía lo lee como piedra fundamental de Passagem-Werk, ya que esa diferencia entre "sueño romántico" y "sueño surrealista" es la que impulsa a Benjamin a "permutar la mirada histórica sobre lo que ya ha sido por la política" (Löwy 2013:39), y pensar la imagen como "aquello en lo cual lo sido se encuentra con el ahora" (Benjamin 2016:875). Las imágenes del surrealismo importan, entonces, no por su capacidad de ruptura o instauración de lo nuevo según podría leerse en una teoría de la vanguardia (Bürger 2009), sino porque ellas son la materia que abre el tiempo de la experiencia.

${ }^{196}$ Particularmente con el concepto de historia: This image occurs at the end of a text which in terms of its style mimetically performs the transformation of the Surrealist revolt into revolution that it invokes, a text which develops as at an increasingly accelerated pace until it explodes in an uninterrupted striking of the alarm (Wecker-Anschlag). Yet at the same moment that the image of the ringing alarm clock freezes sound and motion into permanence, the movement of the text comes to an abrupt standstill. And while the 'alarm clock that in each minute rings for sixty seconds' has on the one hand the precisely opposite implication to the shots fired at the tower clocks during the July revolution 'pour arrêter le jour', of which Benjamin writes in the fifteenth section of his text 'On the Concept of History' (GS I.2, 702; Ill 264), it is also the case that both - the functioning of the alarm clock, intensified into immeasurability, as also the violent arresting of the tower clocks in order to make 'remembrance' possible - have the same ultimate effect. 'Irrités contre l'heure', both are strikes (Anschläge) against clocks, strikes of the now-time (Jetztzeit) against the measured, continuous, linear progression of time — or 'homogeneous, empty time', as Benjamin will call it in the historico theoretical theses. Yet between these two images a difference may be remarked upon, readable as an allegory of the difference in conceptual armatures that give the texts of 1929 and 1940 their respective characters: body-and image-space in 'Surrealism', and the dialectical image in the theses on the concept of history (2005:15).
} 
Habermas. ${ }^{197}$ A partir de esta observación es que me interesa detenerme en el concepto o figura de "iluminación profana", ya que esta aloja el punto de encuentro entre imagen y acción, del que se desprenden otros aspectos largamente discutidos por las vanguardias de la primera mitad del siglo XX, antes que detenerme en la discusión política que lleva a Benjamin a medir la radicalidad de los partidos políticos de izquierda con el alcance de las imágenes ofrecidas por el surrealismo. Por otro lado, esa figura nos permite señalar cuáles son los componentes de la imagen surrealista que identifica Benjamin en relación con una "inspiración antropológica, materialista" (2014:35), a partir de lo cual es posible establecer contrapuntos entre ese surrealismo y la apropiación local que hacen principalmente Aldo Pellegrini y Enrique Molina, así como también con la imagen del constructivismo devenido invencionismo poético que propone una revista como poesía buenos aires.

Tomo entonces una cita extensa, muy conocida, pero igualmente difícil aún hoy:

En realidad de lo que se trata es mucho menos de convertir al artista de procedencia burguesa en maestro del "arte proletario" como de conseguir que opere, aun a costa de su actividad artística, en las zonas importantes de ese ámbito de imágenes. Es más, la interrupción de su "carrera artística", ¿no debiera ser tal vez un elemento esencial de esa función? Tanto mejores serán los chistes que cuente. Y tanto mejor los contará. Porque también en el chiste, en el insulto, en el malentendido, ahí cuando una acción genere una imagen y se encarne en ella, absorbiéndola y devorándola, ahí donde la cercanía se aleje de sí misma para verse mejor, podrá abrirse ese ámbito de imágenes que andamos buscando: un mundo de actualidad universal y total en el que ya no haya "aposento noble", es decir, un ámbito en el que el materialismo político y la criatura física comparten al hombre interior, la psique, al individuo (o lo que fuere $)^{198}$ siguiendo una justicia dialéctica que nada deje intacto. Tras esa destrucción dialéctica, ese ámbito seguirá siendo un ámbito de imágenes ${ }^{199}$,

\footnotetext{
${ }^{197}$ For the precondition of the model of Aktualität put forward in the Surrealism essay is precisely the differentiation from metaphor, the 'distinction between metaphor and image' (GS II.1, 308; OWS 238). What is under discussion here is not, then, the 'encoding' (Habermas 1972:40) of meanings in images, but the insight that memory and action find articulation in images, that ideas are structured as images, and that what is at stake is therefore a praxis that can operate with images - a politics of images, not a figurative or metaphorical politics (2005:8).

${ }^{198}$ Sólo cuando el hombre real, individual, reabsorba en sí mismo al ciudadano abstracto y, como hombre individual, exista a nivel de especie en su vida empírica, en su trabajo individual, en sus relaciones individuales; sólo cuando, habiendo reconocido y organizado sus fuerzas propias como fuerzas sociales, ya no las separe de sí en forma de fuerza política; sólo entonces se habrá cumplido la emancipación humana. (CJ, pág. 201)

${ }^{199}$ La libertad en este campo [del trabajo] sólo puede consistir en el hombre socializado, los productores asociados, que regulan racionalmente su intercambio con la Naturaleza y logran esto con el menor gasto de energía y bajo las condiciones más favorables para su naturaleza humana y dignas de ella. Pero, no obstante, perdura un ámbito de necesidad. Más allá de él comienza ese desarrollo de energía humana que es un fin
} 
pero será más concreto, más corporal. Pues hemos de reconocer que el materialismo metafísico de un Vogt o un Bujarin no se traduce fácilmente en el materialismo antropológico reflejado en la experiencia de los surrealistas o, antes, en las de Hebel, Georg Büchner, Nietzsche o Rimbaud. Siempre queda un residuo. También lo colectivo es corpóreo. (Benjamin, 2014:52-53)

La idea de que la acción debe generar una imagen y a su vez devorarla se vincula con la conclusión final del párrafo, donde la expresión "ámbito de imágenes" se define a partir de lo corporal y no de lo simbólico o la trascendencia. La palabra que articula esa expresión es "Raum" o "Bilderraum" que puede ser traducida como "espacio" ("Dennoch aber wird dieser Raum [espacio] noch Bildraum [espacio de imágenes], und konkreter noch Leibraum [espacio corporal] sein) ${ }^{200}$, y en ese sentido tiene un anclaje más físico o dimensional que la expresión "ámbito". Benjamin diferencia entre "criatura” y hombre / psique / individuo; tensiona lo que el humanismo ha asimilado en su construcción suprimiendo el residuo de su dualismo entre cuerpo y alma. En oposición a "Physique" utiliza "Physische Kreatur", ${ }^{201}$ asociado a una corporeidad no sólo no coincidente con la identidad humana, sino caída de ella; la criatura o creatura está fuera de la cultura y de la lengua. Ese ámbito de imágenes "que andamos buscando" es así "Aktualität" -mundo de actualidad universal y total-, definido, según Weigel, en términos de cuerpo e imagenespacio (6), donde ya no hay "aposentos nobles"; es decir, sin "metáforas morales". La imagen es entonces un espacio concreto, por tanto partible, donde el materialismo político y la creatura "no dejan nada intacto" en la noción de individuo que propone el humanismo. Esa dialéctica "justa" es el tipo de despedazamiento que convierte la imagenespacio en cuerpo espacio (Leibraum). ${ }^{202}$ En otras traducciones, lo que aquí se tradujo como "justicia dialéctica que no deje nada intacto", aparece como "que ni un solo miembro quede sin partir" (Aguirre, 1998:41-62); “daß kein Glied ihm unzerrissen bleibt", unzerrissen se compone con zerrissen adentro, que es justamente desgarrar: entre el materialismo y la corporeidad de la creatura, el ser humano, individuo o psiquis es despedazado, pero lo que se despedaza no es sólo la dicotomía cuerpo / alma, sino la de

en sí mismo, el verdadero ámbito de la libertad que, sin embargo, sólo puede florecer con el ámbito de la necesidad como base. La reducción de la jornada laboral es un requisito básico. (C, vol. 3)

${ }^{200}$ Agradezco especialmente a Juan Ennis por la generosidad con la que me ayudó a indagar en este pasaje compartiendo sus conocimientos sobre el alemán, la filología y la filosofía benjaminiana.

${ }^{201} \mathrm{Al}$ respecto, Ennis observó que la elección del latinismo "kreatur", en lugar del equivalente Geschöpf, debería hacernos pensar sobre el espesor de la palabra "creatura" no del todo idéntica la de "criatura", contenida en el vocablo alemán.

${ }^{202}$ In this space the individual, following his dialectical partition through 'political materialism' and 'physical nature', can remain with 'no limb unrent', thus rendering this image-space at the same time a body-space (Leibraum). (Weigel 16) 
presencia / representación. En ese sentido, la imagen como fuerza performática, como "intervalo hecho visible, la línea de fractura entre las cosas" 203 (Didi-Huberman), lejos de constituir un suplemento que acompaña o ilustra la reflexión, condensa tiempo y acción.

Para no convertir la imagen en un archivo de metáforas o retóricas, Benjamin emplea la figura de "iluminación profana" como el instante de la materialización de la imagen-espacio en un tiempo encarnado (Jetztzeit). Para Weigel, se trata de una huelga contra el tiempo, en tanto huelga a la oposición entre lo orgánico y lo mecánico, entre el ser humano y el dispositivo mecánico. ${ }^{204} \mathrm{Si}$ bien las implicancias de figuras como "iluminación profana" y espacio de imágenes como espacio corporal tienen el fondo espeso del disparate surrealista (Antelo), de la mesa de montaje, los cuerpos lautreamonianos ("En mi nuca crece, como en un estercolero, un hongo enorme de pedúnculos umbelíferos", C.4: 186-7) y las visiones de Rimbaud; la lucha por sortear las trampas de la representación es tal vez el horizonte compartido por todas las vanguardias del siglo XX, cuyas diferencias encontramos luego en las decisiones y énfasis sobre cuáles deben ser los procedimientos para alcanzar una imagen-acción y no una imagensímbolo, entendiendo que en esos procedimientos se define el tipo de política del arte que cada movimiento propuso.

En el plano argentino, porteño más precisamente, ese conflicto fue reapropiado con algunos aspectos particulares. La imagen como cuerpo - potencia cuestionadora de los límites entre lo orgánico y lo mecánico- está en el centro de la polémica oculta que se dio entre quienes veían la liberación del hombre a través del poder de la intuición -la entrega a "ninguna determinación preliminar" (Breton, 37)- según las exaltaciones del automatismo surrealista (Aldo Pellegrini, Enrique Molina, Carlos Latorre) y quienes afirmaban que era necesario "liberar la inocencia y la fluidez poética a través de una sostenida inteligencia" (Edgar Bayley, Camilo ArdénQuin, Alfredo Hlito, Wolf Roitman, Raúl Gustavo Aguirre). En ambos casos se trató, finalmente, de la lucha contra la representación, entendiendo por ello la "ilusión mimética", fundada en el criterio según

\footnotetext{
${ }^{203}$ La imagen no es ni un simple acontecimiento en el devenir histórico ni un bloque de eternidad insensible a las condiciones de ese devenir.

${ }^{204}$ In the exchange of the play of features for the face of the clock, image-space has become body-space. The strike against time is thus simultaneously a strike against the notion of the opposition between the organic and the mechanical, between the human being and the mechanical device. The boundary between the two is here eliminated - in a manner which produces a profound impact, for the face is the very epitome of the 'humanity' of the human being - just as the 'best room' is eliminated in a 'world of universal and integral actuality' which opens itself up in the course of this exchange (GS II.1, 309; OWS 239). It is not by chance, then, that the image of the alarm clock follows a passage in which Benjamin develops and condenses his ideas concerning body-and image-space.
} 
el cual "la obra de arte nacía como signo de una identidad personal, natural, conceptual (...), nacía así como representación (...). Pero nunca una obra ha valido por su capacidad de acuerdo con una realidad cualquiera, exterior a ella" (Bayley 1944:9). La refutación de este principio de acuerdo se vincula con lo que postulaba Aldo Pellegrini en "El huevo filosófico" (1952, n2:3) como cuestionamiento a los escritores realistas, mencionado el capítulo anterior: "admitir como real solo las apariencias sensibles equivale a reducir el mundo y limitar las posibilidades del hombre. (...) Al tratar de transformar esta realidad empírica, de mero aspecto efímero de lo real en una realidad en sí, lo único que se logra es un fenómeno espectral".

A partir de notaciones como las de Bayley y Pellegrini, se advierte que en esa lucha contra la representación, ya sea por las vías del borramiento de las diferencias entre términos opuestos (vigilia / sueño, consciente / inconsciente, realidad / irrealidad) o por la depuración de figuras que engañan la ilusión (la imagen blanca), la noción de imagen fue tan importante como problemática para los modos de intervenir de la crítica en las revistas del corpus. En primer lugar porque la lucha contra la representación estuvo atravesada por un deseo de totalidad (depuración total o síntesis total) que no se correspondía con los cruces entre corrientes estéticas, ampliaciones temporales y heterogeneidades de firmas a partir de los cuales las revistas establecieron sus operaciones de lectura y selección. En segundo lugar, porque, como advertiremos a lo largo del capítulo, la dimensión polémica de la crítica tal como fue ocupada por Ciclo, pba, A partir de cero y Letra y Línea, impuso una forma de la discursividad que resultó contraria a la política de la lengua que suponían tales imágenes. La importancia a partir de la cual se revelan estas tensiones señaladas, radicaría en la centralidad que la noción de imagen, tanto surrealista como invencionista, le dio al problema de lo "real", aspecto relevante en relación con las discusiones contemporáneas sobre el realismo. Parto entonces de las diferencias entre la imagen surrealista y la invencionista, para luego analizar cuáles son sus límites comunes y los devenires en la crítica.

\subsubsection{Síntesis y depuración: formas de lo total}

Como señalamos en el primer capítulo, Aldo Pellegrini entendía que los sentidos y la ciencia aportaban datos parciales sobre la realidad en tanto solo captaban el "velo que oculta lo real" (1952, n2:3); así, al lenguaje "rígido, inmóvil, [que] queda detrás de la 
realidad", oponía el lenguaje móvil del surrealismo con el cual el surrealista persigue la "realidad total, síntesis ilimitada de sujeto y objeto" (3, las cursivas son nuestras). Raúl Gustavo Aguirre también define a la poesía como un dominio "más allá de las formas inteligibles" con las cuales el poeta lucha, pero queda inconforme:

El poeta no puede renunciar a aquello que el empleo de la razón no le proporciona, a aquella parte del mundo que funciona fuera de lo alcances de sus sistemas. Es más, ahora comenzamos a ver que el dominio de la poesía es un dominio que parece funcionar más allá de las formas inteligibles, explicables, de la realidad. Pero el poeta no es un ser irracional, si con esto se quiere dar a entender que ha renunciado a la facultad de intelectualizar la realidad, pero sí irracional si se quiere decir que no se ha quedado conforme con esta intelectualización. (1952, n9:1)

Las dos citas presentan un matiz de incumplimiento respecto a lo que aspiran; en el caso de Pellegrini tematizado con el verbo "persigue" y en Aguirre, con el uso de los términos "irracional" e "intelectualizar", atribuyendo a este último una tarea no acabada.

No es casual que Aguirre hubiera elegido esos términos y les repusiera un movimiento del que carecían tiempo atrás, en los escritos invencionistas de otros miembros de la revista como Edgar Bayley. Aguirre aporta una oscilación, un punto de encuentro y de diferencia con respecto al tipo de definición del que había propuesto Bayley en 1946: "el surrealismo coloca el poema en realidades que le son extrañas. No construye realidad. Se limita a describir el hecho surrealista" (1946, n1:13). La imagen invencionista de entonces no hubiera aceptado el "pero sí irracional" de Aguirre, porque se trataba de una imagen-concepto, que construía en el poema un hecho, y no un símbolo. No buscaba "relacionar el poema con objetos determinados", como en la "antigua estética" (Bayley 1946, n1:13) 205, sino "vivir el poema como acontecimiento de nuestra vida mental, y no como una re-presentación en la que somos meros espectadores" (13).

El acercamiento de una posición como la de Aguirre y la de Pellegrini era posible ya que, como observamos en el capítulo anterior, para $p b a$ "la actitud renovadora (...) no se limita[ba] a una particular tendencia, a un ismo determinado", sino que se fundaba en su capacidad de producir una "combinación inventiva de las palabras" (Bayley, 1952: pba n7). Así, la diferencia persistiría, insuprimible, en torno a la idea de invención. Edgar Bayley afirmaba que "la realidad emocional, imprescindible para la existencia misma de

\footnotetext{
205 El texto continuaba: "no queremos representar realidades ni surrealidades; no queremos publicar biografías ni autobiografías. La vivencia, en cualquiera de sus formas, tiene la recompensa en sí misma; el reemplazo de una vivencia por cualquier otro tipo de realidad es imposible, y los intentos para conseguirlo solo conducen al debilitamiento de la vivencia o, bien, a su completa anulación" ("Sobre invención poética en Invención / Arte Concreto, 1946, n1).
} 
la poesía, no se puede alcanzar por sí sola en el nivel poético" y que por lo tanto "no basta traducir la emoción o el estado de gracia poéticos para obtener un poema" (Bayley, 1952 n7:7); pero ese "nivel poético" sólo se alcanzaría por el poder de la conciencia como instrumento, y no por la escritura automática, la intuición o el inconsciente surrealista.

De manera similar, la afirmación de Pellegrini sobre de la ciencia y los sentidos como insuficientes para captar la "síntesis ilimitada de sujeto y objeto" se acercaba bastante al análisis de un artista concreto - marxista y materialista- como Alfredo Hlito quien, como vimos, había formado parte de la revista Ciclo:

La imagen percibida o representada no agota la realidad del objeto; no hace más que abstraer de él una de sus propiedades (la de ser percibido o representado), pero sin enseñarnos nada sobre la composición de su naturaleza y, menos aún, sobre la multiplicidad de sus relaciones. (1946, $\mathrm{n} 2: 7)$

¿Cuál es esa multiplicidad de relaciones? ¿Relaciones entre qué? Alfredo Hlito sugiere apenas que se trataría de la "actividad real", "su proceso", por lo cual la representación solo puede alienar el objeto ya que no contiene los elementos, sino solo uno -la percepción-:

La representación no retorna de lo subjetivo a lo objetivo, como acontece en la actividad concreta, sino que duplica la subjetividad, y en el producto de la duplicación pretende ver el objeto. (7)

Por este motivo, concluye Hlito: "El arte representativo entraña la alienación del hombre en tanto genérico (social)", ya que "la alienación del objeto es la alienación del sujeto por cuanto es la expresión artística de esa alienación” (7).

Con estos acercamientos y diferencias buscamos señalar que en las revistas argentinas vinculadas con las vanguardias históricas, la noción de imagen estuvo atravesada por tres fenómenos simultáneos que expusieron al mismo tiempo la crisis de los manifiestos y el deseo de no renunciar a la experimentación: 1) el abandono del "invencionismo" como escuela a seguir en $p b a$-"Ningún dogma. Lo que alguna vez hemos distinguido con la palabra invencionismo constituye una incitación útil, pero prescindible" (Aguirre 1953 n13-14:2); 2) el esfuerzo sostenido y compartido por todas para encontrar formas de combatir la "ilusión de representación", que se manifiesta en el intercambio entre "las revistas de Aldo Pellegrini" y "la de Aguirre"; 3) las contradicciones que el uso de la noción de imagen suscitó en muchas escrituras críticas. Si bien las revistas de nuestro corpus encontraron en el rechazo a la metáfora y la comparación un cuestionamiento a las formas representacionales, tal como sugería Walter 
Benjamin, predominó en ellas la aspiración a que la imagen fuera total. Uno de los efectos de ese énfasis fue la sunstancialización de esas ideas, que no se corresponden completamente con las discusiones propuestas en las polémicas más explícitas, ni con la heterogeneidad que postulan las series de la crítica.

En "La imagen y el archivo: formas de contacto", Ana Porrúa vuelve a la imagen surrealista de la mesa de disección -donde se produce el encuentro fortuito de una máquina de coser y de un paraguas- para analizar las operaciones de corte que los surrealistas franceses hacen del texto lautreamoniano, antes que para indagar en ese montaje impertinente donde el tipo de composición a partir de "naturaleza muerta" es entonces sustituida por objetos. Según Porrúa, "la imagen surrealista abandona el archivo que hizo posible el poema en prosa de Lautréamont" (2019:153), ya que no toma lo orgánico que constituye "la arena de las metamorfosis" (155) en Les Chants. Asimismo, mantiene de la lectura lautreamonsiana "la operación de desajuste [...]: el salto de una cosa a otra, que sigue haciendo pie en la diferencia, en la singularidad" (153). Porrúa repone entonces otra cita del Manifiesto del surrealismo que dialoga con la que citamos en el parágrafo anterior:

La imagen es una creación pura del espíritu.

No puede nacer de una comparación sino del acercamiento de dos realidades más o menos alejadas.

Cuanto más distantes y precisas sean las relaciones entre las dos realidades que se ponen en contacto, más intensa será la imagen, y tendrá más fuerza emotiva y realidad poética... (Breton, 2012: 38)

Lo singular es que Aldo Pellegrini, traductor de Breton y en particular de esos manifiestos -publicados por primera vez en Argentina en 1965, aunque traducidos sin éxito de edición treinta años atrás- no reparara en la imagen por distancia, en el montaje, sino en la “fusión”, el momento de síntesis, como si la composición se borrara. Por eso la noción de imagen de Pellegrini, de Molina, y los surrealistas que colaboraban en A partir de cero y en menor medida en Letra y Línea hizo pie en la noción de instante, en la iluminación, de manera mucho más contundente que en otras dimensiones de la distancia. Así como Breton corta "el contexto" de Les Chants de Maldoror, según señala Porrúa, y se queda con el desajuste, con la colección; ${ }^{206}$ Pellegrini ignora el montaje y privilegia la idea de

\footnotetext{
${ }^{206}$ Sobre la idea de "colección", dice Porrúa: "La imagen surrealista, al menos en el corte que hemos visto de la comparación de Lautréamont responde, creo, a otra dispositio que asociamos con la colección. En principio porque los elementos de una colección están separados de su contexto de procedencia; en esa elección se diseña un nuevo conjunto de figuras singulares que se corresponden desde ciertos principios. Si cotejamos la colección de André Breton con los grabados de los gabinetes de curiosidades podríamos
} 
"fusión". La discusión sobre la imagen que proponen los surrealistas argentinos en la mayoría de sus ensayos ${ }^{207}$ se configura en ese intervalo entre la búsqueda de fusión o síntesis y lo que el instante permite aprehender. Si de Les Chants los surrealistas franceses se quedan con la máquina y el paraguas sobre la mesa de disección, Pellegrini escoge el "encuentro fortuito" como un fulgor, recorta esa imagen en relación con la síntesis y no con la disección. Así, una de las funciones de "la imagen que entra en combustión, la imagen iluminadora" (Pellegrini, 1952 n2:3) es que "condensa la suma de los conocimientos posibles" y encuentra "el momento en que el lenguaje poético puede dar con esa síntesis" (3).

Es imposible no ver, en la selección de Pellegrini, el peso del humanismo como horizonte de integralidad para la "liberación", como si el montaje pusiera en riesgo la organicidad del cuerpo. ${ }^{208} \mathrm{El}$ invencionismo, por su parte, vacía la imagen, porque donde Benjamin ve un símbolo a destruir por los efectos de la "iluminación profana", Maldonado, Bayley, Hlito, ven "los residuos que facilitan la aparición ficticia de cosas, que, aunque no se había buscado representar, emergen por sí solas al ojo del espectador" (Maldonado 1946 n1:5). Así, la discusión entre las revistas se encuentra a su vez con dos límites: la cuestión de lo "humano" que permanece imperturbable en la mayoría de las conformaciones de la imagen, y la aspiración de alcanzar una imagen "total". Breton exclamaba la "synthèse du poétique et du politique"; en continuidad con esa cita, Enrique Molina proponía la idea de síntesis como dirección hacia la cual el surrealismo se encaminaba: "día llegará en que las expresiones movimiento continuo o movimiento celeste y MOVIMIENTO SURREALISTA habrán de considerarse absolutamente sinónimas" (1952, n1:4); "Bajo la capa superficial del intelecto se encuentran en un punto único los dos conos opuestos del mundo interior y el mundo exterior" (Molina 1952, $\mathrm{n} 2: 1)$. A esto, y en la estela abierta por las vanguardias constructivistas, se le oponía otra imagen igualmente totalizante que es la depurativa del invencionismo, "Ni aun una supuesta belleza representativa podría justificar una traición al conocimiento", como otra

\footnotetext{
destacar al menos dos cualidades, un universo ordenado en términos estéticos, equilibrado, sopesado: lanzas africanas, máscaras y piezas del arte de Oceanía y Australia, junto a obras de Picabia o Joan Miró. (2019: 162-163).

${ }^{207}$ Especialmente "Vía libre" (Molina 1952 en A partir de cero n1); "Un golpe del sentido sobre el tambor" (Molina 1952 en A partir de cero n2); "El poder la palabra" (Pellegrini en A partir de cero $\mathrm{n} 1$ ); "El huevo filosófico" (Pellegrini en A partir de cero n2); "Aimé Césaire" (Molina en Letra y Línea n1); "Nuevos poemas de Oliverio Girondo" (Pellegrini en Letra y Línea n2).

${ }^{208}$ Sobre el peso del humanismo y la centralidad del hombre en los debates literarios de mediados de siglo en Argentina, ver el tratamiento pormenorizado de Judith Podlubne (2014) que recuperamos en el capítulo III para analizar el tipo de apropiación que hicieron las revistas del corpus de la noción batailleana de "instante".
} 
forma de no ceder a la vigilancia de la aparición de fantasmas o duplicaciones, como reclamaba Afredo Hlito.

En la oposición de esta imagen invencionista al símbolo ${ }^{209}$ también hay un fundamento de carácter político, ya que se según Bayley solo la imagen despojada de referencias a otros signos constituye el terreno común donde cualquier hombre puede participar de la "plenitud creadora, el júbilo intraducible e irremplazable". Pero, mientras para Walter Benjamin el símbolo se destruye porque se despedazan las partes que constituyen una dicotomía y por tanto el sistema dual de presencia / representación por vía de la "iluminación profana"; esto supone un instante, una interrupción donde se materializa una imagen-otra, para los invencionistas, el símbolo se destruye por extremar la conciencia ("la conciencia se libera de referirse a realidades extrañas"). Es decir que, para Bayley, muy tempranamente, a una "nueva forma de organización social" debía proponérsele un nuevo arte, pero no un arte que representara esa novedad sino que fuera él mismo nuevo. Lo que une esa vida nueva con un arte nuevo es entonces una distancia que no los hace corresponder directamente sino entrar en contacto por el pasaje de "un mundo sensible a otro mundo sensible que define otras tolerancias e intolerancias, otras capacidades e incapacidades" (Rancière 2010:69). Por eso "no se trata de embellecer al mundo en la obra de arte o en la imaginación, o de afearlo, o, simplemente de copiarlo. Es preciso inventar nuevas realidades. Es preciso reconstruir el mundo" (Bayley 1945, $\mathrm{n} 2: 3)$.

"El arte realista crea fantasmas de cosas" acusaba el Manifiesto Invencionista que se publica en el primer número de Invención / Arte Concreto (1946). La pregunta que podríamos hacernos es si la representación crea los fantasmas o si acaso la aparición ficticia de cosas es una emergencia "por sí sola”. Ante ambas opciones advertimos que el fantasma es lo incalculado del proceso de depuración al cual la AACI somete a la imagen. Lo insuprimible de esa fantasmagoría recurrente hace resonar toda una tradición de la iconofilia, posible de remontarse - según Alain Besançon 2011 - a la teoría de Platón y Aristóteles:

Según Kant, las ideas metafísicas son ilusorias, pero necesarias. "Ni el más sabio de todos los hombres puede librarse de ellas". La tarea de la crítica es impedir que la ilusión nos engañe: no puede hacerla desaparecer. Lo mismo ocurre con la representación de lo divino en Platón. Fuera de la

\footnotetext{
209 "La fantasía y el hecho gratuito son adversarios del nuevo arte solo en la medida en que lleguen a transformarse en simbólicos. Si carecen de toda significación o justificación, constituyen la alegría que conduce a la comunión" (Bayley 1945, n2:4).
} 
filosofía y de la dialéctica, se convierte en error. Por eso Platón sitúa al artista junto al sofista. (2011:54)

La idea de que la imitación, y por tanto la representación, están lejos de lo verdadero es una idea convergente entre los concretos y los antiguos, aunque el horizonte de resolución sea otro, ya que para los concretos la ilusión propiciada por el arte imitativo puede superarse por la invención estricta; es decir, eliminando la idea "pequeño burguesa del tema" se alcanzaría la novedad, el júbilo, puesto que nada semejaría las experiencias codificadas previamente.

Si la materia es una maldición -“Es que, como dijo Engels, el espíritu lleva la maldición de la materia", reclamaba Hlito-, es en sí misma una forma de la excedencia, y no hay imagen que pueda retener las espectralidades que produce. En el comienzo de Fantasmas, Daniel Link anota que con ese título busca nombrar el "modo en que lo real rebota sin cesar en superficies no siempre planas para producir lo deforme o lo informe" (2009:10). El fantasma es así el que "marca el propio límite de la interpelación” porque la interpelación nunca lo alcanza; se trata de una imagen, según Link recuperando a Alberto Moreiras, que "llega absolutamente, sin considerar las expectativas, un visitante más que un invitado", y agrega:

Una forma misteriosa e inquietante de presencia política, hasta el punto que esta mantiene, en y a través de su llegada, un resto duro, un resto de lo que siempre ha estado ahí, más allá de la sujeción, más allá de la comprensión (...) un invisible punctumde materialidad ineluctable, intratable, siempre en el otro lado de la pertenencia, de cualquier pertenencia. (2009:12)

El fantasma, glosa Link, es "el no-sujeto (y, por eso mismo, político)"; si la clase es un dispositivo de interpelación, el "fantasma es su resto", como lo que estaba ya antes. ${ }^{210}$ Es decir que el fantasma no es ideológico. ${ }^{211}$

\footnotetext{
${ }^{210}$ La proliferación fantasmagórica de residuos representacionales que preocupa a los artistas-teóricos de la AACI, nos puede derivar, a su vez, en la definición que propone Rancière para la estética como una idea de pensamiento que descansa en una afirmación fundamental: "hay pensamiento que no piensa, hay pensamiento que obra no solo en el elemento extranjero del no-pensamiento, sino en la forma misma del no-pensamiento" (2005:46). Esa diferencia en lo mismo define a la estética como heterogeneidad instituyente de pathos y logos por la cual "lo propio del arte es ser la identidad de una acción consciente y de una acción inconsciente, de una acción deseada y de un proceso involuntario" (42); por eso a este régimen le corresponde un tipo de escritura: la palabra muda, aquella que no puede "dar cuenta de lo que profiere, ni discernir quiénes son aquellos a los que conviene o no conviene dirigirse" (46-47). Curiosamente aquí es donde tal vez se manifieste con mayor fuerza la eficacia paradójica del arte, en términos de Rancière, para los mismos artistas de la AACI, ya que son ellos quienes advierten como problemática una parte de esa distancia entre la obra y la voluntad que no pueden reconducir como quisieran para las fuerzas de la Revolución. La obra ha desbordado sus propósitos de eficacia ética.

${ }^{211}$ Lo espectral o ficticio como residuo involuntarios de las obras ciñe una preocupación política, puesto que son los efectos de debilidad o fortaleza (del conocimiento) los que se ponen en juego cuando el fantasma
} 
La imagen anti-representacional, tanto la surrealista como la invencionista, no pueden sino producir los espectros de aquello que quisieran desterrar: el espacio representativo, la ilusión idealista. Se trata en parte de lo que Alain Badiou pensó como "pasión de lo real" alojada en la búsqueda constante de depuración del semblante para que emergiera lo real. La operación de la sospecha sobre la imagen nunca puede detenerse porque "nada puede atestiguar que lo real es real, salvo el sistema de ficción en el cual representará el papel de real", en consecuencia “siempre es preciso depurar públicamente la correlación entre una categoría y su referente, lo cual significa depurar a ciertos sujetos entre aquellos que reivindican su pertenencia a la categoría en cuestión” (2011:75).

Donde Benjamin veía "descarga revolucionaria", ${ }^{212}$ la acción de los concretos e invencionistas persigue ese "residuo" (Benjamin 2014:53) que siempre queda, para suprimirlo, hacer de la imagen no una diferencia mínima, sino depuración absoluta. En la imagen surrealista, la aspiración de totalidad está dada por la síntesis. En "El surrealismo: la última instantánea de los intelectuales europeos", Benjamin advirtió los peligros de la síntesis como ausencia de "resquicios" y por tanto amenaza de totalidad sobre el lenguaje: cuando irrumpió sobre sus fundadores como una ola cargada de sueños (...) hacía suyo cuanto tocaba. El lenguaje parecía serlo solo si sonido e imagen, imagen y sonido se interpelaban con tal automática y feliz exactitud que no

\footnotetext{
emerge. La política remite, explícitamente en las publicaciones de la AACI al marxismo y su correlación en la Unión Soviética post-revolucionaria, según el deseo de generar las condiciones para una sociedad comunista en Argentina. Pero su resonancia inmediata son las políticas del primer peronismo. En ese sentido, tal vez valgan los cruces entre artistas concretos, peronismo y PCA, dados ya no solamente por sus encuentros o desencuentros explícitos, por los finaciamientos o clausuras de las muestras, comunicados o expulsiones partidarias - como las de Hlito y Maldonado del PCA -; sino por las irreductibles fantasmagorías que arroja toda imagen, toda materia, y que“emerge por sí sola al ojo del espectador". ¿Es posible que el arte concreto sea el ojo por el cual mirar la relación entre técnica y progreso que proponía el peronismo?, ¿como si en las ficciones de las cosas emergiera, por ejemplo, la figuración del I.Ae. 27 Pulqui diseñado en 1946 y puesto en funcionamiento en agosto de 1947?, ¿puede ser el peronismo el nopensamiento de una forma?, ¿puede la figuración arrastrar consigo el pathos del logos científicorevolucionario que la AACI intentó instalar con esfuerzos de distinción y depuración? Tanto el peronismo como el arte concreto pensaron que su lugar era "la plaza pública" (Bayley en "Introducción al arte concreto", y Maldonado en "Sobre Humanismo"). El fantasma del realismo, pero que es también imposible de detener frente a cualquier obra, se presenta como un vínculo no-ideológico sino afectivo, un horror a la realización (como ser ceñido $a$, como cristalización, comunidad organizada). Pero a su vez, es un horro al exceso, al gasto. Aparece entonces otra dimensión del arte político donde ya no se trata de la eficiencia paradójica, la depuración, o la debilidad de la imagen como acto democrático, sino de lo incalculado una presencia-otra. Si lo anacrónico del arte consiste, muchas veces, en exceder el régimen de verdad de una época, su reverso posible también se encuentra en una contemporaneidad tal que, queriendo escapar al signo, a la "comunidad organizada" propuesta en la doctrina, produce las espectralidades de su tiempo. La contemporaneidad del arte concreto-invención es tocada por lo desconocido (monstruoso, in-nombrable), el visitante que llega sin considerar las expectativas - ni los programas, ni las diferencias manifiestas.

212 "Solo cuando cuerpo e imagen se hayan interpenetrado tan hondamente que toda tensión revolucionaria se vuelva enervación del cuerpo colectivo y todas las enervaciones del cuerpo colectivo se vuelvan descarga revolucionaria, se habrá superado la realidad tal como lo exige el Manifiesto comunista." (Benjamin 2014:54)
} 
dejaban resquicio alguno por donde insertar la ficha del "sentido". Imagen y lenguaje se imponían. (...) El lenguaje tiene la precedencia. (2013:33)

Años más tarde, Blanchot haría una observación similar sobre esa feliz exactitud entre imagen y sonido que el surrealismo perseguía como anterioridad del lenguaje, en tanto este sería ya una codificación arbitraria, representativa, y parcial de la realidad. Si el surrealismo era una "máquina de guerra contra la reflexión y el lenguaje" (Blanchot 2007:84) y por lo tanto permitiría correr el centro de la noción de compromiso hacia otra, más potente, la de distancia íntima de la literatura respecto de aquello que toca; Blanchot señalaba también un peligro de esa "máquina": que la escritura automática se convirtiera en un nuevo sujeto, un Cogito, afirmada en ser ella la realidad anterior al discurso:

El surrealismo estuvo obsesionado por esta idea: hay y debe haber en la constitución del hombre un momento en que (...) el lenguaje no sea discurso, sino la realidad misma, sin no obstante dejar de ser la realidad propia del lenguaje, donde por fin el hombre toque lo absoluto. (2007: 84).

Frente a esa obsesión, Blanchot piensa la escritura automática como relación de distancia entre lo no dado y lo existente (ni la realidad ni la poesía están nunca donde están, por eso tienen la posibilidad de ad-venir), entre la inconclusión y la totalidad (sólo hay instantes privilegiados en los cuales la escritura es capaz de captar una totalidad como condición de su incumplimiento). Al deseo identitario de supresión de cualquier "residuo", ${ }^{213}$ o el deseo de la literatura por llegar a la presencia anterior ubicada inalcanzablemente detrás del lenguaje, Blanchot lo reconfigura desde una negatividad: la distancia por contacto. No habría, entonces, lenguaje como discurso y lenguaje como realidad misma, sino momentos, "instantes privilegiados" de totalidades inacabadas, y como tales, fragmentos que nos disponen hacia la inaccesibilidad de lo inmediato. El hombre nunca toca lo absoluto sino la desaparición de su aparición. Así, la identificación entre lenguaje y realidad por fuera de lo discursivo, como pretende el surrealismo en la escritura automática, consistiría en una identidad que se manifiesta solo cada vez que intentando manifestarse, fracasa. En esa distancia íntima o distancia por contacto, como "realidad increada", radicaría la potencia del surrealismo si suspende sus sueños de absoluto, capaz de señalar aún veinte años después de su primer manifiesto, una política de la creación que se hace lugar en las pugnas totalizantes:

\footnotetext{
213 Esto puede pensarse también desde lo que Jacques Rancière formuló como "este malentendido conflictivo en torno a la literatura no es otra cosa que la literatura misma en tanto régimen determinado del arte de escribir. La supresión de la distancia entre las palabras y las cosas es el sueño constitutivo a cuya sombra se despliega el recorrido interminable del intervalo que las separa" (2011:217).
} 
La literatura más desapegada es al mismo tiempo la más comprometida, en la medida en que ella sabe que pretenderse libre, en una sociedad que no lo es, es hacerse cargo de las servidumbres de esta sociedad y sobre todo aceptar el sentido mistificador de la palabra libertad por el que esta sociedad mistifica sus pretensiones.

En suma, la literatura debe tener una eficacia y un sentido extraliterarios, es decir, no renunciar a sus medios literarios, y debe ser libre, es decir, comprometida. Quizás, considerando el valor de estas paradojas comprendamos por qué el surrealismo es siempre de nuestro tiempo. (2007: $93)^{214}$

El pensamiento de una distancia íntima o totalidad inacabada es desplegado por Blanchot en el ensayo sobre René Char, que $p b a$ traduciría para el número especial dedicado al poeta, donde propuso la noción de "realidad increada":

Cuando Char escribe en "Partición formal" (Solos permanecen): "La imaginación consiste en expulsar de la realidad varias personas incompletas para, sometiendo a contribución las potencias mágicas y subversivas del deseo, obtener su retorno bajo la forma de una presencia enteramente satisfactoria. Es, entonces, la inextinguible realidad increada", bien se ve cómo la imaginación poética se aleja de la realidad para sumarle ese mismo movimiento de alejarse, para llevar al interior de aquello que es, aquello que no es como en su comienzo, la ausencia que vuelve deseable la presencia, lo irreal que permite al poeta pensar lo real, tener de él un "conocimiento productivo". La imaginación poética no se vincula con las cosas y con las personas tales como ellas son dadas, sino con su falta, con lo que en ellas hay de diferente, con la ignorancia que las vuelve infinitas. ("Un ser a quien se ignora es un ser infinito"). (...) Pero cambiada en deseo, la imaginación, en esa ausencia que ha suscitado, reconoce, no la ausencia de nada, sino la ausencia de algo, el movimiento hacia algo cuya realización exige y cuyo "retorno" obtiene sin renunciar al distanciamiento que permite ese retorno. Ahora , ella disfruta de las cosas que son, como si ellas no le estuvieran concedidas, recibe de su presencia la irrealidad que hace esta presencia posible, y realiza lo imaginario volviendo a encontrar lo imaginario en lo real. Tal es la paradoja suprema del poema, si le ocurre ser el "amor realizado por el deseo que ha seguido siendo deseo". (1953, n11/12:34)

Ambos textos, "Reflexiones sobre el surrealismo" y "René Char", habían sido publicados en 1949 en La part du feu, donde también se incluyó "La literatura y el derecho a la muerte". Este libro, que puede pensarse indirectamente como una respuesta al reciente Qu'est-ce que la littérature? (Sartre 1948), ${ }^{215}$ tiene una relevancia doble para nuestro

\footnotetext{
${ }^{214}$ En "Las novelas de Sartre", también en La parte de fuego, define la literatura de tesis: "en las novelas de esta clase, se les reprocha a los personajes el carecer de vida, pero lo que carece de vida es la idea: ella solo se parece a sí misma, solo tiene su propio sentido; ese mundo facticio la oculta demasiado mal, allí es más visible que en su desnudez de origen, tan visible que apenas tiene secretos que ofrecernos" (2013:175). ${ }^{215}$ Un aspecto de esa respuesta lo analizaremos en el capítulo III. Asimismo, Judith Podlubne (2014) ha señalado esto en un análisis sobre los debates literarios de Sur y Contorno: Casi en los mismos términos de Bianco, Noé Jitrik afirmaba "el valor de una literatura [...] consiste en el buen uso de las palabras y no en
} 
corpus y el problema de la imagen como aspiración de totalidad, según lo analizamos en algunos ensayos de las revistas argentinas. En principio, como podemos suponer, se trata de una lectura que los poetas y críticos argentinos probablemente no desconocieran; no solo como lo demuestra la traducción de Aguirre, sino también porque en La part du feu encontramos el ensayo titulado "De Lautréamont a Miller", que conecta los dos números de la revista Ciclo, cuyos artículos principales habían estado dedicados a uno y otro autor respectivamente. Al margen de estos aspectos de circulación que resultan insuficientes, el ensayo de Blanchot sobre el surrealismo da cuenta de su carácter superviviente al señalar tanto el peligro de que el Cogito ocupe toda esa máquina de guerra, ${ }^{216}$ como el hecho de que la escritura automática puede ser impugnatoria de las mistificaciones. En ese sentido, el pensamiento de Blanchot conecta, para las revistas del corpus, los dos tiempos del surrealismo: el de su primera etapa, y el carácter ya no novedoso de su irrupción y sus programas, sino diferencial respecto de los imperativos literarios e ideológicos de la II postguerra.

Por último nos permite observar una continuidad entre el surrealismo francés y las apropiaciones locales, con respecto a un tratamiento del lenguaje que, en su valor integralista (en la síntesis de los opuestos irreconciliables), osciló muchas veces entre el encuentro de una extrañeza en la lengua y la cristalización de un valor. Las revistas de nuestro corpus se propusieron en más de una oportunidad "acabar con la retórica y la mistificación" de la literatura, pero la imagen de fragilidad de la poesía, como huella, relámpago o fósiles, se consolidó como valor antes que como hallazgo. Así, muchas de las escrituras de Molina, Pellegrini, Svanascini, Aguirre, oscilaron entre la acumulación

\footnotetext{
la arbitrariedad de su empleo. Usarlas bien [...] es tener una conciencia aguda de su sentido y una urgencia impostergable de su aplicación" (1955: 39). Mientras para los integrantes de Sur esa urgencia respondía a la necesidad moral de dar cuenta de los ideales propios de la persona humana cuando los creían amenazados, para los jóvenes denuncialistas remitía en cambio a la exigencia (no menos trascendente) de comunicar el sentido de una realidad histórica determinada cuando experimentaban la necesidad de transformarla. Los contenidos diferían de un modo ostensible; perduraba intacta sin embargo una valoración instrumental del lenguaje contra la que Maurice Blanchot se había pronunciado tiempo atrás con un golpe radical. En "La literatura y el derecho a la muerte", el ensayo de 1948 en el que respondía en forma oblicua a las intimaciones de ¿Qué es la literatura?, Blanchot advertía sobre la mala fe constitutiva de la creencia que atribuye un fin representativo a la escritura. "Como es natural, un escritor siempre puede fijarse como ideal llamar al pan pan y al vino vino. Pero lo que no puede obtener es creerse entonces en camino de la curación y de la sinceridad. Por el contrario, es más mistificador que nunca, pues ni el pan es pan ni el vino es vino, y quien lo afirma sólo tiene en perspectiva esta hipócrita violencia..." (1991: 255). El problema que arrastraba este enfoque era el de postular una literatura de acción cuyo sentido último estaba siempre establecido en otra parte. (2014:62-63)

${ }^{216}$ Cuando Blanchot piensa el "eterno retorno" de Nietzsche vuelve sobre su propia obsesión, la de la noidentidad de lo mismo, y en ese entramado se pregunta “¿Qué es lo que excede el todo?”, con lo que está pensando no la falta constitutiva, sino la excedencia insuprimible. Esa no-identidad de lo mismo, o el excedente de la totalidad, la distancia mínima que señala Blanchot es el límite de lo que una política de la creación como el surrealismo (y también el invencionismo) pueden pensar.
} 
de los atributos ("obra auténtica", "el existencialismo explota en calidad de empresario la angustia provocada por el racionalismo", "el artificio supremo", Enrique Molina en $A$ partir de cero), y la ambigüedad frente a un término o formulación donde resuenan las inconsistencias o extrañezas ("el problema de la literatura argentina es la literatura", Aldo Pellegrini sobre Antonio Porchia en A partir de cero). En el siguiente apartado analizamos el modo en que las consideraciones sobre la imagen anti-representacional se tensionan con respecto al uso que, en las polémicas críticas, los escritores hicieron de la biblioteca vanguardista, en la búsqueda por intervenir en un debate cultural caracterizado por sus mismos actores como un tiempo de confusión, para el cual era necesario establecer criterios contundentes.

\section{3. ¿A quién le importan las obras? Las polémicas de la crítica}

Entre fines de la década del cuarenta y mediados de los años cincuenta, fueron muchas las publicaciones cuyas reseñas, ensayos, artículos, noticias bibliográficas, encuestas, se formularon como intentos críticos por dominar o esclarecer un panorama del crecimiento editorial y artístico en Buenos Aires; y fueron muchas más las que lo hicieron al margen de las exigencias histórico-políticas que aquellas que cumplían con los rasgos paradigmáticos atribuidos a Contorno. En el primer capítulo recuperamos una de las hipótesis culturales sobre ese tema, que postuló la existencia de distintos sectores interesados por consolidar un discurso crítico que fuera capaz de producir "diferencia" o "singularización" en un contexto de creciente "indiferencia" o "masivisación" de las publicaciones (Herzovich 2015). El marco de un proceso de diferenciación no agota, sin embargo, las variables de una relación tensa entre la vanguardia como valor y el presente como búsqueda. Ciclo, A partir de cero, poesía buenos aires y Letra y Línea desarrollaron sus intervenciones críticas en un vínculo inestable con lo contemporáneo, a partir de lo cual introdujeron una noción de tiempo e historia que polemizó con la que proponían otras posiciones críticas como las de Centro, Contorno, Realidad o Imago Mundi. Es decir que en esa redefinición de los valores literarios dentro de una creciente masividad, encontramos variables respecto a cuáles fueron los énfasis de cada revista, ya que no se trataba solo de establecer criterios claros para la circulación no confusa de ciertos materiales, sino también, en el caso de las revistas del corpus, hacerlo conforme a un valor 
de contemporaneidad que se manifestaba indeterminado. Por otra parte, esta búsqueda de criterios con la cual intervinieron críticamente, estuvo marcada por una biblioteca de vanguardia que, en su uso, estuvo tensionada entre la concepción de imagen y lengua poética propuesta en diversos ensayos y la discursividad propia de la polémica.

Entre 1956 y 1957 se publicaron dos libros cuyo objeto era "la crítica literaria" como género: La crítica literaria argentina, de Salomín Wapnir (1956, Ediciones Acanto) y La crítica literaria contemporánea, de Enrique Anderson Imbert (1957, Ediciones Gure). Wapnir proponía un recorrido histórico, desde los escritores del principios del siglo XIX a la actualidad, para mostrar que el ejercicio de la crítica había sido fundante de la literatura nacional; Anderson Imbert, por su parte, buscaba determinar los alcances de una "crítica sistemática" (aquella "ejercida por los críticos que se desvelan por comprender todo lo que entra en el proceso de creación de una obra literaria"), para contrarrestar el efecto de "cualquier profano más o menos familiarizado con la literatura" que se creía "en condiciones de hacer crítica” (1969:14). ${ }^{217}$ Ambos coincidían en inscribir a la crítica literaria como una práctica necesaria en la "babilónica confusión de lenguas" (Anderson Imbert 1969:16). Nos detendremos especialmente en la publicación de Wapnir ya que algunas de sus observaciones son relevantes para pensar las ambigüedades que atravesaron a las intervenciones críticas de nuestras revistas.

Salomon Wapnir era militante del Partido Socialista en el entonces Territorio Nacional de La Pampa, donde dirigía la revista Ensayos, dedicada en parte a interpretar documentos del APRA y producir articulaciones entre el socialismo en Argentina y el ámbito latinoamericano. Desde las primeras páginas presentaba la crítica literaria como un género en particular que se constituía en instrumento contra el "avance y desarrollo de aquellos vicios que más contribuyen a desfigurar la fisonomía de una literatura", ya que colaboraba en la lucha "contra los impotentes del arte" 218 (1956:11) o los "vicios más particulares de la improvisación literaria" (29); asimismo reclamaba que fuera considerada como obra de arte con "derecho a ocupar puesto de honor entre sus camaradas de la estética" (50). Ambas funciones, que hoy pueden resultarnos contradictorias (ser un instrumento contra el equívoco de lo confuso y devenir obra de arte por el ejercicio de la escritura) formaban parte de un mismo objetivo en el horizonte

\footnotetext{
${ }^{217}$ La fecha de 1969 se corresponde con la publicación de Métodos de crítica literaria, donde Anderson Imbert incorpora el prólogo de La crítica literaria contemporánea de 1957 que aquí citamos.

${ }^{218}$ La figura del "impotente del arte" es recursiva tanto en intelectuales del partido socialista como del peronismo.
} 
de debates donde estaban implicadas las relaciones entre literatura y política tanto para sectores de la izquierda, como para el nacionalismo peronista, y el humanismo personalista representado por Sur: que la literatura tuviera una función de esclarecimiento. $^{219}$

La fantasía de una confusión que solapaba valores opuestos bajo un mismo nombre u objeto atravesó a gran parte de las revistas culturales del período que estamos analizando; Letra y Línea exigía distinguir entre "contemporáneos" y "embaucadores" para redelimitar los alcances de una noción como la de presente; poco antes, en Ciclo, Aldo Pellegrini lamentaba: "nos encontramos en un caos de escuelas, teorías, ortodoxias y heterodoxias, donde pululan creadores audaces, junto con mistificadores groseros o geniales" (1948, n1:55); en Ventana de Buenos Aires, Hurtado de Mendoza decía: "No estamos con la literatura de salón, que mueve a abrir las bocas en $o h$ admirativas a quienes no saben separar lo bueno lo de lo malo, lo falso de lo auténtico" (1952, n2:1). En 1946, Roger Caillois manifiesta su incomodidad en "El poder de las palabras", publicado en Sur:

Ya no hay enseñanza que pueda transmitirse o escucharse. Babel no consiste en que de ella surjan, repentinamente, distintas lenguas, sino en que, en el interior mismo de una lengua única, sea preciso traducir sin cesar para comprenderse, y que la traducción sea imposible porque no existen ya relaciones ciertas entre términos confusos y flotantes, que no evocan para nadie las mismas imágenes (1946, n135:24)

Por otra parte, la demanda de considerar a la crítica como una obra de arte por derecho propio, puede asociarse a las discusiones específicas dentro de estructuras partidarias donde se buscaba eliminar las diferencias entre intelectuales, escritores y obreros (Petra 2013). En ese sentido no sería contradictoria la articulación entre un instrumento analítico de discernimiento, tal como pretendía Wapnir, y una escritura literaria que, desde las decisiones de XX Congreso de Escritores del PCUS, debía eliminar las ambigüedades y evitar la confusión de las masas con respecto a la política del partido.

Pero lo que resulta más curioso en la argumentación de Wapnir es que la crítica en tanto género se inicia con aquellos que tienen "páginas hoy dispersas", como "escritas al margen de un libro" (11). La crítica emerge entonces como sobre-escritura, en ese espacio del margen donde se superpone al cuerpo textual, permaneciendo suspendida como lo otro del texto. Por otra parte, en su búsqueda por definir la función de la crítica

\footnotetext{
${ }^{219}$ Contra esta noción va a discutir Aldo Pellegrini en 1957, en Para contribuir a la confusión general.
} 
introduce una ambigüedad significativa: se llama a que "los hombres consagrados a la crítica cesen de apoyarse en el buen gusto y en el prestigio de dos o tres lecturas escogidas, al determinar sus veredictos" (47) -razón que echa por tierra con el criterio del gusto y que podría compartirse con los críticos del arte concreto y poetas invencionistas contemporáneos; pero a vuelta de página afirma que la existencia misma del género "prepara la presencia de un nuevo crítico en cada lector al dotarlo de gusto literario y sentido estético" (48). Contra el buen gusto y por la formación del gusto, la variación aparece ya inscripta en la imagen de un espacio inestable que se figura como primera condición y soporte para la crítica: el margen del libro, que es también ese espacio de tránsito paralelo donde la escritura recomienza, nos habla de un género que circula tanto como reseña, artículos, notas de presentación, ensayos, semblanzas, donde hay más bien gestos críticos antes que teorías fuertes o eclosiones discursivas que modulen esos enunciados. En ese sentido, el acercamiento de Wapnir a la crítica, que llega hasta Crisis y resurrección de la literatura argentina (Ramos 1954), resulta tan poco actualizado (ya que deja afuera a los críticos de revistas como Contorno, Centro, Las ciento y una) como relevante, en tanto nos permite pensar la crítica a mediados de siglo en las revistas culturales como un "bullicio", según señalamos en la introducción, antes que un conjunto de firmas que "cultivaban el tributo (negativo o positivo) a las grandes personalidades, los grandes hombres, las grandes subjetividades" (Panesi sobre Sur y Contorno 2004:53).

Según ha analizado Terry Eagleton, la crítica nace de la voluntad por administrar las normas en las que se desenvuelve el mercado del discurso cultural; ${ }^{220}$ es decir, organizar el proceso por el cual una nueva racionalidad es aquella que dispone la capacidad de articular un cierto discurso en los límites de la esfera pública, convirtiéndose así en una autoridad algo performática que, no sin contraseñas ocultas, desplaza a la autoridad pre-concedida de la clase o título de nobleza. Podríamos pensar entonces que la crítica argentina de mediados del siglo XX -angustiada en buena medida por la confusión- también estuvo movida por la voluntad de traspasar los privilegios heredados -sensibilidad de época, por otra parte, en consonancia con una serie de medidas del peronismo que habían ampliado el campo de lo simbólico correspondiente a cada clasey simultáneamente organizar una experiencia caótica.

\footnotetext{
220 Afirma Eagleton sobre las normas del discurso cutural en el surgimiento de la crítica: "Si lo que resulta embarazoso para la teoría liberal burguesa es el proceso mediante el cual una igualdad abstracta en el nivel de los derechos naturales se transmuta en un sistema de derechos diferenciales reales, la esfera pública burguesa tomará esos derechos diferenciales como punto de partida y los convertirá, en el ámbito del discurso, en una igualdad abstracta." (1999: 18)
} 
Frente a esa confusión, las revistas del surrealismo e invencionismo en Argentina dan cuenta de una serie de términos con los que intervinieron; así a las expresiones "muralla de realidad", "ilusión", "retórica”, "poesía social”, "figuracionismo", con las que se desginaban una perspectiva representacional y mistificadora de la literatura, se le oponían otras como "el destello de lo absoluto" (Enrique Molina), "la realidad increada" (Blanchot), "realidad interna" (Bayley), "verdadera comunicación con el mundo" (Pellegrini), que pretendían señalar una diferencia en esa lengua única donde era precisio traducirse sin cesar, como había afirmado Caillois en Sur. El diagnóstico de la confusión y el modo en que las polémicas tomaron posición, es uno de los aspectos a analizar para responder a la pregunta acerca de cómo se conformaron criterios de lectura con una biblioteca de vanguardia después del declive de los manifiestos, y simultáneamente apelando a un conjunto de términos que proponían un encuadre teórico tan ajeno al de Contorno como el de Sur.

Llamamos a estas polémicas como "críticas" porque es donde más especialmente se ve que el objeto de debate consiste en la clarificación de criterios de valoración o construcción de antologías. En ellas el crítico resultaba una figura responsable de cierta obra en virtud de las palabras que había elegido para ponerla en relación y circulación con otras producciones contemporáneas e históricas. Por momentos importan menos las obras que los argumentos del crítico por los cuales esa obra tiene un lugar determinado. Pero ya no es la imagen total por sí sola como forma depurada del vínculo con lo real la que puede evaluar las obras; incluso estas parecen ser menos responsables que los críticos, quienes deben cuidarse bien de modelar esa imagen con los datos correctos.

El objetivo de este apartado es dar cuenta de cómo esa imagen total del surrealismo y el invencionismo, en sus distintas variaciones, a la que tendían las afirmaciones estéticas de distintos colaboradores de las revistas del corpus es suspendida en las polémicas donde la crítica se vuelve el discurso en disputa. Dice Aldo Pellegrini, "No es que seamos partidarios de una información rigurosa en la crítica, lo que nos parece imprescindible es la sensibilidad. Pero cuando esta falta ¿qué otro justificativo tiene escribir sobre pintura si no es la honrada función didáctica de informar?" En ese sentido es que la figura del crítico no debería ser reducida a la de un des-confusionador, como sugiere Herzovich, sino que es necesario leer esa articulación entre dato y sensibilidad, en tanto reconfiguración de los valores que los mismos actores definen cuando delimitan un programa estético propio. Esta operación, que articula procesos de diferenciación con valores de la vanguardia, se hace manifiesta en tres polémicas que protagonizó Letra y 
Línea, con el crítico de arte Julio Payró, con la revista poesía buenos aires y con la dupla "Bustos Domecq" en Buenos Aires Literaria.

\subsubsection{Aldo Pellegrini y Julio Payró: la lengua y la biblioteca}

En el número 2 de Letra y Línea, Aldo Pellegrini publicó una reseña sobre la muestra curada por Julio Payró en Kraft, a la que tituló “Tres abstractos y un crítico en Kraft”. En primer lugar, presentaba un breve estado de la cuestión del arte abstracto en Argentina, donde afirmaba que su vigencia "está indudablemente demostrada por la cantidad de artistas que materialmente se han volcado a esta tendencia en los últimos tiempos”, pero que mientras algunos "lo hacen después de una consciente reflexión y la seguridad de que el cambio obedece a una necesidad interior y se acomoda a los medios técnicos de que disponen. Otros, los más, consideran la tendencia abstracta como una cómoda posición de modernidad y una posibilidad de expresarse artísticamente sin esfuerzo" (Pellegrini 1953, n2:12). La reseña se organizó en torno a tres objetos, inversamente jerarquizados: comenzaba hablando de las obras, luego se refería al lenguaje con el cual el crítico las había descripto y por último a la información que sustentaba las afirmaciones del catálogo; pero la polémica giraba de forma exclusiva en torno a los últimos dos aspectos.

Con respecto a las obras, Pellegrini destacaba la exposición de Coppola, como "rara calidad" de quien "comienza a pintar a los sesenta y seis años y realiza su primera exposición a los sesenta y ocho años" (1953, n2:12), para afirmar que el arte abstracto no tendría nada que ver con la improvisación sino con la formación de años de recorrer museos y reconocer la herencia de distintas escuelas (tarea a la cual Coppola se había dedicado). Luego se detenía más pormenorizadamente en las obras de Hortensia Tarazi, a las que caracterizó como "materia sucia (...), manejada torpemente", con colores pobres, arbitrarios, formas ingenuas y triviales. Pero principalmente le cuestionaba que no hubiera conjunto sino "la totalidad sustituida por el amontonamiento" (1953, n2:12). Si bien podrían distinciones entre la "improvisacion" de quienes buscan una "posición cómoda" y la espontaneidad surrealista, o bien entre la acusación de ingenuidad sobre Tarazi y la inocencia, ${ }^{221}$ la retórica de Pellegrini tenía poco que ver con la noción de

${ }^{221} \mathrm{La}$ "inocencia" era, tanto para Pellegrini como para Molina, un valor fundamental de la poesía que atentaba contra las falsas decoraciones: "En efecto, basta un poema de Peret, con su juego elemental de guijarros entrechocados por el mar, para provocar en la atmósfera más aplastante el resplandor del 
imagen del surrealismo, tal como constatamos en la relevancia que da al peso de la información por sobre los análisis de las obras.

Los análisis sobre la exposición se abandonaban rápidamente porque, esta "viene avalada por un crítico, Julio Payró, que comparte o mejor dicho asume la responsabilidad de tal pintura en un catálogo que contiene una extensa presentación" (Pellegrini 1953, n2:12), de modo que no son las obras las que debían ser juzgadas, sino los críticos. Así se desplazaba a analizar la escritura del catálogo firmado por Payró, donde se articulaban las razones de la muestra: "Si recurrimos [al catálogo] en busca de aclaración solo encontramos un párrafo oportuno en el que despliega que la pintura no figurativa es para la artista 'arpa sonora del corazón"” (13). La extracción de cita pone de manifiesto que la impugnación de Pellegrini tenía menos que ver con los procedimientos de la escultura que con la articulación entre esos procedimientos y la lectura alambicada del crítico que los sostiene, al que acusaba de adherir a una "literatura cursi". Lo que pareciera molestar al director de Letra y Línea son menos las líneas torpes y amontonadas de una materia sucia (que en el análisis que hace Pellegrini de la obra de Dubuffet son elementos de renovación artística) que la intromisión de una metáfora "cursi" como "arpa sonora del corazón".

A continuación se detenía en el tercer objeto de la polémica: la información que avalaba algunos de los pareceres de la crítica. Para Pellegrini, las malas lecturas serían correlativas con una mala interpretación de la historia del arte que hacía confundir a Payró la noción de "emoción estética" -utilizada en el catálogo aludiendo a términos como "emociones palpitantes" o "comunicación a través de complejos mecanismos psicofísicos"- con la "sensibilidad estética (distinta de la capacidad de sufrir emociones palpitantes y más allá de la pura fisiología)" que Pellegrini consideraba fundamental. Fuera de las interpretaciones, el director de Letra y Línea avanzaba sobre el cuestionamiento de la biblioteca de Payró:

Los pocos datos concretos que menciona están casi todos equivocados y parecen haber sido librados a la "libérrima fantasía" (utilizando palabras del autor). Dice por ejemplo: "la pintura no objetiva, como la bautizó Kandinsky”, error no admisible, porque desde el clásico libro de Barr hasta

relámpago y poner al descubierto por su misma inocencia todo el complicado aparato de la retórica al uso. "El fin del poema - dice Carrouges - no es el de reunir un museo de expresiones poéticas para que se limiten a admirarlas pasivamente, sino el de poner en circulación explosivos mentales destinados a minar las murallas de la costumbre y de la inercia". Asimismo, cfr.: Pellegrini (1961) "Se llama poesía a todo aquello que cierra la puerta a los imbéciles" en Poesía = Poesía 1961. 
los modestos manuales de divulgación se dice que fue Rodchenko en 1918 quien creó dicha designación, usada después con más o menos frecuencia por los teóricos alemanes y difundida por designar un famoso museo en Estados Unidos. (1953, n2:13)

Por último, a la "falta de rigor" del dato sobre la historia europea del arte agrega como contraparte, igual desconocimiento del desarrollo del arte en Argentina:

Dice en su presentación: “... surge hacia 1940 una generación de pintores convertidos a los principios de la no-objetividad”. La única generación de pintores abstractos surge solo en febrero de 1944 alrededor de la revista Arturo y está ella formada por Maldonado, Lidy Pratti y Arden Quin. (13)

En el siguiente número se publicaría la continuación de esta polémica, con la respuesta de Payró y la sucesiva de Pellegrini donde desplegaba en más de dos mil palabras una genealogía del término "no-objetivo" para distinguirlo del término "abstracto", usando distintas fuentes bibliográficas, traducciones comparadas, ediciones revisadas que expone como garantía de su acierto. El objetivo de esa última respuesta de Pellegrini a Payró que se publica en Letra y Línea es señalar que en el arte moderno solo la especificidad de las relaciones entre términos y procedimientos puede asegurar una interpretación correcta de las obras. Esa especificidad solo se encuentra en una biblioteca universal - Ediciones Maeght de París; Editions de Beaune; la revista Art d'aujourd hui, las ediciones del Museo de Arte No-objetivo de Nueva York, Ed. René Drouin, Ed. Witternborn, Schultz, New York, Ed. Origo de Zurich, Rudolf Kaemmerer Verlag de Dresden, Peguin Books Limited de London, Paul Theobald de Chicago - y distingue a un crítico como Payró - "incapaz e improvisado" - de un estudioso de los problemas de la pintura moderna. ${ }^{222}$ La disputa por la taxonomía de la historia del arte fagocita los argumentos de uno y otro crítico, como si en la rigurosidad de los datos se apoyaran los efectos de sensibilidad crítica para el arte. El crítico debe no sólo evitar la confusión del público abrumado "por el caos de escuelas estéticas", sino que debe él mismo orientarse correctamente en el mar de símbolos de la historia del arte (una traducción sospechosa puede arruinarlo todo, afirma Pellegrini) porque confundir los nombres es enturbiar la sensibilidad.

Tanto Alberto Giordano como Jorge Panesi han reflexionado acerca de la polémica como práctica siempre presente en el espacio de la crítica literaria argentina.

\footnotetext{
${ }^{222}$ Para leer la polémica completa y el recorrido por el cual se distingue hasta la oposición "arte no-objetivo" de "arte abstracto", ver Anexo.
} 
Cada uno enfatiza aspectos diferentes que nos permiten repensar la dimensión performática de estas polémicas cuyos "tonos", "sintaxis" y "retórica" -según la caracterización que hacen Nora Avaro y Analía Capdevila de la "política del enfrentamiento" que atravesó un modo de intervención en los años 50 y particularmente a la generación "denuncialista" (2004:65)- configuran morales críticas no homologables a los criterios estéticos que organizaban una posición respecto al tipo de imagen que cada revista pretendía imponer. Si en la noción de imagen del surrealismo, tal como la exponen Enrique Molina y Aldo Pellegrini en A partir de cero -principalmente- se busca una síntesis de los opuestos y la exaltación de las intuiciones y sentidos en forma integral (es decir, sin privilegiar la percepción de lo visible y razonable por sobre lo irracional), en la polémica con Julio Payró no se cuestiona la exposición de los artistas abstractos por su no correspondencia con los criterios surrealistas de la imagen, o como un demérito de la exaltación de los sentidos, sino por el lenguaje alambicado con que se argumenta la selección (la lengua de la crítica), y por contribuir a una confusión histórica al hacer una mala geneaología de los términos "abstracto" y "no-objetivo" (la biblioteca de la crítica); es decir, cómo se habla del arte y cómo se lee determinan lo visible de la cultura contemporánea. En ese sentido, la moral crítica es menos estética que organizadora, y apela a evitar malentendidos, como si en esa transparencia de criterios pudiera recaer la garantía de exhibir lo mejor del arte contemporáneo.

En Modos del ensayo (2005), Alberto Giordano analiza el género "polémica" como un tipo de intervención donde suele manifestarse una contradicción "acaso constitutiva, del modo en que los intelectuales realizan sus intervenciones públicas”, ya que por un lado, y como también ha advertido Panesi, es muy difícil que en ellas "no se mezclen los turbios intereses que mueven siempre la lucha por el prestigio intelectual" o que "la discusión pueda llevarse a término sin una buena cuota de dogmatismo en las posiciones" (2018:31), pero esas subjetividades se inscriben, según Giordano, "en nombre del bien (teórico, ideológico o político) común, trascendiendo el plano de los mezquinos intereses personales" (2005:179), es decir, "bajo la coartada del cumplimiento del deber" (179) o el "bien común" (185). Sin embargo, como contrargumento el mismo Giordano señala que muchas veces es posible advertir una frase donde se "suspende el alcance institucional e histórico de la intervención" y se "desborda la intencionalidad irónica" (combativa, narcisista) (15). Se trata de afirmaciones que contaminan de "ambigüedad e incertidumbre la trama moral con que se teje la política de la literatura" (17). 
Jorge Panesi, por su parte, exploró dos dimensiones de la polémica. Por un lado una serie de imaginarios en torno a los cuales la polémica es experimentada, por parte de intelectuales y escritores, como el momento donde se ilumina a aquellos espectadores que están afuera de la batalla y por el cual se asume un lugar relevante en el escenario social (2018:22). Este aspecto estaría vinculado con lo que Giordano llama dimensión institucional e histórica de las intervenciones. Panesi agrega otra complejidad al exponer que "las disputas son, en su expansión o en su espacio reducido, el flagrante costado político de la literatura que no se borra o se disuelve en el espontáneo acuerdo racional ni en la condescendencia piadosa" (2018:25). Ese aspecto subyacente o involuntario de las polémicas se expande como interpretación histórica en el ensayo "Polémicas ocultas", donde distingue esta denominación de las discusiones universitarias. Las primeras serían huellas que perduran en el tiempo, por eso mismo constitutivas de una cultura, de una parte o sector de una cultura, "reinscripciones de puntos no saldados de la historia" (45), como por ejemplo la polémica civilización/ barbarie, nacionalismo / cosmopolitismo (2018:35):

Iluminista, transparente y democrática (aunque sometida en secreto por las jerarquías y sobre todo por las jerarquías del éxito académico), la discusión universitaria diseña un modo de producción intelectual que naturalmente encuentra un mercado lector global. Me refiero como ejemplo al libro Contingencia, hegemonía, universalidad, publicado en el año 2000 por un conjunto internacional de intelectuales (Judith Butler, Ernesto Laclau y Slavoj Zizek), que como principio de composición han redactado cada uno de ellos un cuestionario al que luego responden sujetándose al principio del diálogo, la discusión y las conclusiones. Las polémicas constitutivas, en cambio, traspasan los protocolos, se cuelan como residuos ideológicos inesperados en la discusión formal y se someten al desconcertante e inexplicable imperio de las pasiones. (2018:36)

La polémica entre Aldo Pellegrini y Julio Payró es tal vez un modelo de la dimensión más institucional y de lucha por legitimar un modo de leer, ya que se busca imponer una moral por sobre otra. Y es en esa afirmación de las impugnaciones donde el deseo de una imagen total se ve suspendido en función de otro fin que en el marco de las disputas críticas parece más importante: determinar la lengua y la biblioteca de la crítica. En estas tres polémicas que se abordan, y que todas tienen como polemista a Aldo Pellegrini, interesa interrogar tanto lo que hay de constitutivo en ellas (la disputa por imponer un modo de lectura), como lo anómalo de ellas: el momento en que abandonan lo que en principio parecía esencial (la sensibilidad, según había afirmado Pellegrini) para dejarse arrastrar por el peso de una biblioteca erudita; o bien ese momento donde no pueden leerse como 
polémicas sino como un discurrir disparatado de los enfrentamientos, tal como leemos en el enfrentamiento con "Bustos Domecq" inicialmente y con Borges luego, cuya retórica desborda los protocolos, las sintaxis y los procedimientos de argumentación de la polémica, hasta arruinarla, convertirla en una política de la literatura que se gesta en la forma de la escritura y no en la enunciación de razones.

\subsubsection{Montaje y genealogía: cómo se delimita la nueva poesía argentina}

Como comentamos en el apartado sobre pba del primer capítulo, su número 13-14 estuvo dedicado a presentar alrededor de cincuenta nuevos poetas que resultaban significativos como parte de un "fenómeno de transición cultural" y habían dejado de lado el manifiesto. En consonancia con hacer de la crítica un instrumento de diferenciación, "Poetas de hoy: Buenos Aires, 1953" se proponía "contribuir a despejar funestos equívocos" y "destacar el valor de estos poetas en medio del desconcierto actual" ya que reunían la característica de integrar "coherentemente, [una] cierta comunidad de experiencias vitales, una dirección capaz de significar un orden, un renacimiento, una salida hacia la universalidad" (1953 n13/14:1). Los criterios eran tanto cronológicos como estéticos. Al igual que se planteaba en el editorial de Letra y Línea, el criterio cronológico no era inequívoco y resultaba preciso fundamentarlo. El número se estructuraba a partir de denominaciones que no correspondían a un mismo sistema -“poetas del espíritu nuevo", "poetas madí” y "poetas surrealistas" - y a su vez parecían excluyentes, en tanto no era posible portar "un espíritu nuevo" y "ser surrealista" o poeta madí. El criterio que unificaba a todos los que “podemos llamar contemporáneos”, según la revista, era el espíritu inconformista, del cual luego derivaría todo lo que no entrara en los límites de la nueva poesía, ya que implicaba el rechazo a las "formas retóricas clásicas concebidas apriorísticamente", la "invalidez de la angustia sin salida" y a la "poesía adjetivada (social, popular, mística, etc.)" (1953 n13/14:1). El “inconformismo poético" era también el valor sobre el cual Aldo Pellegrini y Enrique Molina hacían énfasis desde $A$ partir de cero, circunscribiéndolo particularmente al surrealismo, como una exigencia estética e ideológica -en el ensayo sobre Aimé Cesaire, Molina rescataba su poética porque era capaz de "sacudir la capa de inercia con que el juego de los conformismos aletarga la imaginación" (1953, n1:4). 
En el tercer número de Letra y Línea, donde también circularon las últimas dos cartas del intercambio con Payró, Pellegrini publicó “El hábito no hace al monje o cuando la poesía cambia de traje pero no de paño. Consideraciones sobre el 'Panorama de la poesía argentina moderna’ publicado por poesía buenos aires, $\mathrm{n}^{\circ} 13$ y 14”. Lo que organizaba la respuesta de Pellegrini era, nuevamente, el cuestionamiento a los criterios de selección y exhibición de los nombres (quién puede ser leído junto a quién, y por qué razones ligarlo a una $\mathrm{u}$ otra escuela). En esta oportunidad, no se limitaba al dato informativo, ${ }^{223}$ sino que se centraba en una serie de confusiones que se experimentan como un escandaloso agrupamiento de nombres propios que no deberían aparecer juntos.

La primera observación de Aldo Pellegrini radicaba en el tipo de ejemplos y agrupamientos que proponía $p b a$ para dar cuenta de aquello que no entraba en su concepción de poesía. La presentación del número especial afirmaba que "la invalidez, la angustia sin salida, la miseria espiritual del hombre" se originan "en un superficial contacto con el existencialismo" o "en la influencia de poetas del tedio y el refinamiento burgués”, y ejemplifica con los nombres de “Baudelaire, Rilke, Eliot, etc.”. Con el recurso de la lógica, Pellegrini intentaba desbaratar la elocuencia del criterio, diciendo "la angustia sin salida, ¿podría ser poética si el contacto con el existencialismo fuera profundo?”, o bien reclamando mayores precisiones sobre algunos términos: “¿qué sentido da a "miseria espiritual", expresión muy usada por los surrealistas en forma evidentemente distinta?". Pero la crítica era provocada por la inconsistencia, según Pellegrini, de los ejemplos, cuyo "nivel aclaratorio" solo contribuía más caos al panorama:

Baudelaire, iniciador de la revuelta poética contra el espíritu burgués resulta ahora el más acabado representante de ese espíritu. Solo una epidérmica apreciación del tema del Spleen es responsable de tal interpretación. Faltaría agregar entonces, como representantes de la espiritualidad burguesa a los continuadores de la obra de Baudelaire: Rimbaud, Lautréamont, Kafka, Artaud. Todos ellos (de quienes los verdaderos poetas contemporáneos se sienten continuadores) realizan -según el mentado prólogo- una "escritura de suciedad, de postración, de caos, de patología, que nada tiene que ver con el sólido - y a veces irónico- estoicismo, que sería cuando menos la traducción poética de un mal semejante, si es que realmente fuera experimentado por el poeta". La lectura de este párrafo, al que no queda sino suponer un oculto

\footnotetext{
223 Aunque en dos ocasiones, Pellegrini orientó remató alguno de sus argumentos con sugerencias bibliográficas de este tipo: "cosa fácil de averiguar con la simple lectura del prólogo de Ignacio Montes de Oca a su traducción española de Píndaro" o "basta leer la conocida Historia de la literatura española de Fitzmaurice Kelly si se quiere recurrir a una opinión autorizada” (1953, n3:16), dando por obvio que la disputa de un sentido se corta con la lectura de la fuente correcta.
} 
contenido "a veces irónico", tiene la ventaja de colocar directamente en pleno caos al desprevenido lector.

La observación de "epidérmico" en torno al modo en que pba leería el Spleen baudeleriano tiene una correlación con el "superficial existencialismo" que la revista de Aguirre se propone impugnar. No se trata de una defensa del existencialismo como contraparte del argumento, sino de mostrar que $p b a$ también incurre en lecturas superfluas. En segundo lugar, el punto de cuestionamiento se desplaza, en el párrafo que transcribimos, de una reflexión acerca de la revuelta contra el espíritu burgués, hacia la serie poética en la cual debería ser leído Baudelaire, ya que aparecen criterios diversos sobre la relación de las vanguardias con lo nuevo. El criterio que rige la articulación Baudelaire - Rilke - Eliot en pba tiene que ver con lo pasado, aludiendo a poetas de un tiempo anterior que deben ser superados, además del carácter "angustioso" y "miserable" que expondrían sus poéticas. En el número 2 de $A$ partir de cero, Enrique Molina había cuestionado la figura de Eliot por su "falsa relevancia" en la cultura argentina:

El artificio supremo de un John Perse o un Eliot - fruto de una sociedad "culta" en el más profundo sentido - y de formas personales que recogen esa larga tradición de una cultura que, por otra parte, aparece en plena crisis, no puede imitarse entre nosotros sin caer en un convencionalismo ridículo. A tal imitación, que necesariamente creará un formalismo falso, hay que oponer la inocencia de un primitivo o el lenguaje mágico con que los niños hallan instantáneamente su expresión con una certidumbre que debiera conmovernos hasta las lágrimas. $(1952, \mathrm{n} 2: 1)$

El nombre de Rilke, asimismo había sido apropiado por la autollamada “generación del 40”, con lo cual ni poesía buenos aires, ni A partir de cero, ni Letra y Línea pretendían recuperarlo. Por lo tanto lo que se vuelve problemático y polémico en esa tríada son las relaciones que se infieren del encuentro entre el nombre de Baudelaire -rescatado en A partir de cero dentro de las citas en la sección Línea de fuego-y los otros dos poetas. Si para pba pueden estar juntos porque implican lo que quedó detrás de la línea de corte entre pasado y presente; para Pellegrini, la potencia de una genealogía es motivo de disputa, ya que ese tipo de movimiento histórico era lo propio del surrealismo, especialmente después de 1945. Por eso elige otros nombres, igualmente pasados Rimbaud, Lautréamont, Kafka, Artaud-, para acompañar el del poeta del mal y articularlos en torno a un criterio de contemporaneidad (“de quienes los verdaderos poetas contemporáneos se sienten continuadores") que, como pedía Breton en uno de los fragmentos seleccionados por A partir de cero, echaba sus "hondas raíces en el pasado", pero no cualquier pasado, sino aquel que había tenido un grado de revuelta aún 
incumplida. Es decir que, para Pellegrini, el problema no era solo la epidérmica lectura del Spleen, que llevaba a una confusión de la angustia miserable con la lucha contra el espíritu burgués, sino haber colocado a Baudelaire en una serie errónea. Se trata de una operación donde anacronismo y montaje buscan restituir un poder presente sobre el pasado. Benjamin entendía que "colocar a Baudelaire junto con Blanqui" significaba "salvar [sus obras] de las manos de la asimilación convencional" que se articulaba en torno a claves de lectura como la "valoración", "la empatía", y la "apología" (citado en Opitz y Wizisla 2014:573). Tal era para Benjamin el principio constructivo de la historia: un modelo anacrónico por el cual se mira al pasado como un fragmento que leemos a partir de intereses actuales y no como una "cadena de recuerdos continuos", tiene como objetivo "arrancar a la tradición al conformismo que está a punto de subyugarla" (Benjamin 1973:180). El reclamo de Pellegrini respecto al modo en que pba historizó a Baudelaire, produciendo efectos de mala interpretación sobre el presente, se funda en una lógica del montaje, una sintaxis del "con" para pensar discontinuidades en la tradición, fragmentos que hagan saltar la masa de hechos en un tiempo homogéneo y vacío. ${ }^{224}$

El segundo agrupamiento que parece haber molestado a Pellegrini no tiene que ver con la relación entre pasado y contemporaneidad sino con la clasificación del presente, de manera más estricta, con la confusión de géneros, lenguas y concepciones ambiguas de lo popular. pba había explicitado por qué se debía rechazar la "poesía adjetivada (social, popular, mística, etc.)” (1953, n13/14:1), para lo cual articulaba, por contraposición, una serie de nombres que implicaban "un compromiso vital asumido hasta sus últimas consecuencias (Maiakovski, García Lorca, Vallejo) o una intimidad real, de cultura, de lengua y de espíritu, con el pueblo (Píndaro, Juan Ruiz, Villon, Carlos de la Púa)" (1953, n13/14:1). Pellegrini intervino en esos conjuntos de nombres a partir de una disección: tomó los términos más convenientes para exponer la confusión que quería señalar y luego proponer el esclarecimiento que consideraba fundamental. Así, de "poesía adjetivada", tomó entre las aclaraciones del paréntesis, el término "popular" y de los vínculos de intimidad, la palabra "pueblo":

En el final de dicha introducción llega a aceptarse una poesía de tono popular siempre que signifique "una intimidad real de lengua, cultura, y espíritu con el pueblo" y como ejemplos se menciona a Pirandelo, Juan Ruiz, Villon, Carlos de la Púa. Es evidente que se hace allí una confusión entre el poeta culto que utiliza temas vitales o cotidianos con el versificador popular. No puede compararse a Píndaro, cantor de príncipes y héroes, poeta el más

${ }^{224}$ Cfr. al respecto "El tiempo de una imagen: el tiempo-con” (Antelo 2015:376-399) 
profundo, difícil y refinado de la lírica griega (...) con un poeta del lenguaje popular. (...) Y qué decir de Villon, extraordinario precursor de Baudelaire y Rimbaud, sacudido por la doble angustia del deseo y de la muerte. (Pellegrini 1953-1954, n3:16)

Lo que impugna Pellegrini, sin exponerlo, es la apropiación que hizo la vanguardia porteña de la poesía de Carlos de la Púa. $\mathrm{O}$ en todo caso exige distinguir entre un cantor del lunfardo, de quien la vanguardia puede hacer usos, respecto de grandes exponentes de la lengua que se convierten en precursores. Pero a continuación, la polémica se desplaza hacia una inesperada policiticidad -con respecto al tipo de discusiones que ocupó a las revistas del corpus- donde distingue "auténtico folklore" de "literatura populachera":

De generalizarse ese propuesto sistema de atribuir carácter folklórico a los cantores de lo cotidiano, hoy habría que considerar a Faulkner un representante de la literatura popular. Y conste aquí mi profundo respeto por el auténtico folklore, el producto de una cultura creada por el pueblo y que realmente expresa y condensa las aspiraciones y los deseos de un grupo humano. Pero hay tanta diferencia entre la verdadera literatura folklórica y la literatura populachera como entre el poeta modernoide y el poeta moderno. (Pellegrini 1953-1954, n3:16)

La preocupación por distinguir lo popular de lo "populachero" estaba presente en los ensayos de Pellegrini desde A partir de cero, en el ensayo "El poder de la palabra", donde "popular" es estrictamente la expresión del lenguaje del pueblo. Si bien nunca se definen los alcances del término, es posible advertir que alude a una serie de rasgos de pureza, en tanto el "lenguaje del pueblo" o la "cultura creada por el pueblo" sería una expresión incontaminada de mediaciones políticas partidarias e instituciones literarias. Advertimos el carácter político de esta diferenciación porque no parece menor que entre los términos de la confusión, Pellegrini hubiera elegido palabras como "folklore", "pueblo" o "literatura popular", cargadas de una densidad especial en el marco de las políticas culturales del peronismo. ${ }^{225}$

Por último, Pellegrini marcaba lo que consideró como la gran confusión de pba: que hubiera presentado al surrealismo en términos de "retórica"; esto lo llevaría a calificar el trabajo antológico del número especial como "posición puramente literaria y antivital":

Justamente esa mera actitud literaria que aparentemente sus autores combaten. Es como si se diera vuelta a un viejo traje para adaptarlo a la moda: el paño sigue siendo el mismo. Se trata siempre de una poesía académica o no académica que se deleita en un puro juego verbal sin consecuencias: literatura de entretenimiento para salones más o menos refinados, que

\footnotetext{
${ }^{225}$ Para un análisis pormenorizado de este aspecto, cfr.: Korn (2017).
} 
prescinde completamente de la conmoción o el choque. (Pellegrini 19531954, n3:16)

Ese antivitalismo queda demostrado, según Pellegrini, en la mala lectura que hacen del surrealismo, al confundir técnica o mecanismo con escritura automática o experiencia de la poesía como acontecimiento intenso de la vida:

Se habla así de una "retórica surrealista" sin notar la incongruencia de tal expresión, ya que desde el momento en que se hace retórica, la poesía deja de ser surrealista. Justamente este tipo de retórica seudosurrealista es la que utilizan actualmente muchos poetas en todas partes del mundo (incluso aquí). La diferencia está en que estos últimos en lugar de recurrir al automatismo (impulso de origen vital) utilizan un mecanismo (recurso retórico). Así se sustituye por ejemplo en la frase "el perro mueve la cola" la palabra perro por cualquier otra, digamos "pisapapel" y de este modo se obtiene una especie de sorpresa primaria de tipo carnavalesco con la que cualquiera puede darse aire de poeta moderno. La facilidad atrae y así pueden verse pulular legiones alrededor de la miel de un supuesto surrealismo (si se suprime este nombre comprometedor la sorpresa resulta mayor). Por tal camino se logra una beatitud que puede pasar sin dificultad por optimismo. (Pellegrini 1953-1954, n3:16)

Pellegrini retomaba entonces el punto de partida de $p b a$-el "rechazo a las formas retóricas clásicas concebidas apriorísticamente" (1953 n13-14: 1)- poniendo en el centro de la cuestión a la retórica, pero justamente para apropiarse de ese criterio de lectura en tanto ha sido mal interpretado, ya que de lo contrario no podría incurrirse en un oxímoron como "retórica surrealista" (Pellegrini 1953 n3:16). En ese sentido, procuraba desmantelar la solidez de los argumentos que habían organizado el trabajo de "Poetas de hoy: Buenos Aires, 1953" - donde el surrealismo es sin duda tratado con cierto rezago. Lo que Pellegrini parecía decir era ¿cómo confiar en una antología que postula un criterio cuyos alcances de sentido luego no puede manejar?:

Con tan confusos puntos de partida no puede extrañar que todo el panorama, la clasificación, las "notas orientadoras" de amplia precisión desorientadora, los ejemplos elegidos de modo que no aclaren nada, todo contribuye a hacer de ese intento una obra confusa, contradictoria, incomprensible (en cuya ilegibilidad colabora la utilización de una jerga de grupo y la multiplicación de reticencias). (1953, n3:16)

Así, Pellegrini eludía la verdadera crítica que $p b a$ deslizaba sobre el surrealismo argentino. Para $p b a$ contaba menos si el surrealismo como movimiento de vanguardia era "el compromiso con una ideología y una concepción del mundo total, [que] ningún tipo de consigna puede encadenar, y menos la consigna del estoicismo", según la definición 
de Pellegrini en "El hábito no hace al monje", que la necesidad de explorar qué hacen los poetas argentinos con esa ideología y ese compromiso asumido en sus poéticas.

poesía buenos aires no respondió a la polémica de manera directa, pero sí con un texto titulado "Hoja de ruta" (n15) donde, como comentamos en el primer capítulo, se reflexionaba explícitamente sobre el lugar de los manifiestos en la revista, y se explicitó que esa no era la búsqueda del grupo editor. Puede inferirse de esa intervención un posicionamiento respecto a los reclamos de Pellegrini, donde no solo se niegan las condiciones del debate por no suscribir a la posibilidad de respuestas, sino que además se desliza una lectura donde debemos advertir retrospectivamente que Letra y Línea erró en la construcción del punto de partida por el cual atacó a $p b a$, ya que se centró en un aspecto que a esta le resultaría irrelevante, como el lugar del surrealismo en tanto movimiento programático.

Este tipo de operaciones, marcadas por usos particulares de la vanguardia como dispositivo de lectura en el diagnóstico de confusión, son las que constituyen las intervenciones críticas de las revistas del corpus. Asimismo, evidencian el proceso por el cual los aspectos más programáticos y estéticos, como los que analizamos en torno a la imagen, son reconfigurados cuando devienen "ojo de la crítica", mirilla o perspectiva desde la cual establecer y cuestionar los términos con los cuales se leía, y los agrupamientos de firmas que estos permitían hacer.

La biblioteca de vanguardia es un dispositivo, en el caso de Pellegrini, que trae claridad a una serie de "confusiones", como atribuir calificaciones equivocadas a Baudelaire, o hacer una mala genealogía del término "no-objetivo". En el caso de poesía buenos aires, haber desacoplado el invencionismo y arte concreto de la "imagen invencionista" y luego volver prescindible a esta como fin último del poema, apoyados en poetas como René Char, Carlos Drummond de Andrade, Henri Michaux, les permite volver a pensar la relación entre poesía y manifiesto, y por lo tanto el tipo de política de lectura que proponen con la selección de poetas que hacen como intervención crítica. En ese sentido, el ojo de la vanguardia es un ojo que quiere ordenar el presente, esclarecer, nuevamente, evitar la confusión entre “contemporáneos" y “embaucadores”. En el mismo movimiento por el cual la vanguardia sale del género manifiesto u obra como formas de intervención, produce el fármacon que necesita para contaminarse sin perder la capacidad de construir límites que establezcan relaciones diferenciales entre los objetos culturales. 


\subsection{3. ¿Una polémica arruinada? Bustos Domecq y los surrealistas}

En el el ensayo de Enrique Molina titulado "Vía libre" (1952, n2:1,7-8), encontramos nuevamente la idea de "confusión" asociada a la de "crítica". Como señalamos en el capítulo anterior, ese texto inaugural de $A$ partir de cero reprochaba a la poesía argentina “de los últimos años”, la "carencia de espíritu de ruptura” (n1, 1952:8). Esta falta se debía a la "impotencia aguda de la crítica", cuya "cobardía" provocaba el "confusionismo más bajo". En consecuencia, Molina señalaba a los responsables de ese diagnóstico: la revista Sur, y la "influencia perniciosa" de Jorge Luis Borges.

Sur era cuestionada como el espacio "donde la consabida 'rosa' no deja de perfumar una prosa de juegos florales, con todas las convenciones del caso" (1952, n1:8). Molina se refería a la inclusión de una serie de textos de la poeta uruguaya Arsinoe Moratorio, y para cuestionarla no citaba sus poemas sino la presentación de la revista;,226 es decir que contaba más la lectura a partir de la cual Sur exponía un análisis de su obra que los poemas publicados. La relevancia que Molina daba a la operación crítica de selección y exposición de los textos es más significativa en torno a la figura de Borges, ya que se remarcaba su "condición de escritor" para aludir a su trabajo como editor o antologador, antes que a su producción de ficciones y ensayos:

A Borges, en efecto, ni su obra ni su prestigio lo autorizan a una conducta que señala a las claras su falta de decisión para asumir hasta las últimas consecuencias su condición de escritor. Por momentos parece empeñado en rebajar su criterio hasta colocarlo al nivel de la política y la connivencia literaria. (1952, n1:8)

Molina se refería a la Antología poética argentina (1941), ${ }^{227}$ que Borges había preparado en Sudamericana junto con Silvina Ocampo y Adolfo Bioy Casares, y extraía del prólogo una parte del párrafo donde se anunciaba la selección: “Quiero asimismo enumerar (antología de esta antología) los siguientes poemas: 'Aulo Gelio', de Arturo Capdevila; 'Whalt Whitman', de E. M. Estrada, etc.”, 228 para luego citar, entonces sí, algunos versos

\footnotetext{
226 "SSur] alude a los poemas de una dama, la señora Arsinoe Moratorio: 'Pero su alma poética no pretende dibujar un enigma - que poca importancia tendría - por lo demás. La vestidura de Arsinoe Moratorio es de soledad y echa a correr con sandalias de canto. Se adentra entonces en cifras abismantes, encontrando ríos salobres, desgranando duelos'. Y más lejos: ‘el endecasílabo la reboza de música y acentos y sus preguntas vienen del principio de la poesía...' o 'No trae Arsinoe otra virtud que no sea la de la rosa..." (Molina 1952, n1:8)

${ }^{227}$ Molina la cita erróneamente como Antología de la poesía argentina.

${ }^{228}$ El párrafo completo decía: "He mencionado, en el decurso de este prólogo, algunos nombres; quiero asimismo enumerar (antología de esta antología) los siguientes poemas: 'Aulo Gelio', de Capdevila; 'Walt Whitman', de Martínez Estrada; 'Circuncisión', de Grünberg; 'Poema para ser grabado en un disco de fonógrafo', de González Lanuza; 'Luz de provincia', de Mastronardi; 'Espléndida marea de lágrimas', de
} 
introducidos por $A$ partir de cero con la calificación irónica de "bellezas". ${ }^{229}$ Molina concluye, menos preocupado por analizar los poemas que por las garantías de la crítica, que "si tal es el criterio de Borges (...), ¿de quién fiarnos entonces? ¿Cómo abandonarnos al pequeño traidor o a quien ya se siente comprometido por todas las coronas fúnebres de su "prestigio"?" (8). En esa cita de Molina se articulaban dos dimensiones que desarrollamos a lo largo del capítulo: por un lado, la crítica como ejercicio de los criterios de selección y garantía de la calidad literaria frente al "confusionismo"; por el otro, la relación entre "prestigio" y "cadáver" que los surrealistas franceses habían establecido cuando publicaron el panfleto sobre Anatole France. ¿Era Borges, entonces, el Anatole France de $A$ partir de cero? En todo caso, parece ser el primero quien asumiría el tono provocador de las vanguardias históricas en una polémica con Letra y Línea, iniciada por “Bustos Domecq" en Buenos Aires Literaria (1954, n17), y arruinada por el desparpajo y la sátira que caracterizó al personaje inventado por Borges y Bioy Casares. ${ }^{230}$

El texto que dio inicio a la polémica se titulaba "De aporte positivo" y comenzaba in media res:

Es de lo más tónico el diálogo con Ortega. Al hombre, claro, échele un galgo; hoy toma el micro en Llavallol, mañana nos saluda lo más campante desde la ventanilla del tren lechero que se desplaza como la lombriz por Burzaco, y pasado, qué se yo. Espíritu inquieto, se lo divisa por conferencias, academias y otras muestras de pintura; picoteando por aquí y por allá, hay que ver cómo asimila. Ya se sabe, es comisionista. (Bustos Domecq 1954, n17:61)

¿Quién habla y de quién nos habla ese párrafo inicial? Por el momento podemos suspender la pregunta y afirmar que se habla de una profesión, la de quienes tienen la capacidad de asimilar, se mueven entre espacios de promoción cultural, la de un comisionista, que en este caso se da en llamar Ortega. En la entrada del sábado 6 de marzo de 1954 del Borges de Bioy Casares, leemos:

Sábado, 6 de marzo. Comen en casa Borges y Pepe Fernández, Silvina nos muestra una revista muy enfática y tonta, pagada por Oliverio Girondo: Letra y Línea. Quiere escribir algo en contra, lo que nos parece innecesario. Comentando lo que podría decirse, imaginamos un artículo elogioso, por un periodista suburbano, de estilo comercial y anticuado. Después de comer lo escribimos. Pensamos mandarlo a Sur, sospechamos que Bianco no va a

Petit de Murat; 'Chanson sur deux patries', de Gloria Alcorta; 'Enumeración de la patria', de Silvina Ocampo.” (Borges 1941)

229 "A la mesa de prósperos amigos/ ingeniosos equívocos llevabas,/ o eruditas anécdotas festivas/ con una erudición del todo vana" y luego "A la vera de Atenas, en la finca / señorial, donde bien te regalabas, / armonizaste la elocuencia griega / con la mejor comodidad romana” (1952, n1:8)

${ }^{230}$ Esta polémica fue analizada por Kira Poblete Araya (2003) como una discusión sobre el nacionalismo en la literatura argentina. 
querer publicarlo. Resolvemos enviarlo a otra revista, a Buenos Aires Literaria. El lunes convertiremos el artículo en un cuentito y el redactor será el amigo del que produjo milagros en la segunda de las Fantasías memorables. Dejamos a Pepe en Pueyrredón y Santa Fe y a Borges en su casa. (Bioy Casares 2006:100)

Por esa entrada nos enteramos que la voz narrativa de la intervención es un personaje de Dos fantasías memorables, publicado en 1946. Lo más interesante de ese pasaje es el contraste entre la respuesta a Silvina Ocampo -la negativa a escribir algo en contra de Letra y Línea, puesto que "parece innecesario"-, la acción siguiente - "después de comer lo escribimos"-; y las entradas del 10 de marzo, 13 de marzo, 14, 15 y 16, cinco días más sobre los cuales se apunta haber estado trabajando en esa "nota crítica o cuentito". Es decir que de la prescindencia a la ocupación, los distancian unos seis días de trabajo dedicados casi exclusivamente a "una revista muy enfática y tonta".

Esa "nota crítica o cuentito" titulada "De aporte positivo" continuaba, en el siguiente párrafo, con el mismo tono coloquial que introduce la llegada del comisionista Ortega con un "órgano de publicidad":

- ¡Rataplán, escribano amigo, rataplán! Aquí le traigo un lenitivo en forma de Revista de cultura contemporánea. Artes plásticas. Literatura. Teatro. Cine. Música. Crítica. (Bustos Domecq 1954, n17:62)

"Rataplán" es, como se sabe, la voz usada para reproducir el sonido del tambor, pero lo que trae "un mozo Ortega" (no el mozo Ortega), al compañero "escribano" es un "lenitivo" (nada menos estruendoso), del cual aún no sabemos su nombre pero sí su subtítulo. El redactor no duda en llamarlo "órgano en cuestión" (62) y luego "hebdomadario" (62) en lugar de semanario, aludiendo al uso eclesiástico, de quienes una vez por semana ofician de guías del coro o el altar en una iglesia determinada. A continuación, la reseña recuperaba tres citas del número 3 de Letra y Línea sin nombrar firmas, título de la nota o ensayo, ni ninguna otra referencia que permitiera reponer el marco de las palabras transcriptas. La primera de esas citas provenía de un poema-crítica publicado por Aldo Pellegrini en el homenaje a Francis Picabia de ese tercer número de Letra y Línea. ${ }^{231}$ Las dos restantes habían sido extraídas de "Paradojas de la poesía" (Svanascini 1953-1954, n3:5), de donde Borges y Bioy Casares tomarían el título de la intervención:

\footnotetext{
${ }^{231}$ Del cual se transcriben los siguientes versos: "El tiempo de tu sonrisa despierta a los relojes/ el tiempo de tu sonrisa acelera a los relojes / lanzaste el canto que no se puede detener / el canto que sacude a los personajes inmóviles"
} 
Ya no es posible valorizar la opinión de esos aletargados en relación a su tiempo, que persisten en una ignorancia con respecto a la comunicación actual. El escritor debe servir a su tiempo a pesar de los tranvías.

La destrucción, defensa de las actitudes insólitas o conjugación del fracaso, son elementos de aporte positivo.

Lo que se dice de cada una de ellas no traspasa el efecto de la burla, con expresiones como "cuál no sería mi reacción favorable cuando leí", "quedé engolosinado con esa cita" o "medio trastabillé con el sacudón. Ya nunca sería el mismo", o "me fue dado elevarme a altitud que se relevó aún más considerable" (Bustos Domecq 1954, n17:63). En la réplica del redactor al comisionista, se dice que "a pesar del escaso margen de tiempo que nos deja la profesión, tengo un rinconcito en reserva para las cosas del espíritu, cuando se exhiben con toda seriedad, ¡eso sí!” (63). "Seriedad”, “cosas del espíritu”, "literatura engolosinada", "elevación", "folleto de referencia", "valores sólidos", "aportes novedosos", "candentes y modernos temarios", "vistoso elenco", son los términos con los cuales se califican distintas dimensiones de la lectura de la revista. La burla de Bustos Domecq mezclaba, entonces, términos propios de Letra y Línea (como "cosas del espíritu" y "valores sólidos") con aquellos que, desde el surrealismo, eran antónimos ("literatura engolosinada", "folleto de referencia"). Así, mientras Molina se había preguntado “cómo fiarse?” de un prestigioso escritor que hacía malas selecciones, Bustos Domecq impugnaba la crítica como operación de discernimiento arruinando cualquier enunciado estable en la burla. Es en uno de los últimos párrafos donde la intervención de "Aporte positivo" extrema la retórica de la sátira, al punto de volverla tan grave que se asemeja a la seriedad que cuestiona:

Me hizo un precio especial por el número, que era una ganga, apalabrándose a conseguirme otros parecidos. En eso, un chancho que siempre lo pone un poco nervioso, le devoró la cinta, las iniciales y un sector de su pajizo negro y a Ortega le dio la loca por irse. Salió como si lo persiguiera una fiera y el chancho, que es de un pelaje entre rosillo y moro, lo acompañó personalmente hasta que se perdieron de vista.

¿Qué nos dice esa escena? ¿Por qué un chancho?, ¿era necesario desplegar otra vez un bestiario en el repertorio de Bustos Domecq, para qué en todo caso agregar más grotesco al grotesco inicial del "cuentito"? Este aspecto puede leerse en dos dimensiones. La primera, estrictamente retórica e institucional, tiene que ver con romper los códigos del género y eliminar el "acuerdo básico de igualdad" o "reconocimiento subjetivo del otro" 
(Panesi, 2018: 38). ${ }^{232}$ De esa impugnación se deduciría que, para Borges y Bioy Casares, Letra y Línea no era más que un folleto del mercado, donde se publicaban muchos sonidos de tambor y poco contenido, y donde la cultura moderna era "asimilada" en un "picoteo" que tiene el efecto estimulante de un pan con manteca y té con leche. ${ }^{233}$ Convertir las ambiciones transgresoras de los surrealistas, que habían demandado "ruptura" en el ensayo de Molina, acusando a Borges de protegerse en las pompas fúnebres del prestigio, en una "inyección" de carbohidratos es una intervención crítica tan poco productiva como la inexplicable escena del chancho que asusta al comisionista. Pero es tal vez esa improductividad o impotencia el gesto crítico más provocador con el cual fuera deseable intervenir frente a todas las exigencias de la época hacia la literatura, a las cuales tampoco escapaban las revistas surrealistas e invencionistas. En ese sentido, la burla no echaría a perder la polémica rompiendo los códigos del género, sino que se afirmaría como otra posibilidad crítica, igualmente seria (ya que en la burla no hay ironía) con respecto a otras posiciones.

No obstante ese señalamiento, podemos advertir una segunda dimensión interpretativa en torno al pasaje del chancho. En la entrada del jueves 16 de octubre de 1952 del Borges, Bioy Casares apuntó:

Pensando en Éluard, en Breton, en Queneau, en Michaux, en Supervielle y tantos otros jefes de la literatura ¿Cómo sería el futuro de conversaciones con personas que hablan en serio de Fargue, que encaran el bicornuto dilema de elegir entre Aragon y Prévert, que imaginan que solo hay tres posibilidades: catolicismo, comunismo, surrealismo? Como decía Borges la otra noche, las dos primeras doctrinas permiten, por lo menos, la redacción de libros; los franceses parecen no haber advertido que el surrealismo, valga lo que valga la teoría, impide en la práctica la producción de páginas legibles. Borges me dijo también: ¿qué pensará la señora David- Neel, que conoce el oficio de componer libros aceptables, de personajes como Breton o como Éluard? (2006: 69)

No parece casual que esta entrada coincida en parte con la edición de $A$ partir de cero donde se cuestiona la intervención de Borges como antologador. Tal vez lejos de arruinarse, la polémica se refuerza en tanto su grotesca indeterminación -¿se ha vuelto,

\footnotetext{
${ }^{232}$ Un dato relevante a observar es que Borges ya había cuestionado el surrealismo casi veinte años antes, en la reseña del manifiesto Por una arte revolucionario de André Breton y Diego Rivera publicada en la revista El Hogar, titulada "Un caudaloso manifiesto de Breton".

233 "Se despejó la incógnita! El órgano en cuestión que agitara Ortega no era otro que Letra y Línea, en su número 3 (tres). Me dirán, y no les discuto, que las palabras tan ufanas del gran amigo debieron activar como una inyección de café con leche y pan con manteca mi desanimado organismo, pero lo más cierto es que tantas veces uno se ha pelado la frente con revistitas dañinas e insustanciales que no resulta fácil iqué pucha! suscribir un voto de confianza”. (Bustos Domecq, 1954: 62)
} 
de pronto, fantástico, "el cuentito"?- exponía la escritura imposible de la vanguardia (las páginas ilegibles que derivan de su productividad teórica) como si el contacto con una revista como Letra y Línea diera lugar a escrituras inverosímiles, destartaladas como las de "De aporte positivo". En ese sentido, la polémica hace huella en la estructura formal que la sostiene y que la exhibe, más que en aquello que se dice. ${ }^{234}$

Las respuestas de Letra y Línea en el último y cuarto número en 1954, así como la continuación del enfrentamiento en A partir de cero en su segunda época (1956), insisten, sin embargo, en instalar la polémica en el terreno de las discusiones propias de la crítica acerca de los criterios de selección y publicación de autores. Con un texto breve títulado "Borges y Bioy Casares, paladines de la literatura gelatinosa", Letra y Línea cerraba la publicación (ver imagen 28). Vale recordar que el adjetivo "gelatinoso" había sido usado también por Alberto Vanasco en el ensayo sobre Eduardo Mallea, publicado en ese mismo número de la revista, pero agregan, en un trazo donde es posible reconocer la impronta de Oliverio Girondo, la "gracia hipopotámica" a la dupla de Bustos Domecq. ${ }^{235}$

Así, la conjunción de lo gelatinoso e hipopotámico anunciaba un movimiento que se interrumpe: cuando creemos que Letra y Línea va a continuar la batalla por los medios del absurdo, el grotesco y el desplazamiento de lo verosímil en el campo de las ideas, el texto se vuelve serio y asume las críticas de Borges y Bioy Casares en un sentido unívoco. En el primer párrafo se da curso al tono bufo anterior, y se afirma desprender lo siguiente del enfurecimiento desatado en Buenos Aires Literaria:

$1^{\circ}$ Que el chancho es el Dios tutelar y vengador con el que se identifican los autores (evidentemente, la literatura gelatinosa, nutrida de desperdicios y residuos literarios, se aviene perfectamente con las características del aludido animal). (1954, n4:16)

Pero a continuación, ordenados como segunda y tercera cuestión, Letra y Línea respondía las críticas de sus interlocutores asumiéndolas seriamente:

\footnotetext{
${ }^{234}$ No desconocemos que el "estilo Bustos Domecq" - y por lo tanto su humor característico - es previo a la escritura de "De aporte positivo"; sin embargo, es significativo que Borges y Bioy Casares hubieran elegido ese personaje para escribir sobre Letra y Línea, asociada con la asimilación de teorías improductivas sobre la escritura.

235 "En el n ${ }^{\circ} 17$ de Buenos Aires Literaria, Borges y Bioy Casares, conocidos fabricantes de repostería literaria para uso de las niñas de la buena sociedad, se enfurecen con Letra y Línea. De la confusa mezcla de rencor gelatinoso y gracia hipopotámica de que hacen gala en este texto, se desprende lo siguiente" (1954, n4:16).
} 
$2^{\circ}$ Que nuestra revista se dedica a "atacar a ciertos escritores para ensalzar a otros". Este descubrimiento tan sorprendente resulta un propósito no solo evidente sino razón fundamental de la aparición de Letra y Linea. En el número inicial figura de modo destacado en la declaración de motivos y entonces la designamos como tarea de revalorización o rectificación de las jerarquías literarias y artísticas. En otras palabras: esa actitud, que naturalmente resulta alarmante para Borges y Cía., significa señalar y denunciar la falsedad de la posición destacada de determinados escritores y artistas, lograda por razones variadas, entre las cuales nunca figura el mérito real.

En el mismo sentido, para finalizar, responden que "Borges y Cía." no debieran preocuparse, ya que no están ausentes en Letra y Línea -“de ningún modo han sido olvidados"-, por el contrario están ocupando un lugar destacado "aunque no desempeñando ya el papel dramático sino el cómico”. Letra y Línea insistía así en reconocerse como parte de la tarea "de revalorización o rectificación de las jerarquías literarias y artísticas" que el texto de Bustos Domecq había desbaratado al destruir la validez de cualquier criterio de lectura.

Dos años más tarde, en el número de $A$ partir de cero de 1956, la segunda época dirigida por un comité editorial colectivo, Aldo Pellegrini publicaría el artículo "Comentario a tres frases célebres (La celebridad es la conciencia del horror)", apelando a lo que este último llamaba "humor negro". Las tres frases que toma son: "Buenos días, señora", de Jorge Luis Borges; "Cuando los dos gases mencionados previamente se mezclan en presencia de un filamento de platino, forman ácido sulfúrico", T.S. Eliot; “¡Pamplinas, muchacho!”, William Faulkner. El gesto inicial de Pellegrini es destacar a Borges, y anteponerlo a los ejemplos internacionales, como "nuestro autor nacional". El interés de la expresión, “así, un poco al azar", dice el autor de la nota, se debe a que "más allá de esa transparencia [se descubre] una tenue opacidad", y "en esa profundidad última, en esa sagrada tiniebla, se oculta el horror a la vida, la exaltación del vacío literario". Así, Aldo Pellegrini parecía burlarse de la calificación de Borges como un escritor complejo y agudo, cuya literatura estaba cargada de símbolos a descrifrar:

Puede decirse, sin exagerar, que la frase motivo de este comentario, encierra la mayor síntesis expresiva que pueda dar el lenguaje. En primer término, resulta evidente que la componen dos partes, separadas por la coma. A la izquierda de la coma la expresión "buenos días" representa el universo en su totalidad, lo cósmico, y en ella por sucesivas escalas de significados cada vez más incandescentes se parte de una aparente benignidad climática (lo terreno) hasta un inconcebible fuego monstruoso (lo sideral), de la tibieza se pasa a la ignición, de lo soportable para el hombre a lo insoportable para los dioses. A la derecha de la coma (señora) está lo simplemente humano (señora) pero en 
su forma originaria, en su sentido de gran matriz (señora), como comienzo y fin, como cristalización de la misteriosa energía que es la vida. (1956, n3:3)

A continuación analizaba los efectos de la "coma" en la frase, como un "vaivén" entre "el mundo" y lo "humano", o bien entre lo "objetivo" y "subjetivo":

Si se contempla ahora la frase desde la perspectiva de estos sorprendentes hallazgos se la nota animada de cierto vaivén, que depende seguramente de su asimetría. En efecto: sus partes representan pesos diversos aunque cambiables: en ciertos momentos el mayor peso recae sobre el mundo, en otros sobre el elemento humano (señora). En este vaivén el autor ha querido señalar todo lo que de inquietante tiene el conocimiento, y que este comporta una corriente ininterrumpida, pero alternada, que va unas veces de la objetividad a la subjetividad, otras de la subjetividad a la objetividad. (3)

Lo que Pellegrini cuestionaba, finalmente, era que el encadenamiento de interpretaciones sucesivas e interminables, como las que serían posible hacer de la expresión "Buenos días, señora”, funcionaba como el peso aplanador de la experiencia vital. Y que por lo tanto, las "profundidades últimas" u "opacidades" solo profundizaban una separación entre el arte y la vida:

Mediante [la literatura] los hombres pueden alcanzar un estado de complaciente embeleso y refinada imbecilidad que de generalizarse, puede llegar a la supresión de las guerras y el aniquilamiento total del sufrimiento. Tal es el objeto de la llamada cultura del siglo XX. Gracias al poder de tales escritores, la vida misma puede desaparecer asfixiada por un cúmulo de minúsculas y bien dosificadas sensaciones literarias. Desgraciadamente, las masas, brutalmente vitales, sienten repulsión por la cultura; rechazan el vacío, y prefieren, por encima de todo, simplemente vivir. (1956, n3:4)

Así, el cierre de la polémica que había comenzado en 1954, se desplazaba de la voluntad por discutir, en el caso de Letra y Línea, las funciones de la crítica -“tarea de revalorización o rectificación de las jerarquías literarias y artísticas” (1953, n4:16)- hacia una intervención sobre las relaciones entre literatura y poder (aludiendo con este último término al carácter coercitivo de las "sensaciones literarias") que resultaban cuestionadas por un impulso vital más poderoso que las codificaciones de la cultura.

Como vimos hasta acá, las tres polémicas analizadas parten de la inquietud que les produce un "estado de confusión", donde las posibilidades de renovación a las que aspiraban las revistas del corpus se verían obturadas por malas asociaciones y selecciones. De este modo, la asimilación errónea que Pellegrini atribuye Payró de los términos "noobjetivo", "abstracto" y "concreto" daría lugar a calificaciones cursis para una artista mal incluida en una muestra de Arte Moderno; la mala definición del "inconformismo 
poético" en pba sería consecuente con una mala ubicación de las influencias de Baudelaire en la historia de la poesía, y por lo tanto una lectura incompleta de la poesía contemporánea; y la "cobardía crítica" de los escritores consagrados sería responsable de una falta de ruptura en la poesía argentina de mediados de siglo, según afirmaba Molina en $A$ partir de cero. En ese sentido, las polémicas ponen en escena operaciones propias de la crítica, como establecer un conjunto de selecciones por sobre otras o cuestionar los términos y valores con los que determinada obra es leída.

Como anticipamos en la presentación del apartado, leer estas operaciones críticas supone desplazarnos de las perspectivas dominantes sobre la época, según algunas historias de la literatura (Cella 1999, Mangone y Warley 1981, Rosa 1981) e investigaciones especializadas en historia de la crítica (Rosa 1999, Nacher 2015, Panesi 2004, Avaro y Capdevilla 2004) o historia de las ideas (Terán 1986, 1991). Si la crítica del período había sido analizada en términos de "modernidad", a partir de nociones como la de "irrupción", "punto de viraje", "eclosión de discursividades teóricas"; el tipo de operaciones que analizamos en las polémicas de nuestro corpus, pueden analizarse bajo la figura de "bullicio de la crítica" antes que la del "vozarrón" o "irrupción".

Desde el bullicio es posible enfocar la ambigüedad e impresionismo que moduló muchas de las escrituras críticas de Ciclo, pba, A partir de cero y Letra y Línea, así como también las apropiaciones no sistematizadas de los autores teóricos que incluyeron en sus programas, como Blanchot y Bataille. Por otra parte, nos permite advertir una diferencia cucial con respecto a Contorno, Sur o Buenos Aires Literaria, como la ausencia de números especiales dedicados a un autor en particular (a excepción del número 11-12 de pba sobre René Char), y la relevancia que, por el contrario de las figuras autorales, le dieron a la conformación de pequeños corpus de lecturas, sobre cuyos criterios polemizaron. El bullicio de la crítica sería, entonces, la contraparte a esa eclosión discursiva y vozarrón; en él, la escritura no responde a una discursividad teórica que la fortalezca y justifique, sino que se mueve como un eco donde convergen, de forma contradictoria, diversas inquietudes en torno a la época, más o menos cristalizadas. El bullicio abre el tiempo de esa "estasis" de la crítica, como sugería Deótte para leer otras capas temporales no sujetas a lo acontecimental. Este tiempo no acontecimental, abierto, propone una sintaxis de las conexiones (Antelo 2015a, 2015b) ${ }^{236}$ donde un objeto como

\footnotetext{
${ }^{236}$ Tanto en Archifilologías latinoamericanas. Lecturas tras el agotamiento (2015a), como en “"'El tiempo de una imagen: el tiempo-con" (2015c), Antelo se ha referido a la lógica del "con" o paradoja "de lo moderno: la de tener que conciliar, en la obra, su contemporaneidad; es decir, su pertenencia a los actos de
} 
las revistas del corpus, que había sido leído en tanto expresión de la vanguardia poética, entra en diálogo con la historia de la crítica en Argentina. Estos aspectos son también los que priorizamos en la lectura de las series de la crítica como zonas de contacto.

\subsection{Las series de la crítica. Zonas de contacto}

Como vimos hasta aquí, el lugar de la imagen surrealista e invencionista aparece desplazado en algunos de los argumentos que buscan determinar la validez de ciertas lecturas y la política de conjunto que estas esgrimen (es decir, una política de los agrupamientos, del ensamblaje respecto a lo que puede ser mostrado en determinadas relaciones y las que no). Las polémicas entre Pellegrini y Payró o la polémica con Aguirre y poesía buenos aires corren de lugar la relevancia de la imagen como aquello que debe "cumplirse" conforme a ciertas características y se mueven hacia el cuestionamiento de criterios de selección y lectura. En ese sentido, la crítica opera como sustracción de las aspiraciones de totalidad que se leen en la noción de imagen que tanto el surrealismo como el invencionismo argentinos delineaban, e interviene, desde una biblioteca de la vanguardia histórica, reconfigurando las relaciones entre pasado y presente a partir de un énfasis en lo contemporáneo.

En relación con esas operaciones, en los próximos sub-apartados exponemos tres series de la crítica tomando aquellos espacios significativos donde la política de la exposición conforma una secuencia de lo heterogéneo que se rige por un valor retomado de las vanguardias históricas, pero incorpora otros elementos que dan cuenta de una ampliación respecto a esos mismos valores. El vínculo entre ese valor y su ampliación modula el carácter superviviente de la vanguardia a mediados de siglo, y por lo tanto, discute con las opiniones de otras revistas de la época según las cuales todo intento de experimentación, espíritu lúdico, refractario a lo real, ya habría sido superado veinte años atrás.

La primera serie que analizamos es la que se arma entre Lázló-Moholy Nagy y Georges Bataille, a partir de eso que Raúl Antelo denominó "efigie textual” (2013:179) en Ciclo, y que nos permite tanto articular como contraponer dos modos de pensar las

habla del presente aunque su procedencia se retraiga al más remoto origen, y ello muestra asimismo que la obra, aun cuando sea inspirada por el pasado de la lengua, no deja de operar simultáneamente, sobre el recuerdo de su mismo presente" (Antelo, 2015c: 381). 
herramientas críticas disponibles. En segundo lugar abordamos la serie Roberto Arlt Juan Carlos Onetti y Wilfredo Lam como secuencia que produce una conmoción en las concepciones sobre el realismo argentino de mediados de siglo. Por último, se tomó la lectura que hizo poesía buenos aires de los poetas Vicente Huidobro, Henri Michaux y Tristan Tzara, y algunos contrapuntos respecto al modo en que Letra y Línea analizó a los mismos autores.

Como señalamos en la introducción y en apartados anteriores, estas series no se tratan de algo dado, o prefigurado por las revistas, sino de una construcción críticometodológica a partir de la noción de aparatos estéticos como materialidad que dispone técnicas de aparición que configuran un sentido. En cada caso hay límites materiales para señalar el corte de una serie, y aspectos relevantes que determinan la consideración de ese conjunto de elementos por sobre otros elementos que también podrían leerse de manera conjunta. ${ }^{237}$ Los elementos de la serie, extraídos de la vanguardia histórica, devienen ojo

\footnotetext{
${ }^{237}$ En relación a los límites materiales de las "series críticas", hemos dejado afuera una secuencia que gira en torno a la idea de "monstruo" por no ajustarse a ellos. Entre Ciclo y Letra y Línea hay un conjunto de textos que pueden pensarse desde esa figura potente - especialmente si pensamos que el "monstruo" es, en el pensamiento de Foucualt, la figura que suspende la continuidad de lo naturalizado y corta el tiempo (2008:167-174)-: el fragmento de Trópico de Capricornio traducido en Ciclo 1, el ensayo de Bataille sobre Miller en el mismo número, el ensayo de Enrique Pichon-Rivière en Ciclo 2, el texto de Vanasco sobre Arlt en Letra y Línea 1, la carta de Miller a Fraenkel también en el primer número de la revista dirigida por Pellegrini, el adelanto de novela de Juan Carlos Onetti titulado "La resurrección de Díaz Grey" en Letra y Línea 2, y por último, el ensayo sobre la 'Patafísica de Juan Fassio en Letra y Linea 4, donde postula la noción de "fenomenología del monstruo" como modo de pensar las formas de in-clasificación de la vanguardia. Decimos que excede los límites materiales de la noción de "serie" porque su criterio de conjunto está dado por la insistencia de una figura que es posible rastrear, pero no por su forma de organización. Es por este motivo que hemos dejado de lado un análisis posible sobre la cuestión. Sin embargo, apuntamos a continuación algunas consideraciones que han sido establecidas por Raúl Antelo (2013) y una reseña de los argumentos de Pichon-Rivière que pueden contribuir algunas líneas de un estudio futuro. En "La lectura poslógica de Ciclo", Raúl Antelo ha reparado sobre una triangulación posible entre Georges Bataille leyendo a Henry Miller y Lautréamont leído por Pichon Rivière como resonancias del Sade et Lautréamont de Maurice Blanchot publicado también 1949. En ese mismo año se había publicado, a su vez, La part du feu donde habían los primeros ensayos sobre René Char, Sartre, el surrealismo, Rimbaud, Baudelaire, y el ensayo titulado nada menos que "De Lautréamont à Miller", donde afirmaba: « C'est une curieuse coöncidence que l'on ait pu lire en français les premiers livres d'Henry Miller, au moment où s'évoquaient comme un anniversaire l'oeuvre et le mystère de Lautréamont. (Les éditions G. L. M. ont publié j adis un document qui fixe au 4 avril 1846 la naissance d' Isidore Ducasse.) Ces blocs de prose que sont Tropique du Cancer, Printemps noir, ces champs de mots qu'il faut saisir dans toute leur étendue et non par partie, nous rendent une manière de lire et de comprendre qui, dans notre esprit, est liée à Maldoror » (1949:160). Antelo no señala una red de lecturas sino la presentación de una serie insoslayable en cuanto a lo común que la comparte. "De Lautreámont à Miller" parece sugerir el camino inverso entre el primer y el segundo número de Ciclo, y podríamos aventurar esa pista, preguntarnos qué lee Blanchot en esas "escrituras ligadas" y qué da a leer Ciclo entre las aperturas sus dos números únicos. Pero Enrique Pichon Rivière propone un recorrido particular que resulta pertinente abordar porque da cuenta de la preocupación creciente de la revista por "poner en relieve el propio marco de evaluación" (Foucault 1995 citado en Butler 2001).

"Vida e imagen del Conde Lautréamont" se presenta como transcripción de la primera conferencia -de quince totales- que integrarán un libro dedicado al Psicoanálisis del Conde Lautrémont por Pichon Rivière. Este ensayo puede ser pensado a partir de dos momentos: el análisis que el psicoanalista hace del "estado de la cuestión" en las investigaciones sobre el poeta franco-uruguayo, según la hipótesis de que la represión
} 
de la crítica, el prisma propio por donde se configura la temporalidad del bullicio, antes que el acontecimiento de la irrupción.

\subsubsection{Vanguardia lumínica y fulminación de la conciencia: la serie crítica de Ciclo}

El retrato de Lázló Moholy-Nagy en el primer número de Ciclo nos permite observar un movimiento doble. Si por un lado anticipaba, desde la imagen, la presencia de un artista de la vanguardia constructivista, por otro lado contrastaba con los primeros textos de la revista, que son también lo primero que leemos a vuelta de página, consignados en el sumario: un fragmento extenso de Trópico de Capricornio de Henry Miller, traducido por Pellegrini y un ensayo de Georges Bataille sobre el autor

que la historia de la literatura hizo de su obra es un síntoma del rechazo a lo monstruoso, y en segundo lugar, una lectura psicoanalítica de Lautréamont. El texto abre de la siguiente manera: "Toda investigación sobre la vida del Conde Lautréamont se vio siempre dificultada por factores externos, fortuitos y sobre todo por factores internos, existentes en aquellos que se ocupaban de él. La angustia que condiciona esta situación estaba ligada a los aspectos siniestros de su vida y de su obra." (...) Esto que parece una generalidad irá declinando en función de dos series posibles: por un lado los críticos franceses León Bloy y Remy Gourmont, cuyas escrituras sobre el poeta alimentaron una leyenda maldita que construía la peligrosidad de su lectura; por otro lado, una genealogía de lectores hispanoamericanos sobre los cuales no recae la insignia de "dificultad" con que caracteriza las investigaciones antecedente, sino de apertura, pertinencia y justeza: Rubén Darío, Leopoldo Lugones, Ramón Gómez de la Serna y Juan C. Welker poeta y diputado uruguayo. Para dar cuenta de eso, el ensayista debe mostrar por qué la existencia de un poeta como Lautréamont "fue reprimida por su medio y cómo poco a poco, merced a la labor de muchos, tal como un psicoanalista va venciendo las resistencias del enfermo, se pudo traer a la conciencia de esta época algo de este material previamente reprimido" $(1949$, n2:6). Puesto que Isidore Ducasse será leído "situado en el tiempo y la historia de la literatura", es preciso explicitar las condiciones por las cuales Los cantos de Maldoror ha sido soslayado en la historia de la literatura. En este punto es interesante que Pichon Rivière retome la crítica de León Bloy anotando que este se refiere a su lectura de Lautréamont como "hallazgo de un gran poeta"; es decir el problema no consiste en establecer los criterios de valoración por los cuales se legitima el buen o mal arte en términos individuales, sino las variables de lectura que generan condiciones de apropiación, por eso Bloy, según Pichon Rivière, es "el hombre que decapita por mandato de ley": "Voluntario verdugo de esta generación; más que todo es un Monje de la Santa inquisición. Su juicio decidió el porvenir literario de Lautréamont, pero solo el porvenir inmediato y obró como conciencia moral de su época, como elemento represor, Lautréamont es un genio, pero es un genio loco, hay que tener cuidado de él." (1949 n2:19) Lo que aparece como censura moral según Pichon Rivière en la crítica de Leon Bloy es continuado en la biografía de Remy Goumont, 1891 (un año después de la publicación completa de Los cantos de Maldoror), con la figura del "alienado". Pero si la conciencia moral de un crítico es el elemento represor para una generación, el surrealismo como movimiento colectivo es la trascendencia inconsciente de Lautréamont (1949, n2:10). La figura del editor de la obra completa en 1890, L. Genanceaux, es rescatada en ese doble sentido por Pichon Rivière: por un lado repone las condiciones por las cuales Lacroix - primer editor de Los cantos - había debido retirar todas las copias de circulación: el miedo al procurador general y no una creencia en la desvirtud del texto; y por otro lado lo aproxima a otra generación. Presentado el abanico de lecturas en torno a Lautréamont, con un claro quiebre entre Francia y Argentina y España, Pichon Rivière despliega una lectura biográfica psicoanalítica para discutir las lecturas de la alienación y restituir parte de un archivo inexistente. Un ejemplo de esto es el testimonio de un compañero de Liceo quien recuerda que Isidore amaba Edipo pero le reprochaba a Yocasta que no se suicidara en público; esto es suficiente para que el ensayista lo vincule con el hallazgo de que la madre de Isidore se habría suicidado. 
norteamericano, traducido por Marcia Bastos. ${ }^{238}$ Desde el punto de vista de la imagen, nada más distante que una política de lo mínimo, de la luz como principio constructivo de la obra, mediada por el ejercicio de la técnica, como sugería Moholy-Nagy y el erotismo exuberante, acéfalo, ${ }^{239}$ heterológico que proponía Bataille como estética y política capaces de resistir un mundo dominado por el poder de la técnica. En ese ejercicio del vuelta de página, la disposición de aquello que vemos / leemos (la primera imagen y el primer texto) cobra relevancia si pensamos que cada elemento puede ser leído como el material $^{240}$ del que está hecha la revista-aparato. A partir de esa política de la exposición, la secuencia Moholy-Nagy - Miller - Bataille puede ser leída como una serie crítica donde se configura una posición con respecto a las relaciones entre crítica, vanguardia y temporalidad. Es decir que la posición crítica no sería ni la de Bataille ni la de MoholyNagy, sino lo que emerge de una sintaxis de las conexiones que junta a uno con otro.

Entre el artista concreto y el escritor-crítico se cifran dos formas de pensar las vanguardias en la experiencia de postguerra que la revista pone a consideración de modo casi simultáneo y contradictorio aunque ambas parecen respuestas posibles a las impugnaciones de caducidad que buscaba imponérsele a una expectativa vanguardista, tal como vimos en el primer apartado. Esa respuesta provendría, para Moholy-Nagy, de las posibilidades revolucionarias y comunitarias que ofrecía la técnica. Para Bataille, en cambio, una de las respuestas posibles a la contemporaneidad radicaba en el pensamiento del instante como ruina de todas las cosas ordenadas o desborde de lo total entendido como unidad. De esta manera, la revista Ciclo estuvo atravesada por esas dos formas de pensar la vanguardia, a través de las cuales conformó una lectura del presente.

En la “Carta a Kalidova”, László Moholy-Nagy explicaba por qué había decidido regresar a la pintura de caballete luego de experimentar las relaciones entre luz, técnica y arte. Lo que primaba en su escritura, sin embargo, no eran las razones de esa decisión sino el camino que iba del anhelo - "yo soñaba con aparatos que permitiesen, gracias a un dispositivo manual o automático-mecánico, proyectar visiones luminosas en el aire, en vastos salones, sobre pantallas de sustancias inusitadas: brumas, gases, nubes" (n1, 1948:57) - a la necesidad de "establecer las bases de la futura arquitectura de la luz" (56).

\footnotetext{
${ }^{238}$ Si bien no pudimos rastrear la trayectoria de Bastos, no descartamos que sea un seudónimo de María Luisa Bastos, traductora de El erotismo (1960, Sur).

${ }^{239}$ Ver nota en el capítulo III.

${ }^{240}$ Tomo la noción de material en el uso que le da Ana Porrúa a partir de Theodor Adorno: "todo aquello de lo que parten los artistas: todo lo que en palabras, colores, sonidos, se les ofrece hasta llegar a las conexiones del tipo que sea, hasta llegar a las formas de proceder más desarrolladas respecto del todo: por eso las formas pueden tornarse material" (Adorno en Porrúa 24)
} 
La distancia entre esos dos puntos estaba dada por la exigencia de reflexionar sobre el devenir de las vanguardias, según afirmaba en un párrafo que mencionamos anteriormente:

Hemos publicado muchos programas, hemos lanzado al mundo muchos manifiestos. La juventud tiene derecho a saber por qué han fracasado nuestras aspiraciones, por qué no se han cumplido nuestras promesas. Al mismo tiempo la juventud tiene el deber de no cejar en la búsqueda y difusión de las nuevas formas que han de permitir el progreso del arte. (1948, 59-60)

La simultaneidad de la idea de fracaso de las vanguardias con la de insistencia en la renovación atravesaba toda la carta como fuerzas que lejos de ser excluyentes se correspondían:

(...) es menester restaurar el culto del color tal como lo profesábamos antaño. Y al mismo tiempo debemos esforzarnos por dominar cada vez más la técnica a fin de elaborar la materia coloreada y óptica con un sentido constructivo, en vez de extasiarnos ante una labor basada principalmente en el sentimiento y difícil por lo mismo de sujetar a control. (1948, n1:58)

\section{$(\ldots)$}

Dado que nos resulta imposible realizar cabalmente en estos tiempos nuestro sueño: desarrollar en toda su plenitud la técnica óptica (arquitectura luminosa), no tenemos más remedio que limitarnos por el momento a la pintura de caballete. Sin embargo, considero necesario continuar mis experiencias con sustancias artificiales tales como la galalita, la trolita, el aluminio, el zellón, y usarlos como medios para mi obra, porque el uso de estos materiales en el arte ayudará a demostrar su aplicabilidad en una esfera más amplia (73-74).

Restaurar las teorías del color para no quedar "extasiados" en el sentimiento, y volver al caballete pero continuando con las exploraciones de la materia, eran los movimientos que proponía Moholy-Nagy como parte de la tarea de no cejar en la búsqueda y responder al fracaso de las promesas. En ese sentido, la publicación de la carta nos dice algo sobre el carácter ambiguo de Ciclo en torno al tiempo sobre el que pretendía intervenir, en tanto ella misma asumía la declinación de las vanguardias en Europa y la apuesta por un asombro renovado. Ahora bien, ¿qué aspectos de estas notas sobre la luz y la galactita podían aportar un modo de leer o de mirar el arte moderno a la revista argentina? MoholyNagy inscribía en términos de "técnica" la necesidad de cuestionar el imperio del "gusto" o la "subjetividad" según el cual "el artista no ha de tener más guías que la intuición y el sentimiento" (60), así, lo que se configuraba como procedimiento (restaurar el color, desarrollar la técnica óptica) devenía criterio de evaluación. El artista húngaro entendía 
que la negación de la técnica y la elaboración intelectual constituían un "perjuicio dañosísimo" para el arte, y en ese sentido era urgente recuperar una reflexión técnica acerca de las posibilidades del arte en instalarla en el terreno que va del fracaso a la exigencia de renovación.

La inquietud de Moholy-Nagy, quien como representante de la Bauhäus era entonces un referente de la Asociación Arte Concreto Invención y sus derivas en Nueva visión (1951), se correspondía con el diagnóstico de Elías Piterbarg sobre el surrealismo. Como comentamos en el capítulo anterior, en la crónica titulada "Surrealismo y surrealistas en 1948" (1948, n1:65-73), ese "fracaso" de los manifiestos se pormenorizaba como pérdida del poder combativo, una de cuyas consecuencias era que los jóvenes optaran por asistir a las conferencias sobre existencialismo antes que a los bares frecuentados por Breton. En ese marco, y frente a los diagnósticos de caducidad de las vanguardias, la técnica ofrecía una vía de reflexión y no solo un procedimiento. Desde ese enfoque podemos pensar que no se trataba solo de detenerse frente a lo incumplido como una comprobación de lo desechable, sino de observar lo efectos de dicho incumplimiento, que, para la mayoría de quienes integraban las revistas argentinas de vanguardia, se habían cristalizado en las exigencias del realismo socialista. ${ }^{241}$

En relación con esa experiencia, Moholy Nagy, como otros colaboradores nacionales e internacionales de Ciclo, afirmaba la importancia de una perspectiva vanguardista contemporánea y simultáneamente interroga las vinculaciones del arte con su época:

Según su temperamento, el artista sigue en su labor uno u otro de los dos caminos siguientes. Un sector de ellos aplica sus energías creadoras a los problemas actuales y a los hechos evidentes de la existencia transmitidos por tradición y aceptados sin discusión por sus contemporáneos. Su tarea consiste simplemente en perpetuar nuestra tradición cultural. Otros en cambio, beben su inspiración creadora en todo aquello que no existe aún, que se halla aun en estado embrionario, en todo aquello que se orienta al porvenir y no ha sido aun sometido al testimonio de la experiencia. (Moholy Nagi 63)

Así, el artista verdadero no era aquel que respondía sin discusión al juicio extendido acerca del fin de la experimentación y el imperativo del compromiso inmediato, sino el que se orientaba al porvenir, y aún más, lo no sometido por el “testimonio". Esta palabra es relevante si pensamos que se trató de un término utilizado tanto por Contorno ("nos acercamos a la literatura como un testimonio"), como por Ventana de Buenos Aires,

${ }^{241}$ Cfr. Lucena, Daniela (2015) y Petra, Adriana (2013) 
caracterizada por un revisionismo nacionalista que Contorno calificaría de reaccionario; en ambas, el término se utilizaba para definir la literatura en tanto discurso sobre la realidad antes que como forma de la imaginación o la experiencia.

Ahora bien, aquello con lo que nos encontramos al dar vuelta la portada de Ciclo no es inmediatamente con el ensayo de Moholy-Nagy sino con un extenso fragmento de Henry Miller, de Trópico de Capricornio y a continuación, el ensayo de Georges Bataille, “La moral de Henry Miller". Esa dupla ocupa más de un tercio de la revista (treinta y siete páginas de noventa y cinco). Que Ciclo presentara esos textos como primera lectura constituye un indicio por el cual podemos pensar que la revista se referenciaba antes con la crítica literaria que con un movimiento estético particular. Allí recuperaba el primer ensayo de otra publicación, titulada nada menos que Critique: revue générale des publications françaises et étrangères, y dirigida por el mismo Bataille, premiado en 1948 no como escritor sino como director de la "mejor revista de crítica literaria". ${ }^{242}$ Asimismo, Bataille representaba a finales de los años cuarenta la figura intelectual que discutía y pensaba el surrealismo después de la II Guerra Mundial; Critique, luego Troisième Convoi, las conferencias dictadas en Bélgica y en el Club Maintenant (ver imagen 33) dan cuenta de un interés creciente en Francia por discutir y contrastar la experiencia aparentemente caduca del surrealismo con el desarrollo del existencialismo. Como hemos apuntado en otros pasajes de la tesis, el existencialismo era experimentado, por Elías Piterbarg y Enrique Molina, como un pensamiento que se consolidaba dando respuestas a lo que el surrealismo no había podido formular, pero lo hacía aplanando aquello a lo que no debía renunciarse: el horadamiento del lenguaje o el reconocimiento de que la literatura comporta un tipo específico de incomunicación.

Bataille era, entonces, la presencia contemporánea de la polémica entre surrealismo y existencialismo, donde no intervenía el poeta André Breton, sino el premiado director de una revista de crítica literaria, y cuyo objeto de desacuerdo era una determinada concepción de tiempo. ${ }^{243}$ En ese sentido, publicar un ensayo cuya noción central era la de "crítica del instante" tiene como correlato la amplísima e intensa recepción de la obra de Jean Paul Satre y su revista Les temps modernes en las revistas culturales argentinas contemporáneas. Así, la presencia de Bataille en Ciclo marcaba una diferencia cualitativa respecto a lo que Podlubne (2004) analizó como "moral del

\footnotetext{
${ }^{242}$ Cfr. entrevista titulada "La crítica literaria" en Figaro Littéraire, con motivo del premio, citada en Bataille, Una libertad soberana (2007:89-91).

${ }^{243}$ Esto será tratado en el Capítulo III.
} 
compromiso" compartida, en los años 50, tanto por Sur como por Contorno. Según Podlubne, el humanismo en sus diversas corrientes - y en especial el existencialista habría sido "el suelo común" de los debates literarios a mediados de siglo, que se había traducido "en una compartida y enérgica impugnación hacia los llamados representantes del arte puro o del arte por el arte" (2014:53), "la exigencia de contrarrestar los efectos del arte moderno con el propósito de devolver el lenguaje al dominio del hombre" (64), y la "idea de que un escritor no debía sustraerse a los debates de su época" según el imperativo del compromiso intelectual con la "causa del hombre" (57).

Según anticipamos, "La moral de Henry Miller" como primer ensayo de Ciclo contrastaba de inmediato con lo que un lector instruido en historia del arte moderno podía esperar tras el retrato de un artista concreto. La serie conformaba, así, dos nociones de crítica -el énfasis puesto en la técnica y el pensamiento del instante-que resultaban, a su vez, dos modos de "no cejar en la búsqueda" e intervenir, en palabras de Moholy-Nagy, en lo que "aún no ha sido sometido al testimonio de la experiencia", es decir, dos formas de sustracción respecto a los imperativos del compromiso. Así, Bataille planteaba, en "La moral..." una lectura sobre el tiempo como detención, contraria al progreso, evolución o desarrollo de la conciencia. Esa lectura del tiempo estaba centrada en la figura del instante: aquello por lo que todo se apuesta -sabiendo que se pertenece al porvenir pero se consume en el presente- es el momento que "no se ha definido como tal" y por lo tanto destruye todos los valores, distancias o diferencias, aniquilando la conciencia (Bataille 1948, n1:28). El instante configuraría entonces una subjetividad monstruosa, ya que, si en la recuperación de la infancia se rechaza la esclavitud de "lo que rinde", se rehúsa a lo posible, y por lo tanto, "se acepta en contraposición el ser desgarrado, el quedarse opresado en lo imposible" (28). Tales consideraciones de Bataille sobre el instante estaban en relación con algunos de sus planteos en la conferencia dictada en Club Maintenant titulada "La religión surrealista" (1948), donde había postulado que la literatura y particularmente la escritura automática podían detener el curso por el cual "palabras parecen construir un mundo" y "justificar por medio del pensamiento discursivo el mundo de la acción práctica, de los fines útiles" (2008:48-49).

Por otra parte, según Bataille, la imaginería narrativa de Miller se lanzaba hacia una "búsqueda del valor moral perdido", donde obscenidad e instante desplegaban un orden de lo contingente -por oposición a la eternidad y la perfección-: "hay muerte en el aire y reina el azar" será repetido muchas veces a lo largo del artículo como cita eje de la obra de Miller. De este modo, lo sagrado como violación de lo profano -el tiempo 
utilitario, la entrega al porvenir, la acción, el orden del discurso- es susceptible de ser pensado a partir de un materialismo abyecto, bajo, capaz de llegar al límite radical de la renuncia metafísica. ${ }^{244} \mathrm{El}$ instante, pensado como otra forma de profanación del tiempo, ${ }^{245}$ está en relación con la propuesta de Bataille acerca de la "fulminación de la conciencia", donde el lenguaje pierde todo sentido y se vuelve "inapropiado":

¿Sería posible dejar de expresar un anonadamiento sin límites cuando se lleva en sí el poder del instante? Ya no se puede entonces asociar la expresión literaria a lo perdurable sino a su contrario. Ni siquiera es importante que este mundo humano desaparezca de hecho. El instante aprehendido en su plenitud es, de todos modos, la ruina de las cosas ordenadas. Y el único lenguaje apropiado en tal caso sería el lenguaje del "último hombre": sólo tiene sentido en la medida en que todo sentido se pierde, cambia las perspectivas a las que estamos acostumbrados y les sustituye una visión extática de una realidad que se nos escapa.

Esta articulación entre "instante" y "fulminación de la conciencia" tiene afinidades con la escritura automática, no obstante, la perspectiva de Bataille, no aspira a la introspección del hombre interior sino al no-saber.

Por último, observamos una relación particular entre los fragmentos de Trópico de Capricornio seleccionados por Ciclo, y aquellos que citaba Bataille en su ensayo. Se trata, nuevamente, de un sentido que emerge en aquello que emege en la técnica del aparecer, salta a la vista, podríamos decir, según el uso de las negritas en la revista para enfatizar algunas palabras. Mientras en algunos de los los fragmentos traducidos por Aldo Pellegrini leemos expresiones como “¿Quién tendrá la última palabra? ¡El hombre! El último hombre dirá lo que tenga que decir antes de que todo se acabe" (Miller 1948, $\mathrm{n} 1: 22$, la negrita es del original), ${ }^{246}$ en las citas de Georges Bataille nos encontramos con

\footnotetext{
${ }^{244}$ En la entrada sobre el "Bajo materialismo y la gnosis" del Diccionario crítico, Bataille afirma: "La materia baja es exterior y extraña a las aspiraciones ideales humanas y se niega a dejarse reducir a las grandes máquinas ontológicas que resultan de esas aspiraciones. Así, a lo que hay que llamar verdaderamente la materia, pues eso existe fuera de mí y de la idea, me someto enteramente y en tal sentido no admito que mi razón se vuelva el límite de lo que dije; si procediera de ese modo, la materia limitada por la razón adquiriría de inmediato el valor de un principio superior (que la razón servil estaría encantada de establecer por encima de ella, a fin de hablar como su funcionario autorizado). Esta definición de la materia es una de las principales causas de su polémica con los surrealistas, que ha sido leída por algunos investigadores como el entre-líneas fundamental que está en la base del Diccionario crítico. (completar referencias)

${ }^{245}$ La relación de los términos "profano" y "sagrado" tiene el sentido que le da Agamben en "Elogio de la profanación" (2005), como restitución del uso de aquello que ha sido apropiado por el capital.

${ }^{246}$ Transcribimos el párrafo completo: Cuando pienso en algunos de los persas, árabes o hindúes que yo conocí, cuando reflexiono en el carácter que revelaban, en su gracia, en su ternura, en su inteligencia, en su santidad, entonces escupo sobre los conquistadores blancos del mundo, los degenerados británicos, los alemanes con cabeza de cerdo, los presumidos franceses. La tierra toda constituye un gran ser sensible, un planeta saturado de hombres de un extremo al otro, un planeta vivo que se expresa balbuceando y tartamudeando; no es la residencia de la raza blanca o la raza negra, o de la amarilla, o de la extinguida raza
} 
expresiones como "Nada tengo que ver con la maquinaria rechinante de la humanidad ¡pertenezco a la tierra!” y “¡Yo soy inhumano! Y lo digo con una risa insensata, alucinada..." (Miller en Bataille 1948, n1:27, la negrita es del original). ${ }^{247}$ A partir de este contraste, podemos pensar otro pliegue con respecto a las discusiones de la época, ya que así como Bataille representaba, en tanto lectura, una diferencia en el "suelo común del compromiso humanista" (Podlubne 2014), la apropiación de Pellegrini estaba igualmente tensionada por la moral humanista de la que Bataille se sustrae. Pero a la vez, es al interior del mismo texto de Miller donde esta tensión se produce. Así, esta exposición contrastiva de los fragmentos y los énfasis en negrita se conforma como una aparatología porque antes que explicar da a ver, haciendo aparecer la lectura.

Este ensayo de Bataille proponía entonces, en relación con el programa de Ciclo, un matiz temporal según el cual la época no era reductible a un sentido de historia como proceso o evolución que tendería al desarrollo de la conciencia o el Partido, sino una multiplicidad de tiempos que permanecen suspendidos y por tanto no convergen hacia un tipo de compromiso único. Entre la crítica del instante y una crítica de la técnica, la serie que se desprende de esa "efigie textual" como la denominó Antelo, arma una zona de contacto para la vanguardia donde se expone que, por la forma controlada según el cálculo geométrico o por el éxtasis de lo que no dura ni cuenta, un modo moderno de leer el arte y la literatura consistía en establecer un desacople entre arte y significación social, según el cual una obra fuera irreductible a su ambiente de emergencia (como proponía Cassou en una lectura anti-historicista de la historia del arte y el arte moderno en Ciclo 2), o los órdenes del lenguaje disponibles, y sobre todo que pudiera pensar la técnica, la forma, el estallido de la lengua por sobre la anécdota.

azul, sino la residencia del hombre, y todos los hombres son iguales ante Dios y tendrán su oportunidad, si no ahora, dentro de un millón de años. (Miller 1948, n1:21-22, la negrita es del original)

${ }^{247}$ Transcribimos dos citas más amplias: "Nada tengo que ver con la maquinaria rechinante de la humanidad ipertenezco a la tierra! Me lo digo con la cabeza hundida en la almohada, siento que brotan cuernos en mis sienes. Veo que me rodean todos estos antepasados que me pertenecen, bailando alrededor de la cama, consolándome, excitándome, azotándome con sus lenguas de serpientes, burlándose de mí con sus ojos bizcos y sus cráneos deprimidos. ¡Yo soy inhumano! Y lo digo con una risa insensata, alucinada..." (1948 n1:27). "Cuando el comediante surge en nuestras vísceras, este hombre, que se podría llamar Dios si tuviésemos que dar un nombre, se pone a hablar. Cuando la raza humana entera esté sacudida por una gran carcajada, quiero decir: por una risa tan dura que hace daño, entonces sí, nos encontraremos todo en el buen camino. En este momento ¿por qué no sería posible que alguien fuera Dios o cualquier otra cosa? La conciencia que hace a la materia gris enrollarse en pliegues muertos en la cima del cráneo, aunque fuera, doble, triple, cuádruple, múltiple, la conciencia, digo, queda aniquilada en el instante. En tales momentos se puede verdaderamente tocar con el dedo el agujero que todos llevamos en lo alto de la cabeza; en tales momentos sabemos que antes teníamos un ojo en ese lugar y que ese ojo era capaz de percibirlo todo a la vez. Quien conoce el sentido exacto de la libertad - libertad absoluta y no relativa - no puede dejar de reconocer que un instante como este es el mayor acercamiento a esa libertad que se puede alcanzar." (1948, $\mathrm{n} 1: 30)$ 
2.4.2. Políticas de la visualidad: una crítica de lo contemporáneo como contraste y montaje en Letra y Linea

Como anticipamos en el primer capítulo, una de las características más relevantes de Letra y Línea fue la decisión de publicar un retrato de Roberto Arlt en la portada del número inicial, donde desde el subtítulo se apelaba a la contemporaneidad de las artes. ¿Qué aspectos de la contemporaneidad de Arlt se vinculaban con las ideas del surrealismo? La violencia vital que le atribuía Vanasco era una de ellas; no obstante, podemos advertir otras líneas de lectura a partir del contacto que se establece con Juan Carlos Onetti y Wilfredo Lam en las páginas donde sus notas se encuentran. La serie crítica está conformada por el retrato de la portada, el breve ensayo de Alberto Vanasco sobre Roberto Arlt en un cuarto superior de la página 2, interrumpido por el ensayo de Juan Carlos Onetti sobre Graham Greene ${ }^{248}$ y finaliza en la página siete, esta vez compartiendo la parte superior de la página con un ensayo sobre Wilfredo Lam, el artista cubano surrealista (ver imagen 17, 29 y 30). La interrupción de las notas entre sí, que forma parte de las técnicas del aparecer de un aparato estético como la revista impresa, configura esa zona de contacto entre autores diversos donde podemos advertir un modo de reinventar la vanguardia más allá de la novedad. En ese sentido, la intervención crítica no se agota en los argumentos del ensayo porque está modulada también por las políticas de exposición de la revista que, voluntaria o involuntariamente, ${ }^{249}$ producen un diálogo cuyo sentido es relevante si pensamos cada página como "contexto de publicación" aquello que rodea al texto en la revista (Louis 2014) ${ }^{250}$ de la nota sobre Roberto Arlt.

Vanasco destacaba de Arlt su capacidad para exponer una "violencia vital", un "decirlo todo" que desbordaba el límite de la cultura - con sus "desordenados y superficiales conocimientos literarios"- y la profesión - a pesar de ser "acosado por los

\footnotetext{
${ }^{248}$ Conviene recordar aquí que había sido Onetti quien difundió la obra de Alrt como el narrador moderno en Argentina, según señala Pablo Rocca en la "Introducción" a Revistas culturales del Río de La Plata. Campo literario: debates, documentos, indices (1942-1964) (2009).

${ }^{249}$ Cfr. sobre Letra y Línea el capítulo I, discusión entre las posiciones al respecto de Crespi (2011), Herzovich (2015), Cella (2013)

${ }^{250} \mathrm{El}$ contexto de publicación corresponde a los elementos que se encuentran en la misma página (escritos, ilustraciones), pero también las otras páginas; el concepto se refiere a los elementos materiales más inmediatos, pero no solamente al objeto en sí, sino al movimiento que consiste en la puesta en página del texto, y toma en cuenta los elementos siguientes: cohabitación de textos, tipografías, ilustraciones, etc. (Louis 2014)
} 
más apremiantes problemas de trabajo y de medios"- (1953, n1:2), aspectos que lo convertían en "motivo de polémica":

Aun hoy, a veces, se insiste en considerar a las dos partes de su obra principal con un prurito suficiente y académico y se intenta cubrir bajo los detalles superfluos y formales la extraordinaria y asombrosa potencialidad de este autor, que se adelanta por encima de dichos obstáculos de una manera incontestable y avasalladora, con la violencia vital de todo lo que tiene que decir. (Vanasco 1953, n1:2, 6)

Como un efecto espejo, el ensayo de Onetti sobre Graham Greene, titulado "El fin de la aventura y el principio de la popularidad", señalaba los peligros del escritor profesional y masivo en sus relaciones con la cultura popular. La oposición que aparecía ya no era la de "tener cultura" o no tenerla, sino una asociación entre profesionalismo, técnica y personajes-símbolo que irían en detrimento de la verdadera invención o "aventura":

Todo el libro es un alarde de profesionalismo, de destreza técnica. Esta habilidad es empleada a veces como un exceso de confianza y se hace más visible en la pintura y manejo de los personajes secundarios. Por ejemplo, la pareja Parkis, padre e hijo, ambos han sido inventados sin dudas, para emocionar y ser patéticos. Pero como están hechos con nada más que destreza de artesano, no pasan de símbolos, de datos que se ofrecen al lector para que reconstruya los propósitos de su invención. No pasan de pintorescos, de cómicos; con frecuencia parecen hijos de Wodehouse. (Onetti 1953, n1:2)

Hay contraste y continuidad entre Arlt y Greene en esa página de Letra y Línea, donde lo que se pone en el centro de la discusión es la relación entre la escritura como invención y el trabajo del escritor profesional, ligado a la cultura popular. A partir de esto, el ensayo de Onetti funciona como una lectura que puede iluminar ciertas zonas de la literatura de Arlt. Lejos de ser celebrados sin reparos, Arlt y Greene fueron puestos parcialmente en cuestión, debido a las tensiones entre técnica e invención, o tema y forma, que sus obras revelaban: mientras el primero es el escritor a quien "el entusiasmo por el tema no lo hace olvidar las preocupaciones formales" (Vanasco 1953, n1:6), pero las resuelve con "cierta acentuada afectación" (6); el segundo reduce su escritura a la "destreza técnica" y aplana la invención (Onetti 1953, n1:2). En ese sentido, son notables los argumentos sobre Arlt quedan a uno y otro lado del corte, antes y después del “(continúa en página 6)”. En la primera parte, lo que entra en contacto con la lectura Onetti sobre Greene, es el Arlt polémico, el periodista, "un escritor a pesar de", es decir, la tensión histórica entre arte y mercado, periodismo y literatura, literatura y cultura, tal como Letra y Línea elige 
reapropiársela. La última oración antes del corte es la que dice "con la violencia vital de todo lo que tiene que decir", observación que se opone casi simétricamente a la afirmación de Onetti sobre Green: "todo el libro es un alarde de profesionalismo, de destreza técnica". Así, Arlt sería el escritor profesional que por encima de todos los obstáculos y limitaciones despliega una potencia que va más allá del prurito académico respecto a la afectación con que resuelve problemas formales; mientras que Greene, por el contrario, quedaría subsumido en la construcción de personajes "pintorescos", "cómicos", que "no pasan de símbolos". En ese contraste también se impone la "tarea discriminativa" de la revista, que busca afirmar la diferencia a partir de criterios de la invención escrituraria y no de las condiciones externas como la cultura, el trabajo del escritor y el mercado. En ese sentido, Arlt era puesto a distancia de un autor con el que podía emparentárselo, y en cambio se acercaba a la poética visual de Lam.

Al otro lado del corte, en contacto con el pintor de los trópicos, Wilfredo Lam, el pintor de imágenes exuberantes y terribles, encontramos desplegados los argumentos del Arlt de la violencia vital con expresiones como, "una abrumadora imaginación que se sobrepone a la limitada capacidad creadora de nuestra lengua", "diálogos de poderosa capacidad de observación" (Vanasco 1953, n1:6). En la misma página 6, sobre el margen izquierdo leemos dos columnas enviadas por Julio Llinás desde París en 1952, que llevan por título el nombre del artista, "Wilfredo Lam", junto con dos reproducciones de su obra (ver imagen 30). El texto se separaba de la mayoría de los trabajos que publicaría Letra y Línea, ya que adoptaba un lenguaje poético para hablar de la obra del pintor cubano, también radicado en París después de la Guerra. La imagen que da a leer la escritura de Llinás es la de la exuberancia, los colores, el trópico como lugar del desborde y el deseo, donde ruinas, melancolía y exaltación corporal conviven como fuerzas que suplementarias a lo humano (los monstruos, las bestias, las zarpas), donde la paleta de colores es, asimismo, anti-naturalista: fluorescente:

Es entonces, cuando los monstruos se levantan bajo sus pieles de zapa, con los colmillos plantados en la espalda para evitar la traición, y se devoran los unos a los otros, sobre los ejes del ensueño. Yo he visto en esa bella primavera alcohólica del trópico, las blancas zarpas de la magia posada sobre el vientre de las playas carnívoras y un ibis prolongado hasta la terminación de los puntos cardinales, en un gran cuerpo de mujer, descompuesto en prismas de cristal bajo la amenaza de las holoturias.

Yo he visto los pelícanos cernidos sobre el corazón como un aviso de locura, abriendo sus furiosos abanicos bajo las ruinas salvajes, allí lejos, donde las sales del trópico se mezclan con el gemido del deseo, produciendo una gran fosforescencia. 
Entre las negras vetas que se abren en el alma, Wilfredo Lam, planta esos cuerpos melancólicos, de cuyos pechos sombríos, parte como una exhalación la bestia alada del delirio, con su radiante sortilegio, con su ventana lacustre. (n1, 1953:6)

La presencia del cuerpo en las obras de Lam, el descubrimiento de flores y los animales inventados, como el diptrícotes que menciona Llinás en otro párrafo de la semblanza poética, entran en una zona de contacto particular de la obra de Arlt, vinculada con la "imaginación abrumadora" que Vanasco rescata en las columnas inmediatamente pegadas a la "tierra desmantelada por los perros" de Lam. En ese sentido, la obra de Arlt no es rescatada solo por aquello que la diferencia de otros narradores vinculados con lo popular, sino por lo que la asemeja a estéticas desbordadas de imaginación inventiva. Y asimismo, Arlt devenía el contemporáneo que a su vez iluminaba algo de lo inactual en la obra de una artista como Lam, al que extrañaba por sacarlo de la fácil clasificación de "surrealista".

Por otra parte, hay un aspecto significativo que nos permite vincular los nombres de Roberto Arlt y Juan Carlos Onetti como narradores, y es el lugar que tuvieron ambos tanto en Letra y Línea como en Contorno. En el número especial sobre Roberto Arlt, David Viñas, con el pseudónimo de Juan José Gorini, jerarquizaba las posibilidades de apropiación de la obra de Arlt:

Y así como no puede ser de los comunistas, Arlt tampoco puede ser de los esnobs, de los bien pensantes o de los pulcros. De aquellos que ahora lo utilizan (y hasta lo leen) porque está de moda, porque ha surgido pese a los Roberto Giusti, los Ragucci y a los antologistas. No tiene nada que hacer Arlt, por ejemplo, en una revista que se llama Letra y Línea donde se habla eruditamente de Mondrian y del último novelón francés y donde se desestima a escritores pasatistas o formalistas como Molinari o Bernárdez, o se los injuria gratuitamente, en función de otros que ejercitan un pasatismo diverso, como Oliverio Girondo. Pero tampoco se crea que queremos la exclusiva de Arlt porque ahora resulta una bandera más o menos eficaz. No. Solamente ambicionamos que Arlt sea de todos." (Viñas 1954, n2:8)

Este párrafo nos invita a indagar en el sentido de la expresión "una revista que se llama Letra y Línea donde se habla eruditamente de Mondrian y del último novelón francés", ya que ninguna de las dos cosas ocurren en la publicación dirigida por Pellegrini. Por lo tanto, es posible leerla en el horizonte de homologación que hace Viñas entre Molinari, Bernárdez y Girondo bajo el mismo rótulo de "pasatistas", donde aplana la diferencia por la cual Letra y Línea los distingue, que es la relación con la retórica poética. En el marco de una actitud por igual confrontativa, como la de atacar a los escritores de Sur y poner 
de relieve a Roberto Arlt, lo que variaba entre Letra y Línea y Contorno era el énfasis de lectura: leer la lengua o leer la función de la literatura en términos de compromiso/pasatismo. La simultaneidad con la cual tanto Letra y Línea como Contorno dieron un lugar preponderante a la figura de Roberto Arlt según la imagen-ensayo y el dossier crítico respectivamente, pone en escena la necesidad de identificar y explorar aquellas zonas de la literatura donde se reconocen experimentos posibles en torno al problema de la representación. Lo que leemos ahí no es la adscripción a un movimiento estético determinado o la observancia de un programa cultural propuesto, sino el modo dinámico y contradictorio en que se produce la disputa acerca de cómo definir la contemporaneidad de Arlt: si en tanto permitía cuestionar la historia de la novela argentina (Contorno) o en tanto símbolo de una contemporaneidad anacrónica (Letra y Línea), y en tal caso operador de una poética de experimentación.

Asimismo, encontramos disonancias entre Letra y Línea y Contorno alrededor de la escritura de Onetti -tal vez el único narrador "puro" que tiene mayor espacio en la revista dirigida por Pellegrini, con la publicación de ensayos y el adelanto de un capítulo de novela titulado "La resurrección de Díaz Grey”. En el número 5/6 de Contorno, David Viñas lo acusaba de promover un "estado larval" que impedía ver los contornos de las cosas (1955, n5-6:35-36). Beatriz Sarlo ha leído esa incomprensión como parte del estrabismo de la revista "parricida", ${ }^{251}$ en tanto esta "no podía fijar un foco sobre la literatura"; debido a que por un lado se afirmaba que la literatura es lenguaje, pero su verdad se jugaba en el contenido, en la representación (1983: 807). Sin embargo, a esa lectura estrábica que Sarlo señala en Viñas, no se le opone una mejor en Letra y Línea, ya que, como comentamos antes, Onetti fue parte de sus colaboradores pero no objeto de crítica.

En este sentido, la relación entre Arlt y Onetti en Letra y Linea nos la proporciona la lectura del capítulo titulado "La resurrección de Díaz Grey". ${ }^{252}$ En ella advertimos una moral antiburguesa que lo conecta con los personajes de El juguete rabioso, Los siete locos y Los lanzallamas. Esa moral era parte de los atributos que Letra y Línea asignaba a toda poética de vanguardia. El capítulo anticipado narra una escena donde Barthé manda

\footnotetext{
${ }^{251}$ Según la denominación de Emir Rodríguez Monegal (1956)

${ }^{252}$ Se anuncia como "capítulo de una novela" pero no es posible determinar si corresponde a un fragmento que luego se incluirá en El astillero, o una reescritura de La vida breve. Esta había sido publicada en 1950 y dedicada a Oliverio Girondo y Norah Lange. El primero es considerado uno de los mentores de la revista, y Norah Lange también publicará un adelanto de su novela Los retratos en el último número de la revista.
} 
a buscar a Díaz Grey para conversar sobre el prostíbulo que el primero había instalado en las afueras de la ciudad. La escena es hostil, cargada de aquello que Letra y Línea llamaría “inconformismo" o "humor negro". Así el prostíbulo era definido como "fortaleza erigida contra [...] la hipocresía, la moral burguesa" (...), que forma parte del "progreso" de la sociedad. La conversación es suscitada porque Barthé se ve forzado a cerrarlo y pide ayuda al médico, quien, para evadir el problema le responde "Tal vez me haya interesado en esto - continuó Díaz Grey - por simple curiosidad. Por saber si va a disminuir o aumentar el número de contagios y el de madres de catorce años" (---). ${ }^{253}$ La explícita moral antibuerguesa o la "tradición de las vanguardias anarquizantes" (Ludmer 1977) que atravesó la literatura de Onetti nos reconecta con Roberto Arlt y Wilfredo Lam en una serie donde se recuperan otros valores propios de la vanguardia como la violencia y la exuberancia, que, al mismo tiempo, exceden, en tanto conjunto, cualquier programa o noción de imagen estética. En ese sentido, la serie que aquí desplegamos puede ser pensada en la relación entre realismo y vanguardias tal como la propone Sandra Contreras: a partir de la verdadera "revolución formal" que supuso la escritura de Arlt y que lo conectaría con un lector de las vanguardias como César Aira, y no situando "el comienzo de nuestra tradición realista en la serie inaugurada por Gálvez para pensar, a partir de esa versión "escolar y epigonal", de esa "versión simplificada del realismo decimonónico más tradicional" (Gramuglio 2002: 149-150), sus variaciones y desvíos" (Sandra Contreras 2006). ${ }^{254}$

\footnotetext{
${ }^{253}$ A su vez, al retirarse, lo escuchamos decir: "Vivir es imposible; ahora, esta noche, vuelvo a vivir y a saber que, sin embargo, es imposible. Antes era imposible porque yo necesitaba hechos, gente, cortas aventuras adecuadas a mí, anticipadamente construidas con mi estilo, situaciones a medida. [...]Voy golpeando la vereda con los pies y el bastón; y como no hay nada en mi alma, nada en mi vida, nada que interrumpa la conciencia de estar vivo, la perplejidad y el hastío, trato de ser en mi cuerpo: mido su fiebre, sus dolores, me intereso por lo que traga y elimina, lo examino, profetizo, lo huelo, lo educo, lo purgo, lo acaricio, lo limpio, lo adulo y lo respeto." (11) La relación cuerpo-enfermedad es significativa en el cuento porque excede el plano de lo humano, se extiende a la ciudad, a las cosas mismas. Josefina Ludmer ha leído el par médico-prostituta como una constante de La vida breve, y la obra onettiana en general, que retoma la tradición del naturalismo por un lado y las vanguardias anarquizantes por el otro (1977:16).

${ }^{254}$ Un desvío y una pista para seguir explorando el problema en otras publicaciones contemporáneas a Letra y Línea son propuestos por Julio Cortázar en la revista Realidad. En 1948, Cortázar publicó "Notas sobre la novela contemporánea" donde señala la emergencia de nuevas formas en la novela en las que el orden poético se vuelve preponderante por sobre lo que llama "orden enunciativo del lenguaje" o "instrumental", "sometido al referente". La hipótesis de Cortázar consistía en que hasta principios del siglo XX hubo un doble empleo del lenguaje, un modo enunciativo y un modo poético, que consolidó un orden estético en el cual los modos poéticos estaban subsumidos a embellecer la enunciación (241) o bien son los encargados de entrelazar e imbrincar la trama rectora, "le imprimen su rasgo específicamente literario" (242). Sin embargo, el escritor de "las últimas tres décadas" ha producido "un brusco desacuerdo interno que estalla en la novela" (243): "lo poético irrumpe en la novela porque ahora la novela será una instancia de lo poético; porque la dicotomía fondo y forma marcha hacia la anulación, desde que la poesía es, como la música, su forma" (244). Así el "escritor rebelde" -es decir, un nuevo escritor para Cortázar- muestra que el mundo novelesco es ya solo poesía, donde se continúa relatando dentro de una visión poética, "y eso porque la
} 


\subsubsection{Henri Michaux, Vicente Huidobro y Tristan Tzara: dos miradas de lo mismo}

Como anticipamos en el segundo apartado de este capítulo, poesía buenos aires publicó, en sus primeras apariciones una sección titulada "Los frentes de la poesía", de la cual se concretaron solo dos entregas, una primer dedicada a Francia, y la segunda a América (ver imagen 31 y 32). No sabemos si hubo otras regiones en planes de indagación y muestra, o si acaso sólo se buscaba contraponer unas poéticas a otras para dar cuenta de la articulación entre lo propio y lo universal que buscaban proponer. La diferencia entre una entrega y otra es que mientras la primera es un verdadero tableaux (cuadro / mesa, según cómo se lo quiera leer y diseccionar), hecho con el montaje de textos traducidos, en el segundo, hay una intervención crítica propia que oficia de texto curatorial - firmada por Jorge Enrique Mobili - donde se reflexiona en forma algo excesivamente lírica sobre la función de publicar poesía en una revista. Los poetas de ese "frente" son Paul Éluard y René Char, de quienes se publican dos poemas y una frase; y los textos críticos que los encierran pertenecen a Henri Michaux y Tristan Tzara, en ninguno de estos dos casos se trata de textos específicos sobre los autores sino de reflexiones sobre la poesía, y especialmente, sobre la poesía (surrealista) después de la II Guerra Mundial (tal el título del libro de Tzara que se toma Le surréalisme et l'après-guerre). El frente americano, en cambio, está integrado por Huidobro, Vallejo y Neruda, de quienes se publican tanto poemas como textos teórico-programáticos.

Lo que nos interesa de esos "frentes", que funcionan como cuadros - como nos demuestra el diseño que hace Nélida Fedullo en el desplegado de página par e impar,

realidad, sea cual fuere, solo se revela poéticamente" (246). Esta propuesta supone una refutación de la distinción por la cual Sartre plegaba la noción de compromiso a la novela. En ¿Qué es la literatura?, oponía la intransitividad poética a la transitividad literaria. Rancière lee en esa distinción un nudo del malentendido literario ya que distinguir entre palabras como cosas -utilizadas por los poetas- y palabras como significados de comunicación -utilizadas por los escritores- para anclar el compromiso en la prosa, resultaba en la necesidad de justificar lo político de la literatura por fuera de ella aunque se pretendiera anudar a los usos del lenguaje. Cortázar propone sin dudas un nuevo estado de la cuestión que dialoga con la propuesta de Ciclo para leer a Henry Miller, y ambas con los modos de leer planteados por el existencialismo, influencia decisiva en revistas como Contorno y Centro.La poética como crisis del referente en la novela, según Cortázar en Realidad; y el lenguaje quebrado por la conciencia del instante como imposibilidad de los discernimientos que exige el mundo de lo dado, según Bataille en Ciclo; ambas miradas sobre la narrativa señalan una zona de transformación en la crítica y en la concepción literaria que no es reductible a los programas específicos de las vanguardias. La pregunta de Sandra Contreras por las series del realismo en Argentina, y las discusiones posteriores por definir el término, sus alcances y limitaciones, Letra y Línea nos permiten volver a pensar la encrucijada entre vanguardias y realismos desde la experimentación y no como cumplimiento de unos ciertos tipos sociales en la narrativa. 
enmarcando los poemas con columnas de textos en prosa- es lo que sale de allí, el elemento recursivo que sigue reapareciendo en otros espacios de la revista. Dónde y cómo reaparece es la pregunta que intentaremos seguir. La figura de Tristan Tzara es relevante porque reaparece luego como poeta - ya no con una reflexión histórica - en el siguiente número de $p b a$, al reverso del Frente de la poesía Americana, en la página par del epitafio de Breton. Y por tercera vez es recuperado, pero ya como objeto, en el número 9 de $p b a$, con la traducción del "Prefacio a la poesía de Tristan Tzara" de Jean Cassou y un ensayo de Raúl Gustavo Aguirre titulado "Notas para una situación de la poesía en la escena". Esta insistencia en un poeta icónico de la vanguardia histórica, como fue el Movimiento dadá, pero puesto en relación con el devenir de las vanguardias a mediados de siglo, da cuenta de la preocupación de pba por pensar los avatares y transformaciones que se suscitaron en las poéticas que consideran más importantes. Así, Aguirre parte de $E l$ surrealismo y la postguerra para pensar los alcances de la poesía como concepto, y su pertinencia en el ámbito dramático:

ya no puede dudarse de que la poesía sea una función en la que participa - a sabiendas o no, en mayor o menor grado, activa o pasivamente - todo el mundo. O sea que la poesía no está, necesariamente, limitada a la creación del poeta ni, tampoco, a la esfera literaria, escrita. La poesía es un fenómeno inherente a la condición humana: ella informa constantemente el lenguaje, preside a veces sus extrañas mutaciones, y es por ella que el lenguaje es siempre algo más que un signo, algo más que un mecanismo de comunicación. Allí donde hay lenguaje, hay poesía. (Aguirre, pba 9)

Estas reflexiones de Aguirre, que lo llevan a afirmar que el poeta es un "evidenciador" de la poesía que está en todo lados - "la poesía, fuera del poema, vive siempre en otras partes", dice - o bien que "ningún lenguaje puede escapar de ser poesía", son tomadas para pensar los aportes de esta al género dramático en tanto y en cuanto "el lenguaje poético, desvinculado de elementos anecdóticos, se integre en la situación dramática fuea de toda significación convencional". Sin embargo, el movimiento hacia una poesía fuera del poema es una idea de El surrealismo y la posguerra puesta por el mismo Tzara en relación a otros problemas:

A parte de la tradición ideológica revolucionaria, existe en los poetas contemporáneos una tradición revolucionaria específicamente poética. Yo deseo hablar de la que tiene su origen en los innovadores, en los poetas "malditos", en su espíritu casi heroico frente a los conformismos de la burguesía y que, a través de Nerval, Baudelaire, Lautréamont, Rimbaud, Mallarmè, Jarry, Saint-Pol-Roux y Apollinaire, reunió las diferentes tendencias que van de lo maravilloso al humor, en una visión del mundo a la que, hoy todavía, la poesía no sabría renunciar. (Tzara en pba 3) 
Tzara continúa y afirma: "la poesía no es únicamente un producto escrito, una sucesión de imágenes y sonidos, sino una manera de vivir. La poesía habita en todos los lenguajes porque estos poetas que han llevado esa premisa "hasta sus últimas consecuencias", "previeron a la poesía como una lección de vida, como un estado del espíritu", y en todos ellos se descubre "un desprecio violento por las ideas aceptadas, un presentimiento de la idea de que el mundo es hostil al hombre porque está mal construido".

Es interesante observar dónde corta la traducción de $p b a$ : "Todos ellos llevan a prever el advenimiento de un mundo nuevo, donde el desorden desaparezca, donde la belleza pueda ser contemplada y la vida vivida por todos los hombres", contraponer esa conclusión provisoria - respecto del inicio donde se propone hablar de una "tradición revolucionaria específicamente poética - con el ensayo de Cassou que oficia de "Prefacio a la poesía de Tzara":

Este temperamento debía, naturalmente, inducirlo a tomar el camino real que va de la rebeldía a la revolución y de la explosión inicial a la poesía, a la poesía que sabe que es y acepta no ser otra cosa que ella misma, lo que ya es tanto decir. Dadá ha desempeñado su papel en las aventuras del surrealismo y Tzara ha unido su voz a este prodigioso concierto. Luego ha sido de aquellos a quienes su madurez y su humanidad han llevado a integrar realidades sociales y nacionales de la época más confusa del mundo.

Experimentará, ante esta imperturbable marea, ante esta tumultuosa máquina, la emoción que desencadenaron esos objetos negros u oceánicos, amados por Tzara, y que son la concreción de oscuras energías. (Cassou 1952, n9:4)

La figura de Tzara aparece así como un vórtice entre dos momentos de la vanguardia, cuyos usos pueden ser tomados tanto para imaginar los pasajes hacia otros horizontes de intervención, como a producir la ampliación en el ámbito de otros lenguajes.

En ese sentido no es casual que aparezca también como articulador entre el frente de la poesía francesa, el frente de la poesía americana, y el epitafio al surrealismo. Hay una operación de ajuste en torno a su presencia, que permite a $p b a$ moverse entre tiempos y posiciones diversas. La serie que arma Tzara al referirse a los poetas que entendieron a la poesía como lección de vida (Jarry y Apollinaire en el humor; de Nerval en los límites de la locura; Lautréamont, Saint-Pol-Roux y Mallarmé en el padecimiento como vía de acceso a la conciencia; Baudelaire y Rimbaud en el sentido trágico del vivir poéticamente) parecen el tensor que sostiene el "frente de la poesía americana" con la premisa de que "ser libre significa equiparar la palabra al curso directo de la sangre" (Jorge Enrique Móbili, pba 4) o bien la oposición entre "hacer manifiestos" y "hablar de la vida por el curso estelar de la aventura" que elige a sus sobrevivientes. En ese puente entre un frente y otro se explicita la posición crítica de Móbili: 
Pero no hemos heredado nada, salvo la sospecha invariable de nuestro crecimiento. Llegaremos sobre las aguas, otra vez prodigiosamente pigmentados, otra vez con nuestros grandes ojos, otra vez con nuestra experiencia civilizada. La cultura nos ha dejado más vírgenes. La poesía en la que creemos la publicamos (el milagro del impreso ha de durar hasta la conciencia del lector. La poesía debe resistirse a la altura de la misma conciencia. No queremos litigantes para que omitan en sus liturgias y antologías estos tres nombres del título). Podríamos vindicarlos con ánimo menos disperso, menos delicuescente, menos acuático, con más rigor, con más elementos establecidos contra el olvido, con otro ejército, con la selección establecida en la confianza de los días. Pero la poesía jamás se hace para sobrevivir sino para permanecer. Sus sentidos son el curso de la cosmogonía, la clepsidra sobre el último maremoto. (Mobili 1951, n4:3)

Lo que resulta interesante es que tanto en el texto de Tzara que enmarca la poesía de los franceses Éluard y Char como en el de Michaux, no se refieren a los poetas que $p b a$ elige destacar, de modo que no debemos leerlos en clave de reseña sino de movimiento que interviene en la posibilidad de inventar nuevas series. Leemos en Michaux:

No miremos el arte con ojos de precepto. ¿Por qué razón Baudelaire, Lautréamont, Rimbaud, sujetos poco recomendables en vida, significan tanto para nosotros y son, de algún modo, bienhechores? No por su moral, desde luego, sino por haber dado un nuevo impulso vital, una nueva conciencia. Por eso, lejos de compararlos a predicadores que divulgan la buena doctrina o la mala, debemos compararlos al primer hombre que inventó el fuego. ¿Fue un bien? ¿Fue un mal? No lo sé. Fue una partida nueva para la humanidad. Una serie de partidas nuevas constituye una civilización. He ahí también lo que le importa más al poeta: una partida nueva, una victoria sobre la inercia, sobre la suya, sobre la de la época, sobre el eterno letargo de los reaccionarios. (Michaux 1951, n3:4)

Por otro lado, y para insistir en dónde decide poesía buenos aires cortar la traducción de los poetas ensayistas, en el caso de Michaux, cuyo texto publicado corresponde a un pasaje de la comunicación que leyó en el "Congreso de los P. E. N. Clubs" en Buenos Aires (1936), concluye:

Vemos que, al partir, el poeta está solo, que emprende solo la aventura. Su verdadera acción social empieza más tarde, cuando la humanidad entera se le incorpora, casi a su pesar. Esta incorporación es tan natural que, a veces, creemos retrospectivamente y con alguna ingenuidad que el poeta ha copiado el tono de la época anterior. Así se vuelve enteramente actual el poeta que ha tenido el valor de no serlo demasiado pronto. (4)

De alguna forma, tanto Tzara como Michaux justifican ese frente de la poesía americana, donde Vallejo, Huidobro y Neruda no son, estrictamente, "nuevos poetas" sino contemporáneos, tal como insistirá Móbili en su contribución a "noción de poesía" como 
portada del cuarto número de pba. Contemporáneos es decir, tocados por el doble signo del tiempo como calibre de una espera. En Letra y Línea en cambio, las figuras de Michaux y Tzara están en función de fuerzas muy distintas. En el caso de Michaux es el "esteta en función del hombre" con el cual Molina cuestiona una vez más el "hipócrita humanismo", y Tzara es recuperado junto con Jarry como poetas contra la noción de "arte" en un estadio inicial de las vanguardias. 


\title{
CAPÍTULO III
}

\section{Espacio común y morales de la crítica: el instante y la historia}

\author{
La razón de la crítica con frecuencia sólo tiene la \\ razón del combate, y el malentendido es una manera de comenzar la \\ guerra.
}

Jorge Panesi 2018

La crítica me parece asociada a la tarea de abrir la historia a lo que en ella se desprende de todas las formas de valor y se prepara a otra forma completamente distinta - aun imprevisible de afirmación.

Maurice Blanchot 1949

\subsection{Presentación del capítulo}

Cada uno de esos epígrafes condensa una definición de la crítica que podríamos considerar opuestas. En el primer caso, la crítica asociada a la lucha (de razones, posiciones, poderes), y en el segundo, la crítica como deseo de entrar en relación con aquello que desconoce los valores que sostienen "la razón del combate". Sin embargo, gran parte de las intervenciones críticas dan cuenta de que estas perspectivas no se encuentran de forma opuesta o excluyente, sino que se trata de fuerzas que modulan el espacio de acción de una moral (la potencia de lo imprevisible y al mismo tiempo el rechazo a lo imprevisible en el control de dominio sobre el otro-rival). El bullicio de la crítica del que participaron las revistas del surrealismo e invencionismo no estuvo ajeno a la experimentación conjunta de ambas fuerzas (no siempre con igual alcance, ni igual potencia), aunque los estudios sobre la historia de la crítica hayan rescatado con más énfasis las lecturas y categorías teórico-filosóficas que nos permiten pensar la crítica como "ajuste de cuentas" con la tradición (Sebreli en Contorno 1953, n1). En ese sentido, la idea de una "modernización de la crítica" está asociada más a las "razones del combate" que a la tarea de "abrir la historia".

Ese bullicio es el espacio común, donde tanto las revistas caracterizadas como "de poesía" o "del segundo momento de la vanguardia", como las revistas asociadas a la conformación de una nueva izquierda cultural y política, compartieron una misma definición de crítica: que esta debe contribuir a discernir valores, y principalmente a 
sopesar aquello que del pasado sigue vivo en el presente. Así, formaron parte de una serie debates comunes: por ejemplo, las relaciones entre arte, literatura y vida; la libertad del artista y la historia; o literatura y responsabilidad. Ahora bien, esa definición compartida en principio por todos se declinó según morales tan contradictorias entre sí como en sus propios principios; y en ese marco encontramos una serie de nociones que devienen figuras críticas conflictivas: principalmente las nociones de "instante" e "historia", a partir de las cuales Aldo Pellegrini y Enrique Molina en A partir de cero y Letra y Linea, y Edgar Bayley y Raúl Gustavo Aguirre en poesía buenos aires, se propusieron resignificar los alcances de términos relevantes para los debates como los de "comunicación" y "realismo".

Es a partir de este conflicto que a continuación se estructura el capítulo III, con el objetivo de caracterizar tal espacio común, los debates que lo atravesaron, y cuáles fueron las intervenciones críticas que produjeron las revistas del surrealismo e invencionismo en ese marco. Una de las hipótesis que lo atraviesa consiste en señalar que la singularidad de esas figuras ("instante" e "historia") se conformó tanto en la posibilidad de abrir la historia a otras formas de afirmación, como en la retórica y los fines del combate. En primer lugar, señalamos la necesidad de expandir lo que Oscar Terán denominó, en torno a los años cincuenta y sesenta, un "archivo de categorías" cuyo concepto gravitante era el de totalidad, como apropiación sartreana que hizo la generación de Contorno del pensamiento hegeliano. El campo de lecturas se abre si consideramos otra noción, como la de "instante" que Ciclo había recuperado en 1948 de Georges Bataille, a través de la traducción del ensayo "La moral de Henry Miller", que analizamos en el capítulo II.

La selección de esta noción por sobre otras posibles tiene como correlato el carácter polémico que vinculaba al pensamiento del instante con una exigencia de lo total: el anti-vanguardismo de Contorno, explícito en su rechazo al legado de los escritores martinfierristas, y extensivo al surrealismo e invencionismo, se articuló sobre una serie de categorías donde resuenan las acusaciones de Jean Paul Sartre a las vanguardias por un lado y a Georges Bataille por el otro (hablar del tiempo de las vanguardias como tiempo del gasto, del derroche y la fiesta es una de las críticas más claramente apropiadas por Contorno para referirse al pasado). Una experiencia como la del instante, que postula la precariedad del saber y la ruina del lenguaje, estaba lejos de contribuir a un proyecto de compromiso literario como el que se proponía Les temps modernes. Se ha rastreado minuciosamente la influencia de Sartre en el sistema filosófico de Contorno; pero se repara menos en el hecho de que dos de sus interlocutores polémicos fueron Maurice 
Blanchot y Georges Bataille, quienes a su vez cuestionaron la idea de "fracaso de las vanguardias" en términos de algo que caduca completamente, y cuyas derivas hubiera que buscarlas en valores como los de empresa, acción o finalidad. De modo que recuperar uno de los marcos de debate de Les temps modernes nos permite trazar algunos hilos necesarios para insistir en las relaciones conflictivas de las revistas del surrealismo e invencionismo con otras publicaciones ajenas a la poesía, al arte no figurativo o la narrativa experimental. Este entramado motiva el análisis de la polémica entre Jean Paul Sartre y Georges Bataille -iniciada en 1943 y que podemos rastrear en sus efectos hasta 1949 con las intervenciones sobre el surrealismo en el Club Maintenant- ya que los argumentos que se despliegan en ese intercambio -articulados con categorías fundamentales del pensamiento de cada autor- tienen resonancia en los debates argentinos.

En el segundo apartado analizamos la polémica entre Aldo Pellegrini y Osiris Troiani como parte de las intervenciones sobre la noción de tiempo e historia que subyace a la relación entre instante y totalidad. En las polémicas que abordamos en el capítulo II, el problema central giraba, según nuestra lectura, alrededor de las series críticas: qué autores podían ser agrupados con otros autores, y cuáles eran los criterios de nominación de ciertos grupos. Lo que emerge, en cambio, en este cruce epistolar, cuya última entrega se efectiviza en Contorno, es la incomodad de Troiani por que los surrealistas no pueden "insertarse en su comunidad histórica" o bien se "instalan prematuramente" en ella. En los apartados tres y cuatro la relación entre polémica como combate y crítica como forma de abrir la historia se desplaza hacia los usos que hicieron las revistas Ciclo, poesía buenos aires, A partir de cero y Letra y Línea de una serie de términos relevantes para el debate común. En ese marco analizamos cómo es reapropiada la noción de instante y puesta en diálogo con la propuesta crítica de otras revistas de la época, especialmente Contorno (Cfr. 3.3). Asimismo, en tanto la Historia como exigencia adquiere un lugar relevante en las discusiones, analizamos el modo en que Edgar Bayley reconfigura el sentido de "lo pasado" y una línea de tiempo, haciendo de la cronología una política literaria (Cfr. 3.4).

\subsection{El archivo de categorías se expande}


Tanto en Nuestros años sesenta (1991), como en el ensayo titulado "Rasgos de la cultura argentina en la década de 50" (1986), Oscar Terán propuso recorrer la historia de las ideas en ese mediado del siglo XX a partir de una "entrada por la filosofía". En ambos textos analizó principalmente las revistas culturales y políticas del período, en especial aquellas donde se vislumbraba con mayor claridad lo que denominó "pasiones ideológicas" que produjeron el pasaje de la crítica escéptica a una crítica comprometida y luego al intelectual orgánico. Es decir que se trataba de un recorte muy específico en el marco de un desarrollo que permitiera comprender los avatares de lo que se llamó "radicalización política" en los años '70. Pero el objeto del que partían ambos estudios no eran los hechos políticos, sino los fundamentos filosóficos con los cuales distintos intelectuales pensaron esos hechos -la experiencia del peronismo (1945-1955), la Revolución Cubana (1959), el devenir del PCUS y su injerencia en la política nacional, la Revolución Libertadora (1955) y el Frondizismo (1958). Para determinar cuáles fueron tales fundamentos postuló un "archivo de categorías" que contribuía a "precisar el perfil del actor cultural en cuestión", es decir, los intelectuales de una nueva izquierda nacional. Es en ese marco que la centralidad de Contorno, en tanto revista de crítica cultural y política, se explicaría por las transformaciones filosóficas de las que se hizo eco, ya que se había dejado interpelar por los cambios que experimentaba el pensamiento francés:

(...) si la generación de Sartre se abocó en Francia a la conformación de una filosofía que eludiera el espiritualismo hasta entonces dominante, en la Argentina una preocupación análoga nació en una franja crítica de la cultura nacional, y ese grupo de intelectuales atraídos con vigor por las cuestiones sociales y políticas encontró en aquellos desarrollos filosóficos franceses un referente privilegiado para procesar su propia comprensión de la realidad. Por todos estos motivos, la figura del autor de ¿Qué es la literatura? resulta medular para la comprensión de rasgos considerables de la cultura argentina de esta etapa. (1991:23)

El proceso de esa "propia comprensión de la realidad" estaría dado, según Rodríguez Monegal -quien comparó Contorno con Les temps modernes- por un abordaje donde la literatura era estudiada "más como fenómeno revelador de la realidad que como realidad autónoma" (citado en Terán, 1991:23). Terán exploró entonces las lecturas de los jóvenes “denuncialistas" para reconstruir el bagaje filosófico con el cual se conformó una manera de leer que resultó un comienzo mítico de la crítica moderna (Panesi 2018: 32 y 120). En esa búsqueda, dio cuenta de que una figura central dentro de ese "archivo de categorías" era la noción de "totalidad". Se trataba de una reapropiación particular que vía Jean Paul Sartre, los críticos denuncialistas hacían de la Fenomenología del espíritu de Georg 
Wilhelm Friedrich Hegel, ya que "no en balde también para el filósofo alemán el suyo era un 'tiempo privilegiado en que ya es posible totalizar la experiencia pretérita y comprenderla"” (25). La centralidad y correspondencia de esta categoría como terreno común compartido entre jóvenes porteños y filosofía satreana es rastreada en una serie de citas y pasajes donde la traza de lo total se convierte en medida de una lectura: "El punto de partida de la definición es una totalidad"-escribía Gianotti en Cuestiones de Filosofiay en Pasado y Presente se editorializará acerca de la necesidad de que las diversas posiciones sean "reconsideradas por una teoría que las totalice". (25) Asimismo, ya hacia fines de los años 50, en El Grillo de Papel, se publicaba una entrevista a Jean Paul Sartre donde este concebía la categoría de totalidad "como una propedéutica para alcanzar la verdad" (1991:25). Oscar Masotta, por su parte, sostenía que "hoy se sabe que el corazón de la vida es totalitario, que toda verdad es síntesis, recuperación global de la totalidad de los niveles de la existencia histórica". 255 Terán rescataba a su vez una carta de Masotta a Correas que se iniciaba con las siguientes palabras "La amistad, como dijo Sartre, necesita ella también ser totalitaria" (1991:25). El recorrido por estos fragmentos le permitían afirmar que la categoría de totalidad configuraba una "estructura de sentimiento" (25).

También Beatriz Sarlo, en "Los dos ojos de Contorno", había planteado como hipótesis la idea de que el "sistema literario" de los denuncialistas se afirmaba, contradictoriamente, tanto en la recuperación del lenguaje coloquial, como en una literatura que aspiraba a la "totalidad por la representación crítica" (2009:807): "La cuestión de la verdad literaria se juega en dos espacios: el del lenguaje, que hace creíble (es decir: argentina) a la representación, y el de la representación que debe aspirar a una relación con la totalidad de lo representado, que sea a la vez interna y crítica (806).

Esta aspiración de lo total en términos de representación (que podemos emparentar contrastivamente con la aspiración también total de las vanguardias, por

\footnotetext{
255 "Los hombres de hoy han aprendido; en veinte, en diez años ocurren muchas cosas y lo que ayer era confusión y presentimiento se convierte en certidumbre. Y así como el buen poeta y el buen pintor supieron siempre que no hay sensaciones aisladas, así como los psicólogos han terminado por burlarse de los fisiologistas que hablaban de estímulos puntuales y de respuestas del organismo estrictamente adecuadas a ellos, hoy se sabe que el corazón de la vida es totalitario, que toda verdad es síntesis, recuperación global de la totalidad de los niveles de la existencia histórica. Sí el conocimiento de los engranajes económicos no ha logrado explusar las desgracias del mundo, sí entre el conocimiento de lo real y su transformación ha existido un débito que no pude ser cubierto sino con vidas humanas, sí entre la vida y la economía ha existido una deuda que ha Sido pagada con la vida y que todavía no hemos cancelado, si el movimiento de la historia nos ha mostrado que no hay niveles aislados ni confinamientos felices, que no hay vida individual por fuera de la vida colectiva, que la economía es el sello de las aventuras de la colectividad en el espíritu del individuo, la exterioridad que se ha interiorizado, es porque no hay política y economía por un lado y arte, vida y sociedad por el otro. Sólo hay un todo indiscernible: vida, política y arte a la vez; economía y vida a la vez". Massota en Sexo y traición en Roberto Arlt
} 
alcanzar el movimiento inverso, depurar infinitamente todo resto de semblante), es significada por Terán como una "pasión por lo concreto". Las escrituras de los jóvenes de Contorno como David Viñas, León Rozitchener, Oscar Masotta y Juan José Sebreli habían oficiado, entonces, de pasaje entre ese "espiritualismo" (o, en términos del propio Sartre, "la maloliente salmuera del espíritu" ${ }^{256}$ que se intentaba derribar y unos años sesenta donde la totalidad se habría consolidado como "estructura de sentimientos". Entendidos los años sesenta como una superación de la década anterior, la noción de totalidad cobró un matiz modernizador respecto a las operaciones de lectura que le precedieron (el "manto de escepticismo" según Terán, el estilismo y la filología clásica para Avaro y Capdevilla, el revisionismo nacionalista, según Magnone y Warly). Pero ese "archivo de categorías", donde la noción de totalidad modulaba el pensamiento sobre la literatura y su relación con la verdad, también puede ser repensado a la luz de una expansión anacrónica. Es decir, no en un sentido prospectivo de ampliación -otras categorías que la habrían sucedido- sino a partir de las huellas de un panorama o archivo más amplio en años anteriores a los que Terán ciñe su recorte (1955-1966). Junto a las lecturas de Jean Paul Sartre y H.W. Hegel, hubo otras categorías, imágenes y lecturas que no tuvieron la gravitación transformadora que Terán atribuye a la recepción del existencialismo en la política cultural argentina de los años sesenta, aunque sí establecieron discusiones con esa forma de pensar los vínculos entre lenguaje y realidad.

Con el ensayo de Georges Bataille sobre Henry Miller, la revista Ciclo había introducido en 1948 otra noción, la de "instante" como ruina de todas las cosas ordenadas. La experiencia del instante procuraba una "visión extática" -es decir, sustraída de una determinación de saber- imposible de ser reabsorbida en la cadena de la razón que proponía la dialéctica hegeliana -a través de la cual el ser alcanzaba la conciencia que lo convertiría en sujeto de la historia- (Bataille en "Hegel, el hombre y la historia" 2008: 316-323). ${ }^{257}$ Lo que esa imagen extática arrastraba era otra forma de confrontar el

\footnotetext{
${ }^{256}$ Citado en Terán, 1991:20.

${ }^{257}$ Para Bataille, el problema de la dialéctica hegeliana es que enclaustra al Ser en los límites del Sujeto, y no lo expone al quiebre incesante del afuera. Una visión extática no puede ser reabsorbida en la cadena de la razón, ya que la experiencia del instante es una desgarradura en el orden del sentido. Dice en "Hegel, el hombre y la historia": "En el fondo, es la decepción del hombre que busca en la muerte el secreto del ser y no encuentra nada, a falta de poder conocer y dejar de ser en el mismo instante: debe contentarse con un espectáculo. Puedo imaginar - y representarme - un acabamiento tan perfecto del discurso que a continuación otros desarrollos ya no tendrán sentido, no captarían nada y harían sentir la pérdida del vacío que deja el final del discurso. Pero así abordo el problema último del hegelianismo. Ese momento definitivo de la imaginación implica la visión de una totalidad donde ninguno de sus elementos constitutivos pueda ser separado, lo que en última instancia conduce cada elemento al momento en que la muerte lo toca; más aún, lo que extrae la verdad de cada elemento de esa próxima absorción en la muerte. Pero esta
} 
“espiritualismo” que Terán señaló en tanto perspectiva filosófica que se buscaba superar. "Espiritualismo" era, para Bataille, el reino de la Idea - del cual también el materialismo marxista estaba preso- ${ }^{258}$ y para horadarlo se valía de nociones como las de "bajo materialismo" o "soberanía acefálica". ${ }^{259}$ En esa "bruma" del fin de la guerra y la posguerra que parecía no llegar, según T. Tzara (2014:13), se sucedió la serie de polémicas fundamentales entre Jean Paul Sartre y Georges Bataille. Mientras se consolidaba en Europa la idea generalizada del fracaso de las vanguardias, el autor de "La noción de gasto" (1933) volvía a pensar el lugar de escritores y artistas vinculados con

contemplación de la totalidad no es realmente posible. No deja de estar fuera de nuestro alcance, al igual que la muerte." (323-4) En este aspecto es que la noción de tiempo de Bataille pone en cuestión la idea de Historia hegeliana que articula un valor de la totalidad tal como expresaba Terán acerca de los años 60 y la lectura de un grupo de intelectuales de La fenomenología del espíritu. En Bataille, y su experiencia del surrealismo especialmente, el instante está vinculado tanto con la noción de no-saber como con la de gasto o soberanía; mientras que el tiempo de Hegel en su dialéctica del logos se trama enteramente en el Sentido. ${ }^{258}$ En "El lenguaje de las flores" del Diccionario Crítico cuestiona el idealismo que se esconde detrás de un materialismo dialéctico que ha privilegiado la materia abstracta, formal, a lo informe, y analiza la dimensión pútrida y baja de una rosa (sus raíces, la tierra, el abono). Para Bataille, la mayoría de los materialistas han situado "la materia muerta en la cúspide de un jerarquía convencional" (2003:29), lo que no advirtieron es que esa modulación abstracta de la materia se corresponde con la "idea pura" y con la idea de Dios, y por lo tanto responden a la pregunta "por la esencia de las cosas, más exactamente por la idea mediante la cual las cosas se volverían inteligibles" (29), así se reproducen las correspondencias religiosas que establecen una relación entre la divinidad y sus criaturas, "donde una era la idea de las otras". La materia muerta es una forma ideal (la cursiva es un énfasis de la entrada en el diccionario "Materialismo"), "una forma que se acercaría más que ninguna otra a lo que la materia debería hacer" (30). La filosofía recurre a esa abstracción porque busca hacer que el universo cobre forma, "trata de ponerle un traje matemático a lo que existe". Por el contrario, "afirmar que el universo no se asemeja en nada y que solo es informe significa que el universo es algo así como una araña o un escupitajo" (35). Un poco después, ya como colaborador de La critique sociale formuló esta crítica en un análisis de los fundamentos de la dialéctica hegeliana donde rastrea que desde entonces se considera que la naturaleza le plantea límites a la filosofía precisamente a "causa de su incapacidad de realizar la noción". Para Hegel, afirma Bataille, "la naturaleza es la caída de la idea, una negación, a la vez una revuelta y un sin sentido" (96); y continúa: "nada le hubiera parecido más irracional que buscar en el estudio de la naturaleza los fundamentos de la objetividad de las leyes dialécticas". En función de esta crítica, Bataille propone su propia definición de materia, pero que distingue de la anterior llamándola "materia baja", y que será luego el principio de una teoría de la soberanía como insumisión y no sometimiento de las fuerzas vitales a un principio más elevado que las gobierne. En la entrada sobre el "Bajo materialismo y la gnosis" afirma: "La materia baja es exterior y extraña a las aspiraciones ideales humanas y se niega a dejarse reducir a las grandes máquinas ontológicas que resultan de esas aspiraciones. Así, a lo que hay que llamar verdaderamente la materia, pues eso existe fuera de mí y de la idea, me someto enteramente y en tal sentido no admito que mi razón se vuelva el límite de lo que dije; si procediera de ese modo, la materia limitada por la razón adquiriría de inmediato el valor de un principio superior (que la razón servil estaría encantada de establecer por encima de ella, a fin de hablar como su funcionario autorizado)" (2003:62-63).

${ }^{259}$ Para Bataille, la sobernía consistía en "no someterse, ni uno mismo ni su razón, a algo que sería más elevado, a cualquier cosa que pueda darle al ser que soy, a la razón que estructura ese ser, una autoridad prestada" (2003:62). La figura que Bataille asocia a esa ausencia de sometimiento es la del asno como dios sin cabeza. Este representaba una de las manifestaciones más virulentas del materialismo, ya que ese cuerpo no sometido a la superioridad de un órgano central, la cabeza humana o el valor de la esencia monista (lo único, lo superior que rige hacia abajo el orden de las ideas) era posibilidad de "reconocer la diversidad en la identidad o a la identidad en la diversidad", admitiendo que "lo diversificado no permanece necesariamente idéntico a sí mismo" (100). La cabeza tenía, por el contrario, el efecto casi necesario del fascismo u otras formas de dominación ya que representaba la imposición absoluta de lo uno sobre lo diverso. 
ellas que le resultaban insoslayables en una política del arte soberano; así, a mediados de la década del 40 escribió numerosos ensayos y dictó conferencias sobre las relaciones entre surrealismo y existencialismo, poniéndolas en el marco de una confrontación con aquellos sistemas de pensamiento que buscaban explicitar el desarrollo del sujeto y la conciencia por medio de categorías como las de "Idea", "razón”, "acción”, en detrimento de otras como "materia informe", o "gasto". Una perspectiva como la del "instante" contemplaba una configuración de "sujeto" y de "tiempo" que, en la búsqueda por quitarse de encima el lastre idealista, cuestionó la "totalidad" existencialista en tanto estaba articulada con aquella serie de valores que Bataille buscaba rechazar. Algunas resonancias de esos debates son identificables en la enunciación discusiva de las revistas argentinas entre 1948 y 1956. Si articulamos los argumentos de esas polémicas transatlánticas con las discusiones en el ámbito local, veremos que "instante" y "totalidad" no son dos fuerzas contrapuestas explícitamente, sino operadores críticos que resignifican los límites y alcances de términos relevantes para las discusiones comunes.

Que el enfrentamiento de estas nociones tiene resonancias en las revistas del período que aquí analizamos se verifica en tres aspectos: en primer lugar, que el ajuste de cuentas de Contorno con Martín Fierro se cuela en el presente de la enunciación como extensivo a todo programa que reivindique el legado de las vanguardias históricas; esto se verifica con el segundo aspecto: la polémica entre Aldo Pellegrini y Osiris Troiani se origina en la revista Capricornio ( un debate sobre el lugar del artista en la historia -razón central por la cual se produce el intercambio entre los críticos argentinos- ya que Bernardo Kordon, su director, había decidido dedicar, en los cuatro primeros números de la revista, un tercio de las páginas a la traducción de la polémica entre Jean Paul Sartre y Albert Camus que había circulado en las entregas de Les temps modernes), pero los énfasis que rodean al debate dan cuenta de huellas o trazas donde prevalece principalmente la impronta anti-vanguardias y antiderroche (palabra despectiva usada por Sartre para referirse al "gasto" batailleano). El tercer aspecto, y esto lo analizamos en los últimos apartados, es que las zonas donde los valores de Contorno se condensan son disputadas por A partir de cero, Ciclo, Letra y Línea y poesía buenos aires, usando como operador crítico la noción del instante, o bien haciendo otro uso del sentido de la Historia.

A continuación se desarrolla tanto la apropiación anti-vanguardista que Contorno hace de Sartre, como las implicancias de ese aspecto en la polémica de este último con 
Georges Bataille, que resultan pertinentes para leer la relación entre crítica y época en las revistas surrealistas e invencionistas.

\subsubsection{El antivanguardismo de Contorno}

Uno de los puntos de correspondencia entre Contorno y Les temps modernes fue la apropiación anti-vanguardista del materialismo histórico. Como veremos a continuación, la selección de ciertos términos por sobre otros ("quietud", "responsabilidad", “deber") para consolidar tal posición y sus argumentos, marca una línea sostenida a lo largo de toda la revista. Estos movimientos críticos nos permiten retomar ese espacio común de la crítica donde el archivo de categorías se expande y entran en contacto revistas, discusiones, polémicas, que no han sido pensadas de manera conjunta.

En "El martinfierrismo, su tiempo y el nuestro", Juan José Sebreli describía a la juventud como "edad artificial, un espejismo de la conciencia de clase burguesa" (1953, n1:1), tiempo en el cual "lo que se proponen los jóvenes que abrazan una revolución ya sea social o estética, más que cambiar la vida como quería Rimbaud o modificar el mundo como decía Marx, es sobre todo molestar a sus padres burgueses o a sus madres católicas" (1). Esta juventud encarna una "edad metafísica" y por tanto "elige una expresión metafísica y abstracta de la revolución o sea la rebeldía que no se proyecta hacia nada y que deja todo rigurosamente intacto" (1). Sebrelli buscaba corregir las consecuencias de ese diagnóstico -que se apoya en la lectura de Comte, según explicita la referenciadeslindando lo que consideraba una confusión. Los jóvenes han confundido revolución con fiesta y han caído en la desgracia del derroche porque desconocen que "la revolución es un acto en dos fases", destrucción (o negatividad, aventura) y construcción, "que es orden y disciplina" (1). Esta temporalidad sucesiva era un diagnóstico compartido tanto por Sartre como por el Tristan Tzara de "El surrealismo y la posguerra". ${ }^{260}$ Sebreli se detenía en el aspecto que obsesionó al Sartre de Qué es la literatura, la fiesta, el gasto como acto de consumo:

Los jóvenes adoptan la primera de las dos fases y ponen todas sus esperanzas en el aumento del desorden y la anarquía porque el único porvenir que desean es precisamente no tener ninguno, el horizonte de la juventud es la juventud misma. Una revolución así puramente negativa, destructora, anárquica,

${ }^{260}$ Cfr. Capítulo II, apartado 2.4.3 
suicida, se asemeja más que a una revolución, a una fiesta. La fiesta es un movimiento puramente gratuito, asocial, no productivo es decir, consumidor. Se come, se juega, se baila, se violan las leyes de la moral, se derrocha tiempo y riqueza y se los derrocha para nada, por esplendidez, por generosidad, lujo y placer no son sino disociación, desintegración, destrozo. (Sebreli 1953, $\mathrm{n} 1: 2)$

En la referencia a Rimbaud y Marx resuenan menos el ultraísmo y "creacionismo" que Contorno dice leer en Martín Fierro que la cita de Breton donde juntó a ambos escritores para definir la política del surrealismo. Es decir que en el cuestionamiento al pasado vanguardista, Contorno cerca también la pertinencia de aquellas nuevas manifestaciones que parecieran estimar positivamente una idea de revolución sin "orden" ni "disciplina". Por este motivo, la lectura sobre el grupo Martín Fierro debe ponerse en relación con las críticas de Osiris Troiani a los surrealistas argentinos. Ese pasaje de Contorno está, entonces, estructurado por dos ideas centrales sobre las que gravitó el ataque de Sartre a las vanguardias: 1) el rechazo a la noción de gasto o derroche (si bien no son sinónimos, veremos que en léxico de la confrontación tanto Sartre en Les temps modernes como distintos críticos de Contorno, lo usan de manera indistinta); y 2) la idea de que a la negatividad le corresponde una afirmación responsable posterior (una acción comprometida, se dirá), que la juventud y vanguardia son una misma rebeldía contra los padres, así como la idea de que la "fiesta es un movimiento puramente gratuito":

Hay que señalar, sin embargo, que su luminosidad más magnífica, el superrealismo, enlaza de nuevo con las tradiciones destructoras del escritorconsumidor. Estos jóvenes burgueses turbulentos quieren destruir la cultura porque les han cultivado; su enemigo principal es el filisteo de Heine, el Prudhomme de Monnier, el burgués de Flaubert, es decir, sus papás. Pero las violencias de los años precedentes les han llevado al radicalismo. (Sartre, 1948:162-163)

La concepción de historia y de época es la de una subjetividad fuerte, y la construcción como demanda - "debemos impugnar y construir" (Satre, 1948:198), "Si la negatividad es uno de los aspectos de la libertad, la construcción es el otro" (199). Se ve entonces una correspondencia entre el rechazo a la fiesta, al derroche, la juventud del "épater le bourgeois" y el imperativo de responsabilidad que media en la lectura de Contorno y la posición de Sartre. Para este último el problema consistía en que la negatividad de las vanguardias -que consideraba como tercera generación de escritores burgueses- se mantuviera fuera de la Historia, es decir, que fueran "incapa[ces] de pensar su responsabilidad social en la empresa de la época": 
Este mundo, perpetuamente aniquilado sin que se toque a uno de sus granos de trigo o de arena, a una pluma de sus pájaros, queda sencillamente puesto entre paréntesis. (...) los superrealistas, una vez el mundo destruido y milagrosamente conservado por su destrucción, pueden dejarse llevar sin vergüenza por su inmenso amor del mundo. (...) Hay que salvarse sin romper nada o con una rotura simbólica; hay que limpiarse la mancha original sin renunciar a las ventajas de la propia posición. (1948:166)

"No hay dinamita suficiente para hacer que el mundo estalle" (165), es repetido a lo largo de "Situación del escritor en 1947" para señalar que el surrealismo no ha organizado "ni una sola destrucción real" (164). "Digan lo que digan”, insistía Sartre, el apoyo del surrealismo al PC había sido un gesto infantil, puesto que no le interesaba verdaderamente la dictadura del proletariado, sino continuar abonando al minoritario negativismo ahora representado por Trotsky, "si la IV Internacional hubiera podido pasar también a la fase constructiva, es manifiesto que ello hubiese sido ocasión de una ruptura" (170), afirmaba en Qu'est-ce que la littérature? La razón de ese infantilismo radicaba en la ausencia de una verdadera acción y responsabilidad. El énfasis puesto en la fase "constructiva" como superación de la negatividad, según aparece tanto en el editorial de Contorno como en ese pasaje de Sartre, tenía como fundamento el rechazo a esa otra serie de valores considerados contrarios a "la empresa de la época": instante, gasto, fiesta, derroche. Otra de las insistencias de Sartre en el libro que tuvo popularidad ampliada en la discusión cultural argentina giró en torno a la idea de que el tempo del instante es el favorito del consumo, señalando la teoría del gasto como "eco debilitado de las grandes fiestas pasadas" (183). Para contrarrestar esos despilfarros -también condenados por Contorno, lo que convoca a Sartre es un imperativo de época que consistiera en hacer historia (238), pasar de la exis a la praxis: "no se trata de elegir nuestra época, sino de elegirnos en ella" (202).

En "La traición de los hombres honestos" la expresión gravitante es "responsabilidad de nuestro tiempo": "una obligación que prohíbe la quietud o el silencio" (I. Viñas 1953, n1: 3). Esta experiencia de que hay más deberes y exigencias que la mínima posibilidad de dar por sentada la libertad, es una continuación del modo en que Sebreli caracterizaba, en "Los martinfierristas...", a su propia generación:

La generación posterior a Martín Fierro, gestada entre 1930 y 1943, y que ahora empieza a dar sus frutos en obras de una tonalidad gris, opaca deliberadamente monótona y desnuda como un desierto, totalmente opuesta al pintoresquismo cálido y colorido de Martín Fierro (Alberto Girri: Coronación de la espera y Playa sola, H.A. Murena: Vida nueva; F.J. Solero: Dolor y sueño, Valentín Fernando: Desde esta carne y otros de menor 
importancia) es una generación que vive el día después del coito, el triste amanecer cuando la alegría se ha vuelto tedio, la borrachera fatiga y todos sienten náuseas, pesadez de cabeza, y un sabor amargo en la boca. (Sebreli 1953, n1: 2)

La "quietud" condenada por Contorno estaba, para Sartre, en relación causal con el vínculo entre los escritores y las palabras, por un lado, y la experiencia del deber por el otro. Como si lo primero fuera condición de necesidad -que se cumpliría solo en el uso preciso de las palabras- de lo segundo. En ese sentido, un vínculo problemático con las palabras, o que se daba el lujo de prescindir de la acción, se cristalizaba en una falta de sentido del deber; mientras que el uso preciso de las palabras lo garantizaba. El surrealismo era leído bajo el mal de la "quietud" (1948:167) puesto que este había proclamado "un divorcio con el público obrero mucho más hondo que el divorcio con el público burgués" (167). Había buscado eliminar las fronteras entre los verbos de acción y de inacción ("la vida y la muerte, lo real y lo imaginario, el pasado y el futuro, lo comunicable y lo incomunicable, lo alto y lo bajo, dejan de ser percibidos contradictoriamente", afirmaba Breton en Le manifeste surrealiste), mientras que "el proletariado lanzado a la lucha" necesitaba lo contrario: "distinguir a cada instante si ha de triunfar en la empresa, el pasado del futuro, lo real de lo imaginario y la vida de la muerte. (...) se trata siempre de categorías que la acción revolucionaria necesita más que ninguna otra" (167). Para Sartre, la escritura automática, la búsqueda de lo inconsciente, la invención de imágenes inauditas, atacaban la posibilidad de la acción porque cuestionaban el valor de lo útil. Pero la acción era, para el grupo de Les temps modernes, lo único necesario en ese tiempo, y aquello para lo cual el escritor y su literatura debían estar preparados:

Y el superrealismo, del mismo modo que ha radicalizado la negación de lo útil para transformarla en el repudio del proyecto y de la vida consciente, radicaliza la vieja reivindicación literaria de la gratuidad para hacer de ella un repudio de la acción por la destrucción de sus categorías. Hay un quietismo superrealista. Quietismo y violencia permanente: dos aspectos complementarios de una misma posición. Esto no nos sorprende: hay quietismo en todo parasitismo y el tempo favorito del consumo es el instante. (Sartre 1948:167-168)

La relación entre "quietismo" y lenguaje, o acción y responsabilidad (la de construir un proyecto literario - discursivo claro para el proletariado) se correspondía con el problema de la subjetividad, como anticipamos párrafos atrás. Sartre concluye que los surrealistas no pueden comprometerse porque pretenden destruir tanto lo subjetivo como lo objetivo. 
Según el autor de Qu'est ce que la litterature?, el surrealismo odiaba la "humilde certidumbre" de que los pensamientos nos pertenecieran y responsabilizaran (condiciones de la subjetividad), y deducía de ese "desagrado", que el psicoanálisis y la escritura automática eran medios para escapar a esa certidumbre y por lo tanto a su "situación en el mundo" (163). ${ }^{261}$ Así, Sartre configuraba las oposiciones más pregnantes que leemos en la revista Contorno: "responsabilidad / evasión", "límite / conjetura". Ahora bien, ese propósito de "destruir la subjetividad" no sería tan nocivo si no fuera por el hehco de que los surrealistas pretenden "destruir a su vez la objetividad", involucrando ya no solamente una actitud hacia el mundo, sino el lenguaje:

Pero el segundo paso que da el superrealismo es para destruir a su vez la objetividad. Se trata de hacer que el mundo estalle y, como no hay dinamita suficiente para ello y como, por otra parte, una destrucción real de la totalidad de los existentes es imposible, porque todo se reduciría a pasar esta totalidad de un estado real a otro estado real, los esfuerzos se dedicarán más bien a desintegrar objetos particulares, es decir, a anular en esos objetos-testigos la estructura misma de la objetividad. (...) El esquema elemental de este procedimiento nos lo proporcionan esos falsos terrones de azúcar que Duchamp tallaba en mármol y que se nos manifestaban de pronto con un peso insospechado. El visitante que los sopesaba debía sentir, en iluminación fulgurante e instantánea, la destrucción de la esencia objetiva del azúcar por ella misma.

La pintura y la escultura superrealista no tienen otra finalidad que multiplicar estos estallidos locales e imaginarios que son como desagües por los que va a vaciarse todo el universo. (...) La literatura tratará de imponer la misma suerte al lenguaje y destruirlo por medio del empotramiento de las palabras.

Tanto el "empotramiento de las palabras" como la desintegración de la materia eran problemas centrales que recalaban sobre esa articulación "quietista" entre lenguaje y responsabilidad, donde lo que hay es puro desajuste sin contribuir a superar un estado de desintegración social -observación semejante a la que hacía César Vallejo en "Autopsia

\footnotetext{
${ }^{261}$ Cita expandida: "Hay subjetividad, en efecto, cuando reconocemos que nuestros pensamientos, nuestras emociones y nuestras voluntades proceden de nosotros en el momento en que se manifiestan y cuando estimamos a la vez que es indudable que nos pertenecen y solo probable que el mundo exterior se regule por ellos. El superrealismo odia esta humilde certidumbre sobre la que el estoico fundaba su moral. Le desagrada a la vez por los límites que nos señala y las responsabilidades que nos impone. Todos los medios le parecen buenos para escapar de la conciencia de sí mismo y, como consecuencia, de su situación en el mundo. Adopta el psicoanálisis porque este presenta la conciencia como invadida por excrecencias parasitarias cuyo origen está en otra parte; rechaza "la idea burguesa" del trabajo porque el trabajo supone conjeturas, hipótesis y proyectos y, por tanto, el recurrir perpetuamente a lo subjetivo; la escritura automática es ante todo la destrucción de la subjetividad: cuando nos ensayamos en ella, nos sentimos atravesados espasmódicamente por coágulos que nos desgarran, que tienen una procedencia ignorada, que eran desconocidos por nosotros antes de que ocuparan su lugar en el mundo de los objetos y a los que hay que percibir así con ojos extraños" (1948:63).
} 
del surrealismo" sobre la proliferación de nombres y movimientos estéticos en 1930. Asimismo, es importante advertir que este "empotramiento" está en relación con el uso despectivo de las expresiones "iluminación fulgurante e instantánea" y "destrucción de la esencia objetiva", ya que estas últimas daban cuenta de una noción de experiencia inconmovible que pusiera en crisis la conciencia, y por tanto su vínculo con el lenguaje (cabe recordar que el "instante" era, para Bataille, la fulminación de la conciencia, la ruina de las cosas ordenadas, del que solo podía hablarse en el lenguaje del último hombre).

En ese sentido, la articulación entre "empotramiento de las palabras" e "iluminación fulgurante" o "instantánea" de la esencia objetiva condensaba la idea de quietud como un mal vínculo con las palabras. Entendemos entonces que en ese pasaje se encontraban, de forma polémica, dos concepciones sobre la comunicación que analizaremos en el siguiente apartado: la comunicación como no-saber o contacto intenso y fugaz con la experiencia, y la comunicación de la obra como lucha contra el malentendido de la lengua o sus excesos innecesarios (Cfr. 3.3). En consecuencia, Sartre hacía un anudamiento entre lenguaje y política, a partir del cual reclamaba que no hubiera una acción a la medida de las palabras. Y por lo tanto, proponía:

La función del escritor es llamar pan al pan y vino al vino. Si las palabras están enfermas, a nosotros nos toca curarlas. (...) Ya lo sé: el propósito de muchos autores ha sido destruir las palabras, como el de los superrealistas fue el de destruir conjuntamente el sujeto y el objeto: era la punta extrema de la literatura de consumo. Pero hoy, como lo he demostrado, hay que construir. Si nos dedicamos a deplorar la inadaptación del lenguaje a la realidad, nos hacemos cómplices del enemigo, es decir, de la propaganda. Nuestro primer deber de escritor es, pues, devolver su dignidad al lenguaje. (233)

Los argumentos del tipo de comunicación propuesta por Sartre en "Situación del escritor en 1947”, y retomados por Contorno, se fundan en una idea de totalidad que busca suprimir todo lo posible el malentendido. Si, como veíamos en el capítulo anterior, el deseo de las vanguardias por una "imagen total" (la imagen síntesis-intuitiva del surrealismo o la imagen depurada de los invencionistas), se había articulado en torno a la pasión anti-representacional, en el caso de Sartre, se trataría de hacer coincidir plenamente la representación con la imagen. ${ }^{262}$

\footnotetext{
${ }^{262}$ Se trata de formas de lo total que conducen a caminos muy diversos, o bien se interrumpen en sí mismos, como analizamos en las críticas que tanto Blanchot como Benjamin hicieron al surrealismo y su deseo de encontrar un lenguaje que pueda ser él mismo la realidad sensible. No es casual que tanto Blanchot como Bataille-quienes mantuvieron una amistad intelectual fuerte en los años cuarenta y cincuenta-coincidieran en nociones de totalidad que desbordaban la existencia de lo real representable, ya sea por el movimiento del vacío (en la interpretación de "realidad increada" que hace Blanchot) o en la experiencia soberana que
} 
La pregunta por qué hacer con el desajuste (entre época y experiencia, lenguaje y mundo) atraviesa el debate a ambos lados del Atlántico, con diversos énfasis. En Buenos Aires, la gravedad de las palabras se justificaba en un presente sin la exuberancia del vértigo que marcó a la generación de los años 20, motivo por el cual las palabras no podían participar de una condición privilegiada. Para los contornistas ya no hay tiempo, solo obligaciones:

Por una desdichada condición, tampoco podemos pasearnos por jardines amparadores, discutiendo la belleza intrínseca de nardos o de rosas; ni discurrir en construcciones perfectas. Ni queremos apartarnos del mundo, ni encontramos asegurados este o el otro. Parece que algunos de nuestros contemporáneos aún tienen esa dicha: nosotros creemos que gozarla es hacer oposiciones a la traición, a castramiento, a la muerte. No queremos que nos asusten ni que nos agraden las palabas, ni las grandes, ni las pequeñas, ni las gastadas. Esperamos que, simplemente, nos sirvan. Sentimos que el espíritu es una responsabilidad. (I. Viñas, 1953:n1, 2. La cursiva es mía)

Nos sirvan hace resonar en su contundencia la expresión de otro texto también contundente, y contrario, el "Non serviam" de Vicente Huidobro, que había fundado parte de las inspiraciones vanguardistas en Buenos Aires a principios de los años 40, a partir del rechazo que hacía, en primer lugar, a que el arte tuviera que imitar a la naturaleza, y por ampliación, corresponderse con otros parámetros de representación.

En el editorial "Terrorismo y complicidad", del número 5/6 de Contorno, el grupo nucleado en torno a la revista reaccionaba a la nota de Rodríguez Monegal en Marcha, donde se había referido a ellos como "parricidas", propinadores de "elogios y palos". Contorno -tal como se firma esa nota- decía no molestarse particularmente con esa observación - "algo de guerrero puede ser saludable en nuestra alta cultura" (1955, n5/6:1) - pero temía "estar dando la impresión de malevos o niños terribles" (1). Postulaban entonces el sustantivo usado de forma frecuente por los surrealistas argentinos -“disconformidad"-, como si les estuviera respondiendo a ellos también:

Pero la disconformidad y la angustia deben ser acicates, no drogas. Ni juego gratuito, ni regodeo en la negación, el espíritu crítico no puede ser tampoco remedio para la necesidad de autoafirmación; como tónico de la personalidad debe reconocer sus límites: el terrorismo adolescente ha de abandonarse con el acné. La búsqueda de autenticidad, el esclarecimiento de la realidad, el rechazo del filiteísmo, deben ser perseguidos por otros medios -más difíciles, más exigentes- que tirar manteca al techo, proferir voces o broncas o refugiarse en generalidades, en nubosidades místicas. (1955, n5/6:2)

rebasa los límites de la idea (como en el caso de Bataille). Este señalamiento nos advierte sobre la imposibilidad de leer una trasposición invariada de los debates europeos en las revistas porteñas. 
Como vemos, lo que subyace a estas propuestas político-estéticas son una serie de consideraciones a partir de las cuales se modeló una idea de "tempo" y de "historia": la sucesión correlativa de un momento de "destrucción" o negativismo al que correspondería un momento de construcción; la idea de que en el primero solo hay lugar para la "fiesta" o el "tiempo del consumo", derroche, donde solo se conduce a un estado de "quietud" en el cual de imposibilita la responsabilidad y la acción, busca configurar una subjetividad que no se deje desestabilizar por el desajuste. La relación entre sujeto e historia debe estar anudada en torno a la "empresa de la época".

La idea de que se había terminado el tiempo del derroche, las fiestas, las provocaciones al modo "gifler le cadavre", está asimismo en el fondo de la polémica entre Jean Paul Sartre y Georges Bataille, y se articula especialmente en torno a dos visiones sobre la noción de "tiempo" e "historia" como parte de la confrontación contra lo que Terán llama el "espiritualismo de la época" o - en términos del propio Bataille el "imperio de la Idea". Se trata de dos visiones sobre el materialismo, si la relación entre las palabras y las cosas -las poéticas-intervienen en un materialismo de la acción, de la empresa de la época, que conduciría a comprometerse con un proyecto, o si un materialismo "bajo" puede ser insumiso respecto a cualquier valor que lo organice jerárquicamente, y así fundar una comunidad ausente.

\subsubsection{La polémica entre Jean-Paul Sartre y Georges Bataille}

Según refirió Georges Didi-Huberman (2012), aún por 1941 Bataille y Blanchot mantenían reuniones de "un colegio socrático" en las que leían fragmentos de L'Experience intérieure durante su proceso de escritura; en medio del imperio totalizador y de la guerra, imaginaban una noción de experiencia que no se comprometía sino a "ser contestación de sí misma y no-saber” (2012:110). En 1943 Jean Paul Sartre publicó una reseña de ese mismo libro titulada "Un nouveau mystique", en Cahiers $d u$ Sud, No260261, donde principalmente cuestionaba que Bataille sustantificara "su ignorancia" al convertirla en no-saber y asignarle a esto un valor positivo. Así, la "nada" en $L a$ experiencia interior sería "una pura nada hipostasiada":

... Apenas se hunde en el no-saber, rechaza todo concepto que permita designar y clasificar lo que entonces alcanza: 'si dijera: 'He visto a Dios', lo que veo cambiaría. En lugar de lo desconocido inconcebible - frente a mí salvajemente libre, dejándome salvaje y libre frente a él - habría un objeto 
muerto y propiedad del teólogo'. Sin embargo no todo está tan claro: veamos lo que escribe ahora: 'Tengo una experiencia tan loca de lo divino que se reirían de mí si hablo de ella', y más adelante: 'A mí, el idiota, Dios le habla a la cara'... Finalmente, al comienzo de un curioso capítulo que contiene toda una teología, nos explica una vez más su rechazo de nombrar a Dios aunque de una manera bastante diferente: 'Lo que en el fondo priva al hombre de toda posibilidad de hablar de Dios es que, en el pensamiento humano, Dios se vuelve conforme al hombre en tanto que el hombre está cansado, deseoso de sueño y paz'. Ya no se trata de los escrúpulos de un agnóstico que pretende permanecer en suspenso entre el ateísmo y la fe. En verdad es un místico el que habla, un místico que vio a Dios y que rechaza el lenguaje demasiado humano de quienes no lo han visto. En la distancia que separa estos dos pasajes se asienta toda la mala fe de Bataille. (Sartre citado en Bataille 2018:185 $)^{263}$

Jean Paul Sartre reprochaba a Bataille, en referencia L'expérience intérieure, que no abandonase nunca "el hablar helado de las personas de buen tono", y lo ponía en serie con André Breton, Louis Aragon, Michel Leiris, entre otros. Lo que fastidiaba en gran medida a Sartre consistía en que la noción del no-saber modificaba el vínculo entre sujeto y tiempo, así como también proponía otra noción de la subjetividad. Esto se observa en la cita de Bataille que recupera Sartre, a la que califica de "mala fe": "El no-saber desnuda. Esta proposición es la cumbre pero debe ser entendida así: desnuda, por lo tanto veo lo que el saber escondía hasta entonces, pero si veo, sé. En efecto, sé, pero lo que supe también es desnudado por el no-saber. Si el sinsentido es el sentido, el sentido que es el sinsentido se pierde, vuelve a ser sinsentido (sin detención posible)" (2018:186). Sartre entendía como una ambigüedad "de mala fe" los alcances del no-saber batailleano, ya que habría una "necedad" por parte de Bataille para admitir que el no-saber ${ }^{264}$ es inmanente

${ }^{263}$ El documento sobre el cual trabajamos es la respuesta de Bataille a Sartre publicada en Sobre Nietzsche. Suma Ateológica III (2018) donde se transcribe la reseña de Cahiers $d u$ Sud.

${ }^{264}$ Eso que llamó "estado teopático": momento en el cual saber se convierte en no saber por el instante, porque ya no puede esperarse nada, o, como es enunciado en el ensayo sobre Henry Miller, estado de lenguaje del "último hombre", que "sólo tiene sentido en la medida en que todo sentido se pierde, cambia las perspectivas a las que estamos acostumbrados y les sustituye una visión extática de una realidad que se nos escapa" ("La moral de" 36). La visión "extática" pone en el centro del problema la retoricidad del lenguaje. Mientras la conceptualización del término lo ha estabilizado como fugaz plenitud de los sentidos,

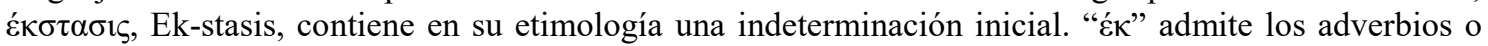

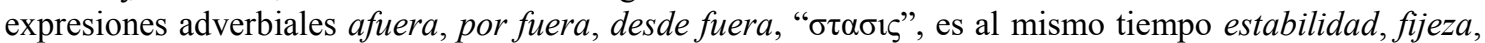
sitio y sublevación, revuelta, disensión, querella ${ }^{264}$. Blanchot advierte esto sobre el pensamiento y la escritura de Bataille en los años '80, cuando vuelve a pensar la experiencia de Acépahle en La comunidad inconfesable, entonces dice: "No hay que olvidar nunca que para él cuenta menos el estado de arrebato en que uno se olvida de todo (y de sí mismo) que el camino exigente que se afirma mediante la puesta en juego y la puesta fuera de sí de la existencia insuficiente, que no puede renunciar a esta insuficiencia, movimiento que arruina tanto la inmanencia como las formas habituales de la trascendencia. (...) Solo se puede escribir esta palabra [éxtasis] poniéndola precavidamente entre comillas, porque nadie puede saber de qué se trata, $\mathrm{y}$, ante todo, si ha tenido alguna vez lugar: al rebasar el saber, al implicar el no-saber, se rehúsa a ser afirmado de otro modo que mediante palabras aleatorias que no podrían garantizarlo. Su rasgo decisivo es que aquel que lo experimenta no está allí cuando lo experimenta, no está, pues, allí para experimentarlo. El 
al conocimiento. Sin embargo, esta crítica se desplaza hacia otra dimensión de la polémica, donde ya no se trata del estatuto ontológico del conocimiento, sino de lo que analizamos antes como articulación entre "instante" y "empotramiento de las palabras" (Sartre 1948: 163-164) en tanto concepciones de la lengua y la experiencia que impedirían, según Sartre, la verdadera acción. Este último convierte su reproche sobre el no-saber en otro reclamo: "Las alegrías, dice, a las que nos invita Bataille, si no deben remitir más que a sí mismas, si no deben insertarse en la trama de nuevos proyectos, contribuyendo a formar una humanidad nueva que se supere en pos de nuevos fines, no valen más que el placer de tomar un vaso de vino o de calentarse al sol en una playa" (Sartre citado en Bataille 2018:188). Lo que aparece aquí es menos la preocupación filosófica de una posible nada hipostasiada que la improductividad de tales exploraciones, carentes de finalidad y poder para insertarse en "nuevos proyectos", tal como le reprochaba Sartre al surrealismo.

En su "Respuesta", Bataille se detuvo solo en algunos aspectos de la reseña para cuestionar la noción de proyecto de Jean Paul Sartre, según la cual eran solo adecuados los métodos que contribuían a "la conclusión del conocimiento". Así, afirmaba;

Sartre tiene razón en recordar con respecto a mí el mito de Sísifo, pero pienso que mi propósito en este caso es el del hombre completo. Lo que se puede esperar de nosotros es que vayamos lo más lejos posible y no que concluyamos. Lo que sigue siendo humanamente criticable en cambio es un proyecto que no tiene sentido si no se remite al momento en que concluirá. (Bataille 2018:190)

Esa moral de la conclusión, "de lo que rinde", para retomar las palabras de "La moral de Henry Miller” (1948, n1:3-22), es la que subyacía en Sartre, a quien, según Bataille "ningún movimiento enloquece y embriaga", porque eso que había nombrado como misticismo para referirse a La experiencia interior no era más que la imposibilidad de lidiar con los límites del sentido en tanto inconclusión: "En efecto, cuando me embriaga,

mismo (pero no es el mismo) puede creer que recupera la posesión de sí en el pasado como un recuerdo: me recuerdo, me rememoro, hablo o escribo en el transporte que desborda y trastorna toda posibilidad de recordar" (2002:22). "Extasis" es, entonces, al mismo tiempo el sitio y el afuera, la fijeza y la sublevación, por cuanto acontece para un sujeto que no está allí cuando acontece, por lo tanto es el mismo y otro. Ese instante que es sin límites para Bataille cambia la visión de las cosas a las que estamos acostumbrados por una visión extática, pero esta visión no tiene lugar, está fuera, es fijeza y revuelta, experiencia y desconocimiento. La imposibilidad de renunciar a la insuficiencia que señala Blanchot tres décadas más tarde, es la imposibilidad de renunciar a lo imposible del instante que Bataille lee en la obra de Miller. La "sustitución" de la cual se nos habla en el párrafo de Bataille es el momento en el cual la escritura advierte que el lenguaje no explica nada acerca de aquello que ha encontrado como lo único de lo cual se quisiera hablar: el anonadamiento sin límites del poder del instante. La sustitución añora, desea, encontrar el nombre de aquello que reemplazaría "la visión de las cosas como estamos acostumbrados", pero tal experiencia ingresa como signo de lo perdurable en la relación entre la "expresión literaria" y el "mundo humano" 
el sinsentido adquiere ese sentido: que me embriaga; es bueno perder el sentido en ese rapto - por lo tanto es un sentido debido a que se lo pierde" (Bataille 2018:188). Así, advertimos que en el centro de la polémica, antes que una discusión acerca de la esencia o inesencia de la "nada" como noción ontológica, se enfrentan dos posiciones distintas en relación a la idea de sujeto y de tiempo, donde se pone en cuestión la experiencia del nosaber. Este problema deriva, como veremos a continuación, en el cuestionamiento que hizo Bataille con respecto a la idea de acción, a partir de su propia noción de instante. Para Sartre, lo que emergía del conocimiento, fuera por vías del pensamiento o la revelación, debía transformarse en otra cosa, esos "nuevos fines" (Sartre 2018:188) que harían mejor a la humanidad. Bataille exponía, en cambio, un doble desacuerdo con respecto a eso ya que, en primer lugar, solo la "voluntad de un conocimiento más allá de los fines prácticos" daría lugar al "momento inherente de la rebelión" (2018:191) -es decir que no habría rebelión con la idea de "nuevos fines" o principios superiores-, en segundo lugar, ese "momento" no puede prolongarse, por lo tanto, tampoco incorporarse a un proyecto o empresa. En ese sentido, a un sujeto de la conciencia, que actúa en su tiempo histórico, se le oponía un sujeto cuya completud estaba dada por la imposibilidad de duración, y que se vinculaba con el tiempo en la experiencia de lo indeterminado, por oposición a la búsqueda de lo que concluirá. Observamos entonces que la idea batailleana del tiempo de la rebelión como un tiempo que "no puede prolongarse indefinidamente", opuesto a la noción de proyecto sartreana, es la que articula la noción de "instante" que leímos en "La moral de Henry Miller" con el rechazo a la acción (como un imperativo al que ninguna fuerza soberana puede someterse). En este haz de concepciones, Georges Bataille había vuelto a pensar el surrealismo después de 1945.

Raúl Antelo (2013) ha enfatizado en el carácter diferencial del tiempo en cada posición, como dos figuras opuestas: el tiempo del aion y el tiempo de chronos. Sin embargo, lo que nos interesa rescatar de estos intercambios es que a la demanda de conclusión de Sartre (quien solicita un "fin posterior" y una contribución hacia la humanidad) se le opone un tiempo de la intermitencia, que en definitiva no rechaza la acción, pero entiende que aquello que vale es lo que no puede prolongarse. Este tiempo intermitente, que entra en conflicto con el tiempo del proyecto o la empresa, ${ }^{265}$ nos permite enfocar algunos aspectos de las discusiones críticas en Argentina a mediados de siglo XX. Así, cuando Aldo Pellegrini afirmaba que la única imagen capaz de iluminar la

\footnotetext{
265 Sartre insistía: "somos proyecto, a pesar de nuestro autor [Bataille]. No por cobardía, ni para evitar una
} angustia: sino proyecto ante todo" (1948:167). 
realidad era la imagen en combustión, y oponía el poder de esa imagen a los procedimientos representaciones de los "realistas fantasmales" (preocupados por los datos empíricos) discutía el carácter intenso y fugaz de la experiencia con lo real. La intervención de Aldo Pellegrini iba más allá de la definición de poesía porque se proponía distinguir entre "realistas fantasmales" y "verdaderos realistas" -es decir, quienes persiguían el acceso a lo real a sabiendas de que "huye cuando se intenta asirlo" (1952, n2:3), ya que la imagen de lo que toca "se produce y se destruye a sí misma" (3). Este tipo de apropiaciones modularon los debates sobre el realismo, considerado entonces como la estética más pertinente para pensar la época. Como para Bataille, la única mímesis posible era la del instante, no la de la representación de lo que hay.

Así, la idea de acción se desprendía del vínculo entre tiempo y conocimiento, ya que como vimos antes, para Sartre solo una relación acertada entre conocimiento y acción podía devolver a las palabras su poder, y liberarlas del "empotramiento". Por su parte, Bataille buscó desarticular ese tipo de correspondencia apoyándose en la experiencia límite del instante. Para este último, la valoración sartreana de la idea de acción -que definía como revelación del ser a través del Discurso- tenía un anclaje en la separación entre hombre y naturaleza que surgía de la lectura de Kojève sobre Hegel según la cual el hombre no solo sería Razón (discurso - logos) opuesto a la Naturaleza, sino que se constituiría como tal por la Acción creadora (Bataille 2008:322). A esta perspectiva le opondría la de "futuro común" o "improbable" de Nietzche: "Si dejo la perspectiva de la acción, se me revela mi completa desnudez. Estoy en el mundo sin recursos, sin apoyo, me derrumbo. No hay otra salida que una incoherencia sin fin en la que solo mi suerte podrá guiarme.” (2008:327). Así, y en relación con la idea de instante, Bataille repensó los fundamentos de la "totalidad". La totalidad no era, desde su perspectiva, la revelación del Ser en una cadena del sentido donde la acción creadora niega lo dado para alcanzar el espíritu general, ${ }^{266}$ sino que, en cambio, se trataba de "disolución fulgurante" (2018:28). ${ }^{267}$ Bataille entonces cambiaba los términos de la noción sartreana de totalidad,

\footnotetext{
266 "El conjunto del devenir donde se cumple la revelación en la conciencia de la Totalidad que incluye ese devenir y la revelación de lo que es la Totalidad" (Bataille 2018:23).

267 "No puedo existir totalmente sino superando el estadio de la acción de alguna manera. De otro modo, seré soldado, revolucionario profesional, científico, no "el hombre completo" ver nota III. El estado fragmentario del hombre en el fondo es lo mismo que la elección de un objeto. Apenas un hombre limita sus deseos, por ejemplo, a la posesión de poder en el Estado, actúa, sabe lo que debe hacer. No importa si fracasa: desde el comienzo inserta ventajosamente su ser en el tiempo. Cada uno de sus momentos se vuelve útil. A cada instante se le brinda la posibilidad de avanzar hacia la meta elegida: su tiempo se vuelve una marcha hacia esa meta (es lo que actualmente se llama vivir). Igualmente si tiene por objeto su salvación. Toda acción convierte a un hombre en un ser fragmentario. No puedo mantener en mí el carácter completo sino rehusándome a actuar, o al menos negando la preeminencia del tiempo reservado a la acción. La vida
} 
oponiendo esta última a la vida fragmentaria y no al instante, ${ }^{268}$ y proponiendo la "disolución fulgurante" donde Sartre pedía el proyecto. Así, la idea de instante buscó desarticular la correspondencia entre "proyecto", "ser" y “acción”.

Rehusar la esclavitud de la acción práctica se presenta como la posibilidad de sustraerse a las palabras que construyen mundo justificando los fines útiles "por medio del pensamiento discursivo" (1948:30). Así, el discurso ordenado, la gramática, es la garantía de la instrumentalidad, mientras que el instante es la destrucción de la conciencia, el rechazo a la esclavitud de "lo que rinde", el lenguaje del "anonadamiento sin límites", lenguaje del último hombre, y por tanto el alojamiento de la imposibilidad. A ese lenguaje de lo que rinde se le oponía tanto el lenguaje del instante como la escritura automática, como "un acto de ruptura con el encadenamiento que, a partir del mundo de la actividad técnica, se da en las palabras mismas, en la medida en que estas palabras participan del mundo profano o del mundo prosaico" (2008:48), y conectaba al surrealismo con la sobernía de la insumisión:

Y no queda ninguna duda de que, junto con los ritos del hombre primitivo, la preocupación del surrealismo fue encontrar, por fuera de la actividad técnica que pesa sobre las masas humanas actuales, ese elemento irreductible por el cual el hombre solo puede asemejarse perfectamente con una estrella (Bataille 2008:47).

El instante es la discontinuidad, el punto, la interrupción en el curso de la necesidad que se manifiesta como discurso. Por eso, Bataille adviertía en "La moral de Henry Miller" que en el momento límite - el "anonadamiento por el poder del instante"-no hay lenguaje sino que este es sustituido por una "visión extática de una realidad que se nos escapa" (1948:36).

Esa serie de discusiones y diferencias en torno a lo que un sujeto puede con relación a la época y el lenguaje, y especialmente con el "lastre idealista" y el "espiritualismo", no puede ser trasladada sin más a las discusiones político-literarias en

\footnotetext{
no sigue estando entera sino al no estar subordinada a determinado objeto preciso que la supera. En este sentido, la totalidad tiene como esencia la libertad" (Bataille 2018:24).

268 "Si quiero efectuar mi totalidad dentro de mi conciencia, debo referirme a la inmensa, cómica, dolorosa convulsión de todos los hombres. Ese movimiento va en todos los sentidos. Sin duda, una acción sensata (que va en un sentido determinado) atraviesa esa incoherencia, pero es justamente lo que le da a la humanidad de mi época (como a la del pasado) su aspecto fragmentario. Si olvido por un instante ese sentido dado, veo más bien la suma shakespeareana tragicómica de los caprichos, las mentiras, los dolores y las risas; la conciencia de una totalidad inmanente surge en mí, pero como un desgarramiento: la existencia completa se sitúa más allá del sentido, es la presencia consciente del hombre en el mundo en tanto que es sinsentido, que no tiene nada que hacer excepto ser lo que es, que ya no puede superarse, darse algún sentido actuando."
} 
Argentina, como mencionamos antes. Sin embargo, es posible leer la traza de una impronta antivanguardista de las posiciones dominantes en Francia, ${ }^{269}$ en la configuración de lo que se llamó "crítica moderna" o "comienzo mítico de la crítica" en torno a Contorno y otras publicaciones denominadas de "de crítica cultural” (Panesi 2002, 2018) como Centro, Las ciento y una, Imago Mundi. Reponer las intervenciones batailleanas que cuestionaron los fundamentos de ideas tales como "empresa de la época", "responsabilidad", "conciencia" y "completud" como rendimiento una conciencia acumulada, no significa que encontremos en las revistas de los surrealistas e invencionistas una apropiación sistemática de sus ideas. Sin embargo, sí es posible observar, especialmente en los textos de Aldo Pellegrini y Enrique Molina, un uso polémico de la noción de instante que se emparienta con la batailleana más que con otras y que les permite, a los directores de Letra y Línea y A partir de cero, respectivamente, cuestionar el sentido que se le daba de manera frecuente a conceptos o categorías como “comunicación" y "realismo".

Para analizar estas fuerzas en tensión, en los próximos apartados nos detendremos en la polémica Troiani - Pellegrini como espacio de encuentro entre la política de la literatura tal como era pensada en Contorno y el surrealismo. La discusión gravitó, a lo largo de tres cartas y notas complementarias (como las de Latorre que da origen al intercambio y la de Brascó como apéndice), en torno a la tarea de la crítica en la Historia, entendida como un presente localizable. La diferencia con las polémicas que analizamos en el Capítulo II es que si bien el problema aquí es la crítica nuevamente, no son las series de forma exclusiva las que causan el desencuentro, sino el "sujeto de la historia", las tareas de un escritor, un crítico, un director de revistas en "esta época". De allí se deriva en los siguientes apartados el modo en que las revistas del surrealismo e invencionismo modelaron sus propios términos para intervenir en esas discusiones.

\footnotetext{
${ }^{269}$ Como afirmaba Elías Piterbarg en Ciclo 1, los jóvenes no se interesaban ya por el surrealismo y sí en cambio por las charlas de Sartre en el Club Maintenant.
} 


\subsection{Insertarse en una comunidad histórica. La polémica entre Aldo Pellegrini y Osiris Troiani: el espacio común de las revistas y las disputas de la crítica.}

Como vimos en los apartados anteriores, una de las formas en que se configuraron las posiciones antivanguardistas de los años 50 en Contorno, estuvo modelada por un sentido de la responsabilidad y la acción en clave sartreana que respondía, en el ámbito francés, a un contexto polémico donde el pensamiento de Bataille representaba uno de los nudos conflictivos. En cierta medida ese pensamiento - que caracterizamos por la relación entre instante, bajo materialismo y lenguaje- también había tenido resonancias en el grupo de las revistas surrealistas de Aldo Pellegrini y Enrique Molina, aunque sin el rigor filosófico con que Contorno había mediado su lectura de Sartre. Raúl Antelo advierte esto en un ensayo titulado "Aldo Pellegrini y la desnudez de la materia" (2014) donde analiza huellas de un posthumanismo porvenir en las lecturas que el médico y poeta hacía sobre Nietzsche, donde resonaba Bataille. Tal es el marco donde tiene lugar la polémica epistolar entre Aldo Pellegrini y Osiris Troiani, cuya última entrega, con el título "Fin de un diálogo de sordos", se publicó en el número de Contorno dedicado a la novela argentina. Según mencionaba el pie de nota, la polémica se arrastraba desde el año 1953 y había itinerado ya por otras publicaciones, involucrando a las revistas Sur, Letra y Línea y Capricornio.

Si consideramos este número 5/6 de Contorno como un "contexto de edición” (Louis 2014) del fin de la polémica, la palabra "inconformismo" utilizada en el editorial contornista se resignifica en relación con la polémica, ya que mientras se trataba de un término usado mayormente por las revistas surrealistas, Contorno habla de "verdadero inconformismo"; en un mismo movimiento arrebata su uso a las vanguardias de la época y repone un fondo de responsabilidad y conciencia histórica para el término. Así, es posible señalar que el número de Contorno donde Troiani decide "ponerle fin" al intercambio nos anticipa algo de las razones que la sostienen: las tensiones entre contemporaneidad y tradición en la literatura y el rol del crítico en el tiempo histórico. Un paradigma crítico cuyo régimen es el de la historia como proyecto, como "empresa de la época”, entra en conflicto con otro cuya incomodidad se funda en torno a un presente en el cual, para decirlo en los términos del Henry Miller traducido por Letra y Línea, "estamos a punto de estallar". Ahora bien, como comentamos en la presentación del capítulo, estas diferencias no se desprenden de concepciones radicalmente opuestas de la función de la crítica, sino que, en esta polémica advertimos nuevamente que la crítica es, 
tanto para Contorno como para Letra y Línea, un instrumento para discernir valores. En ese sentido es que cuando hablamos de resonancias del debate entre Sartre y Bataille en Argentina es preciso advertir que la apropiación del bajo materialismo y el instante batailleano que proponen Aldo Pellegrini y Enrique Molina en A partir de cero y Letra y Línea está sujeta a la búsqueda de discernimiento, es decir a la expectativa de contar con una operación crítica fiable que organice la tradición de una literatura moderna. Por este motivo nos encontramos en el espacio común de la crítica, un horizonte compartido donde las diferencias son las morales que se asientan en los modos de pensar la relación entre lenguaje, representación y realidad. La operación crítica como capacidad de separar, distinguir, tomar distancia para determinar criterios claros, se apoya de forma diferencial en una moral u otra, así por ejemplo, para Letra y Línea, Aimé Césaire es la más alta expresión de compromiso, al igual que Michaux, porque su literatura desmantela a los "hipócritas humanistas"; mientras para Contorno, el compromiso es representado por una figura como la de Viñas.

En el capítulo II analizamos cómo esa función estaba articulada con la búsqueda por determinar qué autores eran susceptibles de ser puestos en relación con otros, por echar luz en la confusión que parecía mezclar a Charles Baudelaire con T.S. Eliot. Es edecir que la función de la crítica estaba asociada - en Letra y Línea principalmente - a una operación en la cual la vanguardia histórica devenía “ojo del presente” y reorganizaba las series, los montajes, que en un tiempo de confusión establecían malas conexiones, o al menos unas conexiones que des-potenciaban las posibilidades transformadoras de la literatura y el arte modernos. A diferencia de ese tipo de operación, en este caso la polémica entre Osiris Troiaini y Aldo Pellegrini nos pone frente a otro dilema. Si bien encontramos entre los argumentos de uno y otro la intención de juzgar a partir del agrupamiento de nombrs que hace el otro, este problema parece un síntoma del que atraviesa la polémica en un nivel más profundo: ¿qué lugar pueden y deben ocupar las vanguardias en el tiempo histórico de la postguerra?

Si la pequeña historia de la novela que sostiene el número $5 / 6$ de Contorno funcionaba como contexto de edición de "Un fin de diálogo de sordos" y por tanto anticipaba algo sobre el valor de la Historia, el número 3 de Letra y Línea que desencadena la polémica con Troiani también nos anuncia su voluntad de "comenzar la guerra" como sugiere Panesi, ya que se trata del mismo número donde se publican las polémicas con Julio Payró y Raúl Gustavo Aguirre en cuyos argumentos o razones se cuenta el cuestionamiento al orden de las series. El ensayo que da motivo a la polémica 
se titula "Sur y la literatura italiana" y no estaba firmado por Aldo Pellegrini sino por Carlos Latorre. La estructura del texto, breve, se encargaba de despejar la apariencia de ser una posible reseña sobre el número especial de Sur dedicado a los nuevos escritores italianos (el número 225 de diciembre de 1953), ya que Latorre decidía comenzar con una sentencia que excedía los límites del monográfico reciente: "Idéntico destino vincula a dos literaturas de las que marchan a la zaga del pensamiento y la ficción en Europa: la española y la italiana" (n3, 1953-1954: 16). Señala rápidamente la labor de Sur que califica de "esfuerzo editorial y dedicación responsable" y explicita su objetivo:

intentar un somero análisis de los valores específicos que informan las letras peninsulares y reducir nuestro elogio al sello editorial que con intención antológica los reúne, al reconocimiento del esfuerzo ya mencionado. En consecuencia, trataremos de censurar o justificar la limitada gravitación de los autores italianos en el ámbito de la poesía y la literatura contemporánea. (16)

La lectura de Latorre es una intervención sobre las relaciones entre contemporaneidad y tradición, ¿qué hacen los nuevos con el pasado?, ¿cómo se dialoga con la fuerza de una literatura universal?, y, principalmente, ¿qué vanguardia hay después de la vanguardia (Marinetti y el futurismo)? La hipótesis de Latorre es que el esplendor de la literatura italiana no ha servido para impulsar su presente, sino que, por el contrario, ha maniatado a sus escritores, tornándolos "nostálgicos, anacrónicos, afectados y reaccionarios como los viejos aristócratas empedernidos que se niegan a acusar el paso del tiempo y las diferencias reales que ese mismo tiempo impone" (16). El argumento que comprobaría este diagnóstico es que el material antológico del especial está compuesto por "la mayoría de los autores importantes de los últimos cincuenta años, muchos de ellos viejos conocidos nuestros traducidos y difundidos profusamente por editoriales y publicaciones locales" (16).

Lo que Latorre califica como retraso respecto a las "posiciones más osadas y clarividentes que asume la poesía y la literatura de vanguardia" (16), parecería tener su causa más intensa en el esteticismo de Croce, la grandilocuencia y el decadentismo de D'Anunzzio, junto con los vestigios del naturalismo y el afecto maniatado por la nostalgia de los "viejos aristócratas" de afán tradicionalista. Frente a esto, para Latorre, ni Giovanni Papini ni Marinetti, alcanzaron a "limpiar, ni siquiera a sacudir el agua estancada en que continúan hundiéndose las artes peninsulares". El problema resulta ser el siguiente: "los representantes de las nuevas promociones (...) se revelan incapaces de propiciar la operación poética profundamente renovadora o la ruptura indispensable con un mundo 
que se empeña en deformar y esclavizar la naturaleza y el sentimiento del hombre". Ahora bien, la relación entre ese pasado de esplendor y la actualidad retrasada se anuda en una serie de males que son los mismos que Letra y Línea parece encontrar en gran parte de la literatura argentina contemporánea, según analizamos en el primer capítulo en relación con las reseñas:

La sociología convencional, la literatura de "opinión", preferentemente política, el lirismo al uso, el hermetismo escapista, deformada herencia del simbolismo; la psicología elemental, la ausencia de espíritu innovador y de audacia verdaderamente revolucionaria, constituyen las limitaciones que, sumadas a las ya citadas anteriormente (realismo narrativo, servilismo hacia las viejas maneras, nostalgia de un antiguo esplendor ya remoto, cierta exuberancia estilística, patrioterismo, etc.) descalifican a la poesía y la literatura italiana para figurar el lugar de privilegio que todos deseamos para ella. (Latorre 1953-1954, n3:16)

La enumeración condensa todo aquello que tanto Ciclo como A partir de cero y Letra y Línea parecían rechazar. Tal vez sea esta la razón por la cual Osiris Troiani decide responder no a quien firma esta breve nota, sino al director de la revista. Así, en la revista Capricornio se publica "Epístola a los surrealistas" que dio inicio a la polémica. De seis páginas que ocupa la escritura de la carta, solo un párrafo es dedicado a cuestionar los argumentos con los cuales Latorre afirmaba la decadencia de las letras italianas. Troiani, como Borges y Bioy Casares en el cuento del comisionista y el chancho, acusa a Latorre de ser un "gacetillero de 5ta edición" al que se le ocurre, por "ignorancia temeraria y estrechez de espíritu", caracterizar a la "moderna literatura italiana" con los nombres de Croce y D'Annunzio:

En Italia han pasado ya por tres fases póstumas de la gloria literaria: aversión (excesiva) de las nuevas generaciones; olvido (primero voluntario y después sinceramente indiferente); inserción objetiva en la historia de la literatura. Ya ni siquiera se reacciona contra esos nombres, que son nombres de calles y plazas. Las letras italianas de hoy se han rebelado contra Ungaretti y Moravia, que ya habían arreglado sus cuentas con Croce y D'Annunzio cuando nosotros nacimos. Las grandes sombras que estorban hoy a los jóvenes se llaman, en filosofía, Carabellese, Varisco, Banfi, Calogero; poetas como Luzi, Montale, Gatto, Penna; críticos como Serra, Cecchi, Apolonio, Bo. Que conocieron el surrealismo en su fase activa y no, como Latorre, el que hoy se sobreviene penosamente. (Troiani 1954, n5:18)

Nuevamente observamos que la crítica aparece como un problema de organización de los nombres y aquello que es posible decir sobre determinados conjuntos. El modo en que se ordenan las series que modelan qué es moderno y qué no. Sin embargo, Latorre no había caracterizdo a la literatura italiana moderna con los nombres de Croce y 
D'Annunzio, sino que los colocaba como un pasado que, en palabras de Marx, oprimía el crebro de los vivos. De modo que el despliegue de nombres que hace Troiani parece estar en función de sostener otra posición polémica, la propia que se quiere instalar: 1) que la última fase de lo que hace una literatura con su pasado es la "insersión objetiva en la historia de la literatura"; 2) que el surrealismo hoy se "sobreviene penosamente" - es decir, una vez más, se trata de un cadáver. Esos énfansis menos jerarquizados en la argumentación retórica explican por qué, a partir de ese párrafo, Troiani dedica las páginas que siguen a cuestionar, en primer lugar el grupo Letra y Línea, luego, el presente del surrealismo en Francia y por último el surrealismo en Argentina. Lo que motiva la carta es, como anticipamos, la necesidad de rechazar una posición frente a la historia, que Troiani evalúa como conjunto de "feas pasiones" - "Forman ustedes un grupo iconoclasta que, en este clima de repugnante conformismo, tardaba demasiado en manifestarse" porque no se sienten "responsables del patrimonio literario de su patria, o de su lengua":

¿Cómo van a hacer ustedes algo vivo, perdurable, cargado de calor y de temblor, si sólo piensan en su tertulia de café? ¿Cómo van a incorporarse a una comunidad histórica, a derramarse en su sistema circulatorio, si no empiezan por descifrar - y por quebrantar, desde luego - las tablas de valores de su comunidad y de su tiempo? (...) Una nueva generación es el eco de un nuevo consenso y, a su vez, rehace la historia literaria. (Troiani, "Epístola a los surrealistas", Capricornio N5, 20).

Para Troiani hay una cadena de sentido entre insertarse en una comunidad histórica, discernir valores del propio tiempo y rehacer la historia literaria, como si cada axioma fuera condición de posibilidad y definición del otro. Así, la noción de Historia que se deduce aparece asociada a una exigencia a la cual debe responderse mediante el consenso de una nueva generación (consenso y comunidad resuenan entonces como términos que se autoimplican). En lo que toca a la literatura, el espesor semántico de "historia" se manifiesta como "tradición", por momentos, bajo la pregunta acerca de cuál es el lugar y el sentido con el que se configura:

La función de la crítica, ya se sabe, consiste en discernir valores, ayudar al artista a tomar conciencia de sí mismo, como he visto en el leal artículo de Molina sobre Guibert. Pero Molina, en ese caso, era infiel (enhorabuena) a la mentalidad que podríamos llamar "a partir de cero". Yo no creo que sólo la que hace tabla rasa con toda la cultura precedente merezca el nombre de nueva generación, o de vanguardia literaria. A mí me gustan los jóvenes que empiezan por sentirse responsables del patrimonio literario de su patria, o de su lengua. (...) (“Epístola a los surrealistas” en Capricornio) 
Adriana Petra (2013) analiza esta polémica en el marco del "impacto y la función que la cultura italiana de posguerra tuvo en el campo cultural argentino" a partir del cual la obra de Gramsci fue ganando presencia y difusión. Según Petra, después de 1945, muchos artistas, filósofos y escritores se afiliaron al PC, o bien pasaron a vincularse con el partido como simpatizantes (2013:362); se trató de un "crecimiento, popularidad y prestigio" (362) del PC en Argentina que estuvo articulado, en el ala artístico-intelectual, sobre el impacto del neorrealismo en el cine y la literatura, una de las particularidades de ese acercamiento entre estética y política en torno a Italia, fue que el neorrealismo había despertado especial interés "entre los jóvenes que hicieron su educación política durante la década peronista y que conformarían las nuevas promociones de escritores e intelectuales comunistas" (364). A la revista Sur le habría tocado el rol de "promover un 'redescubrimiento' de la literatura italiana" en el número especial que Latorre se dedica a comentar y enterrar en tanto no habría nada para descubrir allí. Esta significaba, para Victoria Ocampo, un "doble arraigamiento mediante el cual la literatura de calidad convivía con el compromiso ético del escritor".

La hipótesis que debemos deducir de la investigación de Petra es que Troiani y Pellegrini polemizaron por el interés del primero en defender una vía posible para la articulación entre literatura y política partidaria en el horizonte de posibilidades o apropiaciones que el neorrealismo habría abierto a los jóvenes anti-fascistas y antiperonistas. Si por un lado resulta algo desmedida en relación con el tratamiento que Troiani le da a la literatura italiana, por el otro, es Pellegrini quien parece expliciatarla para volverla inválida cuando responde: "si se me ocurriera imitar su estilo tendría que decir lo siguiente: 'Vamos, amigo Troiani, yo que lo conozco bien, sé lo que en realidad usted piensa; hablemos con las cartas sobre la mesa: ¿no es cierto que usted está conmigo en que el neo-realismo italiano es solo un conglomerado de bodrios?" (Capricornio n7, 1954:9)

Es en las tensiones de la relación entre Partido Comunista y apropiación cultural de los intelectuales de las políticas estéticas afines al partido donde Petra lee la polémica entre Latorre, Pellegrini y Troiani, de la cual reseña la posición de Latorre, y recupera exclusivamente la acusación de epigonismo que el último hace de un "surrealismo a destiempo". La segunda hipótesis del análisis de Petra es que el trasfondo de la carta de Troiani -lecturas vinculadas tanto con el Partido Comunista Italiano como el Partido Comunista Francés, con un marxismo gramsciano- formó parte de un "proceso de revisión crítica de la cultura argentina", que se propuso iniciar un proceso sobre la 
"realidad nacional". Ciertamente, uno de los cuestionamientos que hace Troiani tiene que ver con la nómina de escritores que Letra y Línea se propone "derribar":

Por lo demás, no puedo comprender que ustedes se interesen tanto por arruinar la reputación de Bernárdez, Molinari, González Lanuza, Wilcock, Silvina Ocampo, Julio Payró. Esas gentes aún explotan su modesta gloriola literaria, pero solo entre unos cuantos papanatas, y ustedes no escriben para ellos, se supone. ¿Le parece a usted realmente una hazaña hendir puertas abiertas?

\section{$(\ldots)$}

Ustedes le han tomado el pelo a Rojas. Convenido, don Ricardo es un personaje anacrónico, no se distingue por una fina sensibilidad ni por el "voltaje" de su espíritu. Pero ha hecho en Argentina la obra de varias generaciones, como en España la escuela de Menéndez Pidal. Aquí no tenemos una "escuela", solo tenemos a este hombre de ideas confusas y de triunfante energía. ¿Por qué le niegan ustedes el placer senil de un Premio Nobel, si el Premio Nobel no significa nada sino para el que lo recibe? Cuando uno de ustedes habló de su "incalificable" Historia, me convencí de que no la había leído.

No obstante lo cierto de las hipótesis de Petra, lo que se verifica es que si bien se trata de una articulación entre la defensa del pensamiento italiano de posguerra y la revisión de la "realidad nacional" en Argentina, el problema crítico se anuda en un conflicto anterior: determinada posición sobre la historia que implica, de suyo, un rechazo a las vanguardias porque considera que estas experimentan un tiempo profano, el del gasto, la fiesta, el pasado no actualizable; y que a su vez delimita una noción de libertad particular que considera, contrario a la de "soberanía", el limitarse como la única forma de experimentarla. El otro problema que atraviesa a la polémica es el ejercicio que Pellegrini denomina como "crítica de la crítica" (1954:11). Así, Troiani insiste en la relación entre el pasado y el deber generacional: "Me gustan los jóvenes que dicen: amo la gloria, la mía si ustedes quieren, pero no puedo evitar que mi gloria sea también la de los míos; aspiro a que un día viva en mis nietos algo más que mi sangre, pero yo también he recibido una herencia; todo lo bello y fuerte y noble que se ha hecho (o se hace) en este país, es mío; yo lo amo, lo defiendo, lo enriquezco", dice Troiani. Y un párrafo más adelante, enfatiza:

Los surrealistas franceses, en su insurrección contra toda una literatura en la que veían la amable máscara de una sociedad horrorosa, resucitaban a Lautréamont, buscaban en el macabro O'Neddy, en el opiómano Rabbe, en Borel el licántropo las voces amigas que respondiesen a su desborde vital y a su desesperación. A partir de cero no se va a ninguna parte, se queda uno en cero. 
Por otra parte, y en relación a lo que en el capítulo II analizamos como cadaverización del surrealismo, Troiani acusa a los surrealistas argentinos de ignorar el pasado y al mismo tiempo de que "la poesía y la crítica, la música y la pintura que les gustan", todo "está muerto, irremediablemente muerto y pertenece al buen tiempo, cuando Francia prestaba dinero".

En "Fin de un diálogo de sordos", Troiani da cuenta, nuevamente, de que la inestabilidad del espesor político del surrealismo radica en la Historia entendida como exigencia: "Los surrealistas han tenido siempre una curiosa tendencia a instalarse prematuramente en la historia. De ahí la profusión de antologías con que nos regala. Y de ahí otra de sus características: gracias a él hay poetas inéditos que pasan directamente a las antologías" (1955:57); así, Troiani cuestionaba entonces el desajuste histórico del surrealismo a mediados del siglo XX, y parafraseaba a Jean-Paul Sartre, como alternativa política y estéticamente preferible ("He dicho, simplemente, que el surrealismo estaba muy bien hace tres o cuatro décadas, y que sus actitudes características - invención, violencia, humor negro, provocación, protesta contra los límites de la razón - siguen siendo válidas. Pero con una condición: si admite que, terminada la fase polémica, es patrimonio común de todo el arte moderno y forma parte de la educación estética de todo escritor digno de atención”, 55). Es, entonces, estar fuera de foco con respecto a la historia lo que va en detrimento de su capacidad política; prematuros o tardíos, los surrealistas no han sabido ser responsables de $s u$ tiempo (Troiani, 1955:57), ni en Francia ni en Argentina, donde además se impone el peso de lo epigonal.

Finalmente, estas observaciones confluyen en "incorporarse o no a una comunidad histórica", como el dilema de la Libertad (más aún, de la libertad de espíritu). En "Epístola a los surrealistas", el cuestionamiento a la viabilidad de una revolución por medio de la libertad integral del espíritu se cuestiona como "crítica inocua", o bien como contradicción - "el dogma de la libertad". Y reaparece como insistencia, en la segunda epístola, en el número de septiembre de 1955, en Contorno, como el dilema entre “agitación literaria" y "terrorismo literario". Pero en "Fin de un diálogo de sordos", luego de que Aldo Pellegrini desarrollara nuevamente los trazos vectores del surrealismo en "Respuesta a Osiris Troiani”, este último reinstalaba el problema:

La verdad es que pertenecen ustedes a la época en que la libertad se definía como disponibilidad, y hace mucho tiempo que se la comprende como opción. Tomar partido es una forma de limitar mi libertad (o mi conocimiento) y a la vez mi única forma de experimentarla (o de ascender a él). (1955:56) 
Entonces parafrasea la "ideología surrealista"; que el hombre aspira a liberarse de la coacción racionalista; que la destrucción de todo canon estético es sólo una de las formas posibles de una insurrección más general, y que el sentido de todo el movimiento es la liberación integral del hombre, para acusarlos luego, en un gesto desacreditador, de "conformistas":

Casi nada: la libertad total para todos, la fusión del mundo exterior e interior del hombre, la objetividad hecha subjetividad y viceversa. ¡Vive Dios que no se necesita ser filósofo, efectivamente, para afirmar estas pamplinas! Y la verdad es que en ninguna parte he encontrado una exposición del surrealismo más precisa que la suya. Pero ¿quién asegura que el hombre aspire a la libertad? ¿Es esta posible, deseable? ¿Y por qué ha de ser integral? Y el conflicto entre mi libertad y la suya ¿cómo se resuelve? ¿Lo resolverá verbalmente, como esa otra antinomia, triunfalmente superada, según la cual "el concepto de masa no anula el individuo sino que lo incorpora? (...)

Es necesaria una gran dosis de ingenuidad, un espíritu singularmente conformista para adherir a una ideología formada, con sus inevitables mitos y su edad de oro, situada por igual en el pasado y en el futuro.

Osiris Troiani despliega una serie de estrategias propias del género polémico. Dirigirse a Pellegrini es una estrategia en coherente relación con la voluntad de señalar la ausencia del "verdadero espíritu surrealista". Es decir, si el surrealismo es un colectivo, donde no hay estilo sino lenguaje, donde no hay Poetas sino poesía, Troiani pone expone la evidente existencia de un viejo "líder" de los jóvenes inconformistas, pretendiendo obligar a Pellegrini a que responda por Latorre haciéndose cargo de él. La otra estrategia, funcional al objetivo principal, es armar un juego de paradojas en torno a los surrealistas: los surrealistas deberían ser libres, pero son dogmáticos, son dogmáticos pero aun así "traicionan" a su vestal Breton. Son jóvenes iconoclastas pero no saben a quién degollar, viven del colectivo de las revistas literarias pero en realidad "sólo piensan en la tertulia de café" porque no pueden incorporarse a una comunidad histórica, quieren hacer explosiones pero no descifran las tablas de valores de su comunidad y de su tiempo. Troiani niega a sus enemigos la condición misma de ser quienes son: y por lo tanto, eliminado el programa constitutivo de su movimiento, los elimina como enemigos.

Aldo Pellegrini, por su parte, se propone señalar los errores en que ha caído Troiani, y así le remarca que lejos está de que se pueda establecer una asociación directa entre Letra y Línea y el surrealismo ya que solo él, Enrique Molina y Latorre son "declarados surrealistas" mientras que el resto de los integrantes participan en ella por un 
"criterio de amplia modernidad". Por otra parte establece una diferencia entre "gracejo" y "humor" que nos permite asociarla con el carácter ambiguo de estas vanguardias de mediados de siglo, que por un lado exaltan el vitalismo del júbilo, el humor, y comparten a la vez la seriedad de quienes las impugnan:

Afirma después que somos un grupo iconoclasta y eso parece interesarle, pero a renglón seguido nos destruye comparándonos con el grupo Martin Fierro, "que tenían el don del gracejo". Si la travesura es lo que a usted le interesa en toda aventura del espíritu, resulta evidente que no puede encontrarla en nosotros. La nuestra no es una iniciativa deportiva; desgraciadamente para los que piensan como usted, nos tomamos en serio el mundo y la vida y hacemos prédica del mal humor o simplemente del humor (condición que está en el polo opuesto del gracejo).

Pero lo que organiza la respuesta es que inscribe a la crítica como espacio propio donde el surrealismo tiene un rol particular. Si el movimiento de Troiani es desplazar a Latorre para confirmar, dirigiéndose al director de Letra y Línea, que el surrealismo es un órgano jerárquico y dogmático, y que su lectura sobre esa breve nota vale para todo un programa de publicación, Aldo Pellegrini reinstala los argumentos en el terreno de la crítica, donde se propone dar cuenta de las "inexactitudes, afirmaciones gratuitas, incongruencias y especialmente las actitudes de vidente con que pretende descubrir mi pensamiento secreto siempre del modo más desfavorable":

usted acude por ejemplo a afirmaciones inexactas cuando nos endosa una admiración por Cocteau y René Char que no existe y nos adjudica un repudio por Aimé Césaire que es, en cambio, demostrada admiración total. Cae en incongruencia cuando asesina a Latorre a causa de su falta de respeto por la literatura italiana y a renglón seguido liquida de un plumazo el pensamiento de Breton, Kandinsky y Mondrian. Nos atribuye admiración por todo lo extranjero si es consagrado y no se da cuenta de su flagrante contradicción ya que Latorre discute a los italianos que son extranjeros consagrados (1954, n7:11)

Así, le dice Pellegrini: "estoy - como todo el mundo - de acuerdo con usted en que es misión de la crítica discernir valores". Discute entonces el alcance de la expresión "hacer tabula rasa", y le asigna la acción a destruir la "falsa cultura", no el pasado, aspecto que postula como "tarea de una generación": "valorizar el aporte de lo pasado inmediato, deslindar lo verdadero de lo falso":

No creo que sea tarea menor rectificar los valores considerados vivientes e inamovibles. Es un deber frente al público engañado y aun frente a los más lúcidos que desesperan de toda posibilidad cultural en el país. La nuestra implica, en definitiva, una crítica de la crítica, al tratar de rectificar los errores de apreciadores ineptos o los enjuagues de camarillas literarias o artísticas autobombistas. Cuando usted mismo se permite enumerar una serie de 
escritores argentinos y considerarlos aptos para papanatas (juicio despectivo hacia el público que es injusto y además extraño en usted) lo hace con tal naturalidad gracias a que Letra y Línea ha abierto el camino de una revalorización. (13)

Aldo Pellegrini reclama el derecho de los argentinos a postular como "maestros" y "clásicos" a Apollinaire, Jarry, Reverdy, Artaud y Breton, como grandes creadores cuyos efectos son "aún hoy" los más potentes en la literatura moderna. Párrafos más adelante, insiste: "En el párrafo final de su carta dice que es necesario destruir el provincialismo de nuestra literatura. ¿No es esa la tarea que nosotros y exclusivamente nosotros, estamos intentando en este momento?" (Pellegrini 1954, n7:10). La eficacia de esto último es muy baja, retórica y argumentativamente, porque no produce ningún movimiento en la palabra del otro, sino que opone, de manera especular, una acusación a su negativa. De manera similar funciona la última parte de la respuesta, donde Pellegrini toma una frase de Troiani -"pero pasamos ahora al surrealismo"- para desplegar los malentendidos que suelen producirse en torno a esta "ideología generalmente desconocida por quienes la combaten" (1954, n7:12):

Como lo hacen todos los enemigos de esa ideología se apresura usted a darlo por muerto, mejor dicho, a recitarle una oración fúnebre sin más trámites. ¿No le parece un poco extraño que desde el día de su nacimiento hasta la fecha todos los años se entierre sistemáticamente al surrealismo, corriendo la reacción con todos los gastos? Desde hace exactamente treinta años pasa lo mismo y me parece ya demasiado entierro repetido para un solo cadáver. Por lo menos indicaría que el surrealismo se niega a morir, a pesar de las seductoras y solemnes exequias que se le ofrecen.

Esa negativa del surrealismo a morir está asociada con el hecho de que su función no se agota en realizaciones estéticas sino en la "liberación del hombre". Ahora bien, esta especie de conclusión afirmativa de una poética, y de la relación poesía/vida, poesía/mundo, y mundo/espíritu, es el sustrato de una disputa que oscila entre una polémica que pone en cuestión un modo de conducirse en la crítica literaria -una moral crítica- y la insistencia en postular los efectos aún presentes de un movimiento estético en lo que Troiani denomina como historia "objetiva" y "comunidad de nuestro tiempo". 


\subsection{Hacia una crítica del instante: contra "convencionalismos del lenguaje", "realistas fantasmales" e "hipócritas humanistas"}

Resulta difícil imaginar que una noción como la de "instante", tal como la analizamos en el apartado sobre Sartre y Bataille, pueda ser una herramienta crítica epistemológicamente sólida, ya que opera sobre el límite del lenguaje disponible. De alguna forma sustrae o arruina el poder de la crítica en los términos en que, como vimos a lo largo de la polémica Troiani - Pellegrini, la mayoría de las revistas de mediados de siglo estaban planteando: su capacidad de "discernir valores". A diferencia del modo en que Blanchot definiría la crítica hacia 1949 en la introducción de Sade et Lautrèamont"la palabra crítica es ese espacio de resonancia en el cual, por un instante, se transforma y circunscribe en palabra la realidad inexpresada, indefinida, de la obra" (10)- los ensayos de Molina y Pellegrini cuyas hipótesis se configuran alrededor de la imagen-instante se mueven más bien entre esas dos fuerzas que comentamos al inicio del capítulo, en torno a los epígrafes. Es decir que si la experiencia del instante instaura la posibilidad de desconocer los valores y abre la afirmación hacia el límite del lenguaje, en la apropiación polémica que hacen los surrealistas argentinos, la experiencia se convierte más bien en una noción o concepto que permite distinguir (no desconocer) los valores. Así podríamos seguir el arco de una crítica del instante entre Ciclo y Letra y Línea, pasando por A partir de cero, como la búsqueda por re-definir lo que entonces se entendía por "comunicación", "realismo" y "compromiso". Por ese motivo es importante no aislar su uso en textos de Aldo Pellegrini, Enrique Molina, Osvaldo Svanascini, principalmente, del espacio común de las revistas, es decir, el espacio donde confluyen términos y valores aparentemente similares, por los que se quiere hacer prevalecer un énfasis por sobre otro. Por otro lado, advertimos que el primero de los términos modula el alcance de los segundos.

Según señalamos en el capítulo anterior, a partir de una cita de Roger Caillois, los escritores parecían encontrarse frente a otra Babel, la de "una lengua única" que era "preciso traducir sin cesar para comprenderse" porque solo existían entonces "ciertas relaciones entre términos confusos y flotantes, que no evocan para nadie las mismas imágenes" (1946, n135:24). Esa lengua única plagada de malentendios, que evocaba imágenes diversas, es la que está de fondo en las concepciones opuestas que encontramos en las apropiaciones de esos términos. Asimismo, Judith Podlune (2014) señaló cómo el humanismo fue un suelo común donde ideologías aparentemente opuestas convergieron 
para cuestionar el "arte por el arte". ${ }^{270}$ En este caso encontramos que aquellos que son acusados de frivolidad, irreaponsabilidad, artepurismo, arte burgués (todas las características que encontramos en el reproche de Troiani a Pellegrini), asumen la misma causa del hombre y los mismos términos con que el humanismo del compromiso piensa el arte y la literatura, pero para significar valores opuestos. En ese sentido, la apropiación de Bataille que hacen Aldo Pellegrini y Enrique Molina $^{271}$ es caracterísitca de una moral crítica en los términos en que venimos planteando, porque incorpora una diferencia, un matiz de extrañeza con respecto a los valores, para inscribir esa misma inquietud -como la que suponía pensar la relación entre sujeto y tiempo en términos de "fulminación de la conciencia"- en el horizonte del valor más aceptado que era el valor del hombre. Esta forma de apropiación modifica tanto las relaciones en ese suelo común o lengua común (y tal vez sea este el mayor gesto de politicidad de las revistas) como ilumina un aspecto

\footnotetext{
${ }^{270}$ Una tradición de matriz profundamente humanista, sustentada en una metafísica de la conciencia, que Jacques Derrida impugnó con un golpe definitivo en su conferencia "Los fines del hombre" de 1968: "Después de la guerra, bajo el nombre de existencialismo, cristiano o ateo, y junto con un personalismo fundamentalmente cristiano, el pensamiento que dominaba en Francia se tenía por esencialmente humanista. ... Aunque el tema de la historia esté muy presente en el discurso de esta época, se practica poco la historia de los conceptos; y, por ejemplo, la historia del concepto de hombre no es interrogada nunca. Todo ocurre como si el signo 'hombre' no tuviera ningún origen, ningún límite histórico, cultural, lingüístico. Ni siquiera ningún límite metafísico.” (Derrida 1989: 151-152) El humanismo, explica Derrida, era en esa época una especie de suelo común, desapercibido e incontestado, tanto de las distintas corrientes filosóficas y estéticas que recorrían el campo intelectual como de las diversas tendencias ideológicopartidarias que disputaban el ámbito político. El problema de la humanidad del hombre, una cuestión demasiado flexible, diversa e inconsistente, para retomar los calificativos que utiliza Foucault, en un ensayo posterior y en muchos sentidos afín al de Derrida, impregnaba desde el discurso liberal social-demócrata o demócrata cristiano hasta el discurso marxista. El marxismo era un humanismo, el existencialismo y el personalismo también -afirmaba Foucault (1999: 346). Si retomo esta descripción totalizadora y provisoria de la época, una descripción que alude a sus rasgos dominantes sin pretender reducirla a ellos, es porque en el terreno de la discusión literaria, que es sobre el que me interesa avanzar más específicamente, ese "suelo común" se traduce en una compartida y enérgica impugnación hacia los llamados representantes del arte puro o del arte por el arte. Más allá de las profundas diferencias filosóficas, políticas e ideológicas existentes entre Sartre, Benda y los intelectuales de Esprit, todos acordaban en atribuir una función testimonial (sea espiritual o social) a la escritura y en condenar la tendencia literaria surgida con Mallarmé y el simbolismo. (Podlubne 2014:53-54).

${ }^{271}$ Un aspecto que no pudimos tratar en las páginas de la tesis es la impronta bajo materialista que aparece en la carta de Henry Miller a Fraenkel, como "Si alguna vez el hombre debiera lograr su propia realización, ser hombre y no otra cosa, sería indispensable que se mantuviera fuera del dominio de la Idea y, cada vez más satisfecho de ser él mismo, que siguiera vegetando. Tendría que admitir, forzosamente, que el sueño de la ortiga ociosa, solo dedicada a reproducir su especie, se aproxima mucho más al milagro que el más maravilloso sueño de la evolución" $(1953, n 1)$. Este rechazo a la Idea (en myúsculas) y la afirmación de la materia en una forma no-humana está en relación con la temprana lectura que hizo Aldo Pellegrini del brutart de Dubuffet en el mismo primer número de Letra y Línea. A partir de la lectura conjunta de la revista y la obra temprana de Bataille, podemos afirmar que La filiación no está, como señala Crespi, en que "La filiación que Pellegrini traza entre esta obra y la experiencia vanguardista supone pues sostener para el arte la economía inversa brillantemente delineada por Georges Bataille a partir del Essai sur le don. Forme et raison de l'échange dans les sociétés archaïques (1925)" (2011:44) sino en Documents y la noción de bajo materialismo.
} 
que en el debate francés no encontrábamos: y es que el modo de abordar el problema no consistió en proponer otros términos, sino apropiárselos (es decir, no se reemplaza "realismo" por fantástico o maravilloso). Esta es una operación opuesta, por el ejemplo, al funcionamiento de las discusiones sobre el arte visual, donde se despliegan una cantidad de nombres diferenciales: objetivismo, arte abstracto, no-figuracionismo, concreto, etc.

Así, para Aldo Pellegrini, la comunicación literaria no define el sentido de una expresión o su alcance efectivo, sino la posibilidad traspasar lo que él mismo denominaba "las murallas del lenguaje", es decir, los convencionalismos que garantizan el entendimiento en las acciones de la vida cotidiana pero obturan la verdadera relación del sujeto con la experiencia, ya que esta rechazaría las mediaciones codificadas y los límites de la gramática disponible. Lo que se proponía Pellegrini era, entonces, diferenciar entre la comunicación en tanto código y la comunicación como fuerza de la obra, al modo de El espacio literario (Blanchot 2002). Así, era la obra y su lenguaje la que comunicaba, y independientemente de los interlocutores que alcanzara.

Esta perspectiva discute en primer lugar con la división satreana entre prosa y poesía, que asignaba solo a la primera el poder de comunicar y por lo tanto comprometerse, mientras la seguda no resultaba fiable. En el plano local, se separa de otras revistas como Ventana de Buenos Aires, donde Augusto Roa Bastos hablaba de una “agonía de la lírica actual”: "la elaboración poética de nuestros días parece disminuida al haberse debilitado lo que constituye su fuerza íntima de expresión y comunicación" (n10, 1954:2). Para Contorno la comunicación estaba sujeta a la idea de que "las palabras nos sirvan", a partir de la certeza de que al lenguaje también le había llegado la hora de rendir cuentas y no había tiempo para los lujos de los inciertos y los equívocos. Ahora bien, si pensamos las dos fuerzas que comentamos al inicio del capítulo, también en Contorno encontramos el movimiento de una moral crítica - signada por el imperativo de la “acción" sartreana, en este caso - entre el poder de lo incierto y el rechazo a lo incierto, como veremos en el análisis de León Rozitchener sobre Eduardo Mallea, titulado "Comunicación y servidumbre".

En los ensayos de poesía buenos aires, especialmente los de Aguirre y Bayley, la "comunicación" de una obra, o su capacidad expresiva, está historizada en relación con la imagen del escritor en la vida moderna, su capacidad de construir comunidad, a la vez que en también se pone de relieve una dimensión interna de esa capacidad, lo que Bayley denomina "realidad interna de la poesía". Ambos poetas y ensayistas insisten en que el 
poeta comunica en tanto se expresa de forma "inhabitual"; en este punto coincide con la perspectiva de Aldo Pellegrini y Enrique Molina sobre la ruptura de los convencionalismo y la des-adecuación del lenguaje como vínculo más intenso entre sujeto y experiencia. Pero esa extrañeza o expresión inhabitual no era suficiente si no tocaba algo de la dimensión sensible cotidiana, y se integraban a la vida íntima del "hombre común". De lo contrario se incurriría en aquello que poesía buenos aires cuestionaba de la poesía Madí y el surrealismo, que no trasparon los juegos del lenguaje.

3.3.1. Imagen del instante y comunicación en los ensayos de Aldo Pellegrini y Enrique Molina.

Como anticipamos en el primer capítulo, el ensayo "El poder de la palabra" de Aldo Pellegrini planteaba el problema de la comunicabilidad limitada por las convenciones del lenguaje ya que estas resultaban insuficientes para acercarse a lo desconocido. A la luz de lo que consideraba una paradoja -"hablar de la palabra al servicio del hombre"-, exploraba las implicancias que tiene en las relaciones entre lengua y libertad el hecho de que quien "crea [la palabra] pierde desde el instante en que la lanza al mundo, todo poder sobre ella" (1952, n1:3). Esa pérdida era reactualizada como poder de control, ya que el lenguaje convencional aseguraba la regulación de las instituciones y por lo tanto una alienación:

Donde aparece más clara la reclusión del hombre en su soledad merced al uso de la palabra, es en los distintos lenguajes convencionales. (...) Existen innumerables lenguajes convencionales y en cada uno de ellos la palabra más corriente se despoja de sentido para convertirse en un signo de determinada cosa, signo que permite el acuerdo entre dos o más personas. Así, sobre las bases de estos diversos lenguajes convencionales, se desarrolla la posibilidad de vivir en grupos activos, estabilizar y propagar el conocimiento, organizar la sociedad y la familia en sólidas estructuras. (1952, n1:3)

El poder de la palabra es entonces en este párrafo, un poder reactivo, que limita antes que expandir. El término "palabra" alude a la oposición entre signo y sentido donde prima una necesidad de acuerdo, es decir: el funcionamiento sistémico de la lengua garantizaría la conformación de instituciones como la familia, la justicia y corporaciones disciplinares, pero no el entendimiento vital ya que dicho código permanece "incomprensible para el hombre común" (1952, n2:3). 
En la clave de una lectura batailleana, Pellegrini partía de una noción de palabracódigo como límite de la experiencia: "Cuando dos miradas se encuentran y parecen descubrir bruscamente el sentido de una afinidad humana, de una verdadera comunión, llega oportunamente la palabra para destruir toda ilusión, para afirmar el derecho a la soledad inalienable del hombre". Para Bataille, la palabra como unidad del discurso estaba atrapada en la "luz homogeneizadora de la razón", motivo por el cual una de sus obsesiones fue buscar aquello de la conciencia que no le fuera reductible. Las palabras y el pensamiento discursivo, justifican "el mundo de la acción práctica, de los fines útiles, [mientras que] en la poesía se anularía ese carácter articulado, separado, hecho de conceptos y referencias, y se haría visible la totalidad continua de lo que existe" (Mattoni 2008). Así, es también para Pellegrini la poesía (a la que agrega el lenguaje popular y el amor) la que "abre la puerta de la comunicabilidad, derribando la muralla de las convenciones" -en El muro secreto, uno de los primeros versos decía: “¿Cómo se entienden los hombres con cadáveres de palabras?"- mientras que la función del poeta es "revivir las palabras agotadas por el uso" y descubrir "un resto de vida" para hacerla “resplandecer" (1952, n1:3). En ese sentido, la oposición entre comunicación-código y la comunicación como ruptura dialoga con el problema de la acción como era pensado por los críticos de Contorno en su apropiación de Sartre, según la idea de que la intervención histórica dependía de un uso claro e inequívoco de las palabras. En "El poder de las palabras", comunicabilidad / comunicación / común-unión están, entonces, asociadas no a la transmisión de un mensaje dado, sino a la capacidad de aproximarse a lo desconocido, lo que llama "conquista de lo maravilloso", regida por la indeterminación del azar y lo insólito. Por otra parte, a diferencia de la propuesta de Bataille -comprender el lenguaje como parte de las energías excedentarias e irreductibles a la razón, "lo que une al hombre con una estrella"-, Pellegrini pensó los vínculos irreductibles entre código y singularidad:

Nadie puede discutir la enorme utilidad de todos estos lenguajes [convencionales]: ellos permiten subsistir a los médicos y los pescadores, justifican la organización de la justicia sobre la base de la comprensión de los ladrones entre sí, y permiten la existencia del amor mercenario, base de la organización de la familia. (...)

Pero en todos estos lenguajes convencionales nadie pone absolutamente nada personal: el lenguaje resulta exterior al hombre. Lo vital queda definitivamente excluido. (1952: 3 )

Lo que Pellegrini planteaba en términos de alienación para la palabra - "el hombre mismo que la crea pierde desde el instante en que la lanza al mundo, todo poder sobre ella" -, o "poder de la palabra" se vuelve más amplio en su sentido cuando piensa en la poesía, el 
amor, y el lenguaje popular. Allí, en un movimiento semejante al de Roland Barthes en "La lección inaugural", "poder" deviene "potencia" y "palabra", ruptura de las convenciones. La poesía, capaz de estallar "como una bomba incendiaria cuando se pone en contacto con el lenguaje convencional" es la que desafía a la comunicación en tanto poder y la convierte en "comunicación directa" o "verdadera comunicación". Esa reconfiguración de lo que el lenguaje hace desde su poder de nombrar y organizar categorías a través de las cuales "se desarrolla la posibilidad de vivir en grupos activos, estabilizar y propagar el conocimiento, organizar la sociedad y la familia en sólidas estructuras", resuena cuando Barthes afirma:

Aquel objeto en el que se inscribe el poder desde toda la eternidad humana es el lenguaje o, para ser más precisos, su expresión obligada: la lengua. El lenguaje es una legislación, la lengua es su código. No vemos el poder que hay en la lengua porque olvidamos que toda lengua es una clasificación, y que toda clasificación es opresiva: ordo quiere decir a la vez repartición y conminación. (Barthes 1977: s/n)

Ese sustrato convencional de la palabra que para Pellegrini deviene en excluyente o alienante para el hombre, es, en la lección de Barthes no la causa, sino la condición por la cual el estereotipo funda y garantiza el poder:

Hablar, y con más razón discurrir, no es como se repite demasiado a menudo comunicar sino sujetar; toda la lengua es una acción rectora generalizada. Desde que es proferida, así fuere en la más profunda intimidad del sujeto, la lengua ingresa al servicio de un poder. En ella, ineludiblemente, se dibujan dos rúbricas: la autoridad de la aserción, la gregariedad de la repetición. (...) En cada signo duerme este monstruo: un estereotipo; nunca puedo hablar más que recogiendo lo que se arrastra en la lengua. A partir del momento en que enuncio algo, esas dos rúbricas se reúnen en mí, soy simultáneamente amo y esclavo: no me conformo con repetir lo que se ha dicho, con alojarme confortablemente en la servidumbre de los signos: yo digo, afirmo, confirmo lo que repito. (Barthes 1977: s/n)

Se lee que entre "El poder de la palabra" y "La lección inaugural” pasó el estructuralismo, la noción de poder de Foucault y el cuestionamiento al humanismo que compartían los escritores e intelectuales de mediados de siglo. No obstante esas diferencias, hay dos aspectos que parecen insoslayables. Por un lado, el modo en que ambos autores deslindan la "comunicación" de otras prácticas vinculadas al habla; así mientras para Aldo Pellegrini la comunicación-código se opone a comunicación-verdadera, tanto como “opresión” o "alienación” se oponen a "liberación", para Barthes el "habla" o el “discurrir", asociadas al acto de sujetar, se oponen a "comunicar". De allí se desprende que en ambos textos la idea de "poder" esté atravesada por la ambigüedad de ser a la vez 
una "acción rectora" (Barthes), un "mecanismo de opresión" (Pellegrini) y la potencia incandescente o emancipación. Sobre esta última variable dice el crítico argentino:

Lo realmente vital del lenguaje se encuentra fundamentalmente en tres situaciones: en el lenguaje popular, en el lenguaje del amor y en la poesía. Pero es a la poesía a la que corresponde el lugar de privilegio en un verdadero lenguaje de comunicación humana. La poesía incorpora la esencia vital del lenguaje popular y del lenguaje de los amantes, pero les agrega una exaltación de todos los contenidos posibles de la palabra.

El poeta logra hacer revivir las palabras agotadas por el uso y en ellas descubre un resto de vida reanimándolo, haciéndolo resplandecer nuevamente. Recoge las frases hechas, los lugares comunes, fragmentos muertos del lenguaje, y mediante un proceso particular de fricción conocido solo por el poeta, desarrolla en ello una incandescencia sorprendente. (Pellegrini 1952, n1:3)

¿No leemos en ese "proceso de fricción" que menciona, la famosa expresión "hacerle trampas a la lengua" de Barthes?

(..) a nosotros, que no somos ni caballeros de la fe ni superhombres, sólo nos resta, si puedo así decirlo, hacer trampas con la lengua, hacerle trampas a la lengua. A esta fullería saludable, a esta esquiva y magnifica engañifa que permite escuchar a la lengua fuera del poder, en el esplendor de una revolución permanente del lenguaje, por mi parte yo la llamo: literatura. (Barthes 1977: s/n)

El anacronismo deliberado de poner en relación un texto de 1948 con otro de 1977, que se insertan a su vez en tramas y discusiones muy diversas, ${ }^{272}$ nos permite seguir pensando no solo el modo en que algunas de las escrituras críticas de nuestro corpus dialogan con otras temporalidades, sino también advertir un momento incipiente de la resquebrajamiento de la concepción humanista del sujeto, y acercarnos vía Barthes al vínculo Bataille-Pellegrini. Esta intervención sobre la comunicabilidad literaria, o la comunicabilidad de los lenguajes en la formulación de una poesía como imagen del instante recupera una idea de comunicación que aparece ligada a la soberanía del nosaber, una moral de lo maravilloso desconocido, que se remonta a Bataille y su lectura de Miller. Bataille había puesto en cuestión la idea del sentido en la cadena de la razón hegeliana, ya que entendía el estado de "comunicación (continuum) con el otro" como el espacio donde emerge la carencia, la diferencia irreductible que por no ser ni esto ni aquello, imposibilita cualquier reconocimiento e interrumpe la complicidad servil de la palabra y el sentido.

\footnotetext{
${ }^{272}$ No solo por la diferencia geográfica, también por las tramas institucionales, especialmente si recordamos que "La lección inaugural" es la apertura del seminario de Barthes en el Collége de France.
} 
Si la poesía puede devenir verdadera comunicación, el poder transformarse en potencia, y las palabras-código en ruptura de las convenciones, es porque allí opera el destello de lo instantáneo en la clave de "combustión", "fulguración”, “imagen incendiaria" o "iluminadora" -"solo cuando la imagen es combustión puede iluminar la realidad", "la imagen que entra en combustión, la imagen iluminadora [condensa la suma de los conocimientos posibles]" (Pellegrini, 1952, n2:3)- y, en términos de Barthes, la lengua se desujeta.

Años más tarde, en 1953, Aldo Pellegrini volvería sobre el par comunicación imagen iluminadora, en la presentación a "Nuevos poemas de Oliverio Girondo", publicados en el número 2 de la revista Letra y Línea:

la necesidad de comunicación directa que está en el origen de la poesía resulta trabada de tal modo por las convenciones del lenguaje que el poeta o se reduce al silencio (caso Lord Chandos) o se decide por la ruptura de los esquemas verbales. (...) cuando la intensidad de los contenidos exige el lenguaje de matices que las formas prefijadas no pueden dar, se está ante las puertas de esa ruptura. $(1952, \mathrm{n} 2: 2)$

La comunicabilidad de la poesía se cifraba entonces, para Aldo Pellegrini, en el momento de una imagen: "a la imagen toca destruir el significado convencional al establecer contactos inéditos entre las palabras. (...) La instantaneidad de la imagen debe fundirse con un recorrido en el tiempo dado por la musicalidad y el ritmo poéticos" ("Nuevos poemas de Oliverio Girondo"). Comunicación, instante e imagen se articulan como parte de una serie de las iluminaciones. La experiencia del instante aparece así como una desgarradura en el orden del sentido, y de ese modo, la idea de que "solo cuando la imagen es combustión puede iluminar la realidad" se vincula con la "iluminación profana" (Benjamin 2014), en tanto figura el relámpago por el cual una imagen se sale del curso de la Historia. La iluminación como instante propone el encuentro con lo desconocido, de la descomposición temporal, de la extrañeza subjetiva, en lo cotidiano y común de lo sensible. Se trata de una imagen que vuelve de donde nunca ha estado. En ese sentido, la figura del "instante" tal como es apropiada por Pellegrini, permite modular otro uso de la idea de comunicación, diferente al que se construye en el par comunicaciónacción como era exigido por Sartre en Qu'est que c'est la littérature? y Contorno. Así, esta comunicación propuesta como ruptura, revelación, interrupción de la cadena del orden del sentido, se recorta sobre la pregunta por la relación entre lenguaje y conocimiento, en tanto se opone a la política de la lengua del existencialismo y el 
realismo. Estas perspectivas estético-filosóficas eran consideradas por Pellegrini y Molina como enemigas del conocimiento del hombre.

Así, los ensayos de Enrique Molina -"Vía Libre" y "Aimé Césaire"- también abordaban la necesidad de re-significar el alcance del término "comunicación" a partir de la figura del instante. Para Molina, "la imposibilidad de comunicación" en el arte se debía a que la razón y el utilitarismo ocupaban todo el espacio de la reflexión del hombre. Molina señalaba que el "existencialismo" oficiaba de "empresario" frente a la angustia generalizada. Con la metáfora de lo "sombrío" lo contraponía al relámpago iluminador de la imagen poética: "[el existencialismo] colora con un tinte sombrío la conciencia contemporánea” (Molina 1952, n1:1).

El ensayo sobre Aimé Césaire, publicado en el primer número de Letra y Línea, es otro momento donde se condensa un cuestionamiento a la noción "codificada" de “comunicación” a través de una imagen particular de lo instantáneo o fugaz. La poesía de Césaire actúa como un "relámpago blasfematorio" que "nunca ilumina las versificaciones y los ejercicios donde la retórica consciente no es otra cosa que el testimonio de la más baja sumisión" (1953, n1:4) y pone al descubierto a los "hipócritas humanistas":

Aimé Cesáire se halla muy lejos de la llamada "poesía social", fruto de un espíritu reaccionario incapaz de comprender que es imposible reducir la verdadera poesía a la categoría de un epidérmico excitante elaborado como un tema político. (...) En cambio la suya es verdadera poesía social en el sentido en que lo es la de un Whitman o un Vallejo, por la profundización de su subjetividad hasta llegar a reconquistar en ella todo cuanto es desechado, frustrado, por una moral equívoca, un orden mental que deforma toda personalidad y un sociedad que engendra en su seno la mayor injusticia. $(1953, \mathrm{n} 1: 4)$

Por otra parte, ese "fulgor" de la imagen es el momento donde se recupera la "gran unidad perdida". Porque nuevamente se está frente un efecto de desnaturalización:

La poesía de Aimé Cesaire produce una relampagueante solución de continuidad en todas esas matemáticas del onanismo. Quiero decir que a medida que se ahonda en la conducta severa, asumiendo en la catástrofe, de un Rimbaud, un Lautreámont, un Artaud, desaparece el viejo decorado convencional para dar paso al hombre vestido de negro que persigue, a través de la ciega muralla de las apariencias sensibles, un destello de lo absoluto. (1953, n1:16)

La idea de una "comunicación total” o "integral", la recuperación de la unidad, reaparece en "Paradojas de la poesía" de Svanascini cuando afirma que 
[los aletargados en relación a su tiempo] persisten en una ignorancia con respecto a la comunicación total. (...) ¿Es lógico, además, que hablen de movimientos caducos - refiriéndose al creacionismo, dadaísmo, surrealismo, etc. - quienes continúan en un sospechoso parnaso o ni siquiera hundieron sus magros pelos en otros ámbitos que los de su propia y discutible inepcia?

En varios ensayos de Letra y Línea la idea de "comunicación" es adjetivada, atribuida a una característica que la recorta de otras nociones "confusas" - lo que Aguirre llama, como veremos en el apartado siguiente "aparentes formas de comunicación actual, periodística y sencillista". Así, por ejemplo, Molinari habla de "comunicación profunda", y cuando Svanascini se refiere a la poética de Michaux se pregunta: “¿Hasta dónde importa el descubrimiento de Milarepa y Lautréamont, a los veinticinco años, como aporte a una formación que acepta los extremos más inexcusables de la comunicación verbal?"

En la poética surrealista y tropical de Césaire, se nos dice, "el idioma es deshecho, destruido, desarticulado en sus resortes lógicos para volver a inventarlo con la libertad sin límites de la inocencia", y logra así "sacudir la capa de inercia con que el juego de los conformismos aletarga la imaginación” (Molina 1953, n1:4). La vía de la fulguración que puede deshacer el lenguaje es la que permite que "el enigma oculto bajo las apariencias de la "realidad rugosa" sea "penetrado por medio de oscuras oscilaciones hasta crear el sentimiento de una íntima comunicación con el mundo". Comunicación directa, íntima comunicación con el mundo; este modo de pensar la lengua poética es una oposición a la idea de literatura como expresión. Es decir, a la comunicabilidad que procuran leer los jóvenes denuncialistas en el lenguaje, Letra y línea la desarma diciendo que la comunicación, en la literatura, es incompatible con lo disponible del lenguaje, y se manifiesta en la figura del silencio, tal como postula Pellegrini, el fulgor, o la intraducibilidad.

No casualmente esas imágenes son las que aparecen apuntalando el valor de la poesía de César Moro en A partir de cero: "Entre la miseria verbal que invade la poesía americana César Moro abre una brecha fulgurante, en cuyo fondo se destaca el perfil tenso, preciso, tierno, audaz, feroz, dulcísimo, salvaje y en llamas de César Moro"; ya que su poesía está plagada de imágenes de la fragilidad, huellas, fósiles, relámpagos:

\section{UN CAMINO DE TIERRA EN MEDIO DE LA TIERRA}

Las ramas de luz atónita poblando innumerables veces el área de tu frente asaltada por las olas 
asfaltada de lumbre tejida de pelo tierno y de huellas

leves de fósiles de plantas delicadas

ignorada del mundo bañando tus ojos y el rostro de lava verde

¡Quién vive! Apenas dormido vuelvo más lejos a tu encuentro de tinieblas a paso de chacal mostrándote caracolas de espuma de cerveza y probables edificaciones de nácar enfangado.

Vivir bajo las algas.

El sueño en la tormenta sirenas como relámpagos el alba incierta un camino de tierra en medio de la tierra y nubes de tierra tu frente se levanta como un castillo de nieve y apaga el alba y el día se enciende y vuelven la noche y fasces de tu palo se interponen y azotan el rostro helado de la noche.

Para sembrar el mar de peces moribundos

Y que las plantas carnívoras no falten de alimento

Y crezcan ojos en las playas

Y las selvas despeinadas giman como gaviotas.

Comunicación, instante e imagen se articulan como una moral crítica donde lo que se promueve no es la expresión de lo dado, sino el contacto intenso con lo que emerge en el límite de pasaje, de una palabra como poder y una palabra como potencia. Hablamos de moral porque estas intervenciones trabajan sobre la afirmación de un valor en la ambigüedad entre la extrañeza y los presupuestos ampliamente admitidos. En los ensayos de Aldo Pellegrini, el intento por configurar una lectura de lo desconocido, por acercarse simultáneamente a aquello de la palabra que constituye "cadáveres", convención, pero también a su dimensión emancipatoria, desubjetivadora, chocaba con "lo admitido" en una noción de sujeto fuerte, humanista, al que llama frecuentemente "el Hombre". Al respecto, Bayley advierte que "es evidente que en los últimos tiempos - desde mediados del siglo pasado - la poesía se ha vuelto ambiciosa". La poesía buscó "transformar la vida, la sociedad, el mundo", pero esta ambición "le ha hecho recaer a veces en la vieja retórica didáctica, en la elocuencia exterior", aunque, insiste, "también muchas veces la ha llevado a nuevos territorios de poesía, a descubrimientos a nuevas experiencias y expresiones" (81). 


\subsubsection{La "comunicación” literaria en Contorno}

Estas articulaciones entre imagen, instante y comunicación para delimitar "la unidad de la verdadera poesía: la poesía que expresa, la poesía que comunica”, se superpone a otros recorridos en torno a la literatura y capacidad de expresión: lo que Contorno denominó como "testimonio". La aproximación de esas palabras de Aldo Pellegrini y las escrituras en la revista Contorno puede parecer forzada e injustificada. Sin embargo, Letra y Línea remonta un entramado de cruces con Contorno en especial pero con otras revistas también.

Por otro lado, afirmar la comunicabilidad de la poesía, como una torsión de los lenguajes convencionales, era una forma de discutir con las afirmaciones más recientes de Jean Paul Sartre en Qué es la literatura, donde separaba prosa de poesía en relación a su capacidad de compromiso al carecer esta última de un límite en la significación. A partir de esa lectura discutía con la vigencia del surrealismo después de la II Guerra Mundial. "Si la negatividad es uno de los aspectos de la libertad, la construcción es el otro" (199) -, de aquí que se derive un deóntico artístico para el lenguaje que se opone a las políticas de la creación propuestas por el surrealismo: "La función del escritor es llamar pan al pan y vino al vino"

Como señalamos en el apartado anterior (Cfr. 3.1), Ismael Viñas postulaba en el primer número de Contorno una moral de la utilidad: "No queremos que nos asusten ni que nos agraden las palabras, ni las grandes ni las pequeñas, ni las gastadas. Esperamos simplemente que nos sirvan" ("La traición de los hombres honestos"). Es posible observar, entonces, que los fundamentos valorativos puestos en juego, de modo divergente en torno a la literatura como comunicación y expresión - que, siguiendo la historización de Barthes no es otra cosa que la crisis de la escritura en la literatura moderna - en la escritura crítica de Aldo Pellegrini - aunque se podría hacer extensivo a Enrique Molina, Edgar Bayley - y las escrituras de Contorno, son parte de una discusión más amplia en torno a figuras del tiempo y de la historia, que recuperan el embate en torno a instante y totalidad ${ }^{273}$. La idea de comunicación como imagen que arde, según

\footnotetext{
273 Tanto para pensar "nuestros años 60" como en el ensayo más breve titulado "Rasgos de la cultura argentina en la década de 50", Oscar Teran propone un "archivo de categorías" que "contribuyen a precisar el perfil del actor cultural en cuestión", los intelectuales de una nueva izquierda nacional. Como es sabido, su recorrido por una historia de las ideas en ese mediado del siglo XX se establece a partir de una "entrada por la filosofía" a partir de la cual se van precisando las "pasiones ideológicas" que produjeron un pasaje de la crítica escéptica a una crítica comprometida y luego al intelectual orgánico. La centralidad de
} 
postulaba Aldo Pellegrini es una variable de las figuraciones del instante como modo de pensar la literatura y sus efectuaciones sobre lo real. A su vez, en consonancia con las exigencias del editorial de Contorno, sobre una revolución como construcción del orden y la disciplina, en el número $5 / 6^{274}$ de la revista configuraron su noción de literatura como testimonio - "Aun no siendo la exclusiva ocupación de todos nosotros, nos asomamos a la literatura como testimonio"-, y en ese armado de una breve historia de la novela se inscribe el ensayo de León Rozitchner titulado "Comunicación y servidumbre: Mallea".

En el desarrollo de la escritura asistimos a otra forma de la inestabilidad en la moral crítica que despliega. Si en la noción de "literatura como comunicación" de Pellegrini leíamos cómo al mismo tiempo se procuraba una paradoja entre la palabra como poder y como potencia, un espacio de tembladeral en los límites de lo conocido y las convenciones, pero a su vez esas ideas volvían sobre sí a la afirmación de lo conocido -el sujeto del humanismo-; en la escritura de Rotizchner leemos una moral de la historia como forma que oscila entre un instante soberano, donde la palabra "se abre paso a través de las prohibiciones o merced a la violación de las prohibiciones", como una "rebeldía que se levanta dentro de la separación organizada de los hombres" (1955:29-30), y la exigencia de la acción para reconocerse, en términos hegelianos:

La literatura aparecerá como una manera de expresar el ser, porque, escribiendo, el hombre no supera el plano de lo real por el plano de lo imaginario, sino que participa como todos los hombres de nuestra misma problemática fundamental. El escritor no nace a un mundo de excepción sino al mundo de la cotidianeidad donde asume su lote de gracias y desdichas.

Hay una falta de reconocimiento entre los hombres que la comunicación literaria a veces explota y hace aún más sensible. Cabe preguntarse por la finalidad de la palabra. (30)

En esa pregunta por la "finalidad de la palabra", Rozitchner afirma la exigencia dialéctica: "y es precisamente por hacerse cargo de esa dialéctica de la acción concreta y del acto

Contorno y su construcción de una nueva mirada sobre la literatura que se apoya también en los cambios que experimenta la filosofía en Francia resulta clave en ese sentido

${ }^{274}$ El lenguaje de Arlt, finalmente, es pobre, y no solo en la cantidad de vocablos. Es un lenguaje vulgar, material, salpicado (por lo menos) de lunfardo. Curiosamente Arlt parece haberse avergonzado de esa pobreza: no sólo cae en un idioma afectado, desmayadamente literario, cuando la urgencia de expresión cede, sino que después de su viaje a España intenta cierto virtuosismo denominativo, sin mejor resultado apreciable: Arlt parece ignorar decididamente que la lengua que usa naturalmente, la que aflora cuando se expresa a sí mismo, ese dialecto inventado por él en tanta medida como es el lenguaje familiar porteño, pobre y ruda, es ya en sus manos un instrumento que da expresión al alma, una lengua que se está legitimando con ella construye sus anhelos. (...) Pero aún hizo más: expresó los elementos especiales del drama particular cuyo signo es su obra. El hombre que Arlt descubre es el de nuestra urbe, cifra a su vez del país. Ese hombre es europeo, pero, he aquí la fuente de su particular drama: no lo es del todo. 
imaginativo vivida trágicamente que el escritor hace posible, como anticipación, la comunicación que abre al reconocimiento" (29).

Así, a su vez, Rozitchener, abre la enunciación más difundida de Contorno "Esperamos simplemente que [las palabras] nos sirvan"-, se acerca y se distancia de las formulaciones de Aldo Pellegrini en las posibilidades de transgresión de la palabra, pero reconduce eso mismo al plano de la acción sobre la Historia, donde triunfa una noción de totalidad:

La contemporaneidad nivela a todos por igual. Cada hora histórica es una síntesis vital, cada generación tiene un repertorio o tema personal, un ritmo propio al cual habrán de responder todos sus elementos aun los más antitéticos. ("Los martinfierristas, su tiempo y el nuestro", 1)

Por otra parte, y alejado del paradigma de Contorno, en 1946 Roger Caillois, publicó en la revista Sur un ensayo titulado "El poder de las palabras", donde el problema principal ya no es la relación ambigua entre poder y potencia de la lengua, o si la comunicación es una vía de la expresión para la acción o una detención en el curso de las convenciones, sino otro mucho más general que atravesaba las discusiones de Letra y Línea y Contorno especialmente: la confusión.

\subsubsection{El problema de la comunicación en poesía buenos aires}

Como anticipamos en el primer capítulo, a partir de la lectura de Luciana Del Gizzo, uno de los movimientos por los cuales poesía buenos aires alcanza una mayor amplitud respecto de los movimientos que la precedían - tanto el invencionismo en Contemporánea como el arte concreto en las revistas de la AACI - se produce en torno a la idea de comunicación de la poesía, en tanto condición integral de existencia de la poesía en la vida. Si una de las afirmaciones que atraviesan a la revista tiene que ver con que así como el poema (aunque más notablemente "el poeta") adopta ese carácter algo sagrado, trascendental que atraviesan las miserias y los riesgos del mundo y pueden devolver un estado superior de la condición humana, también se dice que la poesía excede al poema y que la encontramos en todos lados, en diversas formas. En ese sentido, resulta claro que el valor de la comunicación sea puesto en el centro de los debates. Y por eso Aguirre reprocha a los poetas Madí que se hayan limitado a una poesía que tiende a la nofiguración ("a partir de conceptos e imágenes no traducible gráficamente”), sin buscar la “integración con la realidad vital, emotiva y coherente del individuo". Esto coincide con 
la definición de "lenguaje poético" que hace Bayley en "Realidad interna y función de la poesía" cuando dice:

hay un lenguaje específicamente poético. Todo poeta se expresa de una manera inhabitual. (...) Este hecho, aunque no implique la definición más cabal de la poesía, constituye una de sus características o fatalidades más persistentes. El poeta no puede eludirlo. Y por mucho que se acerque en el estilo de su producción al lenguaje cotidiano, algo tornará extrañas para nosotros sus líneas de palabras.

Para que ese lenguaje sea válido desde el punto de vista poético, es necesario que se muestre, aunque diferente del lenguaje habitual, como otra capacidad del hombre, útil para su comunicación. De este modo, esas formas expresivas, inicialmente extrañas para nosotros, se integrarán en nuestra vida íntima y servirán a nuestra expresión cotidiana. (Bayley 1952, n6:3)

Comunicación e invención aparecen como términos que deben ser re-defenidos y refrendados cada vez, puestos en perspectiva histórica, porque la pregunta de poesía buenos aires es cómo seguir siendo vanguardia, "no devenir institución" (de la lengua en este caso) sin resignarse a la soledad del poeta, a la incomprensión absoluta. Raúl Gustavo Aguirre retoma, en el número 13/14 de poesía buenos aires, un ensayo de Maldonado sobre la comunicación en las artes visuales y recupera un panorama histórico:

En un excelente artículo que publica Nueva Visión (1953), Tomás Maldonado se refiere, con lúcidas consideraciones, a los "Problemas actuales de la comunicación". Las notas que siguen, derivan de algunas cuestiones que el trabajo mencionado plantea a la poesía. En el planteo que deriva de la línea Hegel - Scheler - Kahler, la comunicación sería la consecuencia de un orden creciente de objetivaciones (tiempo, mudo, hombre) por el cual se expresa la historia. La facultad de trascender de un yo a un no-yo (definición del espíritu) es susceptible de hallar en la comunicación humana un acabado sentido. (...) Pero la situación espiritual de nuestro tiempo demuestra un estado insuficiente de este proceso. Ello explica por qué el arte contemporáneo (como todo acto del espíritu) tropieza en el mundo actual con esa muralla insalvable que impide la comunicación: ella no puede existir sin el previo reconocimiento del semejante. (Aguirre 1953, n13/14:19)

En este panorama, dice Aguirre, el poeta se ve "conducido a la desesperación: ha robado el fuego pero la bella especie que ha de utilizarlo no ha hecho todavía su aparición sobre la tierra". Entonces da cuenta de las dos opciones para la poesía: que "se resigne a ser un hecho solitario", o, por el contrario, agrega,

acontece también que el poeta no acepte la soledad a que se ve condenado e intente, por medios ingeniosos, imitar las aparentes forma de comunicación actual: su poesía se hace entonces periodística, sencillista, "social" (Prévert, Sandburg), y como de alguna manera pacta con el orden actual, renuncia así a su propia naturaleza. (19) 
El tipo de comunicación que Aguirre reclama en las vanguardias más antirepresentacionales, antifigurativas no es, sin duda, el que encuentra en una moral de la lengua como expresión o claridad. En ese sentido, el modo en que pba interviene en la modulación del término-concepto, es un juego doble entre la comunicación de la obra, y lo que esta puede tocar en la sociedad que la recibe. Encuentra como "modelos" de verdadera comunicación, una tercera vía:

Por último puede suceder que, entre ambas alternativas el poeta resuelva por una admirable solución: asumir la identidad de la poesía y la vida, y combatir por ambas, comprometerse en toda la línea, ya en el ámbito de una gran aventura colectiva (Maiakovski), ya en el difícil e ilimitado partido del hombre (Char). (19)

Edgar Bayley se esfuerza por distinguir la singularidad de la comunicación en poesía en el marco de ese encuentro integral con el hombre donde no debe perderse el lazo comunitario por el cual una palabra impacta como un "tono". ${ }^{275} \mathrm{Y}$ entonces advierte, en "El arte, fundamento de la libertad", que la distinción entre la experiencia estética y aquello que "caracteriza toda información y conocimiento", radica en que solo la primera hace desaparecer la "identidad permanente":

esas experiencias frente a la obra no son siempre iguales en el mismo espectador, como tampoco lo son en el propio artista, quien una vez realizada la obra actúa frente a ella como un espectador más. (1955, n18:5)

El término "comunicación" nombra una disputa con la época porque designa tanto esa dimensión singular como experiencia de lo común a través de la lengua, como el carácter "ornamental” y "técnico" que la "burguesía le asigna”. Veamos cómo historizan el problema. Según Edgar Bayley, la situación cultural del mundo "de nuestros días" no puede definirse por la actividad del arte de vanguardia, exclusivamente. La novedad de la época está dada por la aparición de una "cultura de masas", donde desaparece la comunidad y “el valor máximo reside en la segregación del individuo del todo, en la vida privada, en todo aquello que cada uno no puede compartir con los demás”. Las artes de la comunicación, como las llama Bayley, cobran “cada vez mayor importancia comercial

\footnotetext{
275 Una palabra cualquiera, considerada independientemente de toda relación, constituye más que un transmisor de ideas, un excitador de estados mentales. O sea, que la palabra aislada cobra sentido para nosotros, merced a una actividad libre del espíritu, distinta en cada uno, pero de un tono igual en todos. Es este tono el que la hace universal, accesible, sino desde un punto de vista lógico, al menos para la sensibilidad de cada uno.
} 
y política". Por ese motivo es necesario incorporar otros "factores derivados de las condiciones sociales, políticas y técnicas de nuestra época". De este panorama, poscapitalista para Bayley, deriva que "las técnicas de comunicación están destinadas paradójicamente a operar la incomunicación entre los individuos de la masa, (...) convirtiéndolos en piezas, de las que se espera determinadas reacciones en razón de los estímulos empleados". Con el desarrollo de la técnica el pueblo habría quedado huérfano de un arte propio, y "en razón de los nuevos condicionamientos sociales y técnicos, cree encontrar en este arte prefabricado, de elaboración ad hoc, para las masas, la satisfacción de la subsistente necesidad estética".

El problema de la comunicación no es el de la poesía solamente, sino más en particular el del hombre:

si se consigue distinguir estos dos términos será posible advertir que lo que aparece a menudo como lucha por la poesía es, en realidad - como en el surrealismo - lucha por la validez humana, es decir, no un problema que se refiere a la poesía en cuanto posible forma de comunicación sino un problema que se refiere al hombre en cuanto posible objeto de esta comunicación. Así lo saben quienes hoy nos dan el ejemplo de una poesía que no renuncia a ser ella misma y de una vida que no pacta con sus enemigos, de una poesía que tiene derecho a no ser comprendida, a ser oscura porque es fraternal. (Bayley, 1955, n18:8)

\subsubsection{La imagen en combustión y los realismos posibles}

Los ensayos de Aldo Pellegrini y Enrique Molina que comentamos en el primer inciso de este apartado ("El poder de la palabra", "El huevo filosófico", "Vía libre para la poesía” y “Aimé Césaire”) como configuraciones de un movimiento crítico donde la figura del instante -en sus distintas variables: combustión, incendio, fulguración, relámpago, iluminación- era usada para producir una hendidura en el sentido de un término de amplio consenso, como el de comunicación por ejemplo, se ocuparon también de discutir otro de los grandes temas del período: si acaso existía un nuevo realismo. Ambos autores se proponen distinguir entre "verdaderos realistas" y "realistas fantasmales" o "fotográficos"; la diferencia entre unos y otros estaría dada por el hecho de que los segundos tratan de transformar la "realidad empírica, de mero aspecto efímero de lo real, en una realidad en sí”, motivo por el cual "lo único que se logra es un fenómeno espectral". Así, los realistas fantasmales son "los que solo pueden aprehender el mundo 
por lo datos de la percepción sin elaboración (la realidad nos transforma, nosotros transformamos la realidad)" (Pellegrini 1952, n2:3).

Así, la imagen en combustión se vuelve problemática en tanto figura crítica, ya que por un lado postula que se "destruye a sí misma" -y en ese sentido produce una inestabilidad en el orden del saber como bien de acumulación porque se relaciona con lo instantáneo antes que con la construcción de aquello que perdura-, pero al mismo tiempo se propone cumplir una función "discriminativa" propia de la tarea crítica, donde la fugacidad y el conocimiento que permanece suspendido debe convertirse en saber confiable. Es por ese motivo que Pellegrini cuestiona al realismo empírico su falta de "espíritu crítico".

También Edgar Bayley y Tomás Maldonado, ambos vinculados al movimiento concreto- invención, uno desde la literatura y el otro desde las artes visuales, escribieron entre 1944 y 1946, sobre el realismo representacional en clave fotográfica y fantasmal, y buscar apropiarse del término "realismo":

Así, estamos contra la cobardía mental y técnica de los neorrealistas, fotógrafos "a mano" de sus representaciones paralíticas y morbosas; contra los que se nutren del recetario del tránsfuga Lothe; contra los líricos del clavel marchito y de los mundos interiores, que pretenden reditar, en nuestro tiempo de reconstrucción y de lucha, un romanticismo para interiores; y, finalmente, contra los superadores, falsos dialécticos, que hablan de la "abstracción" como un suceso artístico de hace 20 años, ignorando el desarrollo formidable del arte no representativo de la última preguerra". (Maldonado 1946, n2:5)

Considero que la expresión, entendida como comunicación a través de símbolos y signos, es absolutamente ajena al arte. Sin embargo, no creo, como pretenden algunos, que la cancelación de la expresión en una obra aleje a su creador de los hombres; creo, por el contrario, que inventar nuevas realidades estéticas que afirmen el poder humano sobre el mundo, es estar de un modo más esencial entre los hombres. (Maldonado 1946, n2:6)

Nuevamente el término "comunicación" se delimita como terreno de disputa que debe deslindarse de otros términos como "expresión" y "representación". ${ }^{276}$ Uno de los

\footnotetext{
${ }^{276}$ Dice Bayley al respecto: "La época que se inicia, época de reconstrucción y de socialismo, exige un arte acorde con la vida material de la sociedad que nace y se desarrolla. Pero este arte no puede fundarse ya en las formas representativas, que han constituido el denominador común de todas las escuelas y estilos artísticos del pasado porque la representación en el arte es el trasunto espiritual de las organizaciones sociales clasistas, de aquellas en donde la vida mental, que se nutre de una diferenciación del grupo o el individuo con respecto al resto de la comunidad, impone a las obras de arte el aditamento representativo, es decir, su enfrentamiento o relación con objetos y procesos ajenos a la vivencia estética." (1945, n2:3)
} 
movimientos que propone Maldonado es suprimir la representación de los alcances del término "realista" y poner en su lugar a la "acción":

"El arte representativo muestra "realidades" estáticas, abstractamente cristalizadas. Porque todo el arte representativo ha sido abstracto. Solo a causa de un malentendido idealista se dio en llamar abstractas a las experiencias estéticas no representativas.

El arte representativo no es realista; no puede serlo nunca; solo crea fantasmas de cosas. Para nosotros, marxistas, real es lo que es acción, la práctica, puede verificar. Una representación gráfica, mecánica (fotografía) o manualmente ejecutada (que puede ser un medio de conocimiento), es una ilusión o un simulacro de conocimiento. Una representación gráfica es la estatización abstracta de un solo momento del proceso cognoscente, nunca del conocimiento mismo. El arte concreto es el único arte realista, humanista y revolucionario. Tomás Maldonado, 1946

En ambos casos, a lo largo de sus manifiestos, por el "Invencionismo", y el "Arte concreto- invención”, no se distingue claramente entre arte visual y literatura o poesía, sino que se va de un lenguaje a otro indistintamente como susceptibles de ser pensados desde estas teorías de lo que llaman "verdadero realismo marxista". Edgar Bayley había afirmado también en un momento: no queremos representar realidades ni surrealidades, solo invención.

A pesar del aparente enfrentamiento con Aldo Pellegrini, director de Ciclo y Letra y Línea luego, coincidirán en sus ensayos en una idea central durante las transformaciones críticas de esos años: el agotamiento y crisis del "tema" y "la expresión": "No se trata ni de nuevos modos de expresión ni de nuevos temas", dirá Bayley "lo que estaba en crisis era la idea misma de representación en la obra de arte"; y dos años después Pellegrini, leyendo a Wolfgang Paelen habla de la resolución de una crisis del tema. Es decir que a fines de la década del cuarenta y principios del '50, la noción de realismo no era una categoría, ni siquiera una estética clara a la que se oponía otra. Tampoco así la idea de un arte para la transformación. Hallamos objetivos y nombres iguales para formas disímiles. Ambas miradas apuntan a lo que llaman como "lenguaje convencional", entendiendo que se trata de una trampa de la comunicación. Sin embargo, donde una variable más invencionista o constructivista ve la necesidad de "extrañar", torcer la lengua, es decir, establecer una opacidad de la forma, Enrique Molina y Aldo Pellegrini, mediatizados por una noción de imagen como combustión, o imagen ardiente, leen un repliegue de la palabra sobre el olvido de todo lo que se ha nombrado: 
Ante todo hay que comenzar por libertar la palabra, demasiado sometida al orden exterior de la razón. Es necesario (...) dejarla expresar la vida con el olvido absoluto de cuanto se ha expresado, adocenado, endurecido y momificado durante siglos de cultura racionalista. (Molina en "Vía Libre")

Algo de eso intenta poner de relieve Héctor Agosti en 1945 con su conferencia y libro, Defensa del realismo, donde incorpora, a las conocidas lecturas de Engels y Marx, a Lukács y Ortega y Gasset. Al igual que Lukács, Agosti deplora las vanguardias por considerarlas decadentes y epigonales. Propone entonces una "superación hereditaria del arte abstracto en el nuevo realismo", y define por nuevo realismo aquel que no se detiene en "la corteza de los fenómenos" sino que intenta captar la sutil y endiabladamente dialéctica realidad social. No en vano Maldonado cuando escribe el manifiesto de 1946 repudia también a los "falsos dialécticos" que proponen superaciones como si el arte concreto o "abstracto" hubiera quedado atrás. Finalmente en 1961, Portantiero también hace un rescate de las vanguardias para el nuevo realismo social.

Ahora bien, la imagen en combustión, con la cual Pellegrini opone un acercamiento a lo real como intermitente a las pretensiones de empiria del realismo social, queda suspendida entre la capacidad expurgadora del discernimiento (los realistas ingenuos o fantasmales de los verdaderos realistas), y el exceso instantáneo que le retira la capacidad de durar. Vías que la reconducen a las mismas tensiones en las cuales se debatía el surrealismo después de la II Guerra Mundial. El "relámpago magnífico" que atraviesa "el campo de la conciencia contemporánea" podía ser un instrumento de reorganización de la contemporaneidad y la llamada "literatura universal", o podía permanecer en el "gesto débil" de las vanguardias fieles a la promesa de que el arte como conocimiento aloja la potencia inoperante de un luz muy fuerte que se apaga y de cuya huella no vale fiarse. Esa pregunta queda latente en los dos primeros números de $A$ partir de cero, en cierto modo se la recupera con las exploraciones que hace Letra y Línea en su peculiar forma de establecer un contacto con el mercado editorial, y retorna transformada en la segunda época de A partir, luego de la clausura de Letra y Línea.

Tanto Aldo Pellegrini como Enrique Molina oponen a quienes luchan "permanentemente contra los límites que significan las apariencias de las cosas" respecto de "algunos [que] oponen la realidad empírica como resumen de toda realidad posible". La idea de fantasmas suscita una discusión que no sería abordable aquí pero que se relaciona muy directamente con los ensayos y manifiestos de la AACI entre 1944 y 1948; 
tal vez un poco incontroladamente por la voluntad de los surrealistas de A partir de cero, estas espectralidades son un resto insumiso que retorna constantemente, porque al parecer, el problema es que tales "alucinaciones" -que generan la confusión de tomar por total una realidad parcial- provocan fantasmas cuando no se las trata con "pensamiento crítico", una soga a la razón para impedir excedentes fantasmales. Y porque insiste la cuestión de la totalidad como uno de los temas que convoca la discusión entonces.

\subsection{La forma de la historia: Edgar Bayley}

Una de las constantes en los ensayos de Edgar Bayley es su preocupación por trabajar de forma diferencial, pero inescindibles entre sí, dos dimensiones del "lenguaje poético": "realidad interna" o "realidad" y "función" o "comunicación". Tales han sido los pares con los que pensó tanto el lugar de la poesía "de nuestro tiempo" o "nueva poesía" en el curso de la historia, como su especificidad en relación con las exigencias de lo social.

$\mathrm{Si}$ tomamos las primeras intervenciones de Bayley en el "Manifiesto invencionista" de 1945 hasta sus últimos ensayos en poesía buenos aires, como "El arte, fundamento de la libertad", o "La poesía como realidad y comunicación”, advertimos que esas dos dimensiones son puestas en perspectiva histórica. La nueva poesía no puede ser pensada o relevada sin dar cuenta de un juego de alternancias, continuidades y diferencias con el pasado, aquello que hace que la poesía sea siempre un diferencial del tiempo. ¿Qué es lo que hace Bayley con la historia, entonces?, y en este punto vale recordar que poesía buenos aires publica, hacia 1956, el mismo texto de Jean Cassou sobre el arte moderno que analizamos en el programa de Ciclo, donde fue publicado y traducido al español en 1948. Bayley propone un recorrido por el cual suspende o ignora variaciones de "época", como la alegoría mística, el simbolismo, que moderaban las formas de escribir, para demostrar que la verdadera poesía siempre se desujeta de esos imperativos. La historia es el hilo de continuidad donde leer cómo la poesía se desujeta de las codificaciones sociales / literarias que operan en ella. Por eso la función comunicativa es puesta en diálogo con esa "vida cotidiana del estilo", donde el lenguaje poético aumenta lo decible sobre el mundo. Así, la historia es una política de la literatura antes que una exigencia.

En "La batalla por la invención", Bayley se propone derribar la "mística del individuo", es decir, los valores por los cuales, en la "sociedad alienada", el individuo 
considera que la confusión con los demás es su propia anulación. Hay una relación directa, dice Bayley, entre Arte Representativo e individualismo, que se produce por la búsqueda de "establecer relaciones de cosa a significación", es decir, por buscar establecer un sentido de la diferencia entre los objetos que se corresponde con un valor asignado que los traduciría. Así, para Bayley hay tanta diferencia entre la "expresión” (de carácter meramente representacional) y la "invención", como entre la "separación" y “comunión". La perspectiva representacional o expresiva es, para el poeta y crítico, un anti-vitalismo ya que va contra toda experiencia de lo vivo:

La vivencia, en cualquiera de sus formas, tiene la recompensa en sí misma; el reemplazo de una vivencia por cualquier otro tipo de realidad es imposible, y los intentos para conseguirlo solo conducen al debilitamiento de la vivencia o, bien, a su completa anulación. (1945:4)

Así, el artista no tiene un reino aparte de la realidad común, por eso "reconstruir el mundo" - su tarea - es "inventar objetos que participen en la vida cotidiana de los hombres" y que sean parte común de las "cosas que deseamos modificar".

Para Bayley, muy tempranamente, a una "nueva forma de organización social" debía proponérsele un nuevo arte, pero no un arte que representara esa novedad sino que fuera él mismo nuevo. Lo que une esa vida nueva con un arte nuevo es entonces una disonancia, distancia, una torsión que no los hace corresponder directamente sino entrar en contacto por el pasaje de "un mundo sensible a otro mundo sensible que define otras tolerancias e intolerancias, otras capacidades e incapacidades" (Rancière, 2010:69). Por eso hablamos de la historia como "política de la literatura", porque lo que operan son

disociaciones: la ruptura de una relación entre el sentido y el sentido, entre un mundo visible, un modo de afección, un régimen de interpretación y un espacio de posibilidades; es la ruptura de las referencias sensibles que permitían estar en el propio lugar en un orden de cosas. (...) Disposiciones de los cuerpos, en recortes de espacios y de tiempos singulares que definen maneras de estar juntos o separados, frente a o en medio de, adentro o afuera, próximos o distantes. (Rancière, 2010:69)

Porque lo que interesa a Bayley es el tipo de disposición de los objetos concretos, su relación con los cuerpos. Lleva al borramiento de la línea que separa al individuo de la confusión. Lo que es sin significado constituye una comunión. Una forma de "definir la realidad" - y con ella la relación con el comunismo - desde la suspensión de las significaciones.

Un año más tarde, en un ensayo sobre el arte concreto, Bayley insiste en el problema de la representación como forma de organización de las sociedades clasistas 
que necesitan establecer significados con objetos ajenos a las experiencias artísticas para poder reducir la vivencia a un signo que forme parte de los bienes de cambio y consumo:

la representación en el arte es el trasunto espiritual de las organizaciones sociales clasistas, de aquellas en donde la vida mental, que se nutre de una diferenciación del grupo o el individuo con respecto al resto de la comunidad, impone a las obras de arte el aditamento representativo, es decir, su enfrentamiento o relación con objetos y procesos ajenos a la vivencia estética. (Bayley en Cippolini 2011:195) ${ }^{277}$

Sin el dogmatismo de este manifiesto, la misma idea persiste en un ensayo mucho más amplio y de carácter eminentemente histórico como "Realidad interna y función de la poesía". Bayley parte de una suerte de evidencia: "hay algo que permanece a través de toda esa evolución, ya que podemos llamar poesía tanto a una oda de Píndaro como a un soneto de Petrarca o a un poema de René Char", pero, agrega, "la poesía, lo mismo que otras formas artísticas, ha experimentado a lo largo de su evolución cambios notables en sus modos expresivos". Cambio y continuidad son las matrices en las que va a inscribir la noción de "realidad interna" y la de "función" que a continuación definiremos. Significativamente, Bayley explica menos la fuerza del cambio que la forma en que persiste esa continuidad que en parte se sustrae a las modulaciones de determinadas escuelas estéticas. En ese sentido resulta una lectura disruptiva de la articulación entre poesía e historia para las discusiones que comentamos anteriormente. En dos entregas de pba durante 1952, Bayley se propuso explorar de manera diacrónica el carácter singular de la poesía, aquello que no podía explicarse únicamente por los parámetros retóricos, religiosos o políticos de la época. Y es esa historicidad de una merca diferencial no reductible a lo codificable lo que le permite

demostrar que hay un estilo (en nuestro tiempo) que reúne las mismas condiciones de existencia de estilos anteriores. Cierta poesía de nuestro tiempo no constituye un hecho contingente, un corte, una ruptura, o un capricho dentro de la evolución poética contemporánea, sino que existe como una tendencia orgánica y en desarrollo de una determinada dirección, independientemente de las opiniones y los propósitos de sus cultores. (1952 n6:4)

Por "realidad interna" de la poesía, Bayley entiende la "combinación inventiva de las palabras". A la "realidad emocional, imprescindible para la existencia misma de la poesía", debe suceder una "elección objetiva". Es decir, inventar, no traducir. El interés del poeta, insiste, "no está en mantenerse fiel a la emoción inicial, sino en aprovecharla

\footnotetext{
${ }^{277}$ El texto "Sobre arte concreto" fue publicado en la revista Orientación del 20 de febrero de 1946.
} 
estéticamente, combinando las valencias poéticas de las palabras que la emoción hace surgir de su espíritu". Es en esa búsqueda que el expresarse de "manera inhabitual" del poeta no puede escindirse de un poder liberador de la palabra, "es necesario que se muestre, aunque diferente del lenguaje habitual, como otra capacidad del hombre, útil para su comunicación. De este modo, esas formas expresivas, inicialmente extrañas para nosotros, se integrarán en nuestra vida íntima y servirán a nuestra expresión cotidiana":

El lenguaje poético libera el poder de la palabra, porque la dota de una coherencia nueva, inventiva.

Es en este acto de liberación creadora de la energía emocional de las palabras, donde parece residir el proceso interno de la poesía, que señalé como uno de los aspectos de su condición permanente-

La realidad interna es la combinación inventiva de las palabras.

Existe poesía no cuando se expresa meramente una emoción o cuando se habla de un modo distinto al habitual, sino cuando se relacionan las palabras de una cierta manera, válida para la sensibilidad.

Por "función de la poesía" se entiende la "actividad mental" que "existe en todo individuo". Para Bayley es por el poder liberador de la palabra en la poesía que el hombre se relaciona con las cosas y las domina:

en otras palabras, la poesía ha servido para que el hombre mantuviera tensa una disposición de su espíritu, sin la cual no hubiera podido construir el mundo que le rodea, edificándose, por añadidura, a sí mismo. $\mathrm{O}$, como dice Reverdy, sin la actividad poética, que él define como el acto de transmutación de lo real exterior en lo real interior, el hombre no hubiese podido superar nunca el obstáculo inconcebible que la naturaleza levantaba frente a él.

A partir de esta distinción, Bayley se propone demostrar cómo esa "realidad interna" o “combinación inventiva de las palabras" está presente a lo largo de toda la historia. Al mismo tiempo que ese propósito le permite eximirse de hacer un análisis total de las obras. El primer ejemplo que toma es un poema de San Juan de la Cruz:
Nuestro lecho florido
de cuevas de leones enlazado, en púrpura tendido de paz edificado de mil escudos de oro coronado.

¿Qué es lo singular para Bayley en ese poema? Sin duda, aclara desde un comienzo, "Hay para estos versos una explicación mística, realizada por el mismo San Juan de la Cruz en 
el Cántico Espiritual", 278 pero si bien es cierto "que antes de llegar a la estructura poética, San Juan pensó la significación indicada por él y posteriormente trató de hallar la relación verbal de tipo alegórico correspondiente", hay un elemento desestabilizador que interrumpe esa serie de correspondencias codificadas. Para Bayley en el la versión de una experiencia mística no hay "estrictamente hablando, invención poética (el alma se une con Dios)", nos dice. Donde sí encontramos esta "realidad interna" como continuidad es en la segunda parte, cuando

hallamos ya un elemento que no es pura traducción de una experiencia religiosa, sino un producto de la sensibilidad poética de su autor. Aquí la alegoría cobra un valor autónomo, independiente del significado al que corresponde, por lo que tendemos a olvidarnos de la experiencia mística representada, la cual por otra parte, pudo simbolizarse de otros diversos modos, ajenos a la poesía. Atendemos así a ese "lecho florido de cuevas de leones enlazado", tal cual se presenta, de primer intención, a nuestra sensibilidad, y no buscamos en el Cántico espiritual su significado, puesto que ningún poema, antiguo o moderno, puede tener otro que el yacente entre sus líneas.

De manera similar analiza dos versos de Góngora en Soledades: “quejándose venían sobre el guante / los raudos torbellinos de Noruega"

Para mí, las razones probables de su belleza no se encuentran en el hecho de que esos torbellinos quejándose sobre el guante sean, en realidad, halcones sobre las manos de los halconeros. Lo importante, me parece, es que Góngora haya dado vida a una relación, a un concepto poético donde las palabras "guante" y "torbellinos" valen por el vínculo inventivo que une sus significados, o sea por la fortuna poética implícita en el encuentro de estas palabras.

Para Bayley el momento de "desvitalización de la poesía" se produce cuando Boileau intenta ordenar los parámetros de la retórica y "sustituyó con ella la experiencia de fondo. La invención poética se debilita al máximo y lo sustituye el didactismo y la frase remanida, de pretendido buen gusto". El romanticismo sería una respuesta a eso, y toma el poder de las correspondencias de Baudelaire como ruptura total con las prescripciones. De esa "batalla por la invención", parafraseando su primer manifiesto, deriva la marcha de las escuelas poéticas que han luchado por la construcción de “imágenes autónomas, depuradas de referencias descriptivas”. Pero, advierte rápidamente Bayley: no hay que

\footnotetext{
278 . En ocho páginas el poeta explica allí lo que ha deseado significar en ellos. (El lecho "designa el lecho del alma, o sea el Esposo, Hijo de Dios"; "cuevas de leones", virtudes del alma en estado de unión con Dios, etc.).

Es indudable que San Juan de la Cruz, cuya poesía era una resultante de su experiencia mística, escribió la canción que analizamos, por vía alegórica.
} 
apresurarse, por ese motivo, a considerar la "invención poética" como "una ruptura dentro del proceso de que estamos hablando", sino como parte de las tramas de continuidades y diferencias de una característica transversal de la poesía, que es la de desujetarse de las prescripciones impuestas.

Este carácter diferencial de la poesía a lo largo de una historia extensa es lo que nos hace pensar en la noción de Historia para Bayley en tanto política de la literatura y no en tanto exigencia o "empresa de la época", ya que en términos de Rancière, lo que une a la realidad interna con su función es una disonancia, distancia, una torsión que no los hace corresponder directamente sino entrar en contacto por el pasaje de "un mundo sensible a otro mundo sensible que define otras tolerancias e intolerancias, otras capacidades e incapacidades". Y en ese pasaje, operan las disociaciones, rupturas, que disponen de tiempos singulares. En ese sentido, la historia es, para Bayley, una de la proyección de intensidades, antes que un conjunto de exigencias o representaciones. 


\section{CONCLUSIONES}

A partir de una carta enviada por Nelson Rockefeller a María Rosa Oliver en septiembre de $1945,{ }^{279}$ Andrea Giunta concluía que tanto "para Sur, como para los Estados Unidos, la Argentina del peronismo no era más que un tiempo de espera; un tiempo que había que saltar y, en lo posible, eliminar” (2001:55). El crítico Luis Gregorich escribía, a su vez, sobre los años 60, que "la eclosión intelectual y creativa que siguió a la caída del régimen" fue un despertar a la vida y a la acción después de "un largo letargo" (1981:533). Tiempo saltado, tiempo del letargo y el agobio, como leíamos en la correspondencia de Aguirre con Char, o del desierto y la soledad, como se mencionaba en el editorial de Contorno, los años del período analizado en la tesis (1948-1956) se configuraron, en parte, como tiempo homogéneo, ${ }^{280}$ tiempo de la neblina o no bendecido por los dioses según caracterizó Jean Louis Déotte (2013) lo que hay "en el medio" de los grandes acontecimientos. Ahora bien, como intentamos mostrar a lo largo de los tres capítulos que conforman esta investigación, esa misma experiencia se inscribió de manera ambigua y abierta en las intervenciones críticas de las revistas Ciclo, poesía buenos aires, A partir de cero y Letra y Línea. Esa ambigüedad estuvo dada, principalmente, por el carácter desestabilizador que atravesó a la idea de vanguardia -entendiendo por ella la exigencia de renovación, la búsqueda de un arte no representacional, el rechazo a las formas cristalizadas del lenguaje y la imagen- en tanto se trataba de una forma de leer y pensar el arte y la literatura que resultaba desfasada para el tiempo histórico en que buscaba intervenir. Ese desfasaje estuvo ligado a la condición temporal de las vanguardias, ya que las propuestas de los movimientos estéticos experimentales fueron consideradas por otras revistas (Contorno, Cosmorama, Cabalgata, Verde memoria, El 40) como un momento superado de la historia del arte, asociado al derroche y la irresponsabilidad. Frente a esa posición, las revistas del corpus rechazaron la noción de "novedad" y propusieron que se trataba, en todo caso, de un pasado inconcluso o una extensa y "viva línea del pensamiento contemporáneo" (Molina 1952), convirtiendo a los valores vinculados a las vanguardias

279 “Si las cosas se hubiesen movido más rápido en Argentina, nosotros habríamos podido enfrentar los problemas de la paz con un frente sólido en las Américas. (...) De ninguna manera mi interés en nuestros problemas comunes disminuye con mi alejamiento del gobierno, y cuidaré en el futuro continuar las asociaciones que han tenido tan buenas intenciones hacia mí durante los pasados cinco años. Hay mucho que todavía debe realizarse - su sabiduría y juicio, su integridad y perspicacia son extremadamente necesarios". Nelson A. Rockefeller to María Rosa Oliver, septiembre 1945, folder 45, box 7, RG 4 (NAR Papers), Rockefeller Family Archives, RAC. En Giunta, 2001:55.

${ }^{280}$ Cfr. Benjamin 1973 
estéticas en criterios de lecturas. En ese sentido, la perspectiva de Jean Louis Déotte fue fundamental para nuestras indagaciones porque, en contraposición a las lecturas acontecimentalistas de la época, propuso pensar una "historia del medio", donde el tiempo se recuperara en la multiplicidad de lo que no había sido codificado a partir del acontecimiento. A su vez, permitió cuestionar el carácter homogéneo y lineal del tiempo de la neblina, la espera, el salto, el agobio, o el desierto. Así, antes que refutar los términos que los propios actores culturales utilizaron para nombrar cierta experiencia de la época, nos interesó señalar, a lo largo de la tesis, el modo según el cual, en todo caso, ese tiempo borroso dio lugar a una conexión de temporalidades y sensibilidades donde advertimos una heterogeneidad mayor a la que ha sido leída para caracterizar el período. Por otra parte, las intervenciones de las revistas analizadas dan cuenta de un proceso conjunto en torno a la crítica como género, donde no es posible analizar de forma separada aquello que las historias de la literatura denominaron como "modernización de la crítica" y "segundo momento de la vanguardia argentina".

En relación con estas consideraciones, el desarrollo de la tesis intentó aportar otras claves de lectura a aquello que se había cristalizado como "lo moderno" de la crítica a mediados de siglo XX, y que partía, especialmente, de la evaluación hecha hasta el momento sobre los modos de leer de la revista Contorno. El objetivo fue, por un lado, ampliar los elementos y las aristas que conformaron esa historización, y por el otro, dar cuenta de que las intervenciones de Contorno estuvieron moduladas, también, por el carácter relacional que la unió a otras publicaciones, entre ellas Ciclo, poesía buenos aires, A partir de cero y Letra y Linea.

Esos otros elementos y aristas que dan cuenta de una transformación crítica no restringida al análisis de la literatura como testimonio de la realidad histórica, los encontramos en las siguientes intervenciones propuestas por las revistas de nuestro corpus: la búsqueda por calibrar en qué medida si bien una obra de arte tiene relación con su época no se reduce a ella ni es determinada por ella; reparar en la disfunción o incoincidencia entre escritura y lenguaje convencional; la idea de que la literatura tiene menos que ver con la afirmación de un saber que con un instante donde se produce "la ruina de todas las cosas ordenadas" (Bataille 1948, n1) y que el tipo de iluminación que produce la literatura es "incandescente", es decir, tan brutal como intermitente (Pellegrini 1952, n2); la insistencia en la técnica como espacio donde se juega una dimensión singular de la obra de arte que escapa al tema y a la forma, son algunas de las ideas sobre el arte y la literatura que las revistas pusieron de manifiesto a partir de esa biblioteca de vanguardia 
de la cual se apropiaron, con sus propias tensiones, morales, y con el peso de una tradición artístico-literaria local. El carácter relacional de las intervenciones a partir de las cuales podemos pensar un proceso de búsqueda por definir modos de leer, lo encontramos en la forma del bullicio de la crítica, donde las distintas concepciones sobre la literatura no se condensaron como un discurso que fuera identificable con corrientes teóricas o con firmas fuertes, sino que estuvieron atravesadas por la ambigüedad que caracterizó a ese "suelo común" de los debates literarios (Podlubne 2014) o la "otra babel" (Caillois 1946, n135) donde los términos se superponían produciendo confusión.

Para dar cuenta de estos aspectos analizamos tres tipos de operaciones diferentes, que fueron abordadas en los tres capítulos de la tesis respectivamente: la conformación de una moral crítica del anacronismo; las polémicas y las series de la crítica como intervenciones que operan por selección, agrupamieno y recorte; y las disputas por el sentido en torno a un conjunto de palabras clave en el marco de un "archivo de categorías", que caracterizamos en el marco del bullicio de la crítica. Así, en el primer capítulo nos abocamos al modo en que las revistas del corpus hicieron de la temporalidad un problema crítico. Con la idea de anacronismo como moral buscamos dar cuenta del modo en que determinados criterios de lectura propuestos por Ciclo, poesía buenos aires, A partir de cero y Letra y Línea buscaron articular una relación entre obra y épocahistoria-sociedad que se sustrajera de los imperativos eucrónicos y sincrónicos por los cuales otras perspectivas explicaban esa relación (por ejemplo, la lectura histórica de una obra como representación de las condiciones económicas en que se gestó, o la desginacion de "contemporánea" a una obra que describía temáticamente aspectos de la época). En el caso de Ciclo advertimos el cuestionamiento al historicismo, en pba la exaltación de un lenguaje que fuera a la vez no-convencional y común, en $A$ partir de cero encontramos la figura de la "imagen combustión" como operador crítico que conectaba el pasado con el presente y se oponía a los "realistas fantasmales" que pretendían representar la realidad "fotográficamente", por último, en relación con Letra y Línea analizamos el problema de la contemporaneidad como un problema de discriminación, donde la crítica tenía la función de distinguir entre los "auténticos exploradores de lo desconocido" y los "embaucadores de lo nuevo".

En el Capítulo II nos propusimos caracterizar la noción de imagen surrealista e invencionista según distintas intervenciones de las revistas del corpus. En torno a ese recorte encontramos que, a pesar de las diferencias, tanto una como otra imagen estaba atravesada por la aspiración a alcanzar una forma de lo total. En el caso del surrealismo, 
esta consistía en la síntesis absoluta de los opuestos, mientras que en la imagen invencionista se trataba de la depuración total de las representaciones. Ahora bien, estos aspectos resultaban contradictorios con respecto a los modos en que las revistas del corpus intervinieron críticamente: la polémica y la configuración de conjuntos heterogéneos a los que llamamos series de la crítica. La polémica y la serie dieron cuenta de que el problema central para la crítica era el problema de la selección y los criterios de agrupamiento que permitían poner en diálogo a un autor con otro. En ese sentido nos interesó destacar que si bien los valores vinculados a las vanguardias históricas modularon las escrituras críticas de Ciclo, A partir de cero, poesía buenos aires y Letra y Línea, estas ya no pudieron valerse de la noción de imagen tal y como esta condensaba las características principales de los movimientos estéticos. O bien, como en el caso de la "imagen en combustión" - que resulta a la vez un operador crítico- no es la aspiración de totalidad el énfasis que funciona como criterio de valoración.

Por último, en el Capítulo III buscamos explorar ese el espacio común de la crítica literaria donde las revistas del corpus intervinieron resignificando términos utilizados por otras publicaciones, como los de "comunicación" y "realismo". Para dar cuenta de esa problemática que se inscribe en lo que denominamos como bullicio de la crítica, en la primera parte del capítulo intentamos aportar otra noción al "archivo de categorías" que según Oscar Terán había conformado un modo de leer la literatura desde la filosofía. Así, la idea de "totalidad" - central, según Terán en el pensamiento de Contorno y en los años sesenta- fue interrogada desde la figura del instante a partir de dos movimientos: por un lado, en la recuperación de la polémica entre Jean Paul Sartre y Georges Bataille donde rastreamos tanto las huellas del anti-vanguardismo de Contorno como las marcas de una reapropiación de la imagen del instante por parte de las revistas de nuestro corpus; así, y en segundo lugar, nos propusimos rastrear cómo esa imagen adopta otras nominaciones -fulguración fugaz, imagen en combustión, iluminación, bomba incendiaria- a partir de las cuales las revistas vinculadas con el surrealismo e invencionismo definen qué es la comunicación en literatura, y qué es el realismo. Según observamos, este doble movimiento está atravesado por la doble fuerza de una moral crítica: la emergencia de una figura extraña, inquietante, vinculada con el no-saber y la suspensión de la conciencia, que se vuelve operador crítico para establecer diferencias y discriminaciones en la "babel de una lengua única" donde nadie se entiende, como reclamaba Caillois.

A partir de esos abordajes podemos concluir que el modo en que las revistas del corpus articularon la relación entre vanguardia, crítica y temporalidad, modifica nuestras 
consideraciones sobre "lo moderno" de la época, y se constituye en un nuevo matiz dentro de la historia de la crítica en Argentina. Finalmente, tras el recorrido realizado, nos parece más pertinente referirnos a nuestro objeto de estudio como "escrituras críticas en las revistas vinculadas con el surrealismo e invencionismo" antes que discursos de la crítica. La primera variable da cuenta de un espacio menos articulado en torno a un saber previo o mirada teórica organizadora que las fundamente. Por otro lado interroga o desestabiliza la certeza de que toda crítica está en relación con una red o canal institucional, ya que los devenires de estas escrituras no se consolidaron en torno a firmas que fueran retomadas de manera sistemática en años posteriores. En ese sentido, el vínculo de estas escrituras en relación con las historizaciones de la crítica es divergente del proceso por el ual Contorno (1953-1959), Los Libros (1969-1976), Punto de Vista (1978-2010) fueron retomántose al modo de una tradición crítica.

Las consideraciones sobre los modos en que la historia de la crítica literaria argentina revela la interacción entre temporalidades diversas - aquello que se experimenta como actual y ciertos elementos que resultan anacrónicos, sea porque refieren a un pasado que parece superado, como la idea de vanguardia, o porque no se condensan en la cadena se sentidos más representativa de la época, como la presencia de Georges Bataille y Maurice Blanchot- nos abren una serie de proyecciones como futuras líneas de investigación. Con respecto a esa segunda variable de lo anacrónico, es posible seguir explorando las lecturas y apropiaciones de Bataille en la cultura argentina en los años siguientes a nuestro recorte. Según planteamos a lo largo de la tesis, la presencia de Bataille fue tan contingente como significativa. Si bien consistió en una sola traducción publicada en Ciclo (1948), con apropiaciones locales que no atravesadas por la crisis del humanismo que el autor francés exponía, señalamos que su lectura aportó otros matices a la relación entre escritura y época. El estallido de la conciencia, la suspensión de los valores, el cuestionamiento a la utilidad del lenguaje, fueron modos de producir diferencias en los debates sobre el artista y su deber histórico, como analizamos en el capítulo III. Una de las preguntas que podemos hacernos, entonces, es qué lugar tuvo el pensamiento batailleano en años posteriores, cuando la apropiación de la teoría literaria francesa fue aún más significativo y sistemático, según han analizado distintos investigadores en torno a la revista Los libros. ${ }^{281}$ Asimismo, tanto Aldo Pellegrini, como Enrique Molina, Edgar Bayley, Alberto Vanasco, Julio Llinás y Raúl Gustavo Aguirre,

${ }^{281}$ Cfr.: Panesi (2004), Peller (2016), Starcembaun (2017), Mendoza (2011). 
continuaron su participación protagónica en otras revistas literarias -Macedonio (19681972), Zona de la poesía latinoamericana (1963-1964), Boa (1958), La rueda (1967)que nos invitan a preguntarnos si la perspectiva batailleana se re-significó o re-configuró a partir de otros intereses.

Una primera aproximación a estos interrogantes es motivada por la existencia de traducciones más completas del autor en formato libro -El erotismo, Sur 1964; Breve historia del erotismo, Ediciones Caldén 1968; Las lágrimas de eros y otros ensayos, Signos $1968-^{282}$ y por el hecho de que observamos huellas o marcas de la lectura de Bataille en las revistas Macedonio, Zona de la poesía, Boa y La rueda, así como también en Sur, Los libros, Literal y Setecientos monos, especialmente en las firmas de Aldo Pellegrini, Enrique Molina, Nicolás Rosa, Alejandra Pizarnik y Oscar del Barco. En continuidad con lo analizado en la tesis, postulamos dos hipótesis provisorias. En primer lugar, encontramos nuevamente una serie de cruces y diálogos entre las revistas vinculadas con los movimientos poéticos, y aquellas que se reconocen más específicamente como revistas de crítica literaria; por otro lado, advertimos que las relaciones entre arte, literatura y política (particularmente agudizadas en el período posterior al que analizamos en nuestra tesis) pueden ser repensadas a la luz de otros matices que ponen en suspenso el peso de lo acontecimental en la crítica (por ejemplo, la irrupción del estructuralismo y el psicoanálisis). En ese sentido, seguir la pista de las presencias de Bataille en las escrituras críticas nos permitiría seguir pensando una historia de la crítica en la perspectiva temporal que nos abrió la idea de bullicio, esto es: no como secuencia de discursividades reconocibles, sino de aquello que permanece menos codificado en esas discursividades. En relación con esa inquietud y la serie de concepciones que enumeramos como aquellas más o menos formuladas por las revistas del corpus es posible preguntarnos si tales ideas conformaron una suerte de repertorio de figuras críticas.

Por otra parte, nos interesa retomar una de las preguntas que surgió en el camino de la investigación y que no podía ser respondida con el corpus acotado de revistas, y el período al que nos ceñíamos. La pregunta tenía que ver con la persistencia de determinados nombres, imaginarios, objetos, vinculados con el surrealismo que son constantes y recursivos en la cultura argentina en tanto aparecen dispuestos en series extrañas. Así, es posible pensar, por ejemplo, las derivas de las vanguardias en una serie

\footnotetext{
282 Traductores: María Luis Bastos (1964), Oscar del Barco, Alberto Drazul, Emilio Terzaga y Alfredo
} Paiva (1968). 
de editoriales contemporáneas cuyos catálogos ponen en diálogo a autores como Raymond Rousell con jóvenes poetas y narradores argentinos, o a Arthur Cravan con María Negroni y Jonas Mekas. Nos referimos en uno y otro caso a la editorial Mansalva y Caja Negra. El problema sigue siendo, en parte, la inquietud por la intervención en la contemporaneidad que justifica tales elecciones, y qué debates en torno al arte y la literatura aparecen implícitos. Sin duda que la presencia de Aira es insoslayable para pensar estas derivas y los modos en que la relación entre vanguardias y temporalidad se fue reconfigurando.

Por último este recorte temporal, ceñido estrictamente a la relación entre revistas de surrealistas e invencionistas y las intervenciones críticas que produjeron, no ignora la decisión interesada de esos límites. Considerar a estas revistas como una apertura hacia lo heterogéneo de una época, es pensar la lógica del “con”. Poner en contacto la noción de realismo de Edgar Bayley y Aldo Pellegrini con las de González Tuñón y David Viñas también es propiciar otra historia que no reproduzca el sistema de la poesía y el poeta. Leer las escrituras de estas revistas en otra serie, y en nuestro "ahora de cognoscibilidad", nuestros intereses actuales. “La critique n'est pas un «hommage» à la vérité du passé, ou à la vérité de «l'autre», elle est construction de l'intelligible de notre temps", afirmaba Barthes en Essais critiques, como reformulación del concepto benjaminiano. En ese sentido, lejos de "sortear casi inmediatamente la inclinación a la ironía anacrónica", lo que Beatriz Sarlo explica como "juzgar el índice de la revista desde la perspectiva de este presente y no de aquel presente", los intereses de esta investigación no desconocen el tiempo que les hizo lugar y que imprime ciertas miradas sobre los materiales, selecciona ciertos objetos e imágenes por sobre otros. 


\section{5. Índice de imágenes citadas}

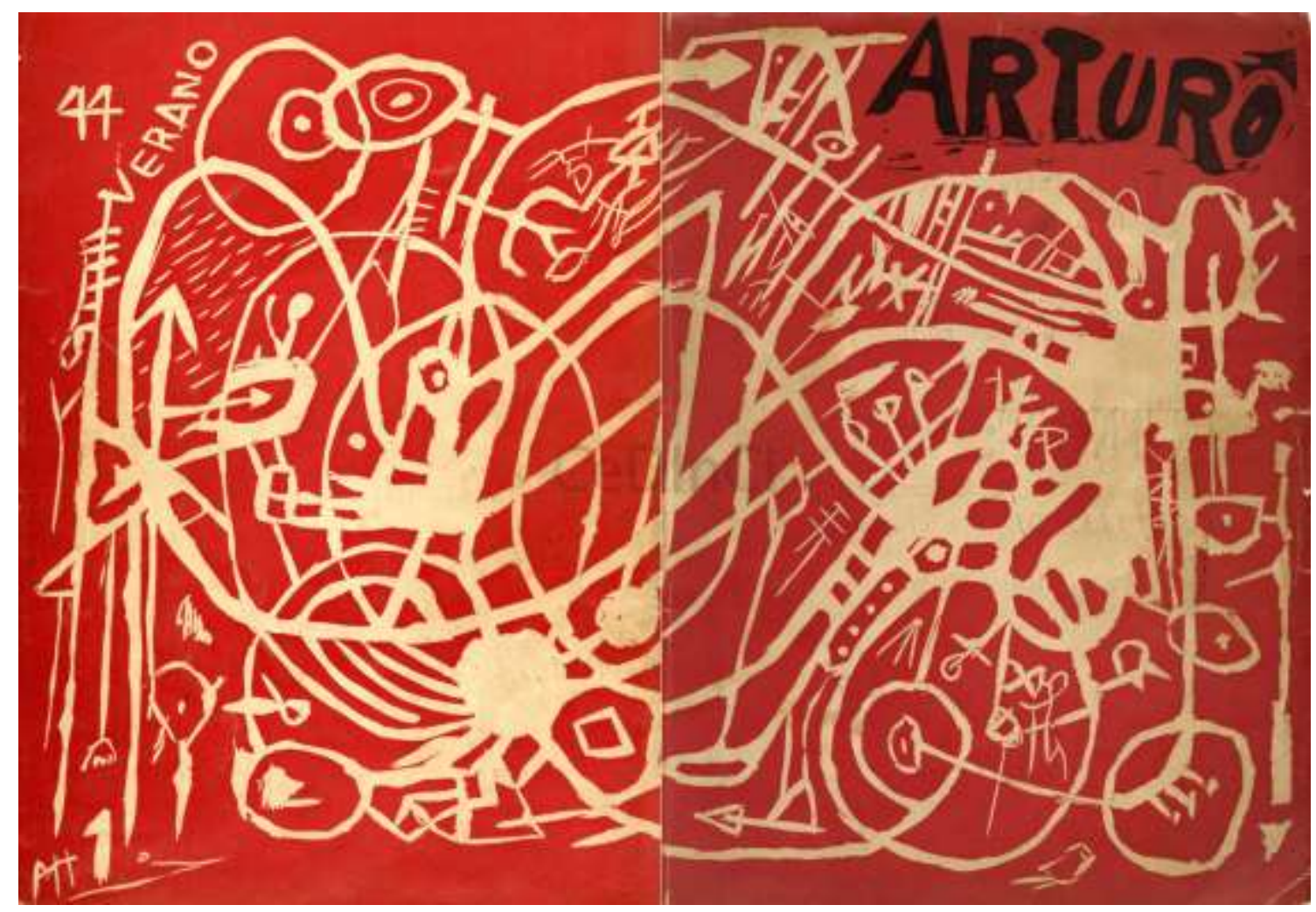

Imagen 1. Grabado de la portada revista Arturo 1944, n1 
INVENTAR: Hallaro oderembitin fuerza de ingenio o meditarión, o por mero acaso, una co: a nuesa o no conocida. / Hallar, imagginar, crear su obra el poeta o el artittal

\section{INVENCIÓN: inventar. /Cosa inventada. / HA. LLAZGO/}

I N V E N C I Ó N contea AUTOMATIS MO)

\section{Ninguna Expecsión}

\section{Representación}

Significación

El homber conquistarí el espacio multidimensicnal.

Jübilo. Megación de toda melancolia. Qoluntad consteuctiua. Comunión. Poesía del conteato social.

Imagen 2. Manifiesto de la revista Arturo 


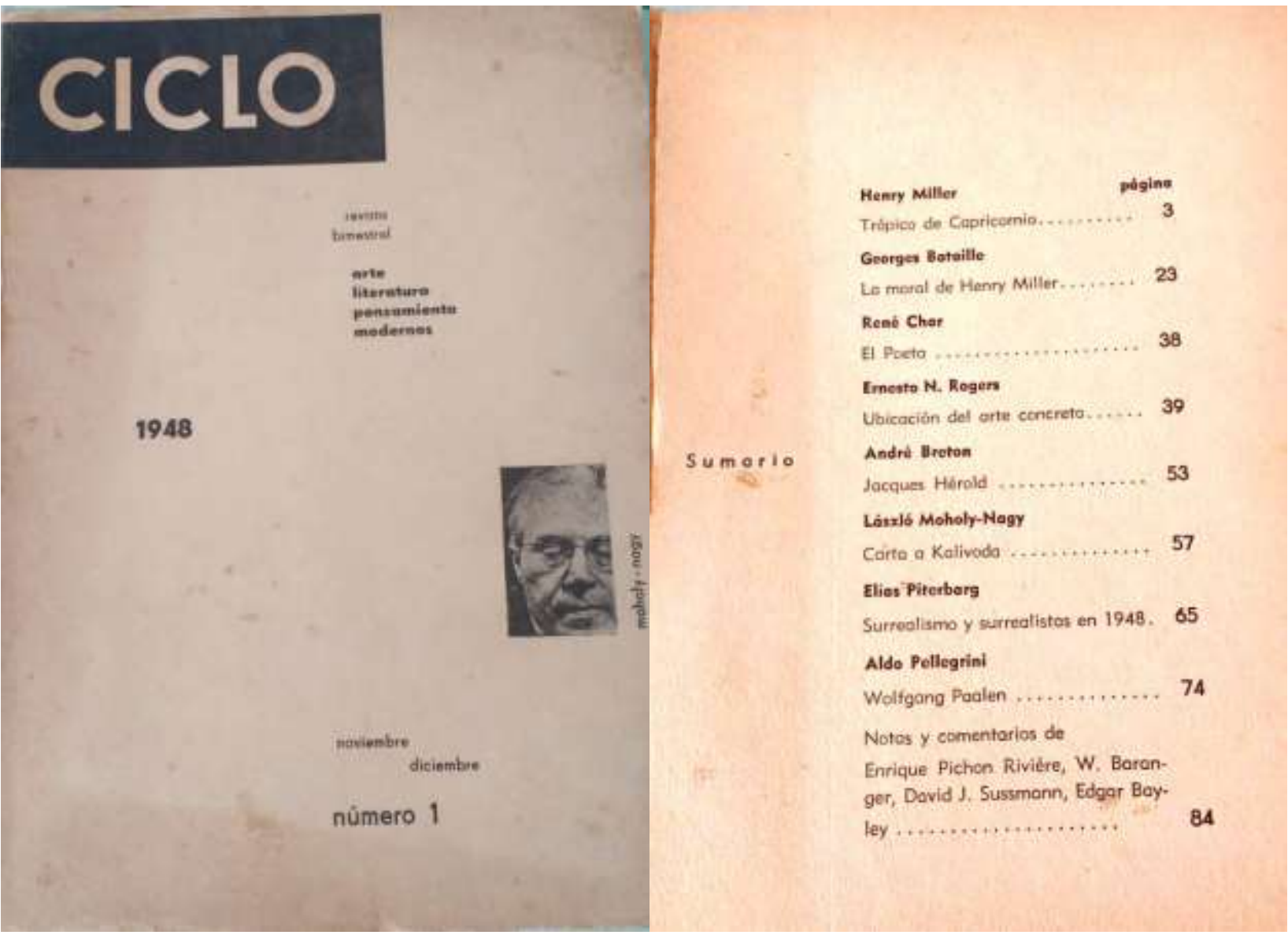

Imagen 3 (arriba) y 4 (abajo), portadas y sumarios de Ciclo números 1 y 2

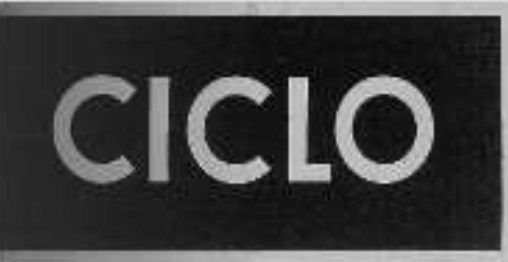

revista bimestral

urta, literstura y pensamiento modernos

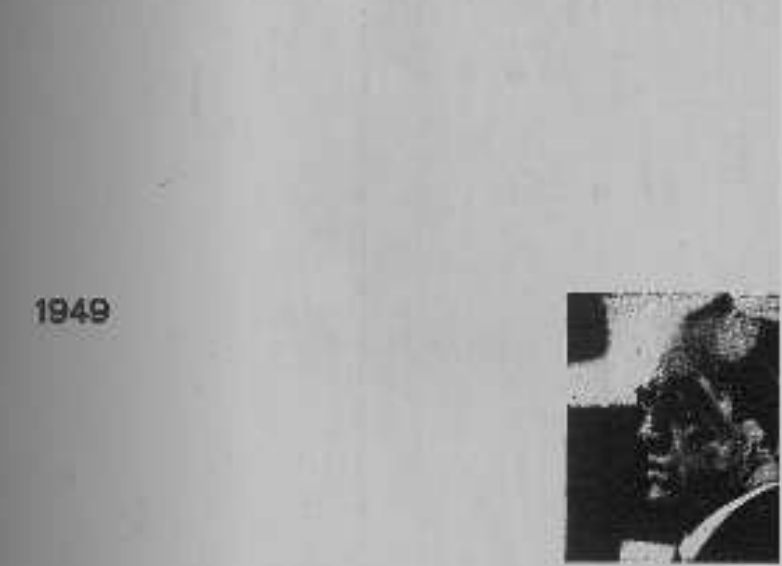

net whate.

marzo-abtil

númar 2
Enrique Pichon Rivière Vida $\theta$ imagen del Conde de Lautréamont

Mario Trejo Apollinaire y Para partir (poemas)

Max Bill La expresión artistica de la construcción

Jean Cessou

La libertad del artista anuneia la libertad del hombre

Sebastib́n Salazar Bondy Noticia de Szyszlo

Elías Piferbarg Proposiciones

Aldo Pellegrini

La conquista de lo maravilloso

Documentos de arte contemporáneo: Piet Mondriant Fragmentos de "Le Nooplasticisme"

Netas y comentarios 77 


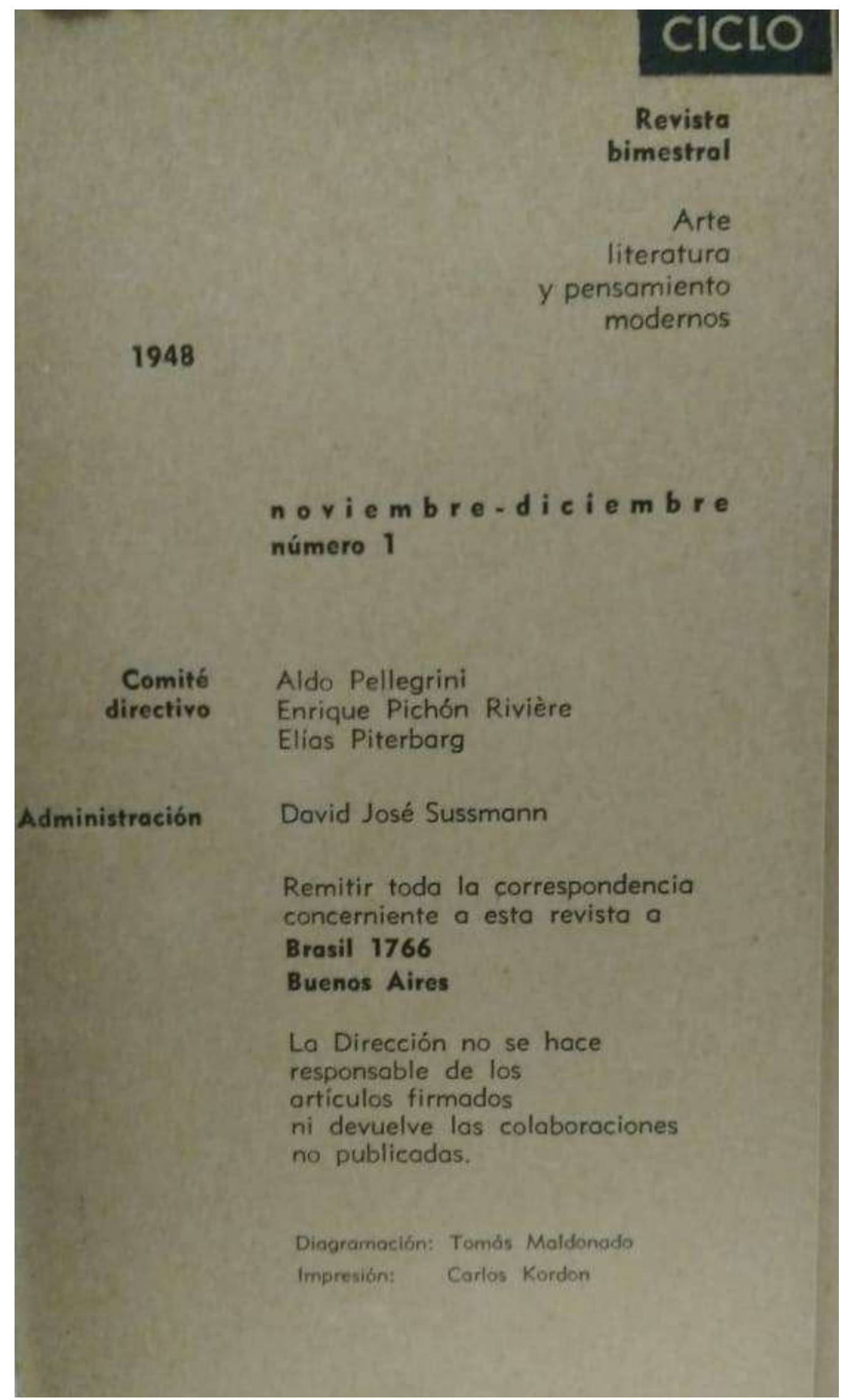

Imagen 5. Retiro de tapa de Ciclo y conformación del grupo editor. 

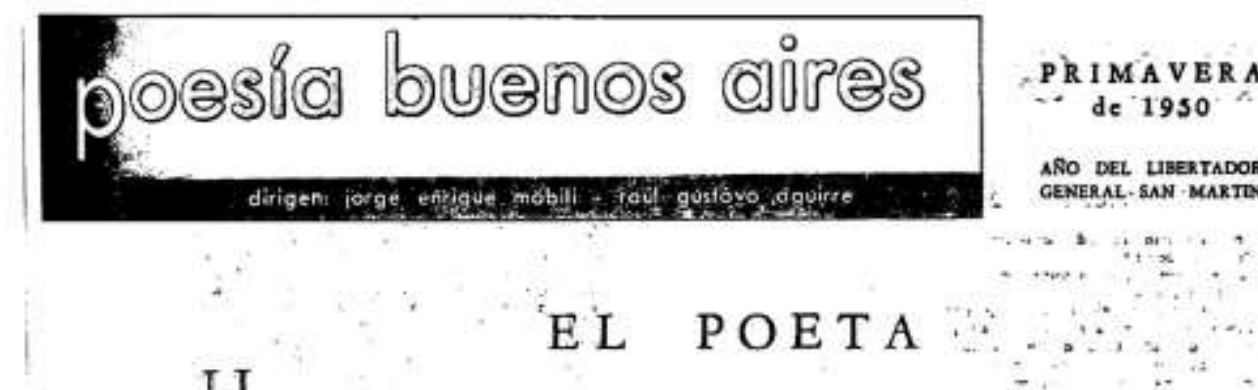

$\mathrm{H}$ venido a sustituir razones, $\alpha$ hundirse en crecimiento por el tiempo agobiado. Es el geómetra de los prismas incisivos, de la esfera que cae, y cae vertical el que pregunta por la consideración de su esfuerzo y su traslado.

Suelta un idioma que golpea en el trasfondo aquietado de los siglos, su estatura libre $\mathrm{y}$ sin ventajas para la presencia de los demás. No canta un desáhogo, no ha bebido los liqueries dé la soledad para mostrar su yo cristalizadô en el trazo azul de una palabra concedida. Ha arrancado su idioma al universo. jugando entero cada nombre en la ruptura de su tránsito.

$\cdots$

Da la víspera superada en la conjetura del futuro, su vida abierta sobre las lineas del espacio asegurado. Transmuta su amor y lo vuelve a encontrar incandescente, alli donde la muerte ensaya una porosa adhesión a sus perimetros humainots.

Con ritmo acuatico, filtra en los seres y las transiciones. Está en la'guerra rescatando la cracia, la clara sintoinia del estupor. No está seguro ni tranquilo sino de su inquebrantable pericia. No sufre alucinaciones que podifan controvertir la responsabilidad que se otorga.

La poesía es una impiedad sin término para cualquiera que sep̀a reconocer su sangre en un momento de plenitud. los huesos en asamblea con los sucesos, para quien no ha de toner' historia ni familia entrotanto sostiene ante aquéllos que lo condicionan $\alpha$ su doblo desgáte, un caminante sin memoria; para quien sacrifica su capa. cidaid de placer a la conquista del júbilo $\mathrm{y}$ la esperanza.

El poeta no tendrá tierras porque no habrá de'terminar jamá sti tránsito ha. da la imagen del mundo. No ha de enfermat en alcobas seculares. No lo asimilarí la quietud. $Y$ emplearł́ cada dia su permanencia en el riesgo para procurar el equilibrio en que crece sin cesar, para no morir, creciendo en la civilización, en la ciudad de la cual es el más agudo justificativo, el caudal, el más encarnizadó proteta y amante. En la calle donde vive su iníancia, carutivadora de edificios, cuando trabaja y récla. ma su substancia y la última voz donde roposa su vehemencia, la más entēra saludid. Sufrín los que ól quiere, porque está fundido en la edád de sus ojos, porque supera $\alpha$ su naturaleza y a su ciencia. Pero habran de acéredrsele, porque en tanto conserva sus razones, su juventud y la inviolable pujanza détsu origeń. trasimitira un júbilo insospechado pára aquél que resista la intensidad dé su desnudez y la justiticación de su'dramática paradoja.

El poeta esquiva la debilidad, la palidez, la muerte de una mariposa. Ha de tardar en la solicitud de los alimentos: en el momento del hambre será el último, la alegria entreabierta sobre el pan de los hombrea.

Se arroja aplo y fértil, responde a la eafinge y so desplaza a voluntad pór. que renueva interminablemente la densidad de sus sensaciones.

No se acostumbra, no deja qué los hábitos disminuyan el tiompö. Trátá âl üniverso como un igual, insulta los errores de la ralz, disuelve-la semejanza $Y^{*}$ se contempla.

Aqứ se madura largamente, su signo no trankige. Moritá. pero de furia. de agrua y de tierra, de piel.

E convoca a los hombres'a su tuego, al feastejo de las viojas ruinas, de las anécdotas paralizadas. Convoca a los volatineros, a los jugiares, a los siglos donde cada esclavo mira su reloj. $Y$ vo la pieda revestida $y$ el arbol talado, $\gamma$ saluda interminablemente.

El poeta sigue reisistiendo la dietadura y la anarqufa, la melancolia y la carcajada sin brazos, la muerte y la vida. El poeta ha superado'la filosofia, ha movido el horizonte con todas sus consecuencias, ha salido a carar ojivas y medallas, a quemar los presagios, Su inmonsa volùntad esta empeñada por la confianza. Vieno pisando historias. Va a concebir los planos del mundo.

Y nada ha de explicar, ni la puerta entreabiorta, ni la expansión del misterio, ni la múrsica que escribe en el espacio.

Ha de dar su poema $\gamma$ los dicos siguientes.

Imagen 6. Porta del primer número de poesía buenos aires 1950 


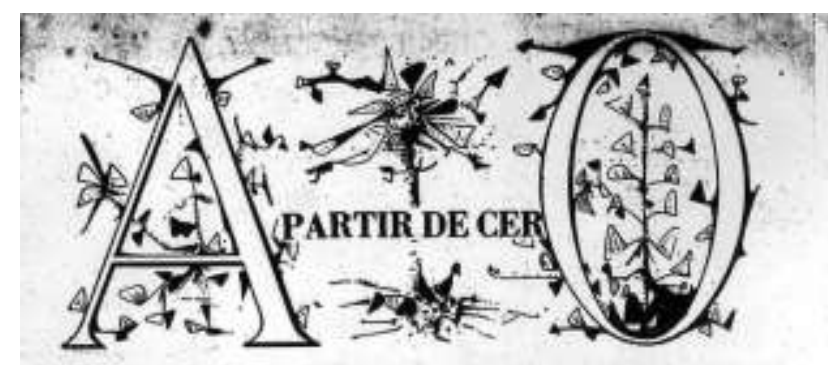

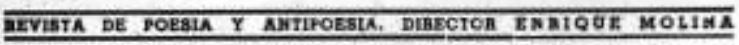

\section{VIA \\ LIBRE}

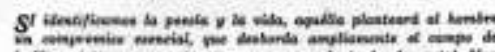

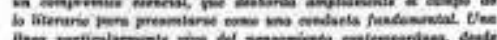

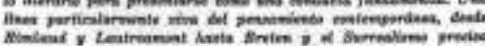

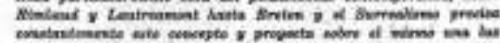

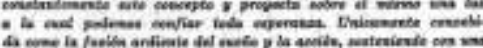

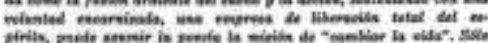

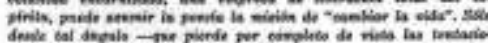

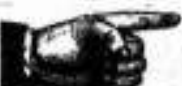

1

TExros DK C. LTrouns 1. A. .1DNA

CASA MOCA

A. FUISaking ingaves reasi. Denugo de. 1 sutue muscas

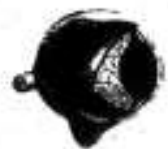

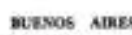
NovisMke.

CORBESPONUERCA A

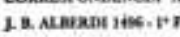

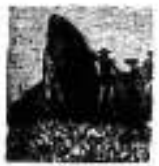

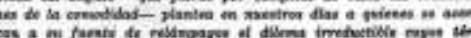

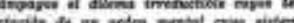

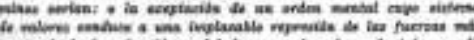

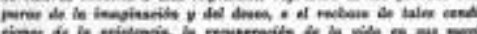

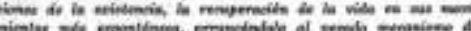

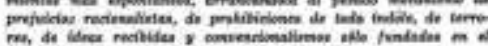

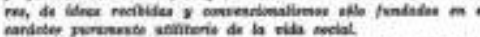

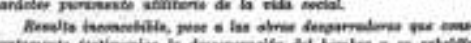

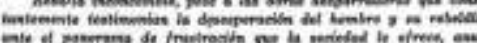

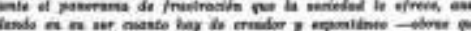

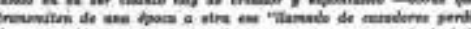

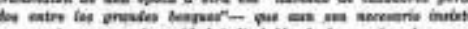

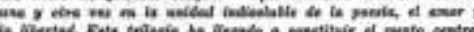

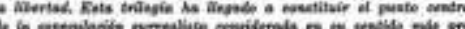

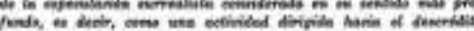

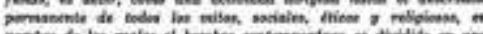

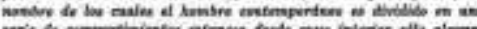

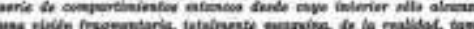

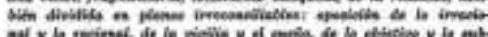

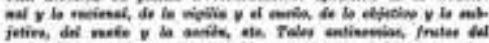

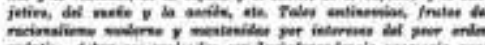

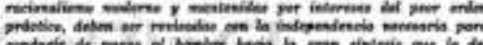

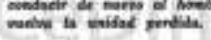

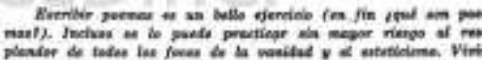
plender is these lise for

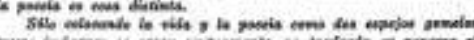

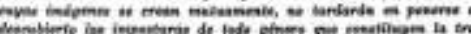
ne do meevirs miturn

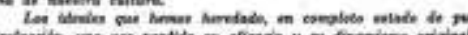

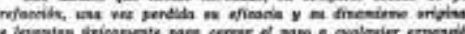

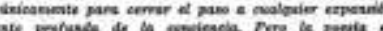

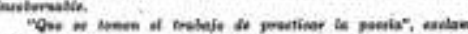

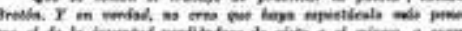

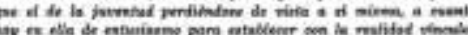

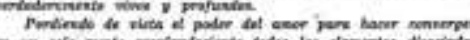

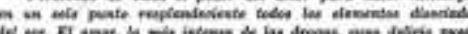

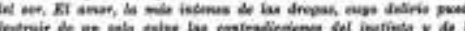

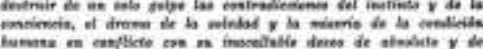

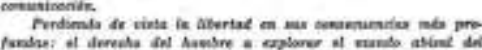

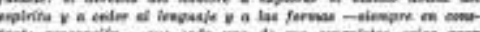

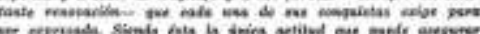

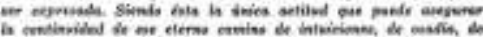

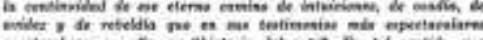

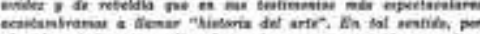

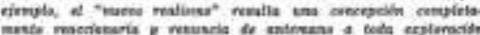

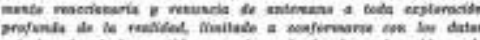

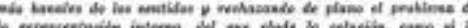

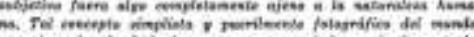

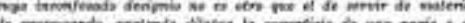

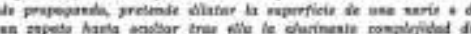

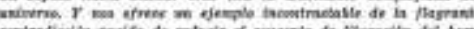

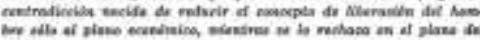

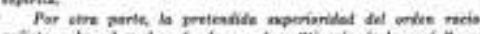

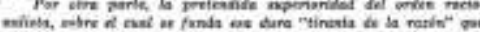

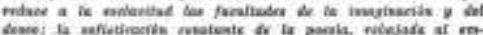

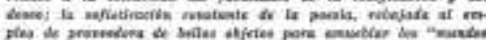

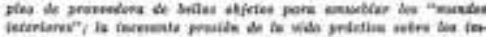

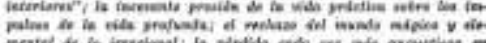
sion ming

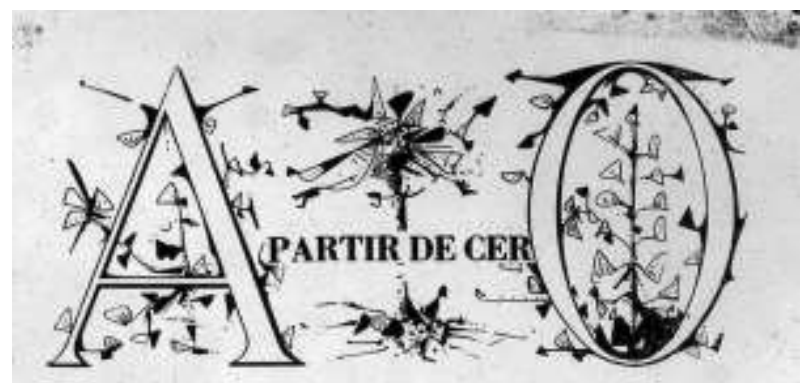

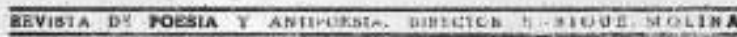

UN

GOLPE

อest mexosuter

TAMBOR

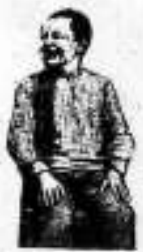

2

rexros os:

MNDRE anzros

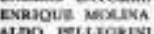

jeny a, YNSCO

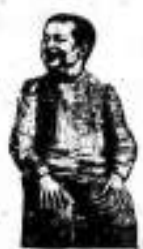

Dicarsane-19:-20 MUENOS AIRE conassmospencis A

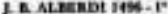

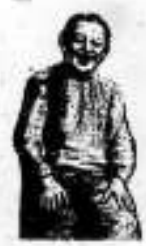

LA

POESIA reat max maxn nas TODOS

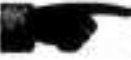

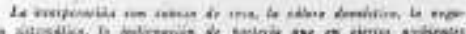

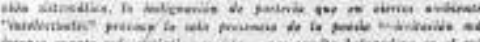

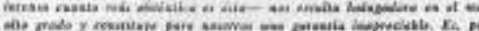

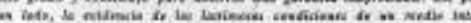

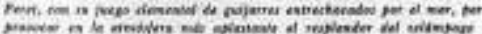

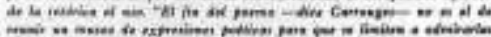

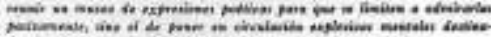

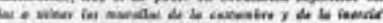

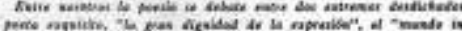

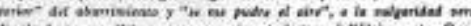
(1)

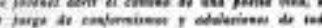

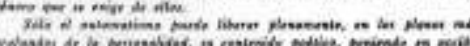

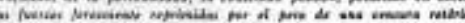
-

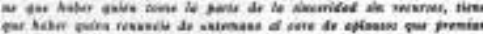

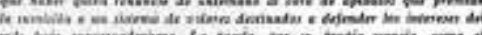

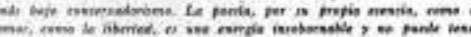

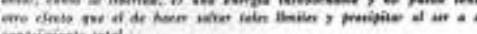

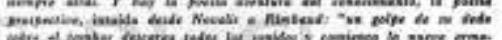

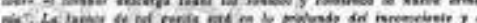

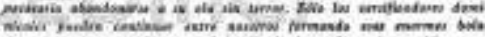

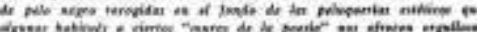

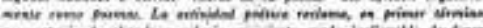

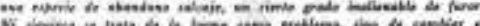

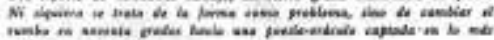

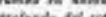

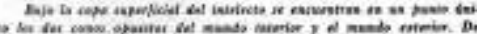
lo

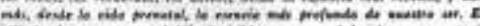

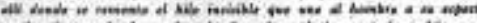

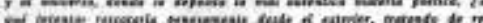

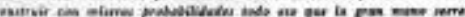

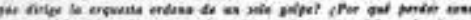

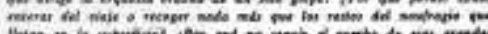

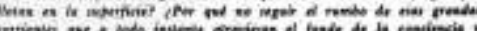

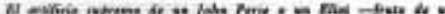

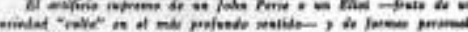

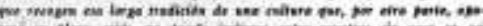

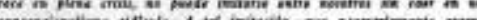

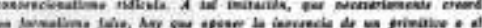

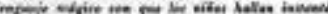

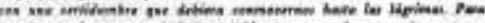

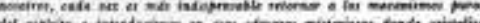

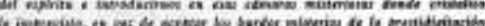

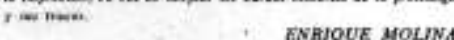

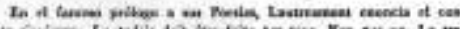
Yo per inos"i,

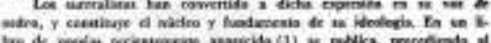

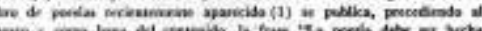

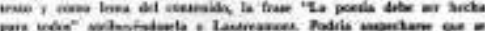

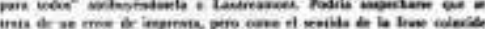

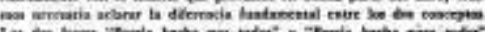

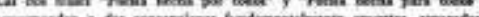

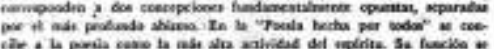

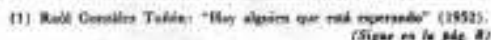

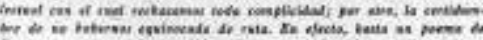

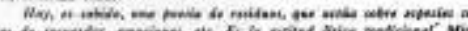

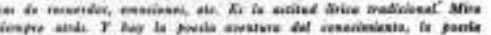

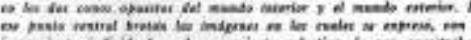

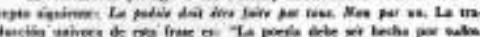

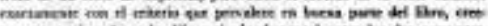


Imagen 7 y 8 . Portada de los dos números de 1952. Ilustraciones Juan Battle Planas

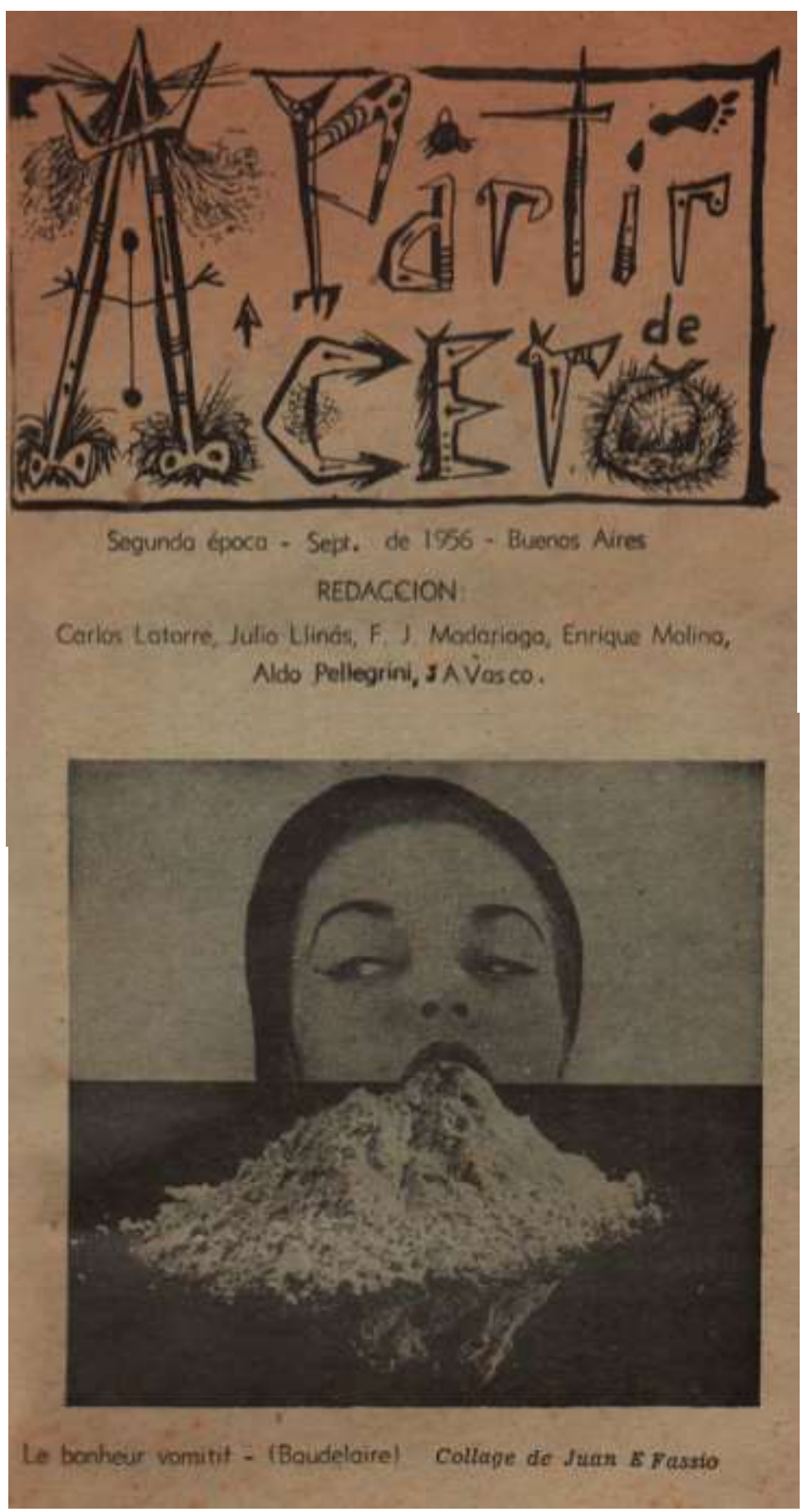

Imagen 9. Portada del tercer número, segunda época. 1956

Collage de Juan Fassio 


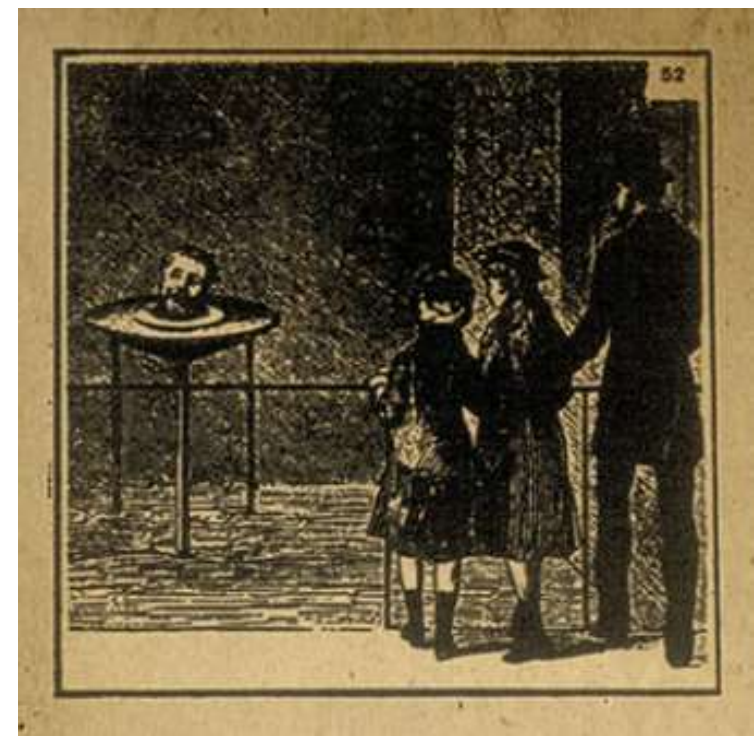

Imagen 10. Collage de Battle Planas en el primer número de $A$ partir de cero

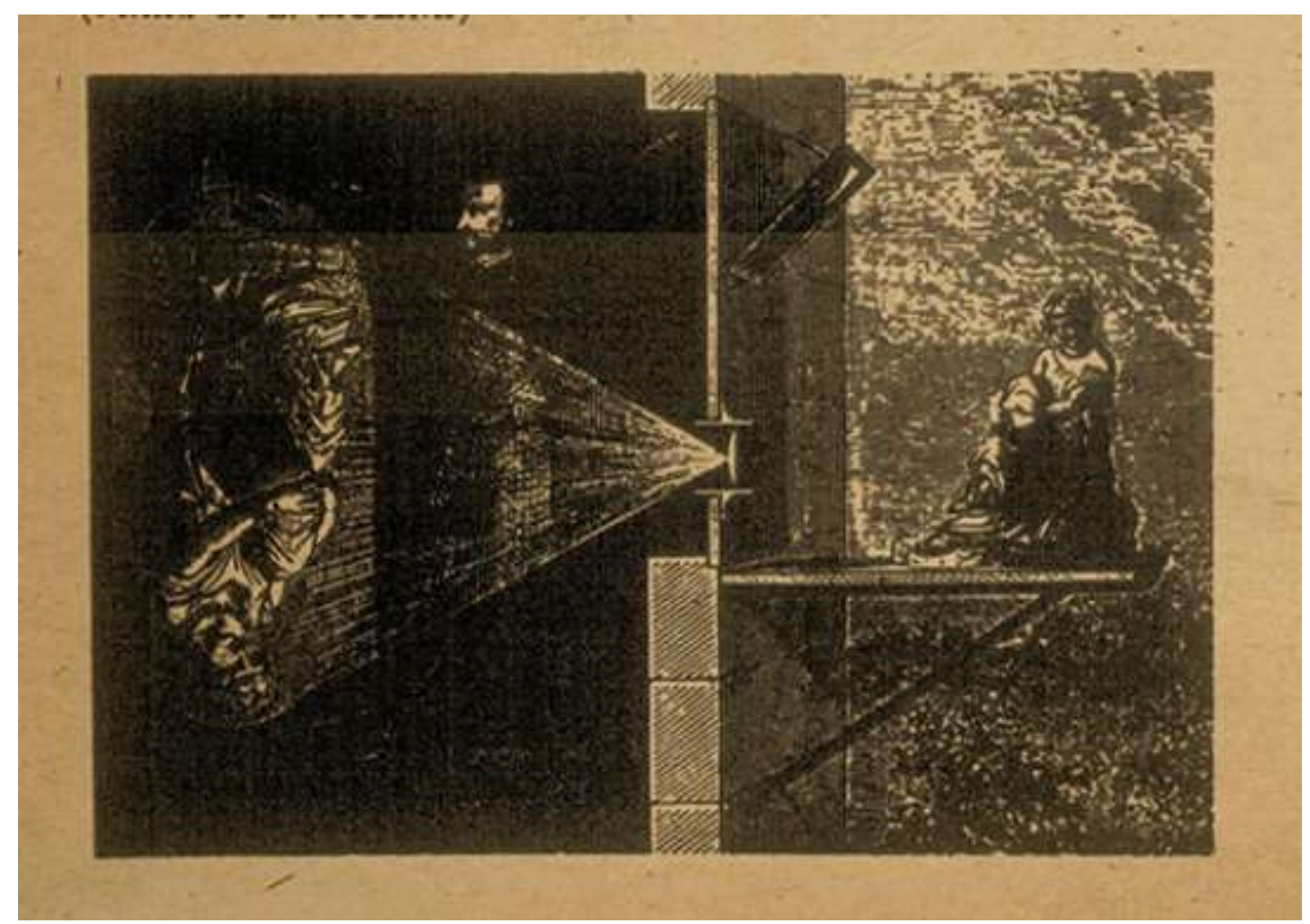

Imagen 11. Collage de Battle Planas en el primer número de $A$ partir de cero 


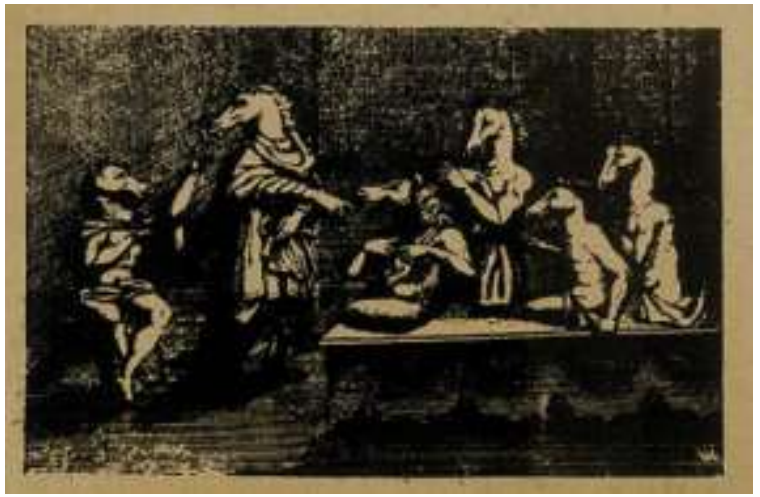

Imagen 12. Collage de Battle Planas en el segundo número de $A$ partir de cero

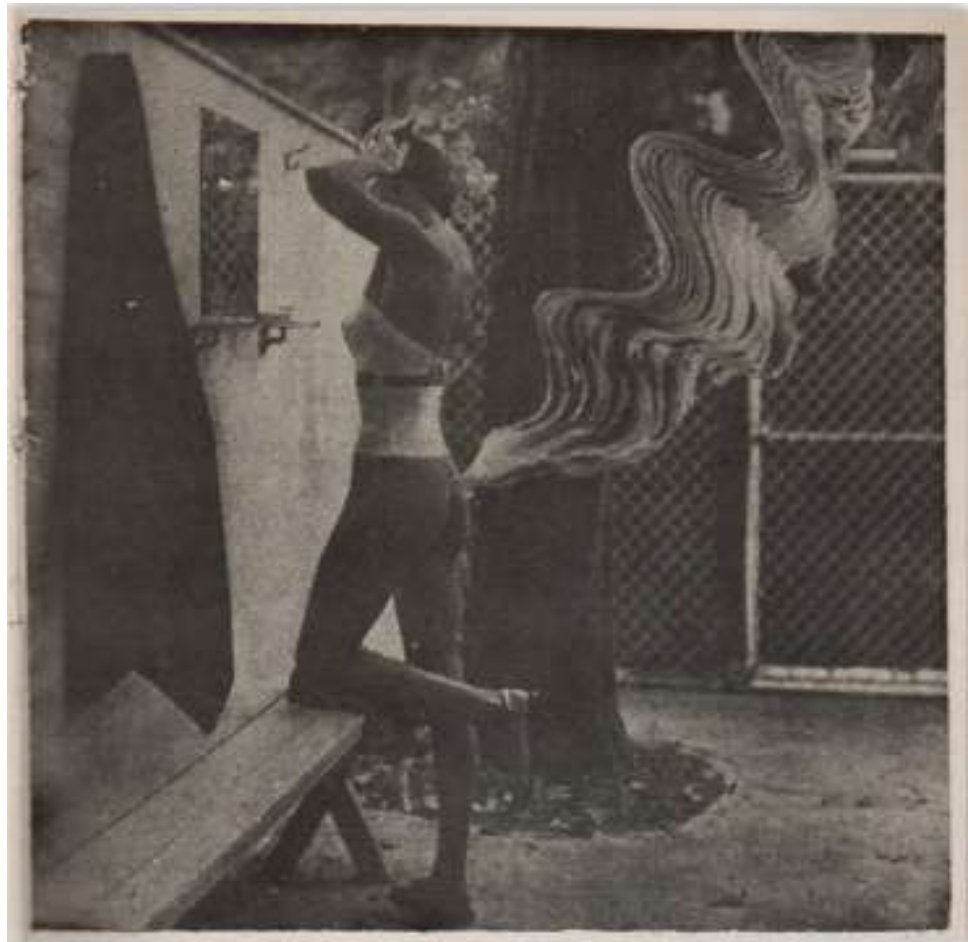

Imagen 13. Collage de Juan Fassio en A partir de cero 3

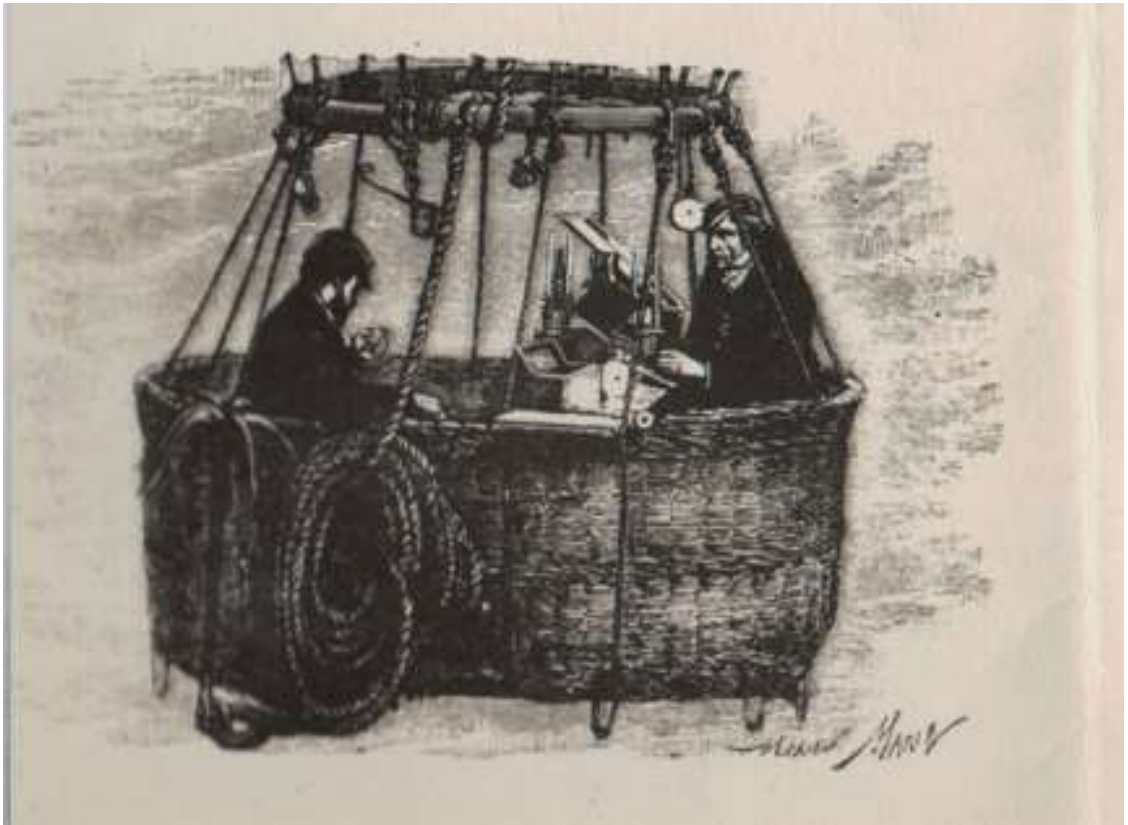

Imagen 14.

Collage de Marien Mariz. A partir de cero 3 


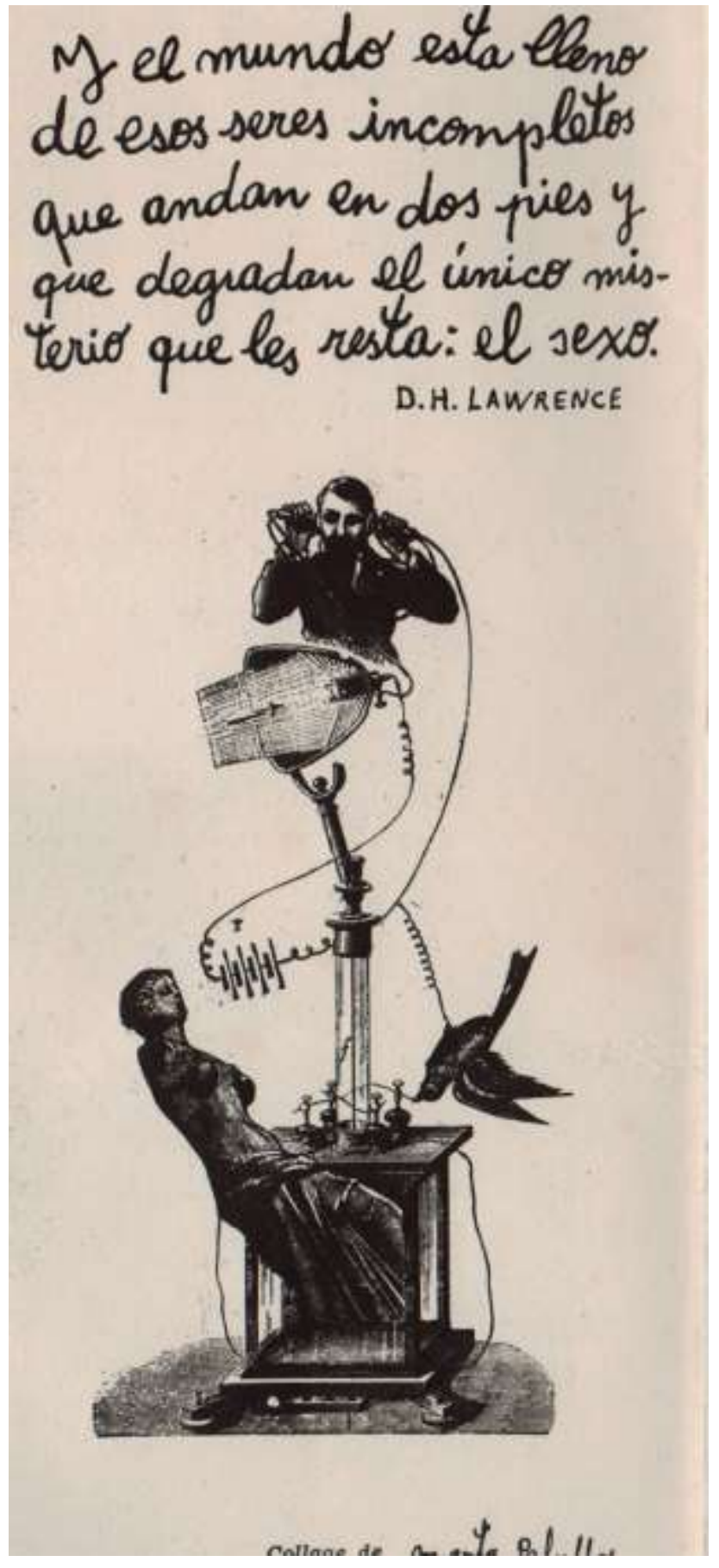

Imagen 15. (izquierda)

Collage de Martha Peluffo

Imagen 16 (abajo). Collage sin nombre.

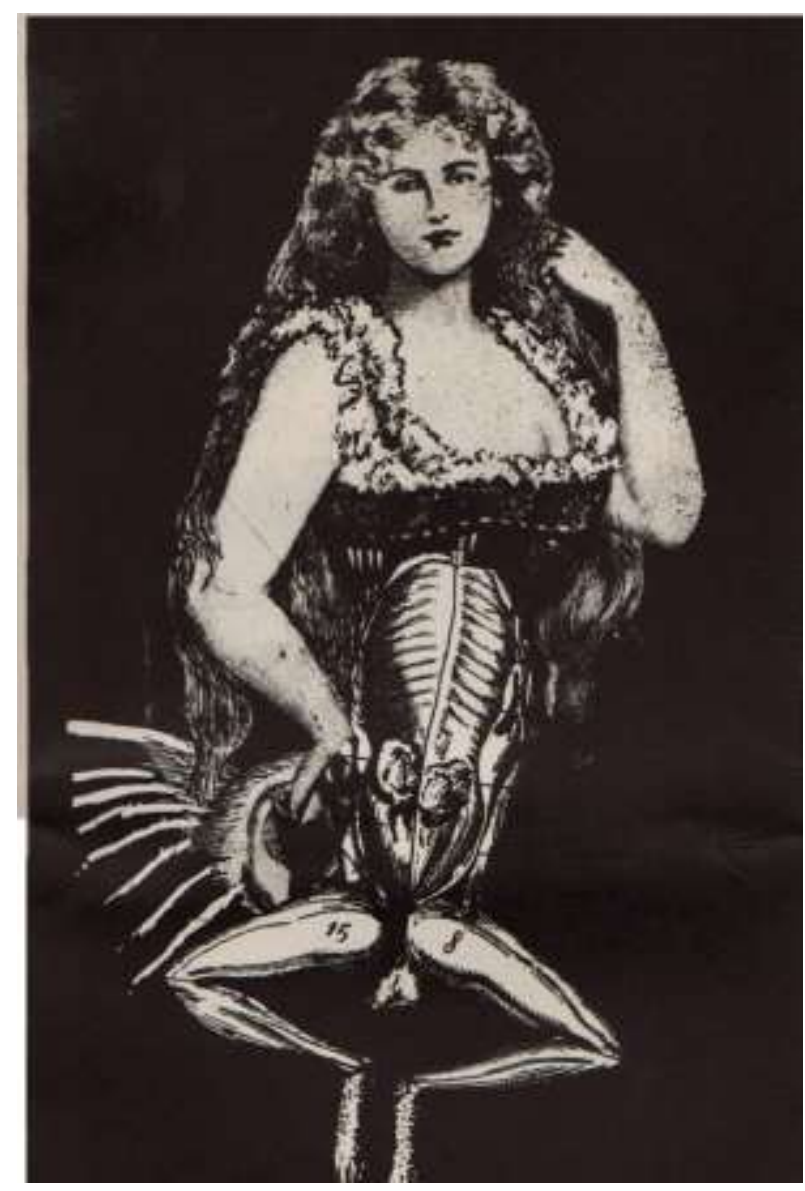



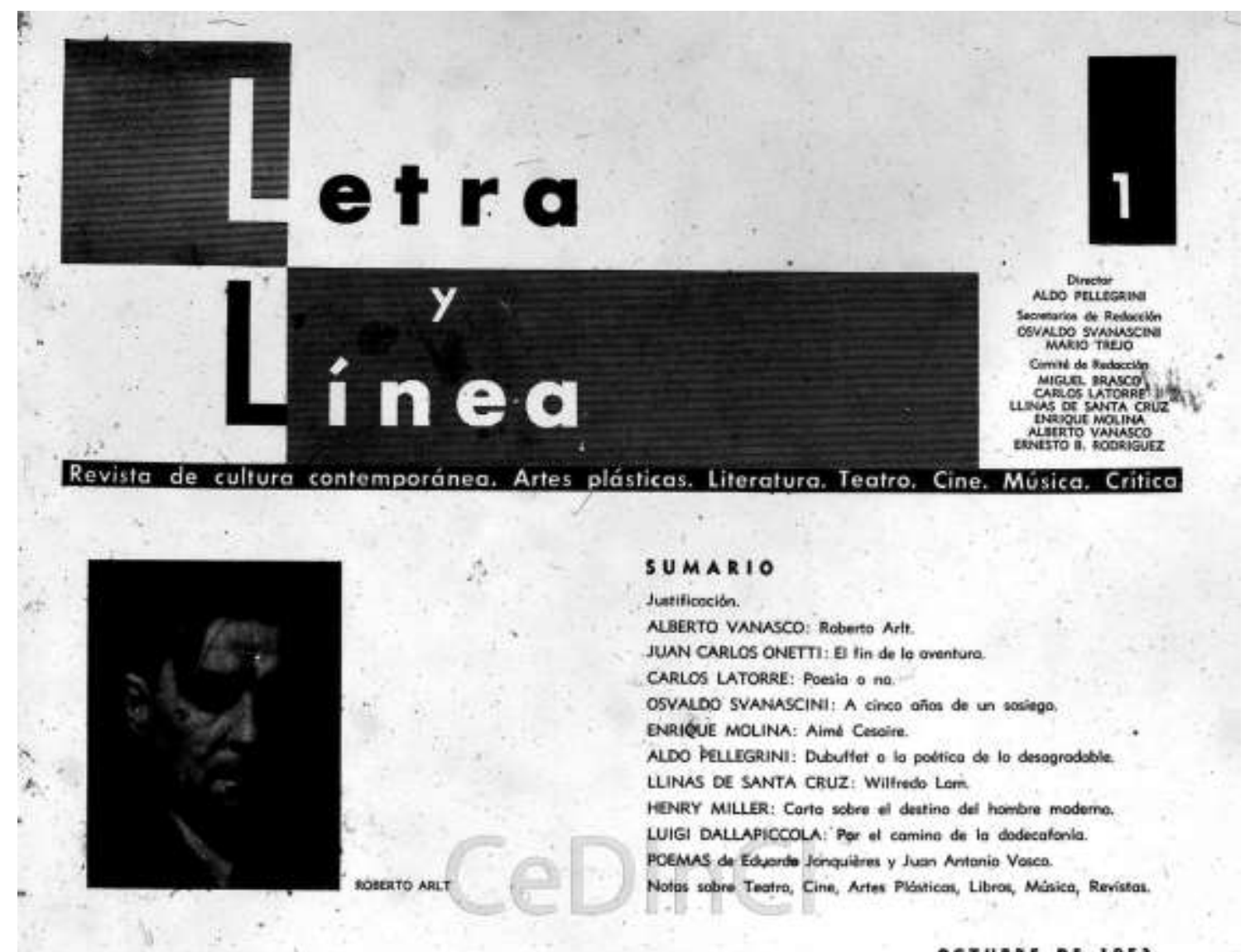

\section{SUMARIO}

Juatificoción.

NLBERTO VANASCO: Roberto Arit.

JUAN CARLOS ONETTI: $\mathrm{B}$ lin de le amentura.

CARLOS LATORRE: POEUia o na.

OSVALOO SVANASCINI: A cirnoo oñon de un rosiego

ENRIEUE MOLINA: Aimd Cesoire.

ALDO ReLEGRINI: Dubuttot o lo poutica de lo desogrodable

LLINAS OE SANTA CRUZ: Wiltredo Lem

HENRY MILER: Corto sctre ef deatine del hambre modeme.

LUIG DALLAPICCOLA: Por et camine de la dodecatonia.

POEMAS de Eteperto Jenquitres y Juen Artanio Vosico.

Notas sobre Testro, Cine, Artes Plistican, Libros, Música, Revistas. Nit)

\section{JUSTIFICACION}

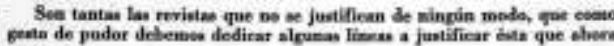
eptrese.

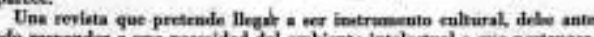

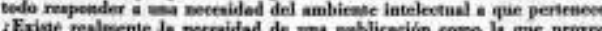

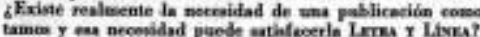

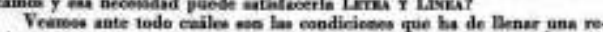

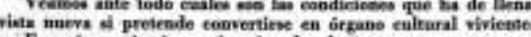

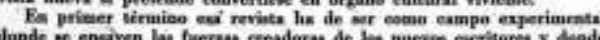

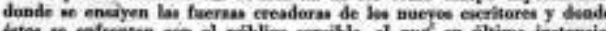

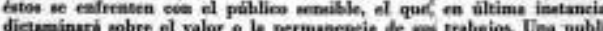

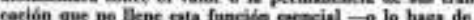

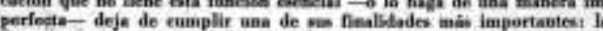

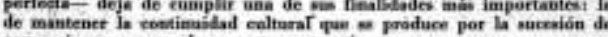

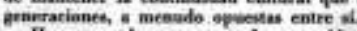

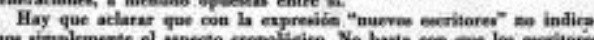

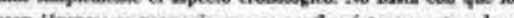

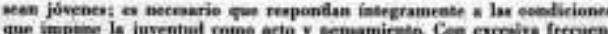

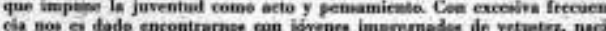

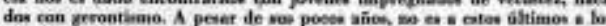

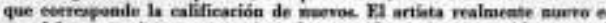

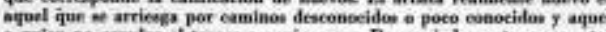

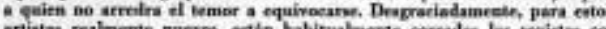

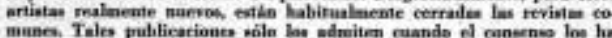

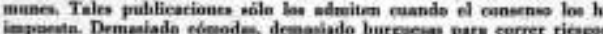

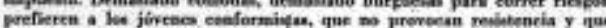

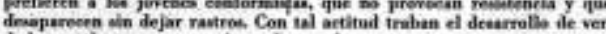
dadetos teleatas y en ocsiones los amplan.

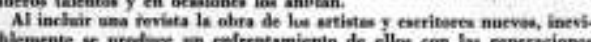

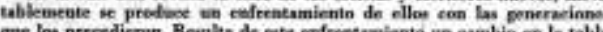

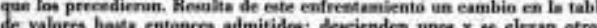

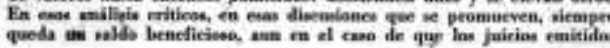
8.

Imagen 17. Portada de Letra y Linea, n1, 1953
OCTUERE DE 1953

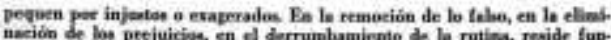

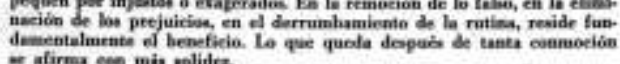

- afirma eee mis nelitez.

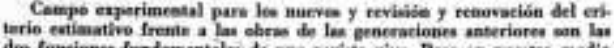

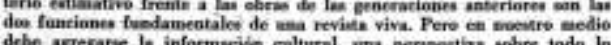
gue $x$ decarrolla cantemporinesumeate en el punto co el plans del arte

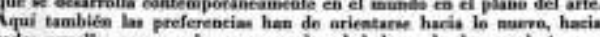

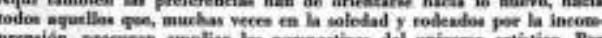

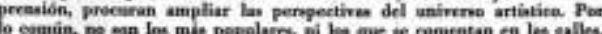

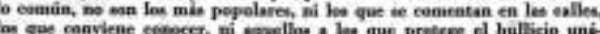

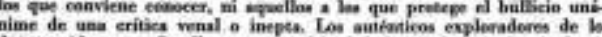

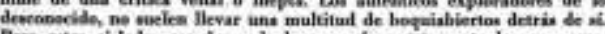

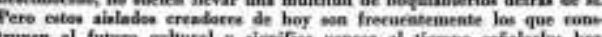

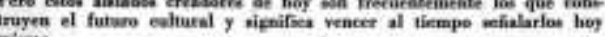

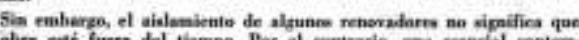

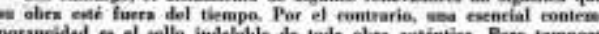

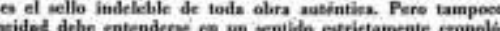
piner so beata que un artiele viva is nastra ipora para quer lo conside

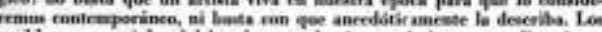

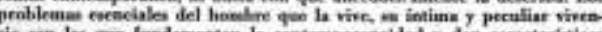

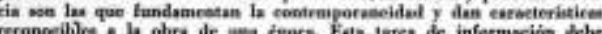

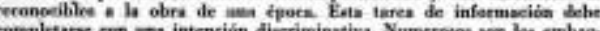

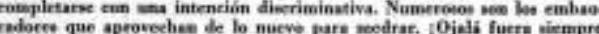

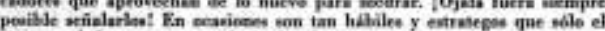
thempe, al demoetrat wi naderia, he dearuge.

1. jotamente en cois tarna dierriminativs, en la que una revise de

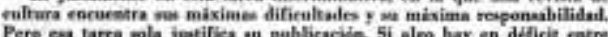

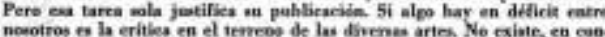

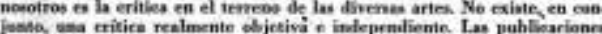
que, por an antigiedad y centinuided, deberlan sez les reppansables de 


\section{Editorial ande}

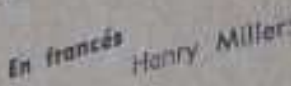

Maurice Nodeau:

Julien Graeq:

poul Eluord: jean poul Sortre:

Camus:

simane do Beauvair:

Joan Paulhan:

Jules: Supervielie:

André Gida:

Antonin Artaud:

En castelleno

G. Apollinaire:

Morcel Schwob:

Eustav Morrink:

Frederic Prok:

Jean Mistler:

André Gide:

C. F. Ramuz:

Arnold Zwoig:

Fichard Aldington:

Hermann Hesse:

Tropleue de cancer $\ldots \ldots \ldots$ \$ 7.50 Pringosse de Maroussi, i... \$ c. Cala du surroalisme, II.. s 9.50 Hustoire da surrealsmo, li... s Histoiro an ........... \$ Andro Broton ........... \$ $\$ 7, \overline{50}$ Le nol pach díargal $. . . .2 . .$. s Le Chateu art ............. \$ 8. Le livre ouvert ......... के 8.Lo lix do poemes ......... 13 choix de p........... goudela Situations ins de la ibertic, it \$ $10 .-$ Ins chemins de la liberte, if of 7.Les chamins de la wes Chametion ... Imagination ............ s 7 . to peste $\ldots . . . \ldots \ldots \ldots$ s 10 Etranger ............ के 9 Colligule ................... Caligulantialisme ............ L'existential lambiguité ..... Morale de lambigunt mortels Tous les hommes sont grain .... Tous les hille et du grain .... De la paile bois ............ Le Penphorie pastorale .... La symporte btroite $\ldots . . . . .$. . ...... 6 Van Gogh $\ldots . . . . . . . . . . .20$

Heresiarca y Cia. ......... \$ $6 . \overline{3}$

Her libro de Monelle ....... है 5.50

El dominica blanco $\ldots . . . \cdots$ s 7 -

La edod del trueno $\ldots \ldots \ldots$. 5.50

El marques de sade ........ s 5 .

Vida de Hoffmonn

Las cuevas del Vaticano... क 4 -

Ei expento en la montana ... \$ 4 -

Cloudia.................

Todos los hombres son ene-

mings

Domián 5 . 5 -

Siddhorta $\quad \ldots \ldots \ldots \ldots \ldots \ldots$.

Lo ruta interior $\ldots . . . . . . \$$ \$ 8 .

TEATRO FRANCES CONTEMPORANEO [Lenormand, Coctedu \%.). Bernard, Claudel, Giraudoux, Pellerith Vildroc, Peirat-Chappuis, Anhouit, Serment, J.

Romains), 2 grandes tomos ............... \& $\$ 30$ -

Dos obrar de gran interés paro el artisto moderno

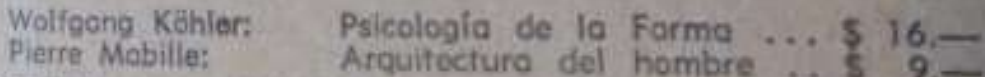
Pedidos a EDITORIAL ARGONAUTA, Brasil 1766, Bs Aires. se envia o cualquier punto del pais a del extranjero, contro rembolso o previo emvio de cheques o giros postales.

Imagen 18. Publicidad de Ciclo, 1948 n1 


\section{editorial argonauta}

obras de interés para el artista moderno

\section{marilú bragance}

W. Köhlert Palcologia de la forma

Emile Borelt El Azor

4 te-

Robent Goffint Historia del Jozx

3230

la cesa de le mujer elegante

Andre Glde: Los Cuevas dal Vaticano

Hermann Hasse: Pater Camenzind

Guillaume Apollinains: El Heresiorca y Cla,

Mareel Schwoba El Libro de Monelie

5 15:-

850

8 :-

3 :1-

$5.8 x$

R. Aldingtont Todos lot hombres son enemigot s 12 a

Walt Whitmenn Dias ejemplares de Americo

$57-$

Edith Silwell: to reina Vietoria

s $10=$

Teatro franchis contempordineo (2 tomos)

$s \mathrm{x}$

S. envio contre feembola

Reunión

LAS MORADAS

publickaidn trimestral os

wrtes y letras

reviluts de

ins artea y las letras

alreetor Adolfo Weaphueren

Bermianto 980

Lima - Fard

Brosil 1766 Buenes Alres

Imagen 19. Publicidad de la editorial Argonauta en Ciclo 1949, n2. 


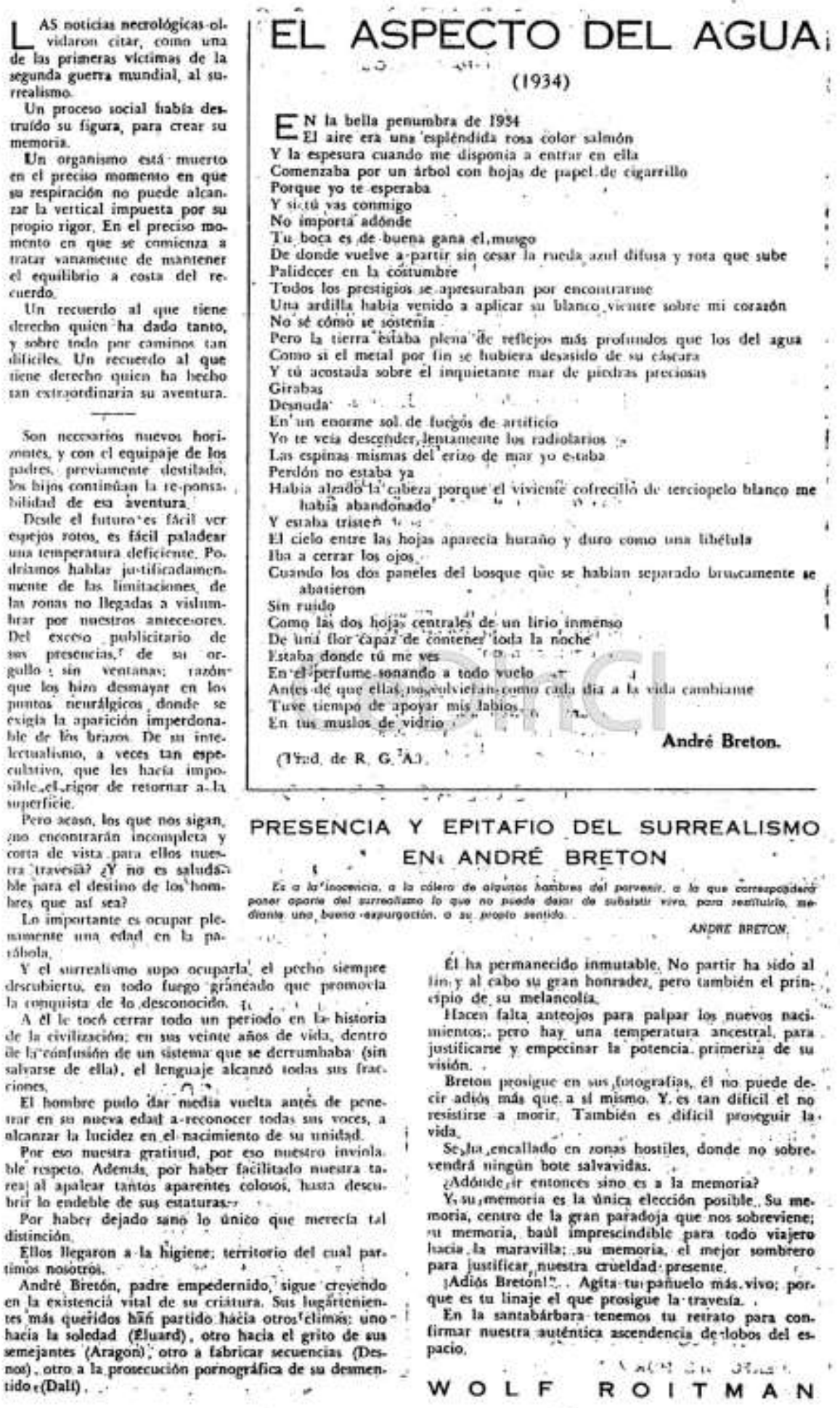

Imagen 20. - poesía buenos aires $\mathrm{n}^{\circ} 4,1951$ 


\section{T E R R I T O RIOS \\ (FRAGMENTOS)}

5

desde los corredores de la semilla el futuro trama sus anios

la oscuridad desnuda el último eco

y el silencio protege sus eclipses boreales

desde el fondo del mar y los glóbulos del arpe

ya mi nombre se nutre en la parábola de la gravedad

y en los esfuerzos presentidos

te veo en la misma extensión y suspenso

no puedes mover los mapas ni murmurar de cerca

el peso de los últimos esquemns

$$
7
$$

eatoy inventando el color de los ecos

y cada golpe trenzado por el pergamino

eato me recuerda los papiros de tu susurro

temes y me enternezco

por la rápida ecuación de tus dudas

hablo millones de planetas

por si una palabra puede sostenerte

8

eacucha atentamente

porque un remo se agria en alguna parte

con todas sus historian de sargazon y tribus

busca con cuidado

porque en tu pecho rota un nuevo follaje

respira sin cuartel la arboladura de los dias

su altura inmarchitable

el porvenir de todas lan veletas

ensordecidas por el ácido sur.

\section{NICOLAS SPIRO}

\section{ediciones poesía buenos aires}

E encuentran ya en la calle, viviendo su aventu. ra de objetos en el espacio, los primeros cua. de las EDICIONES POESIA BUENOS AIRES. En ellos, como lo adelantíramos en el número anterior, nos propusimos presentar una nueva poesía. El adjecivo no tiene aquí más que una valider circuns tancial. Tods poesia $\rightarrow$ i lo es verdaderamente- que se presente como nueva, dejart un dia de serlo para devenir, simplemente, poesia Pero, en el espacio con. devenir, simplemente, poesia Pero, en el espacio con. semporaneo, los poetas que presentamos disponen de in amplis territario para ejercitar su presencia

Vamos a traer también aqui, a estas ediciones, la obra y la ligura de grandes poetas de allesde nues. cras fronierar y allende nuesiro ticmpo, quienes, por obra de múliples circunstancias, son aqui desconoci.

dox disimuladios o desfiguradon,
Todas las naciones tienen sus poetas oficiales, los que se ensefian en el colegio. Existen cambien las poetas aparte, aquellos de los casles no se puede ha. blar, aquelios cuya poesia no ha sido situada, mere. cida. Ellos lon los únicos que nos han interesado des. de que salimos del colegio, los únicos que nos han ayudado a vivir y a comprender, Lo demás es lítera. tura $y$ no nos importa.

\section{TITULOS PUBUICADOS}

1 - CUERPO DEL HORIZONTE (poemas), POR
Raúl Gustavo Aguirre, 128 p. ........ \$ 5.2 - CONVOCACIONES (poemas), por Jorge Enti. que Mobili. \$2 p. .................... \$ 2.EN PRENSA

9 - ANTOLOGIA DE LA POESIA ARGENTINA CONTEMPORANEA

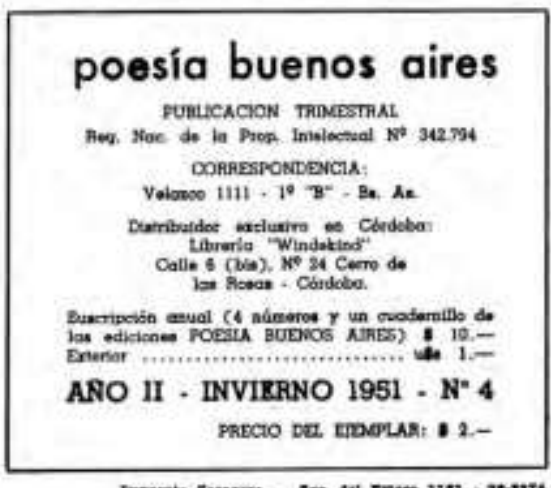

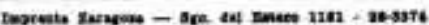

Imagen 21. 


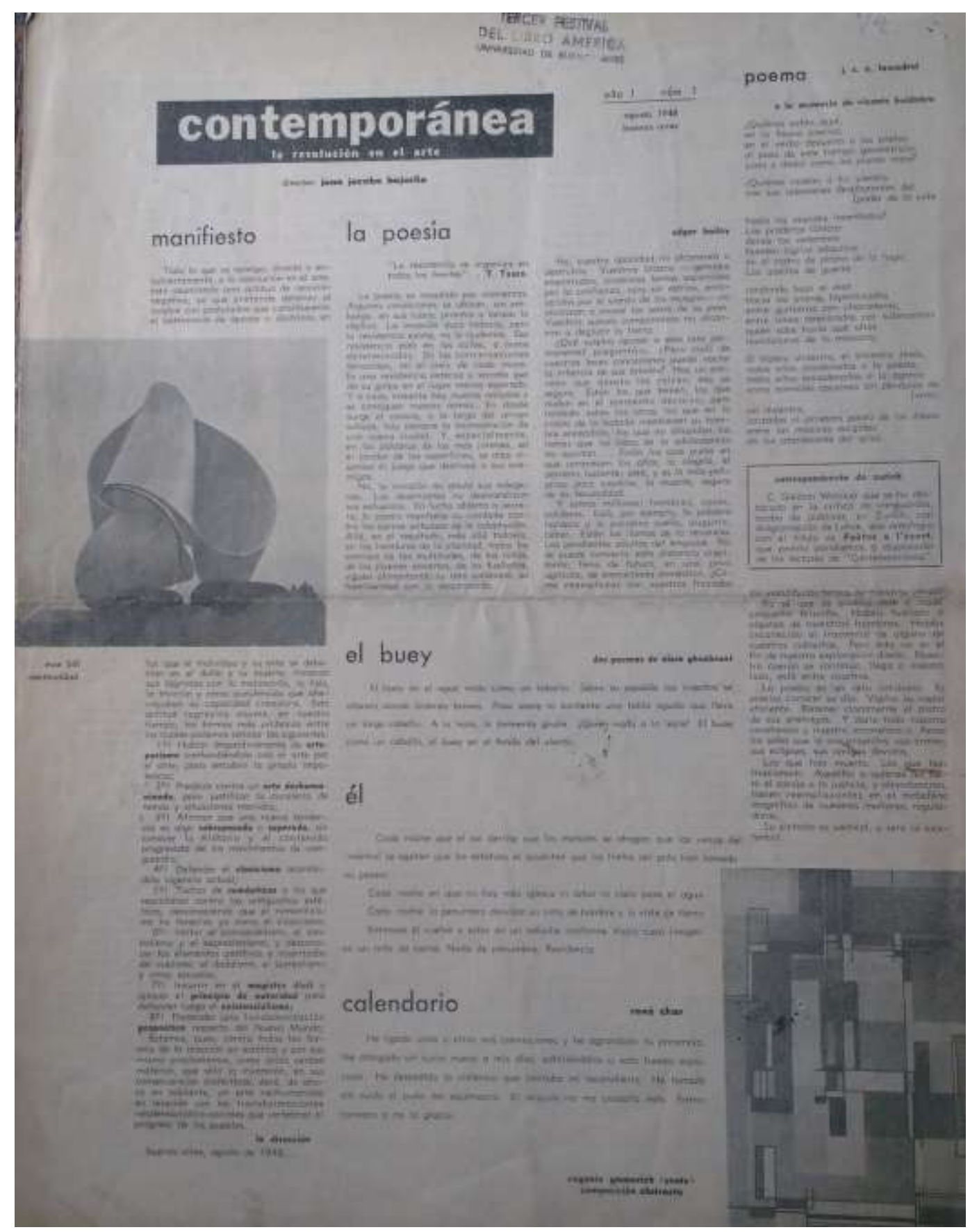

Imagen 22. Portada de la revista Contemporánea 1948, n1. 
LETRA Y LINEA

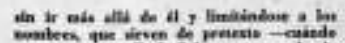

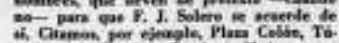

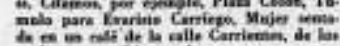

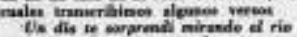

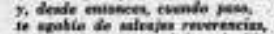

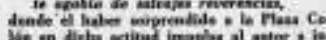

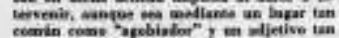

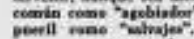

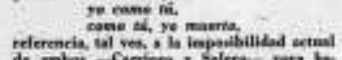

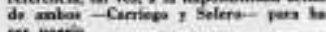

Soied an ente?

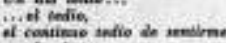

Seir mitas

dichat de todor

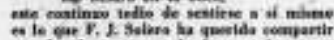

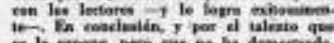

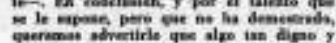

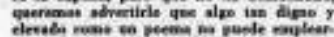

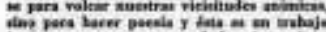

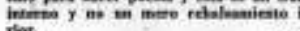

A. $v$,

LESAR DE LOS CARBONES CELESTEY Alberto Probis. Ed Pedeutal (1553).

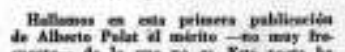

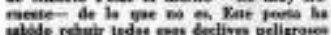

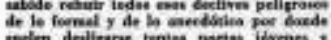

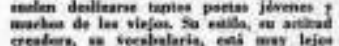

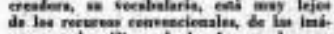

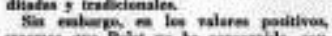

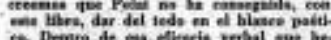

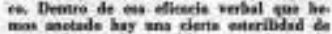

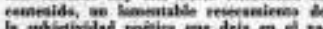

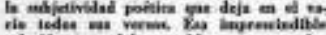

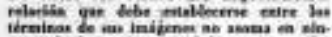

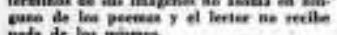

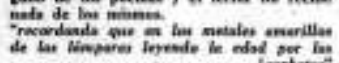

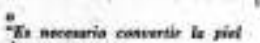

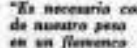

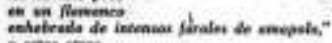

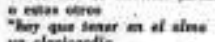

a dochandio

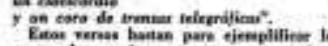

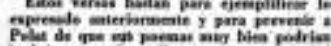

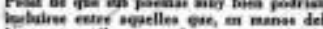

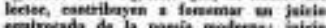

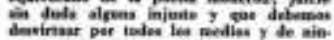

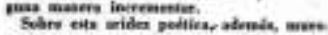

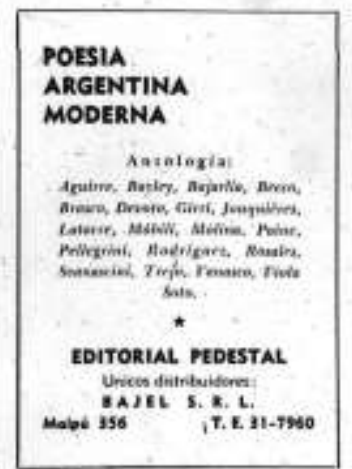

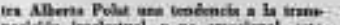

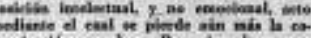

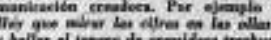

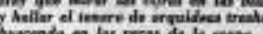

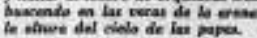

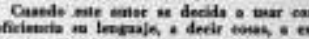

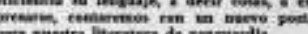
A. $\mathbf{v}$

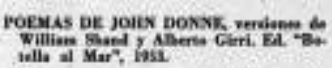
the breve volasen an isic silingle tim.

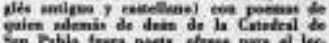

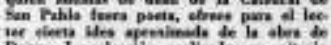

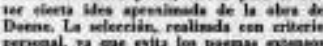

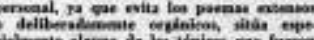

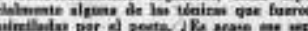

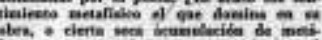

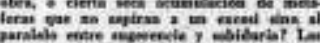

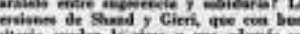

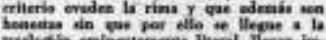

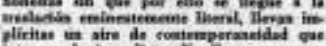
fliritas os aire de contrupgraneded pat

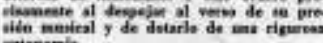

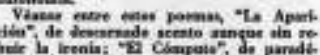

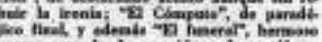

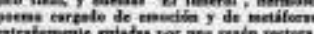

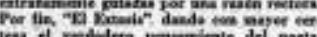

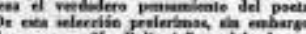

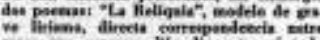

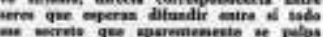

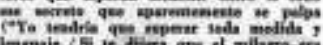

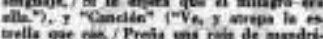

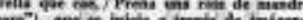

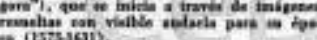

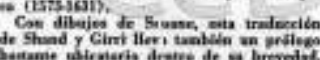
O. 9.

\section{LECTIIEA DE "EL FETO AMARCO}

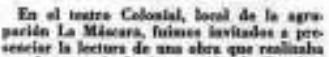

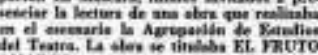

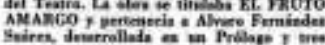

\section{REVISTAS}

PLATICA" INTENT CONVESAR CON

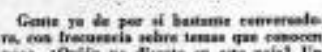

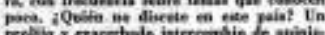

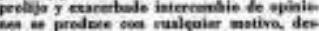

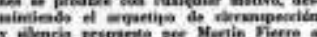

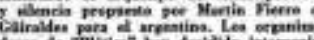

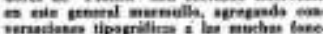

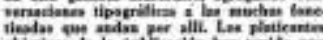

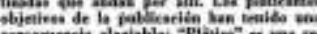

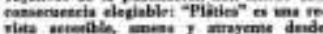

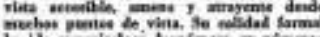

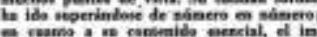

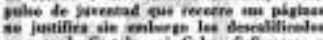

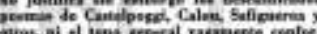

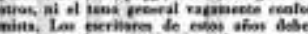

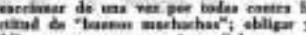

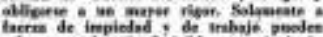

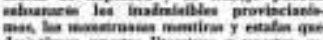

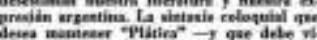

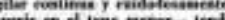

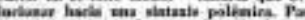

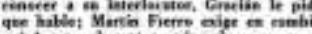

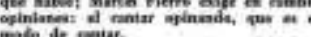
M. $\mathrm{R}$

ULTIMOS LOTES EN LOS EX LINKS DEL GOLF CLUB

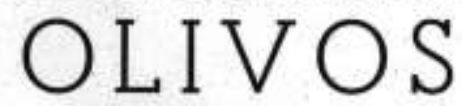

C E N T RAL 170 LOTES

Base \$85.- el metro cuadrado

Domingo 29 de Noviembre a las 16 hs., alli LUIS GUARAGLIA RIVADAVIA $648 \quad$ T. E. $30 \cdot 5531$ P. A. $110 \cdot 310 \cdot 51$

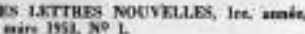

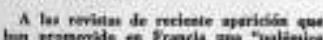

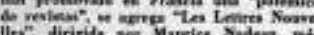

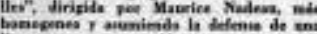

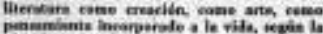

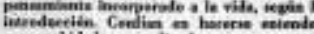

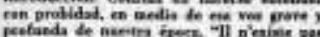

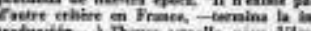

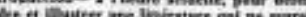

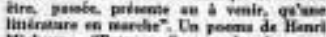

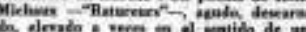

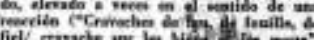

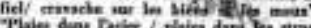

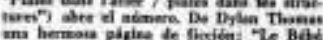

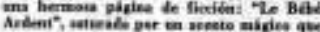

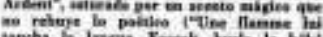

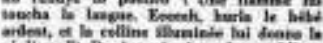

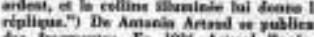
Mesies het

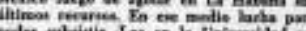

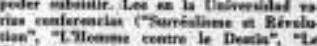

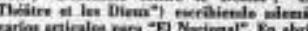

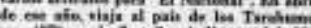

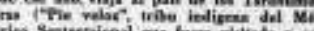

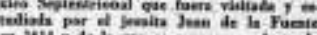

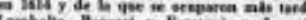

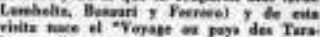

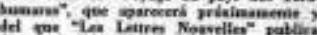

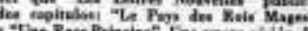

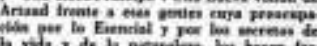

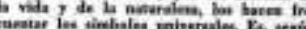

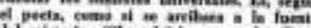

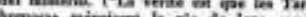

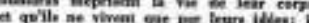

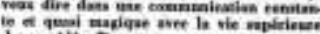

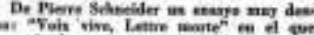

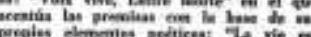

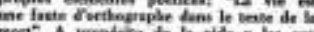

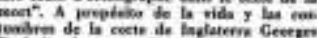

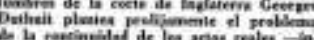

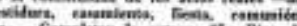

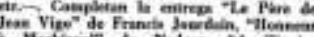

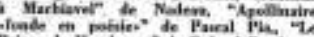

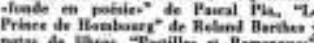

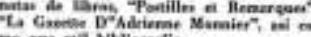
a. $\mathrm{s}$

EL. SUPLEMENTO DE LA NACAON CLitentara pare les diar doningoit.

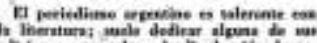

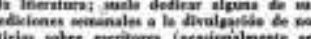

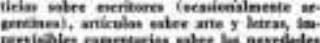

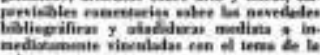
thime

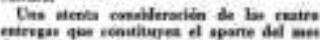

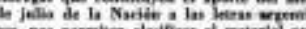

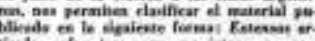

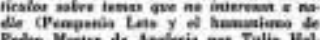

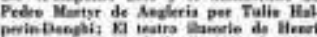

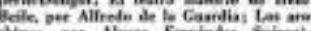

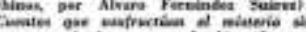

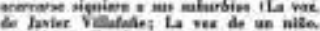

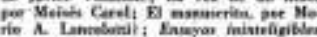

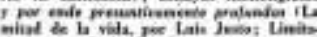

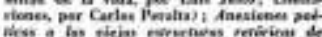

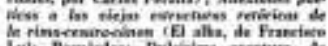

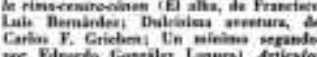

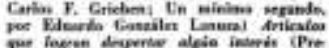

Imagen 23. 


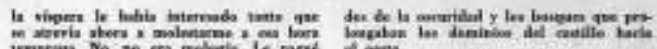

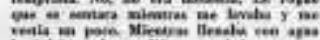

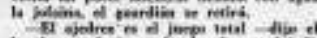

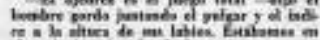

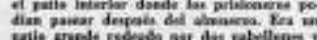

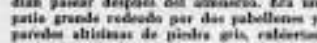

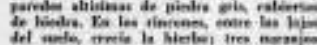

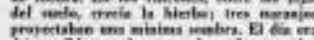

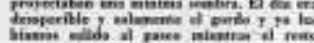

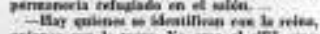

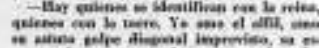

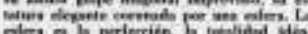

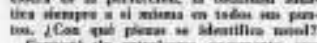

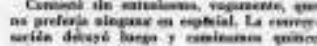

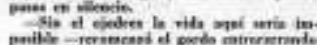

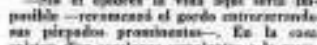

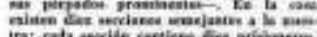

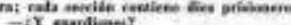

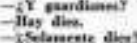

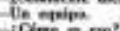

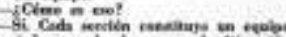

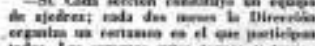

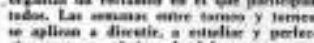

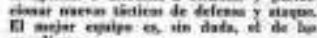

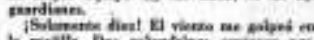

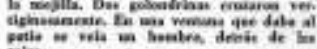

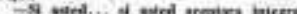

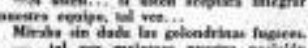

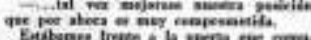

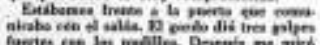

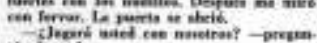
is derenta

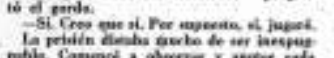

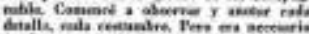

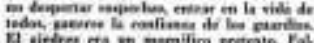

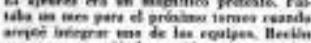

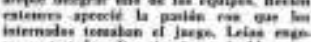

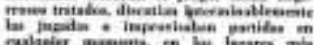

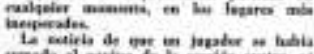
Lation

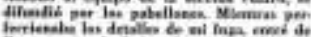

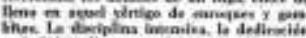

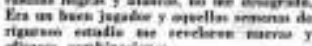

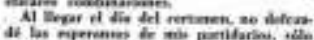

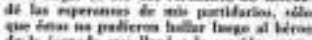

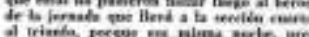

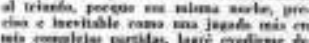

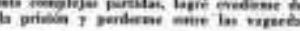

\section{LIBRERIA FAUSTO}

Recientemente inauguroda Literenurs $y$ Arise conkiewr's ian

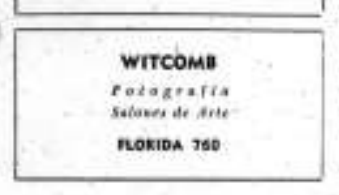

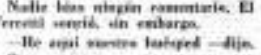

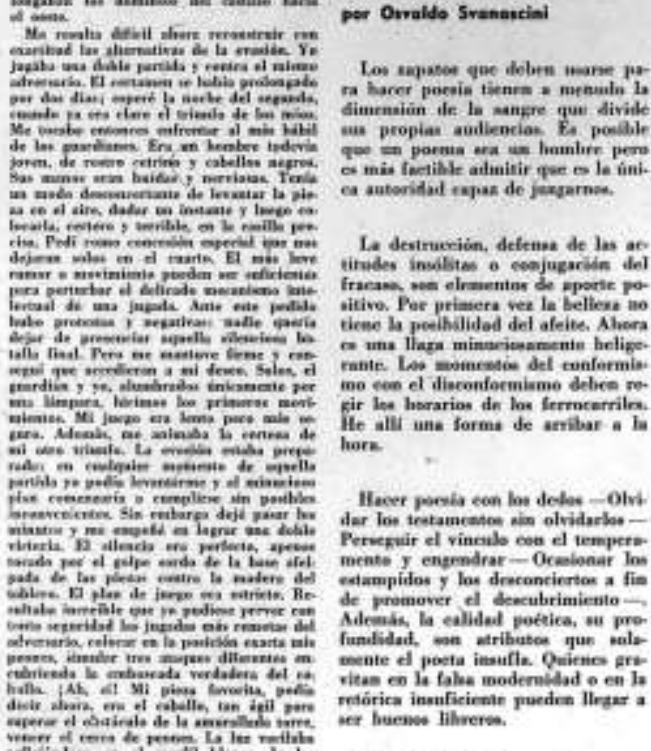

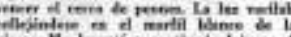

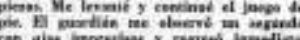

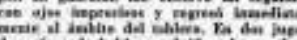

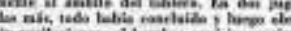

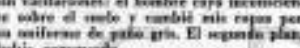

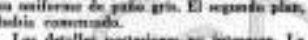

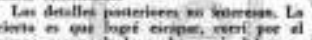

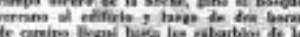

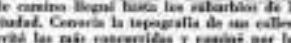

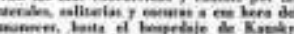

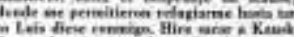

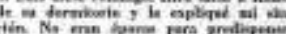

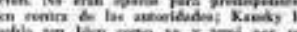

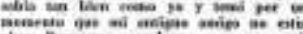

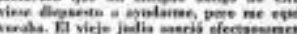

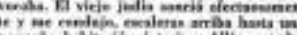

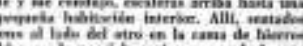

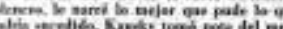

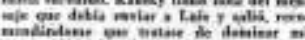

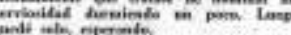

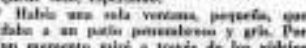

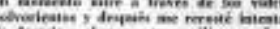

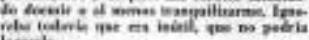
lamel.

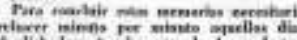

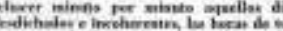

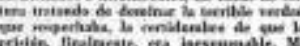

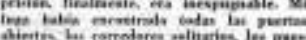

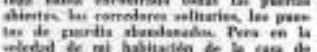

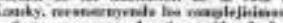

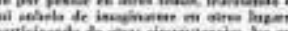

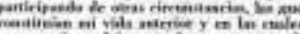

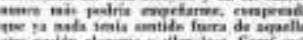

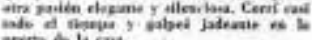

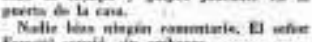

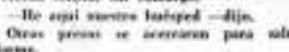
mameside nomo el homber ${ }^{2} \mathrm{Q}=$ do material innorado?

\section{ARADOJAS PARA LA POESIA}

Los aproves que dobern mane incheiben arteal. El eneritac debe arrvir

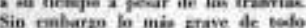

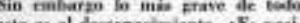

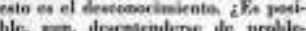

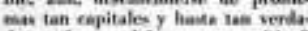

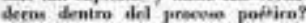
¿Es lógino, ademis, que haliles ot movimiesten rederes - refiritastom al erracianismon, dallaiemos, surma.

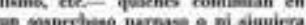
In cospecisas perkas on ni siquiera

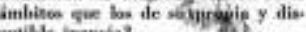
entible hopera?

Por priauena ras el reerdero entra on la pescia sin derrartar a lo ranpm tremon $n$ mez not paroe un ele meste navido por palalira nome $m$ mis cmiences Pere tambirin la poe 4e se coingone at etra marva mati.

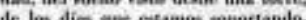

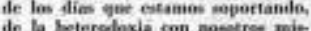
mex del erito y is dowentara, pero

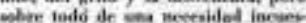

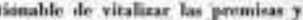
lo concinseie de nodro prepia fo.

Alemelo de un lipie los poetes de

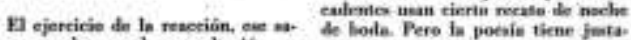

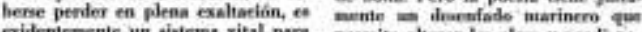

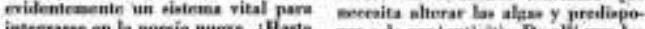

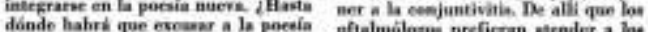
tin comprounian? Hop-ahara of prinejpio de Is poedia tiene gae ser cow

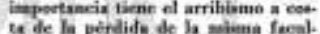

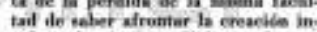

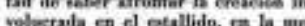
tamorfosis on el recasonentro de to

$Y$ oi el habits en et enemipo ife lo

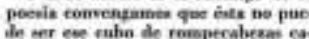

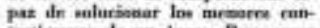
intiempes de un juepa. Parz cerar los dondemes der la poesis fueron mese-

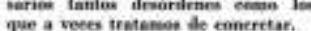

Exprosiain: teo que a were idra. las hoegurvas y que alowa ge prest. fa en las formas itel knkeje.

Ya no e paille valorizar ba apt ión tirmper

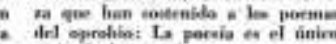
Esta épors nes ollitiza = hactram

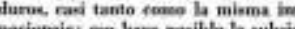
paciencisar cos liace pasithe la mulen.

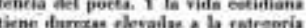

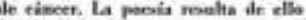
Gavited de resumeni as agmiviAnd merida nate el centraste ene of

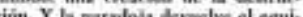
inim. Y la paraloja develve ef equidad: $y$ sim - emberse wames 4 plas:

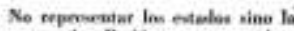
coss on wi-Pasinin y cenupromiso:

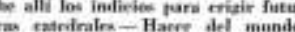

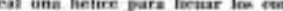
ventionalismes - Inflair sedtere los

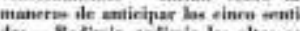
dos - Restimin tetimir bos altas on

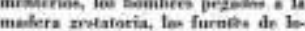
vieio de la virtaul.

\section{NEIRA Y EZCURRA} INGENIEROS AGRONOMOS

\section{PARQUES Y JARDINES}

TUCUMdiN 346 TE. 31-RETMO 5735-56E8 GUENOS AIEES

Imagen 24. 


\section{SOBRE LA POESIA ORFICA}

(A propótito de "Lea Nembres", de Silkina Ocempo)

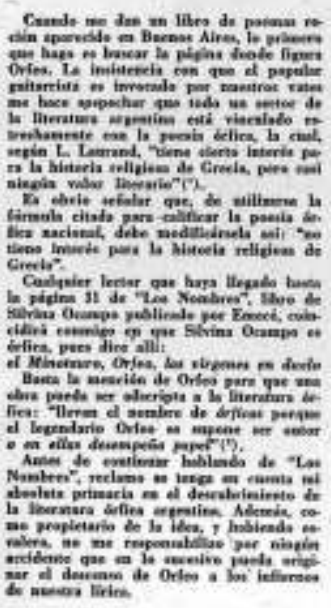

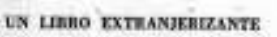

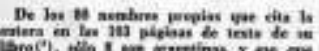

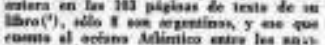

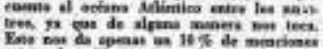

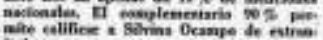

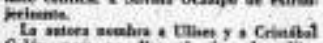

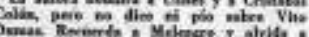

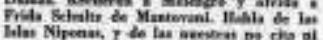

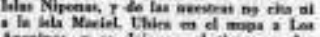

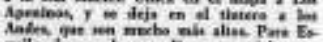

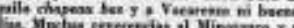

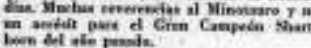

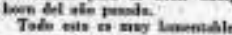

MEPAROS DE FONDO

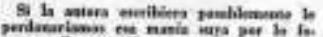

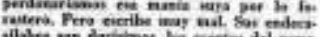

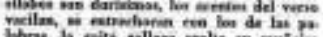

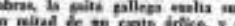

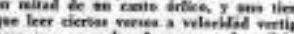

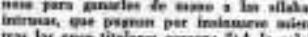

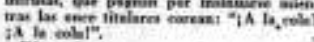
ix lo whet:"

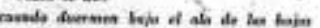

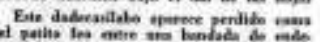

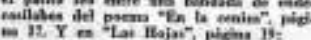

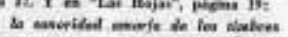

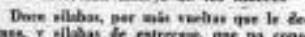

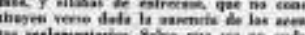

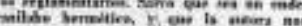

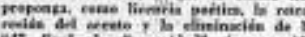

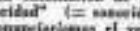
de mer meda

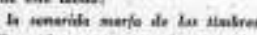

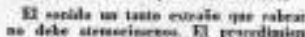

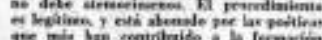

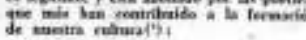

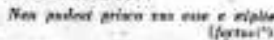

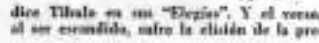

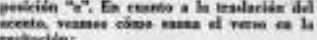

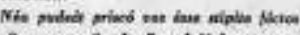

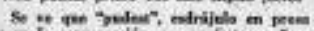

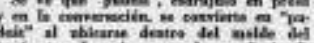

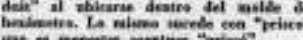

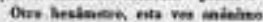

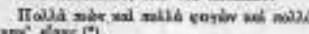
$4 x^{2} \operatorname{tanc}(0)$

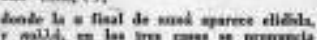

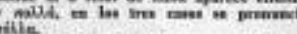

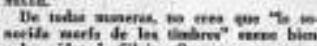

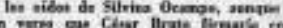

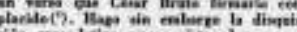

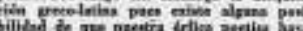

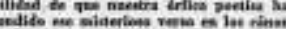

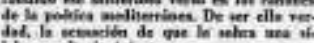

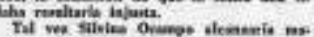

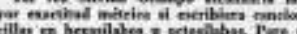

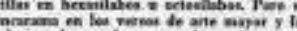

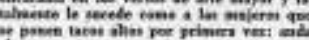

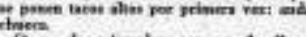

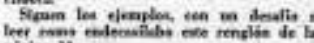

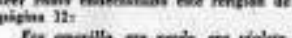

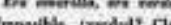

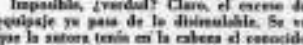
ing hat

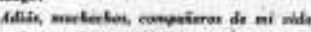

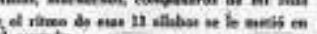

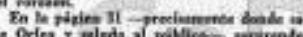

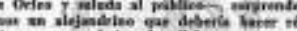

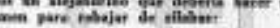

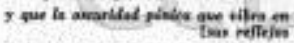

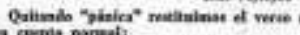

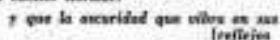
Due adus de non on vis Jer pelice.

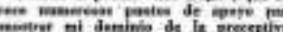

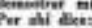

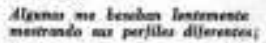

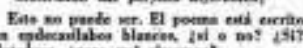

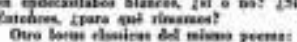

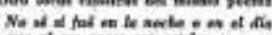

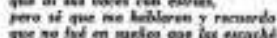

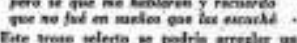

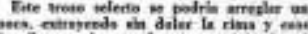

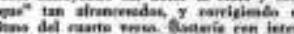

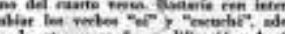

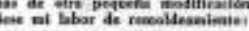

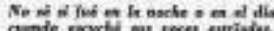

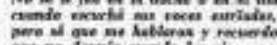

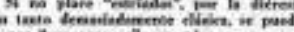

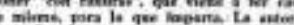

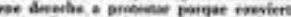

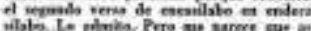

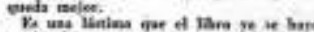

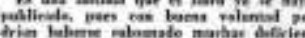

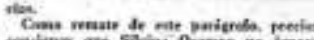

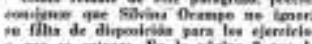

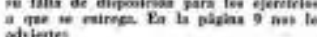

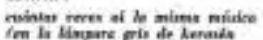

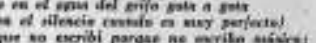

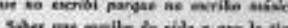

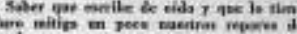

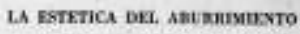

En ed perme ticital del there sevion

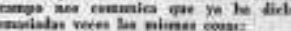

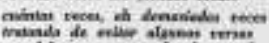

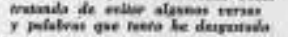

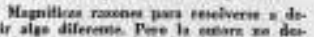

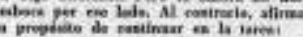
mor nower a nepesit to nume

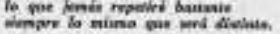

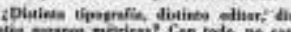

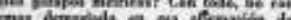

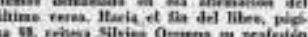

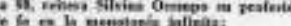

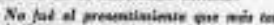

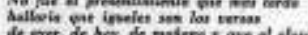

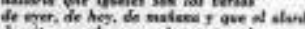

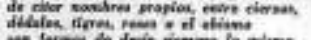

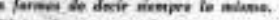

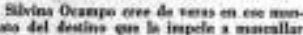

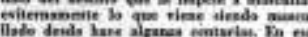

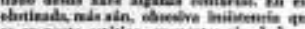

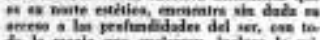

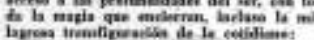
conter neres iedulithreste.

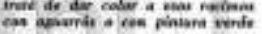

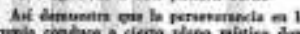

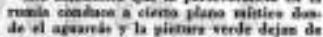

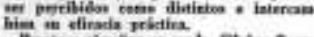

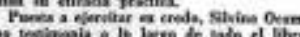

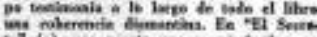

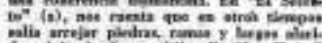

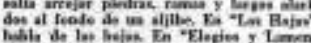

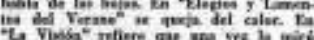

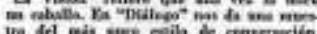

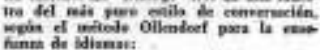

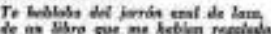

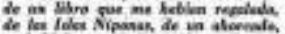

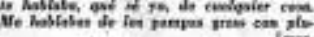

de in monblo deade ne pondas nouts

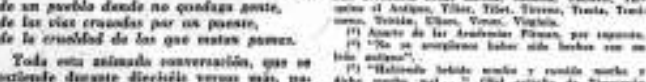

min pa st

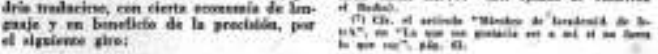

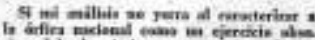

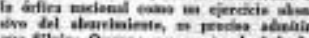

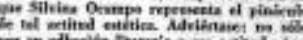

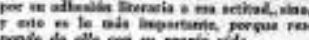

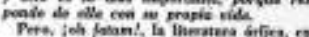

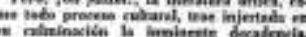

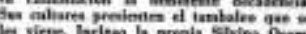

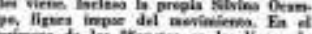

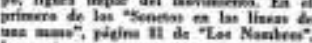

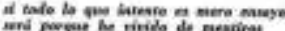

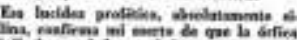

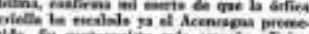

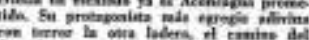
Oregien of jubile.

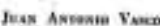

$2=154=25$
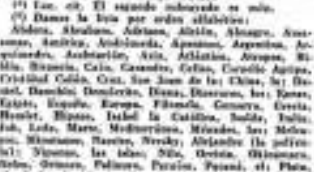

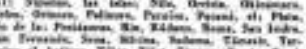
-

\section{NEIRA Y EZCURRA \\ INGENIEROS AGRONOMOS}

\section{PARQUES Y JARDINES}

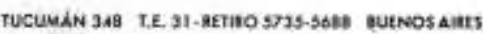

Imagen 25 
Il était devenu si hideux, qu'en passant la main sur son visage il sentit sa laideur.

\section{L'erreur}

Anatole France n'est pas mort : 11 ne mourra jamais. Quelques braves ecrivarins dans une dizlino darnees aurom invente un nouvel Anatole. In y a des gens qui no peuvent pao se passer de ce

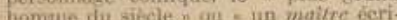
viin On recueille-sus moindres mots, on étudie sa laye ses moindres phrases at pus of bele - Comme d'est

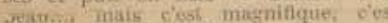
splencido: "Lo maxitre cterne. Celun qui vient de disparaltre n'etai pourant pas tres sympathiques II $\mathrm{n}^{2}$ jamais songe quis son pedit imteret, a salpotila sante. Hattondation cla scriouement qu'a.til fait at quo a-toil penste Puisquil ne s'agit aujourd hui que de déposer une palme sur un cercieil. quelle solt aussi lourde qu possible of qu'on trouffo ce souvenir. Un peu de dignila Messteurs de famille: Plaursa toutes les lames de

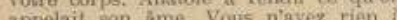
aitenale de cette mómoire mollo et à che Cost Ani:

La nuit desnend dófis. On reste etonne. lorsquon a le conrage de pareourir les articies nécrologiques, de la pauvrete des eioges decernts a teu France. Quelles

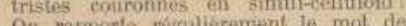
On rapporte resulieremem le mot de

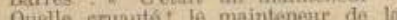
Inngue francrise c cels fait penser a un adiudiant or a un maitre drécole trể, pédant. Je pense que c'est une finguliere idee que de nerdie quetques minutes a adresser des adieux a un cadavere dont on a retire lo carveaut puisquentin tout est fivi, nen partons plas.

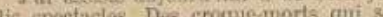
dispitaient en marehant devant un cescneil, Jai vi anssi une fermme an deuil, soile de crempes, aller \& Yhopital triller

one baverte avou son moribond of rmar et fui montrer les becux latails too ate

PнLAPr: SOUPAULT

Un vieillard

\section{comme les autres}

Le visage de la gloire, le visage de la morl. coliti d'Anatole France vivant on mort. Tes semblables, cadurre, nous he les aimons pas. Que de bonnes raisons, pourtant, ils ont de durer, comme la beate et liturmonite qui les remplissen datse, qui teur mettent aux leves un bon sourire, un sourire de pere de fathille. La beaute, cadavie, nous la connaissons bren of si nous nous y prétons. c'est qu' elle ne nous domne pas precisement a sourire. Nous $n$ aimons te fou of reau que depais que nous avons envie de nous y ieter. Lharmonic, ah I tharmonie, le noud de ta cravale, mon cher cadawe, ct ta cervelle d ceart, bien rangee dans le cercuent et les larmes qui soni si douces, n est-ce pas.

Co que je ne pris plins imaginer sans avoir les larmes anx yeax, la vie, che apparait ezcoro aujourd hul dans de pehites choses densoires anxquetiles la tendresse setale sor maintenant de souticn. Le scepticisme, Ironte, la lachete, Pran. ce. lespric rancais. queti-ce ? On grand

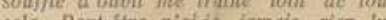
cela. Peut-itre n atice famais ren In, nèn vu, de ce qui desk PAUL ELUARD.
A. FRANCE (Thats)

Le gouvernement et la foule des admirateurs du Maitre sont venus ce matin apporter leur hommage

Cest dis 9 leures du matin, et non pas a. parilir de 11 heures, comme on Pavait primilivement decide, que les portes do
a maleon d Atiatole France ont blo ou, la maleon dAnutole France ont eto ou
vertes unx visiteurs degiroux de suluer une derniere fols la dèper

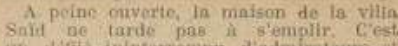

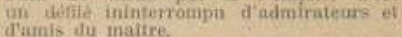
to cercuell, plach dans lo salon nous te firand dals noir brodé d'argent, dispacelces Les dernieres itolles neurs umonin pouvait volr tout ithewre encor miller sur le drap mortuaire s'effacent it lejur tour, fteintes sous les aillets dout glinents.

Pas to moindre candelabre, pas la plus

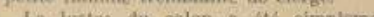
Ee lustro du salon a eté simpirment sur ie monceau de lenrs sans cesse accru. On franehit lo vestibule, on sineline devant le cercueil, et ton sort tin salon par la pitite galeria ou, bur une cotisole Bourdelle, paralt ferrangement vivant, par Dans le vastifule, devaut la vltrine tembiti de fretes Tariugra, on a disposet sur uno table des fetrilles voluntes qui se couVrent bicator dos signatures kiles sont trop Ail haeard tonci jos noma. Mime Lu ovic Lallove, MM, Flse ot Drmicl Hatevy, M. ot Mme Jean Hentessy, Aristide Briand Severin, Retri Boylasve; Pterard, depat

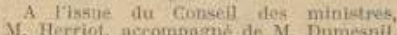
ministre de la marine, et do M. Isra ê, secrituire onmaral â la riésidence dí Con

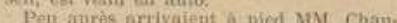

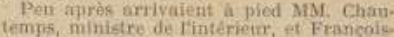
Albert, ministre de linstraction ppoblique.

Imagen 26- - Panfleto Un cadavre, 1924 


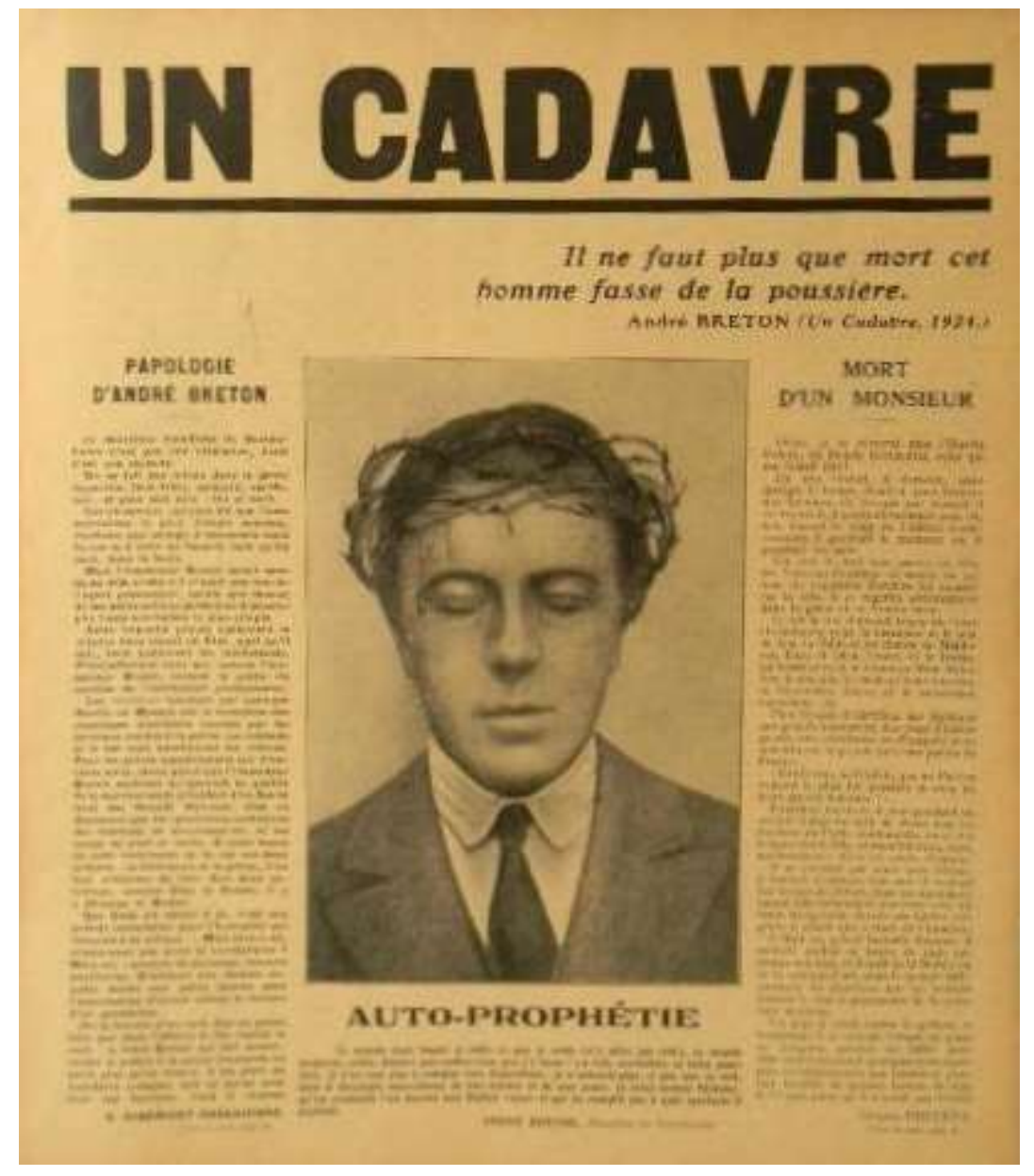

Imagen 27. Un cadavre 1930 


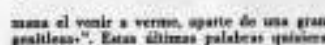

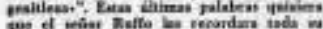

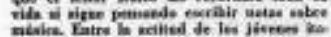

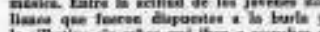

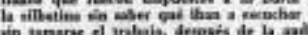

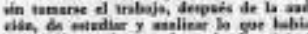

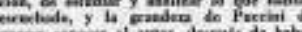

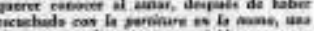

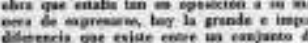

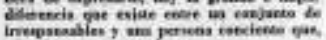

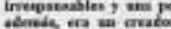

Cuess cornases

UN TMUanE EN LA NOCHE

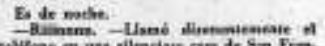

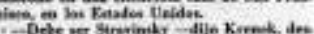
Dipece ser Sinnim

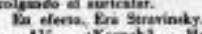

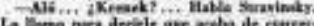

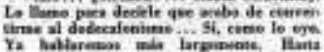

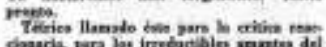

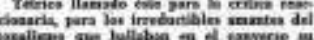

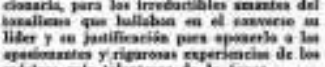

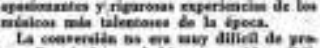

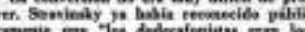

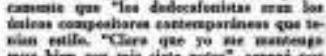

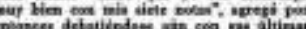

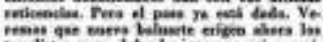

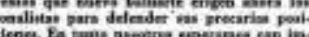

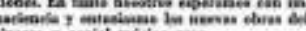

AGRUPACION NUEVA MUSICA

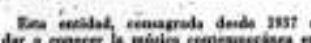

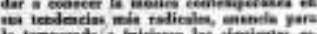

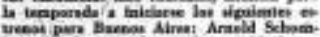

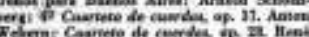

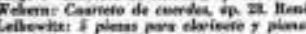

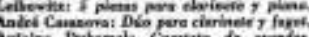

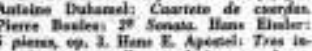

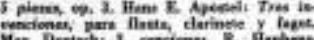

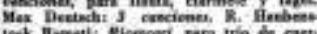

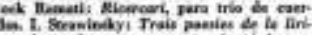

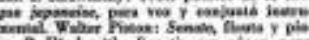

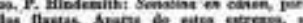

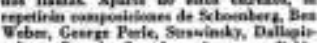

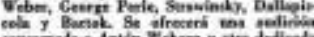

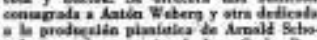

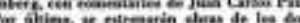

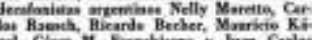

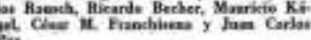
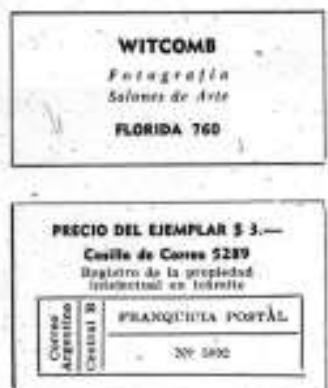

ESPEJO DEL MUNDO - POESIA BeEvos AREs" Y LOS XTOS DE DNSENANZA
SEct

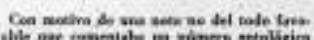

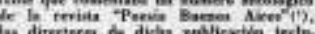

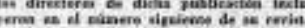

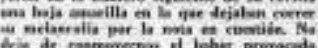

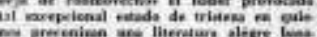

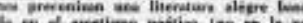

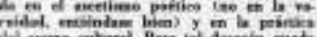

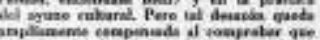

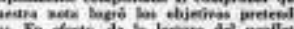

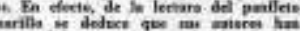

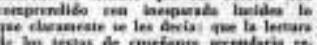

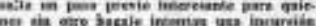

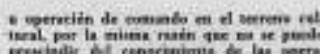

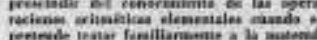
tirm nopersion.

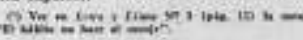

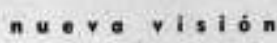

revista de culture vinual

enter

erevinetions.

saste iesurice

simonetio

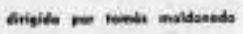

cumas 137 buses enes

follorial

H MERICALEE

Acaba de aparecer:

NACIONALISMO Y CULTURA

Do RUDOLF ROCKER

\section{JUICIOS AUTORIZADOS}

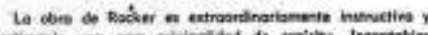

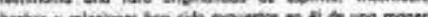

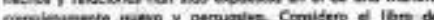

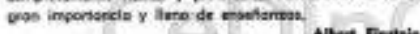

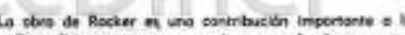

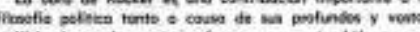

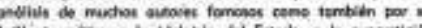

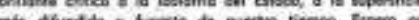

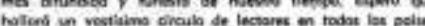

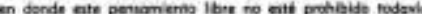

$$
\text { tomine turast. }
$$

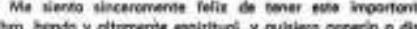

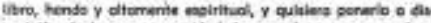

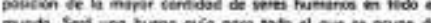

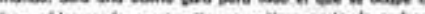

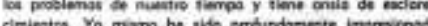

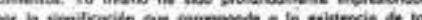

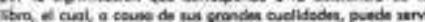

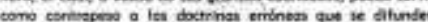
on miskenoo ton potigrom.

\section{Thenes Mana}

Un volumen do 532 páginas, formato $16 \approx 24$ $\$ 50$ -

TUCUMAN 353 T. E. 32.0958 BUENOS AIRES

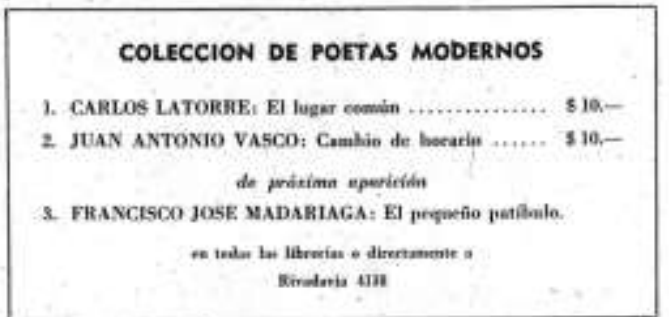

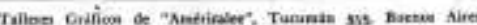

SAVichac Y LAS recenencass den.

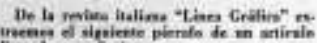

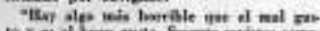

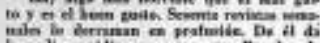

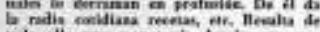

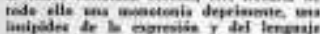

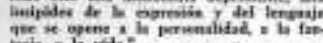

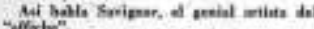

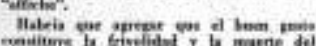

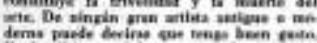

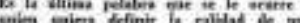

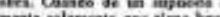

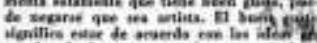

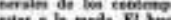

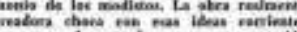

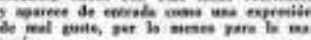

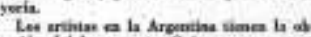

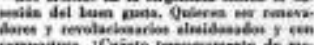

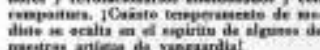

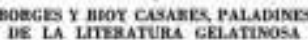

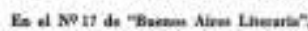

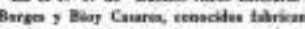

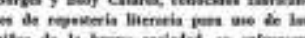

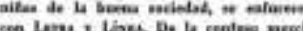

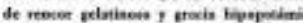

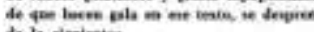

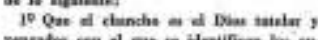

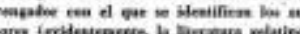

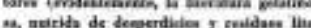

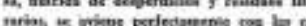

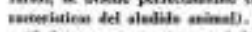

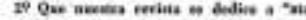

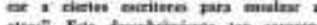

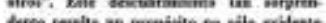

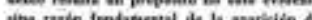

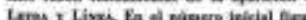

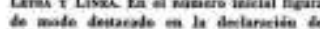

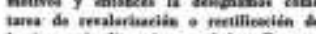

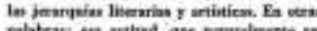

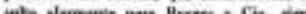

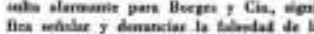

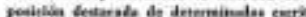
nes $y$ entitata, hograde por pawaes sariad

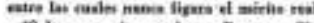

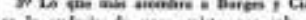

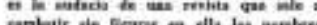

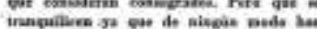

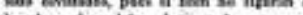

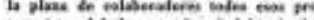
tapenitas del drusa culanit del pais, is

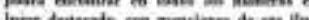

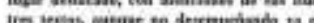

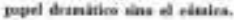

MIGUEL BRASCO OTROS POEMAS E IRENE

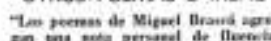

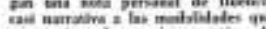

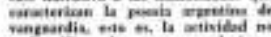

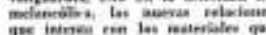

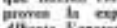

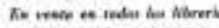
GMCIONE cologen

Imagen 28. Última página de Letra y Línea n4. 


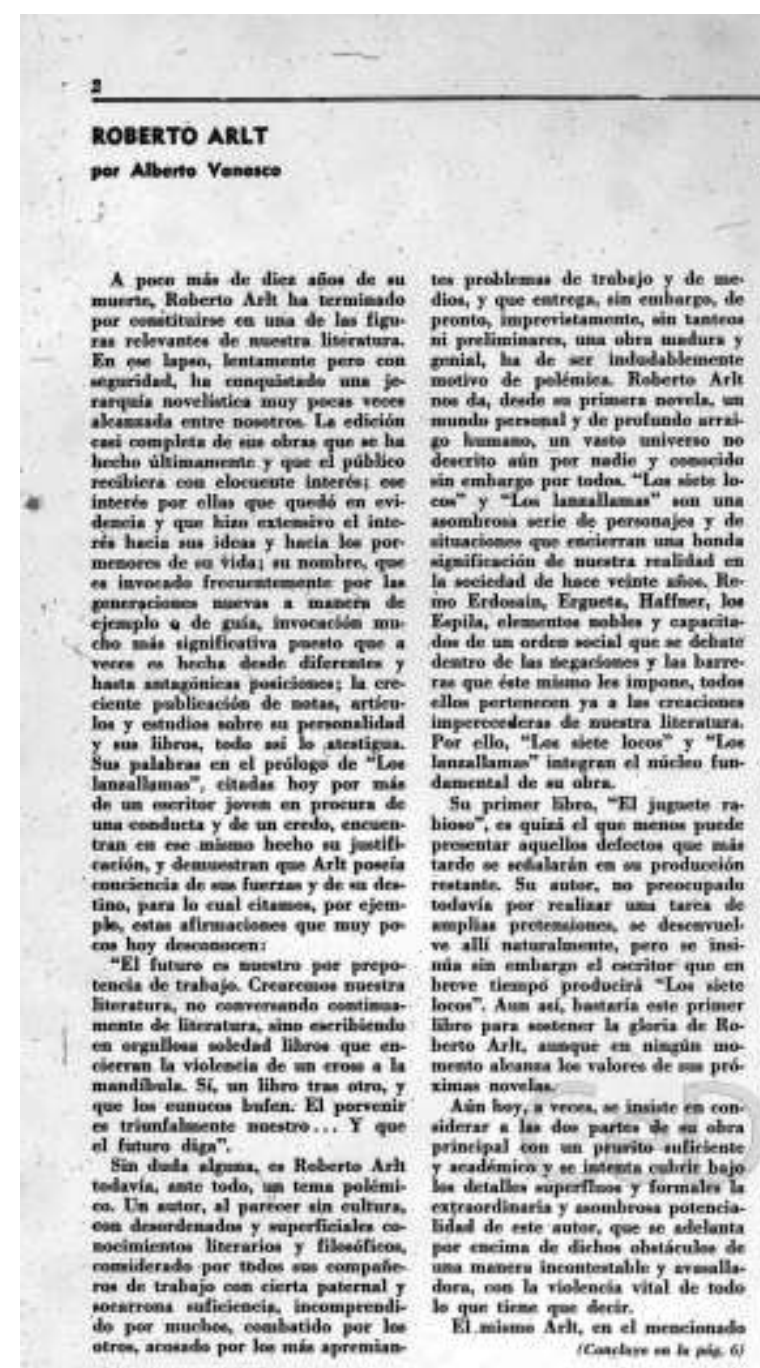

\section{Justificacion}

ete tares, has demoetrado une iepeis caid tonal Cusndo la eritica ne

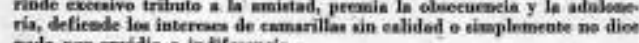
anda por envidia o indifereweis.

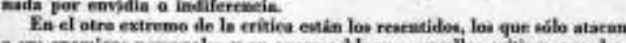

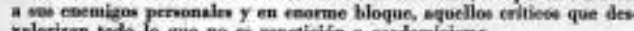
clerizan todo lo que no e repeticián o mastemirisma

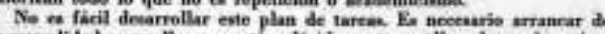

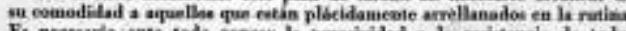

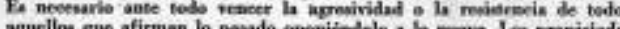

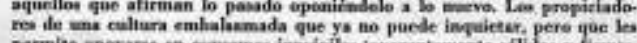

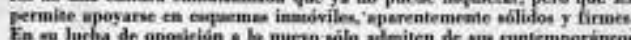

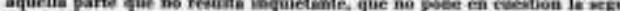

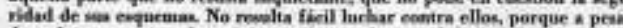

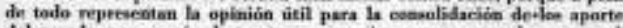

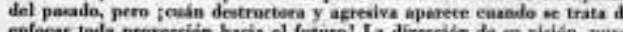

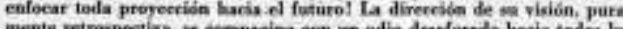

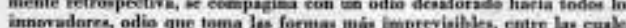

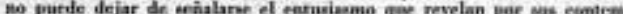
puraneus medior

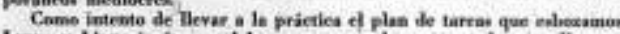

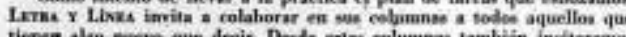

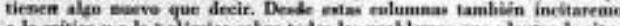

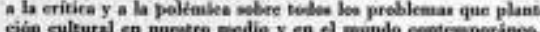

EL FIN DE LA AVENTURA Y EL PRINCIPIO dE LA ROPULARIDAD per Juen Carlos Onetri

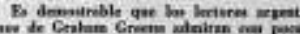

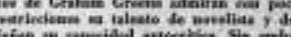

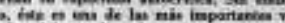

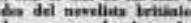

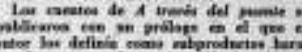

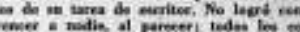

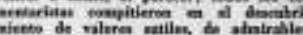

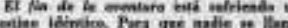

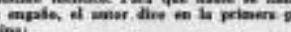

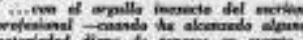

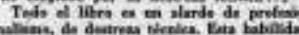

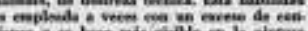

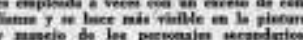

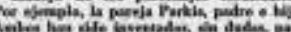

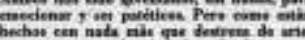

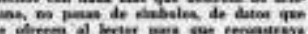

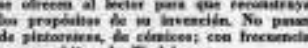

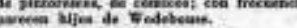

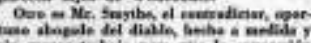

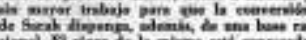

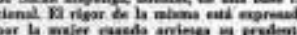

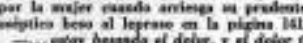

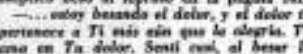

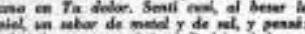

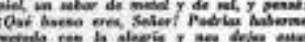

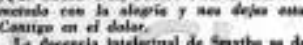

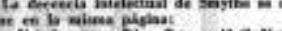

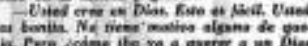

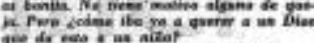

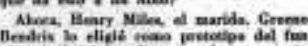

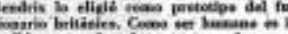

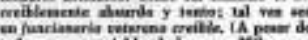

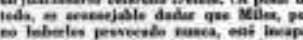

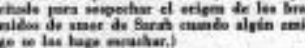

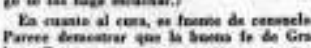

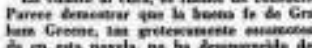

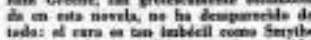

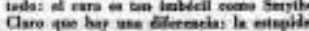
Let

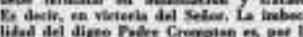

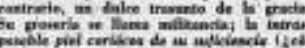

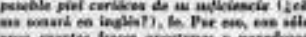

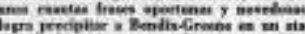

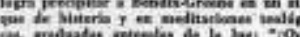

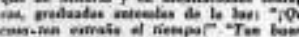

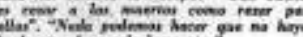

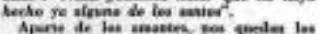

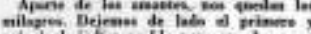

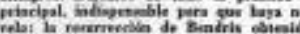

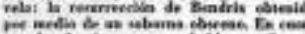

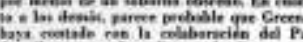

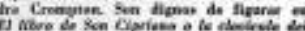

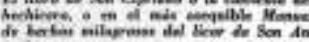

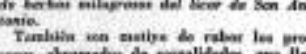

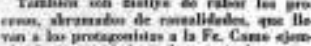

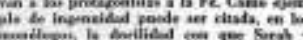

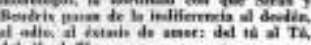

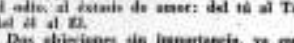

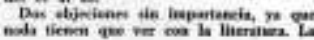

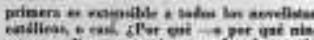

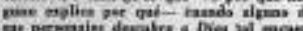

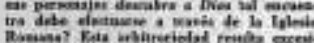

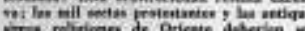

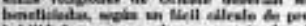

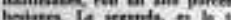

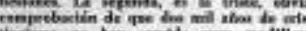

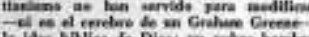

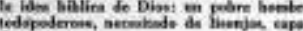

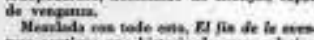

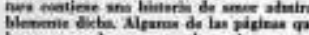

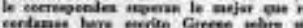

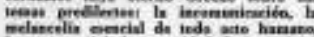

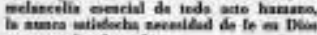

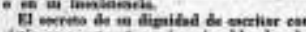

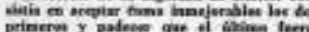

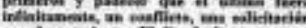

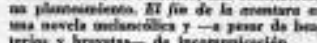
...

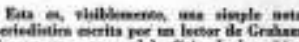

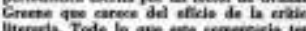

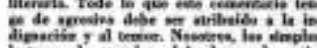

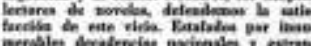

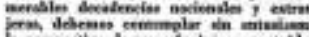

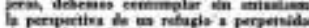

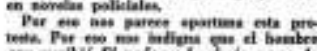

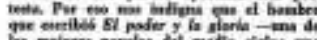

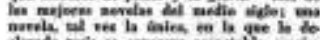

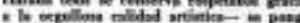

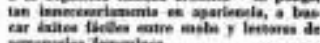

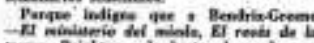

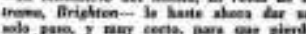

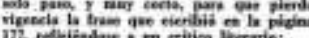

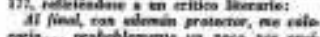

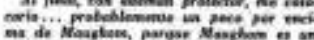

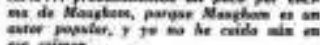
, .

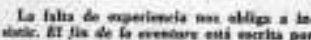

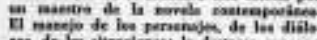

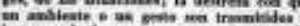

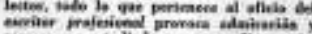

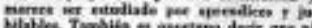

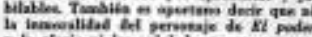

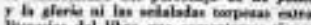

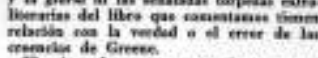

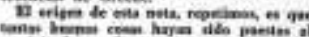

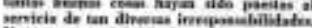

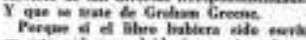

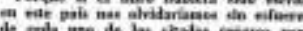

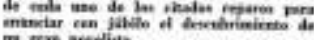

\section{LIBRERIA KRAFT} Oferto espociater:

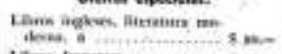
Fonion 681

Imagen 29- Arlt y Onetti 


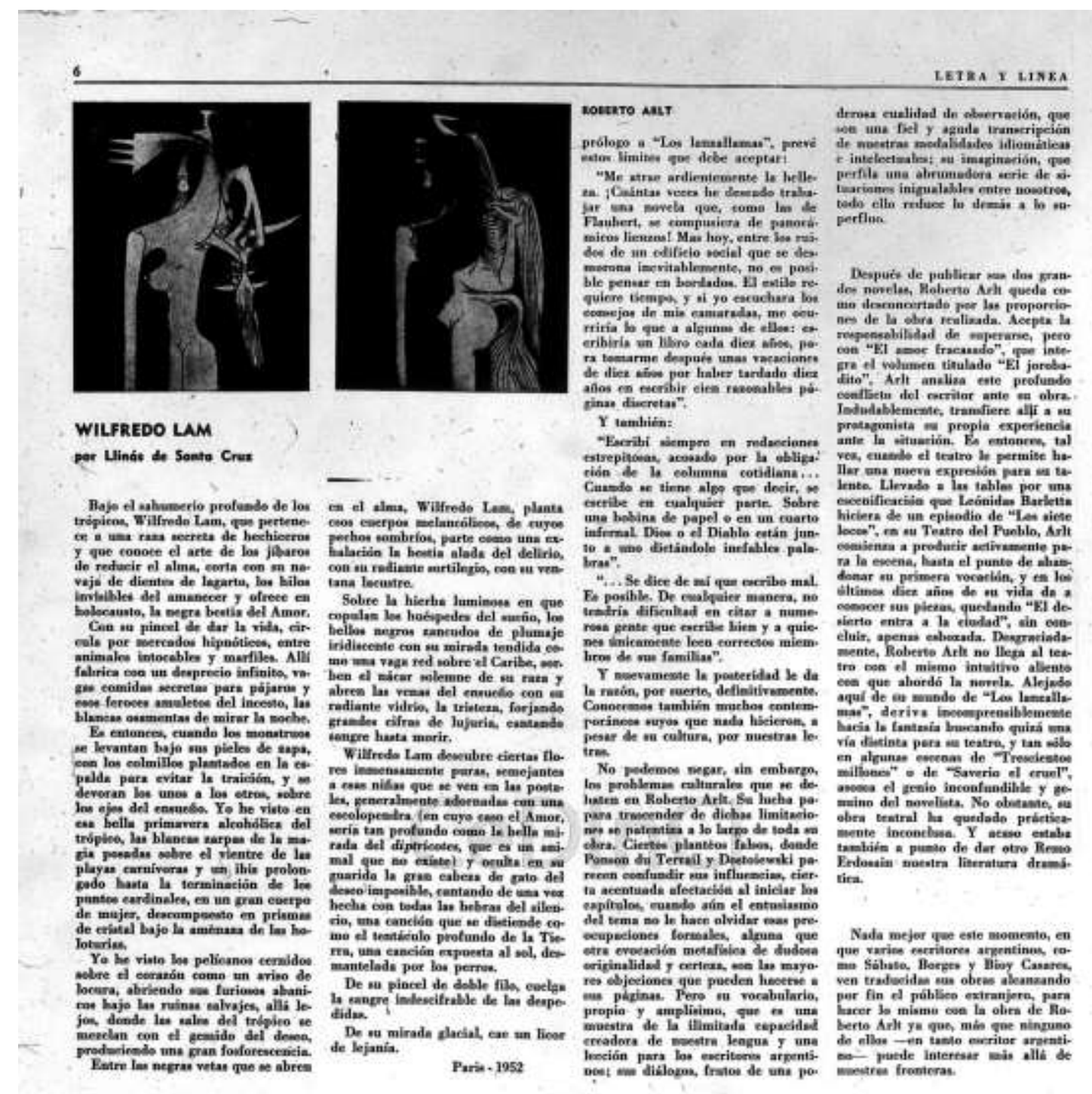

POEMAS DE JUAN ANTONIO VASCO

LOS FUECOS DE SAN TELMO

Barcos

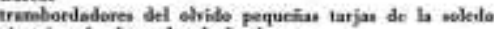

eiratriest foeds malte de lot berees

fando de las mejallas dondo ereoe ol eahe pue lace andar a los harese barcos niempre el

ELOGIO DEL, SENTIDO COMTN

Bella sin operarle la miquins del apas máerdo con su labies menudos sna mes mominio del verihuge

Arrastrando us pieras seceimatas de un tajo

recorre los aposentes echa profeties por debajo de les puents

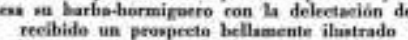

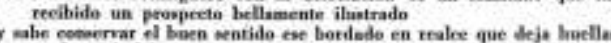

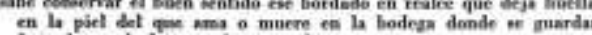
las calbesas de los arandes pensadares

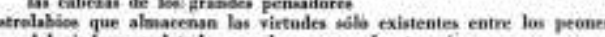
del ajedrec explatados por los peenes de otres fuegos

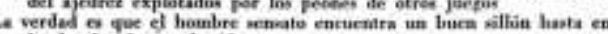
low bories de una herids

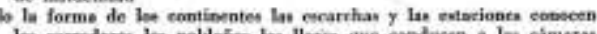

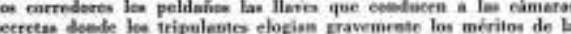
nets lavia $x$ pinta

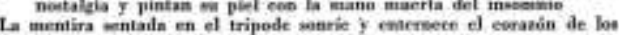
hembres distribage lanest part el ataque fimal

pans una suelta de ron con on propies hurses parz que el odie arde Eohre la ohra moerts come una majer arrojacis al acoto de les merineso ve putal entre los dientes

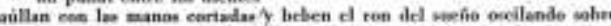

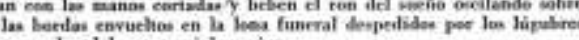
eonsuelos idel eer

cabera por le escotille por los palos y las ruentas murmurando vo jerga mariners goe entiendem todos los humilies.

Imagen 30 - Arlt y Lam 


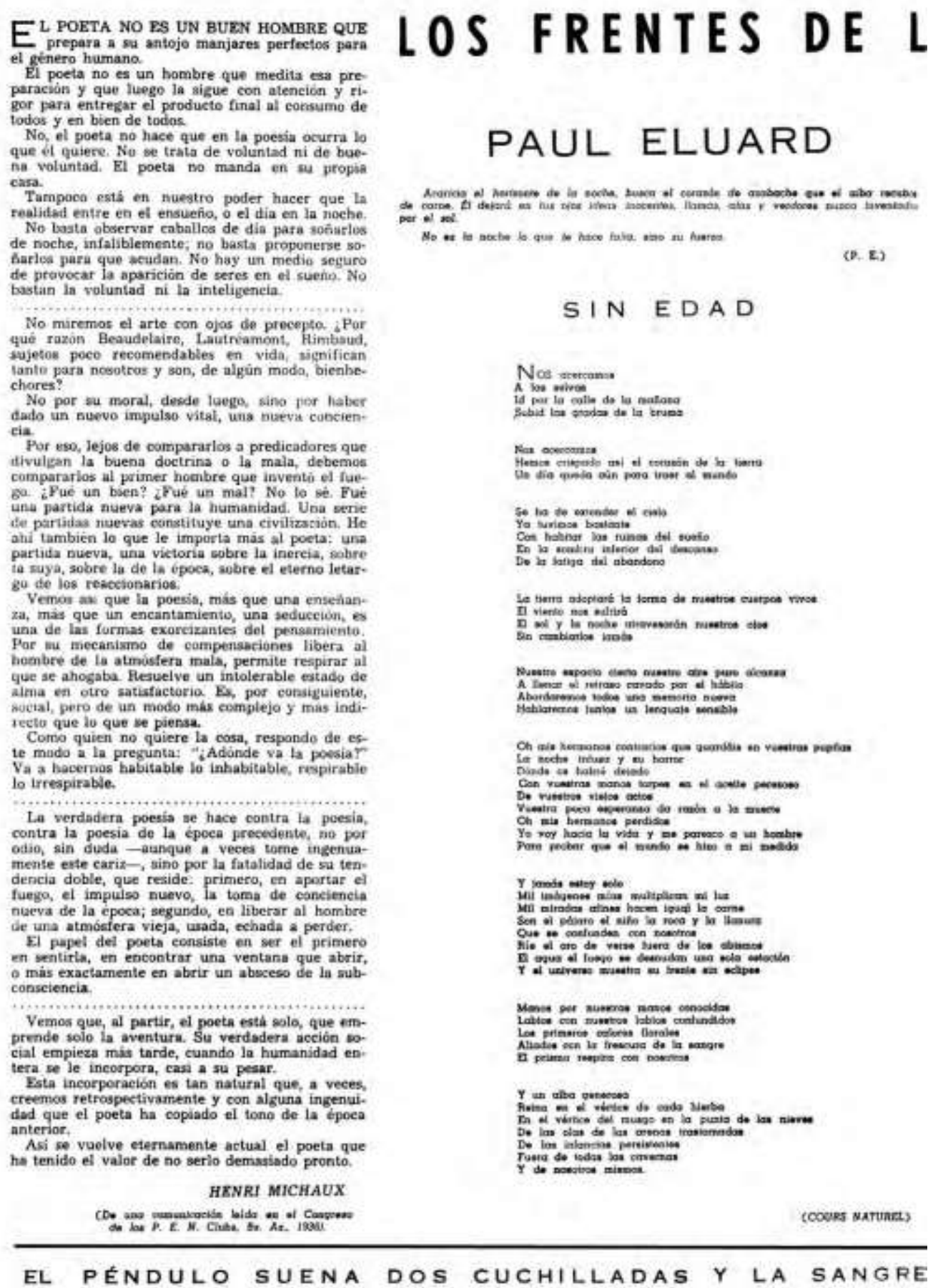

Imagen 31 - - Frente de la poesía francesa (1) 


\section{A POESIA: FRANCIA}

\author{
RENE CHAR

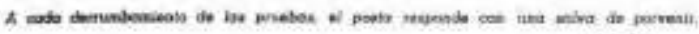

(a. c)

EL SEMBLANTE NUPCIAL

(fragmento)

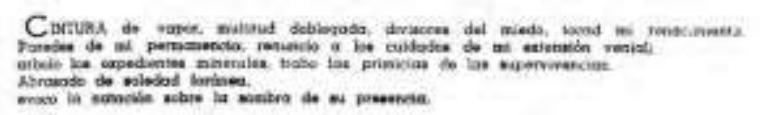

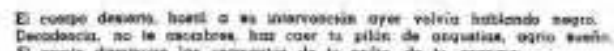

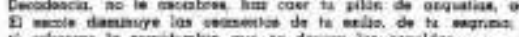

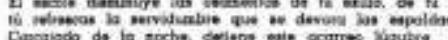

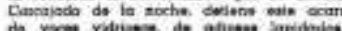

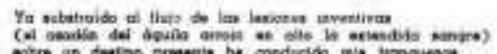

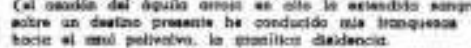

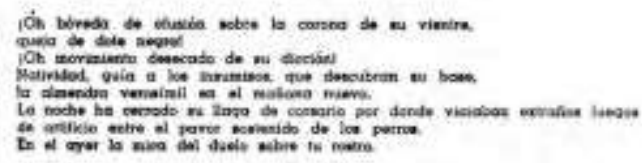

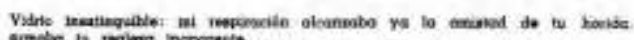

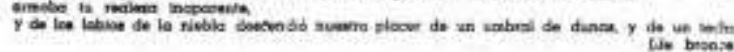

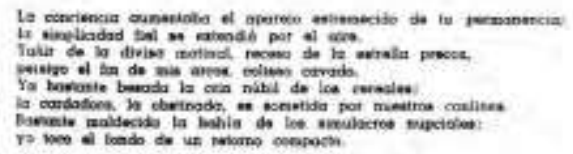

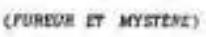

$P O E M A$

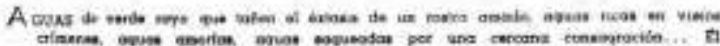

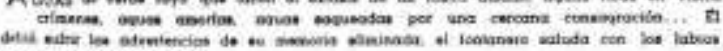

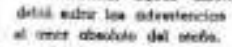

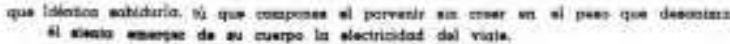

croxun an Mratene)
A PARTE DE LA TRADICION IDBOLOGICA porineos ana tradición revolucionaria especificamente poetica. Yo deseo hablar de la que tiene su origen en los innovadores, en los poetas "malditos", en su espiritu casi heroico frente a los conformismos de la burguesia y que, a través de

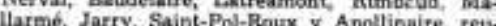
nió las diferentes tendeneias que yan de bo ma ravilloso al humor, en una visión del mundo ma. que, hoy todavia, la poesin no sabr.a renuneiar. Toda adeuisición legitima en el domint dej espirita debe ser negada y as el dominis del esjuirita debe ser negada y asimitada a la vez. es un desmentido a la ley de progresión y debe ser considerado como reaccionario. La poesia no es ánicamente un producto es-
crito una sucesión de imágenes y de sonidos, sino crita, una sucessón de imágenes y de sonidos, sino baut hacen presentir of sentido trigice de esta manera de vivir poéticamente que dada y el su. perrealismo han tratado de llevar hasta sus consecueneias

La rebeliún de Rimbaad $\mathrm{es}$ la de toda adolescenciat es reconocida eomo un valor permanente al que no se trata ya de refrenar sino de liberar. En su rensnciamiento s ia poesia y en su partids para Hartar, se ha querida ver la significacián que, si la aceitn es eval ha puedada ackarado poesia no es una actividad de "magia", sino una wetividad humana, una actividad particular de la necesidad de expresión que se asienta en el ofden de todas las demás preocupaciones La objeivacion de la poesia debe buscarse sobre el te.

Lo absurdo se convierte en un valor poético, coeno el dolar $y$ el amot. Sóso profundizando en la absurdo de mundo aparece una claridad nuebradnes que equels otra que. lourtad de deslumintento no resiste a la que, lograda de primer mont, Mallarmé y Saint-Pol-Bous nos enerian que es necesario padeces lasmomente parn llegar - esta claridad, la conciencia- ésta no se enar sen̂a. Esta dado a cada uno el descubrifia en las profundidades de su ser eon todos los riesgos que la aventura supone, en esferas donde el pos ligro es grande. Tal fué, para Gerard de Nerval. en las timites de la locura, la leeción que recibio en su busqueda de un absoluta. Tal es el precio que pağa lis razoin sl salir del tunel donde eneuesIra su recompensa en la sabiduria y en la laz. Ds ssta, en un resumen quirin demasiado es. quemiltico, la sucesión de poetsil que previeron a la poesia corno una lectión de vida, como un estado del espiritu El humor $y$ la sorpress, con Jarry y Apolinaire, tienen entrada real en el dominio de la poesia, en tanto que la poesiacujeta, como ia poesia del abjeto usual de las cubistas, esa resceion cantra el simbotismo luego Iat al mundo moderno luis de una verdad ger mundo exterior, a la izado, ltapojindola de los orvolet convencio nales de los mitos romknticos

En todios estos poetas se descubre un desprecio vioiento por las ideas aceptadas un presenticiento de la liea de que ef mundo es hootil al llevan a prever el advenimiento de un mundo nuevo, donde el detorden desaparemes, donde bellezs pueda ser contemplada $y$ la vida vivida por todica las hombres.

TRISTAN TZARA.

de LA ViRgen VUELA DULCEMENTE Bajo LA Luna (P. E.)

Imagen 31 - Frente de la poesía francesa 2 
L A poeain ea el vocablo virgen de todo preL juicio; el verbo creado y creador, la palabra recién nacida. Ella $⿻$ desarrolla en el albe primera del mundo. Su precisión no consiste en denominar las cosas, tino en no alejarne del albe.

Su vocabulario es infinito, porque ella no cree en la certeza de todas sus posiblea combinacio nes. $Y$ su rol es convertir las probabilidades en certeza.

Toda poesia vélida tiende al último limite de la imagineción. $Y$ no eólo de ln ínaǵinación, aino del expíritu mismo, porque la poetris no es otra cosa que el último horizonte, que es a ad vez la ariata en donde los extremos tocan. en donde no hay contradicción alguna. Al llegar a ese lindero final, el encadenarniento habitual de los fenómenos rompe su Ígica, y al otro lado, en donde empiezan las tierras del poeta, la cadena se rehace en una lógica nueva.

El azar es bueno cuendo los dados marcan cinco ases o por lo menos cuatro reinas. Fuern de este caso, debe ser excluido.

Nada de poeman tirados a la suerte; sobre la mesa del poeta no hay ningún tapete verde.

Sobre . . . . . . . . . . . . . . . . . cantar o aimplemente colvoco obligatorio, sino con algunas olns disciplinadas.

Una voz grande y calms, fuerte $y$ ain vanidad. La voz de una nueva civiliznción naciente, la voz de un mundo de hombres y no de clases. Una voz de poeta que pertenéce a la humaniUna voz de poeta que pertenece a la humani-
dad $\mathbf{y}$ no a cierto clan. Como' eapecialiata, to primers especialidad, poeta, es ser humano, integralmente humano. No se trata de negar to ofieio, pero tu oficio en oficio de hombre y no de flor.

"Basta señora erpa de las bellas imágenéa de los furtivos comos iluminadón otra cosa otra cosa buscamos.

...........

Aqui comienza el campo inexplorado redondo a cause de los ojos que lo miran y profundo a causa de mi propio corazón tleno de zafitos probables

de manos de sonámbulos

de entierros atreos

conmovedores como el evenio de ló enanos o el ramo cortado en el infinito

que trae la gaviota parn was hijos.

El tiempo tiene un sombrero nuevo de tiem. po en tiempo.

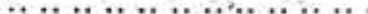

No hay poema ai no hay lo inhabitual

¿Entonces) Hay que buscar siempre.

Vicento Huidobro.

\section{LOS FRENTES DE}

\section{VICENTE HUIDOBRO}

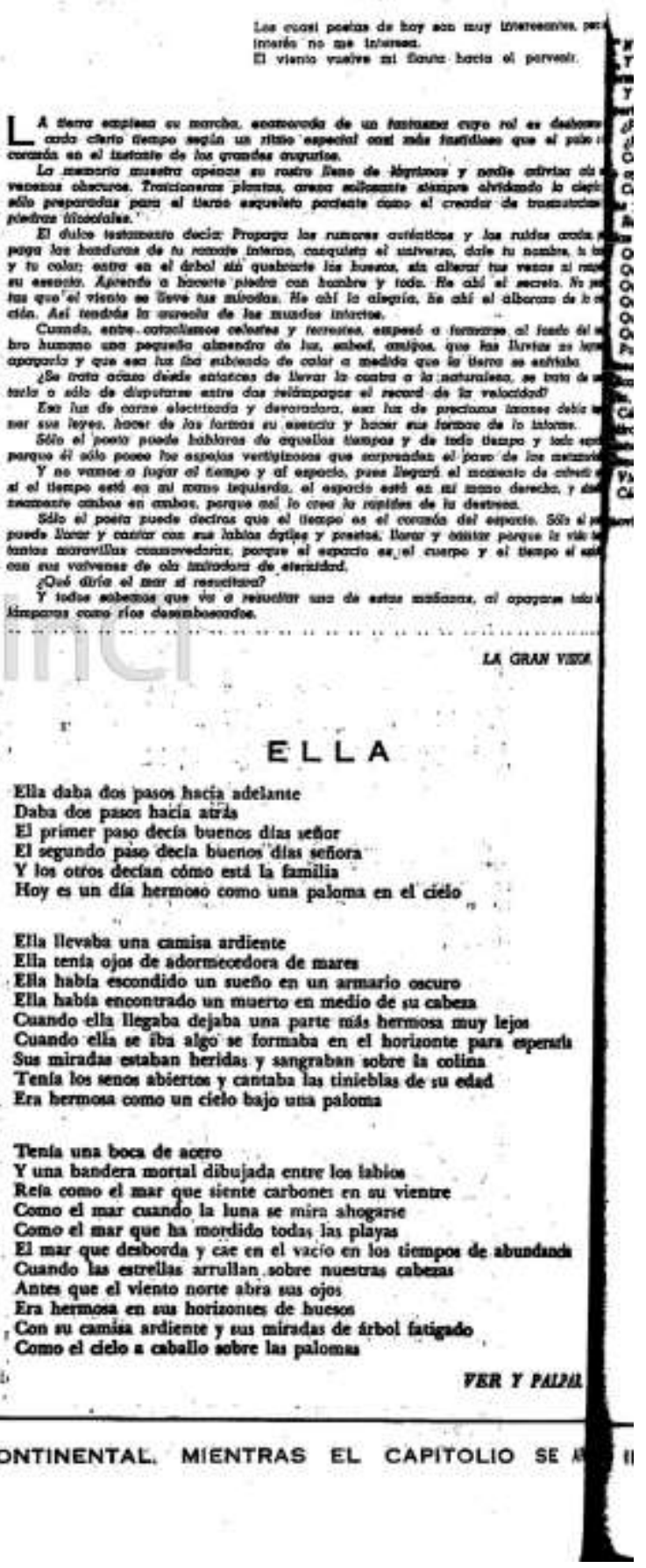

Imagen 32 - Frente de la poesía Americana 1 


\section{OESIA: AMERICA CESAR VALLEJO

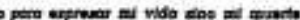

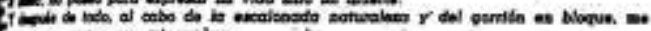

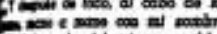

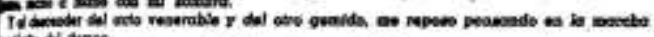 Notis anges

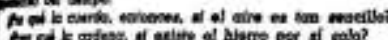

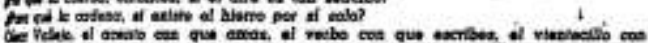

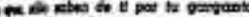

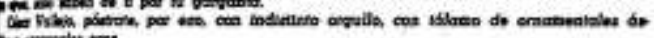

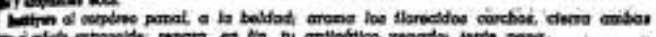

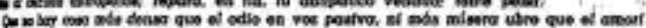

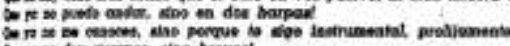

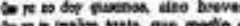 \\ On

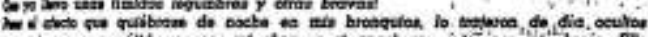

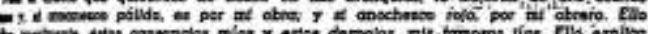

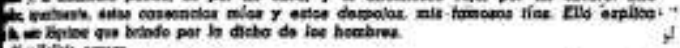

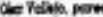

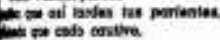 \\ itam

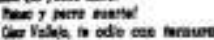 \\ ming in \\ porures moveros \\ PABLO NERUDA}

\section{A L I A N Z A}

De rindas polvorientas caidas al suelo

ode tojas sin sonido y sepuléádose.

De metale sin lus, con el vacio.

mo ba ausencia del dia muerto de golpe.

wo la ausencia del dia muerto de golpe,

el arancar de mariposas cuya luz no tiene termino.

Tá grardabas la etcha de luz, de geres raton

gue el wol abandonado, acardeciendo, arroja a las igleain:

tetida con miradas, con objeto de abejes,

is moterial de ineaperada tlama huyendo

Lon dias acechando cruan en sigile

peo caen adentro de tu vor de hin.

Oh butba del amor, en tu descanto

farde mi sueto, mi actitud callado.

Coa tra cuerpo de nímero timido, extendido de ptonto

twa las cantidades que definen is tierra,

deria de la pelea de los días blancos de espacio

firsos de muertes lentas y etimulos marchitos.

tetos arder to regazo y transitar tos betos

haderdo polondrinas frescas en mi owefos.

A vece el destino de tus Iygrimas avelende

was la edad hasta mi frente, alli

etin golpeando las olsu, deatruytndose de muerte: - i I

RESIDENCIA EN LA TIERRA.
SIN aceptar deliberamente nada, la entrado en la profundidad de las comas en un aćto de do dé pélomas digitales, con huellas de dientea y hielo, roido tal vez levemente por el sudor $y$ ef uso. Hasta alcanzar ean dulce superficie del instrumento tocsdo sin descanso'r resá suavidad durisima de la madera manejada, del orgullowo hierro. La flor, el trigo, el agúa'tienén también esa consiatencia eupecial, ese recurso de un magnifico tacto.

Hacia el camino del nocturno extiende los dedos la' grave estatua férrea de estatura implacable. Los cantos ain contulta, las manifertaciones del corrazón corren' con ansiedad a su dominio: la poderosa'estrella polar, el allheli planetario. las grandea sombras invaden el azul. El espacio, la magnitud 'herida se avecinan. Nó las frecuentan loa tuinerableo hijos de las capocidades y del tiempöo a' tiémpo. Mientras la infinita luciérnaga deshiace en polvò ardiendo gú cola fosf́́rica', los eatudiantés dé la tierra. los seguros géógrafos, los empresarios se deciden a dormir. Los nbogados, "los destinatarios.

'Solo solamente algún' casador apriaionado en medio de los bosques, agobiado de aluminio celeatial, estrellado por furiosas eatrellas, solemnemente levanta ls mano enguàntada y se golpeá el sitio del corazón.

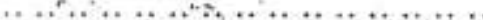

Como lava o' tinieblas, 'cotno temblor bestial, como camperinada 'sin rumbo, la poeaia me. te las manos en el miedo.

Yo hago la noche del soldädo el tiempo del hombre sin melancolia ni exterminio, del tipo tirndo lejos por el octano y una ola, $y$ que no sabe que el agún amnign lo ha separado $y$ que envejece, phulatinamente $y$ ain miedo, dedicado a lo normál de là vida, ain catncliamos, in ausencis, sin ausencines, viviendo adéntro de st piel $y^{\prime}$ 'de su traje," sinceramente obacuro. Asi, pues, me' veo con camninidas eatúpidos y ale gres, que fuman $y$ cecupen $\dot{y}$ horrendamente beben, y que de repente caen, enfermos de muerte.

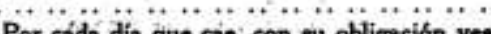

Por códn dí que cae; con uu obliģación veoperal dê suicuimbir, pasco,' haciendo' una guar dia innecesaria, $y$ paso entre los mercaderes mahometnnos, entre genté que adoran la cobre: paso yo, inadorable Ty cotnún' de roetro.

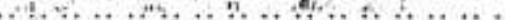

Yo tengo siempre predilëcciones por las grandes idens, $y$ aunque la literatura se me ofrece con grandes vacilaciones $y$ dudns, prefiero no hacer nada a eseribir beilablea o divertiones.

................................

Como ciudadano, soy hombre tranquilo, enemigo 'de' leyes, gobieinos e indtituciones estabecidas: Tengo repulsión por el burgsuée, y me kusta la vida de la gente intrangitila $e$ innatisfechn, sean Éstos 'artiatso o criminales.

MTIMO DERRUMBE $Y$ LA ASAMMBLEA EN LANZAS CLAUSURE MI DESFILE (C. V.)

Imagen 32 - frente de la poesía americana 2 


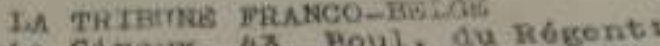

A Ia Cajerie Gix

Daux conférences eusvies do.

GEORGES BATATLLF, DTRACTEUR DE LA REVUIV " CRITIQUE *

GUPREALTSME FT FXISTVGWTAUISMM

(I) Maxal II ma1, is $20 \mathrm{~h} .15=$

(2) Mexorodi I2 mat, a $20 \mathrm{~h} .15$ - Jean-Paul Sarté, Mavelce Ba anchot

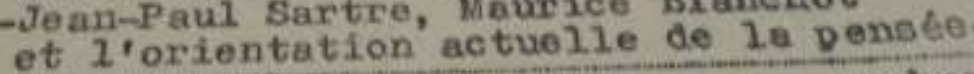

Places: 10 a 50 franes (Réduction aw membre Ranseignements a la Tribune Franco-Belge : PE1. 34.00 .77 -matj.né- 6, avenue GrLbavmon \& Galerie Giroux, lundi to $\mathrm{ms} 1$, de 4 aे 6 y

Imagen 33 - Serie de conferencias dictadas por Bataille en La Tribune Franco-Belge sobre surrealismo y existencialismo. 


\section{AnEXos}

A continuación se adjuntan tres tipos de materiales complementarios al desarrollo de la tesis doctoral. En primer lugar, las fichas técnicas de las revistas estudiadas en el corpus propuesto, a continuación agregamos datos sobre otras publicaciones citadas. Por último transcribimos algunos textos que fueron citados parcialmente en la tesis, para una consulta completa.

\subsection{ANEXO I. FICHAS TÉCNICAS}

\section{Ficha técnica de las revistas del corpus}

Título: Ciclo

Subtítulo: Arte, literatura, pensamiento modernos

Años de publicación: 1948 - 1949

Cantidad de números: 2

Lugar de edición: Buenos Aires

Directores: Aldo Pellegrini, Enrique Pichon-Rivière y Elías Piterbarg.

Administración: José David Sussman

Diagramación: Tomás Maldonado

Autores: Aldo Pellegrini, Edgar Bayley, Enrique Pichon-Rivière, Elías Piterbarg, Willy

Baranger, David Sussman, Mario Trejo, Sebastián Salazar Bondy, Najmen Grinfeld, Alfredo

Hlito; Henry Miller, George Bataille, René Char, Ernesto N. Rogers, André Breton, László

Moholy Nagy, Max Bill, Jean Cassou y Piet Mondrian

Ilustraciones: $\sin$ ilustraciones. En los artículos dedicados al arte moderno hay reproducción de obra impresa en papel especial

Manifiestos, programas y notas editoriales: no

Publicidad: publicidades afines, librerías, revistas, traductores. Mayormente en el segundo número y hacia el final de la revista.

Sección de novedades: Sí

Traductores: Aldo Pellegrini, Marcia Bastos, Bernardo Kordon

Impresión: Carlos Kordon / Taller de Boris Kordon e hijos. Bacacay 3800

Lectores y/o suscriptores: no especifica

Corresponsales y distribuidores: no especifica, pero figura un precio para el extranjero Precio, venta y periodicidad: $\$ 4$. Se había pensado como una revista bimestral, pero solo salieron dos números.

Título: Contemporánea

Subtítulo: La revolución en el arte

Años de publicación: 1948 - 1950 / 1956-1957

Cantidad de números: cuatro números en la primera época; dos números en la segunda época Lugar de edición: Buenos Aires

Director: Juan Jacobo Bajarlía 
Autores: Juan Carlos Lamadrid - Edgar Bayley - Juan N. Mele - Camilo Arden Quin - Matilde Werbin - Miguel Ángel Speroni - Antonio de Undurraga - Paul Eluard - Hans Arp - Michel Seuphor - Osvaldo Svanascini - Flausino E. Valle - entre otros. ${ }^{283}$

Ilustraciones: reproducciones de obra

Manifiestos, programas y notas editoriales: Sí - en el número 1, "manifiesto".

Publicidad: Sí - principalmente galerías de arte y otras revistas. Reunión. Publicación

trimestral; Caballo de fuego. Revista de poesía; Antú - Galería de Arte, representante exclusivo de Juan del Prete.

Sección de novedades: Sí - no necesariamente reseñas, novedades más generales del mundo del arte y literario.

Traductores: Juan Jacobo Bajarlía - Esteban Eitler

Impresión: Araujo Hermanos.

Lectores y/o suscriptores: no especifica en las páginas.

Corresponsales y distribuidores: Cerrito 466 - dirección postal.

Precio, venta y periodicidad: $\$ 0.60$ - sin periodicidad precisa

Título: poesía buenos aires

Subtítulo:

Años de publicación: 1950 - 1960

Cantidad de números: 30

Lugar de edición: Buenos Aires

Director: Raúl Gustavo Aguirre a lo largo de los 30 números. Jorge Enrique Móbili, Wolf

Roitman, Nicolás Espiro y Edgar Bayley en distintos períodos, la dirección.

Autores: La revista publicó más de doscientos autores a lo largo de diez años. Para un índice onomástico, ver la edición de la Biblioteca Nacional, disponible en pdf-online.

Diagramación: Nélida Fedullo.

Ilustraciones: no

Manifiestos, programas y notas editoriales: sí - a pesar de que la revista se pensó como superadora de los manifiestos, en los primeros 15 números es posible rastrear algunas notas que funcionan como programas de lo que la poesía debería ser y cómo se posicionan los miembros de poesía buenos aires al respecto.

Publicidad: no - la revista rechazó la posibilidad de tener publicidades

Sección de novedades: no - la revista buscó no parecerse a esas "publicaciones misceláneas" donde hay reseñas o noticias del mundo literario.

Traductores: Aguirre principalmente; Ramiro Casasbellas, Mario Trejo, Gabriella de Sanctis, Ludovico Rosenthal, Cirillo San Miguel, Enrique Mobili,

Impresión: Imprenta y editorial El Mangutino, Montes de Oca 1999. A partir del número 3 la imprenta pasa a ser Zaragoza, Santiago del Estero 1181

Lectores y/o suscriptores

Corresponsales y distribuidores: En el primer número se indica que "la correspondencia se recibe en Vallejos 2386. En el tercer número, en cambio, no solo aparece ya otra dirección para correspondencias - Velazco $1111^{\circ} \mathrm{B}$ - sino que además se indica un distribuidor en Córdoba, la librería Windekind, y se sugiere una suscripción anual de cuatro números a $\$ 10$, y de un dólar para el exterior. A partir del número 19/20 se incorpora la mención a la librería Krayd, en Buenos Aires, Tucumán 533, como "autorizada para recibir suscripciones".

Precio, venta y periodicidad: La periodicidad fue principalmente trimestral. Los precios que se registran son variables, y depende tanto de la cantidad de páginas por número como del año de publicación; el primer número tuvo un P.V.P. de $\$ 3$, segundo, de $\$ 1$, mientras que el número $19 / 20$, en “otoño-invierno 1955 ”, costaba $\$ 6$. En el número 7 se detalla la cantidad de ejemplares, 500 .

${ }^{283}$ Tanto en la hemeroteca del CEDINCI, Biblioteca Nacional, Hemeroteca de la Facultad de Filosofía y Letras de la UBA, Biblioteca Pública de la Universidad Nacional de La Plata, no hallamos los números dos $\mathrm{y}$ tres de la primera época. 
Título: A partir de cero

Subtítulo: Revista de poesía y antipoesía

Años de publicación: 1952 (números 1 y 2), septiembre de 1956 (segunda época, número 3)

Cantidad de números: 3

Lugar de edición: Buenos Aires.

Correspondencia. Primer y segundo número J. B. Alberdi $1496-1^{\circ}$ F. Segunda época: Enrique

Molina, Austria $1735,6^{\circ}$ piso, Depto. F.

Director: Enrique Molina (números 1 y 2). En el número 3 ya no hay más "dirección” y se indica una "Redacción", integrada por Carlos Latorre, Julio Llinás, F.J. Madariaga, Enrique Molina, Aldo Pellegrini y J. A. Vasco.

Autores: (no se distingue entre autores de poesía y ensayo, ordenados alfabéticamente en la publicación)

Número 1: C. Latorre, J. A. Llinás, E. Molina, César Moro, A. Pellegrini, Benjamin Peret, Giselle Prassinos.

Número 2: André Breton, Paul Eluard, Carlos Latorre, Enrique Molina, Aldo Pellegrini, Antonio Porchia, Georges Schehade, Juan A. Vasco

Número 3: Antonin Artaud, Leonora Carrington, Ingemar Gustafson, Enrique Molina, Aldo

Pellegrini, Carlos Latorre, Julio Llinás, Olga Orozco, Francisco José Madariaga, Blanca Varela, José Antonio Vasco.

Ilustraciones:

Número 1: dibujos de J. Batlle Planas

Número 2: no indica (suponemos por indagaciones, J. Batlle Planas)

Número 3: Juan Esteban Fassio, Enrique Molina, Álvaro Rodríguez, Julio Llinás, Martha

Peluffo, Carlos Latorre.

Manifiestos, programas y notas editoriales: los dos ensayos de Enrique Molina pueden considerarse como programas de la revista, aunque no están presentados así.

Publicidad: no tiene

Sección de novedades: no. Hay una sola "sección" o división de contenido titulada "Línea de fuego" que funciona como exposición de citas del surrealismo.

Traductores: en general las revistas se refieren a la traducción como "versión de" cuando se trata de poesía o narrativa, y como "traducción" cuando es ensayo.

Número 1. "El gran cheque" de Gisélle Prassinos, traducido por Enrique Molina. "Imperativo"

y "El cuadrado de la hipotenusa" de Benjamin Peret, traducido por Aldo Pellegrini

Número 2: En relación a los poemas de Georges Schehade, se indica "Versión de Aldo

Pellegrini". En la sección dedicada a Paul Eluard (ver)

Impresión: en el número 1 no figura

Lectores y/o suscriptores: no figura

Corresponsales y distribuidores: Correspondencia remitir a Enrique Molina

Precio, venta y periodicidad: no figura

Título: Letra y línea

Subtítulo: Revista de cultura contemporánea. Artes plásticas. Literatura. Teatro. Cine. Música. Crítica.

Años de publicación: 1953 - 1954

Cantidad de números: 4

Lugar de edición: Buenos Aires

Director: Aldo Pellegrini

Secretarios de Redacción: Osvaldo Svanascini y Mario Trejo

Comité de Redacción: Miguel Brascó, Carlos Latorre, Llinás de Santa Cruz, Enrique Molina, Alberto Vanasco, Ernesto B. Rodríguez.

Autores: Enrique Molina, Edgar Bayley, Oliverio Girondo, Tomás Maldonado, Juan C. Onetti, Osvaldo Svanascini, Mario Trejo, Alberto Vanasco, Juan Filloy, Norah Lange, Francisco José 
Madariaga, Juan Carlos Paz, Juan Esteban Fassio y otros. Textos de Tristán Tzara, Dylan Thomas, Alfred Jarry.

Ilustraciones: reproducciones de obra

Manifiestos, programas y notas editoriales: Editorial inicial, "Justificación"

Publicidad: Sí - de variada procedencia

Sección de novedades: Sí - ocupa un 30\% de la publicación y es motivo de debate interno

Traductores: Aldo Pellegrini, Osvado Svanascini, Enrique Molina, Miguel Brascó, principalmente

Impresión: no aparece explicitada. Una de las publicidades más destacadas es la de Imprenta López.

Lectores y/o suscriptores: no explicita lista de suscriptores

Corresponsales y distribuidores: Casilla de correo: 5289

Precio, venta y periodicidad: $\$ 3-$ se propuso como una revista mensual

\section{Otras publicaciones mencionadas en la tesis}

\section{Capricornio. Revista de literatura, artes y actualidades}

Primera época: Número 1 (julio 1953) - Número 8 (noviembre / diciembre 1954).

Segunda época: Número 1 (mayo/ julio 1965) - Número 3 (noviembre 1955)

Director: Bernardo Kordon

Colaboraciones de César Tiempo, Héctor Biancotti, Ernesto B. Rodríguez, Horacio Jorge Becco, Horacio Raúl Klappenbach, Bernardo E. Koremblit, Juan J. Sebreli, Arturo Cerretani, Luis Soler Cañas, Orgambide, García Martínez.

\section{Centro}

Noviembre de 1951 - en 1948 se había interrumpido Verbum.

Edita trece números.

En Centro está presente el grupo de jóvenes escritores que impulsará Contorno.

\section{Conjugación de Buenos Aires}

Primer número 1951. Dirigida por Edgar Bayley y Juan Carlos Lamadrid.

\section{Contorno}

Director: Ismael Viñas.

Luego: Ismael y David Viñas.

$\mathrm{N}^{\circ} 1$ : Noviembre de 1953 - $\mathrm{N}^{\circ}$ 9-10: Abril de 1959

\section{El 40}

Primer número 1951. Seis números a lo largo de dos años. Un grupo de integrantes de la "generación del 40" -César Fernández Moreno, León Benarós, Alberto Ponce de León, y otrosdan vida en plena primavera a "un órgano común y representativo de los poetas y escritores de nuestra promoción y no sólo de estos, sino de todos los que, por razones de convivencia personal o por incentivos puramente éticos, se sienten ligados a nuestro movimiento".

Nombres: César Rosales, Juan Rodolfo Wilcock, León Benarós, María Granata, César Fernández Moreno, José María Castiñeira de Dios, Eduardo J. Jonquiéres.

\section{Semirrecta}


Primer número: Agosto - septiembre 1952. Desde la exégesis filosófica a la indagación sobre poesía. Conrado Eggers Lan. Colaboraciones de Roberto Hurtado de Mendoza, Edgar Bayley, María Eugenia Valentié, Mario Jorge de Lellis, María Adela Agudo, Marcelo Núñez Achard, Julio Ardiles Gray.

\section{Serpentina}

Primavera 1957

Dirigida por: Tilo Wenner. Y un comité de redacción integrado por Luis E. Massa, Simón Kargieman y Raúl Quevedo. Línea de la exasperación de la forma poética. Aparecieron cuatro números con periodicidad trimestral.

\section{Ventana de Buenos Aires}

Primer número: noviembre de 1952.

Número 14: agosto de 1956

Mario Jorge de Lellis y Roberto Hurtado de Mendoza.

Colaboraron: José Portogalo, Alfredo Martínez Howard, Manrique Fernández Moreno, Hurtado de Mendoza, Raúl González Tuñón, Miguel Ángel Asturias, Córdova Iturburu, Klappenbach, Américo Calí, Luis Soler Cañas, Francisco Tomat Guido, Rafael Mauleón Castillo, Nicolás Olivari.

\subsection{ANEXO II. TRANSCRIPCIÓN DE TEXTOS CITADOS PARCIALMENTE}

\section{Polémica entre Osiris Troiani y Aldo Pellegrini}

Esta polémica fue suscitada por una reseña de Latorre en Letra y Línea $\mathrm{N}^{\circ}$ 3, donde a raíz de un número monográfico en la revista Sur dedicado a la nueva literatura italiana, cuestionaba que hubiera algo de novedad en ella. Meses más tarde, Osiris Troiani escribió una "Epístola a los surrealistas" que aparecería no en Letra y Línea, ni tampoco dirigida a Latorre, sino en la revista Capricornio - bajo la dirección de Bernardo Kordon - y con Aldo Pellegrini como destinatario. La respuesta de Pellegrini también se publicó en Capricornio, pero el final de la polémica se dio en la revista Contorno, en el famoso número dedicado a la historia de la novela argentina. Es un punto a destacar el hecho de que una sola polémica involucre a cuatro publicaciones periódicas, ya se trata de un aspecto relevante para pensar lo que en la tesis hemos llamado "bullicio de la crítica", atendiendo a la diversidad de espacios de intervención que modelaron formas de lectura. A continuación transcribimos el recorrido textual de la polémica, desde la reseña de Latorre en Sur hasta "Fin de un diálogo de sordos", firmado por Troiani en Contorno. 
- “Sur y la literatura italiana”. Carlos Latorre en Letra y Línea N³, diciembre 1953-enero 1954

Idéntico destino vincula a dos literaturas de las que marchan a la zaga del pensamiento y la ficción en Europa: la española y la italiana. Ambas viven del recuerdo del esplendor pasado, la primera del Siglo de Oro, la segunda del Renacimiento. Estos estupendos antecedentes que debieran servirles de catapulta y de brújula, consiguen en cambio maniatarlos, tornarlos nostálgicos, anacrónicos, afectados y reaccionarios como los viejos aristócratas empedernidos que se niegan a acusar el paso del tiempo y las diferencias reales que ese mismo tiempo impone. No nos toca aquí agotar las posibles relaciones de este paralelo. La literatura italiana constituye nuestro objetivo. Y esto debido al número especial que Sur acaba de dedicarle. Puesto a salvo el esfuerzo editorial y la dedicación responsable que esta selección supone, preferimos intentar un somero análisis de los valores específicos que informan las letras peninsulares y reducir nuestro elogio al sello editorial que con intención antológica los reúne, al reconocimiento del esfuerzo ya mencionado. En consecuencia, trataremos de censurar o justificar la limitada gravitación de los autores italianos en el ámbito de la poesía y la literatura contemporánea.

Nutridos por el esteticismo de Croce, la grandilocuencia y el decadentismo de D'Annunzio, el realismo naturalista del siglo pasado, la nefasta dirección de más de veinte años de fascismo, y el ciego afán tradicionalista del que casi todos aparecen contagiados, no sorprende demasiado descubrir el retraso de las letras italianas con respecto a las posiciones más osadas y clarividentes que asume la literatura de vanguardia.

Giovanni Papipi y el irracionalismo por un lado, y Marinetti con el futurismo que tanto iba a influenciar con su dinámica agresiva sobre los posteriores movimientos de vanguardia en Europa por el otro, no alcanzaron a limpiar, ni siquiera a sacudir el agua estancada en la que continúan hundiéndose la literatura y las artes peninsulares. Recorriendo las páginas del número especial de Sur es fácil comprobar lo que hasta aquí hemos afirmado. No solo lo admiten de una u otra manera los ensayistas cuyos trabajos figuran en la revista, sino que también lo traducen y mucho más claramente, los fragmentos, los poemas o los relatos que componen el frondoso material antológico. Están presente la mayoría de los autores más importantes de los últimos cincuenta años, muchos de ellos viejos conocidos nuestros traducidos y difundidos profusamente por editoriales y publicaciones locales.

Montale, ni Quasimodo, ni siquiera el mismo Ungaretti cuyo talento y calidad resultan indiscutibles, llegan, entre los ya consagrados, a deslumbrar totalmente; y en cuanto a los representantes de las nuevas promociones, ninguno de ellos acusa un verdadero deseo de romper los límites de una tradición que se revela incapaz de propiciar la operación poética profundamente renovadora o la ruptura indispensable con un mundo que se empeña en deformar y esclavizar la naturaleza y el sentimiento del hombre. Quizás lo más digno de destacar sean los ensayos o los panoramas mediante los cuales se trata de situar objetiva y sinceramente la verdadera dimensión del trabajo de creación en sus múltiples aspectos en esa Italia decepcionante sometida a las clásicas maneras de expresión.

La sociología convencional, la literatura de "opinión", preferentemente política, el lirismo al uso, el hermetismo escapista, deformada herencia del simbolismo; la psicología elemental, la ausencia de espíritu innovador y de audacia verdaderamente revolucionaria, constituyen las limitaciones que, sumadas a las ya citadas anteriormente (realismo narrativo, servilismo hacia las viejas manejas, nostalgia de un antiguo esplendor ya remoto, cierta exuberancia estilística, patrioterismo, etc.) descalifican a la poesía y la literatura italiana para figurar el lugar de privilegio que todos deseamos para ella.

Si el espacio lo permitiera sería posible poner a salvo el mérito de algunas firmas que integran la selección. Ricardo Baccheli con "La verdad sobre el pavoroso caso Mary Bonfield", tenso relato en el que se mezclan afortunadamente el humor y el horror, por ejemplo; y algunos otros trabajos que no pueden ser citados sin comentarios justificatorios más extensos, no bastan, sin embargo, para salvar 
una muestra que en su conjunto da el tono exacto de una literatura que está situada a apreciable distancia de toda verdadera peripecia actual y de toda lucidez salvadora.

Carlos Latorre

- "Epístola a los surrealistas", Osiris Troiani. En Capricornio 5/6, septiembre 1955.

\section{Amigo Aldo Pellegrini:}

Apuesto a que colaboradores y lectores de Letra y Línea se han sentido incómodos ante esa noticia insustancial con que Latorre, en el número 3, sepultó bajo su desprecio a toda la literatura italiana (y de paso a la española). El desenfado me parece bien (aunque allí no veo la gracia traviesa que es su tono natural, sino la perorata de un señor que se toma demasiado en serio). Pero no confundamos el desenfado con la ignorancia temeraria y la estrechez de espíritu. Alguien tenía que señalarle a la simpática hueste que usted anima el peligro de que su combatividad se degrade en el mero ejercicio del pasquinismo literario; como esa inepcia trivial me ha dolido (no por la literatura italiana sino por Letra y Línea) ese alguien seré yo.

Latorre imagina a los italianos de hoy "nutridos por el esteticismo de Croce, la grandielocuencia (sic) y el decadentismo de D'Annunzio". No podía yo suponer en nuestro vehemente amigo tamaña afición al lugar común. Solo a un presuroso gacetillero de $5^{\mathrm{a}}$ edición podría ocurrírsele caracterizar la moderna literatura italiana con esos dos nombres que forman parte de la erudición de mi peluquero. En Italia han pasado ya por tres fases póstumas de la gloria literaria: aversión (excesiva) de las nuevas generaciones; olvido (primero voluntario y después sinceramente indiferente); inserción objetiva en la historia de la literatura. Ya ni siquiera se reacciona contra esos nombres, que son nombres de calles y plazas. Las letras italianas de hoy se han rebelado contra Ungaretti y Moravia, que ya habían arreglado sus cuentas con Croce y D'Annunzio cuando nosotros nacimos. Las grandes sombras que estorban hoy a los jóvenes se llaman, en filosofía, Carabellese, Varisco, Banfi, Calogero; poetas como Luzi, Montale, Gatto, Penna; críticos como Serra, Cecchi, Apolonio, Bo. Que conocieron el surrealismo en su fase activa y no, como Latorre, el que hoy se sobreviene penosamente.

$\mathrm{Y}$ aquí hemos llegado al punto donde usted y yo, Pellegrini, debíamos explicarnos cordialmente, lejos de los cachorros de tigre que usted ha criado y que ahora, ¿no es cierto?, le intimidan un poco, no vayan a acusarle de herejía, de blasfemar contra el dogma surrealista. Nada más desgarrador que el asombrado silencio de los jóvenes a quienes hemos revelado una verdad nueva y ardiente, cuando descubren que esa verdad no nos interesaba sino como medio de interesarlos. No era insinceridad, era un malentendido: ellos buscaban una certeza en nuestro saber y nosotros en su entusiasmo.

Forman ustedes un grupo iconoclasta que, en este clima de repugnante conformismo, tardaba demasiado en manifestarse. Otro tanto hizo el movimiento Martín Fierro, pero aquellos muchachos tenían el don del gracejo, y así su ironía era saludable e intempestiva, como el ozono que purifica la atmósfera después de la tormenta. Quite usted el ingenio, tendrá la ironía forzada, malévola, y podrá leer en ella toda una gama de feas pasiones (no he dicho perversas, sino algo peor: inelegantes). Por lo demás, no puedo comprender que ustedes se interesen tanto por arruinar la reputación de Bernárdez, Molinari, González Lanuza, Wilcock, Silvina Ocampo, Julio Payró. Esas gentes aún explotan su modesta gloria literaria, pero solo entre unos cuantos papanatas, y ustedes no escriben para ellos, se supone. ¿Le parece a usted realmente una hazaña hendir puertas abiertas?

La guerrilla en que se regodea Letra y Línea es faena secundaria, y debería ser ingrata. La función de la crítica, ya se sabe, consiste en discernir valores, ayudar al artista a tomar conciencia de sí mismo, como he visto en el leal artículo de Molina sobre Guibert. Pero Molina, en ese caso, era 
infiel (enhorabuena) a la mentalidad que podríamos llamar "a partir de cero". Yo no creo que solo la que hace tabla rasa con toda la cultura precedente merezca el nombre de nueva generación, o de vanguardia literaria. A mí me gustan los jóvenes que empiezan por sentirse responsables del patrimonio literario de su patria, o de su lengua. (Perdamos el horror a las palabras, que es un prejuicio estúpido, y hablemos como hablaban los hombres que buscaban la grandeza en sí mismos en vez de ridiculizarla en los demás). Me gustan los jóvenes que dicen: amo la gloria, la mía si ustedes quieren, pero no puedo evitar que mi gloria sea también la de los míos; aspiro a que un día viva en mis nietos algo más que mi sangre, pero yo también he recibido una herencia; todo lo bello y fuerte y noble que se ha hecho (o se hace) en este país, es mío; yo lo amo, lo defiendo, lo enriquezco.

Ustedes le han tomado el pelo a Rojas. Convenido, don Ricardo es un personaje anacrónico, no se distingue por una fina sensibilidad ni por el "voltaje" de su espíritu. Pero ha hecho en Argentina la obra de varias generaciones, como en España la escuela de Menéndez Pidal. Aquí no tenemos una "escuela", solo tenemos a este hombre de ideas confusas y de triunfante energía. ¿Por qué le niegan ustedes el placer senil de un Premio Nobel, si el Premio Nobel no significa nada sino para el que lo recibe? Cuando uno de ustedes habló de su "incalificable" Historia, me convencí de que no la había leído.

¿Cómo van a hacer ustedes algo vivo, perdurable, cargado de calor y de temblor, si solo piensan en su tertulia de café? ¿Cómo van a incorporarse a una comunidad histórica, a derramarse en su sistema circulatorio, si no empiezan por descifrar - y por quebrantar, desde luego - las tablas de valores de $s u$ comunidad y de $s u$ tiempo? El concepto de nueva generación debe entenderse en un sentido funcional: eso lo comprende hasta Guillermo de Torre a pesar de sus prolijas y enfadosas digresiones sobre el tema. Una nueva generación es el eco de un nuevo consenso y, a su vez, rehace la historia literaria. Los surrealistas franceses, en su insurrección contra toda una literatura en la que veían la amable máscara de una sociedad horrorosa, resucitaban a Lautréamont, buscaban en el macabro O'Neddy, en el opiómano Rabbe, en Borel el licántropo las voces amigas que respondiesen a su desborde vital y a su desesperación. A partir de cero no se va a ninguna parte, se queda uno en cero.

No pretendo que Brascó, para hacer una crítica eficiente del hermoso libro de Guibert, no tuviera otro medio que escribir un libro mejor; podía también, aunque la maleza le estorbara el paso, meterse en ella, dejarla a sus espaldas e ir en busca del corazón del poema. Sartre se inclinaba con fervor sobre la obra de Giacometti, de Césaire, y escribe la más voluminosa de sus obras para sacar de la oscuridad a Gênet; su fervor encendido hace más bella, más comunicativa su prosa; la generosidad, la nobleza, si tibias, extravían el juicio; si exaltadas, lo iluminan, son virtudes esencialmente críticas. Si usted me permite, Pellegrini, lo mejor que ha publicado su revista (aparte de los poemas de Girondo, muestra prepotente de capacidad inventiva y de voluntad poética) ha sido el sencillo artículo de Vanasco sobre Arlt, porque concedía talento y autenticidad a un réprobo (todo aquel a quien le importan un comino el surrealismo y el arte abstracto es un réprobo) y porque hablaba bien de un mal escritor. Me explicaré: había centenares de frases huecas, pueriles, y decenas de páginas incongruentes, para demostrar que Arlt padecía una incultura casi salvaje y tenía un caos en la cabeza. Hubiera sido más fácil poner en ridículo a Roberto Arlt que a César Rosales. Pero Vanasco desdeñó la oportunidad de probar su agudeza a expensas del prójimo: proclamó - y eso es lo esencial - que su instinto narrativo era una fuerza natural, un torrente, y que fue si no el único novelista argentino, el único que no vino de la burguesía, por lo que supo ver la vida a lo ancho, sin las limitaciones de la óptica de clase, y por menos convencional más bella.

¡Cuánto mal hacen las revistas literarias, Pellegrini! (No a los pocos que la leen sino a los muchos que la escriben). Cultivan una literatura de entrenamiento. Crean una vecindad propicia entre el lector y el autor, pero con la condición de que este se resigne al menor esfuerzo, a la ligereza, a la frivolidad. Imprimen a los colaboradores el sello de "la casa". La personalidad que cada autor cobra en la revista se sobrepone, domina a la suya propia. Obligan a hacer política literaria. Degeneran en asociaciones de bombo mutuo. Y así salen los Ernesto Sábato. A veces, la madera es buena: Murena, 
por ejemplo, que no pertenecía a la secta de los Solemnes ni a la de los Delicados. Su sinceridad vibrante y descomedida, las resonancias catilinarias de su seudónimo importaban un desafío. ¿Cómo harían para neutralizarlo? El hecho mismo de que ambas sectas le acogieran con los brazos abiertos le despojaba de lo más valioso que todos tenemos: el derecho a ser odiado por quienes uno odia. (Shaw, durante un siglo, le dijo al burgués provocativamente, mirándole a los ojos: Eres una carroña. Pero el burgués se levantó de su asiento y gritó: ¡Qué bueno! G.B.S. tiene razón. ¡Muera la burguesía! Contra esa jugarreta no hay defensa, mi viejo amigo). Un día Murena descubrió América, todos lo celebraron, ya no habla de otra cosa y ha venido a ser inocuo.

Pero volvamos al surrealismo.

La poesía y la crítica que ustedes proponen, la música y la pintura que les gusta son las de la primera posguerra. Mira uno la fecha de los cuadros y siempre es 1915, 1919, 1924. Tengo la impresión de entrar en una de esas salas antiguas con los sillones enfundados y con una claraboya que difunde su tristeza. Todo eso está muerto, irremediablemente muerto, y pertenece al buen tiempo viejo; el de Cocteau, el de Satie, el del Bateau-Lavoir; cuando Francia aun prestaba dinero (por entonces, esperaba cobrar los empréstitos rusos) y cuando las rentas de la burguesía alcanzaban para la dote de la chica y las extravagancias del hijo varón. Era la época de las "conversiones": se convertía uno al catolicismo, al comunismo, a la pederastía (o todo a la vez).

¿Valdrá la pena referir una vez más la historia de esa carrera hacia la libertad desenfrenada, que no tardó, como es natural, en tener su dogma, sus concilios, sus herejías, sus luchas a mano armada? Todos los que hoy significan algo en las letras francesas tienen un origen surrealista. Todos, fieles al espíritu del movimiento, han seguido transformándose, vivido distintas aventuras, abandonado los excesos que suscitaba la polémica misma, elaborado su propio lenguaje, a veces de una pureza y desnudez franciscanas (como la de Eluard). Todos, menos uno. Mientras aquellos ahondaban en su Lautréamont y en la poesía viva del pasado, y se entregaban a la necesaria ilusión de transformar el mundo que Rimbaud compartía con Marx, uno, prisionero de su panel de pontífice implacable, siguió proponiéndose a la admiración de los árabes y los sudamericanos que visitaban París. Lo que había en el surrealismo de gozosa mistificación (y este es un elemento precioso en el arte, pero amalgamado con otros de más recónditas virtudes) se polarizó en Breton; lo que en él había de diletante (reivindiquemos el noble epíteto con que se designa a todo espíritu abierto a lo nuevo) se enquistó en una mentalidad de militante, en una frecuente psicología de faccioso autoritario. Él, que se quedó en la taberna donde el grupo juvenil había estado de paso para echar un trago, es ahora dueño del negocio, está detrás del mostrador, se dedica sobre todo a la exportación de pretendidos alcaloides; y desde ese puesto mezquino y confortable persigue con sus sarcasmos y con su odio tenaz a los que se embarcaron. Breton no es surrealista: ha petrificado el surrealismo. Su incompetencia filosófica (nunca he comprendido por qué desdeña Sartre, por ejemplo, dispararle el tiro de gracia) su psicoanálisis mal digerido, su fondo de anarquismo vulgar y su típico resentimiento intelectual, le condenaban a vivir de su pasado, a mantenerse en una actitud extremista que solo acompaña a la irresponsabilidad.

Y he aquí que treinta años después, en una ciudad con un horrible obelisco y unos cementerios sin nobleza alguna, aparece un surrealismo a destiempo. Y es el surrealismo de Breton. ¿Dónde está el buen tiempo de la vida barata y las esperanzas fáciles, dónde los soldados vuelven del frente con ganas de cobrarse su cuenta pero se distraen en la bacanal que paga el profiteur, dónde la industria del libro que imprima plaquetas de lujo para exportarlas con potiches y bibelots? Ahora y aquí hacemos una revolución industrial (demorada, tímida); los sindicatos están con ganas de transformarse en Estado; comemos, vestimos, viajamos y habitamos mal (pero comemos todos); y como nuestra patria es chica para tener una política mundial y a nosotros nos repugna la política pequeña, hemos recordado que tenemos otra patria mayor, la de todos los que hablan nuestra lengua, y vamos a rehacerla con el trabajo de generaciones. En medio de esta visa rica, fecunda, ambiciosa, ¡qué anacrónica y exótica es una literatura que se veda los grandes temas de la filosofía, la política, la religión (el existencialismo, 
el marxismo, el catolicismo han sabido, en cambio, identificarse con la hora presente), una literatura que desprecia los clásicos e ignora el mundo moderno!

El vanguardismo por principio es un nuevo academicismo: importa una beata inactualidad y la suspensión del espíritu crítico. No puede uno declarar que tal artículo de Kandinsky es de una desoladora inanidad, que Picabia era un bon viveur y nada más. Hay que jurar que Mondrian nunca ha dicho una estupidez y reunir los catálogos de las exposiciones que se hicieron en Budapest o La Haya en 1920. El surrealismo argentino, para colmo, rinde tributo a los consagrados cuando son extranjeros y aquí se muestra intratable, es oficialista en Europa y aquí opositor. Nos ayuda a librarnos de la literatura de tema único que se practicaba hasta ahora, esa vulgaridad trasnochada del individualismo, del apartamiento melancólico y despectivo, pero no cae en la cuenta de que está haciendo poesía dominical de 1960. Acepta a Char sin comprender que es un clásico, y exonera a Césaire porque no accede a disociar en sí el poeta del político. Retarda la hora en que descubriremos a Tardieu, Guillevic, Audiberti, porque han enriquecido la estética surrealista. Ejecuta sumariamente a libros, autores y países enteros, porque piensa que todo lo que no es surrealista es detestable (criterio faccioso que le ha transmitido Breton, en quien se da, insisto, la paradoja ridícula de una ideología de diletante en una psicología de militante, seca e imperativa). Y no se le ocurre pensar que su juicio sobre la nueva literatura italiana, conocida a través del número especial de una revista, es tan aventurado como el de los surrealistas italianos que escribieran sobre nuestra poesía sin conocer a Latorre, Svanascini o Vanasco.

Querido Pellegrini: nuestras charlas de café, siempre gratas, no siempre permiten ser sinceros; la perfecta comunicación se resiste al lenguaje sumario, tosco y brutal de todos los días. Bástele con saber que mi amistad por usted, por los muchachos de Letra y Línea, ella sí es sincera. Usted no estará de acuerdo, pero excusará mi vehemencia. Tengo mis razones: es preciso destruir el provincialismo de nuestra literatura, la poesía bonita, el mero lujo verbal. Estamos maduros para esa obra. Va a inaugurarse la gran poesía, que busca sus temas en la conciencia, en la vida moral del individuo, que cavila y se debate entre el bien y el mal, que azota a los fariseos en paz consigo mismos, que no consuela sino que atormenta. Ese tormento es necesario y es precioso: aquellos a quienes toque no se sumarán al abyecto hedonismo de masas que degrada a nuestra civilización y que, desde el norte cretinizado y frenético, amenaza también a nuestro país. Ya lo ve usted, nos hace falta no solo una revolución en nuestra poesía, sino también una Poesía y una Revolución. Aunque las dos palabras apareadas constituyen una redundancia: una y otra nos proyectan hacia una vida más bella. Y una revolución se hace con todos, aun con aquellos que, separados de nosotros por una cortina de malentendidos y ofuscaciones, convienen en que es necesario hacerla y que vale la pena.

Hasta siempre.

O.T.

- “Respuesta a Osiris Troiani”, Aldo Pellegrini. N7, Capricornio, septiembre-octubre 1954

Estimado Troiani:

He leído atentamente su carta y creo que debo contestarle. No es fácil hacerlo, porque yo sí me he sentido amigo suyo y el tono de su carta no invita a una respuesta amistosa. No por el hecho de discutir mis ideas y las de mis amigos, sino por la salsa de inexactitudes, afirmaciones gratuitas, incongruencias y especialmente por las actitudes de vidente con que pretende descubrir mi pensamiento secreto siempre del modo más desfavorable. Se dará cuenta usted que todo eso no resulta un buen condimento para la amistad. Pero ya que he hecho afirmaciones sobre su carta quiero 
adelantarle las razones de lo que digo: usted acude por ejemplo a afirmaciones inexactas cuando nos endosa una admiración por Cocteau y René Char que no existe y nos adjudica un repudio por Aimé Césaire que es, en cambio, demostrada admiración total. Cae en incongruencia cuando asesina a Latorre a causa de su falta de respeto por la literatura italiana y a renglón seguido liquida de un plumazo el pensamiento de Breton, Kandinsky y Mondrian. Nos atribuye admiración por todo lo extranjero si es consagrado y no se da cuenta de su flagrante contradicción ya que Latorre discute a los italianos que son extranjeros consagrados. Y en este último punto, si se me ocurriera imitar su estilo tendría que decir lo siguiente:

"Vamos, amigo Troiani, yo que lo conozco bien, sé lo que en realidad usted piensa; hablemos con las cartas sobre la mesa: ¿no es cierto que usted está conmigo en que el neo-realismo italiano es solo un conglomerado de bodrios?" Y siempre siguiendo su estilo agregaría: "Yo sé que usted no es nada tonto, entonces, amigo Troiani, ahora que estamos en tren de confianza, quítese la capa y dígame: ¿qué juego se oculta detrás de todo este ataque a Letra y Línea?"

Pero no; creo que por estar planteada nuestra diferencia frente al público, este se merece más consideración y debo contestarle seriamente. Tiene usted el mérito de haber intentado recopilar, por primera vez y de modo frontal, una argumentación contra nosotros. Digo recopilar, porque como usted perfectamente sabe, muchos de sus argumentos son los que nos lanzan habitualmente desde hace un tiempo. Usted les ha agregado, sin duda, la salsa que menciono más arriba.

Ya de partida comete un error al asociar Letra y Línea con los surrealistas, error que no le van a perdonar la mayor parte de los colaboradores de la revista. De los nueve nombres que figuran en la nómina inicial, solo tres se declaran surrealistas: Latorre, Molina y yo. De los otros, algunos se consideran (y no tienen reparos en declararlo) enemigos francos de dicha ideología. La revista -como aparece claramente en su justificación del primer número y se repite en los siguientes-admite toda clase de colaboraciones dentro de un criterio de amplia modernidad.

Afirma después que somos un grupo iconoclasta y eso parece interesarle, pero a renglón seguido nos destruye comparándonos con el grupo Martin Fierro, "que tenían el don del gracejo". Si la travesura es lo que a usted le interesa en toda aventura del espíritu, resulta evidente que no puede encontrarla en nosotros. La nuestra no es una iniciativa deportiva; desgraciadamente para los que piensan como usted, nos tomamos en serio el mundo y la vida y hacemos prédica del mal humor o simplemente del humor (condición que está en el polo opuesto del gracejo).

Estoy -como todo el mundo- de acuerdo con usted en que es misión de la crítica discernir valores. Eso intentamos hacer nosotros; no comprendo, por lo tanto, por qué le disgusta. Nuestra mentalidad "a partir de O" no trata de tabla rasa de toda la cultura precedente (además, usted mismo se contradice al decir más adelante, que nosotros solo pensamos en función de un pasado muerto), sino que hacemos tabla rasa de la falsa cultura y nunca damos nada por admitido sin examinarlo previamente. ¿No le parece que esa tarea de revalorizar el pasado compete normalmente a toda generación?

No creo que sea tarea menor rectificar los valores considerados vivientes e inamovibles. Es un deber frente al público engañado y aun frente a los más lúcidos que desesperan de toda posibilidad cultural en el país. La nuestra implica, en definitiva, una crítica de la crítica, al tratar de rectificar los errores de apreciadores ineptos o los enjuagues de camarillas literarias o artísticas autobombistas. Cuando usted mismo se permite enumerar una serie de escritores argentinos y considerarlos aptos para papanatas (juicio despectivo hacia el público que es injusto y además extraño en usted) lo hace con tal naturalidad gracias a que Letra y Linea ha abierto el camino de una revalorización.

Si nosotros proponemos la poesía y pintura surgida en el primer cuarto de siglo es porque sus autores representan nuestros clásicos. Los artistas de hoy son descendientes directos de ellos, así como ellos lo fueron a su vez de otros anteriores a quienes respetaron y admiraron. ¿Resulta eso extraño? ¿Resulta extraño que nuestros maestros sean Apollinaire, Jarry, Reverdy, Artaud, Breton? ¿Resulta extraño que los pintores nuevos admiren al Picasso de las luchas por el cubismo, a Delauney, a Kandinsky, a Klee, a Mondrian? La influencia de estos grandes creadores se ha producido en extensión 
y profundidad y hoy ni siquiera los reaccionarios están libres de ella. Pero nosotros combatimos también a los mercachifles y mistificadores de lo moderno, por eso rechazamos a Cocteau que usted nos enjareta tan gratuitamente. Y esa es gran parte también de la tarea de una generación: valorizar el aporte de lo pasado inmediato, deslindar lo verdadero de lo falso.

La afirmación de que el vanguardismo por principio es un nuevo academicismo resulta bastante extraña. Quizás se deba a que no ha expresado claramente algo en que posiblemente estemos de acuerdo: mezclados siempre con los verdaderos creadores de un mundo nuevo se encuentran los factores de material de vanguardia para tontos, los fabricantes de "pastiches". Todo esto inevitable, siempre ha sucedido y constituye la revancha de los mediocres. Pero tal cosa no ha invalidado nunca a ningún movimiento renovador.

$\mathrm{Su}$ juicio contra Picabia es tan categórico que me hace sospechar su desconocimiento de la obra de este extraordinario personaje de la vanguardia artística de nuestro siglo. La influencia de Picabia no resulta tanto de su obra (de las que quedan sin embargo, ejemplos notables de permanente validez; su obra poética, por ejemplo, aunque no muy abundante tiene excepcional calidad) como de su actitud e influencia personal. Pertenece a la serie de hombres ejemplares, tipo socrático, cuya conducta y palabra dejan una influencia perdurable. En el mismo sentido, la influencia de su amigo Duchamp es considerable, y si usted tuviera en cuenta solamente el volumen de la obra realizada por él, debería considerarlo, de acuerdo con su criterio, simplemente un jugador de ajedrez.

Entre otras afirmaciones gratuitas, usted enuncia que aceptamos a Char y rechazamos a Césaire. No puedo comprender en qué se funda esta convicción, pero por lo menos revela que no ha leído sino muy parcialmente nuestra revista. En efecto, en el primer número de Letra y Línea aparece un extenso artículo de Molina dedicado a exaltar del modo más admirativo posible la figura de Césaire. Y para terminar con todo malentendido debo declararle que de ningún modo admiro a Char a quien considero no un clásico sino un académico, vanguardista para horteras y profesores de enseñanza de literaria, que hace el pastiche de las "Iluminaciones" vistiéndolas a los Racine y que no tiene más "Furor y misterio" que en los títulos. A él oponemos el verdadero furor y misterio de Césaire cuya obra despierta nuestra admiración sin reservas.

Por otra parte la razón por la cual tardamos en hablar de Tardieu, Gullevic y Audiberti es porque se trata simplemente de poetas menores, sin originalidad. Ninguna razón sino una elección al azar puede haber inducido a preferirlos a Verdet, Tourky o Ganzo, que tienen - por orden características similares. Otros son los poetas que nos interesan por aportar una voz realmente nueva y los irá usted conociendo si lee nuestra revista. Como usted ve, no aceptamos con facilidad lo extranjero.

Le declaro que no entiendo qué quiere decir con sus alusiones a los escritos de Kandinsky y Mondrian y menos qué relación tienen dichos artistas con el surrealismo (porque no creo que usted adhiera a la opinión popular que designa a toda manifestación de vanguardia como surrealismo, así como antes se la llamaba futurismo. Debo confesarle que nunca he roto lanzas por defender los textos de Kandinsky o Mondrian y que ellos me interesan enormemente como pintores. De todos modos esos textos - en lenguaje que seguramente no responde al más estricto rigor filosófico, ni lo pretenden contienen ideas luminosas y reflexiones de inestimable valor para quienes se interesan por la evolución del pensamiento artístico. Ese es el valor de tales textos, el mismo valor que tienen los textos de Leonardo. Su tono despectivo resulta, pues, fuera de lugar.

Y pasemos ahora al surrealismo que parecería ser el motivo fundamental de su carta. Como lo hacen todos los enemigos de esa ideología se apresura usted a darlo por muerto, mejor dicho, a recitarle una oración fúnebre sin más trámites. ¿No le parece un poco extraño que desde el día de su nacimiento hasta la fecha todos los años se entierre sistemáticamente al surrealismo, corriendo la reacción con todos los gastos? Desde hace exactamente treinta años pasa lo mismo y me parece ya demasiado entierro repetido para un solo cadáver. Por lo menos indicaría que el surrealismo se niega a morir, a pesar de las seductoras y solemnes exequias que se le ofrecen. 
El segundo paso que todo el mundo realiza después de la oración fúnebre al surrealismo es el ataque a Breton y en eso sí que usted es original, porque se le ha ido realmente la mano. He conversado con enemigos mortales de Breton y ninguno llega ni de lejos a lo que usted afirma, y no llegan tan lejos simplemente para no caer en lo ridículo. Usted dice que Breton no es filósofo y tiene razón porque no solo Breton no pretende serlo sino que repudia directamente todo pensamiento especulativo. No siendo filósofo no puede ser liquidado como filósofo. Quizás usted quiera referirse a su labor doctrinaria (palabra que no me disgusta por su sabor subalterno) en la que Breton ha codificado o mejor ha reunido determinados principios que los surrealistas consideran fundamento de su ideología. Hacer una declaración de principios, si bien significa tomar una posición frente al mundo, no implica una filosofía sistemática y es obra que realiza consciente o inconscientemente todo ser humano. En realidad Breton es esencialmente un poeta, uno de los más importantes de este siglo, aunque su obra tenga consecuencias filosóficas.

$\mathrm{Y}$ entremos a aclarar algunos malentendidos sobre el surrealismo que tiene el curioso mérito de ser una ideología generalmente desconocida por quienes la combaten.

El surrealismo no es la creación de un solo hombre y en su formación han confluido todas las corrientes que señalan la insurrección esencial del hombre del siglo XX. Esta insurrección abarca todos los planos de la actividad humana y no es puramente estética como pretenden algunos. Deteniéndonos, sin embargo, en este terreno, se ha producido desde comienzos de siglo una profunda conmoción en las convicciones estéticas del hombre actual. Podríamos sintetizarla como derrumbe definitivo de la noción de canon heredada de la cultura grecolatina. El arte se hace más universal al aceptar el valor estético de los productos de otras civilizaciones desde los primitivos hasta los pueblos orientales, incluyendo los denominados salvajes. En el plano de la pintura se ha desarrollado la revolución más importante, pues de todas las artes era la más sometida a la consigna aristotélica de la imitación.

Pero las realizaciones estéticas no son para el surrealismo más que uno de los factores de la liberación del hombre. $\mathrm{Y}$ en este sentido, para quienes consideran erróneamente al surrealismo un movimiento pesimista, vale aclarar que nada hay más optimista que creer en la libertad integral. Los surrealistas la creen posible en una futura edad de oro. Creen en un hombre libre sin represiones y con la posibilidad de realizarse íntegramente. Creen en un destino humano para el hombre. En lo que no creen es en la sonrisa imbécil y convencional de los que intentan disfrazar la vaciedad y la carencia de rumbos. El optimismo no consiste en la aceptación cándida de que vivimos en el mejor de los mundos posibles. El surrealismo señala la situación angustiosa del hombre del presente, pero no la considera sin salida, lucha por señalar la existencia de esa salida y combate los obstáculos que se la ocultan; entre ellos, un obstáculo que habita en el interior mismo del hombre: el de las convenciones. Por eso el surrealismo es esencialmente disconformista y fundamentalmente optimista.

El pensamiento surrealista es antidogmático (por eso no puede hablarse de ortodoxia en el sentido en que usted lo hace). Sus características son la fluidez dialéctica (en el gran significado de esta palabra, hoy tan desprestigiada) confrontándose con las circunstancias y exponiéndose a juicio continuamente. La superrealidad no significa vivir en un mundo extraterreno sino vivir en la única y verdadera objetividad: la unión de los mundos exterior e interior del hombre. Esta misma concepción holística vale para lo social, en la que el concepto de masa no anula al hombre sino que lo incorpora.

Todo esto para explicarle que cuando se refiere a mí como temiendo caer en heterodoxias, puede quedarse tranquilo porque me declaro surrealista por el hecho mismo de ser fundamentalmente heterodoxo y el surrealismo no me impone más dogma que el de la libertad integral. En ese sentido no he dejado de chocar con las opiniones de algunos surrealistas amigos. El homenaje que preparé para Eluard en A partir de cero, mi artículo sobre "Surrealismo y Arte Concreto" en Nueva visión han sido motivo de disgusto para algunos, pero no cometo la debilidad de atribuir a la doctrina, lo que es defecto de interpretación de los hombres.

De todos modos formamos en este momento los surrealistas en Argentina un grupo de camaradas, ligados por una amistad fraternal sin ejemplo y poseídos del mismo fervor. Conviene que 
conozca sus nombre para no equivocarse en adelante: son ellos hasta este momento: Carlos Latorre, Francisco José Madariaga, Enrique Molina, Juan Antonio Vasco, Juan Esteban Fasio y yo. Y no menciono a una multitud de amigos que piensan como nosotros y nos apoyan.

En el párrafo final de su carta dice que es necesario destruir el provincialismo de nuestra literatura. ¿No es esa la tarea que nosotros y exclusivamente nosotros, estamos intentando en este momento? Luego habla usted de que estamos maduros para la gran poesía, esa que "no consuela sino que atormenta". Si cambiara el término enfermizo de "atormenta" por el más preciso de "inquieta" estaríamos de acuerdo, con la diferencia, todavía, de que no se trata de la gran poesía, sino simplemente de la poesía, la única posible, la que es expresión de la vida, para la cual siempre estamos maduros cuando somos naturalmente humanos y nos arrancamos los tabús del GRAN ARTE, del artificio, del exhibicionismo, de la vanidad.

Y como tema final propongo el de la amistad con que usted empieza y termina su carta. Le manifiesto que no comprendo una amistad que no pueda ser sincera en el diálogo directo, en el contacto humano y deba recurrir a la epístola brillante para lograr la sinceridad a través de frases más o menos bien construidas. Creo que se puede ser sincero mediante cualquier medio de expresión y yo siempre lo he sido con usted en nuestros diálogos, aun usando el "tosco" lenguaje de la conversación diaria. Le ruego, por lo tanto, que no me haga cómplice de su falta de sinceridad en esos casos, ni ella le autoriza a suponer o adivinar cosas distintas de las que he expresado siempre con entera claridad.

De todos modos ya que se ha presentado la oportunidad de poder explicarnos por escrito, espero que esta también sea la oportunidad de iniciar una nueva etapa en nuestra relación de amigos: la de la sinceridad en todos los terrenos y con todos los lenguajes.

Cordialmente

Aldo Pellegrini

- " "Fin de un diálogo de sordos", Osiris Troiani en Contorno N5/6, septiembre 1955.

¿No estaremos haciendo el ridículo, Pellegrini? ¿No hemos caído en una de esas interminables discusiones en que cada uno no puede sino explicar lo que ya había dicho, y que el otro hizo todo lo posible por no entender? Es lo que yo quise evitar al situar nuestra conversación lejos de la mesa de café. Pero el diálogo de sordos puede igualmente practicarse por carta. Tenía la ilusión de que, puesto a explicarme en público, usted trataría de no parecer sectario. Pero veo que toma como un reproche de duplicidad mi insinuación de que es usted prisionero de su círculo, o más precisamente de su "actitud". Si así está cómodo, ¿quién me manda turbar su inmóvil perfección de Buda? ¿La amistad? Oh, no. Usted me enseña que la amistad debe ser discreta y complaciente, no suscitar cuestiones enojosas, no poner al amigo frente a frente consigo mismo.

A decir verdad, la primera vez que sentí la necesidad de explicarme seriamente con ustedes fue un día en que Latorre confesó que Aimé Cesaire lo pone fuera de sí, como todos los poetas que toman partido. Yo quise recordar que hubo tiempos en que el surrealismo, antes de estar al servicio de Breton, se decía "al servicio de la revolución". Que esas ideas de prescindencia política proceden del tartufismo literario, y son propias de los vates solemnes que han firmado contrato con la belleza y la justicia eternas; pero que suenan curiosamente en labios de jóvenes intrépidos, veraces, con gusto por todo lo vital y afirmativo. Ustedes salieron del paso con un chiste; es posible que yo contestara con otro; pero me quedé con ganas de saber por qué Aimé Cesaire había dejado de ser poeta al despertar a la vida política. Eso será muy sincero, pero no es conversar.

Las frecuentes oraciones fúnebres que se consagran al surrealismo prueban su actualidad, dice usted. Es un recurso casuista muy conocido, pero aquí no cuadra. Usted sabe muy bien que yo no atacaba al surrealismo. Atacaba a cualquier capilla, el concepto mismo de escuela, que corresponde a otra época de la vida literaria, cuando los escritores formaban pequeños grupos refractarios al margen 
de la sociedad. Yo siento nostalgia por esa época que no he conocido, sin duda más hermosa que la nuestra; pero no pretendo resucitarla, como usted. He dicho, simplemente, que el surrealismo estaba muy bien hace tres o cuatro décadas, y que sus actitudes características - invención, violencia, humor negro, provocación, protesta contra los límites de la razón - siguen siendo válidas. Pero con una condición: si admite que, terminada la fase polémica, es patrimonio común de todo arte moderno y forma parte de la educación estética de todo escritor digno de atención.

Entre la capilla bretoniana y el espíritu surrealista ha surgido el mismo conflicto que siempre se manifiesta entre una idea y su dispositivo de propagación: el ejemplo clásico opone al cristianismo y la Iglesia Católica. ¿Quién es surrealista: el coro de vestales más o menos decrépitas que aún rodean a Breton, sin más afán que mantenerse incontaminadas, o quienes, fieles al espíritu inicial del movimiento, lo han convertido en una experiencia más junto a otras que el surrealismo ignora y que el hombre moderno no puede ignorar? Lo que yo atacaba - y donde veía una prueba de provincialismoes, pues, esa ridícula "militancia" surrealista, seductora quizás para unos muchachos que mañana la traicionarán (la libertad de espíritu era uno de los principios más hermosos del surrealismo), y que hoy alborotan para tener la ilusión de ser los enfants terribles de nuestra vida literaria y artística; y yo no conozco nada tan inocente, $\tan$ sage, $\tan$ convenable, como ese vanguardismo que encuentra la mejor acogida en las revistas de modas, baluarte supremo del conformismo y la cursilería. La poesía surrealista y el arte abstracto son tan intransigentes, tan revolucionarios, que encantan a las niñas elegantes.

Otro de sus recursos polémicos consiste en denunciar la falta de información de sus contradictores, aunque primero tenga que hacerles decir lo que no han dicho. Así, por ejemplo, su carta me hace saber formalmente que los redactores de Letra y Línea admiran a Césaire y detentan a Char. Ante todo, yo no entiendo cómo puede un grupo de hombres coincidir así en materia tan antojadiza y personal como es el gusto literario. Ustedes admiran y detestan en corporación. Por otra parte, yo me he limitado a sostener que su grupo "exonera a Césaire porque no accede a disociar en sí el poeta del político". Eso no significa que no amen ustedes al Césaire que fue, es decir al Césaire que repudia (lo cual, dicho sea de paso, no les impedirá mofarse de los comunistas que rechacen al primer Neruda). La verdad es que pertenecen ustedes a la época en que la libertad se definía como disponibilidad, y hace mucho tiempo que se la comprende como opción. Tomar partido es una forma de limitar mi libertad (o mi conocimiento) y a la vez mi única forma de experimentarla (o de ascender a él).

Lo que más le indigna es, sin embargo, la sospecha de que su cenáculo acepte a Char. Dije mal: debía decir "aceptaba". Porque sus copiosas injurias a Char no pueden hacer olvidar el hecho de que fue uno de los principales animadores del surrealismo, y que escribió alguna obra en colaboración con Breton. Pero es, según parece, un "desviacionista": el pope lo excomulga y usted lo suprime de la historia. ¿Un clásico? No, no, apenas un académico. Veo que tenía razón: ustedes no comprenden que Char es un clásico de la poesía de nuestros días. Porque ambas expresiones significan más o menos la misma cosa, pero una tiene un valor preciso en la terminología literaria y la otra envuelve una intención despectiva. Usted opta por esta en forma emocional, simplemente por Char es un "traidor" del surrealismo.

También habría yo cometido el sacrificio de atribuirles una culpable inclinación por Cocteau. ¿Quiere usted señalarme, se lo ruego, dónde he dicho tal cosa? Mencioné a Cocteau una sola vez, de paso, para describir la atmósfera de la posguerra anterior: "Todo está muerto, irremediablemente muerto y, pertenece al buen tiempo viejo: el de Cocteau, el de Satie, el del Bateau-Lavoir; cuando Francia aún prestaba dinero...", etc. No, Pellegrini, sé muy bien que el dogma no les permite a ustedes gustar de Cocteau; soy yo, en cambio, quien me expondré a sus sarcasmos: Cocteau me gusta. Me gusta porque es fino y es gracioso, aunque no hace la poesía que yo llamo poesía. Como admiro la límpida dicción de Char, aunque no me conmueve. Como me interesan ciertas páginas de Breton, aunque su pensamiento no esté a la altura de su talento verbal. ¿No comprende usted que los juicios absolutos no tiene validez más que en la mesa de café, y que el matiz es esencial en la valoración crítica? ¿Nunca se le ha ocurrido que su corazón adhiera a formas de arte que su razón no aprueba? ¿Por qué dividir la literatura en dos bandos: el de los buenos y el de los réprobos?

Mi juicio sobre Picabia le hace pensar que no lo frecuento bastante. Es verdad. No he leído de él más que unos fragmentos en las revistas y en algunos libros acerca del surrealismo. Me dirá usted que no es suficiente para juzgarlo; pero fue suficiente para que dejara de interesarme. Es insulso. Descubre la pólvora. Dice simplezas en las que no hay más oscuridad que la atribuible a su escasa familiaridad con el arte de escribir. Como uno no puede leerlo todo, debe necesariamente fiar en su 
instinto y pagar cierto tributo al criterio de autoridad. Pues bien, el instinto me dijo que se trataba de un curioso "personaje de la vanguardia artística", cuya significación reside menos en su obra que en "su actitud e influencia personal": es decir, lo mismo que usted se sirve revelar a lo profano. En cuanto al criterio de autoridad, nadie hasta ahora ha explicado cómo y por qué ilumina Picabia la comprensión de nuestro tiempo. Lo que he leído sobre él son digresiones más o menos vagas, unas anécdotas, los cumplidos de sus amigos a un tipo simpático. Es usted quien nos debe, si está tan convencido de la importancia de este autor y pintor (que en la muestra retrospectiva del surrealismo en 1953, dicho sea de paso, no ha merecido de los críticos más que una indulgencia unánime) la exégesis que exponga los aportes de Picabia al pensamiento moderno. ¿Verdad que no la intentará? Claro que no: usted es demasiado razonable. Todo lo que puede hacer por él es calificarlo de "hombre ejemplar", de "tipo socrático". Esto es solemne, pomposo, parece un discurso de banquete, pero no compromete mucho; en todo caso, provoca una sonrisa...

¡Pero qué! Le reconozco de buena gana su condición de iniciado. Ustedes han leído a Duchamp, saben cuántos ejemplares se tiraron de L'amour feu y discuten sobre quién gritó "Abajo Francia" en cierto banquete surrealista. Pero, a la verdad, con este acopio de saber no asustan a nadie, y si se tomaran el trabajo de leer a Collin Clark, por ejemplo, podríamos creer que siguen con cierta atención el movimiento intelectual contemporáneo, y tendrían una visión más coherente del mundo en gestación. Usted, que es un hombre de gusto y que ha visto mundo, podría suscitar entre los más desorbitados de su tertulia un saludable sentido del ridículo. Dígales que ya no es posible practicar el terror iniciático contra los que se niegan a plegare al pompierismo vanguardista: los intelectuales argentinos ya no tiemblan al oírse acusar de no estar a la page. En su mayoría, se encogen de hombros ante las novedades que ustedes les revelan y que ellos han olvidado; otros confiesan que las ignoran, pero agregan que también ignoran otras cosas importantes.

¿He atacado yo a Breton porque no es filósofo? Al aludir a su "incompetencia filosófica", solo he querido señalar su escasa versación en un tipo de conocimiento que creo imprescindible para no ser un crítico irresponsable, un revolucionario verbal, y hasta nuestros días, un poeta desdeñable. (Confío en que no tratará de interpretar mal_ he dicho imprescindible, no suficiente). Todos hacemos filosofía, incluso las comadres que van a un velorio. Filosofar, pero diciéndose uno no filósofo, no es ninguna originalidad, desde Kierkegard. Pero ¿cree usted seriamente, Pellegrini, que hoy la filosofía es, como entonces, la filosofía de los profesores? Esa pretensión no es sino un recurso de que se valen algunos literatos para disertar sobre todo lo que se les antoja sin exponerse a las críticas. Usted lo confiesa candorosamente al decir que Breton "no siendo filósofo, no puede ser liquidado como filósofo". ¡Eso sí que es jugar a dos puntas! Ha elaborado una ideología, un pensamiento, una concepción del mundo que "no es puramente estética, como pretenden algunos"; pero no es un filósofo. Prohibido refutarlo.

¿Y en qué consiste, por otra parte, esa ideología? Pues que estamos en crisis; que la civilización grecolatina es ya difunta; que el hombre aspira a liberarse de la coacción racionalista; que la destrucción de todo canon estético es solo una de las formas posibles de una insurrección más general, y que el sentido de todo el movimiento es la liberación integral del hombre. Casi nada: la libertad total para todos, la fusión del mundo exterior e interior del hombre, la subjetividad hecha objetividad y viceversa. ¡Vive Dios que no se necesita ser filósofo, efectivamente, afirmar estas pamplinas! Y la verdad es que en ninguna parte he encontrado una exposición del surrealismo más precisa que la suya. Pero, ¿Quién asegura que el hombre aspire a la libertad? ¿Es esta posible, es deseable? ¿Y por qué ha de ser integral? ¿No cree usted que una regulación en cierto dominio puede asegurar una latitud más amplia en otro? ¿Y seremos capaces de hacer el menor esfuerzo si no pesa sobre nosotros una coerción? Y el conflicto entre mi libertad y la suya, ¿cómo se resuelve? ¿Lo resolverá verbalmente, como esa otra antinomia, triunfalmente superada, según la cual "el concepto de masa no anula al individuo sino que lo incorpora"? La palabra-amuleto, "dialéctica" (y usted protesta, justamente, porque se la usa con ligereza) exorciza una vez más la contradicción. Si todo es tan sencillo, me explico que el surrealismo cumpla esa otra proeza de ser, a un tiempo, "esencialmente disconformista y fundamentalmente optimista". No tiene nada que envidiar a nadie.

"Si nosotros proponemos la poesía y la pintura del primer cuarto de siglo es porque sus autores representan nuestros clásicos", dice usted. (A propósito: vincular el surrealismo y el arte abstracto, como hice yo y como hace usted, no es adoptar la "opinión popular que designa toda manifestación de vanguardia como surrealismo"; es comprobar un hecho real: el surrealismo, que no ha tenido, según mis noticias, un desarrollo equivalente en las artes plásticas, mantiene con los abstractos unas relaciones de facto, que se reflejan en Letra y línea y en su propia actividad personal). ¡Cómo! Gentes 
que pretendían quemar los museos, destruir el concepto mismo de literatura, y que por momentos llegaron a negar a los antepasados de que estaban más orgullosos (Sade, Rimbaud, Lautréamont, Jarry) se han forjado sus clásicos en menos de un cuarto de siglo. No conozco ejemplo semejante de celeridad en la cristalización de formas, conceptos y nombres de un movimiento artístico. Los surrealistas han tenido siempre una curiosa tendencia a instalarse prematuramente en la historia. De ahí la profusión de antologías con que nos regala. Y de ahí otra de sus características: gracias a él hay poetas inéditos que pasan directamente a las antologías.

La categoría de clásico presupone la de epígono; es el epígono el que designa, escoge, instituye su clásico. Y usted admite que, pasado el primer cuarto de siglo, surrealistas y abstractos han caído en el epigonismo. Esa era mi tesis. ¡Bastará con revivir la época creadora del movimiento!, me dirá usted. Pues háganlo; nadie se lo impide al surrealismo, sino su propio agotamiento. La Iglesia dice también: si los hombres volvieran a Dios, acabarían todos los males. Pero, justamente, el mal es que no vuelven a Dios, y que el cristianismo no puede hacer más que lamentarlo.

Para el surrealismo de 1925, para esa "vague de reves" que estremeció entonces a una generación inolvidable, mi actitud no puede ser más simpática. Aprecio su maravillosa influencia en todos aquellos que han terminado por librarse de él. Pero quienes persisten en aquellas formulaciones demasiado sumarias, y pretenden transformarlo en cuerpo de doctrina - en ideología, como dice usted - viven de un capital que no se regenera. Es necesaria una gran dosis de ingenuidad, un espíritu singularmente conformista para adherir a una ideología formada, con sus inevitables mitos y su edad de oro, situada por igual en el pasado y en el futuro. Prefiero a Sartre: "toujours en question; toujours en sursis, peut-être doit-on perpétuellement se faire » (Baudelaire, pág. 47).

Otro de mis errores consiste en asociar Letra y Línea con los surrealistas, porque en su primer consejo de redacción res lo eran y seis no. Cuesta trabajo imaginar una coartada más elemental. Aplica usted el sistema de los camaradas de ruta, cuya presencia en una empresa no tiene otro objeto que disimular el carácter sectario del grupo dirigente. Y, como hemos visto, los colaboradores que no eran surrealistas, al percatarse de la función que cumplían, empiezan a marcharse. Para ensañarse con el prójimo, invocan ustedes la necesidad de agitación literaria (que yo no niego). Pero la agitación literaria se hace con libertad de espíritu, con amplitud de criterio; ustedes, militantes de una ideología, poseen la verdad. El que posee la verdad no puede sino practicar el terrorismo, y Letra y Línea hace terrorismo literario. Pero no en el estilo directo y brutal de los primeros surrealistas, sino arrebujándose en un grupo que solo tendría de común el amor a la verdad ...

Acabemos. Algunos me decían: "Pellegrini se molestará". Yo respondía: "Este es un test. Si se molesta, nuestra amistad era un malentendido, y nada se perderá". Pero usted se ha imaginado no sé qué torva confabulación. “QQué juego se oculta detrás de este ataque contra Letra y Línea?” Mi juego estaba a la vista, yo discuto con la gente que me parece valiosa. Como los muchachos de Letra $y$ Línea me interesan, creo que ya es hora de que dejen de jugar al surrealismo. Algunos se han librado, otros lo harán; yo quise adelantar la hora. No puedo explicarme con más franqueza, ¿verdad?

Puesto que el surrealismo argentino tiene ya sus desertores, prefiero seguir en diálogo con ellos.

Osiris Troiani 


\section{POLÉMICA ENTRE “BuSTOS DOMECQ" Y LETRA Y LÍNEA}

En el mismo número de la revista Letra y Línea donde Juan Carlos Latorre publicó la reseña sobre Sur y la literatura italiana que desató la polémica con Osiris Troiani, encontramos una respuesta a Jorge Luis Borges y Adolfo Bioy Casares. La "redacción" se refiere ahí a una nota aparecida en la revista Buenos Aires Literaria que transcribimos a continuación, así como también el texto publicado en Letra y Línea. Dos años más tarde, en la segunda época de A partir de cero (1956), Aldo Pellegrini volvió a apuntar contra Borges en un ensayo burlesco sobre la noción de "literatura".

- "De aporte positivo". Revista Buenos Aires Literaria n¹7. Firmada por Bustos Domecq.

Es de lo más tónico el diálogo con Ortega. Al hombre, claro, échele un galgo; hoy toma el micro en Llavallol, mañana nos saluda lo más campante desde la ventanilla del tren lechero que se desplaza como la lombriz por Burzaco, y pasado, qué se yo. Espíritu inquieto, se lo divisa por conferencias, academias y otras muestras de pintura; picoteando por aquí y por allá, hay que ver cómo asimila. Ya se sabe, es comisionista.

Vez pasada yo estaba francamente caucho, incapaz de levantar la menor cabeza, insumiendo unos mates que, le aseguro, se perfilaban de lo más tibiones que se puede pedir, cuando, a las cansadas, enfoco la visual y ... ¿a quién veo? No se maten queriendo adivinar que esto no lo acierta ni el más garifo. A quien vi muy campante, saludándome desde lo lejos con un órgano de publicidad y levantando tierra con el calzado, fue a un mozo Ortega, que es comisionista.

Eran las diecisiete en la cocina y yo gozando de la fresca detentaba mi buena parte del porche de esta, su casa. El hombre progresaba sin desmayar, bordeando el horno de ladrillos y los fondos de curtiembre. Cuando ya salvó el charco seco, me dijo desde el suelo:

- ¡Rataplán, escribano amigo, rataplán! Aquí le traigo un lenitivo en forma de Revista de cultura contemporánea. Artes plásticas. Literatura. Teatro. Cine. Música. Crítica.

¡Se despejó la incógnita! El órgano en cuestión que agitara Ortega no era otro que Letra y Línea, en su número 3 (tres). Me dirán, y no les discuto, que las palabras tan ufanas del gran amigo debieron activar como una inyección de café con leche y pan con manteca mi desanimado organismo, pero lo más cierto es que tantas veces uno se ha pelado la frente con revistitas dañinas e insustanciales que no resulta fácil ¡qué pucha! suscribir un voto de confianza. Terminan por hartar esos hebdomadarios de los eternos jovencitos irrespetuosos, que para hacerle bombo a Fulano le pegan a Mengano y se despachan con una suficiencia chocante.

Con más resignación que otra cosa barajé el impreso y cuál no sería mi reacción favorable cuando leí:

El tiempo de tu sonrisa despierta a los relojes

el tiempo de tu sonrisa acelera a los relojes

lanzaste el canto que no se puede detener

el canto que sacude a los personajes inmóviles.

Medio trastabillé con el sacudón. Ya nunca sería el mismo. Pero bien pronto me fue dado elevarme a altitud que se relevó aún más considerable, cuando topé con el inciso que luce a continuación: 
Ya no es posible valorizar la opinión de esos aletargados en relación a su tiempo, que persisten en una ignorancia con respecto a la comunicación actual. El escritor debe servir a su tiempo a pesar de los tranvías.

Quedé engolosinado con esta cita, como cuando a uno le rellenan la boca con azúcar molida, pero se me hizo bueno y atiné a manotear este otro concepto, que revista en la misma hoja:

La destrucción, defensa de las actitudes insólitas o conjugación del fracaso, son elementos de aporte positivo.

Para ese joven Ortega ¡diablo de hombre! mi tesitura no constituyó una sorpresa. Humano y benevolente me sonreía, como si fuera mi señor padre. ¡Bien sabía mi benefactor, que a pesar del escaso margen de tiempo que nos deja la profesión, tengo un rinconcito en reserva para las cosas del espíritu, cuando se exhiben con toda seriedad, eso sí!

Me hizo un precio especial por el número, que era una ganga, apalabrándose a conseguirme otros parecidos. En eso, un chancho que siempre lo pone un poco nervioso, le devoró la cinta, las iniciales y un sector de su pajizo negro y a Ortega le dio la loca por irse. Salió como si lo persiguiera una fiera y el chancho, que es de un pelaje entre rosillo y moro, lo acompañó personalmente hasta que se perdieron de vista.

Despejado el ambiente por la partida del chancho, etc., me afiancé en el sillón de hamaca, donde, perfectamente acondicionado, pasé de la lectura a vuelo de pájaro a un repaso en orden, sesudo, del folleto de referencia. ¡No se chingó la expectativa! A la disparada, vuelco en el papel mi impresión:

Es con encomiable satisfacción que se saluda a un esfuerzo nuestro. La entrega de Letra y Línea que tenemos a la vista, tan entonada como las que inician la marcha, brega exitosamente por mantenerse al nivel que ya le exige el grueso público. Firmas expectables, valores sólidos, plumas de fuste, con aportes siempre meritorios y novedosos, los más candentes y modernos temarios. Se destacan, en el vistoso elenco, Vasco, Vanasco, etc.

Seamos francos, el desprevenido lector no puede menos que preguntarse: estos escritores, profesores y juventud estudiosa ¿es que constituyen un núcleo? A la espera que un cerebro más preparado nos dé la clave de tan espinoso intríngulis, no trepidamos en adelantar que constituyen todo un ateneo, en que se pugna por los fueros de la cultura iy son nuestros votos que por mucho tiempo sigan luciendo en el tope de la página, el letrero que los encabeza: Letra y Línea!

Empresa esta de honda raigambre en nuestro medio, tuvo ya sus notables antecedentes en diversas publicaciones y boletines de academias, casas de estudio y otras corporaciones. Lo que le da, no obstante, su cuño propio, es el tono ponderado que, unido a las relevantes dotes de solvencia y de ilustración, recoge los sufragios del suscritor.

\section{H. Bustos Domecq.}

- “Borges y Bioy Casares, paladines de la literatura gelatinosa". Letra y Linea, ${ }^{\circ} 4$, julio 1954. Firma: Letra y Línea

En el n ${ }^{\circ} 17$ de Buenos Aires Literaria, Borges y Bioy Casares, conocidos fabricantes de repostería literaria para uso de las niñas de la buena sociedad, se enfurecen con Letra y Línea. De la confusa mezcla de rencor gelatinoso y gracia hipopotámica de que hacen gala en este texto, se desprende lo siguiente: 
$1^{\circ}$ Que el chancho es el Dios tutelar y vengador con el que se identifican los autores (evidentemente, la literatura gelatinosa, nutrida de desperdicios y residuos literarios, se aviene perfectamente con las características del aludido animal),

$2^{\circ}$ Que nuestra revista se dedica a "atacar a ciertos escritores para ensalzar a otros". Este descubrimiento tan sorprendente resulta un propósito no solo evidente sino razón fundamental de la aparición de Letra y Línea. En el número inicial figura de modo destacado en la declaración de motivos y entonces la designamos como tarea de revalorización o rectificación de las jerarquías literarias y artísticas. En otras palabras: esa actitud, que naturalmente resulta alarmante para Borges y Cía., significa señalar y denunciar la falsedad de la posición destacada de determinados escritores y artistas, lograda por razones variadas, entre las cuales nunca figura el mérito real.

$3^{\circ}$ Lo que más asombra a Borges y Cía., es la audacia de una revista que sale a combatir sin figurar en ella los nombres que consideran consagrados. Pero que se tranquilicen ya que de ningún modo han sido olvidados, pues si bien no figuran en la plana de los colaboradores todos esos protagonistas del drama cultural del país, los podrá encontrar en todos los números en lugar destacado, con menciones de sus ilustres textos, aunque no desempeñando ya el papel dramático sino el cómico.

- "Comentario a tres frases de autores célebres. (La celebridad es la conciencia del horror)". A partir de cero, $\mathrm{n}^{\circ} 3$, 1956. Aldo Pellegrini

"Buenos días, señora" (1) Jorge Luis Borges

"Cuando los dos gases mencionados previamente se mezclan en presencia de un filamento de platino, forman ácido sulfúrico" (2) T.S. Eliot

“¡Pamplinas, muchacho!” (3) William Faulkner

(1) Como lo imponen la ley y la costumbre, inicio estos comentarios con un autor nacional. Esta costumbre impuesta por un sano nacionalismo, nos permite apreciar a celebridades que por el hecho de estar muy próximas tenemos tendencia a desvalorizar. Me atrevería a decir que la frase de nuestro autor nacional gana en su cotejo con las celebridades internacionales, y debo añadir que su hallazgo no fue resultado de una búsqueda minuciosa. La elegí así, un poco al azar, seducido quizás por su delicada transparencia. Sin embargo, si se la contempla atentamente, se descubre más allá de esa transparencia una tenue opacidad, como un vaho que se fuera densificando a medida que se penetra más hondo; entonces es necesario detenerse, pues de avanzar un solo paso más se caería verticalmente en la noche universal de la infamia. En esa profundidad última, en esa sagrada tiniebla, se oculta el horror a la vida, la exaltación del vacío literario.

Puede decirse, sin exagerar, que la frase motivo de este comentario, encierra la mayor síntesis expresiva que pueda dar el lenguaje. En primer término, resulta evidente que la componen dos partes, separadas por la coma. A la izquierda de la coma la expresión "buenos días" representa el universo en su totalidad, lo cósmico, y en ella por sucesivas escalas de significados cada vez más incandescentes se parte de una aparente benignidad climática (lo terreno) hasta un inconcebible fuego monstruoso (lo sideral), de la tibieza se pasa a la ignición, de lo soportable para el hombre a lo insoportable para los dioses. A la derecha de la coma (señora) está lo simplemente humano (señora) 
pero en su forma originaria, en su sentido de gran matriz (señora), como comienzo y fin, como cristalización de la misteriosa energía que es la vida.

Si se contempla ahora la frase desde la perspectiva de estos sorprendentes hallazgos se la nota animada de cierto vaivén, que depende seguramente de su asimetría. En efecto: sus partes representan pesos diversos aunque cambiables: en ciertos momentos el mayor peso recae sobre el mundo, en otros sobre el elemento humano (señora). En este vaivén el autor ha querido señalar todo lo que de inquietante tiene el conocimiento, y que este comporta una corriente ininterrumpida, pero alternada, que va unas veces de la objetividad a la subjetividad, otras de la subjetividad a la objetividad.

Lo admirable en esta frase es que la coma no solo separa sino que - como todo lo que separa - une, y esta unión es definitiva y absoluta: en ella se funden el ser humano, la gran matriz (señora) con el universo, con su clima (buenos días) con todos los climas posibles hasta llegar a la definitiva y absoluta ausencia de clima (literatura).

Pero hay además en esta frase cierta severidad aristocrática, cierto tomar partido por lo mejor, unida a una sutilísima ironía como si se diera a entender que las letras exangües son el mejor remedio para la vida. Hasta diría que este matiz de vaga y lejanísima burla es lo que la distingue de la misma frase pronunciada por un hombre de pueblo. Cuando este la pronuncia, quiere significar simplemente "buenos días" y se vuelca íntegramente en ella, no así nuestro celebrado autor, quien al deshabitarla del hombre concreto y del mundo concreto, alcanza esa sublime inexistencia de todo, que es la literatura pura o parametafísica, mediante la cual nos sumergimos en la universalidad del vacío.

(2) Esta frase nos sorprende por su mirada sibilina. En la lenta amplitud de su desarrollo revela el proceso de la creación del cosmos con extraordinaria riqueza simbólica. Explica cómo nace la materia y adquiere al instante su siniestra cualidad corrosiva (ácido sulfúrico) de una presencia casi inexistente (filamento de platino); diríamos de una presencia sin presencia. La creación del mundo es inútil y esta inutilidad se revela en el carácter corrosivo (ácido sulfúrico) de la realidad. A la realidad quemante y destructora el poeta opone un universo originario hueco y desierto. El simbolismo del filamento de platino es aún más concreto: representa el sol hueco, la idea metafísica de la existencia vacía frente a la vida peligrosa y ardiente. ¿Qué es, entonces, en última instancia, la creación del mundo? Es la creación del vacío. En el chisporroteante orgullo de la materia circula una sangre del vacío. El hombre es hueco, y el mundo desierto. Solo la literatura domina todo, eterna, inextinguible. La literatura es la envoltura de ese mundo vacío: un vacío que envuelve al vacío.

Dios creó el mundo en siete días. Fue una tarea un poco apresurada. El mundo no es perfecto. Al literato no le cuesta trabajo vaciarlo. Dio creó la vida y la literatura recubre de vacío esa creación vergonzosa. La naturaleza que nos rodea es peligrosa y agresiva (ácido sulfúrico), la literatura la vuelve inocua. La vida nada tiene que ver con la literatura; la literatura nada tiene que ver con el vacío. Cuando el poeta cumple rigurosamente esta función de la literatura, cuando devuelve el universo y la vida al vacío, entonces recibe solemnemente el Premio Nobel de Literatura.

(3) Hay frases que nos reciben con una mueca y esta es una de ellas. Creo necesario aclarar que ciertas sutiles excelencias que nos sorprenden de entrada pueden atribuirse al traductor, pero en su esencia, la frase expresa tan bien el espíritu y la obra de Faulkner, que parece como si el traductor hubiese querido contribuir a la exactitud del comentario.

Para Faulkner el mundo es un universo de sufrimientos, narices sangrantes, violaciones, abortos, gangrenas, pero (ipamplinas!) no nos apresuremos, todo ello puede ser mejorado por la literatura. No hay que tomar las cosas demasiado en serio (ipamplinas!), los sufrimientos y la carroña tienen su lado pintoresco, y la literatura revela su grandeza al utilizarlos como materia prima para el arte. Hábilmente empleado por un literato que conozca su oficio, el sufrimiento en su aspecto anecdótico, comunica a la obra de arte un no sé qué de picante, cierto refinamiento agridulce, que abre el apetito y despierta el interés de esa sensibilidad un poco embotada por los placeres comunes, me refiero a la sensibilidad del snob, consumidor fundamental de la mercadería artística. 
El sufrimiento, en su aspecto anecdótico y pintoresco, nada tiene que ver con la verdadera vida, es solo un motivo para excelentes ejercicios literarios. El diálogo interior, la confusión del tiempo, la imbricación de temas, la confusión mental, son todas pequeñas técnicas que están a disposición del literato hábil. Manejadas con buen gusto y equilibrio y mezcladas con una razonable dosis de realismo, se ogra hacer perder al sufrimiento su carácter, obteniendo exquisitos e incitantes platos literarios, llenos de ambiente y rutilantes de color para placer y regocijo de los snobs. Entonces las narices sangrantes y los abortos, las piernas gangrenadas y cosquilleo en los sentidos adormecidos de estos sutiles señores (los snobs). Los críticos se entusiasman, los novelistas avanzados de todos los países imitan, y el sufrimiento gesticula cada vez más distante.

La vida auténtica es peligrosa, pero la literatura (ipamplinas!) la encierran detrás de sólidas rejas y entonces resulta un espectáculo divertido como el de los leones de circo.

\section{Conclusión}

Del análisis de las frases de estos escritores célebres se desprende el incalculable poder de la literatura. Mediante ella los hombres pueden alcanzar un estado de complaciente embeleso y refinada imbecilidad que de generalizarse, puede llegar a la supresión de las guerras y el aniquilamiento total del sufrimiento. Tal es el objeto de la llamada cultura del siglo XX. Gracias al poder de tales escritores, la vida misma puede desaparecer asfixiada por un cúmulo de minúsculas y bien dosificadas sensaciones literarias. Desgraciadamente, las masas, brutalmente vitales, sienten repulsión por la cultura; rechazan el vacío, y prefieren, por encima de todo, simplemente vivir.

Aldo Pellegrini 


\section{Bibliografía:}

\section{Fuentes primarias}

\section{Revistas del corpus:}

A partir de cero / Dir.: Enrique Molina. 1a época, $\mathrm{n}^{\circ} 1$ noviembre 1952 - $\mathrm{n}^{\mathrm{o}} 2$ diciembre 1952; 2a época, $\mathrm{n}^{\mathrm{o}} 1$ : septiembre 1956.

Ciclo. Arte, literatura, pensamiento moderno / Dir.: Aldo Pellegrini, Enrique Pichón Rivière, Elías Piterbarg. $N^{\circ}$ 1: noviembre/diciembre 1948 - nº 2: marzo/abril 1949.

Letra y línea. Revista de cultura contemporánea / Dir.: Aldo Pellegrini. No 1: octubre 1953 - no 4: julio 1954.

Poesía buenos aires / Dir.: Raúl Gustavo Aguirre. No 1-30: primavera 1950 - primavera 1960

\section{Revistas consultadas y citadas:}

Boletín de la Asociación Arte Concreto-Invención y su suplemento de poesía (diciembre, 1946)

Buenos Aires literaria / Dir.: Ramón Vázquez. N 1: octubre 1952 - nº 18: marzo 1954.

Canto. Hojas de poesía / Dir.: Miguel A. Gómez, Julio Margasot, Eduardo Calamaro. No 1: junio $1940-\mathrm{n}^{\mathrm{o}}$ 2: agosto 1940.

Capricornio. Revista de literatura, arte y actualidades / Dir.: Bernardo Kordon. $1^{\text {a }}$ época, $\mathrm{n}^{\mathrm{o}}$ 1: julio 1953 - $\mathrm{n}^{\mathrm{o}} 8$ : noviembre/diciembre 1954.

Centro. Revista del Centro de Estudiantes de la Facultad de Filosofía y Letras de la Universidad de Buenos Aires / Comisión: Darío Cantón, Noé Jitrik, Ana Goutman, Esther Smud, Adelaida Gigli, Adolfo Prieto, Ismael Viñas, Ana Ilstein, Rodolfo Borello, etc. (Eliseo Verón dirigió los $\mathrm{n}^{\mathrm{o}} 11$ y 12; Jorge Raúl Lafforgue los $\mathrm{n}^{\mathrm{o}} 13 \mathrm{y}$ 14). $\mathrm{N}^{\mathrm{o}} 1$ : noviembre 1951; $\mathrm{n}^{\mathrm{o}} 14$ : cuarto trimestre 1959.

Contemporánea / Dir.: Juan Jacobo Bajarlía. 1ª́poca, nº 1: agosto 1948 - nº 4: 1950.

Contorno /Dir.: David Viñas, Ismael Viñas. No 1: noviembre 1954 - nº 9/10: abril 1959.

El 40. Revista de una generación / Dir.: Dora S. de Boneo. No 1: Primavera 1951 - nº 6: invierno 1953. 
Cuaderno Invención, n². "La batalla por la invención: manifiesto", por Edgar Bayley, 1945.

Invención Arte Concreto / Comité de redacción: Egdar Bayley, Simón Contreras, Alfredo Hlito, Raúl Lozza. №1, agosto 1946

Los anales de Buenos Aires / Dir.: Jorge Luis Borges. No 1: enero de 1946 - $\mathrm{n}^{\circ} 23$ : diciembre 1948.

Realidad. Revista de ideas / Dir.: Francisco Romero. $\mathrm{n}^{\circ} 1$ (enero/febrero 1947) - $\mathrm{n}^{\circ}$ 17/18 (septiembre/diciembre 1949).

Sur / Dir.: Victoria Ocampo. $n^{\circ} 1$ (enero 1931) - no 371 (1989).

Verde Memoria. Revista de poesía y crítica / Dir.: Ana María Chouy, Juan Rodolfo Wilcock. $\mathrm{N}^{\circ}$ 1: junio 1942 - no 6: junio 1944.

\section{ARTÍCULOS Y POEMAS CITADOS}

Aguirre, Raúl Gustavo (1954). "Hoja de ruta". Poesía buenos aires, n¹5, p.8 (1951). "La poesía". Poesía buenos aires, n², p.2.

(1951). "Proposiciones. En la poesía reside la facultad de migración de la especie”. Poesía buenos aires, n`2, p.4.

(1951). "Poesía para respirar". poesía buenos aires, n³, p.1

(1951). "Noción de poesía". poesía buenos aires, nº 4, p. 1

(1950). "Mario Trejo". poesía buenos aires, $\mathrm{n}^{\circ} 1, \mathrm{p} .5$

(1952). "Violencia de la poesía". poesía buenos aires, $\mathrm{n}^{\circ} 7, \mathrm{p} .1$

(1952). "Presencia de la realidad en la poesía". Poesía buenos aires, n9, p.1

Bajarlía, Juan Jacobo (1948). "Manifiesto”. Contemporánea, n 1, p. 1

Bataille, Georges (1948). “La moral de Henry Miller”. Ciclo, n 1, pp. 23-37. Traducción:

Marcia Bastos.

Bayley, Edgar (1944). "Hoy". Arturo, pp.17-18

(1944). Texto sin título. Arturo, pp.9-10

(1945)."La batalla por la invención: manifiesto." Invención $\mathrm{n}^{\circ} 2, \mathrm{p} .4$

(1946). "Sobre invención poeta". Invención / Arte Concreto, $\mathrm{n}^{\circ} 1, \mathrm{p} .13$

(1950). "invencionismo". poesía buenos aires, $\mathrm{n}^{\circ} 1, \mathrm{p} .4$

(1950). “esa tensión fugitiva". poesía buenos aires, n¹, p.4

(1952). "Realidad interna y función de la poesía”. poesía buenos aires, nº, pp.

3-5 y nº, pp. 7-12

Berger, Pierre y René Char (1953). «Conversación con René Char ». Poesía buenos aires, $\mathrm{n}^{\circ} 11-12, \mathrm{pp} .1-3$

Bill, Max (1949). "La expresión artística de la construcción”. Ciclo, n 2, pp

Blanchot, Maurice (1953). "René Char". Poesía buenos aires, n 12, pp. 32-34. 
Bustos Domecq, H. (1954). “De aporte positivo”. Buenos Aires Literaria, n¹7, pp. 6164

Brascó, Miguel (1953). "El suplemento de La Nación. (Literatura para los días domingo)". Letra y Línea, $\mathrm{n}^{\circ} 2$, pp. 15-16

(1953) “Retablos de Navidad y de la Pasión, Eduardo González Lanuza”. Letra y línea, $\mathrm{n}^{\mathrm{o}} 1, \mathrm{p}$

(1953-1954) "Poeta al pie de Buenos Aires". Letra y línea, no 3, p.12

Breton, André (1952). "Diálogos con Breton”. A partir de cero, n 2, pp. 7-8

Breton, André (1948). “Jacques Hérold”. Ciclo, n 1, pp. 53-56. Traducción: Aldo Pellegrini.

(1952). Fragmentos de Haute Fréquence. A partir de cero, $\mathrm{n}^{\circ} 1$, pp. $4-5$

Caillois, Roger (1946). "El poder de las palabras". Sur, n'135, pp.:7-28

Cabrera (1953). "Desde esta carne, Valentín Fernando". Letra y línea, no 1, p.14

Cassou, Jean (1949). "La libertad del artista anuncia la libertad del hombre". Ciclo, n², pp. $35-38$

Char, René (1948). "El poeta". Ciclo, nº 1, p.38

Dirección Editorial (1952). “Apuntes para una situación de poesía buenos aires”. Poesía buenos aires, $\mathrm{n}^{\circ} 6, \mathrm{p} .1$

Drummond de Andrade, Carlos (1954). Poesía buenos aires, $\mathrm{n}^{\circ} 15, \mathrm{p} .1$

Editorial A partir de cero (1952). "Diálogos con Breton". A partir de cero, n², pp.7-8.

Editorial Contorno (1955). "Terrorismo y complicidad”. Contorno, n5/6, pp. 1-2

Editorial Cosmorama (1944). "Nota variada". Cosmorama, ${ }^{\circ} 4, \mathrm{p} .: 12$

Editorial El 40 (1951). “Testimonio". El 40. Revista de una generación, n 1, pp.:3-5

Editorial Letra y Línea (1953). “Justificación”. Letra y Línea, n 1, pp. 1-2.

(1954). "Borges y Bioy Casares, paladines de la literatura gelatinosa". Letra y Línea, $\mathrm{n}^{\circ} 4$, pp. 16

Editorial poesía buenos aires (1950). "El poeta”. Poesía buenos aires, n¹, p.1. (1950). "Carta a todos nosotros", n¹, p.2

(1953). "Poetas de hoy: Buenos Aires, 1953”, n¹3-14, p.1

(1953). "Poetas surrealistas", n¹3-14, p.10

Editorial Ventana de Buenos Aires (1952). "Nacionalismo", n², p.1

E.L.R. (1948). "Revistas". Sur, n¹62, pp.:120-121

Espiro, Nicolás (1951). "Noción de poesía". Poesía buenos aires, n 5, p.1

(1952). "La personalidad del arte". Poesía buenos aires, n 8, pp. 5-6

García, Jorge (1953). "Otras reflexiones sobre el concepto de generación”. Centro, n7, pp. $46-51$

Hlito, Alfredo (1946). "Representación e invención”. Boletín de la Asociación Arte Concreto Invención, $\mathrm{n}^{\circ} 2, \mathrm{p} .7$

Latorre, Carlos (1953). "Poesía o no". Letra y Línea, n¹: pp. 3 y 7

(1953). "Poesía o no: el caso Molinari”. Letra y Línea, n², pp. 6 y 10

(1953-1954). "Sur o la literatura italiana”. Letra y Línea, n³, p. 16

Madariaga, Francisco (1953). Fragmento sin título. Poesía buenos aires, n¹3-14, p.4

Maldonado, Tomás (1946). "Lo abstracto y lo concreto en el arte moderno". Invención/ Arte Concreto, $\mathrm{n}^{\circ} 1, \mathrm{p} .5$ 
Mastronardi, Carlos (1947). "Guillaume Apollinaire”. Sur, n¹50, pp. 88-92

Móbili, Jorge Enrique (1951). "Noción de poesía”. Poesía buenos aires, n, p.1.

(1950). "La energía del espacio en nuestra ciudad", n¹, p.4

(1950). "Nos proponemos dar a la poesía", n¹, p.2

Miller, Henry (1948). Fragmentos de Trópico de Capricornio. Ciclo, n¹, pp. 3-22.

Traducción: Aldo Pellegrini

(1953) "Sobre el destino del hombre moderno". Letra y línea, $\mathrm{n}^{\circ} 1 \mathrm{p}$

Molina, Enrique (1952). "Vía libre”. A partir de cero, n¹, pp.1, 7-8

(1952). "Línea de fuego. Presentación”, n¹, p. 4

(1952). "Un golpe del sentido sobre el tambor", n², p.1

(1952). "La poesía debe ser hecha por todos", n², p.1, 8

(1953) “Aimé Césaire”, Enrique Molina. Letra y Línea, n¹, pp. 4,16

(1956). "Cambio de domicilio. Segunda época”. A partir de cero, $\mathrm{n}^{\circ} 3$, pp.1-2

(1953-1954). "Buenos Aires y Guibert. (A propósito del libro Poeta al pie de Buenos Aires)"

Moholy-Nagy, László (1948). “Carta a Kalidova”. Ciclo, nº1, pp. 57-64

Onetti, Juan Carlos (1953). "El fin de la aventura y el principio de la popularidad". Letra y Linea, ${ }^{\circ} 1$, p. 2

Payró, Julio y Aldo Pellegrini (1953). “Correspondencia”. Letra y Línea, n³, pp. 13-14

Pellegrini, Aldo (1952). "El poder de la palabra". A partir de cero, $\mathrm{n}^{\circ} 1, \mathrm{p} .3$

(1952). "El huevo filosófico". A partir de cero, n², p.3

(1953). "Nuevos poemas de Oliverio Girondo". Letra y Línea, n², p.2

(1953). "Tres abstractos y un crítico en Kraft". Letra y Línea $\mathrm{n}^{\circ} 2$, p.

(1953). "El hábito no hace al monje o cuando la poesía cambia de traje pero no de paño. Consideraciones sobre el 'Panorama de la poesía argentina moderna' publicado por poesía buenos aires, $\mathrm{n}^{\circ} 13$ y 14”. Letra y Línea, $\mathrm{n}^{\circ} 3$, pp.15-16

(1956). "Comentario a tres frases célebres (La celebridad es la conciencia del horror)". A partir de cero, $\mathrm{n}^{\circ} 3$, pp.3-4

(1961). "Se llama poesía a todo lo que cierra la puerta a los imbéciles". Poesía = Poesía

Pérez, J.O. (1953). “Los ídolos, Manuel Mujica Láinez”. Letra y Línea n 1, p.14

Pichon-Rivière, Enrique (1949). "Vida e imagen del Conde de Lautréamont”, de (n2),

Piterbarg, Elías (1948). "Surrealismo y surrealistas en 1948”. Ciclo, n¹, pp. 65-73

(1949). "Proposiciones”. Ciclo, n², pp. 43-49

Rogers, Ernesto Nathan (1948). "Ubicación del arte concreto". Ciclo, n¹, p

Rousset, David (1948). "Reseña sobre Les jours de notre mort”. Ciclo n¹, pp. 85-87

Salazar Bondy, Sebastián (1949). "Noticia de Szyszlo”. Ciclo, n² 2, pp.39-42

Sebreli, Juan José (1953). "El martinfierrismo, su tiempo y el nuestro”. Contorno, n¹, pp. 1-2.

Svanascini, Osvaldo (1953-1954). "Paradojas de la poesía”. Letra y Línea, n³, p.5 (1953). “A cinco años de un sosiego". Letra y Línea $\mathrm{n}^{\circ} 1$, pp. 3, 13 (1953). "Henri Michaux". Letra y Linea, n², p.1

Sussman, David (1949). "Reseña sobre Sens-Plastique de Malcom de Chazal". Ciclo, $\mathrm{n}^{\circ} 2$, pp. $78-80$ 
Tzara, Tristan (1951). Fragmento del Le surréalisme et l'après-guerre. Poesía buenos aires, $\mathrm{n}^{\circ} 3$, p.5

Vanasco, Alberto (1953). "Roberto Arlt”. Letra y Línea, n¹, pp. 2, 6

Viñas, David (1954). “Arlt y los comunistas". Contorno, n², p.8

Viñas, Ismael (1953). "La traición de los hombres honestos". Contorno, n¹, pp. 2-3.

Svanascini, Osvaldo (1953). "Henri Michaux". Letra y línea, n², p. 1

Vanasco, Alberto (1954). "Eduardo Mallea o así anda la literatura". Letra y Línea, n4, p.7

\section{FUENTES COMPLEMENTARIAS}

Bataille, Georges, et. al. (2005). Acèphale. Religión sociología filosofía (1936-1939).

Buenos Aires, Caja Negra. Traducción y prólogo: Margarita Martínez. (2005). El erotismo. Barcelona, Tusquets. (2007). La parte maldita. Ensayos sobre economía general. Buenos Aires, Las cuarenta. Traducción: Lucía Belloro, Julián Fava. $\left(2008^{a}\right)$. La religión surrealista. Conferencias 1947-1948. Buenos Aires, Las cuarenta. Traducción y prólogo: Julián Fava.

(2008b). La felicidad, el erotismo, la literatura. Ensayos 1944-1961. Buenos Aires, Adriana Hidalgo. Traducción y prólogo: Silvio Mattoni.

(2018). Sobre Nietzsche. Suma Ateología III. Buenos Aires, Cuenco del Plata.

Traducción: Silvio Mattoni.

(2007). Una libertad soberana. Buenos Aires, Paradiso. Textos y entrevistas:

Michel Suyra. Traducción: Hugo Savino.

(2003) La conjuración sagrada. Ensayos 1929-1939. Buenos Aires, Adriana Hidalgo. Traducción: Silvio Mattoni.

Bataille, G.; Desnos, R.; Einstein C. ; et. Al. (2016). Dictionnaire critique. Paris, Editions Prairial.

Bataille, Georges y Leiris, Michel (2008). Intercambios y correspondencias. 1924-1982.

Buenos Aires, El cuenco de plata. Edición establecida y anotada por Louis Yvert. Postfacio de Bernard Noël. Traducción de Silvio Mattoni.

Bayley, Edgar (1966). Realidad Interna y función de la poesía. Rosario, Editorial Biblioteca Popular Constancio C. Vigil.

Blanchot, Maurice [1955] (2002). El espacio literario. Madrid, Editorial Nacional. Traductores: Vicky Palant y Jorge Jinkis.

[1949] (2007). La parte del fuego. España, Arena Libros. Traducción: Isidro Herrera.

[1971] (1976). La risa de los dioses. Madrid, Taurus. Traductor: J.A. Doval Liz. (1949). Sade y Lautréamont. Buenos Aires, Ediciones de Mediodía. Traducción: Marcia Cerretani.

(2008). "Un habla plural", "El habla cotidiana". La conversación infinita. Madrid, Arena Libros. Traducción: Isidro Herrera. 
Fondane, Benjamin (1937). "El poeta y la esquizofrenia. La conciencia vergonzosa I". Sur $\mathrm{n}^{\circ} 34$, Buenos Aires.

Guillot Muñoz, Gervasio (1935). "Revisión y justiprecio del superrealismo". Sur nº10, Buenos Aires.

Kusch, Rodolfo [1956] (2013). "Maldoror, monstruo americano". La negación en el pensamiento popular. Buenos Aires, Las Cuarenta.

Pellegrini, Aldo (1967). Panorama de la pintura argentina contemporánea. Buenos Aires, Paidos.

(2016). La conquista de lo maravilloso. Buenos Aires, Editorial Argonauta.

(1965). Para contribuir a la confusión general. Buenos Aires, Ediciones Nueva Visión.

Sartre, Jean Paul [1948] (1981). ¿Qué es la literatura? Buenos Aires, Losada. Traducción: Aurora Bernárdez.

(1965). "El silencio de Orfeo". La república del silencio. Buenos Aires, Losada. Traducción: Alberto L. Bixio.

\section{BIBLIOGRAFÍA CRÍTICA Y TEÓRICA CITADA:}

Adorno, Theodor (2013). Estética (1958/9). Buenos Aires, Las Cuarenta. Traducción: Silvia Schawarzböck

Agamben, Giorgio (2005). Lo que queda de Auschwitz. El archivo y el testigo. Homo Sacer III. Valencia, Pre-textos.

(2003). Infancia e historia. Buenos Aires, Adriana Hidalgo.

(2005). Profanaciones. Buenos Aires, Adriana Hidalgo

(2008). "Lo contemporáneo". Texto inédito en español. Traducción: Verónica

Nájera. https://etsamdoctorado.files.wordpress.com/2012/12/agamben-que-es-locontemporaneo.pdf

(2009) Signatura rerum. Buenos Aires, Adriana Hidalgo. Traducción: Flavia Costa y Mercedes Ruvituso.

(2014). ¿Qué es un dispositivo? Buenos Aires, Adriana Hidalgo.

[2000] (2006). El tiempo que resta. Comentario a la carta de los romanos.

Madrid, Editorial Trotta. Traducción: Antonio Piñero.

(2005). Lo abierto. Madrid, Pre-textos. Traducción: Antonio Gimeno Cuspinera (2016). La comunidad que viene. Madrid, Pre-textos.

Aguilar, Gonzalo (2002). "Vanguardias" y "Modernismo". En Carlos Altamirano (dir.), Términos críticos de sociología de la cultura. Buenos Aires, Paidós. 180-186, 231236. Impreso.

(2003). Poesía concreta brasileña: las vanguardias en la encrucijada modernista. Rosario, Beatriz Viterbo.

Aguirre, Raúl Gustavo (2016). Las poéticas del siglo XX. Buenos Aires, Audisea.

Aguirre, Raúl Gustavo y René CHAR (2016). Correspondencia y poemas. Buenos Aires, EdHASA. Traducción: Magdalena Cámpora y Raúl Gustavo Aguirre. Notas: Magdalena Cámpora. 
Altamirano, Carlos y Sarlo, Beatriz (1980). Conceptos de sociología literaria. Buenos Aires, Centro editor de América Latina.

Altamirano, Carlos (1993). Literatura-Sociedad. Buenos Aires, Edicial.

(1997). Ensayos argentinos: de Sarmiento a la vanguardia. Buenos Aires, Ariel.

Anderson Imbert, Enrique (1969). Métodos de crítica literaria. Madrid, Editorial Revista de Occidente.

Antelo, Raúl (2015). Archifilologías latinoamericanas. Lecturas tras el agotamiento. Villa María, EDUVIM.

(2015). "A potencialidade do arquivo", traducción a cargo de Delfina Cabrera para el libro en preparación El archivo como política de lectura. Mimeo

(2015). "El tiempo de una imagen: el tiempo-con". Cuadernos de Literatura. Volumen XIX, n³8. Págs. 376-399

(2001). "Política del archivo". Revista Iberoamericana. Volumen LXVII, nº197.

Págs. 709-720

(2008). Crítica acéfala. Buenos Aires, Editorial Grumo.

(2016). "Programa para un posgrado futuro". El taco en la brea. Revista del Centro de Investigaciones Teórico-Literarias. CEDINTEL, Año 3, Volumen 3, mayo 2016. Págs. 144-171. Santa Fe, Universidad Nacional del Litoral.

(2004). "Poesía hermética y surrealismo". Historia crítica de la literatura argentina (Noé Jitrik, director). Tomo 9: El oficio se afirma (Sylvia Saítta, directora). Buenos Aires, EMECÉ. 373-400

(2013). "La lectura poslógica de Ciclo" en El surrealismo y sus derivas: visiones, declives y retornos, Eduardo Becerra (coord.). Madrid, Abada. 177-197

(2014). “La desnudez de la materia”. En G. Herzovich e I. Cadenas Cañón (Ed.), Dossier Aldo Pellegrini. Salagrumo, no 37, pp. 19-39

(1984). Literatura em Revista. Sao Paulo, Ática.

Aira, César (2016). Sobre el arte contemporáneo. Buenos Aires, Literatura Random House.

(2001). Alejandra Pizarnik. Rosario, Beatriz Viterbo.

Alcaide, Carmen (1997). "El arte concreto en Argentina. Invencionismo - Madí Perceptismo". Arte, Individuo y Sociedad, nro 9. Madrid, Servicio de Publicaciones Universidad Complutense.

Alonso, Rodolfo (2009). poesía buenos aires (1950-1960). Antología íntima. Selección, prólogo y notas a cargo de Rodolfo Alonso. Buenos Aires, Ediciones del Dock

(2014). "Alrededor de poesía buenos aires". poesía buenos aires. Edición facsimilar. Tomo I 1950-1955. Buenos Aires, Ediciones Biblioteca Nacional.

Alonso, Fernando; Lafleur, Héctor, Y Provenzano, Sergio (2006). Las revistas literarias argentinas 1893-1967. Buenos Aires, El octavo loco. Prólogo: Marcela Croce.

Aragon, Louis [1924] (2004). Una ola de sueños. Buenos Aires, Biblos. Estudio preliminar, traducción y notas: Ricardo Ibarlucía.

Arce, Rafael (2014). "Las novelas de Alberto Vanasco: en la estela del surrealismo". RECIAL. Revista del Ciffyh Área Letras. Facultad de Filosofía y Humanidades. Córdoba, Universidad Nacional de Córdoba. ํ5-6, pp. 
(2013). "La novela conjetural” en Badebec. Revista de teoría y crítica literaria, Rosario, Universidad de Rosario. Volumen 3, N5.

Aribit, Frédéric (2007). "Breton-Bataille : autopsie du Cadavre », disponible en : http://f.aribit.free.fr/notes de lecture/breton bataille autopsie du cadavre.pdf

Artundo, Patricia M. (2010). "Reflexiones en torno a un nuevo objeto de estudio: las revistas", IX Congreso Argentino de Hispanistas: el hispanismo ante el Bicentenario, Asociación Argentina de Hispanistas, Instituto de Investigaciones en Humanidades y Ciencias Sociales (UNLP/CONICET), Universidad Nacional de La Plata, La Plata, 27 al 30 de abril de 2010, disponible en http://ixcah.fahce.unlp.edu.ar/actas/artundo-patricia-

Avaro, Nora y Capdevilla, Analía (2004). Denuncialistas. Literatura y polémica en los '50. Buenos Aires, Santiago Arcos editor.

Bachelard, Gastón [1932] (2002). La intuición del instante. México, Fondo de Cultura Económica. Traducción: Jorge Ferreiro.

Badiou, Alain [2005] (2011). El siglo. Buenos Aires, Manantial. Traducción: Horacio Pons.

Badiou, Alain et al. (2014) ¿Qué es un pueblo? Buenos Aires, Eterna Cadencia.

Bajarlía, Juan Jacobo (1946). Literatura de vanguardia. Del Ulises de Joyce y las Escuelas Poéticas. Buenos Aires: Editorial Araujo.

Barthes, Roland [1966] (1972). Crítica y verdad. Buenos Aires, Siglo XXI. Traducción: José Bianco.

(2003). El placer del texto, seguido por Lección inaugural de la cátedra de semiología lingüistica del Collège de France pronunciada el 7 de enero de 1977. Buenos Aires, Siglo XXI. Traducción: Nicolás Rosa y Oscar Terán. (1997). S/Z. México DF, Siglo XXI.

(1992). Lo obvio y lo obtuso: imágenes, gestos, voces. Barcelona, Paidós. Traducción: César Fernández Medrano.

(1985). El grado cero de la escritura. Seguido de Nuevo Ensayos críticos. México DF, Siglo XXI. Traducción: Nicolás Rosa.

(2018). Roland Barthes por Roland Barthes. Buenos Aires, Eterna Cadencia. Traducción de Alan Pauls.

Baumgart, Claudia et al. (1982). "Las propuestas poéticas de vanguardia" en Capitulo. Historia de la literatura argentina. Tomo IV. Buenos Aires, Centro Editor de América Latina. Pp: 217-241

Becerra, Eduardo, coord. (2013). El surrealismo y sus derivas. Visiones, declives y retornos. Raquel Arias, Belén Castro Morales, Armando Minguzzi, Claudia Montero, José Teruel y Eva Valcárcel (eds.) Madrid: Abada editores.

Benjamin, Walter (2014). "El surrealismo. La última instantánea de los intelectuales europeos”. El surrealismo, Madrid, Casimiro. Traducción de Paul Laidon.

(1998). "El surrealismo. La última instantánea de la inteligencia europea". En Iluminaciones I. Imaginación y Sociedad. Traducción de Jesús Aguirre. Madrid, Taurus. Pp.: 41-62

(1973). Discursos Interrumpidos I. Filosofía del arte y la historia. Madrid, Taurus. Traducción: Jesús Aguirre. 
(1973) Tesis de la filosofía de la historia. En Discursos interrumpidos I. Filosofía del Arte y de la historia. Madrid, Taurus. Traducción: Jesús Aguirre.

(1986). Sobre el panorama de la filosofía futura y otros ensayos. Barcelona, Planeta-Agostini. Traducción: Roberto J. Vernengo.

(1988). El concepto de crítica de arte en el Romanticismo alemán. Barcelona, Península. Traducción: J.F. Yvars y Vicente Jarque.

(1998). Iluminaciones I. Imaginación y sociedad. Madrid, Taurus. Traducción: Jesús Aguirre.

(1991). Iluminaciones IV. Para una crítica de la violencia y otros ensayos. Madrid, Taurus. Traducción: Roberto Blatt.

(1993). La metafísica de la juventud. Barcelona, Paidós. Traducción: Luis Martínez de Velasco.

(2016). Libro de los pasajes. Madrid, Akal. Traducción: Luis Fernández Castañeda, Isidro Herrera y Fernando Guerrero.

(2012). Origen del 'Trauerspiel' alemán. Buenos Aires, Gorla. Introducción: Miguel Vedda. Traducción y notas: Carola Pivetta.

Besançon, Alain (2003). La imagen prohibida. Una historia intelectual de la iconoclastia. Madrid, Siruela. Traducción: Encarna Castejón.

Bioy Casares, Adolfo (2006). Borges. Buenos Aires, Destino.

Book Moors, Susan (1995). Dialéctica de la mirada. Walter Benjamin y el proyecto de los pasajes. Madrid, Visor. Traducción: Nora Rabotnikof.

Borges, Jorge Luis (1991). Discusión. Buenos Aires, Emecé.

(1953). Historia de la eternidad. Buenos Aires, Emecé

(1964). Otras inquisiciones. Buenos Aires, Emecé.

Bossi, Alfredo (1991). "La parábola de las vanguardias latinoamericanas". Schwartz, J. (dir) Las vanguardias latinoamericanas. Textos programáticos y críticos. México, Fondo de Cultura Económica.

Breton, André (2012). Manifiestos del surrealismo. Buenos Aires, Argonauta. Traducción y notas: Aldo Pellegrini.

(2005). Los vasos comunicantes. Madrid, Siruela. Traducción: Agustí Bartra.

Bugnone, Ana (2017). Vigo: arte, política y vanguardia. La Plata, Malisia editorial.

(2014). La revista Hexágono '71 [1971-1975]. La Plata, Biblioteca Orbis Tertius y Centro de Arte Experimental Vigo.

Butler, J. (2001). ¿Qué es la crítica? Un ensayo sobre la virtud de Foucault. Transversal Texts. Instituto Europeo de Políticas Culturales Progresivas. Conferencia traducida por Marcelo Expósito y revisada por Joaquín Barriendos. Recuperado de http://eipcp.net/transversal/0806/butler/es

Bürger, Peter (2010). Teoría de la vanguardia. Buenos Aires, Las cuarenta. Traducción: Tomás Joaquín Bartoletti.

(1972). El surrealismo francés. Estudio sobre el problema de la literatura vanguardista.

Calbi, Mariano (1999). "Prolongaciones de la vanguardia". Historia crítica de la literatura argentina (Noé Jitrik, dir.). Tomo 10: La irrupción de la crítica (Susana Cella, dir.). Buenos Aires, EMECÉ. Pp.: 235- 255 
Carter, Boyd (1959). Las revistas literarias de Hispanoamérica: breve historia y contenido. México, Colección Studium 24.

Cella, Susana, dir. (1999). Historia crítica de la literatura argentina. Noé Jitrik dir. Tomo $\mathrm{X}$ : La irrupción de la crítica. Susana Cella dir. del volumen. Buenos Aires, Emecé.

Cella, Susana (2013). "Letra y Línea, entre la parábola y la elipse”. El surrealismo y sus derivas: visiones, declives y retornos. Eduardo Becerra (Coord.). Madrid, Abada. (1999). "La irrupción de la crítica" y "Panorama de la crítica". Historia crítica de la literatura argentina. Noé Jitrik dir. Tomo X: La irrupción de la crítica. Susana Cella dir. del volumen. Buenos Aires, Emecé.

Chartier, Roger (2007). La historia o la lectura del tiempo. Barcelona, Gedisa

Cippolini, Rafael (2003). Manifiestos argentinos. Politicas de los visual 1900-2000. Buenos Aires, Adriana Hidalgo.

Colección Juan Batlle Planas: patrimonio de la Universidad Nacional de La Plata (2017). Contribuciones de Julieta Suárez Guerrini, Luis di Salvo, Julieta de Marziani, Guillermo E. Sierra, Eva Cabrera. La Plata, Papel Cosido - Editorial de la Facultad de Bellas Artes de la UNLP.

Constantin, María Teresa y Diana Beatriz Wechsler. (2005) Los surrealistas. Insurrectos, iconoclastas y revolucionarios en Europa y América. Buenos Aires, Longseller.

Contreras, Sandra. "Discusiones sobre el realismo en la narrativa argentina contemporánea". Revista Orbis Tertius XI (12) (2006), s/n. http://www.orbistertius.unlp.edu.ar/issue/view/102

Cortázar, Julio (1994). "Teoria del túnel” en Obra crítica/1. Madrid, Santillana.

Cragnolini, Mónica (2009). "El sexto siempre vuelve” en Revista Otra Parte.

Crespi, Maximiliano (2011). La conspiración de las formas. Apuntes sobre el jeroglífico literario. La Plata, UNIPE: Editorial Universitaria.

(2016). Viñas crítico. Buenos Aires, 17 grises.

Crespo, Regina (coord.) (2010). Revistas en América Latina: proyectos literarios, politicos y culturales. México, UNAM.

Crispianni, Alejandro (2011). Objetos para transformar el mundo. Trayectorias del arte concreto-invención, Argentina y Chile, 1940-1970. Quilmes, Ediciones ARQ.

Cristófalo, Américo (2007). "La metafísica en la poesía de los '50". Historia social de la literatura argentina. El peronismo clásico (1945-1955). David Viñas (dir.), Guillermo Korn (compilador del tomo). Buenos Aires, Paradiso.

Croce, Marcela (2006). "Las revistas literarias argentinas o una historia colectiva de la literatura local”, en Lafleur, Héctor René et al. Las revistas literarias argentinas: 1893-1967. Precedido por un ensayo de Marcela Croce. Buenos Aires, El 8vo. loco, p. 9-30.

(1996). Contorno: izquierda y proyecto cultural. Buenos Aires, Colihue.

Dalmaroni, Miguel (2004). La palabra justa. Literatura, crítica y memoria en la Argentina (1960-2002). Santiago de Chile, RIL editores y Melusina editorial.

(2015). "Resistencias a la lectura y resistencias a la teoría. Algunos episodios en la crítica literaria latinoamericana". Cuatrocientos cincuenta y dos grados 
Fahrenheit. Revista de Teoría de la Literatura y Literatura Comparada. Barcelona, Facultad de Filología, pp 42-62

Delgado, Verónica (2010). El nacimiento de la literatura argentina en las revistas literarias: 1896-1913. La Plata, Edulp.

(2015). “Algunas cuestiones críticas y metodológicas en relación con el estudio de revistas". Tramas impresas: Publicaciones periódicas argentinas (XIX-XX), Geraldine Rogers, Alejandra Mahille y Verónica Delgado (coords.); Colección Estudios/Investigaciones. La Plata, Universidad Nacional de La Plata. http://www.libros.fahce.unlp.edu.ar/index.php/libros/catalog/view/33/48/165-1.

de Diego, José Luis (2014). “(1938-1955) La época de oro de la industria editorial”. Editores y políticas editoriales en Argentina (1880-2010). Buenos Aires, Fondo de Cultura Económica.

de Man, Paul (1990a). La resistencia a la teoría. Madrid, Visor. Edición: Wlad Godzich. Traducción: Elena Elorriaga y Oriol Francés.

(1990b). Alegorías de la lectura: Lenguaje figurado en Rosseau, Nietzsche, Rilke y Proust. Barcelona, Lumen. Traducción: Enrique Lynch.

de Rueda, María de los Ángeles (2000). "La nostalgia de las Vanguardias en Argentina. La Aventura Concreta-Madi-Cinética”. La Plata, UNLP

de Sagastizábal, Leandro (1995). La edición de libros en la Argentina: una empresa de cultura, Buenos Aires, Eudeba.

de Torre, Guillermo (1971). Historia de las vanguardias literarias. Madrid, Guadarrama.

Del Barco, Oscar (2011). Escrituras filosofía. Buenos Aires, Ediciones Biblioteca Nacional.

Del Gizzo, Luciana (2012). "El fin de la elocuencia: figuraciones de lo poético y transformación lingüística en Buenos Aires a mediados del siglo XX". Cuadernos Americanos, 140, México, Feb.: 187-220 pp.

(2010). "Arturo, terreno de prueba. Acerca del origen conjunto del invencionismo y del arte concreto en Argntina". Investigación, 3, Chile, Primavera: 1-19. URL: http://revistalaboratorio.udp.cl/

(2017). Volver a la vanguardia. El invencionismo y su deriva en el movimiento poesía buenos aires (1944-1963). Buenos Aires, Ediciones en Danza; Madrid, Aluvión Editorial

(2018). "El inconsciente de la vanguardia. Relaciones entre la primera y la segunda oleada vanguardista en argentina". Káñina, Rev. Artes y Letras, Univ. de Costa Rica XLII (3) 2018 (Octubre-Diciembre): p.235-255

Deleuze, Gilles y Guattari, Félix [1977] (2010). “Rizoma. Introducción” en Mil mesetas. Capitalismo y esquizofrenia. Valencia, España. José Vázquez Pérez y Umbelina Larracleta, traductores.

Deleuze, Gilles [1968] (2002). Diferencia y repetición. Buenos Aires, Amorrortu editores. Traducción: María Silvia Delpy y Hugo Beccacece.

Déotte, Jean-Louis [2007] (2012). ¿Qué es un aparato estético? Benjamin, Lyotard, Rancière. Santiago de Chile, Metales Pesados. Traductora: Francisca Salas Aguayo.

(2013). La época de los aparatos. Buenos Aires, Adriana Hidalgo. Traducción: Antonio Oviedo 
Didi-Huberman, Georges (2008). "Das Archiv brennt" en Das Archiv brennt, Georges

Didi-Huberman y Knut Ebeling (eds.). Berlin, Kadmos. Traducción: Juan Antonio

Ennis para la Cátedra de Filología Hispánica de FAHCE, UNLP.

[2000] (2015). Ante el tiempo. Historia del arte y anacronismo de las imágenes.

Buenos Aires, Adriana Hidalgo. Traductor: Antonio Oviedo.

(2010). Ante la imagen. Pregunta formulada a los fines de una historia del arte.

Madrid, Cendeac

(2011). Atlas ¿Cómo llevar el mundo a cuestas? Madrid, Museo Nacional

Centro de Arte Reina Sofía. Traducción María Dolores Aguilera.

(2012). La supervivencia de las luciérnagas. Madrid, Abada.

(2009). La supervivencia de la imagen. Madrid, Abada.

Dobry, Edgardo (2007). Orfeo en el quiosco de diario. Ensayos sobre poesía. Buenos Aires, Adriana Hidalgo.

Dubbuffet, Jean y Gombrowicz, Witold [1970] (1972). Correspondencia. Barcelona,

Anagrama. Traducción: Javier Fernández de Castro.

Duchamp, Marcel (2012) Escritos. Barcelona, Galaxia Gutenberg.

Durozoi, G. y Lecherbonnier, B. (1974). El surrealismo. Teorías, temas, técnicas.

Madrid, Guadarrama.

Eagleton, Terry (2005). Después de la teoría. Barcelona, Debate.

Elizalde, Lydia (org.) (2008). Revistas culturales latinoamericanas, México DF, Consejo

Nacional para la Cultura y las Artes, Universidad Autónoma del Estado de Morelos,

Universidad Iberoamericana.

Englekirk, John (1961-1963) "La literatura y la revista literaria en Hispanoamérica", Revista Iberoamericana, n. 51-53 y 55.

Espejo, Miguel (1984). La ilusión lírica. Buenos Aires, Hachette.

(2009). "Los meandros surrealistas". Historia crítica de la literatura argentina,

(Noé Jitrik dir). Tomo VII: Rupturas (Celina Manzoni, dir). Buenos Aires, EMECE, pp.12-47.

Eujanian, Alejandro (1999). Historia de revistas argentinas: 1900/1950, la conquista del público, Buenos Aires, Asociación Argentina de Editores de Revistas.

Fer, Brioni, David Batchelor y Paul Wood (1999). Realismo, racionalismo y surrealismo.

El arte de entreguerras. Madrid, Akal.

Fiel, David (2915). "El nacimiento de la teoría. Roland Barthes y El grado cero de la escritura". Roland Barthes. Los fantasmas del critico Rosario, Nube Negra.

Fiorucci, Flavia (2007). "La administración cultura del peronismo. Políticas, intelectuales y Estado". Latin American Studies Center/ Working Papers. University of Maryland, College Park

(2011). Intelectuales y peronismo. 1945-1955. Buenos Aires, Biblos.

Fondebrider, Jorge, Daniel Freidemberg y Daniel Samoilovich (1988-1989). «Dossier PBA». Diario de Poesía, ${ }^{\circ} 11$.

Foster, Hal (2001). El retorno de lo real. La vanguardia a finales de siglo. Madrid, Akal. Traducción: Alfredo Brotons Muñoz.

Foucault, Michel (2008a). Las palabras y las cosas. Buenos Aires, Siglo XXI. Pp: 167174 
(2008b) La arqueología del saber. Buenos Aires, Siglo XXI

Freidemberg, Daniel (1984) "La poesía del cincuenta". Capítulo. Historia de la literatura argentina. Tomo 5. Buenos Aires, Centro Editor de América Latina. Pp.:553-573

García, Carlos y Dieter Reichardt (editores) (2004). Las vanguardias literarias en Argentina, Uruguay, Paraguay. Bibliografia y antología crítica. Frankfurt am Main; Madrid. Vervuert/Iberoamericana.

García, Germán (2011). Para otra cosa. El psicoanálisis entre las vanguardias. Buenos Aires, Liber Editores.

Ghiano, Juan Carlos (1957). Poesía Argentina del Siglo XX. Buenos Aires, Fondo de Cultura Económica.

Gilbal Blacha y Quatrocchi-Woisson (eds.) (1999). Cuando opinar es actuar. Revistas argentinas del siglo XX. Buenos Aires, Academia Nacional de Historia

Gino Germani y Grete Stern (2017). Los sueños. Buenos Aires, Caja Negra.

Gilman, Claudia (2003). Entre la pluma y el fusil. Debates y dilemas del escritor revolucionario en América Latina. Buenos Aires, Siglo XXI.

Giordano, Alberto (1999). Razones de la crítica. Sobre literatura, ética y política. Buenos Aires, Ediciones Colihue.

(1995) Literatura y poder. Rosario, Beatriz Viterbo.

(2005). Modos del ensayo. De Borges a Piglia. Rosario, Beatriz Viterbo.

(2015) "Roland Barthes y la ética del crítico ensayista". Seis formas de amar a

Barthes. Gonzalez Roux, Maya y Schmukler, Enrique (dir) . Buenos Aires, Capital Intelectual.

(2016). El pensamiento de la crítica. Rosario, Beatriz Viterbo.

Giordano, Carlos. (1992) “Poesía Buenos Aires, 1950-1960”. América: Cahiers du CRICCAL. Le discours culturel dans les revues latino-américaines, 1940-1970, $\mathrm{n}^{\circ}$ 9-10: pp 385-392

(1983) "Entre el 40 y el 50 en la poesía argentina". Revista Iberoamericana vol. XLIX, 125: p.783-796

Giunta, Andrea (2001). Vanguardia, internacionalismo y política. Arte argentino en los años sesenta. Buenos Aires, Paidós.

Goloboff, Mario (2008). Presentación del dossier: entrada e itinerarios del surrealismo en la literatura argentina. Orbis Tertius 14.

Gómez de la Serna, Ramón (1947). Ismos. Buenos Aires, Poesidón.

González, Horacio (1990). "Elogio del ensayo". En Babel, III, 18; dossier "Últimas funciones del ensayo" (p.29).

Gramuglio, María Teresa (2013). Nacionalismo y cosmopolitismo en la literatura argentina. Rosario, Editorial Municipal de Rosario.

Gramuglio, María Teresa et al. (1983). "Dossier: la revista 'Sur”, Punto de Vista, Buenos Aires, a. 6, n. 17, abril-julio, p. 7-14.

(1989) "Historias de la literatura: pasión y deseos." Punto de vista. Revista de cultura, año XII, n. ${ }^{\circ} 36$, diciembre de 1989, pp. 25-29.

Groys, Boris (2014). Volverse público. Transformaciones del arte en el ágora contemporánea. Buenos Aires, Caja Negra. Traducción: Paola Cortés Roca. 
(2008). Obra de arte total Stalin. Valencia, Pre-textos. Traducción directa del ruso: Desiderio Navarro.

Grüner, Eduardo (2015). "El ensayo, un género culpable". En A. Giordano (ed.) El discurso sobre el ensayo en la cultura argentina desde los 80 (pp.59-72). Buenos Aires, Santiago Arcos.

Heidegger, Martin y Sartre, Jean Paul (1982). El existencialismo es un humanismo. Carta sobre el humanismo. Buenos Aires, Ediciones del 80.

Herzovich, Guido (2016). "Vanguardia y mercado en Argentina: el caso Pellegrini". Revista Aletria. V.26, № 1, p.195-215, Belo Horizonte

(2015). La desigualdad como tarea. Crítica literaria y masificación editorial en Argentina (1950-60). Tesis doctoral, Columbia University, 2015 (en prensa).

Huyssen, Andreas (2006). Después de la gran división: modernismo, cultura de masas y postmodernismo. Buenos Aires, Adriana Hidalgo. Traducción: Pablo Gianera

Ibarlucía, Ricardo (1998). Onirokitsch : Walter Benjamin y el surrealismo. Buenos Aires, Manantial.

Iglesias, Claudio (2017). "La familia surrealista: puntos de acceso a un arte aficionado, travesti y barrial" en S. Villanueva, C. Iglesias, J.C. Pedroni, Objeto móvil recomendado a las familias. Buenos Aires, Fundación OSDE.

Indij, Guido, comps. (2014). Sobre el tiempo. Buenos Aires, La Marca editora.

Jacoby, Roberto y Fernandez Vega, Jose (2017). Extravíos de la vanguardia. Del Di Tella al siglo XXI. Buenos Aires, Edhasa

Jarry, Alfred; Launoir, Ruy; Fassio, J.E. y Sainmont, J. Hughes (2009). Patafísica: epitomes, recetas, instrumentos y lecciones de aparato / Alfred Jarry. Compilación: Rafael Cipollini. Buenos Aires, Caja Negra.

Jitrik, Noé et al. (1993). El rol de las revistas culturales, Espacios, Buenos Aries, n. 12, junio-julio de 1993, p. 3-16.

Jitrik, Noé (1987). La vibración del presente. México, Fondo de Cultura Económica.

Jorge, Gerardo (2012). "Dilemas en la poesía argentina de los años cincuenta. Las primeras publicaciones de Leónidas Lamborghini, la revista Poesía Buenos Aires, lo antipoético y la modernización". Exlibris 1/1: 283-298.

King, John (1989). Sur. Estudio de la revista argentina y de su papel en el desarrollo de una cultura 1931-1970. México, Fondo de Cultura Económica.

Korn, Guillermo, dir. (2007). Literatura argentina siglo XX. David Viñas Director. Tomo 4: El peronismo clásico (1945-1955). Descamisados, gorilas y contreras. Guillermo Korn compilador. Buenos Aires, Paradiso.

(2017). Hijos del pueblo. Intelectuales peronistas: de la Internacional a la Marcha. Buenos Aires, Las Cuarenta.

Korn, Guillermo y Claudio Panella (2010). Ideas y debates para la Nueva Argentina. Revistas culturales y políticas del peronismo (1946-1955). Volumen I. La Plata, EDULP.

(2014). Ideas y debates para la Nueva Argentina. Revistas culturales y políticas del peronismo (1946-1955). Volumen II. La Plata, EDULP.

(2016). Ideas y debates para la Nueva Argentina. Revistas culturales y políticas del peronismo (1946-1955). Volumen III. La Plata, EDULP. 
Laplantine, François y Nouss, Alexis (2007). Mestizajes. De Arcimboldo a zombi. Buenos Aires, Fondo de Cultura Económica.

Lamborghini, Leónidas (1955). Saboteador arrepentido, Buenos Aires, El peligro amarillo.

(1956). "El nombramiento", "Fragmento" y "Final”. Poesía Buenos Aires 21: 27-31.

(1957). Al público, Buenos Aires, Poesía Buenos Aires.

(2010). Mezcolanza. A modo de memoria, Buenos Aires, EMECE.

Libertella, Héctor (1977). Nueva escritura en Latinoamérica. Caracas, Monte Ávila.

Link, Daniel (1994). "Historia de una pasión argentina. La crítica literaria 1955-1966", Cuadernos Hispanoamericanos 527.

(2003) Cómo se lee y otras intervenciones críticas. Buenos Aires, Norma. (2009). Fantasmas. Imaginación y sociedad. Buenos Aires, Eterna Cadencia.

Longoni, Ana (2006). "La teoría de la vanguardia como corset. Algunas aristas de la idea de "vanguardia" en el arte argentino de los 60/70". Pensamiento de los confines, $\mathrm{N}^{\mathrm{o}}$ 18. Pp.: 61-68

Louis, Annick (2014). "Las revistas literarias como objeto de estudio". Hanno Ehrlicher/ Nanette Rißler-Pipka (eds.) Almacenes de un tiempo en fuga: Revistas culturales en la modernidad hispánica. Leer y mirar las revistas: desafios materiales, metodológicos y tecnológicos. Aachen, Shaker Verlag.

Louis, Marin (2015). Destruir la pintura. Buenos Aires, Fiordo.

Lowy, Michel (2007). La estrella de la mañana. Surrealismo y marxismo. Buenos Aires, El cielo por asalto.

Löwy, Michael [1996] (2014). "Walter Benjamin y el surrealismo: historia de un encantamiento revolucionario". Prólogo a El surrealismo, Walter Benjamin. Madrid, Casimiro libros.

Lucena, Daniela (2015). Contaminación artística. Vanguardia concreta, comunismo y peronismo en los años '40. Buenos Aires, Biblos.

(2011). "Arte concreto y Nueva Visión: una lectura en clave política". Revista Aurora, 10.

Mangone, Carlos y Warley, Jorge (1982). "La modernización de la crítica: la revista Contorno". Capitulo. Historia de la literatura argentina. Tomo 5 (Dir. Susana Zanetti). Buenos Aires, Centro Editor de América Latina.

(1984). "Las revistas Verbum y Centro". "La revista Contorno. Sus números políticos”. Universidad y peronismo: 1946-1955. Buenos Aires, Centro Editor de América Latina.

Mangone, Carlos y Jorge Warley (1993). El manifiesto. Buenos Aires, Editorial Biblos. Manzzoni, Celina, dir. (2009). Historia crítica de la literatura argentina, (Noé Jitrik dir). Tomo VII: Rupturas, Celina Manzoni, dir. Buenos Aires, EMECE.

Mattoni, Silvio (2003). La forma del ensayo en la argentina de los años '50. Córdoba, Universitas.

Marx, Karl (1971). El 18 Brumario de Luis Bonaparte. Buenos Aires, Ariel. Traducción: O.P. Safont. 
Massiello, Francine (1986). Lenguaje e ideología. Las escuelas argentinas de vanguardia. Buenos Aires, Hachette.

Maturo, Graciela. (2015) El surrealismo en la poesía argentina. Buenos Aires, Prometeo. Minguzzi, Armando (2013). "Los diálogos estéticos del segundo momento del surrealismo argentino: la revista Ciclo (1948-1949)". El surrealismo y sus derivas. Madrid, Universidad Autónoma de Madrid.

Minguzzi, Armando (2014). "La revista Qué: prácticas editoriales y filiaciones estéticas en el inicio del surrealismo argentino". Delgado, V. y G. Rogers (dir) Tramas impresas. Publicaciones periódicas argentinas $(X I X-X X)$. La Plata, UNLP.

(2013) La revista Qué: albores de la estética surrealista en el horizonte de la vanguardia porteña. https://www.uam.es/proyectosinv/surreal

Molloy, Silvia (1972). La diffusion de la littérature hispano-américaine en France au $X X^{e}$ siècle. Paris, Presses Universitaires de France.

Nacher, Max Hidalgo (2015). Dossier Historia y usos hispánicos de la teoría (19531984). En $452^{\circ} F, \mathrm{n}^{\circ} 12$, Universitat de Barcelona. Pp.: 2-152

(2015). "Los discursos de la crítica literaria argentina y la teoría literaria francesa (1953-1978)". Dossier Historia y usos hispánicos de la teoría (1953-1984). En 452 ${ }^{\circ} \mathrm{F}, \mathrm{n}^{\circ} 12$, Universitat de Barcelona. Pp.: 102-131

Nadeau, Maurice (1948). Historia del surrealismo. Buenos Aires, Santiago Rueda.

Nancy, Jean-Luc (2016). La comunidad revocada. Buenos Aires, Mardulce.

Nietzsche, Friedrich. Sobre verdad y mentira en sentido extramoral

Páez, Roxana (2013). Poéticas del espacio: Juan L Ortiz, Francisco Madariaga. Buenos Aires, Mansalva.

Panesi, Jorge (2004). Críticas. Buenos Aires, Norma.

(2018). La seducción de los relatos. Crítica literaria y política en Argentina. Buenos Aires, Eterna Cadencia.

(1996) "La caja de herramientas o qué no hacer con la teoría". El taco en la brea $\mathrm{N}^{\circ} 1$. Revista del Centro de Investigaciones Teórico-literarias -CEDINTELFHUC / UNL

http://bibliotecavirtual.unl.edu.ar/ojs/index.php/ElTacoenlaBrea/article/viewFile/4 $218 / 6373$

$\left(2005^{\mathrm{a}}\right)$. "Hegemonía, excepciones y trivialidades en la crítica cultural argentina”. El interpretador $\mathrm{N}^{\circ} 12$, marzo 2005.

(2005b). "Los dos tiempos de la crítica". Orbis Tertius 10 (11). Revista de teoría y crítica literaria de la Facultad de Humanidades y Ciencias de la Educación, UNLP. http://www.orbistertius.unlp.edu.ar/

Pariente, Ángel (2014). Repertorio de ideas del surrealismo (1919-1970). Barcelona, Pepitas de Calabaza.

Patiño, Roxana (2013). "Itinerarios de la teoría y la crítica latinoamericanas (1970-2000)" en Escrituras latinoamericanas: Literatura, teoría y crítica en debate; Roxana Patiño y Nancy Calomadre (ed.). Córdoba, Alción.

(1997). Intelectuales en transición: las revistas culturales argentinas (19811987). Sao Paulo, Universidade de Sao Paulo. 
Patiño, Roxana y Schwartz, Jorge (2004) (comps.). Revista Latinoamericana. Vol. LXX, No. 208-209. Pennsylvania: Universidad de Pittsburgh, julio-diciembre, 2004. Número Monográfico sobre las Revistas en América Latina.

Parra, Nicanor [1954] (2014). Poemas y antipoemas Santiago de Chile, Universidad Diego Portales.

Paz, Octavio [1974] (2005). Los hijos del limo. Del romanticismo a la vanguardia. Guadalajara, Ligeia.

Pérez-Barreiro, Gabriel (1994). "La negación de toda melancolía: Arte Madi / ConcretoInvención 1944-1950”. David Elliott, Argentina 1920-1994. Museum Of Modern Art Oxford.

Pereyra, Washington (1996). La prensa literaria argentina 1890-1974. Buenos Aires, Librería Colonial.

Petra, Adriana (2013). Intelectuales comunistas en la Argentina (1945-1963) [en línea]. Tesis de posgrado. Universidad Nacional de La Plata. Facultad de Humanidades y Ciencias de la Educación. En Memoria Académica. Disponible en:

http://www.memoria.fahce.unlp.edu.ar/tesis/te.896/te.896.pdf

Piglia, Ricardo (1990), Crítica y ficción. Buenos Aires, Siglo Veinte.

Pita González, Alexandra (2014). "Las revistas culturales como soportes materiales, prácticas sociales y espacios de sociabilidad". Hanno Ehrlicher/ Nanette RißlerPipka (eds.) Almacenes de un tiempo en fuga: revistas culturales en la modernidad hispánica, Aachen, Shaker Verlag. p. 227-245, disponible en https://www.revistasculturales.de/es/buchseite/alexandra-pita-gonz $\% \mathrm{C} 3 \% \mathrm{~A} 1$ lez-las-revistasculturales-como-soportes-materiales-pr $\% \mathrm{C} 3 \% \mathrm{~A} 1 \mathrm{cticas}$

Pizarro, Ana (1981). "Vanguardismo literario y vanguardia política en América Latina". Araucaria de Chile. No 13,1981

Plotkin, Mariano (2007). Mañana es San Perón. Propaganda, rituales políticos y educación en el régimen peronista (1946-1955). Caseros, EDUNTREF

Poblete Araya, Kira. "Las revistas literarias del surrealismo argentino". Revista de Literaturas Modernas Vol. 46, №2 (2016): 209-235

Podlubne, Judith (2003). "Moral y literatura' en Sur: un debate tardío". Boletín del Centro de Estudios de Teoría y Crítica Literaria, Diciembre 2003, N¹1, Rosario.

(2012a). Los escritores de Sur. Los inicios literarios de José Bianco y Silvina Ocampo. Rosario, Beatriz Viterbo.

(2012b). "Sur en los '60. Hacia una nueva sensibilidad crítica". Badebec. Revista del Centro de Estudios de Teoría y Crítica Literaria №2. Rosario, Universidad de Rosario.

(2014). "Un arte para el hombre. Compromiso intelectual en Contorno y Sur". BADEBEC. Revista del Centro de Estudios de Teoría y Crítica Literaria, Rosario. Universidad Nacional de Rosario; Año: 2015 p. 487 - 511

(2017). Dossier Fin y resistencia de la teoría. Presentación: "La edad de la teoría literaria”. El Taco En La Brea, 1(5), 83-94. https://doi.org/10.14409/tb.v1i5.6617

Porrúa, Ana (2001). Variaciones vanguardistas. Rosario, Beatriz Viterbo.

(2011). "Como el que sin voz estudia canto. En torno a la poesía de Leónidas Lamborghini”. Estudios 18/36 (enero-junio): 11-32. 
(2011). Caligrafía tonal. Ensayos sobre poesía. Buenos Aires, Entropía. (2019). Bello como la flor de cactus. La Plata, Barba de Abejas.

Prieto, Adolfo (1953). Borges y la nueva generación. Buenos Aires, Letras Universitarias. (1956). Sociología del público argentino. Buenos Aires, Leviatán. (1969). Estudios de literatura argentina. Buenos Aires, Galerna.

Prieto, Martín (2006). Breve historia de la literatura argentina. Buenos Aires, TaurusAlfaguara.

(2011). "Diccionarios, enciclopedias, cannon". Bazar Americano. http://www.bazaramericano.com/buscador.php?cod=5\&tabla=resenas\&que=prieto

Prieto, Martín (2010). "Poesía y peronismo: un episodio en la historia de la literatura argentina”. La Biblioteca, Edición Bicentenario, 9-10: 174-187.

Rancière, Jacques (1996). "El concepto de anacronismo y la verdad del historiador". L'Inactuel, $\mathrm{n}^{\circ}$ 6. Traducción: Marie Lourties.

(2005). El inconsciente estético. Buenos Aires, Del Estante.

(2005) Sobre políticas estéticas. Barcelona, Museu d Art Contemporani de Barcelo

(2003) (2006). "The Politics of Aesthetics", Universidad de Aarthus en Dinamarca. "Política de la estética". Otra parte, primavera 2006.

(2007). Sobre politicas estéticas.

[2007] (2009). La palabra muda: Ensayos sobre las contradicciones de la literatura. Buenos Aires, Eterna Cadencia. Traducción: Cecilia González.

(2010). El espectador emancipado. Buenos Aires, Manantial. Traductor: Ariel Dilon.

(2011). Politica de la literatura. Buenos Aires, Libros del Zorzal. Traducción:

Marcelo G. Burello, Lucía Vogelfang, J.L. Caputo

(2005). El inconsciente estético. Buenos Aires, Del estante editorial. Traducción de Silvia Duluc, Silvia Constanzo y Laura Lambert.

(2014). El reparto de lo sensible. Estética y política. Buenos Aires, Prometeo Libros.

Raymond, Marcel (1960). De Baudelaire al surrealismo. México, Fondo de Cultura Económica.

Revistas argentinas del siglo XX. El Matadero. Revista crítica de literatura argentina. Buenos Aires, Instituto de Literatura Argentina "Ricardo Rojas", Facultad de Filosofía y Letras, UBA - Ediciones Corregidor, segunda época, n. 4, 2006.

Robbe-Grillet, Alain [1963] (2010). Por una nueva novela. Buenos Aires, Cactus. Traducción: Pablo Ires.

Rocca, Pablo, comp. (2009). Revistas culturales del Río de La Plata. Campo literario: debates, documentos, índices (1942-1964). Montevideo, Instituto de las Letras.

Rogers, Geraldine (2008). Caras y Caretas. Cultura, política y espectáculo en los inicios del siglo XX argentino. La Plata, EDULP.

(2019) "Las publicaciones periódicas como dispositivos de exposición". Revistas, archivo y exposición. Publicaciones periódicas argentinas del siglo XX, Colectivo Crítico, FAHCE, UNLP, 2019. 
Rosa, Nicolás (2003). La letra argentina. Crítica 1970-2002. Buenos Aires, Santiago Arcos Editor.

(1982) "La crítica literaria contemporánea: la interpretación del símbolo", en Capítulo. Historia de la literatura argentina. Tomo 5. Buenos Aires, CEAL.

(1992). Artefactos. Rosario, Beatriz Viterbo.

(1999). "Introducción. Hipótesis sobre la relación entre la historia y la literatura argentina", "Veinte años después o la 'novela familiar' de la crítica literaria". Políticas de la crítica. Historia de la crítica literaria en la Argentina, Rosa, N (ed.). Buenos Aires: Biblos. Pág.: 9-20, 321-348.

Saavedra, María Inés y Patricia Artundo (dirección) (2002). Leer las artes: las artes plásticas en 8 revistas culturales argentinas. 1878-1951. Buenos Aires, Facultad de Filosofía y Letras. Universidad de Buenos Aires.

Saer, Juan José (2005). Trabajos. Buenos Aires, Planeta.

Sager, Valeria (2014). El punto en el tiempo: Realismo y gran obra en Juan José Saer y César Aira. Universidad Nacional de La Plata. Tesis doctoral publicada en:

http://www.memoria.fahce.unlp.edu.ar/library? $\mathrm{a}=\mathrm{d} \& \mathrm{c}=$ tesis \&d=Jte1079

Saítta, Sylvia, dir. (2004). Historia Crítica de la Literatura Argentina. Noé Jitrik director de la colección. Tomo IX: El oficio se afirma. Saítta directora del volumen. Buenos Aires, Emecé.

Sarlo, Beatriz (1992). "Intelectuales y revistas: razones de una práctica”, en Le discours culturel Dans las revues latino-américaines (1940-1970), París, América-Cahiers du CRICCAL, n. 9/10, p. 9-16.

Sarlo, Beatriz (1988). Una modernidad periférica: Buenos Aires 1920-1930. Buenos Aires, Nueva Visión.

(1983). "Los dos ojos de Contorno" en Revistas Iberoamericana. Pittsburg, Universidad de Pittsburg. Vol. XLIX, Núm. 125, Octubre-Diciembre 1983. Pp797-807.

Schwartz, Jorge (1991). Las vanguardias latinoamericanas. Textos programáticos y críticos. México, Fondo de Cultura Económica.

(2016). Fervor de las vanguardias. Arte y literatura en América Latina. Rosario: Beatriz Viterbo.

Sola, Graciela de (1967). "Las revistas del surrealismo y otras que denotan su influencia", "El grupo surrealista argentino", "Consideración de las obras surrealistas más importantes”. Proyecciones del surrealismo en la Argentina. Buenos Aires, ECA. (pp. 107-138).

(1967). Proyecciones del surrealismo en la República Argentina. Buenos Aires, Culturales Argentinas

Soler Cañas, Luis (1981). La generación poética del 40. Buenos Aires: Ediciones Culturales Argentinas.

Sollers, Philippe (1978). La escritura y la experiencia de los límites. Madrid, Pre-Textos.

Sosnowski, Saúl (ed.) (1999) La cultura de un siglo. América Latina en sus revistas. Buenos Aires, Alianza Editorial.

Soto, Luis (1967) "Los problemas de Iberoamérica y las revistas", Comentario, Buenos Aires, n. 52, p. 9-16. 
Sucre, Guillermo (2001). La máscara, la transparencia: ensayos sobre poesía hispanoamericana. México DF, Fondo de Cultura Económica.

Surya, Michel (2013). «Contre-attaque: l'offensive révolutionnaire ou la mort », Preface, Contre-attaque. Union de lutte des intellectuels révolutionaires. 1935-1936. Georges Bataille - André Breton. Paris, Ypsilon editeur.

Verani, Hugo (2003). Las vanguardias literarias en Hispanoamérica. Manifiestos, proclamas y otros escritos. México DF, Fondo de Cultura Económica.

Tatián, Diego (2013). Lo impropio. Buenos Aires, Editorial Excursiones.

Terán, Oscar (1991). Nuestros años sesentas. La formación de la nueva izquierda intelectual (1956-1966). Buenos Aires, Punto Sur editores.

(1986) "Rasgos de la cultura argentina en la década del cincuenta", en En busca de la ideología argentina. Buenos Aires, Catálogos.

Todorov, Tzvan (1991). Crítica de la crítica. Buenos Aires, Paidós. . Antología del formalismo ruso.

Tzara, Tristan (2014). El surrealismo de hoy. Buenos Aires, Godot Ediciones. Traductor: Raúl Gustavo Aguirre.

Urondo, Francisco (1968) (2009). Veinte años de poesía argentina y otros ensayos. Buenos Aires, Mansalva.

Viñas, David [1969] (2005). Literatura argentina y realidad política. Buenos Aires, Santiago Arcos.

(1981). "Nosotros y ellos. David Viñas habla sobre Contorno" en Punto de vista, a. $4, \mathrm{~N}^{\mathrm{o}} 13 \cdot \mathrm{pp} .: 9-12$

Wapnir, Salomon (1956). La crítica literaria Argentina. Buenos Aires, Ediciones Acanto.

Weigel, Sigrid (2005). Body-and image-space: re-reading Walter Benjamin. London and New York, Routledge. Traducción al inglés: Georgina Paul with Rachel, McNicholl and Jeremy Gaines

Williams, Raymond (2003). Palabras claves. Un vocabulario de la cultura y la sociedad. Buenos Aires, Nueva Visión. Traducción de Horacio Pons

(2009). Marxismo y literatura. Buenos Aires, Las cuarenta editorial. Traductor: Guillermo David.

Yepez, Heriberto ....

AA.VV. Operaciones de la crítica.

\section{LIBROS DE LOS AUTORES VINCULADOS AL CORPUS:}

Bayley, Edgar (2011). Poesía completa. Volumen I. La Plata, Turkestan (2011). Poesía completa. Volumen II. La Plata, Turkestan

(1952). Realidad interna y función de la poesía. Buenos Aires, poesía buenos aires.

(1966). Realidad interna y función de la poesía y otros ensayos. Buenos Aires, Nueva Visión.

Madariaga, Francisco (1954). El pequeño patíbulo. Buenos Aires, Letra y línea. (1960). Las jaulas del sol. Buenos Aires, A partir de cero. 
(1963). El delito natal. Buenos Aires, Sudamericana.

Miller, Henry (1988). Trópico de Capricornio. Madrid, Cátedra. Traducción, Bernt Dietz. (1988). Trópico de Cáncer. Madrid, Cátedra. Traducción: Bernt Dietz.

Molina, Enrique (1941). Las cosas y el delirio. Buenos Aires, Sudamericana.

(1946). Pasiones terrestres. Buenos Aires, Emecé.

(1951). Costumbres errantes o la redondez de la tierra. Buenos Aires, Botella

al mar.

(1961). Amantes antípodas. Buenos Aires, Losada.

Pellegrini, Aldo (1965). Para contribuir a la confusión general. Buenos Aires, Nueva Visión.

(1949). El muro secreto. Buenos Aires, Argonauta.

(1953). La valija de fuego. Buenos Aires, Américalee.

(1956). Artistas abstractos argentinos. Buenos Aires- París, Cercle d'Art.

(1957). Construcción de la destrucción. Buenos Aires, A partir de cero.

(1959). "El movimiento surrealista", Cursos y conferencias, año 19, n²22,

Buenos Aires.

(1961). Antología de la poesía surrealista en lengua francesa. Buenos Aires, Argonauta.

(1966). Antología de la poesía viva latinoamericana. Barcelona, Seix-Barral

$\left(1967^{\mathrm{a}}\right)$. Panorama de la pintura argentina contemporánea. Buenos Aires,

Paidós.

(1967b). Nuevas tendencias en la pintura. Buenos Aires, Muchnik.

Vanasco, Alberto [1964] (2011). Los muchos que no viven. La Plata, Mil Botellas. (1954). Ella en general. Buenos Aires, poesía buenos aires. (1947). Sin embargo Juan vivía. Buenos Aires, HIGO Club.

(1943). Justo en la Cruz del medio del camino. Buenos Aires, Edición de autor. (1957). Para ellos la eternidad. Buenos Aires, Doble P.

(1967). Nueva York, Nueva York. Buenos Aires, Sudamericana.

Vanasco, Alberto y Trejo, Mario (1957). No hay piedad para Hamlet. Buenos Aires, Comisión Nacional de Cultura 
Quienes pasamos por la experiencia de escribir una tesis sabemos que es un trabajo solitario y a la vez, solo es posible porque se hace en compañía de muchxs. A esa compañía y sostén va el agradecimiento de haber podido darle punto final a un momento del trabajo, que no es nunca el final de la investigación ni de la escritura. Agradecimiento al amor de mi compañero, con quien transitamos juntxs el desafío de este proceso mientras esperábamos la llegada de Javiera. A mi mamá y mi hermano, Violeta y Víctor, que me escucharon contar las idas y vueltas, las dudas, las angustias y entusiasmos, que estuvieron en todos los detalles para que esto fuera posible. Durante meses mi mamá llegó a casa con bolsos de comida deliciosa y frizada en porciones; ella decía que era para ayudarme a ganar tiempo, pero en la decoración de cada plato estaban el amor y el cuidado de todos mis años. A mis amigas, las de esa conversación infinita, siempre interrumpida y retomada, atenta a cualquier horario, duda y ocurrencia sin argumentos, ¿con quién podríamos delirar si no con las amigas? Guille Torres y Lea Hafter fueron mis otras manos y ojos de lectura cuando los tiempos no alcanzaban. Si el día no puede tener más de $24 \mathrm{hs}$, por suerte tenemos amigas como ellas, y como Euge Rasic, Samanta Rodríguez, Vi Calvente.

A mis compañeres de los Proyectos de Investigación y sus directores, porque fueron espacios fundamentales de formación y discusión, que acompañaron los distintos avances de la tesis. "Literatura" como "lectura" en la teoría literaria, la crítica, las ficciones y las poéticas, y en situaciones de "enseñanza", en la Argentina contemporánea, dirigido por Miguel Dalmaroni, es el proyecto que nuclea nuestras preguntas sobre la teoría, y se expande a charlas inverosímiles. Malena Pastoriza, Federico Cortés, Natalí Incaminato, Julieta Novelli, Juliana Regis, Laura Conde, Valeria Sager, están siempre a un wasap de distancia de cualquier duda. Las publicaciones periódicas como contextos formativos de la literatura argentina (siglo XX), dirigido por Geraldine Rogers y Verónica Delgado fue el marco de una reflexión permanente sobre qué hacemos cuando estudiamos revistas; Mariángeles Mascioto, Víctor Gonnet, Margarita Merbilhaá, Iván Suasnábar, acompañaron distintas versiones de trabajos, índices y capítulos en las jornadas internas que organizábamos cada año, en los Coloquios dedicados a las publicaciones y reuniones. A Graciela Goldchluk por la lucidez de sus lecturas, por ayudarme a escribir en voz alta, y mejorar con sus palabras lo que tantas 
veces pensaba pero no me salía decir. A Fede Brugaleta, por la virtud de sostener, los sábados de trabajo en la C204, los mates litoraleños, y el mejor refranero de mantras para tesistas desesperades. Anita Jouli por las largas conversaciones en las que nos salvamos de las tareas inventando planes de viajes y talleres que se acumulan.

A mis directores, Verónica y Miguel, por haber confiado en este proyecto desde el comienzo y ayudarme a que pudiera mutar. Ambos me enseñaron mucho de cómo se construye una relación de escucha. Gracias también por aceptar el ritmo vertiginoso de trabajo que se impuso en las últimas semanas, cuando pudiendo decirme que no, decidieron acompañar.

A las juradas que evaluaron esta tesis, Laura Juárez, Judith Podlbne y Ana Porrúa, por la generosidad de sus devoluciones, el compromiso con la lectura, y sobre todo, por hacer del momento de la defensa una instancia más donde la evaluación también forma parte del aprendizaje.

A aquellxs otrxs investigadores que estimo y admiro, y tuvieron la disposición a leer distintas versiones de algunos capítulos; Raúl Antelo, Annick Louis, Alberto Giordano, Ana Bugnone, Federico Bibbó, Sara Bosoer, Mario Ortiz, Marie Audran, Sylvie Josserand, Fernando Colla. A Juan Ennis, por compartir su sabiduría sobre el alemán y la filología benjaminiana.

Nada de esto hubiera sido posible sin la Universidad Pública, y un Ministerio de Ciencia y Tecnología que promueve la investigación desde el Estado. Tuve la suerte de comenzar mi beca doctoral otorgada por CONICET en el marco de una ampliación de las políticas públicas en el ámbito científico, en 2015. Los años que siguieron fueron difíciles, y agradezco a mis compañeres de trabajo en el Instituto de Investigaciones en Humanidades y Ciencias Sociales (IdiHCS), Federico, Belén y Nicolás por el aprendizaje colectivo, por ponerle el cuerpo a cada marcha y asamblea. Ir a la Universidad Pública, ser alumna de la FaHCE, es una de las experiencias más transformadoras que viví; porque la construcción de subjetividades no es solo personal sino también política, y porque sabemos la potencia que significa el acceso a la educación, nunca dejaremos de insistir en que se trata de un derecho.

A Los Alfonsos, ese grupo humano maravilloso que conocí en las aulas de la vieja Humanidades, hace más de diez años, y nos siguen uniendo los pasos de baile mal hechos y el amor por no juzgarnos.

A mis amigues de Malisia y El Espacio, porque son parte de todo esto. Con quienes aprendí que no hay construcción política sin cuidado del otre. Especialmente a la 
Negra Magallanes, compañera de tantas aventuras que juntas nos animamos a esto de maternar en tribu. 